UNIVERSIDADE DE SÃO PAULO

FACULDADE DE ECONOMIA, ADMINISTRAÇÃO E CONTABILIDADE DEPARTAMENTO DE CONTABILIDADE E ATUÁRIA

PROGRAMA DE PÓS-GRADUAÇÃO EM CONTROLADORIA E CONTABILIDADE

EDUARDO BONA SAFE DE MATOS

(IN)COMPLETUDE E (IN)CONSISTÊNCIAS NA APLICAÇÃO DOS PRINCÍPIOS DO DUE PROCESS DO IASB: ANÁLISE COM BASE NO PROCESSO NORMATIVO DA IFRS 16 - LEASES

São Paulo 
Prof. Dr. Vahan Agopyan

Reitor da Universidade de São Paulo

Prof. Dr. Fabio Frezatti

Diretor da Faculdade de Economia, Administração e Contabilidade

Prof. Dr. Valmor Slomski

Chefe do Departamento de Contabilidade e Atuária

Prof. Dr. Lucas Ayres Barreira de Campos Barros

Coordenador do Programa de Pós-Graduação em Controladoria e Contabilidade 


\title{
(IN)COMPLETUDE E (IN)CONSISTÊNCIAS NA APLICAÇÃO DOS PRINCÍPIOS DO DUE PROCESS DO IASB: ANÁLISE COM BASE NO PROCESSO NORMATIVO DA IFRS 16 - LEASES
}

\begin{abstract}
Tese apresentada ao Departamento de Contabilidade e Atuária da Faculdade de Economia, Administração e Contabilidade da Universidade de São Paulo como requisito parcial para a obtenção do Título de Doutor em Ciências.
\end{abstract}

Linha de Pesquisa: Contabilidade para Usuários Externos

Orientador: Prof. Dr. Fernando Dal-Ri Murcia

Versão Corrigida

(versão original disponível na Biblioteca da Faculdade de Economia, Administração e Contabilidade)

São Paulo 
Catalogação na Publicação (CIP)

Ficha Catalográfica com dados inseridos pelo autor

Matos, Eduardo Bona Safe de.

(In)completude e (in)consistências na aplicação dos princípios do Due process do IASB: análise com base no processo normativo da IFRS 16 Leases / Eduardo Bona Safe de Matos. - São Paulo, 2020. $368 \mathrm{p}$.

Tese (Doutorado) - Universidade de São Paulo, 2020.

Orientador: Fernando Dal-Ri Murcia.

1. Teoria pós-estruturalista do discurso. 2. IFRS 16. 3. Regulação contábil internacional. 4. Due process handbook. 5. Boas práticas de governança. I. Universidade de São Paulo. Faculdade de Economia, Administração e Contabilidade. II. Título. 
Dedico a todas as minorias, aos que lutam diariamente pela sobrevivência e aos que lutam por um mundo de mais justiça social. Dedico aos impactados pelos catastróficos crimes de Mariana e Brumadinho, que sofreram os reflexos de uma hegemonia institucional injusta. Às vítimas da Covid-19 e a todos que lutam para ao menos compreender os efeitos do status quo! 


\section{AGRADECIMENTOS}

Se eu cheguei e estou passando pelo ano de 2020 foi porque nunca estive sozinho. Dizem que somos a união das pessoas com quem mais convivemos. Com as múltiplas mudanças que já tive na vida, posso dizer então que tive diversos Eduardos formados por constelações das mais diferentes possíveis durante minha vida.

Esta tese foi escrita durante um momento de tremenda instabilidade política e social e isso com certeza impactou na sua escrita. Foram dias de tristeza e angústia por uma eleição presidencial de alto risco social, com grande instigação de ódio entre a população. Ainda, foi escrita em momentos de dificuldade humana, como no terrível crime ambiental provocado pela Mineradora Vale no município de Brumadinho e uma pandemia causada por um vírus descontrolado. Meus pêsames a todos os impactados por esses eventos.

Este momento, que pode ser de vitória para mim, é de grande perda para a sociedade, não somente brasileira. Perdas humanas, animais e da flora jamais serão reparadas. Apesar das perdas, tenho muito a agradecer, muito mesmo!

Inicialmente, agradeço às energias da vida que me fizeram chegar até aqui. Agradeço à minha mãe. Tenho certeza de que ela é a maior torcedora pelo meu sucesso. Mesmo de longe, sempre me apoiando. Aceita-me como sou, com meus defeitos e minhas qualidades, e confia plenamente em mim. Agradeço às minhas avós, pelas mulheres fortes e inspiradoras que são.

Agradeço de coração ao Henrique, marido e companheiro de vida, por todo o apoio, parceria, paciência e pela convivência diária. Durante esse doutorado tive dias maravilhosos e dias não tão bons; tive reviravoltas na vida; tive surpresa; tive viagens espetaculares; tive amor e tristeza; tive sucessos e insucessos; tive angústias e tranquilidade; ansiedade e calma... porém você esteve sempre ao meu lado e me ajudou a ter equilíbrio. Esse equilíbrio só aumentou quando adotamos o Risoto e o Canjica. Eles trouxeram toda uma nova energia à nossa casa. Então, também agradeço aos meus queridos e amados gatinhos!

Agradeço ao meu orientador, prof. Fernando Murcia, que sempre foi um grande parceiro, apoiando e me defendendo. Agradeço por ter me deixando livre para realizar minhas escolhas. Agradeço também aos professores com quem tive a honra de estudar nesse doutorado e que levarei seus modelos para sempre durante minha carreira.

Não posso deixar de agradecer aos mais diversos professores que colaboraram para que esse projeto se tornasse realidade, contribuindo diretamente para esta tese. Não citarei nomes, pois com certeza estaria sendo injusto com alguém. Agradeço aos que participaram das bancas de qualificação e defesa pelas inúmeras contribuições e insights: Profa. Elionor Weffort, Profa. Camila Boscov, Prof. Guillermo Braunbeck e Prof. Artur Nascimento.

Durante esse doutorado fiz ótimas amizades e, infelizmente, uma dessas amizades partiu de forma precoce. Agradeço ao meu grande amigo Alan Góis (in memorian). Desde que viramos amigos no doutorado, você sempre foi um grande amigo, irmão e vizinho. Foram muitos almoços sem avisar, muitas caronas, faxinas, jogos e sujeiras com tapioca na cozinha. Outro grande amigo que fiz no doutorado também conhece essas sujeiras, né Vitor? Agradeço ao Vitor Nasu, com quem divido muitas experiências, conversas e uma grande amizade. Outra grande amiga que este doutorado me trouxe foi a querida Raquel Sarquis. Raquel é um exemplo de tudo que deve e não deve ser feito ao mesmo tempo. 
Agradeço também aos meus colegas de turma, em especial às minhas amigas Marília Ohlson e Patrícia Garcia. A amizade cresceu em uma viagem para o AAA na Flórida e foi além da academia. Agradeço aos amigos que me motivaram a fazer esse doutorado. Claudia Cruz, suas dicas foram essenciais. Obrigado!

A todos os funcionários que passaram pela secretaria do FEA3 e, em especial, aos queridos amigos Gisele Oliveira e Andrés Torres. Foram muitas tardes de conversas, trocas e chocolates. Meus sinceros agradecimentos por tudo que sempre fizeram por mim.

Agradeço aos colegas da UnB, que não hesitaram em me ajudar a obter uma licença para dedicação ao doutorado, em especial, às amigas Mariana Guerra e Fernanda Fernandes. Ambas passaram anos (e continuam) puxando minhas orelhas e torrando minha paciência. Foram, com certeza, as pessoas que mais me cobraram por esse título de doutor.

Aos amigos de tempos de escola, que são os que carrego e convivo até os dias de hoje, especialmente, à Thaissa e à Luisa. São anos e anos de conversas, visitas em São Paulo, visitas em Brasília, viagens, saídas, comidas e participação constante em minha vida. Se eu pudesse escolher melhores amigas, com certeza as escolheria de novo!

O presente trabalho foi realizado com apoio da Coordenação de Aperfeiçoamento de Pessoal de Nível Superior - Brasil (CAPES) - Código de Financiamento 001. 


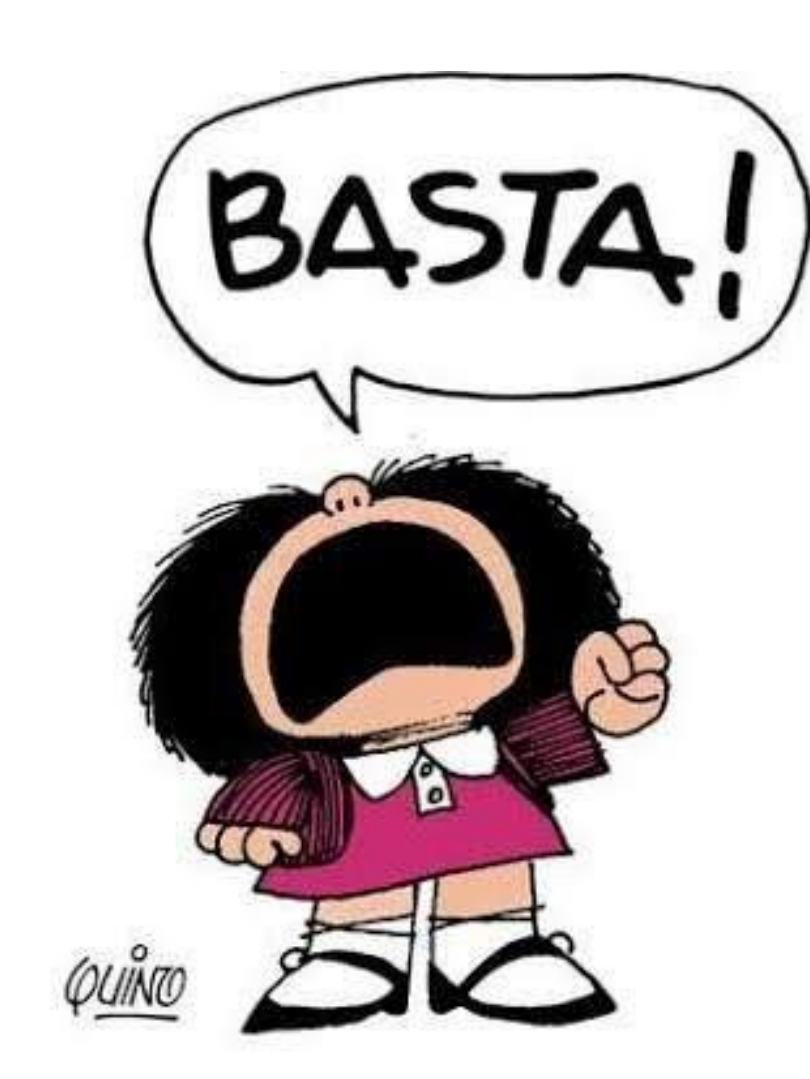




\section{RESUMO}

Matos, E. B. S. de (2020). (In)completude e (in)consistências na aplicação dos princípios do Due process do IASB: análise com base no processo normativo da IFRS 16 - Leases (Tese de Doutorado). Faculdade de Economia, Administração e Contabilidade da Universidade de São Paulo, São Paulo.

As IFRS resultam de um processo de normatização guiado pelo due process handbook do IASB, em que se elencam três princípios para a elaboração das normas: (i) transparência; (ii) consulta completa e justa; e (iii) accountability. Amparando-se neles, o regulador constrói um discurso de independência e tecnicidade relacionado com boas práticas de governança. Entretanto, parto de uma visão ontológica e teórica - baseada na teoria pós-estruturalista do discurso de Laclau e Mouffe (1985) - de que a política é intrinsecamente presente nos fenômenos sociais. Com base nessa construção discursiva dicotômica entre a tecnicidade e a política, objetivo reconstruir o processo normativo do IASB - por meio da articulação de lógicas sociais, políticas e fantasmáticas - e analisar momentos em que há (in)completude e (in)consistências na aplicação dos princípios do due process handbook durante a condução deste processo. Para a consecução do objetivo, utilizo-me da aplicação das Lógicas da Explicação Crítica (Glynos \& Howarth, 2007) sobre o conjunto de documentos gerados internamente pelo IASB durante o processo de edição da IFRS 16 - Leases. A partir desse arcabouço, problematizo a dicotomia técnicopolítica amparada na alegada expertise atingida por meio de um discurso de atomização e independência do IASB como regulador internacional. Ainda, reconstruo e descrevo o processo com uma nova teorização da normatização do IASB com base nas lógicas sociais (financialização, atomização/independência, boas práticas, constituintes e expertise), políticas (discursos da essência sobre a forma; da necessidade de mudança; da capitalização; do modelo único; e da simetria) e fantasmáticas (fantasias da qualidade da norma; da tecnicidade; da comparabilidade; da globalização; e da justiça processual). Para a articulação, identifico e descrevo os principais cenários de mudanças da norma (construção da necessidade de mudanças, da capitalização total dos arrendamentos, da simetria entre arrendadoras e arrendatárias e do projeto conjunto entre o FASB e o IASB), de forma a demonstrar a (in)completude na aplicação dos princípios. Posteriormente, desenvolvo um framework de análise dos processos normativos que relaciona dois eixos: princípios versus bases de análise (atores envolvidos, processo organizacional e conteúdo da norma). As discussões, as críticas e os julgamentos, aliados à análise do framework, nos levam à compreensão de que as (in)consistências nos discursos de mudanças do board representam momentos políticos, rechaçando a alegada tecnicidade neutra na tomada de decisões. Essas (in)consistências também são observadas ao confrontarmos os discursos formais e práticos. Demonstro, ainda, que a (in)completude na aplicação dos princípios tende a ser intencional, refutando eventual falta de condições na sua aplicação. Argumento, portanto, que há um anseio na construção de um sistema discursivo baseado na ilusão da tecnicidade. Para isso, utilizam-se de estratégias para o controle de antagonismos, como a articulação por meio de significantes vazios e de constantes silenciamentos das (in)consistências. A construção do discurso tecnicista no processo de edição de normas, portanto, é uma estratégia retórica de purificação do processo que objetiva manter a hegemonia do discurso. Por fim, contribuo, para uma nova leitura do processo normativo contábil internacional, sob o paradigma pós-estruturalista, fundada na assunção da política como dinâmica central na análise das normas. Para a literatura, contribuo com a criação de um framework de análise passível de replicação em outras normas e que possibilita a análise do fenômeno da regulação com uma visão mais crítica com relação ao status quo da normatização.

Palavras-chave: Teoria pós-estruturalista do discurso, IFRS 16, Regulação contábil internacional, Due process handbook, boas práticas de governança. 


\begin{abstract}
Matos, E. B. S. de (2020). (In)completeness and (in)consistencies in the application of the IASB Due process principles: analysis based on the IFRS 16-Leases - standard setting (Tese de Doutorado). Faculdade de Economia, Administração e Contabilidade da Universidade de São Paulo, São Paulo.
\end{abstract}

The IFRS result from a standard setting process guided by the IASB due process handbook, in which three principles are listed: (i) transparency; (ii) full and fair consultation; and (iii) accountability. Based on that, the regulator builds a discourse of independence and technicality related to good governance practices. However, I start from an ontological and theoretical view - based on the Laclau and Mouffe (1985) post-structuralist discourse theory - that politics is present in all social phenomena. Relying on this dichotomous discursive construction between technicality and politics, I aim to reconstruct the IASB standard setting process - through the articulation of social, political and fantastic logics - and to analyze moments when there are (in)completeness and (in)consistencies in the application of the due process handbook principles during the standard setting. To achieve this goal, I apply the Logics of Critical Explanation (Glynos \& Howarth, 2007) on the set of the IASB internally generated documents during the development of the IFRS 16 - Leases. Thereby, I problematize the technical-political dichotomy based on the alleged expertise achieved through a discourse of atomization and independence of the IASB as an international regulator. After that, I reconstruct and describe the process with a new theorization of the IASB standard setting based on social (financialization; atomization/independence; good practices; constituents; and expertise), political (discourses of the economic substance; the need for change; the capitalization; the single model; and symmetry) and fantasmatic logics (fantasies of the quality of the norm; of technicality; of comparability; of globalization; and of procedural justice). For the articulation, I identify and describe the main scenarios of changes in the norm (construction of the need for changes, total capitalization of leases, symmetry between lessors and lessees and the joint project between FASB and IASB) in order to demonstrate its (in)completeness. After that, I elaborate a framework for the analysis of the standard setting through the relationship of the axes: principles versus bases of analysis (actors involved, organizational process and content of the standard). The discussions, criticisms and judgments, combined with the analysis of the framework, bring us to the understanding that the (in)consistencies in the board's discourses represent political moments, in addition to the absence of the alleged technicality in decisions making. These (in)consistencies are also observed when confronting formal and practical discourses. I also demonstrate that the (in)completeness in the application of the principles tends to be intentional, refuting eventual lack of conditions in their application. I argue that there is an urge to build a discursive system based on the illusion of technicality. For this, strategies are used to control antagonisms, such as articulation by means of empty signifiers and constant silencing of (in)consistencies. The construction of technicist discourse in the standards setting, therefore, is a rhetorical strategy for purifying the process that aims to maintain the hegemony of discourse. Finally, I contribute for a new reading of the international accounting standards setting, under the post-structuralist paradigm, founded on the assumption of politics as central dynamics in the analysis. For the literature, I contribute through the creation of an analysis framework that can be replicated in other standards, and which makes it possible to analyze the phenomenon of regulation with a more critical view regarding the status quo of standard setting.

Keywords: Post-structuralist discourse theory, IFRS 16, International accounting regulation, Due process handbook, Good governance practices. 


\section{LISTA DE FIGURAS}

Figura 1 - Objetivos, missão e princípios da IFRS Foundation e do Due process Handbook .............. 37

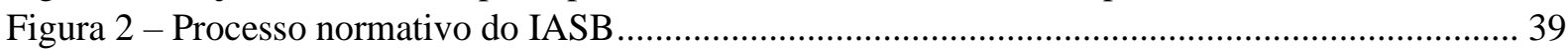

Figura 3 - Documentos Base e Documentos Emitidos durante o Processo Normativo .......................... 47

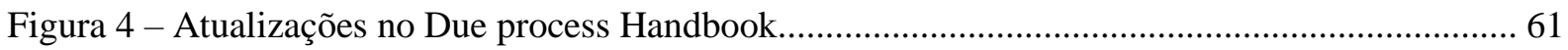

Figura 5 - Princípios, Conceitos e estratégias dos Due process Handbooks....................................... 66

Figura 6 - Esquematização dos conceitos-chave da Teoria do Discurso (Laclau \& Mouffe, 1985) .. 115

Figura 7 - Modelo de Construção da Estratégia Metodológica ........................................................ 135

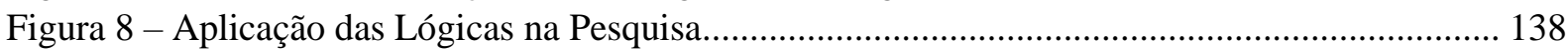

Figura 9 - Principais Documentos Analisados na Pesquisa ............................................................... 146

Figura 10 - Documentos Emitidos pelo Due Process Oversight Committee...................................... 148

Figura 11 - Framework de Análise Crítica dos Pontos de (in)consistências e (in)completudes......... 150

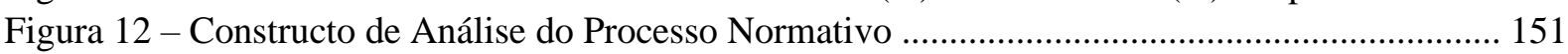

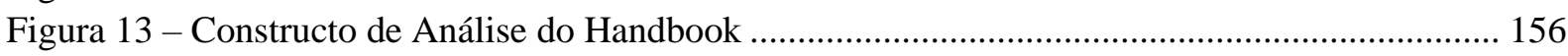

Figura 14 - Evolução e modificações das Normas de Leasing Americanas e Internacionais.............. 161

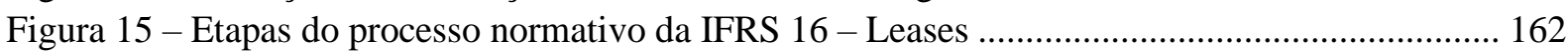

Figura 16 - Relação dos documentos descritos, órgão emissor e citação ............................................ 165

Figura 17 - Pontos de Diferenças e Semelhanças entre Nailor e Lennard (2000) e Ryan et al. (2001)

Figura 19 - Definições de Arrendamento Mercantil apresentadas nas (propostas de) normas ........... 173

Figura 20 - Definições de "Prazo do Arrendamento" apresentadas nas (propostas de) normas ......... 174

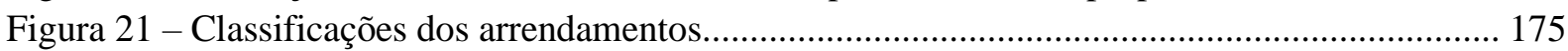

Figura 22 - Relação das Lógicas Identificadas no Processo Normativo Contábil .............................. 181

Figura 23 - Necessidade da Lógica Social da Financialização...................................................... 184

Figura 24 - Interrelação das Lógicas da Independência, das boas práticas, dos constituintes e da

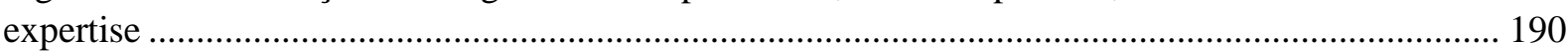

Figura 25 - Relação das lógicas sobre o tema da "Necessidade de Mudança" ................................... 221

Figura 26 - Argumentos do IASB para a entrada do projeto na agenda ........................................... 222

Figura 27 - Relação das lógicas sobre o tema do "Reconhecimento das operações de arrendamento"

Figura 28 - Críticas/Inconsistências dos argumentos à classificação ou não de operações de

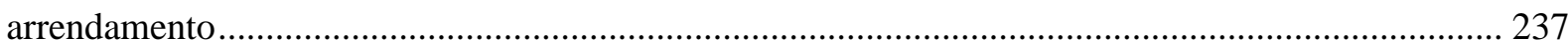

Figura 29 - Modificações nos critérios de reconhecimento das arrendatárias durante o processo ..... 241

Figura 30 - Modificações nos critérios de reconhecimento durante o processo ................................. 247

Figura 31 - Relação das lógicas sobre o tema do "Simetria entre arrendadoras e arrendatárias" ....... 249

Figura 32 - Principais articulações que envolvem mudanças nas arrendadoras - Parte 1.................. 251

Figura 33 - Principais articulações que envolvem mudanças nas arrendadoras - Parte 2................... 256

Figura 34 - Principais articulações que envolvem mudanças nas arrendadoras - Parte 3.................. 258

Figura 35 - Principais articulações que envolvem mudanças nas arrendadoras - Parte 4 ................... 262

Figura 36 - Relação das lógicas sobre o discurso do projeto conjunto entre FASB e IASB ……....... 266

Figura 37 - Modelo de Interpretação do Framework de Análise Crítica ........................................... 271

Figura 38 - Usos dos pronomes indefinidos nos documentos formais de feedback de consulta ........ 283

Figura 39 - Descrição dos modelos de Arrendamento Financeiro - IAS 17 ...................................... 330

Figura 40 - Lançamentos Contábeis de Arrendamento Financeiro - IAS 17 ..................................... 331

Figura 41 - Descrição dos modelos de Arrendamento Operacional - IAS 17 ..................................... 332

Figura 42 - Lançamentos Contábeis de Arrendamento Operacional - IAS 17 .................................. 332

Figura 43 - Descrição do modelo para Arrendatárias - ED/2010/9 .................................................... 333

Figura 44 - Lançamentos Contábeis do Arrendatário - ED/2010/9 ................................................... 333 
Figura 45 - Descrição dos modelos para Arrendadoras - ED/2010/9 …………................................. 335

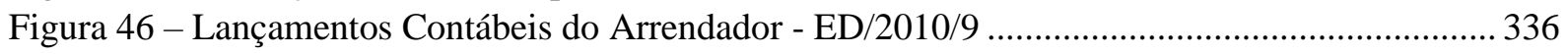

Figura 47 - Descrição dos modelos para Arrendatárias - ED/2013/6 …............................................ 337

Figura 48 - Lançamentos Contábeis do Arrendatário - ED/2013/6 .................................................. 338

Figura 49 - Descrição dos modelos para Arrendadoras - ED/2013/6 ………………………............ 339

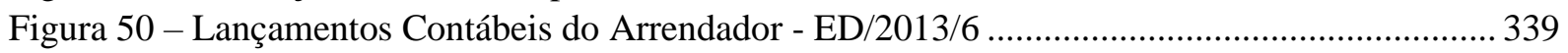

Figura 51 - Descrição do modelo para Arrendatária - IFRS 16 ......................................................... 341

Figura 52 - Lançamentos Contábeis do Arrendatário - IFRS 16 ....................................................... 341

Figura 53 - Descrição dos modelos para Arrendadoras - IFRS 16 ................................................... 342

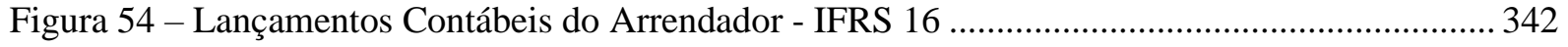

Figura 55 - Documentos que Compõem o Processo Normativo de Leasing ...................................... 343

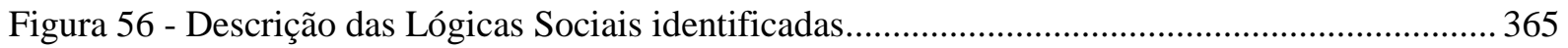

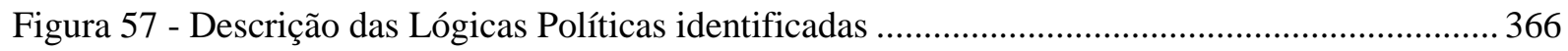

Figura 58 - Descrição das Lógicas Fantasmáticas identificadas .......................................................... 367 


\section{LISTA DE TABELAS}

Tabela 1 - Grupos de Subgrupos Temáticos da Produção Científica de Leasing... 


\section{LISTA DE ABREVIATURAS E SIGLAS}

\begin{tabular}{|c|c|}
\hline AAA & American Accounting Association \\
\hline $\mathrm{BP}$ & Balanço Patrimonial \\
\hline CL & Comment letter \\
\hline $\mathrm{CPC}$ & Comitê de Pronunciamentos Contábeis \\
\hline DA & Derecognition Approach \\
\hline DFC & Demonstração dos Fluxos de Caixa \\
\hline DR & Derecognition approach \\
\hline DRE & Demonstração do Resultado do Exercício \\
\hline DP & Discussion paper \\
\hline DPOC & Due process Oversight Committee \\
\hline EBITDA & Earnings Before Interest, Taxes, Depreciation and Amortization \\
\hline ED & Exposure draft \\
\hline EFRAG & European Financial Reporting Advisory Group \\
\hline EITF & Emerging Issues Task Force \\
\hline EUA & Estados Unidos da América \\
\hline FASB & Financial Accounting Standards Board \\
\hline FMI & Fundo Monetário Internacional \\
\hline G4+1 & The Group of Four Plus One \\
\hline GRI & Global Reporting Initiative \\
\hline IAS & International Accounting Standard \\
\hline IASB & International Accounting Standards Board \\
\hline IASC & International Accounting Standards Committee \\
\hline IASCF & International Accounting Standards Committee Foundation \\
\hline IFRIC & IFRS Interpretations Committee \\
\hline IFRS & International Financial Reporting Standards \\
\hline IOSCO & International Organization of Securities Commissions \\
\hline LEC & Lógica da Explicação Crítica \\
\hline PIR & Post-Implementation Review \\
\hline POA & Performance Obligation Approach \\
\hline PME & Pequenas e Médias Empresas \\
\hline SEC & Securities and Exchange Commission \\
\hline SFAS & Statement of Financial Accounting Standards \\
\hline SPELL & Scientific Periodicals Electronic Library \\
\hline VRG & Valor Residual Garantido \\
\hline
\end{tabular}




\section{SUMÁRIO}

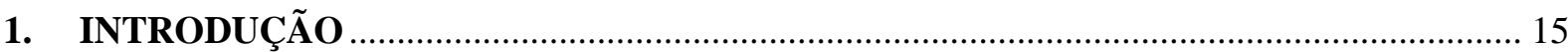

1.1 Contextualização e Definição do Objetivo da Pesquisa ....................................................... 17

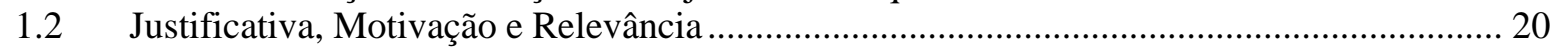

1.3 Base Ontológica, Epistemológica, Teórica e Metodológica ………….................................. 23

1.4 Contribuições Esperadas e Breve Apresentação dos Resultados ........................................... 26

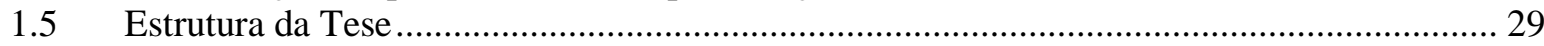

2. REVISÃO DO PROCESSO NORMATIVO E DA LITERATURA EM REGULAÇÃO .... 32

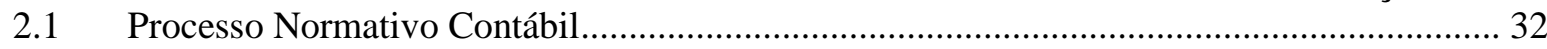

2.1.1 IASB, Processo Normativo e Documentos Emitidos ................................................... 34

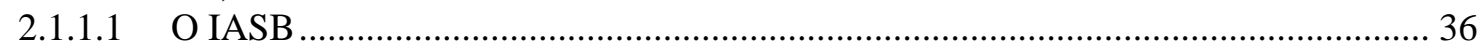

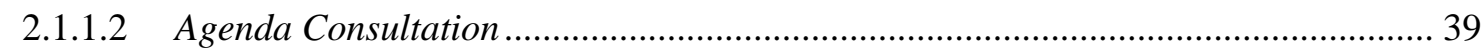

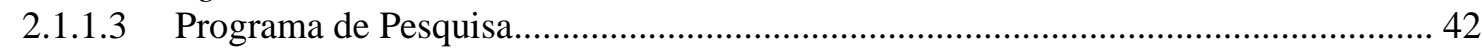

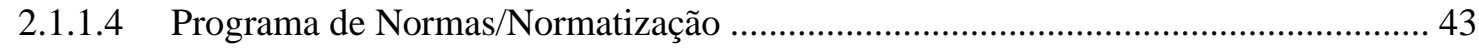

2.1.1.5 Programa de Implementação e Manutenção.............................................................. 45

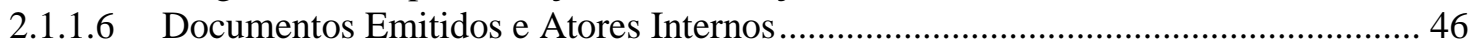

2.2 Estratégias de Normatização Contábil ................................................................................... 51

2.2.1 Governança como pilar da Normatização Contábil........................................................ 54

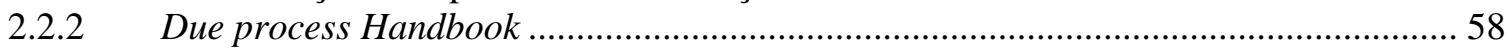

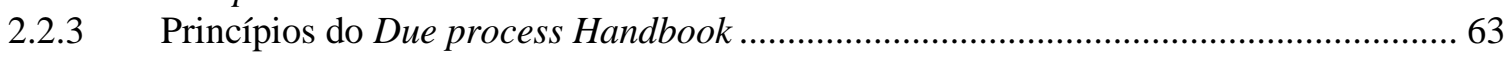

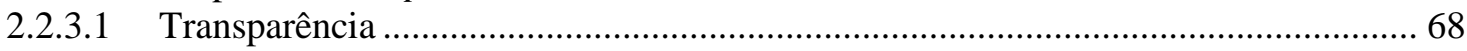

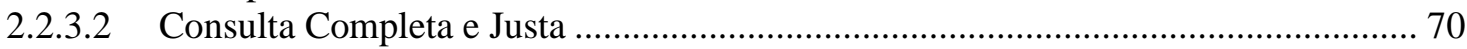

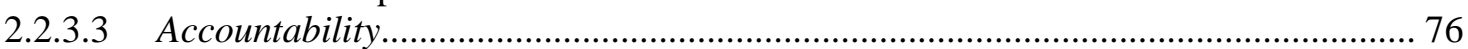

2.3 Pesquisas críticas e pós-estruturalistas sobre Regulação..................................................... 78

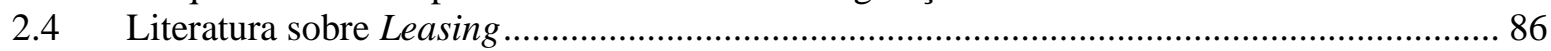

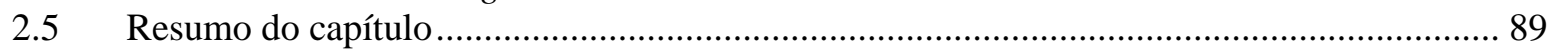

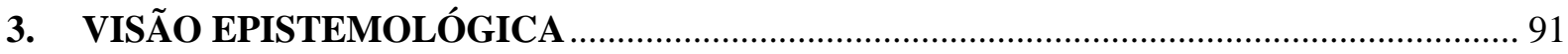

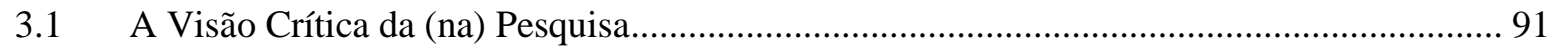

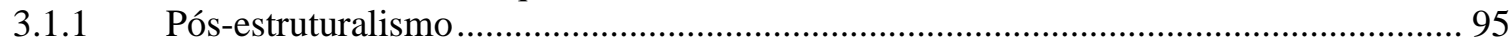

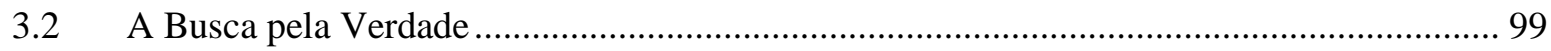

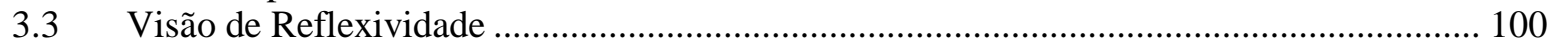

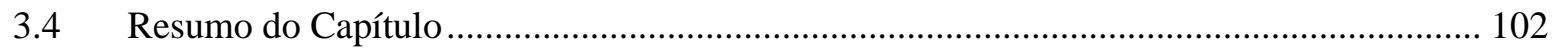

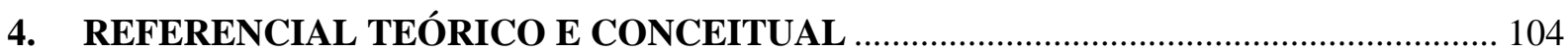

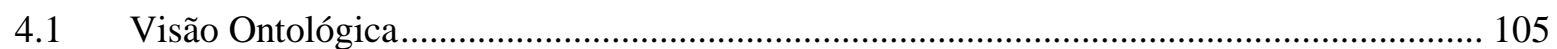

4.2 A Teoria do Discurso de Laclau e Mouffe (1985) ............................................................................ 110

4.3 Esquematização do Funcionamento da Teoria do Discurso de Laclau e Mouffe ................ 114

4.4 Os Significantes Vazios e a Lógica da Equivalência ........................................................... 119

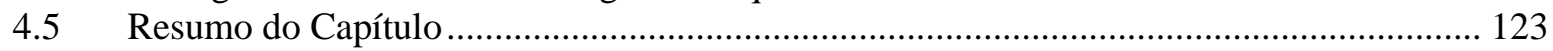

5. ESTRATÉGIAS E VISÕES METODOLÓGICAS........................................................... 125

5.1 Relação Metodológica com a Teoria e com a Epistemologia ............................................. 126

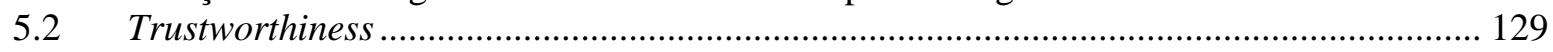

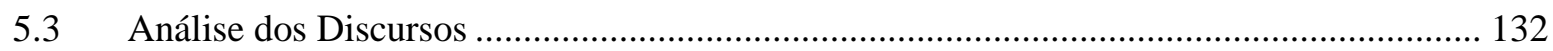

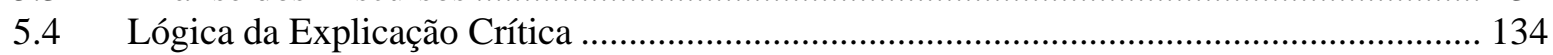

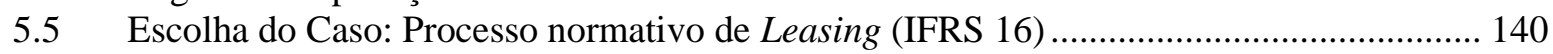

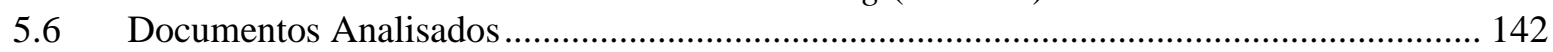

5.7 A Criação de um Framework de Análise do Processo Normativo....................................... 149

5.7.1 Criação do Eixo Vertical - Elementos do Processo Normativo.................................... 151

5.7.2 Criação do Eixo Horizontal - Princípios do Handbook ……........................................ 155

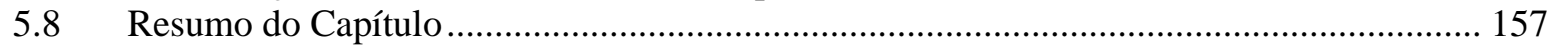


6. EXPICAÇÃO CRÍTICA: APLICAÇÃO NO PROCESSO DA IFRS 16 ............................. 160

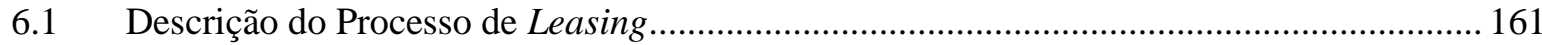

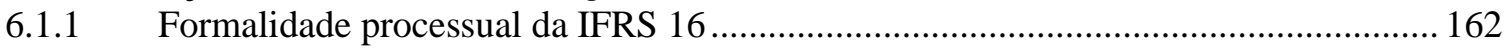

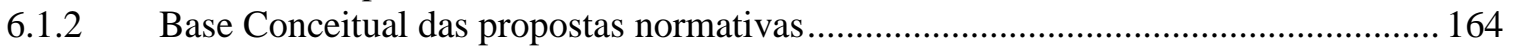

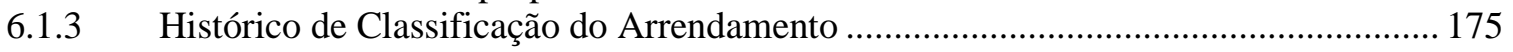

6.2 Problematização do Processo normativo (de Leasing) ...................................................... 177

6.3 As Lógicas da Normatização Contábil Internacional ......................................................... 181

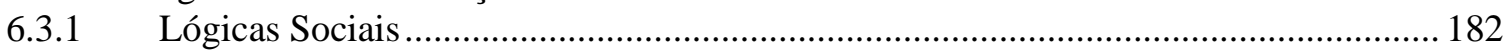

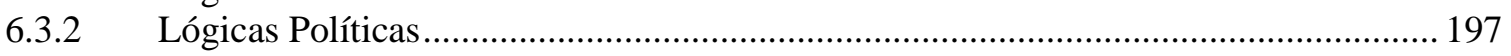

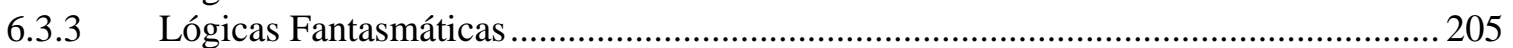

6.4 Articulação, Julgamentos e Críticas ao Processo ................................................................... 218

6.4.1 Análise dos Principais Discursos de Mudanças: Explicitação das Contradições ........ 219

6.4.1.1 A Necessidade de uma Mudança Normativa para Leasing ....................................... 221

6.4.1.2 O Reconhecimento das Operações de Leasing: temos uma métrica conceitual? .... 234

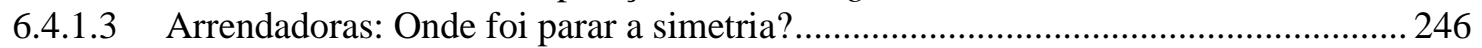

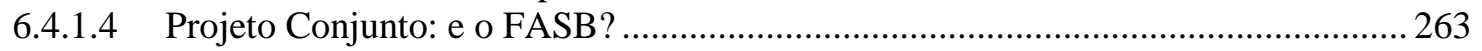

6.4.2 Análise da Aplicação dos Princípios do Processo Normativo Internacional ................ 269

6.4.2.1 Desenvolvendo o Framework de Análise do Processo............................................. 270

6.4.2.2 A (In)completude dos Princípios: Críticas com base no Framework de Análise .... 273

6.4.2.2.1 Relação dos Atores Envolvidos com os Princípios ......................................... 273

6.4.2.2.2 Relação do Processo Organizacional com os Princípios ...................................... 279

6.4.2.2.3 Relação do Conteúdo da Norma com os Princípios ............................................. 290

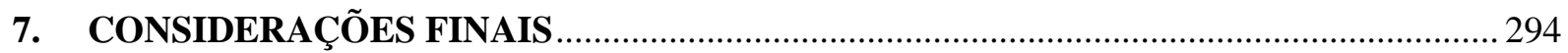

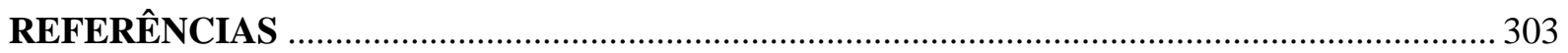

APÊNDICE A - Modelos e Lançamentos Contábeis Propostos ...................................................... 329

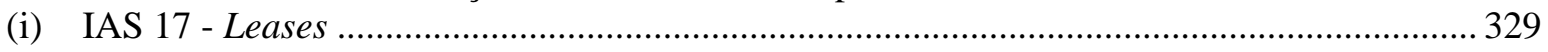

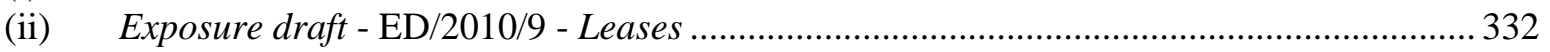

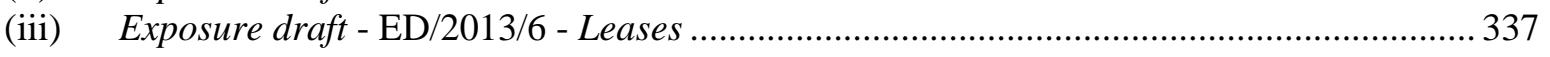

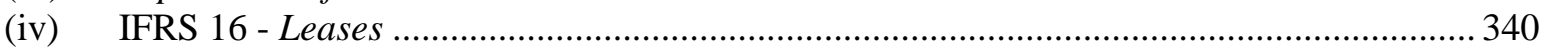

APÊNDICE B - Documentos Formais que Compõem o Processo Normativo de Leasing ................ 343

APÊNDICE C - Resumo das Lógicas da Explicação Crítica identificadas ........................................ 365 


\section{INTRODUÇÃO}

"Faça o que eu digo, mas não faça o que eu faço."

O IASB (International Accounting Standards Board) cumpre o papel de normatizador internacional da contabilidade por meio da regulação em modelo soft-law. Por sua característica não vinculante, esse modelo implica a necessidade de que o regulador mantenha seus processos atualizados com base em boas práticas de governança, de forma a garantir aceitação frente às diversas partes interessadas (Black, 2008; Botzem, 2012; Botzem \& Dobusch, 2012; Burlaud \& Colasse, 2011; Chua \& Taylor, 2008; Königsgruber, 2010; Pelger, 2016; Pelger \& Spieß, 2017; A. J. Richardson \& Eberlein, 2011).

A regulação no âmbito contábil, portanto, depende não somente da edição de normas de qualidade, mas também de estratégias que envolvem a produção de discursos sociais de convencimento. Considerando que o poder e a hegemonia discursiva são vitais para a explicação dos fenômenos relacionados com a regulação, já que o poder produz as práticas sociais (Howarth, 2010), podemos dizer que o board necessita de constante aprimoramento de suas práticas (Mayntz, 2010; Moll \& Hoque, 2011) para se manter reconhecido como um órgão de sucesso com um status de hegemonia na contabilidade (Botzem, 2012; Camfferman \& Zeff, 2018; Chua \& Taylor, 2008; Durocher \& Gendron, 2011).

Uma das formas de assegurar essa aceitação é pela constante ênfase nos discursos do IASB acerca da qualidade do processo de elaboração das normas internacionais, o que consequentemente - com base nesse discurso - levaria a edição de normas também de alta qualidade (Madsen, 2013).

Considerando que esse discurso é apenas uma estratégia de governança para atingir aceitação, acabo por observar outros pontos que representam discursos e estratégias similares, como os discursos de: expertise, tecnicidade, neutralidade, independência, qualidade, due process, usuários, consulta pública e informação útil (Botzem, 2012; Botzem \& Quack, 2009; Gallhofer \& Haslam, 2007; Herbohn \& Herbohn, 1999; Hoffmann \& Zülch, 2014; Hopwood, 1994; Madsen, 2013; Pelger \& Spieß, 2017; Ram \& Newberry, 2013; A. J. Richardson, 2008; Stenka \& Jaworska, 2019; Suddaby \& Greenwood, 2005; Young, 2003, 2006).

Apesar da existência desse discurso tecnicista, entendo que o processo normativo internacional contábil é intrinsecamente político. Para um modelo como o da regulação que se diz ser democrático e inclusivo, "questões políticas não são simplesmente problemas técnicos que devem ser resolvidos por especialistas" (Mouffe, 2015, p. 9). A democracia exige um 
modelo em que existam adversários. Modelos que aceitam uma visão única (ou um consenso fictício) ignoram a dimensão do político e "reduzem a política a um conjunto de mudanças supostamente técnicas e a procedimentos neutros” (Mouffe, 2015, p. 32).

Vejo a contabilidade não como um reflexo estático e objetivo da realidade econômica, mas sim como uma atividade social partidária, política e subjetiva em seus meios e fins (Baker \& Bettner, 1997). A partir disso, esse discurso relacionado com uma dicotomia entre política e tecnicidade nada mais é do que um simbolismo de forma a trazer credibilidade às decisões do regulador como sendo neutras; sem viés ideológico.

Essa visão da contabilidade parte do entendimento da política como "referência às tensões e contradições internas que formam o processo de normatização na contabilidade, e que podem, ao final desse processo, continuar não resolvidas" (Warren, Carter, \& Napier, 2019, p. 125), ou seja, envolve a presença de conflitos, tomada de decisões, atores, conteúdos e normas organizacionais que nem sempre são consensuais e levam para além do alegado tecnicismo (Burlaud \& Colasse, 2011; Gallhofer \& Haslam, 2007; Perry \& Nöelke, 2005; Porter, 2005; Warren et al., 2019; Young, 2003, 2014)

Minha visão nesta tese, portanto, é que se não aceitarmos as dimensões políticas e sociais como integrantes da contabilidade - e continuarmos a nos apegar a uma dimensão técnica - não evoluiremos como ciência (Gallhofer \& Haslam, 2007; Hopwood \& Miller, 1994; Leuz, Pfaff, \& Hopwood, 2004; Macintosh, 2002; Shafer \& Gendron, 2005). As demandas atuais, em que cada vez há mais presença de elementos imensuráveis, necessitam que a contabilidade não seja mais vista como um tradicional conjunto de postulados e normas. Para isso, há uma necessidade de revisar como as normas internacionais são produzidas de forma a verificar possíveis modificações no papel da própria contabilidade como área científica e de atuação profissional (Macintosh, 2002), o que leva a um aumento da preocupação com relação à construção de normas pelos diferentes países do mundo, inclusive ao seu processo de aceitação (Barth, 2000; Pelger \& Spieß, 2017)

O fato de o IASB se amparar em um "devido processo normativo" baseado em princípios - transparência, consulta completa e justa e accountability - funciona como uma estratégia para esconder a questão política da regulação, pois devemos entender que a política está presente até mesmo nas situação que enxergamos como mundanas e técnicas (Warren et al., 2019). Ao dizer que segue um processo neutro e técnico, o órgão perpetua o não questionamento por parte dos impactados, conseguindo "ignorar, silenciar ou mascarar certas vozes" (Warren et al., 2019, p. 145). 
Parto, portanto, da mesma visão crítica de Madsen (2013, p. 867), para quem a crença de que "normatizadores contábeis possuem a expertise da contabilidade, feedback dos constituintes e independência política, e por isso produzem, com segurança, normas contábeis de alta qualidade" é a crença mais incorreta que circunda a regulação contábil e os "experts" nela envolvidos.

\subsection{Contextualização e Definição do Objetivo da Pesquisa}

Por mais que haja uma vasta literatura crítica que argumente que o IASB e o processo de normatização contábil são políticos e subjetivos (Baudot, 2018; Chapman, Cooper, \& Miller, 2009; Fogarty, 1994; Madsen, 2013; Ordelheide, 2004; Young, 2003, 2014), a contabilidade continua, como área, utilizando-se principalmente de teorias advindas de bases conceituais da área da economia sob um paradigma positivista para a explicação de fenômenos contábeis, principalmente identificando questões relacionadas aos atores envolvidos, como práticas de lobbying e grupos de interesses (Gipper, Lombardi, \& Skinner, 2013; Hansen, 2011; Königsgruber, 2010; Sutton, 1984; Watts \& Zimmerman, 1978). Entretanto, essa visão tecnicista/positivista carece de uma argumentação voltada para a dimensão política intrínseca (ontológica) ao processo de normatização contábil (Chua \& Taylor, 2008; Hopwood, 1994; Pelger \& Spieß, 2017).

A política é inevitável quando há relações envolvidas (Danjou \& Walton, 2012). Essas relações, por sua vez, trazem à tona o conceito de poder, sendo que há várias formas de se observar esse poder e a presença da política. Entre elas, podemos dizer que o processo de emitir normas e procedimentos, assim como o discurso de autoridade, de conhecimento e de expertise são as mais presentes em organizações transnacionais (Warren et al., 2019; Wickramasinghe, 2006).

Especificamente com relação à normatização contábil, há um destaque para o discurso de expertise na contabilidade baseado nas decisões estritamente técnicas acerca do conteúdo das normas (Shafer \& Gendron, 2005). Esse discurso acaba por representar uma dualidade (retórica) com a visão acerca do caráter político do processo normativo (Young, 2014). Para justificar a tecnicidade, o IASB criou o due process handbook, que representa uma estratégia de governança por meio da publicação de um documento que apresenta as principais lógicas organizacionais do board e os passos que devem ser levados em consideração para a consecução de um processo normativo dito como justo e neutro (IFRS Foundation, 2016b). 
A continuidade do sucesso do IASB depende, além de um due process de alta qualidade, de sua habilidade para administrar críticas sobre seu caráter político e conseguir manter uma aderência/consistência entre o discurso formal e a prática diária, que possuem impacto na credibilidade das normas editadas (A. J. Richardson \& Eberlein, 2011). O processo de construção de normas internacionais - não exclusivamente na contabilidade - depende de processos que devem ser considerados "desejáveis, convenientes e apropriados" (Suchman, 1995, p. 574).

Apesar da aparente "neutralidade/objetividade" decorrente do discurso do handbook, o próprio documento baseia o processo de criação de normas em três princípios subjetivos: transparência, consulta completa e justa e accountability. Consequentemente, a simples existência de um due process com princípios subjetivos como forma de garantir a alegada neutralidade das normas e credibilidade frente às partes interessadas permite que critiquemos esse processo e sua aplicação por parte do IASB, isso porque, no discurso da normatização internacional, manter a qualidade das normas equivale a manter normas técnicas, neutras e apolíticas (Richardson \& Eberlein, 2011).

Ainda que os princípios sejam subjetivos, Botzem $(2012,2014)$ argumenta que eles representam uma parte relevante das estratégias para se atingir aceitação internacional. Neste estudo, questiono esses “conceitos, crenças e práticas” subjetivas (Durocher \& Gendron, 2011, p. 236). Argumento, com base na lógica de significantes vazios de Laclau (Laclau, 2007b; Laclau \& Mouffe, 1985) e na identificação de lógicas sociais, políticas e fantasmáticas (Glynos \& Howarth, 2007), que os princípios norteadores do due process do IASB existem no discurso escrito, mas carecem de aderência ao discurso prático: o "fazer" e o "dizer" dessas normas acabam sendo retóricos (Young, 2003, 2014) ou efeitos de uma criação de mitos (Hoffmann \& Zülch, 2014). Em outras palavras, os três princípios funcionam como significantes vazios e lógicas fantasmáticas, que são dados como garantidos e acabam por limitar os discursos antagônicos, uma vez que esses discursos muitas vezes sequer são elaborados (Young, 1996).

Chego, portanto, a uma motivação em torno de uma pergunta levantada por Durocher e Gendron (2011, p. 255): “o quão legítimo é o due process se os usuários estão principalmente envolvidos em uma reprodução de mitos em vez de se envolverem criticamente?”. Com base nisso, as estratégias de governança empregadas, assim como a prática do processo, representam os discursos presentes na normatização contábil e devem ser analisados frente ao formal e ao efetivamente realizado (Pelger \& Spieß, 2017).

Para a criação dessa aceitação e credibilidade perante os usuários, o IASB utiliza-se de uma antagonização caracterizada por uma simplificação da dualidade técnico-política. Essa 
simplificação em dois polos opostos é vista, nesta tese, como um obstáculo epistemológico (Bachelard, 1996) e funciona como estratégia discursiva criada pelo normatizador para purificar seus produtos. O que quero dizer é que a antagonização da técnica com a política é uma ferramenta fictícia e simbólica com o intuito de trazer credibilidade às normas internacionais. Na minha visão, portanto, não existe essa antagonização e os produtos são sempre uma mistura desses dois conceitos, ou seja, nunca se é inteiramente técnico nem inteiramente político como se constrói a discurso normativo do IASB.

Ao considerar que a antagonização da política com a tecnicidade representa o principal discurso normativo do IASB; e que os princípios do due process handbook do board podem ser retóricos ou representar mitos, procuro nesta tese observar momentos em que esses princípios apresentam (in)completude ${ }^{1}$ ou (in)consistência para com discurso pregado. Portanto, objetivo reconstruir o processo normativo do IASB - por meio da articulação de lógicas sociais, políticas e fantasmáticas - e analisar momentos em que há (in)completude e (in)consistências na aplicação dos princípios do due process handbook durante a condução deste processo.

Para isso, apesar de o board afirmar que seu processo de tomada de decisão é realizado com base na objetividade e em evidências (IFRS Foundation, 2016b), proponho verificar de forma empírica se essas diretrizes realmente podem ser observadas na prática durante a elaboração específica de alguma norma (Botzem \& Quack, 2006a; Pelger \& Spieß, 2017). De forma a contribuir empiricamente ao tema, selecionei como objeto de análise o processo normativo de leasing, que culminou na publicação da IFRS 16.

Operacionalizo a pesquisa por meio da desconstrução discursiva do processo de elaboração de uma norma específica pelo IASB. Para a desconstrução, desenvolvo o principal produto desta tese, que se materializa por meio do desenvolvimento de um framework de análise que possibilita a identificação, a análise e a demonstração dos pontos de (in)completudes e (in)consistências. Para tanto, reconstruo esse processo com base na teoria pós-estruturalista do

\footnotetext{
${ }^{1}$ Tendo como base o conceito de harmonização/convergência (de fato e de direito) discutido por Weffort (2005), faz-se uma analogia para a concepção de (in)completude que é utilizada na presente tese. Assim, (in)completude de direito refere-se à (falta de) aplicação dos passos formais do processo normativo do IASB, que são estipulados pelo handbook; e (in)completude de fato refere-se à (falta de ) aplicação do processo normativo em sua essência, levando-se em consideração a utilidade dos princípios elencados no handbook. Ressalto que, assim como no conceito de harmonização/convergência (Weffort, 2005), as (in)completudes de fato e de direito não são excludentes, podendo ocorrerem concomitantemente ou de forma separada. O interesse da presente tese é com relação à aplicação do conceito de fato. Questões pertinentes ao conceito de direito são discutidas de forma subsidiária, em momentos oportunos, porém não correspondem à principal intenção do trabalho.
} 
discurso (Laclau, 2007b; Laclau \& Mouffe, 1985) e na Lógica da Explicação Crítica (Glynos \& Howarth, 2007, 2008).

Podemos dizer que "há pouca dúvida de que o IASB veio para ficar" (Botzem, 2012, p. 179). Porém essa estrutura pode ser abalada em decorrência de acontecimentos sociais, o que resulta na importância de pesquisas sobre a normatização (Meyer \& Rowan, 1977). A crítica parte, por isso, das práticas diretamente relacionadas ao processo normativo por ele conduzido, tomando como base a desconstrução dos aspectos de governança dados como garantidos neste mesmo processo, já que esses aspectos funcionam como justificativas de credibilidade para o comportamento de agentes hegemônicos e reguladores que operam em um contexto de soft-law (Durocher \& Gendron, 2011; Mayntz, 2010; Mehrpouya \& Salles-Djelic, 2019; Pelger, 2016; Stenka \& Jaworska, 2019; Wingard, Bosman, \& Amisi, 2016).

O objetivo aqui não é de o de questionar a validade da contabilidade, da profissão ou até mesmo das organizações pertencentes a esse sistema, mas sim mostrar uma visão crítica diferente da convencional (taken for granted), referente à natureza do processo de elaboração de normas na contabilidade. Minha intenção não é analisar se o IASB é legítimo ou hegemônico, mas sim investigar a construção do processo normativo de normas contábeis internacionais de forma a discutir as ações que foram tomadas dentre as mais diversas possibilidades discursivas.

Em um paralelo com a visão de Laughlin e Puxty (1983) sobre a teoria e a regulação da contabilidade, não viso a sanar todos os problemas relacionados com a normatização contábil. Almejo chamar atenção para questões fundamentais eclipsadas pelo domínio da atual visão sobre o processo normativo do IASB, que prejudicam a concretização dos próprios princípios norteadores desse órgão, e, por consequência, explorar o potencial de mudança.

\subsection{Justificativa, Motivação e Relevância}

Entre as motivações para a realização desta tese está a inquietação com relação ao que é apresentado sobre a tecnicidade e neutralidade da contabilidade. A maior parte dos estudos em regulação busca analisar efeitos de normas já prontas, a fim de buscar a tal neutralidade (dos números contábeis), porém pouca atenção se dá ao processo de elaboração de tais normas (Botzem, 2012, 2014; Botzem \& Dobusch, 2012; Botzem \& Hofmann, 2010; Botzem \& Quack, 2006b). Devemos questionar e incluir nas agendas de pesquisa assuntos que se relacionem com as condições da produção dos fatos/normas contábeis que, se não questionadas, são tomadas 
como dadas (Hopwood, 1994; Hopwood \& Miller, 1994; Moll \& Hoque, 2011; Young, 2018; Young \& Oakes, 2009).

Defendo também que, assim como os resultados finais da contabilidade são dados políticos e sujeitos a interpretações subjetivas, o processo de criação das normas também é baseado em valor (value-based), ou seja, sujeito a participação política (Young, 2006, 2014, 2018). Young (2018, p. 14) resume tal pensamento ao afirmar que "os números contábeis não decidem, pessoas decidem e essas decisões podem e devem estar abertas a questionamentos e debates vigorosos".

Essa questão da objetividade/tecnicidade versus subjetividade/política já é vista nas mais diversas áreas e, inclusive, é utilizada na teoria do discurso aplicada nesta tese (Laclau \& Mouffe, 1985). Argumentos de objetividade e tecnicidade nada mais são que ferramentas políticas (mitos/retóricas) de articulação para a naturalização de conceitos (Morgan, 1988). Baseado nessa premissa teórica e no objetivo da pesquisa, a minha missão como pesquisador é, por um lado, desvendar conteúdos naturalizados e, por outro, revelar suas críticas não naturais (Jørgensen \& Phillips, 2002).

Essa dualidade entre trabalho técnico e político também já está presente em diversas esferas de discussões na contabilidade e no trabalho próprio do IASB. Enquanto representantes da organização defendem sua qualidade técnica, por meio da retórica da "neutralidade apolítica", da valorização da "independência" no processo decisório e de procedimentos adequados do due process (Li, 2011; McGregor, 2012; Mehrpouya \& Salles-Djelic, 2019; Pelger \& Spieß, 2017; Shafer \& Gendron, 2005; Street, 2006), o paradigma pós-estruturalista questiona tal visão e toma como premissa que o processo de tomada de decisão na regulação contábil é sim político (Ferguson, 1990; Howarth, 2010; Königsgruber, 2010; Laclau \& Mouffe, 1985; Torfing, 1999; Young, 2014). Além disso, há, também, estudos que demonstram que a presença da política nesse processo é inevitável, ainda que se argumente o uso de razões econômicas (Pelger, 2016).

Mas qual seria o motivo de estudar um processo de elaboração de norma do IASB? Inicialmente, o IASB é um ator de relevância para a Contabilidade. Trata-se de um caso de autoridade transnacional, de influência sobre o processo de normatização, atualmente, de mais de 140 países. Além disso, o financiamento dessa instituição por parte de diversas entidades, como as big four e outras entidades reguladoras, pode levar ao envolvimento de interesses econômicos de atores considerados poderosos (Black, 2008; Gallhofer \& Haslam, 2007; Palea, 2015; Wingard et al., 2016). 
Uma das formas de garantir a alegada independência e a qualidade na emissão de normas contábeis pelo IASB é a defesa de que os oponentes ao processo são partes interessadas e políticas, que não levam em consideração a tecnicidade dos fatos, sendo o due process a ferramenta que limita a inserção de política nesse processo (Street, 2006). Considerando que esse discurso possa ser meramente retórico, devemos diminuir nossas atenções para os resultados finais de aplicação de normas, e retornar as análises ao passo que representa as condições pelas quais essas normas foram criadas e hoje são tidas como factuais (Young, 2018). É interessante, portanto, uma análise que não envolve apenas o estágio final e sim uma análise que demonstre a direção para a qual aquele processo normativo tomou (Müller, 2014).

Entretanto, a decisão final - exercida pelos membros votantes - pode não apresentar necessariamente critérios de transparência e consulta (Pelger, 2016). Por mais que se sigam todas as etapas formais e se emitam todos os documentos necessários, a decisão final pode desacreditar as fases anteriores ao não levar em conta as diversas interferências que foram realizadas. Assim podemos questionar o próprio motivo da existência dos princípios. A literatura tende a responder tal questionamento tomando como base a necessidade de se trazer credibilidade perante os diversos atores e a ausência de controle efetivo por parte deles (Bamber \& McMeeking, 2016; Botzem, 2008, 2012, 2014; Burlaud \& Colasse, 2011; Chua \& Taylor, 2008; Gipper et al., 2013; Pelger, 2016; Pelger \& Spieß, 2017; A. J. Richardson \& Eberlein, 2011; Suddaby \& Greenwood, 2005; Suddaby \& Viale, 2011).

A partir desse ponto de vista, podemos entender que as normas contábeis e os documentos intermediários, assim como o próprio andamento e aplicação do due process, representam estratégias escritas e práticas conduzidas com a finalidade de persuadir a comunidade a enxergar aquele processo como um fato politicamente neutro e necessário (Young, 2003).

Minha missão aqui é diferente. Ao já aceitar a premissa da busca da credibilidade/aceitação por meio da aplicação de estratégias de governança processuais (Bamber \& McMeeking, 2016; Burlaud \& Colasse, 2011), procurei, na verdade, questionar uma dessas estratégias: a aplicação dos princípios do due process handbook. Ao questioná-la e mostrar seus pontos de (in)completudes e (in)consistências com base na identificação de lógicas críticas, acabo por apresentar um antagonismo até então silenciado (Mouffe, 2015; Pelger \& Spieß, 2017) e contribuo para uma maior compreensão da caixa-preta que é a condução dos processos normativos por parte de reguladores transnacionais (Cortese \& Irvine, 2010), já que análises de consistências internas ao processo normativo são "sub-representadas" (overlooked) pela literatura (Morley, 2016; Pelger, 2016; A. J. Richardson \& Eberlein, 2011). 
O avanço na literatura pode ser visto por diferentes frentes. Ao aplicar teorias (Laclau \& Mouffe, 1985) e ferramentais (Glynos \& Howarth, 2007) oriundos do paradigma pósestruturalista e pouco explorados na literatura sobre regulação, defendo um avanço tanto teórico quanto metodológico. Apesar disso, não posso deixar de ressaltar a limitação na forma como enxergo o fenômeno de análise. Ao escolher um paradigma específico, uso uma "lente" que pode não ser aplicável a outros paradigmas, portanto, ressalto que deixei de visualizar o fenômeno sob as mais diversas perspectivas possíveis para focar nesta aplicada na tese. Essa limitação, entretanto, possibilita que outros estudos sejam realizados de forma a contribuir com a discussão.

Não enxergo a aplicação da pesquisa a um processo específico como uma limitação da tese, mas sim como uma delimitação que visou à seleção de um ambiente polêmico que possibilita a criação do ferramental de análise. Assim pesquisas futuras podem se aproveitar do framework construído para analisar outros processos e contribuir de forma mais geral ao modelo de análise do processo de construção de normas do IASB.

Ressalto que não tenho como objetivo justificar a "correção" ou a "aptidão" da IFRS 16 tampouco argumentar qual seria o melhor modelo contábil para os arrendamentos nem dizer como a norma deveria ser. Ainda que as diversas mudanças de propostas contábeis ocorridas ao longo do processo normativo de leasing sejam um dos principais motivadores desta tese como forma de demonstrar a presença da política nesse processo, não é meu objetivo dizer se as mudanças estão corretas ou não. A pesquisa sobre regulação, em especial a análise de construção das normas, embora contribua para a compreensão do objeto regulado, não deve especificar como a norma deve ser. O objetivo deste tipo de investigação é levantar pontos importantes aos normatizadores, provendo ideias para resoluções de questões relacionadas ao processo normativo, que são amplas, difíceis e complexas (Barth, 2006). A análise do processo específico de leasing - da IFRS 16 -, portanto, funciona como objeto de análise, e não como tema de pesquisa.

\subsection{Base Ontológica, Epistemológica, Teórica e Metodológica}

Faço uso das visões de Laclau e Mouffe ${ }^{2}$, principalmente por meio de sua teoria do discurso (Laclau \& Mouffe, 1985), como bases ontológica e teóricas nesta tese. Para esses

\footnotetext{
${ }^{2}$ A lógica do pensamento de Ernesto Laclau e Chantal Mouffe está presente em diversas obras desses autores, sendo que estas foram escritas tanto em conjunto como de forma individual por algum deles. Entretanto, a principal obra, e também a principal base teórica/ontológica para o pensamento geral da teoria do discurso, é o livro escrito
} 
autores, a política é parte constitutiva da sociedade e do seu funcionamento. Esse pensamento foi utilizado como premissa central para a observação dos fenômenos relacionados com a normatização contábil internacional.

Essa emancipação ontológica implica entender a contabilidade como algo além da prática estática e técnica que é utilizada como forma de garantir suas posições e produtos sociais (Gallhofer \& Haslam, 2003). Assim podemos partir de uma prática que existe para construir algo melhor e que contribua ao interesse de mais stakeholders (Macintosh, 2002; Roslender, 2006).

Epistemologicamente, a visão crítica entende esse contexto social como constituído por poder e conflitos, repletos de antagonismos, silenciamentos, retóricas, mitos e naturalização de conceitos. Por isso, aplico uma visão pós-estruturalista, pois essa visão tem seu espaço em áreas que envolvem comunicação, cultura e sociedade, incluindo análises de organizações e instituições que tenham como objetivo questões locais ou que envolvam aspectos internacionais (Jørgensen \& Phillips, 2002).

A (in)completude e as (in)consistências, que são parte do objetivo da tese, são vistas como ferramentas de observação que podem ser subsídios para o argumento de que o processo normativo muitas vezes é mais "simbólico do que substantivo" (Bamber \& McMeeking, 2016, p. 60; J. Brown \& Dillard, 2015; Fogarty, 1994; Hopper, Lassou, \& Soobaroyen, 2017; Weetman, 2001).

Com essas premissas ontológicas, epistemológicas e teóricas brevemente apresentadas, tenho como lógica central nesta tese que: mudanças nas normas se baseiam na credibilidade processual do normatizador por meio da existência de um due process bem aceito. Essa aceitação do IASB como normatizador internacional ocorre por meio do discurso hegemônico, o que leva a compreensão de que tanto o status quanto a aceitação devem ser conquistados e mantidos (Humphrey, Loft, \& Woods, 2009; A. J. Richardson \& Eberlein, 2011). O pilar dessa hegemonia é o due process, que representa uma das "boas estratégias" de governança.

No caso do IASB, a aplicação desse due process ocorre por meio de princípios, que serão investigados como possíveis significantes vazios e lógicas fantasmáticas que assumem função de proteger a entidade de antagonismos entre discurso e práticas. Esses conflitos antagônicos podem se referir não apenas ao processo normativo, como principalmente às mudanças normativas (principal produto do IASB), em que há diferentes interesses e interessados. Os antagonismos podem ser demonstrados sob diversos pilares, porém, para esta 
tese, optei por discutir aspectos relacionados aos atores envolvidos, ao processo organizacional e ao conteúdo da norma (Botzem, 2012).

Para a aplicação dessa lógica, escolhas foram realizadas. Primeiro, escolhi como objeto de análise empírica da teoria do discurso um processo específico do IASB (IFRS 16). Outra escolha se refere aos principais documentos analisados, que compõem os documentos públicos apresentados pelo IASB nas diversas etapas desse processo. A análise se limitou a documentos gerados internamente pelo board ou por instâncias da IFRS Foundation.

Metodologicamente, as pesquisas sobre regulação apresentam maior foco em análises externas ao board, sendo mais escassas as pesquisas que analisam interações produzidas por documentos internos (Morley, 2016; Ram \& Newberry, 2013, 2017; Warren et al., 2019). A análise dos discursos por meio de desconstrução de argumentos internos é um diferencial por meio do qual tento mostrar aspectos da estrutura que são tomados como garantidos e naturalizados e, por meio disso, demonstro que a construção social é um efeito político com base na lógica laclauniana (Jørgensen \& Phillips, 2002).

Apesar de serem os membros do board os responsáveis pela votação das normas, a condução do processo normativo é amplamente realizada pelos membros do staff técnico do IASB. Sua relevância está no fato de serem os membros desse staff que realizam as minutas para votação, as respostas aos passos de consulta, a condução das reuniões públicas e diversas outras etapas formais que devem ser observadas de acordo com o due process. Ao investigar esses documentos que representam uma peça-chave na criação das normas, analiso o processo normativo, porém sob uma ótica distinta da mais usual (Hoffmann, 2011; Howieson, 2009; Morley, 2016; Pelger \& Spieß, 2017; Young, 1994, 1996), ou seja, com foco no que é produzido por esse staff.

Por fim, a escolha desse processo específico se deu tanto pela necessidade para a análise da teoria do discurso quanto pela complexidade do projeto e pela gama de atores envolvidos. Essa diversidade levou a várias propostas de mudanças normativas e, muitas vezes, controvérsias argumentativas (Madsen, 2013). Esse fato acaba por ameaçar a real independência, pondo em cheque a qualidade processual do board (Martinez-Diaz, 2005). As mudanças normativas, portanto, servem como combustível para essa discussão, uma vez que podem ser questionadas se realmente ocorreram de forma a garantir a "melhor opção técnica" ou a satisfazer algum ator envolvido ou até mesmo a convergência. O processo de leasing, por ter passado por todas as etapas normativas com mudanças e, inclusive, duas emissões de exposure drafts, torna-se um bom teste da aplicação dos princípios do due process handbook. 
1.4 Contribuições Esperadas e Breve Apresentação dos Resultados

Uma situação discursiva (ou processo normativo) ideal é algo utópico e de impossível consolidação ao percebermos a amplitude de atores envolvidos e as diferentes esferas de poder (Roslender, 2006). Entretanto, podemos colaborar por meio da criação de frameworks e argumentos que nos mostrem o quão distantes estamos do ideal. Podemos, assim, diminuir o gap entre as práticas atuais e o ideal utópico (Broadbent, 1998) ao tornarmos as práticas mais visíveis e compreensíveis (Gallhofer \& Haslam, 1997, 2003).

Portanto, entendo não haver transparência absoluta nem comunicação perfeita nem verdades universais. Se observarmos bem, esses são os três princípios que norteiam o processo normativo do IASB, que seriam, em um paralelo, com a transparência, a consulta completa e justa e a accountability (IFRS Foundation, 2016b). Ao desenvolver a análise, esses formarão um dos pilares de análise e desconstrução do processo normativo realizada nesta tese.

Com base nessa visão e no objetivo da tese, criei um ferramental de análise do processo de arrendamentos baseado nos passos da LEC (Glynos \& Howarth, 2007): problematização; lógicas; articulação; julgamentos; e críticas. Munido com essa estrutura analítica, viso a explicar como se dá, sob uma ótica distinta da tradicional, a condução do processo e, com base nisso, construo as críticas que demonstram as (in)consistências e (in)completudes na aplicação dos princípios que norteiam o processo normativo do IASB.

A problematização gira em torno da dualidade técnico-política (retoricamente construída) do processo normativo em geral. Digo retoricamente porque no ambiente da normatização contábil internacional há sempre um discurso que contrasta as decisões técnicas como sendo de qualidade e as decisões políticas como sendo enviesadas e que priorizam alguma população. Essa dualidade, na visão ontológica aplicada nesta tese, nada mais é que uma ferramenta de diminuição da política (impureza) e de defesa de uma qualidade advinda da técnica (purificação), sendo esta técnica comumente associada a uma objetividade ilusória.

Com base nessa problematização, descrevo o processo amparando-me nas seguintes lógicas articuladas por meio das análises da dualidade já citada: (i) lógicas sociais (lógica da financialização; lógica da independência/atomização; lógica das boas práticas; lógica dos constituintes; lógica da expertise); (ii) lógicas políticas (discurso da essência sobre a forma; discurso da necessidade de mudança; discurso da capitalização; discurso do modelo único; discurso da simetria); (iii) lógicas fantasmáticas (fantasia da qualidade da norma; fantasia da tecnicidade; fantasia da comparabilidade; fantasia da globalização; fantasia da justiça processual). Por meio da identificação dessas lógicas, apresento principal teorização social 
substantiva desta tese, que é exatamente a leitura do processo normativo do board com base em lógicas até então silenciadas.

Após a visualização dessas lógicas como forma de explicar a dualidade técnico-política construída no discurso do processo normativo de qualidade do IASB, as articulações, os julgamentos e as críticas ficam a cargo de um framework que funciona como auxiliador no processo de encontrar e entender as (in)consistências nos discursos e as (in)completudes na aplicação do processo. Esse framework baseia-se em dois grandes grupos de análises: $(i)$ princípios do due process (transparência, consulta completa e justa; e accountability); (ii) pilares do processo (atores envolvidos; processo organizacional; e conteúdo da norma).

A construção do framework foi amparada nos conceitos teóricos, epistemológicos e metodológicos já apresentados e o objetivo é que sirva como uma ferramenta contributiva para a análise da aplicação dos princípios do handbook sobre os mais diversos processos normativos na contabilidade. A partir disso, a relação entre os grupos de análise do framework me possibilita realizar questionamentos que trazem críticas relacionadas com o objetivo da tese. Essas críticas demonstram limitações do processo e a retórica da aplicação dos princípios com o objetivo de criar discursos de neutralidade.

Contribuo, então, ao apresentar e discutir as principais propostas normativas, suas características e seus processos de elaboração normativa tendo como base a demonstração das (in)consistências discursivas presentes na prática do normatizador, sob um enfoque pósestruturalista. É esta visão crítica que nos permite compreender os fenômenos de forma diferente do quadro desenhado por meio do positivismo e em pesquisas quantitativas. Dessa forma, consigo demonstrar como o discurso do normatizador não se fundamenta em critérios estritamente técnicos e como a presença de questões políticas e a não aplicação dos princípios do processo normativo influenciam o conteúdo das normas editadas.

Assim como em Young e Oakes (2009), este trabalho também contribui ao oferecer novas maneiras de pensar acerca dos conceitos e ideias que já percebemos de forma natural e sem questionamentos (por exemplo, que as normas são elaboradas por meio de um processo normativo justo, técnico e neutro). Repensar tais conceitos e suas aplicações auxilia na compreensão mais abrangente dos fenômenos contábeis relacionados com a normatização, principalmente ao se entender este processo como político, que envolve diferentes atores, interesses, conteúdos e processos organizacionais.

A descrição do processo normativo internacional possui especial contribuição para o cenário nacional. Nos países que adotam as IFRSs, embora haja discussões sobre seus processos 
internos de adoção e sobre o conteúdo das normas, é comum que se aceite sem ressalvas o processo normativo internacional, atentando-se apenas ao documento final (norma final, IFRS).

Essa discussão do processo normativo do IASB por uma pesquisa nacional abre portas para o interesse sobre a internalização de normas contábeis. Estamos, como participantes de uma normatização nacional/internacional, aceitando como dado e legítimo um processo que pode ser alvo de críticas e, como consequência, deixamos de avaliar tal processo e as discussões que nele ocorreram. Com a baixa participação de brasileiros no processo internacional, acabamos por nos tornar um público diretamente afetado pelos silenciamentos produzidos pela norma internacional, pois não conhecemos o que realmente houve nas decisões.

Argumento que a contribuição vem exatamente do conhecimento do processo. Para compreendermos os fenômenos, devemos conhecer suas histórias; como as decisões foram tomadas e as opções que estavam em jogo. Isso nos permite conhecer a lógica dos cenários e nos tornarmos agentes ativos do processo. Apenas receber informações prontas sem a efetiva vivência do processo nos transforma apenas em atores passivos, meramente aplicadores das normas.

Por fim, vejo que a construção desse ferramental de análise do processo (lógicas e framework) contribui ao auxiliar a literatura por meio de uma teorização substantiva que pode ser utilizada na operacionalização de outras pesquisas. Essa teorização das lógicas e a aplicação do framework aqui construído podem ser reproduzidas por pesquisas futuras que visem a analisar outros processos normativos políticos, tanto na contabilidade como fora dela. Isso auxilia de forma a prover uma trilha que permite que esse problema de pesquisa seja analisado por outros pesquisadores em outras normas. Para exemplificar objetivamente, as lógicas elencadas e o framework de análise criados nesta tese podem auxiliar eventuais investigações da seguinte forma: o discurso formal do IASB, enquanto guia expresso do processo de elaboração de normas, realmente se fez presente de forma empírica em suas práticas?

A contribuição, portanto, circula em torno de trazer mais informações (sheds light) que auxiliam na compreensão de como se dá o processo normativo internacional, por meio da discussão de silenciamentos e abordagens alternativas à aplicação dos princípios (Young \& Oakes, 2009), uma vez que o conhecimento geral se volta mais para as normas finais já editadas (Pelger, 2016; Shortridge \& Smith, 2009). Assim, posso dizer que esta tese contribui para diferentes frentes de literatura. Uma delas é para a contabilidade financeira, que há anos discute sobre os melhores critérios para reconhecimento, mensuração e apresentação das operações de arrendamento nos diversos contextos mundiais (Barth, 2006; Barth \& Schipper, 2008). 
Contudo, será que esses critérios realmente são neutros e "representam fielmente" a dita informação contábil?

\subsection{Estrutura da Tese}

Inicialmente, como já pôde ser observado nesta introdução, gostaria de esclarecer que a tese está escrita em primeira pessoa, principalmente por entender ser essa a forma mais adequada de escrita para um trabalho que se ampara no paradigma pós-estruturalista (Burke, 2012). Em alguns momentos, a escrita se dá na primeira pessoa do singular, em que apresento a minha opinião direta como autor. Em outros momentos, na primeira pessoa do plural. Quando escrevo no plural, não demonstro uma opinião de dois sujeitos específicos, mas sim um convite ao diálogo por toda a tese. Isso quer dizer que não há um "eu" e um "você" claramente delineados. Há um "nós" que corresponde a um diálogo participativo com qualquer sujeito que se encontra no papel de leitor deste trabalho.

Já com relação à estrutura das seções, busquei amparo em Crotty (1998). O autor sugere que a pesquisa em ciências sociais apresente os seguintes elementos: epistemologia, perspectiva teórica, metodologia e métodos, sendo que a categoria anterior sempre informará a categoria seguinte. Além disso, com base em Baker e Bettner (1997, p. 306), ao pesquisador dá-se "o direito de avaliar sua visão sobre o mundo social, definir sua posição epistemológica, e selecionar uma abordagem metodológica consistente com sua visão social e base epistemológica".

Em alguns momentos sei que peco pelo excesso de informações na apresentação e nas justificativas das escolhas da pesquisa, mas por adentrar em um paradigma incomum na área contábil, entendo ser útil a discussão mais pormenorizada de conceitos gerais, sejam eles teóricos, ontológicos, epistemológicos ou metodológicos. Sigo a premissa de que "devemos ser o mais explícito possível acerca dos parâmetros sociológicos, éticos, e normativos da nossa análise crítica" (Glynos \& Howarth, 2007, p. 163). Não por presunção, mas espero que esse maior detalhamento das informações auxilie outros pesquisadores na compreensão de conceitos e lógicas que, por não serem comuns em nossos dia a dia, muitas vezes não são simples para nós.

Portanto, após a apresentação da introdução, sigo com as seguintes seções:

- Seção 2: Nesta seção realizo uma revisão da literatura, incluindo uma discussão preliminar do processo normativo do IASB, das estratégias de normatização, das 
pesquisas em regulação contábil sob o paradigma pós-estruturalista e da literatura de arrendamentos.

- Seção 3: A visão epistemológica funciona como uma seção explicativa da minha visão como autor sobre o processo de pesquisa, sobre o conceito de verdade científica nesta pesquisa e uma breve discussão da reflexividade.

- Seção 4: Inicio o referencial teórico e conceitual por meio da discussão da minha visão ontológica e sua aplicação à teoria do discurso. Além disso, realizo a discussão de conceitos específicos desta teoria que são importantes para a compreensão dos resultados.

- Seção 5: Na parte referente a estratégia e visões metodológicas discuto as principais premissas, atitudes e escolhas que tomei na condução da pesquisa, como: a opção pelo caso de arrendamentos, os documentos analisados e as limitações e validade da pesquisa. Ainda nesta seção discuto uma estratégia aplicada à análise da teoria do discurso, que é a Lógica da explicação Crítica de Glynos e Howarth (2007), e construo a base conceitual do framework de análise do processo.

- Seção 6: Já nas discussões, inicialmente faço uma narrativa do processo específico que foi analisado (IFRS 16). A análise e narrativa do contexto analisado encontra-se em resultados, já que nessa epistemologia toda a narrativa "técnica" se mistura com a análise e os pressupostos ontológicos da teoria do discurso (Laclau \& Mouffe, 1985). Após isso, sigo a LEC, com apresentação da problematização; das lógicas na normatização contábil; e da articulação, julgamentos e críticas ao processo aplicados aos principais cenários de mudança da norma. Por fim, realizo a análise aplicada do framework, em que apresento o modelo geral de análise e a discussão da limitação dos princípios do handbook frente às categorias do processo normativo de arrendamentos conduzido pelo IASB.

- Seção 7: Por fim, nesta seção apresento as considerações finais da pesquisa.

- Apêndice A: Neste apêndice apresento as propostas de lançamentos contábeis para cada modelo normativo discutido no projeto de arrendamentos, na visão tanto da arrendadora quanto da arrendatária. A partir disso, há a possibilidade de compreender melhor os possíveis efeitos contábeis de cada modelo.

- Apêndice B: Neste apêndice apresento a relação dos documentos que compuseram o processo normativo de arrendamentos e estão à disposição no sítio do IASB. 
- Apêndice C: Neste apêndice apresento, de forma simplificada e condensada, a descrição central que caracteriza cada uma das lógicas (sociais, políticas e fantasmáticas) integrantes da teorização desta tese. Com isso, é possível observar, em um só lugar, os conceitos que amparam a teorização do trabalho.

Por fim, ressalto que o uso de palavras entre aspas, sem que representem citações diretas, é feito recorrentemente na tese. Seu objetivo é dar destaque para aquela palavra/conceito quando utilizado de forma retórica ou não alusivo diretamente ao significado literal daquela palavra. Funciona como uma espécie de ironia quanto ao uso de determinados discursos nos contextos do IASB. 


\section{REVISÃO DO PROCESSO NORMATIVO E DA LITERATURA EM REGULAÇÃO}

Um dos objetivos da pesquisa crítica é o de desmistificar a formação discursiva, de forma a possibilitar que o ator possa participar de forma mais completa em um processo de decisões e não que seja induzido a cooperar como agente passivo em uma situação discursiva “ideal” para o tomador de decisões (Roslender, 2006).

Entre esses discursos, discutirei um que possui similaridades com aquele que defende que entes e organizações "mais desenvolvidas" possuem mais expertise e, por consequência, maior responsabilidade para regular a contabilidade internacionalmente, de modo que, com base em seus conhecimentos técnicos e de estruturas "desenvolvidas" de mercado, poderão colaborar com o desenvolvimento de entes menos desenvolvidos (Shafer \& Gendron, 2005; Warren et al., 2019). Para defender tal discurso, utilizam-se outros discursos correlatos.

Diversos são os discursos que compõem a normatização contábil, como o de convergência (Bach \& Newman, 2010; Baudot, 2014; Chua \& Taylor, 2008; De Lange \& Howieson, 2006; Hughes, Larson, Sander, \& Xiques, 2017), comparabilidade (Durocher \& Gendron, 2011; Homero Junior, 2018), globalização (Ball, 2016; Barth, 2006; Eaton \& Porter, 2008; Porter, 2005; Simmons, 2001) e qualidade (Madsen, 2013; A. J. Richardson \& Eberlein, 2011; Street, 2006; Zeff, 2002).

Devemos levar em consideração, porém, que há compreensões diferentes do contexto desses discursos. Por um lado, defende-se maior acesso de países emergentes a tecnologias e meios de produção, por outro, também aumenta a desigualdade por meio de oportunidades também assimétricas de poder (Hopper et al., 2017; Martell, 2016).

Para isso, nas próximas seções discutirei os principais temas que influenciam e são alvos de pesquisas na área de normatização contábil internacional, com foco nas principais estratégias para que a área seja regulada por um normatizador hegemônico.

\subsection{Processo Normativo Contábil}

Desde antes da existência do IASB já se discutiam questões relacionadas à necessidade de regulação contábil (nacional e internacionalmente) e à influência da política nesse processo (Walker \& Robinson, 1993). Hopwood e Miller (1994), por exemplo, já questionavam o discurso de normatização internacional. 


\begin{abstract}
[...] nosso entendimento de muitos aspectos-chave da contabilidade internacional é mais rudimentar do que muita gente pensa e do que alguns gostariam que acreditássemos. O processo de institucionalização na área é pobremente compreendido. [...]. Para quem está de fora, pouco se sabe sobre a política complexa e instável que permeia a área. O que se sabe é um discurso oficial de normatização e seus benefícios, cujo status geralmente é dado como certo e não sistematicamente explorado (Hopwood \& Miller, 1994, pp. 250-251).
\end{abstract}

Com um pensamento anterior, Laughlin e Puxty (1983) problematizaram sobre a viabilidade de um processo de normatização contábil político em consonância com a existência de uma estrutura conceitual fixa e baseada em princípios. Para os autores, aliar os dois conceitos seria algo utópico e impossível e, portanto, defendem a inexistência de uma estrutura conceitual e a aceitação da condução do processo de forma explicitamente política (Laughlin \& Puxty, 1983).

Apesar de eu discordar do posicionamento de Laughlin e Puxty (1983), que defendem estratégias políticas para se atingir consensos fixos e duradouros na contabilidade - algo que pessoalmente julgo inviável e desconexo com a teoria do discurso e o conceito de contingência explorado por Laclau e Mouffe (1985) -, os autores apresentam, já nas décadas de 1980/90, posicionamentos acerca: da necessidade ou não de regulação; da inconsistência de um projeto dito como técnico em vez de político; da incoerência do objetivo de "utilidade da informação para decisão" (decision-usufulness); da inconsistência da visão de quem são os usuários da contabilidade; da justificativa do processo contábil com base econômica; da ausência de estudos que analisam a contabilidade internacional com uma visão mais social; e dos atores envolvidos (Hopwood \& Miller, 1994; Laughlin \& Puxty, 1983).

Essas discussões estão em consonância com outros autores que, antes mesmo desses estudos, defendiam não só que o processo deveria ser político, mas também que a política seria a única forma possível para definir o conteúdo da normatização contábil (Hope, 1979). Já nesses artigos, havia uma dicotomia entre técnico e político, além da defesa da normatização contábil como política (Gerboth, 1972). Entretanto, o que os autores consideram como política, naquele caso, seria a condução da normatização contábil por esferas intrinsecamente políticas (deputados e senadores - congressmen), já que a contabilidade seria uma necessidade (bem) pública(o) para informação. Assim, dever-se-ia respeitar a democracia representativa dos países, que possuiriam soberania sobre o processo normativo (Laughlin \& Puxty, 1983).

Apesar da antiguidade e da vasta quantidade de estudos sobre contabilidade internacional, os assuntos levantados por Gerboth (1972), Hope (1979), Laughlin e Puxty (1983) e Hopwood e Miller (1994) são explorados até os dias atuais (Allini, Aria, Macchioni, \& Zagaria, 2018; Baudot, 2018; Botzem, 2012; Camfferman \& Zeff, 2018; Erb \& Pelger, 2015; 
Gipper et al., 2013; Islam, Khan, Hughes, \& Ali, 2018; Mehrpouya \& Salles-Djelic, 2019; Pelger \& Spieß, 2017; Young, 2006, 2014, 2003; Zhang, 2014).

Para esta tese, o importante dessa contestação é a visão dicotômica e oposta dos conceitos de técnica e política, ponto este que acompanha as discussões sobre a normatização contábil até os dias atuais e representa uma das principais estratégias para aceitação dos normatizadores americano/FASB (Financial Accounting Standards Board) e internacional/IASB (Young, 2014), como argumentarei nas próximas subseções.

\subsubsection{IASB, Processo Normativo e Documentos Emitidos}

Organizações transnacionais, assim como o IASB, são vistas pela teoria como os novos agentes do mercado, sendo que já possuem seu espaço nos diversos ambientes, como na política, nos direitos humanos, na economia, na regulação ambiental e na imprensa, entre outros (Risse, 2013). Suas formas de estrutura são estudadas de modo que a governança dessas organizações privadas tende a levar como preceitos características presentes na estrutura do IASB, como autorregulação privada, adoção pública das regulações privadas e consulta e participação pública.

As organizações transnacionais funcionam como "interações regulares além das fronteiras nacionais quando ao menos um ator é um agente privado não estatal", sendo esse conceito naturalmente derivado do advento da globalização (Nye \& Keohane, 1971; Risse, 2013). Diversas são as frentes de pesquisa que podem envolver a regulação contábil e os órgãos (transnacionais) que a conduzem. Considerando que a normatização contábil internacional ocorre por meio de soft-law (Botzem, 2012; Chiapello \& Medjad, 2009; Wingard et al., 2016), as pesquisas, em sua maioria empíricas (Gipper et al., 2013), podem e são realizadas com os objetivos de: arguir sobre a posição dos órgãos internacionais que conduzem o processo de regulação (Botzem, 2014; Dye \& Sunder, 2001; Pelger, 2016; Street, 2006), teorizar sobre o seu funcionamento (Black, 2008; McGregor, 2012; Pelger \& Spieß, 2017; Zeff, 2012), criticar os conteúdos desenvolvidos (Kabir \& Rahman, 2018; Whittington, 2008), analisar a independência dos órgãos (Camfferman \& Zeff, 2018; Danjou \& Walton, 2012; Eaton, 2005; Hewa, Mala, \& Chen, 2018; Zeff, 2002) e aferir acerca da qualidade das normas editadas (Biondi et al., 2011, 2012), entre outros.

Para Risse (2013), devido ao crescente número de estudos dessas organizações, podese dizer que essas teorias já fazem parte de uma "ciência (política) normal", nos preceitos de Kuhn (1996), havendo espaço para estudos de diversas naturezas. Slaughter (2004) demonstra 
que essas organizações mostram uma visão moderna de "ordem mundial desagregada" na qual, em decorrência da complexidade social atual, as hierarquias perderam poder e o "trabalho em rede" se tornou dominante para a conexão entre indivíduos e grupos da sociedade. A autora demonstra a própria contabilidade e a regulação de mercados como exemplos dessa atividade.

Especificamente com relação ao processo normativo, mesmo sendo um tema de complexidade por envolver um órgão transnacional (Black, 2008; Botzem, 2012; Dingwerth, 2007; Graz \& Nölke, 2008) e um cenário internacional com diversas especificidades (Georgiou, 2010; A. J. Richardson \& Eberlein, 2011; Zhang, 2014), pesquisas são realizadas com a finalidade de avaliar tópicos como: os processos normativos locais (Homero Junior, 2018; Königsgruber, 2010; Zhang, 2014), a participação e a origem de usuários no processo normativo (Georgiou, 2010; Larson \& Herz, 2013), as etapas específicas do processo (Holder, Karim, Lin, \& Woods, 2013; Pelger \& Spieß, 2017; Weetman, 2001), os projetos específicos (Baudot, 2018; Hughes et al., 2017; Ram \& Newberry, 2013), a qualidade geral das decisões tomadas (Madsen, 2013; P. F. Williams \& Ravenscroft, 2015), os grupos de interesse (Carmo, 2014; Chua \& Taylor, 2008; Hewa et al., 2018; Larson \& Herz, 2013) e as atividades de lobbying (Georgiou, 2004; Hansen, 2011; Hoffmann \& Zülch, 2014; Morley, 2016; Orens, Jorissen, Lybaert, \& Van Der Tas, 2011; Zeff, 2002), entre outros.

Apesar da vastidão de temas que podem ser pesquisados acerca do processo normativo contábil internacional, a ampla maioria das pesquisas incorpora, direta ou indiretamente, aspectos relacionados com a legitimidade do IASB como normatizador (Black, 2008; Chua \& Taylor, 2008; Pelger \& Spieß, 2017; A. J. Richardson \& Eberlein, 2011). Diversos são os tipos de legitimidade e as visões desse conceito que podem ser empregadas, porém a maioria segue por uma discussão normatizadora em que a legitimidade se assemelha ao conceito de aceitação e vê como principal estratégia o poder de argumentação do board internacional (Dingwerth, 2007; A. J. Richardson \& Eberlein, 2011).

Essa visão da legitimidade, ainda que não expressada nos estudos, é a mais presente nas pesquisas atuais que analisam o processo normativo e está em consonância com o pensamento de que os normatizadores contábeis são tomadores de decisão racionais que buscam a maximização econômica das transações (Watts, 1977; Watts \& Zimmerman, 1978, 1979) e, em sua maioria, empregam teorias de cunho positivista de análise de lobbying, como a de Sutton (1984) (Gipper et al., 2013; Pelger, 2016; Pelger \& Spieß, 2017).

Considerando que a legitimidade (no sentido de aceitação e credibilidade) ainda é um ponto discutido, podemos dizer que há uma vasta gama de possibilidades de pesquisa, sob os 
mais diversos paradigmas, de forma a auxiliar na compreensão desse fenômeno para a contabilidade. Na presente tese, por exemplo, não vejo o board como sendo neutro e formal, como a maioria das pesquisas positivistas. Para mim, o board foi considerado como um elemento intrinsecamente político em seu processo normativo, sendo a pesquisa mais relacionada com a credibilidade em um sentido processual (Botzem, 2012; Dingwerth, 2007; Pelger \& Spieß, 2017; A. J. Richardson \& Eberlein, 2011).

Para isso, irei apresentar, inicialmente, aspectos da estrutura e da organização geral do IASB e como se dá a consecução do processo normativo internacional. Em seguida, discutirei as pesquisas que estão relacionadas com cada uma das etapas desse processo.

\subsubsection{O IASB}

O processo normativo contábil internacional é conduzido, principalmente, pelo IASB. Sua história de emergência como normatizador, desde os tempos do IASC (International Accounting Standards Committee), já foi amplamente discutida em pesquisas de naturezas científica e histórica, assim como sua estrutura organizacional e financeira (Botzem \& Quack, 2009; Camfferman \& Zeff, 2006). Portanto, realizarei uma breve revisão dos aspectos mais relacionados com a presente tese.

A IFRS Foundation, conforme ela se descreve, é uma organização internacional independente, sem fins lucrativos, que opera para servir o interesse público (IFRS Foundation, 2015). Foi criada com o objetivo de desenvolver normas de alta qualidade, compreensíveis, executáveis (enforceable) e aceitas mundialmente, além de promover a adoção dessas normas (IFRS Foundation, 2018b). Para tanto, a organização é estruturada em três pilares (IFRS Foundation, 2018b):

(i) Accountability pública: formado pelo "Conselho de Monitoramento", que tem como responsabilidade realizar a interface entre os conselheiros e as autoridades públicas do mercado financeiro;

(ii) Governança: composto pelo “Conselho Curador”, responsável pela supervisão do IASB, da sua constituição e do seu due process;

(iii) Normatização independente: composto pelo IASB, com a função de elaboração da normatização contábil de forma independente, e pelo IFRIC (IFRS Interpretations Committee), que deve garantir a aplicação das normas emitidas (IFRSs). 
Com base nesses pilares, o IASB e o IFRIC se localizam no pilar de "normatização independente". O IASB e os órgãos correlatos se "vendem" por meio do discurso de que são baseados em expertise técnica e independente e, por isso, emitem normas de alta qualidade (Botzem, 2008, 2014; Botzem \& Quack, 2009; Dillard \& Ruchala, 2005; Madsen, 2013; Martinez-Diaz, 2005; Pelger \& Spieß, 2017; Warren et al., 2019; Young \& Williams, 2010), sendo essa uma tarefa característica de normatizadores transnacionais (Dingwerth, 2007).

Diversos são os princípios que envolvem a estrutura como um todo do IASB. Na Figura 1 apresento os objetivos e a missão do IASB, assim como os princípios do handbook, já que estes são os que se referem ao principal produto do órgão, a emissão das IFRSs.

Figura 1 - Objetivos, missão e princípios da IFRS Foundation e do Due process Handbook

\begin{tabular}{|l|l|}
\hline Objetivos & $\begin{array}{l}\text { - Desenvolver normas de alta qualidade, compreensíveis, executáveis e aceitas mundialmente; } \\
\text { - Promover o uso e a aplicação rigorosa dessas normas; } \\
\text { - Cuidar das necessidades, na normatização, das entidades dos diversos tipos, tamanhos e } \\
\text { ambientes econômicos; } \\
\text { - Promover e facilitar a adoção dessas normas por meio do processo de convergência. }\end{array}$ \\
\hline Missão & $\begin{array}{l}\text { - Promover a transparência, accountability e eficiência dos mercados financeiros por meio de } \\
\text { edição das IFRSs. } \\
\text { - O trabalho serve ao interesse público por meio da promoção da confiança, do crescimento e da } \\
\text { estabilidade de longo prazo da economia. }\end{array}$ \\
\hline Princípios & $\begin{array}{l}\text { - Transparência; } \\
\text { - Consulta completa e justa; } \\
\text { - Accountability. }\end{array}$ \\
\hline
\end{tabular}

Fonte: Elaborado pelo autor, com base em IFRS Foundation $(2016,2018)$.

Há uma preocupação em afirmar a transparência do board. No próprio documento em que se explica a estrutura do órgão há a afirmação: “O processo de desenvolvimento das normas é altamente transparente; todas as etapas envolvem consulta pública" (IFRS Foundation, 2018b, p. 4). Além disso, podemos perceber na Figura 1 (trechos com grifos pelo autor) que há palavras-chave que representam princípios (ou premissas) que podem ser avaliados por um contexto tanto subjetivo como objetivo.

Por mais diversos que sejam os objetivos, as missões e os princípios do órgão e do processo normativo, esperamos que eles apresentem certa consonância entre si, pois há interrelação entre tais conceitos. Deve-se levar em consideração que a entidade tem princípios para atingir seus objetivos e poder exercer sua missão. Entretanto, a natureza subjetiva da maior parte desses termos deixa a sua interpretação aberta, com difícil mensuração efetiva do seu nível de consonância. Imaginamos que, quando há uma descrição, haveria uma diminuição do problema de compreensão, porém inclusive nas descrições a subjetividade e a amplitude de significados continua presente. Assim, entendo que os princípios representam, na mais pura 
essência, o que é visto como significante vazio pela teoria pós-estruturalista do discurso (Laclau, 2007b; Laclau \& Mouffe, 1985).

Em decorrência dessa dualidade entre objetividade e subjetividade dos termos e da visão como significantes vazios, percebo margem para a realização de críticas e sugestões com relação ao funcionamento e à organização da entidade, principalmente se a enxergarmos como uma organização política, o que faz a teoria do discurso (Laclau \& Mouffe, 1985) aplicável. Nesse sentido, reitero aqui ser este um dos objetivos da tese, com aplicação sobre seu $d u e$ process, já que este - a institucionalização de determinado procedimento - pode ser interpretado como um mecanismo que reconcilia (parcialmente) os princípios organizacionais conflituosos (Botzem \& Quack, 2006b, 2009).

Especificamente com relação aos termos, podemos observar a aparição em dois momentos (missão e princípios): accountability e transparência. Em razão disso, certo cuidado deve ser tomado quando da leitura/argumentação desta pesquisa, pois suas conceituações são diferentes, já que, em um momento refletem o órgão (missão) e em outro refletem o processo conduzido pelo órgão (princípios).

Com relação à transparência, sua aparição na missão se refere a uma questão mais contábil, ou seja, relacionada com a missão de trazer comparabilidade e qualidade das informações financeiras (IFRS Foundation, 2018b). Já nos princípios, que são referentes ao handbook, a transparência relaciona-se com a abertura (no sentido de validação) do processo aos interessados (IFRS Foundation, 2016b).

A accountability, quando relacionada com a missão, refere-se ao fato de que o órgão procura diminuir a lacuna informacional entre provedores e tomadores de capital, ou seja, entre participantes do mercado de capitais (IFRS Foundation, 2018b). Quando citada nos princípios, refere-se ao fato de que o órgão procura analisar os diversos efeitos da norma e explicar os racionais para as decisões tomadas (IFRS Foundation, 2016b).

Por mais que os conceitos apresentados na Figura 1 estejam presentes em documentos formais, encontram-se outras formas de descrição, tanto da missão quanto dos objetivos, em trechos dos mesmos documentos ou outros documentos também emitidos pelo órgão. Por exemplo, na apresentação do handbook, fala-se em missão de prover uma "representação fiel" (que também é uma característica qualitativa da informação contábil), "transparência" e "integridade" das demonstrações financeiras. Além disso, afirma-se, ainda, que o cumprimento do objetivo se dá por meio de "princípios claramente articulados" (IFRS Foundation, 2016b, p. 4). 
Com relação à missão, percebe-se certa ambição do órgão, trazendo como missão servir ao interesse público, por meio da confiança, do crescimento e da estabilidade da economia. Discussões aqui podem ser levantadas com relação à função da contabilidade e do seu contexto social, assim como a utilização de conceitos retóricos para garantia de aceitação (Durocher \& Gendron, 2011; A. J. Richardson \& Eberlein, 2011; Young, 2003). Porém, para manter o foco nos objetivos do presente estudo, procurarei descrever e discutir os princípios efetivos do handbook, que, em teoria, são aqueles diretamente levados em consideração para a condução dos processos de edição de normas pelo IASB.

Para tanto, iniciarei a discussão com a explicação do processo normativo em geral. Procurando atingir o objetivo de normas de alta qualidade, o board argumenta que se espelha em um processo normativo neutro, formal e justo (Dingwerth, 2007). Com base nesse entendimento, o processo foi desenvolvido de forma a criar quatro programas, compostos estes por seis principais etapas, conforme apresentado na Figura 2.

Figura 2 - Processo normativo do IASB

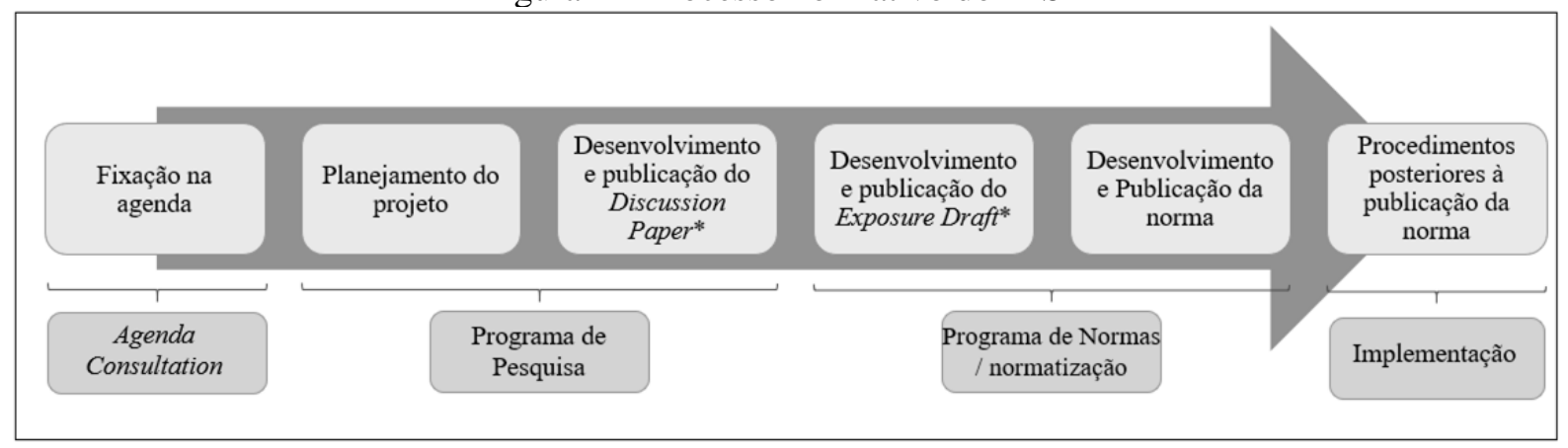

Fonte: Elaborado pelo autor, com base em IFRS Foundation (2016).

* Inclui etapa de consulta pública.

Quatro são os programas de edição de normas, nesta ordem: (i) a agenda consultation, (ii) o programa de pesquisa, (iii) o programa de normas/normatização; e (iv) o programa de implementação e manutenção. Esses programas são divididos em seis principais etapas formais, que são as de desenvolvimento de uma norma propriamente dita.

\subsubsection{Agenda Consultation}

O primeiro programa - "agenda consultation" - possui apenas uma etapa formal, a fixação na agenda: a primeira etapa da condução de um processo que culminará em uma IFRS. Nesse momento, o IASB decide sobre os assuntos e os temas que devem fazer parte do próximo 
programa: o de pesquisa. Para auxiliar nesse processo, o staff técnico identifica, revisa e levanta os pontos que devem ser levados à atenção do órgão, tendo como premissa verificar se o tema está em consonância com a necessidade dos usuários e os custos de tais mudanças no que concerne aos relatórios contábeis (IFRS Foundation, 2016b).

Devemos entender que o processo de formação da agenda é a porta de entrada (ou a barreira de segurança) para a discussão futura sobre determinados temas. Nesse momento, não se decide apenas se tal tema será ou não debatido, mas também são discutidas questões sobre a amplitude do escopo, ponto este que guiará as discussões futuras do board (Gipper et al., 2013). Não é apenas um fator que influencia na entrada, mas um emaranhado de fatores, atores e interesses (Ram \& Newberry, 2017).

Após a modificação do handbook em 2013, essa etapa passou, formalmente, a contar com participação pública. Agora a cada cinco anos o board se propõe a consultar o público para que este possa auxiliar na identificação dos principais temas e questões contábeis que podem ser de interesse do órgão para normatização. Apesar da existência dessa consulta, o handbook não esclarece até que ponto as sugestões são ou não acatadas, apenas deixando a entender que as sugestões são avaliadas com base nos critérios para a fixação de um tema na agenda, que são: (i) existência de problemas contábeis em algum tipo de transação ou evento; (ii) importância do tema para os usuários; (iii) entidades e jurisdições que serão impactadas pela proposta e; (iv) como o tema impactará os relatórios financeiros (IFRS Foundation, 2016b).

Há pesquisas que buscam entender a entrada de itens no processo normativo dos reguladores em contabilidade, em especial FASB e IASB (Dick \& Walton, 2007; Gipper et al., 2013; Pelger \& Spieß, 2017; Ram \& Newberry, 2017), porém ainda é considerada uma área que necessita de maiores esclarecimentos e entendimentos (Barth, 2006; Camfferman \& Zeff, 2018; Howieson, 2009; Pelger \& Spieß, 2017; Weetman, 2001; Young, 2014). Atualmente, o IASB informa que a entrada na agenda do órgão se dá mediante solicitações dos constituintes (IFRS Foundation, 2016b), mas como verificar se isso ocorre de fato considerando os diversos atores que fazem parte de um processo democrático?

Por ser uma etapa inicial e com critérios subjetivos de avaliação, Sutton (1984) e Georgiou (2010) afirmam ser esta a etapa mais suscetível a ações políticas de intervenção no processo, como, por exemplo, o lobbying. Para os autores, esta etapa tende a ter maior presença de atores interessados na normatização, que podem ter como finalidade travar (acelerar) a entrada de projetos indesejados (desejados). Além disso, há evidências de que o board prioriza o andamento de determinados projetos em detrimento de outros, focando, normalmente, em 
processos mais recentes que envolvem atores mais poderosos, seja esse poder advindo de aspectos empresariais, geográficos ou financeiros (Dick \& Walton, 2007; Hallström, 2004).

Em complemento, Perry e Nöelke (2005) identificam que os participantes mais ativos nesse início de processo são os normatizadores locais (nacionais), alguns órgãos e associações profissionais e as maiores empresas de auditoria (Big four). Os autores ainda descrevem o poder existente das instituições financeiras nas decisões iniciais do IASB e a falta de presença de entidades sindicais ou qualquer entidade que represente os interesses sociais, ou seja, identificam que há disparidade entre a participação de interessados e a forma como essas participações são tratadas (Pelger \& Spieß, 2017).

Também podemos observar argumentos em torno da participação da academia e a sua força para a formação de agendas para os normatizadores (Álvarez, Calvo, \& Mora, 2014; Barth, 2006; Camfferman \& Zeff, 2018; Gillis, Petty, \& Suddaby, 2014; Larson \& Herz, 2011; Tandy \& Wilburn, 1996). Contudo, não se sabe até que ponto o board está realmente interessado na contribuição acadêmica para a formação das agendas. Apesar de haver solicitação de participação dessa comunidade, ainda se observa que a agenda de regulação "definitivamente influencia a pesquisa acadêmica, porém a literatura contábil não parece representar um pilar para o desenvolvimento das IFRSs" (Michele et al., 2016, p. 77)

Com base em uma análise de legitimidade do processo específico de agenda consultation, Pelger e Spieß (2017) também analisam a forma como os atores são convocados a participar e como evoluem, na prática, suas efetivas participações e contribuições ao processo de construção da agenda do board. Os autores demonstram que o discurso de que os investidores são os principais atores do IASB e que as normas são realizadas com o intuito de suprir suas demandas é mais "formal do que substancial” (Pelger \& Spieß, 2017, p. 1) e que o processo de consulta não é objetivo como se prega, mas sim dá maior poder de discricionariedade aos membros do staff técnico e do board (Pelger, 2016).

Muito de nossa atenção se direciona aos projetos que entraram na agenda dos normatizadores, porém há também o outro lado. Se o processo da agenda envolve uma consulta, devemos entender que há sugestões e temas que não entram nessa agenda. Strange (1998) afirma que, assim como a decisão por incluir um tema na agenda, não tomar atitudes, ou seja, não incluir algum projeto na agenda, também representa uma decisão política. Isso quer dizer que tanto a inclusão como a não inclusão de algum tema na agenda do órgão podem ser interpretadas como políticas e investigadas de forma mais profunda com base em teorias da área (Howarth, 2010). 
Dahl (1958) já mostrava que qualquer análise unidimensional que envolva a tomada de decisões sobre entradas em agendas se caracteriza pela exclusão e pelo silenciamento de grupos específicos que apresentem questões que não são de interesse de quem controla o processo. Essa constatação é válida até os dias atuais em processos ditos como democráticos, pois o grupo que detém o poder naquele ambiente têm o controle para moldar opiniões e preferências dos demais para transparecer que houve aceitação das diversas demandas (Burke, 2012). Esse poder encontra explicação na lógica de equivalências discutida por Laclau e Mouffe (1985) e analisada em maiores detalhes no REFERENCIAL TEÓRICO.

Em resumo, o que as pesquisas demonstram com relação ao programa de agenda consultation é que esta representa uma das etapas mais importantes do processo normativo (Beresford, 1997), embora tende a não ter tanta atenção das pesquisas, sendo que muito material pode não estar sendo utilizado, já que o foco é no que teve continuidade, ou seja, em produtos finais do board (Chiapello \& Medjad, 2009). Apesar de ser uma carência, essa ausência de pesquisas é compreensível, uma vez que um dos impedimentos para investigações científicas acerca disso é que muitas das participações de atores influentes não são realizadas por meio exclusivamente de canais formais de comunicação e transparência do órgão, o que leva a uma carência de documentos para análises (Georgiou, 2002, 2010). Entretanto, uma das possíveis estratégias de análise desse processo é por meio de narrativas construídas com base em entrevistas (Ram \& Newberry, 2017).

\subsubsection{Programa de Pesquisa}

Após a fixação de determinado tema na agenda, inicia-se o "programa de pesquisa", que é dividido em duas etapas ("Planejamento do projeto" e "Desenvolvimento e publicação de um Discussion paper"). O IASB, por meio do staff técnico, tem como objetivo, durante esse programa, conduzir pesquisas (não de natureza científica) para levantar os principais problemas relacionados ao tema e desenvolver as possíveis soluções (IFRS Foundation, 2018b).

Especificamente a cada etapa no planejamento do projeto, decide-se se o projeto será realizado em parceria com outro órgão ou de forma individual. Ainda, os membros do staff técnico iniciam as pesquisas para montar uma proposta de tópicos a serem levados em consideração na elaboração da norma, tendo como resultado dessa etapa a emissão de Research papers.

Após isso, há uma etapa com participação pública formal dos usuários e interessados no projeto: o desenvolvimento de um Discussion paper. Essa etapa visa a desenvolver um 
documento que apresentará as visões preliminares do board (ou boards, caso o projeto seja conjunto) sobre determinado tema, tendo como base as discussões de possíveis abordagens contábeis realizadas na fase anterior. Após a publicação desse documento, a etapa de participação pública é refletida com um convite aos interessados para o encaminhamento de suas opiniões, por meio de perguntas pontuais sobre os tópicos em discussão, como: "Você concorda com a análise dos órgãos sobre os direitos e obrigações, e ativos e passivos que surgem de um contrato simples de leasing? Se você discorda, favor explicar o motivo" (IASB, 2009a, p. 32).

Ressalta-se que, de acordo com o handbook (IFRS Foundation, 2016b), os “Discussions Papers não possuem um Basis for Conclusions ou quaisquer opiniões dissidentes. A discussão em si deve refletir e transmitir diferenças de visões dos membros do IASB” (p. 22). Nesse sentido, podemos inferir que a afirmação citada deixa aberta ao órgão a decisão sobre a apresentação, ou não, de maiores detalhes que podem ser (ou gerar) conflitos durante o processo de edição da norma contábil, principalmente no que concerne ao apoio interno dado às propostas ali contidas.

Como essa fase envolve um trabalho burocrático e interno mais intenso, as pesquisas que se relacionam diretamente com as etapas que compõem o programa de pesquisa são mais restritas. Em sua maioria, as pesquisas são realizadas com base nos discussion papers e possuem objetivo de analisar a participação de usuários nesse processo por meio de análises de conteúdo baseadas em categorizações (Carmo, Ribeiro, \& Carvalho, 2014; Larson \& Herz, 2011).

\subsubsection{Programa de Normas/Normatização}

Após a finalização do programa de pesquisa, inicia-se o "Programa de normas/normatização", também dividido em duas etapas: "Desenvolvimento e publicação do Exposure draft" e "Desenvolvimento e publicação da norma". Nesse programa, o objetivo é que, já possuindo as informações e opiniões obtidas na fase anterior, o board emita documentos com propostas específicas e já detalhadas (IFRS Foundation, 2016b).

O primeiro momento, que consiste no desenvolvimento e na publicação do Exposure draft, resume-se à elaboração de um documento já no formato de uma norma, a fim de apresentar ao público a proposta normativa do assunto tratado. O documento é elaborado, conforme descrito no handbook (IFRS Foundation, 2016b), pelo staff técnico, amparado nos 
comentários recebidos na etapa anterior e nas sugestões de outros normatizadores e órgãos interessados. Representa o primeiro documento formal já em formato de uma norma.

Ao mesmo tempo em que se abre o documento para posicionamentos por meio de consulta pública (comment letters) e esses posicionamentos dos respondentes são aguardados, o board realiza roundtables em diversas jurisdições, também com o objetivo de somar opiniões e poder consolidar argumentos acerca de particularidades dos países. Após a análise dos comentários recebidos sobre o ED e nas roundtables, o staff técnico emite o comment letters summary que, em tese, é um documento formal emitido como meio de prestação de contas acerca das opiniões recebidas e serve para que os membros votantes do board possam embasar suas opiniões/votos sobre o projeto de norma (IFRS Foundation, 2016b).

Após isso, o board pode decidir pelo desenvolvimento e posterior publicação da norma, no caso, a IFRS; ou pelo que se chama reexposure draft. Este se refere a documento emitido quando não se chega a um consenso ou maioria, momento em que se decide pela reestruturação da proposta normativa e, por consequência, repetição da fase de exposure para comentários. Com base nesse processo, o IASB, por meio de sua constituição e formalização do processo (IFRS Foundation, 2016b), afirma que, para a emissão da norma, leva-se em consideração os principais pontos identificados nos comentários ao Exposure draft após a avaliação das evidências por parte do staff técnico (IFRS Foundation, 2016b).

Em todas as fases podemos dizer que o staff técnico trabalha de forma a conduzir o processo de forma relevante, porém nesta, que já é a definição de normas finais, esse poder é ainda mais forte, pois esse grupo técnico redige todos os documentos: tanto os que servem como base para a opinião dos membros do board como os próprios documentos votados. Ou seja, o staff é responsável tanto pelas pesquisas como pelos produtos finais. Entretanto, pouca atenção tem sido dada ao seu papel e documentos intermediários (Hoffmann, 2011; Morley, 2016; Pelger \& Spieß, 2017; Wingard et al., 2016).

Podemos dizer que são mais comuns as pesquisas que tratam dessa etapa, uma vez que esta já envolve documentos em formato de norma e os impactos positivistas, assim como críticos e políticos, já podem ser observados e discutidos. Os principais documentos analisados são as próprias normas finais e as comment letters e os estudos variam de paradigmas, métodos e objetivos. 


\subsubsection{Programa de Implementação e Manutenção}

Por fim, o último programa do processo normativo é o "Programa de implementação e manutenção", consistindo na etapa chamada de "procedimentos posteriores à publicação da norma", ou PIR (Post-Implementation Review). Esse programa consiste em um acompanhamento da norma para a identificação de possíveis pequenas alterações e na elaboração, se necessário, de interpretações que auxiliem na aplicação da norma por parte das mais diversas entidades. Além disso, nesta etapa também se realizam ações e materiais educativos; webcasts para tirar dúvidas e discutir pontos polêmicos para a aplicação da norma com a intenção de convergência; e pequenos artigos técnicos que possam auxiliar nos projetos de convergência com os normatizadores locais (IFRS Foundation, 2016b). Esse processo é conduzido pelo IFRIC, órgão ligado ao IASB por meio da estrutura da IFRS Foundation.

Como nessa fase as normas já estão prontas, esse último programa não possui grande efeito e responsabilidade pelos conteúdos normativos. Ainda assim, essa etapa tem a incumbência de fazer com que esses conteúdos tenham a "melhor" aplicação possível de acordo com as exigências normativas, principalmente por meio da emissão de interpretações.

Como esse programa ocorre de forma menos concentrada e possui menos resultados materialmente analisáveis, as pesquisas sobre essa fase também são mais restritas, porém podemos encontrar papers que tratam sobre o PIR por meio da análise: das funções do órgão; das interpretações emitidas; e da participação de atores nesse processo (Kenny \& Larson, 2009; Larson \& Herz, 2011).

A carência de pesquisas que englobam os PIR, entretanto, não significa que não há relevância no tema. Apesar de as normas já estarem publicadas, é por meio do PIR que há a possibilidade de discussões sobre problemas da aplicação da norma e, para tanto, o IFRIC também possui um due process com passos formais de emissão de pronunciamentos (Kenny \& Larson, 2009), sendo que esses passos também podem ser analisados por pesquisas científicas. Além disso, "não é claro como essas atividades ex-post podem realmente influenciar as IFRSs" (Michele et al., 2016, p. 77), levando a uma necessidade de aprofundamento de pesquisas sobre o tema. Entretanto, podemos dizer que as pesquisas que avaliam efeitos e impactos das normas podem ser base de uso para a condução dos PIRs. 


\subsubsection{Documentos Emitidos e Atores Internos}

Por ser um processo com diferentes etapas e responsabilidades, ressalto aqui a importância dos principais atores (internos) envolvidos e, também, dos documentos formais emitidos. Os principais atores que conduzem o processo normativo são os board members e o staff técnico (Botzem, 2012; Pelger, 2016). Os board members possuem como principais funções as de aprovar as normas contábeis e as interpretações. Já os participantes do staff técnico se dedicam a conduzir o processo normativo do início ao fim, participando inclusive da decisão sobre os tópicos que serão votados, ou não, pelos board members.

Diversos são os documentos formais emitidos e as ações realizadas durante um processo normativo, como os discussion papers, os exposure drafts, as IFRSs, as comment letters, os comment letters sumaries, os webcasts, as press releases e os snapshots, entre outros. Para simplificar a compreensão de quando esses documentos são emitidos e quais são os documentos utilizados em cada etapa, elaborei a Figura 3. Nela podemos observar que, ao longo do processo normativo (qualquer que seja o projeto), existem os documentos que funcionam como "base" das decisões e andamentos de determinada etapa e os documentos que são emitidos em decorrência da realização de tal etapa.

Além destes atores e documentos, existe a figura do DPOC (Due process Oversight Committee), que permeia todo o processo. O DPOC é o órgão designado pela IFRS Foundation o qual tem como responsabilidade "supervisionar os procedimentos do due process, por meio de uma operação tempestiva e que procure aprimorar, em detrimento de dificultar, a operação eficiente das atividades do IASB ou o desenvolvimento tempestivo das IFRSs" (IFRS Foundation, 2016b, p. 5). Esses órgãos de controle possuem responsabilidades com relação ao processo normativo formal, de modo a garantir o que o board chama de "melhores práticas". Ademais, normalmente são criados por meio da exigência de atores para dar mais credibilidade às normas editadas (McGregor, 2012; Samsonova-Taddei \& Humphrey, 2014). Além de acompanhar, possui como função recepcionar denúncias externas que podem ser realizadas pelos mais diversos envolvidos. Essas denúncias devem ter publicidade e ser disponibilizadas no website da IFRS Foundation (IFRS Foundation, 2016b), sendo que este não é um documento emitido diretamente pelo IASB, embora represente um documento formal que serve para análise dos processos normativos. 
Figura 3 - Documentos Base e Documentos Emitidos durante o Processo Normativo

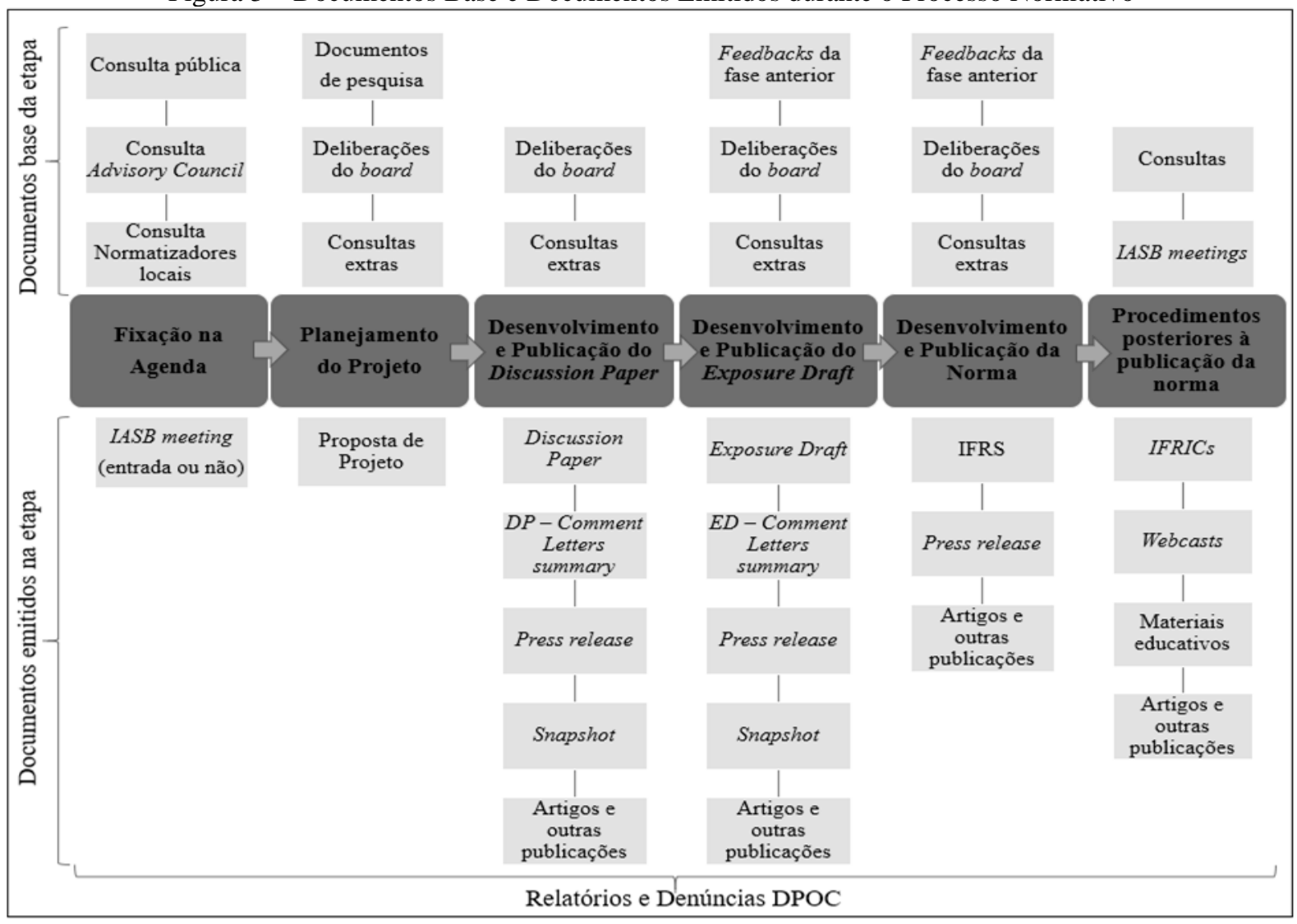

Fonte: Elaborado pelo autor, com base em IFRS Foundation (2016).

Além da responsabilidade pela condução do processo, os membros do staff técnico também são encarregados de redigir a ampla maioria dos documentos emitidos pelo IASB. Por isso, esse grupo de funcionários representa um elemento importante no direcionamento das normas, em sentido de tempo e de conteúdo (Dick \& Walton, 2007; Erb \& Pelger, 2015; Hoffmann, 2011; Mehrpouya \& Salles-Djelic, 2019; Morley, 2016; A. J. Richardson \& Eberlein, 2011; Wingard et al., 2016; Young, 2003).

O staff é visto como "o recurso central que permite ao IASB se envolver na construção da base do conhecimento que somente é trocado com as grandes empresas" (Botzem, 2014, p. 946). Até mesmo dentro do contexto dos membros do board, há discussões que reforçam que o staff possui uma função de destaque na condução do processo e das escolhas normativas, levando a questionamentos sobre o real papel desses membros como atores coadjuvantes ou principais no processo (Pelger \& Spieß, 2017).

Embora seja de conhecimento que os membros do staff técnico são responsáveis por conduzir o processo normativo, esses membros e os documentos emitidos durante o processo têm sido alvo de poucas pesquisas. Isto é, apesar da importância desse corpo técnico e de sua citação recorrente nos documentos, a maior parte das pesquisas que envolvem algum nível de 
análise política visa a analisar apenas as normas finais, os membros efetivos do board ou os documentos gerados por atores externos ao IASB (Gipper et al., 2013; Pelger, 2016). A relevância desses membros e dos documentos intermediários, portanto, representa, além de um campo menos explorado, uma gama de dados fortuita para análises políticas.

Entre esses documentos externos que são alvo de grande parte das pesquisas que envolvem aspectos políticos na regulação contábil estão as comment letters. Estes documentos representam as respostas aos passos formais de consulta pública do IASB, ou seja, são as participações explícitas dos interessados externos ao IASB, que podem ser das mais diversas origens geográficas e interesses profissionais. As pesquisas se dedicam a analisar origens, qualidade, nível de participação e cooperação, formas de participação, estratégias de argumentação e diversos outros aspectos (Bamber \& McMeeking, 2016; Comiran \& Graham, 2016; Cortese, Irvine, \& Kaidonis, 2010; Georgiou, 2004, 2010; Larson \& Herz, 2011, 2013). Já internamente, o tratamento dado a essas comment letters é realizado, mais uma vez, pelo staff técnico, responsável por elaborar documentos de feedback que resumem os posicionamentos de tais respondentes, chamados de comment letters summaries.

Esses summaries, portanto, ocorrem em resposta a uma etapa de consulta. Cabe ressaltar que essas consultas públicas envolvem, além do recebimento de cartas-comentário, as reuniões com os mais diversos atores, normatizadores e com o advisory council. Considerando que os demais documentos são padronizados (DPs, EDs, IFRSs), os summaries representam aqueles que demonstram como o trabalho do staff é feito, uma vez que as próprias cartas comentários também ficam disponíveis para conferência (Botzem \& Quack, 2009; Hoffmann, 2011).

Mesmo possuindo processos e etapas formais de consulta, pesquisas demonstram que na prática o órgão não enxerga que o processo de consulta possa trazer novas visões técnicas, mas considera essa etapa como um propósito de aumentar sua credibilidade por meio da disseminação da sua visão sobre determinado assunto (Botzem, 2012, 2014; Pelger \& Spieß, 2017).

Isso ocorre porque as ações de interessados externos influentes tendem a ocorrer fora do processo normativo formal, ou seja, não aparecem nos processos de consulta públicos que são abertos durante a elaboração das normas. Depreende-se, portanto, que as etapas em que atores externos podem participar, na realidade, não são momentos de participação efetiva no processo normativo, e sim um exercício de consulta realizado de forma a resguardar o órgão frente a críticas futuras (Botzem, 2012).

Apesar disso, podemos dizer que a maior parte das pesquisas que analisam o processo normativo e alguma forma de política nesse processo, assim como legitimidade, grupos de 
interesses e participações, utilizam como base as comment letters (Georgiou, 2002, 2004, 2010; Gipper et al., 2013; Larson \& Herz, 2013; Pelger, 2016), porém são mais restritos os estudos que olham o lado interno do board, ou seja, os documentos que são emitidos de dentro do board (Baudot, 2018; Erb \& Pelger, 2015; Hoffmann, 2011; Morley, 2016; Warren et al., 2019).

Por mais que o natural seja pensar que as estratégias de influências no processo de elaboração de normas ocorram de fora para dentro e que as instituições são blindadas pela governança para que não haja vícios internos em seus processos, há, também, lobbying e estratégias para influência que ocorrem internamente. Morley (2016) afirma, assim como penso nesta tese, que o IASB não é uma organização técnica, rígida homogênea e impenetrável, mas sim uma entidade social que possui um papel perante a sociedade e é vulnerável pelas identidades sociais internas e as que a circundam.

A melhor compreensão interna do board auxilia os agentes externos, também, em suas estratégias para a preponderância dos seus interesses, uma vez que ajuda na elaboração de críticas, principalmente processuais, que podem gerar denúncias e questionamentos que levem até a interrupção de algum projeto, fato este demonstrado em pesquisa de natureza crítica que avaliou o projeto de "passivos" do IASB (Morley, 2016). Inclusive, no que a autora chama de "lobbying interno", dão-se argumentos similares ao que o próprio IASB utiliza para se legitimar como normatizador perante o público geral, que são os argumentos retóricos de expertise técnico, quantidade de experiência, vivência e participação em organizações internacionais como o G4+1 (Morley, 2016; Warren et al., 2019).

Por mais que no IASB possamos observar uma governança em redes, a nomeação dos membros do board e as votações ainda ocorrem por meio de uma forma adaptada de democracia representativa (Black, 2008). A própria ideia de representação é uma ferramenta utilizada para se manter uma ordem social e política. Isso quer dizer que essa estratégia democrática acaba por mistificar que o poder é exercido por um limitado grupo social que empodera o sistema como um todo (Burke, 2012). Aqui não critico a representação, mas deixo claro que é um modelo escolhido pelo IASB ao criar as barreiras para a escolha de membros votantes do board. Apesar da alegada representatividade, críticas a normatizadores privados tendem a esbarrar nesse conceito ao demonstrar que esses normatizadores são tipicamente dominados pelos mesmos poderes do mercado, em que não se dá interesse aos players menores, humanos, ambientais e sociais, mas sim agrada-se (para se manter) os interesses econômicos $(\mathrm{K}$. W. Abbott \& Snidal, 2001). 
Considerando, além da estrutura organizacional do IASB, que ele está sob uma lógica de poder exercido por meio de soft-law, ou seja, quando não há uma obrigação efetiva de que os países e as empresas devem seguir seus pronunciamentos (Mayntz, 2010), o órgão necessita de estratégias, além das organizacionais citadas, de boas práticas de governança (Hopper et al., 2017) para atingir seu objetivo de ser o normatizador internacional e a fim de que os atores realmente se comprometam com a aplicação de seus produtos finais, que são as IFRSs (Wingard et al., 2016). Essa etapa é importante, uma vez que críticas à condução do processo normativo podem levar ao encerramento ou pausa de algum projeto (Morley, 2016).

A visão geral advogada pelos normatizadores é a de que a elaboração de normas contábeis que siga um processo normativo com base em boas práticas de governança vai “consertar" a contabilidade à medida que problemas forem surgindo (Macintosh, 2002), mas será que devemos entender o conhecimento, a sociedade e as instituições como homogêneas e ordenadas de forma que essa visão seria aplicável? Palea (2015, p. 3) questiona: "A governança atual do processo normativo contábil promove a inclusão social, a justiça e a proteção, ou ao invés disso é controlada por grupos de interesse especiais?”.

A intenção é que esses questionamentos estejam incorporados ao longo das discussões nesta tese. Entretanto, na presente seção farei uma discussão mais aplicada à essa defesa/ataque dos princípios de governança utilizados na normatização contábil como forma de advogar para uma credibilidade/aceitação internacional e para a qualidade de normas emitidas.

Mais uma vez cito o ponto central que levou ao interesse nesta tese, que é a dualidade técnico-política. Essa dualidade representa uma eficiente estratégia de governança, uma vez que se constrói um discurso retórico de que a neutralidade técnica é vantajosa por atender as necessidades dos mais diversos usuários (Arrington \& Schweiker, 1992; Botzem \& Quack, 2009; Gallhofer \& Haslam, 2007; Hoffmann \& Zülch, 2014; A. J. Richardson \& Eberlein, 2011; Street, 2006; Young, 2003). Além do IASB, outras organizações com estruturas similares utilizam-se desta estratégia (Gillis et al., 2014), como a GRI (Global Reporting Initiative) (Dingwerth, 2007), o FASB (Young, 2014), o G4+1 (Street, 2006), o FMI (Fundo Monetário Internacional) (Mehrpouya \& Salles-Djelic, 2019) e o Comitê de Basileia (Tsingou, 2008). A intenção desse discurso é trazer a ideia de que decisões baseadas no expertise profissional e na competência técnica são pilares centrais de um bom processo normativo (A. J. Richardson \& Eberlein, 2011; Warren et al., 2019), entretanto, quem possui o poder para ditar quem são as pessoas/organizações capazes de realizar tal tarefa? Normalmente são as mesmas que realizam, ou seja, há uma autoafirmação da sua capacidade técnica, sendo esta, por si só, uma estratégia política (Madsen, 2013). 
Outro artifício utilizado para garantir essa aclamada neutralidade e tecnicidade advinda das boas práticas de governança refere-se ao discurso de fatos contábeis como isolados dos reflexos que eles proporcionam nos diversos atores e ambientes (Hopper et al., 2017; Street, 2006). Normalmente, reguladores tomam como discurso que seus oponentes são "partes interessadas", ou seja, enviesadas, ou "agentes políticos" que se recusam a aceitar a objetividade dos fatos (Young, 2018).

Afinal, tendo como base a neutralidade, objetividade não seria algo bom? Mas o que nos faz pensar que os reguladores também não são, ou sofrem pressões, de "partes interessadas" ou “agentes políticos"? Entretanto, entendo que “o foco no 'trabalho técnico', [...], não esconde o fato de que a normatização é uma questão motivada por interesses” (Botzem \& Quack, 2009, p. 990), fato este que é, inclusive, reconhecido na obra oficial que conta a história do até então IASC (Camfferman \& Zeff, 2006).

\subsection{Estratégias de Normatização Contábil}

As estratégias de normatização devem ser analisadas observando-se a constelação de atores envolvidos, os devidos processos organizacionais e os conteúdos discutidos durante o processo normativo (Botzem, 2012; Botzem \& Dobusch, 2012). Mesmo havendo tal constelação, a maior parte das pesquisas restringe as análises a algum conteúdo ou fase do processo normativo tomando como base teorias econômicas de viés positivista de forma a simplificar a realidade da normatização (Gipper et al., 2013; Pelger, 2016).

Nesta seção, apresentarei principalmente as pesquisas de Sebastian Botzem³ ${ }^{3}$ que se dedicou a estudar diversos aspectos acerca do papel do IASB na regulação contábil. Suas propostas e seus argumentos demonstram o interesse do IASB, que é considerado um órgão transnacional de sucesso, na busca legitimidade por meio de diferentes estratégias, porém o enfoque não reside especificamente no conceito da legitimidade, mas sim nos processos realizados pelo órgão e na sua organização (Botzem, 2012, 2014; Botzem \& Dobusch, 2012; Botzem \& Hofmann, 2010; Botzem \& Quack, 2006b).

Em sua principal pesquisa (Botzem, 2012), o autor discute diversas perguntas que envolvem questões relacionadas a essas estratégias do órgão, entre elas: “Como o surgimento

\footnotetext{
${ }^{3}$ Sebastian Botzem é um pesquisador alemão com formação na área de ciência política, porém que se dedica aos estudos sobre regulação na contabilidade. Suas pesquisas circulam sobre a temática de legitimidade na regulação contábil internacional, sendo analisadas diferentes estratégias aplicáveis ao IASB. A principal obra do autor é o livro "The Politics in Accounting Regulation: Organizing Transnational Standard Setting in Financial Reporting" (Botzem, 2012).
} 
de um regulador privado pode ser caracterizado e explicado? Quais são os mecanismos subjacentes à normatização transnacional em contabilidade? Quais são os principais atores e como eles influenciam o desenvolvimento normativo?”. Com essas perguntas, o próprio autor caracteriza sua obra como um theory building sobre a normatização contábil (Botzem, 2012, p. 176).

Tomando como base a visão histórica e qualitativa da pesquisa, o autor aplica o desenho metodológico do process tracing para a análise e apresentação dos achados. O process tracing tem como lógica ir além da correlação entre variáveis dependentes e independentes, sendo seu objetivo o de mapear e analisar as dimensões (condições) que levam a determinado comportamento. Os métodos de process tracing são, portanto, ferramentas para o estudo de mecanismos que levam a determinados resultados, ou comportamentos dos agentes, tomando como base um desenho de estudo de caso único, na busca de desvelar a "caixa-preta" e o "backstage" dos processos analisados (Beach \& Pedersen, 2013).

Grande parte do relato histórico do IASB/IASC se baseia em Camfferman e Zeff (2006), que recontam a história do IASC com base em diferentes entrevistas e documentos internos. Em outra obra, Botzem e Quack (2009) realizam uma revisão detalhada sobre a produção de Camfferman e Zeff (2006), na qual descrevem os pontos fortes e fracos, limitações e contribuições detalhadas, principalmente com relação a um possível viés dos autores sobre a história do órgão.

Para responder às perguntas de pesquisa e propor sua teoria sobre a normatização transnacional da contabilidade, Botzem (2012) é dividido em capítulos históricos e propostas teóricas. O autor entende que o processo de normatização contábil internacional é antigo, porém apenas após muitos anos houve a difusão internacional de tais normas. Assim, o que precisa ser explicado é como os acordos de desenvolvimento dessas normas aconteceram e se estabilizaram em um período que demorou mais de trinta anos. Suas proposições teóricas sobre tal fato são baseadas em questões sobre sociologia e política econômica (Botzem, 2012).

Considerando que a maior parte dos estudos contábeis sobre normatização se baseiam unicamente sobre o conteúdo das normas e como estas são aplicadas na prática, Botzem (2012, p. 176), autocaracterizada como crítica, visa teorizar sobre a natureza política da normatização contábil internacional. $\mathrm{O}$ autor afirma, ainda, que o diferencial reside, entre outros, no fato da maior parte das pesquisas realizadas sobre política na normatização serem realizadas em âmbitos locais, sendo sua proposta no âmbito transnacional.

Para o autor, entre os principais mecanismos utilizados para o sucesso do IASB está a utilização de estratégias como a manutenção de status técnico e de expertise (McGregor, 2012; 
Posner, 2010; Warren et al., 2019; Young, 2014), principalmente por meio de procedimentos de consulta que, em sua opinião, representam estratégias apenas de legitimação de participação, mas que não possuem efeito real sobre as decisões do órgão (Botzem, 2012).

Simmons (2001) afirma que "classes profissionais [normatizadores] se apresentam como sendo acima da retórica, mesmo utilizando-a (no sentido mais simples) para se legitimar" (p. 3). Como forma obter aceitação, os órgãos normatizadores tendem a separar a sua qualidade técnica da política, além de separar, também, sua capacidade técnica da dos demais envolvidos (Hoffmann \& Zülch, 2014). Nesse sentido, tendem a demonstrar, por meio do uso argumentativo, que as normas não representam suas opiniões, mas sim um arcabouço técnico, com credibilidade, feito por especialistas que possuem conhecimentos e habilidades que só poderiam existir dentro de um órgão normativo (Gieryn, 1995; Young, 2003, 2014). Para Botzem (2012), essa atitude pode ser vista como uma forma de atestar aos profissionais da área que o normatizador é o "locus of knowledge/expertise" daquela área (Botzem, 2012; Botzem \& Hofmann, 2010).

Os principais atores, também teorizados, são representados pelas maiores empresas de auditoria (Big4) e pelo próprio IASB, que se inclui como ator por meio da lógica de demonstrar seu staff como técnico na tomada de decisões (Botzem, 2012). Essa afirmação constante sobre a natureza técnica do órgão é tida como uma das principais estratégias de transformar o órgão transnacional em uma visão "apolítica", ou seja, demonstrar que não há questões políticas relevantes na normatização contábil internacional (Botzem, 2012). Assim, Botzem (2012) mantém sua tese, amparada também em Porter (2005), de que “os resultados apresentados não confirmam a noção funcionalista e apolítica da autoridade técnica aplicada nos trabalhos [...] enquanto eles [IASB] atestam a relevância atribuída ao seu modelo de elaboração de normas com base em expertise" (p. 177).

Em resumo, Botzem (2012) demonstra o IASB como sendo um caso de sucesso de órgão regulador, privado e transnacional. Nesse sentido, reconta como esse órgão conseguiu superar os desafios da distinção entre autoridade pública e privada, além das mudanças de filosofia das normas. Argumenta, ainda, que a filosofia das normas é amplamente direcionada pelo perfil anglo-americano e baseada na objetividade, que "tecnicamente" é considerado algo vantajoso em um processo normativo.

\footnotetext{
objetividade na regulação favorece a noção de que os reguladores podem adotar a visão de lugar algum com o resultado aparente de que o conhecimento e os fatos são 'verdades'. Com esse ponto de vista, as distorções associadas com perspectivas enviesadas podem supostamente ser evitadas no processo regulatório. A objetividade na regulação, com suas alegações de neutralidade e imparcialidade, então age como forma de proteção entre a expertise e a poluição da política. (Young, 2014, p. 717).
} 
O mito da objetividade é discutido em diversas partes desta tese, muito em decorrência de ser uma das principais estratégias da área contábil de garantir que suas normas e resultados sejam confiáveis e reflitam a "melhor verdade" do mercado (Erb \& Pelger, 2015). Isso representa, na teoria, a noção da financialização. Porém a contabilidade não é e nem será objetiva, pois ela está ligada diretamente a princípios, convenções e práticas que fazem com que a "técnica" seja arbitrária e sujeita a diferentes formas de intervenção (Morgan, 1988).

Corroborando tal visão, Young (2014) teoriza que o processo de normatização contábil procura se conectar a normas sociais de validação, como objetividade e transparência, normas estas que, em teoria, sugerem a separação entre a normatização e as impurezas associadas com a política e opinião. Conecta-se tal afirmação com os princípios estudados na tese, que são o da transparência, consulta completa e justa e accountability, entendendo que estes são princípios que Young (2014) afirma serem estratégias de "purificar" a normatização contábil.

Diversas são as pesquisas críticas que demonstram aspectos contraditórios entre princípios e missões dos normatizadores contábeis e as ações ou decisões efetivamente tomadas. Há evidência de que, mesmo os investidores e participantes diretos do mercado financeiro sendo alegados como os principais usuários das normas contábeis, decisões normalmente são tomadas pelos boards em desacordo com o que esses usuários sugeriam (Pelger, 2016). As pesquisas críticas serão discutidas em seção posterior.

\subsubsection{Governança como pilar da Normatização Contábil}

A governança e suas estratégias representam a principal ferramenta utilizada atualmente para dar garantias e fidedignidade ao processo de transferência de poder que ocorre na normatização contábil policêntrica (Black, 2008; Hopper et al., 2017), em que temos - sob diversos níveis (subnacional, nacional e transnacional) - a transferência dos Estados para os atores globais e transnacionais (Müller, 2014; Neumann \& Sending, 2010; Urry, 2000). Nesse sentido, entendo a governança tanto como as condições estruturais da entidade, assim como as principais estratégias (formais ou informais; burocráticas ou não) que os órgãos transnacionais utilizam-se para garantir qualidade de seus processos e produtos (Botzem, 2008; Müller, 2014).

Apesar da positividade na aplicação do conceito, as boas práticas de governança (incluindo a governança participativa utilizada pelo IASB) também representam uma construção social (J. Brown \& Dillard, 2015) que pode ser articulada de forma retórica e vista como simbólica, já que muitas vezes estão presentes nas missões institucionais, porém suas 
práticas não são realizadas, ou, quando realizadas, não chegam a um nível que possui substância e poder nas reformas de mercado (Hopper et al., 2017).

Com base nisso, apesar de a participação ser um dos pilares para uma política democrática, não podemos inferir que essa participação é sempre positiva e, muitas vezes, esse discurso é utilizado apenas como forma de reiterar decisões por parte dos atores que realmente detêm o poder de decidir. Assim, a forma como a governança é estruturada afeta diretamente a participação e os interesses dos diversos stakeholders de forma diferente (J. Brown \& Dillard, 2015).

Mas qual o motivo de se entender e estudar sobre governança no IASB? Para responder tal questionamento, utilizo-me do trecho:

\footnotetext{
A normatização contábil representa um ótimo exemplo de como agentes privados de governança transnacional são inclinados para uma maior formalização do que é esperado. Formalização é um processo que cria e fortalece a autoridade. Atores privados dependem desta autorização, uma vez que a lei internacional não os reconhece como sujeitos. Como os atores privados não podem criar hard law, a primeira opção vira o soft law. Assim, para se tornarem reguladores privados efetivos, os profissionais codificam seu conhecimento em normas e programas formais (Graz \& Nölke, 2008, p. 230)
}

Muitas dessas estratégias de governança foram aparecendo e se desenvolvendo ao longo do tempo e em decorrência de críticas específicas recebidas que poderiam afetar o alcance das normas internacionais. A contabilidade e suas normas, principalmente na área de mensuração e aplicação dos conceitos de custo histórico e valor justo, foram criticadas como sendo um dos principais fatores para a crise financeira de 2007/2008. Paralelamente, as críticas atingiram o normatizador internacional, que se viu na obrigação de continuamente revisar suas estratégias de forma a acompanhar os desenvolvimentos organizacionais e as melhores práticas atuais (Botzem, 2014).

A apresentação de estratégias de governança, mesmo que não desenvolvidas na prática, podem fazer com que os envolvidos sejam "induzidos ao erro, manipulados e sistematicamente cegos" (Roslender, 2006, p. 251). Isso é um dos motivos que levam a ausência de revoluções por parte da população contábil, uma vez que essa impressão de que as coisas estão funcionamento corretamente é presente na área. Além disso, há uma limitada resistência ao IASB por um pensamento de que essa é a única opção disponível para se obter informações padronizadas e internacionais (Dye \& Sunder, 2001; Palea, 2015).

Os usuários acabam por se tornarem dóceis (Young, 2006) porque, mesmo sendo os mais interessados, são excluídos do processo normativo por meio da retórica aplicação dos conceitos básicos que são tomados como garantidos, o que os leva a raramente questionar algo relacionado ao processo em si (Durocher \& Gendron, 2011); e, aqueles usuários que possuem 
maior poder não necessitam de contestação, já que suas opiniões tendem a prevalecer nas escolhas normativas (Madsen, 2013). De forma geral, "ao invés de questionar as aberrações de uma forma geral e de um ponto substantivo, os usuários purificam as impurezas e reproduzem o status quo" (Durocher \& Gendron, 2011, p. 254).

Considerando, portanto, que o IASB busca atingir uma aceitação global de suas normas e, para isto, deve se manter como órgão hegemônico e de confiança por parte dos órgãos locais que o legitimam (Bamber \& McMeeking, 2016; Mayntz, 2010; Pelger \& Spieß, 2017; A. J. Richardson \& Eberlein, 2011), a estrutura geral da IFRS Foundation é baseada em lógicas de governança que auxiliam nessa estratégia de se manter como regulador internacional (Gallhofer \& Haslam, 2007).

Graz e Nölke (2008), com base em uma extensa literatura de governança, listam seis condições que constituem o framework para que uma entidade transnacional atinja a aceitação desejada. (i) sistema de produção com identificação ao neoliberalismo; (ii) limitado grau de competitividade (oligopólio); (iii) suporte de instituições internacionais, em especial da União Europeia; (iv) foco em política regulatória; (v) baseada fortemente em especialização técnica e conhecimento profissional; e (vi) valores comuns de reguladores privados.

Em complemento, para Hallström (2004) a governança da normatização internacional deve ser capaz de convencer não somente atores do mercado, mas autoridades públicas também. Para isso, as estratégias se baseiam em uma união de quatro pressupostos, que são: $(i)$ expertise; (ii) representação; (iii) necessidade dos usuários; e (iv) financiadores. Esses pressupostos, juntos, possuem a capacidade de afetar o processo de decisão, os procedimentos organizacionais e as questões de aceitação e associações. Por isso, todos devem ser, mesmo que retoricamente (Young, 2006), constantemente articulados de forma a garantir a hegemonia na normatização.

Todas as condições são cumpridas pelo IASB, auxiliando, portanto, no seu sucesso atual na normatização internacional (Botzem, 2012). Há quem diga, inclusive, que o IASB somente consegue se manter na hegemonia porque não há outra opção (Chiapello \& Medjad, 2009; Sunder, 2011). Nesse sentido, para obter e manter certo nível de poder contínuo, as entidades necessitam, além das características citadas, de estratégias que garantam a sua aceitação. Entre essas estratégias, está a chamada "boa governança" (Bevir, 2010).

Organizacionalmente, as principais estratégias englobam a definição de objetivos, missões e valores; alianças por meio de associações com órgãos internacionais; aproximação normativa de mercados mais desenvolvidos; existência de uma estrutura organizacional com comitês de controle e assessoramento; membros diversificados geograficamente e profissionalmente; dedicação exclusiva de membros; política de financiamento que envolva 
entidades internacionais; e diversificação profissional dos funcionários, entre outros (Bevir, 2010; Bevir \& Rhodes, 2003; Botzem, 2008; Camfferman \& Zeff, 2006; Gallhofer \& Haslam, 2007).

Além disto, as constituições atuais de muitas organizações demonstram uma estrutura que sai da lógica hierárquica Weberiana para uma estrutura em forma de redes (Giddens \& Sutton, 2017). As organizações estruturadas em um modelo de governança em redes (policêntrica) não são mais organizadas em uma estrutura fixa, mas sim em um emaranhado de relações sociais que envolvem os mais diversos atores sociais, tanto nos níveis subnacionais, nacionais e transnacionais (Black, 2008).

O sucesso dessas organizações na regulação pode ser dado, portanto, não somente pela explicação econômica, mas por cumprir características de governança tecnológica consideradas essenciais na atualidade, como: financiamento por meio de grupos de interesse e reguladores poderosos; internacionalidade e plasticidade (Chua \& Taylor, 2008). O argumento se baseia na teoria do ator-rede (Latour, 1987), entendendo ser fundamental o fato de que o IASB não engessa suas normas ao se basear em princípios e dar a devida plasticidade aos atores internacionais de forma a poder realizar ajustes de acordo com as necessidades nacionais (Chua \& Taylor, 2008).

Processualmente e em questões relacionadas ao conteúdo, as mais diversas estratégias para se manter como regulador derivam da argumentação e defesa do técnico frente ao político, sendo as principais aquelas voltadas para um discurso de que as normas são de alta qualidade, independentes e a favor do interesse público (Gallhofer \& Haslam, 2007; Humphrey et al., 2009; Shafer \& Gendron, 2005; Willmott, 1990).

Porém, as limitações começam com a aferição da qualidade da participação direta dos atores internos, da aceitação das normas internacionais e da sua posição como normatizador internacional. Por exemplo, para "espelhar" o técnico, apesar de formalmente permitida, a sociedade civil é excluída do processo de regulação, sendo seu acesso restrito devido às mais diversas limitações (Botzem, 2014).

Botzem e Dobusch (2012) afirmam que, apesar da discussão e da barganha assumirem papeis importantes na normatização contábil, o acesso é restrito e o discurso normativo normalmente já está formado. Mais uma vez, um exemplo é o discurso de tecnicismo feito pela contabilidade como forma de aferir qualidade e independência ao seu trabalho (McGregor, 2012). 
Para essa exclusão, o IASB se ampara, principalmente, no discurso de que ele representa o "locus of knowledge” (Suddaby, Cooper, \& Greenwood, 2007) da contabilidade, em especial com relação ao seu conteúdo (Botzem, 2014, p. 122), sendo, portanto, algo inalcançável para a sociedade civil. Essa estratégia leva para a condução da normatização por atores que possuem "um melhor conhecimento contábil". Por isso, a governança direcionada por "experts esconde a política atrás do véu da tecnocracia" (Warren et al., 2019, p. 127).

Esse discurso de locus tem como fundamento a "alta qualidade e representatividade" da composição do board (expert-driven), já que ele envolve pessoas com amplo conhecimento profissional, tanto no setor privado, como no setor público, acadêmicos, auditores e representantes de boards nacionais que estão em contato direto com as entidades e investidores (Hallström, 2004). Essa composição por meio de exterts pode apresentar críticas desde a nomeação de quem são esses membros até a forma como votam. Apesar disso, por criar a impressão de que são neutras, positivas e baseadas em premissas estritamente econômicas, suas decisões tendem a não ser questionadas e a participação tende a ser diminuída (J. Brown \& Dillard, 2015; Stirling, 2008). A criação de comitês de experts, portanto, é uma estratégia de normatização e visa "garantir" a qualidade das normas. Esse discurso técnico continua sendo uma estratégia política, mesmo que não dito formalmente (Martinez-Diaz, 2005; Morley, 2016; A. J. Richardson \& Eberlein, 2011).

Com essas diversas estratégias e discursos, constrói-se o discurso de independência (McGregor, 2012) uma vez que a experiência dessas pessoas os torna técnicos e conhecedores das necessidades do mercado de capitais e dos investidores. Em uma lógica Gramsciana, o conhecimento (expert knowledge) também é uma das principais estratégias políticas existentes (Palea, 2015).

Mas será que essa independência realmente existe? Considerando que são esses membros "técnicos e neutros" que se autoafirmam como representantes do "arcabouço" do conhecimento contábil e, ao mesmo tempo, são esses mesmos atores que conduzem o processo normativo, podemos levantar diversas questões com relação a independência do órgão. Mais especificamente, com relação ao processo normativo em si e a sua condução baseada em princípios, conforme discutirei a seguir.

\subsubsection{Due process Handbook}

O devido processo normativo (due process) deve ser visto como uma das principais (se não a principal) aplicações das estratégias para a hegemonia do IASB como regulador 
internacional (Camfferman \& Zeff, 2018; Gallhofer \& Haslam, 2007; Ram \& Newberry, 2013). "O due process do órgão é a chave para se obter credibilidade e preservar a regulação na contabilidade" (Botzem, 2014, p. 942), pois, já que o IASB encontra-se em uma rede de atores e financiadores (K. W. Abbott \& Snidal, 2001; Bach \& Newman, 2010; Bevir, 2010; Perry \& Nöelke, 2005), o processo funciona como uma ferramenta de controle retórica (A. J. Richardson \& Eberlein, 2011) para a manutenção de seu status técnico por meio da apresentação de critérios administrativos, procedimentais e organizacionais (Ram \& Newberry, 2013). Com isso, ele reúne, em um mesmo documento, diversas outras estratégias que foram citadas na seção anterior.

A compreensão seria de que:

o due process se baseia na existência de uma política bem definida a quem devem ser prestadas contas e o acesso deve ser fornecido. Por isso, o devido processo adotado pelo IASB deve simultaneamente construir e envolver a comunidade à qual deseja prestar contas (A. J. Richardson \& Eberlein, 2011, p. 225)

Porém não há perfeição (nem totalização) e esse processo deve ser criticado com vistas a uma demonstração das falhas e, também, a um aprimoramento em benefício dos envolvidos. O órgão depende de um due process que seja aceito, desejável, considerado de qualidade, apropriado, adequado e válido pelos mais diversos atores da normatização internacional (Botzem \& Dobusch, 2012; Ram \& Newberry, 2013; A. J. Richardson \& Eberlein, 2011; Wingard et al., 2016), uma vez que o due process apresenta os "procedimentos que são considerados 'apropriados' e rigorosos para se atingir qualidade professional substantiva e credibilidade" (A. J. Richardson \& Eberlein, 2011, p. 224).

Para atingir esses objetivos, sua principal função é a de estabelecer as diretrizes para a consecução do processo normativo e informar os envolvidos acerca do andamento desses processos (Pelger \& Spieß, 2017; A. J. Richardson \& Eberlein, 2011). Além disso, age de forma a integrar "várias visões, diferentes experiências nacionais e setoriais, e constituintes divergentes" (Botzem \& Quack, 2009, p. 994), sendo que esses participantes são constantemente reconstruídos e dinâmicos (Botzem, 2008).

O handbook, além de elencar os princípios que o regem, também apresenta a missão do órgão, suas áreas de responsabilidade e o detalhamento do processo normativo. Ainda, em seu conteúdo podem ser observadas as características do processo técnico/formal de edição de normas, pesquisa, implementação e interpretações. Ao mesmo tempo em que há a defesa de um due process com diversas etapas e que limite a ação do normatizador por meio de princípios, 
há o argumento de que processos tão burocráticos e longos fazem com que a regulação não seja tempestiva.

Com essa visão agregativa do handbook, ele constitui um dos principais documentos/ações do IASB que explica a efetividade das suas normas (Botzem \& Quack, 2006b; A. J. Richardson \& Eberlein, 2011). Assim, o board busca que esse documento tenha papel fundamental na resolução de conflitos que possam surgir durante um processo normativo de forma a resguardar o discurso acerca da qualidade das suas normas (Botzem \& Quack, 2009).

Para tentar defender a necessidade do due process e da "independência", o board se baseia centralmente na defesa da transparência, participação pública e prestação de contas contínua de forma a garantir a aceitação dos agentes públicos e privados que o empoderam por meio da utilização de suas normas (Botzem \& Quack, 2006b; Erb \& Pelger, 2015; Pelger \& Spieß, 2017; A. J. Richardson \& Eberlein, 2011). Entretanto, essa estratégia também é vista como uma "manobra cínica" e retórica para agradar os estados e demais atores na sua aceitação (Eaton \& Porter, 2008; Porter, 2005; A. J. Richardson \& Eberlein, 2011).

Primeiro, devemos questionar a visão do board sobre o "público", já que todos os princípios derivam indiretamente dessa premissa. Além de informar que o processo é aberto publicamente, fala-se que as informações contábeis representam bens públicos (IFRS Foundation, 2016b). Apesar de afirmar, na prática não se intenta beneficiar a ampla maioria de usuários (Rosenfield, 2006). Se entendermos "público" como um conceito de abrangência geral e a todos, esse conceito é esvaziado, pois o "público" utilizado nesse contexto limita-se aos usuários que possuem grande conhecimento da contabilidade e aos membros de grandes empresas, em especial as de auditoria e de investimentos (Botzem, 2014). Até mesmo os investidores (de forma ampla), que são descritos como o principal usuário da contabilidade, acabam por não ser englobados nesse conceito. Assim, a esfera pública que se alega não é realmente pública se considerarmos o espaço democrático das últimas décadas (Fraser, 1992). "Seria irreal pensar que as normas contábeis refletem a vontade do povo somente por seguir o due process" (Ram \& Newberry, 2013, p. 13).

Apesar de a defesa, por parte dos membros, de um due process que represente as melhores estratégias de governança para a manutenção da alegada independência, seu processo de formação e modificações foi amplamente motivado por exigências de atores, em especial da União Europeia, de membros do G20 e da SEC (Securities and Exchange Commission), ou seja, envolveu diferentes grupos de interesse que tiveram o poder político de influenciar na elaboração deste documento (McGregor, 2012; A. J. Richardson \& Eberlein, 2011). Assim, as 
atualizações também se tornam estratégias para se manter a "validade" processual na normatização internacional (Bengtsson, 2011; Mehrpouya \& Salles-Djelic, 2019).

Entre as mudanças, o órgão cita que sempre busca aumentar a qualidade do processo normativo e da aplicação dos princípios, como a criação de comitês de acompanhamento, criação de prazos para consultas e o estabelecimento de procedimentos para análise das consultas (Street, 2006), porém tais procedimentos não são detalhados ou descritos.

Se o próprio documento que norteia a elaboração das normas é efeito de uma demanda política, por que diríamos que o processo de elaboração de normas é estritamente técnico e não político? Passado tal questionamento, entendemos a política como premissa nesta tese. Assim, devemos questionar o quão efetivo é esse documento na prática. Por isso, este documento acaba por representar a base da análise, uma vez que procurarei ver, sob um engajamento crítico, os pontos em que esse ele se mostra falho e acaba por reproduzir mitos de governança (Durocher \& Gendron, 2011).

Apesar de ser um guia a ser seguido no processo normativo, até a última atualização continuou apresentando subjetividades que possibilitam ações discricionárias por parte do board, como as palavras/expressões: "normalmente" (normally), "geralmente" (generally), "usualmente" (usually), “é esperado" (expected to), "pode também” (may also), "quando considera apropriado" (where the IASB considers it to be appropriate) e "necessidade dos usuários" (needs of users) (A. J. Richardson \& Eberlein, 2011).

Durante o processo normativo de leasing (2006-2016), o due process handbook passou por quatro documentos, sendo duas atualizações (Março/2006; Fevereiro/2013) e duas emendas (Outubro/2008; Maio/2016), conforme apresento na Figura 4.

Figura 4 - Atualizações no Due process Handbook

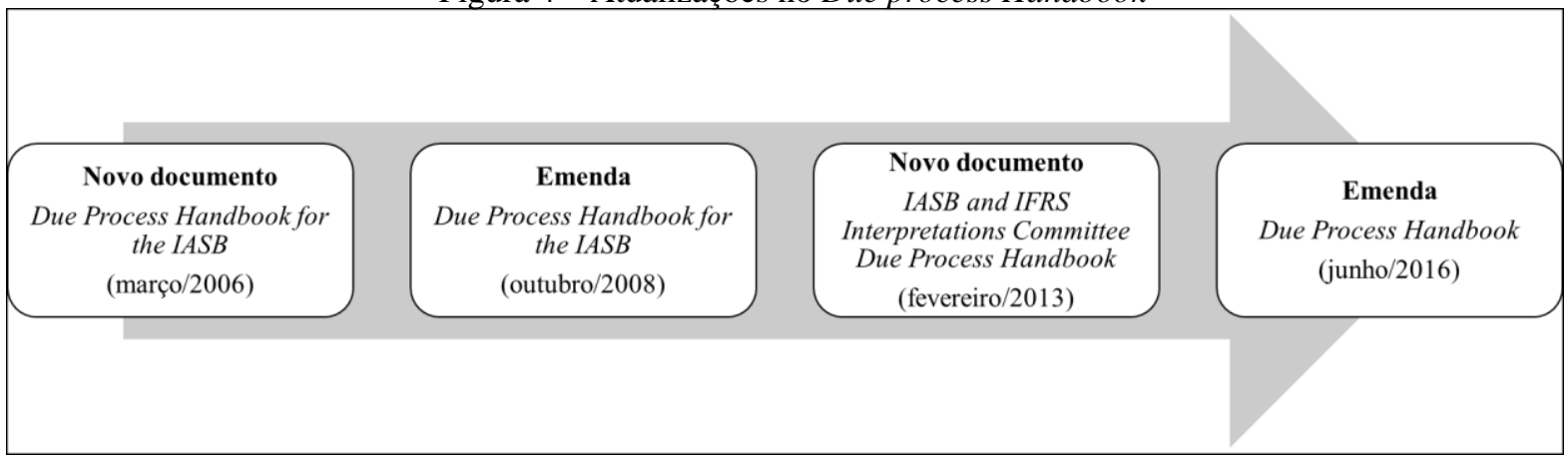

Fonte: Elaborado pelo autor.

Considerando que houve mudança nos handbooks ao longo do processo, observei os pontos para verificação de algum critério de análise da tese que possa ter sofrido modificação. 
Formalmente, as etapas do processo continuaram as mesmas. Em resumo, as mudanças referem-se a questões relacionadas com atualizações da constituição do board, como: prazos para realização de alguma etapa normativa, quantidade de votos para aprovações, incrementos nos documentos com informações mais detalhadas e inclusão de questões gerais de "garantidores da qualidade", como missão e objetivo do board. Os princípios também sofreram alterações e as discutirei na próxima seção.

Além disso, entre os handbooks de 2008 e 2013 foi criado o DPOC. Com isso, questões relacionadas com a "fiscalização" dos procedimentos aparecem apenas a partir do handbook de 2013. Os detalhamentos acerca do novo órgão se limitam a informar funções de fiscalização formal dos procedimentos elencados no handbook.

Pesquisas já foram realizadas tomando como base o due process handbook (Hewa et al., 2018; A. J. Richardson \& Eberlein, 2011; Wingard et al., 2016; Young, 2014). De modo semelhante a esta tese, Richardson e Eberlein (2011) analisaram pontos fortes e fracos com relação ao que o IASB executa, porém tendo como base o handbook versus bases culturais de normatizadores locais (EUA - Estados Unidos da América - e Inglaterra). Além disso, de forma diferente, os autores se utilizaram de teorias da legitimidade normativa, em especial do conceito de legitimidade input, through-put e output, com uma discussão utilizando-se do pragmatismo de Jürgen Habermas. Apesar das diferenças, a pesquisa contribui para a discussão da atual tese, uma vez que elenca algumas dificuldades de aplicação dos princípios, como o acesso geral ao processo de consulta e a limitação da accountability (A. J. Richardson \& Eberlein, 2011).

Meu argumento central nesta tese gira em torno de que o handbook e seus princípios (transparência, consulta completa e justa, e accountability) também representam significantes vazios na mais pura essência, uma vez que podem ter diversos significados e, também, nenhum significado claramente definido (Torfing, 1999). A própria utilização de um vocabulário institucional específico já representa uma estratégia de validação de conteúdo (Suddaby \& Greenwood, 2005). Isso traz a tona o que defendo como (in)completude.

O objetivo deste documento é, então, uma estratégia retórica que agrega, em um documento único e formal, aspectos que trariam "melhor qualidade" para a condução do processo. Isso faz com que, ao mesmo tempo que tenha abertura, o processo represente um fechamento social, uma vez que o board possui a autonomia para a construção e decisão das normas. Assim, o documento se baseando nas premissas de transparência e consulta completa e justa acaba por demonstrar uma accountability maior do que de fato ocorre (Suddaby \& Viale, 2011). 
Em resumo, podemos nos valer da seguinte conclusão com relação ao due process do IASB:

\footnotetext{
O due process pode ser comparado a um voto de questões altamente técnicas, participação na qual deve-se pagar, e um resultado o qual não precisa ser compulsoriamente aplicado por aqueles que organizam. O due process é suportado por uma governança para especialistas. (Burlaud \& Colasse, 2011, p. 30).
}

\subsubsection{Princípios do Due process Handbook}

Uma das formas de se obter a aceitação dos atores é por uma estrutura moral, em que se totalizam conceitos/princípios com base na visão de que o envolvido enxerga os procedimentos da organização como moralmente aceitos (Black, 2008). As premissas totalizantes representam, ao mesmo tempo: uma estratégia de governança, já que agradam a diferentes públicos; e uma limitação epistemológica - se observarmos o fenômeno sob um paradigma pós-estruturalista já que a universalização e a totalização são consideradas impossíveis no mundo político (Collier, 2009). Os princípios funcionam, portanto, como uma totalização impossível, mas, apesar disso, na estrutura ideal não se poderia escolher quando eles seriam aplicados ou não (Mehrpouya \& Salles-Djelic, 2019).

Com base nessa estrutura de "totalização", podemos observar que o processo de normatização contábil está centralizado no discurso de "normatização independente", tendo como principal órgão de atuação o IASB. Para cumprir suas funções, o órgão baseia seu processo no due process handbook, que apresenta como objetivo "estabelecer os princípios a serem aplicados pelo IASB e pelo IFRS Interpretations Committee" (IFRS Foundation, 2016b, p. 1).

Podemos fazer um paralelo desses princípios com o discutido na literatura sobre aceitação e poder de órgãos transnacionais e de soft-law (Pelger \& Spieß, 2017; A. J. Richardson \& Eberlein, 2011). Esforços de regulação privada são criticados por questões como falta de accountability e de representação de shareholders (Botzem \& Hofmann, 2010). Nesse sentido, a literatura sobre o tema demonstra que essas entidades, das mais diversas áreas, procuram certo grau de formalização por meio de padrões institucionais como forma de se manterem ativas (Hopwood \& Miller, 1994). Esses padrões circulam em torno da transparência, accountability e abertura para participação pública, ao serem tidos como conceitos/princípios modernos que garantem certa autoridade às práticas nos regimes internacionais (Hall \& Taylor, 1996). 
Quando falamos em democracia, três termos são chave para seu sucesso perante os atores envolvidos: comunicação, informação e accountability (Bronner, 2002; Gallhofer, Haslam, \& van der Walt, 2011). Ainda, quando falamos em sucesso da normatização transnacional, devemos pensar em situação de propriedade, conhecimento social e controle social, que são, respectivamente: ( $i$ ) base inclusiva de participação; (ii) persuasão por meio de deliberação; (iii) transparência e accountability (Beisheim \& Dingwerth, 2008; Luthardt \& Zimmermann, 2009).

Ao utilizar tais premissas para a realização de um processo normativo dito democrático e que siga o estabelecido no handbook, devem ser levados em consideração esses mesmos princípios: transparência; consulta completa e justa; e accountability. Aqui podemos perceber o paralelismo entre os termos (retóricos) (Suddaby \& Greenwood, 2005) exigidos para a consecução de um processo democrático e aqueles escolhidos pelo IASB como sendo os pilares do seu processo normativo.

$\mathrm{Na}$ leitura desta tese, esses princípios representam, portanto, ferramentas que demonstram o interesse de um órgão transnacional, como o IASB, em atingir aceitação para com seus atores envolvidos por meio da compreensão e do acompanhamento das etapas de edição das normas. Apesar disso, considerando os diversos contextos em que a regulação contábil pode atuar, esses princípios são vistos como "subdesenvolvidos e/ou equivalentes a uma retórica ruim que serve ao status quo" (Gallhofer \& Haslam, 2007, p. 643).

A maior parte dos estudos acaba por analisar os princípios a partir da aplicação de normas, como a transparência das demonstrações financeiras após a edição de uma norma, ou a accountability das empresas (Bertomeu \& Magee, 2015). Em um contraponto, nesta pesquisa os princípios são similares, porém analisados durante o andamento do processo normativo, ou seja, o objeto de estudo é o próprio normatizador e não as empresas que aplicam as normas editadas. Entendo que os princípios podem servir como uma limitação à ação política sem controle por parte dos normatizadores (Bertomeu \& Magee, 2015).

Considerando que esses princípios representam uma categoria central das discussões presentes nesta tese, dediquei esta seção para uma argumentação acerca das suas possibilidades de definições e funções no processo normativo contábil. Inicialmente, apresento a forma como o IASB vê atualmente cada princípio elencado nos handbooks e suas principais estratégias. Podemos observar que não há uma definição claramente articulada, mas sim uma breve explicação do que seria o princípio, ressaltando suas funções de significantes vazios no processo. 
Nos quatro documentos que existiram durante o processo normativo, há grandes semelhanças entre os handbooks de 2006 e 2008 e os handbooks de 2013 e 2016. Por isso, apresentei esses handbooks de forma conjunta na Figura 5.

Podemos fazer um paralelo na diferença de nomenclaturas. Antes se chamavam requisitos e, após a modificação, passaram a se chamar princípios. Há, também, mudança no nome dos princípios e nas descrições de como esses princípios são alcançados. Esses critérios serão discutidos ao longo das próximas seções.

Como houve alterações no nome dos princípios, porém eles representam, na essência, os mesmos vazios conceituais, optei por me referir nesta tese sempre pelo nome dos princípios mais atuais. Essa modificação de nomenclatura, porém mantendo uma ausência de significados semelhante, acaba por reforçar a lógica que defendo na tese de que esses princípios representam significantes vazios com base na ideia de universalização na conjugação de diversos sujeitos com demandas diferentes (Laclau, 2007b; Laclau \& Mouffe, 1985). 
Figura 5 - Princípios, Conceitos e estratégias dos Due process Handbooks.

\begin{tabular}{|c|c|c|c|c|}
\hline Documento & Nomenclatura & Princípio & Definição & Descrição \\
\hline \multirow[t]{2}{*}{$\begin{array}{l}\text { Handbook } \\
2006 \\
\text { Handbook } \\
\quad 2008\end{array}$} & \multirow[t]{2}{*}{$\begin{array}{c}\text { Requisitos } \\
\text { (Requirements) }\end{array}$} & $\begin{array}{l}\text { Ampla consulta e capacidade } \\
\text { de resposta } \\
\text { (Extensive consultation and } \\
\text { responsiveness) }\end{array}$ & Não há & $\begin{array}{l}\text { - São solicitadas participações formais após a emissão dos } \\
\text { documentos (DP e ED). } \\
\text { - Há reuniões com diversos grupos de usuários. } \\
\text { - Os comentários são sumarizados e o IASB justifica suas } \\
\text { principais posições. }\end{array}$ \\
\hline & & $\begin{array}{l}\text { Accountability } \\
\text { (Accountability) }\end{array}$ & Não há & $\begin{array}{l}\text { - Adotam um sistema de "cumprir ou explicar" com relação } \\
\text { aos momentos em que não se realiza alguma etapa formal. }\end{array}$ \\
\hline \multirow{3}{*}{$\begin{array}{l}\text { Handbook } \\
2013 \\
\text { Handbook } \\
2016\end{array}$} & \multirow{3}{*}{$\begin{array}{l}\text { Princípios } \\
\text { (Principles) }\end{array}$} & $\begin{array}{l}\text { Transparência } \\
\text { (Transparency) }\end{array}$ & $\begin{array}{l}\text { "O IASB conduz seu processo de emissão } \\
\text { de normas de uma forma transparente" } \\
\text { (IFRS Foundation, 2016b, p. 7). }\end{array}$ & $\begin{array}{l}\text { - Envolve reuniões públicas, votações e balloting. } \\
\text { - Todos os documentos formais são disponibilizados no } \\
\text { website. }\end{array}$ \\
\hline & & $\begin{array}{l}\text { Consulta completa e justa } \\
\text { (Full and Fair Consultation) }\end{array}$ & $\begin{array}{l}\text { "Considera as perspectivas daqueles } \\
\text { afetados pelas IFRS em todo o mundo" } \\
\text { (IFRS Foundation, 2016b, p. 7). }\end{array}$ & $\begin{array}{l}\text { - Envolve etapas obrigatórias e discricionárias de consultas, } \\
\text { tanto formais como informais. } \\
\text { - Há priorização para consultas informais aos investidores, jáa á } \\
\text { que afirmam que estes participam menos do processo formal, } \\
\text { além dos normatizadores locais e do IFRS Advisory Council. } \\
\text { - Os principais documentos são as comment letters. }\end{array}$ \\
\hline & & $\begin{array}{l}\text { Accountability } \\
\text { (Accountability) }\end{array}$ & $\begin{array}{l}\text { "O IASB analisa os potenciais efeitos de } \\
\text { suas propostas sobre as partes afetadas e } \\
\text { explica os racionais para o motivo das } \\
\text { decisões tomadas no desenvolvimento ou } \\
\text { mudança de alguma norma" (IFRS } \\
\text { Foundation, 2016b, p. 7). } \\
\end{array}$ & $\begin{array}{l}\text { - Emissão de "Effect analysis". } \\
\text { - Emissão de "Basis for Conclusions". }\end{array}$ \\
\hline
\end{tabular}

Fonte: Elaborado pelo autor com base nos Due process Handbooks. Foundation, 2016b, p. 7). 
Como forma de diminuir as críticas externas, a transparência se tornou um conceito importante para o IASB (Botzem \& Hofmann, 2010). Podemos observar no handbook que, para garantir o princípio da transparência, o processo normativo deve envolver reuniões públicas, votações e balloting. Afirma-se que a maioria das reuniões serão públicas, sendo que, mesmo sabendo que existe um limite entre questões técnicas e não técnicas, buscar-se-á discutir apenas assuntos de natureza dita técnica durante as reuniões (IFRS Foundation, 2016b, p. 8). Questiono, aqui, se essa divisão e discussão apenas de questões técnicas deve ser feita, fato este que será discutido como sendo uma das possíveis críticas com relação às atitudes tomadas e seus efeitos para a transparência do processo. Ainda com relação à transparência, nos processos de votação são analisados os mínimos de votação por parte de cada membro para a aprovação de documentos, sendo a aprovação final composta pelo processo do balloting, que não é público.

O segundo princípio do processo normativo é o de consulta completa e justa. O órgão afirma que o processo de consulta realizado de forma ampla melhora a qualidade da norma emitida (IFRS Foundation, 2016b). Para que o processo seja considerado completo e justo, o órgão afirma que devem ser realizados convites para comentários, reuniões individuais com interessados e trabalhos de campo, sendo este último um passo não obrigatório. Como instrumentos, o IASB utiliza-se, portanto, de comment letters, reuniões individuais com investidores e reguladores de diversas naturezas, e visitas a empresas que podem ser impactadas pela possível norma contábil.

O terceiro princípio é o da accountability, em que o órgão afirma haver relação estreita com o princípio da transparência e da consulta completa e justa. Nesse momento, afirma-se no handbook (IFRS Foundation, 2016b) que, com base nos trabalhos de campo realizados, são dadas explicações, por meio de documentos públicos, das decisões tomadas, da sua relação de custo $x$ benefício e dos seus principais efeitos. Os documentos citados em que se pode observar o cumprimento do princípio seriam os emitidos juntamente com a norma final, que seriam, por exemplo, o effect analysis e o basis for conclusions.

Os princípios também são interrelacionados, por exemplo, não pode haver accountability sem algum nível de consulta, nem pode haver uma consulta sem a presença da transparência, e assim por diante. Além disso, a transparência é vista como um princípio central, em que a operação dos demais princípios depende do seu correto funcionamento (A. J. Richardson \& Eberlein, 2011). Devido a subjetividade observada em tais conceitos, realizarei 
nas próximas subseções uma discussão acerca do seu papel e dos efeitos esperados com a "aplicação" desses princípios.

Apesar de a existência e a articulação dos princípios, e das funções do handbook, não há mecanismo efetivo de controle que seja legalmente válido. Isso quer dizer que essas entidades, apesar de buscarem atrair seus atores por meio desses princípios, não são reguladas por nenhuma outra entidade que possui poder para puni-las ou repudiá-las formalmente, nem mesmo outras entidades internacionais que a apoiam ou o DPOC (A. J. Richardson \& Eberlein, 2011). Assim, podemos dizer que aplicação dos princípios não é compulsória, mas sim uma questão ética (Young \& Williams, 2010).

\subsubsection{Transparência}

A transparência é apresentada como um dos marcos centrais das estratégias contemporâneas de boas práticas de governança (Hopper et al., 2017), sendo vista como uma norma social para entidades transnacionais. Apesar dessa importância dada e observada, não se sabe ao certo como a transparência se tornou uma ferramenta institucional tão importante, principalmente como estratégia de governança no setor econômico e de mercado, porém sabemos que ela é constantemente reinventada (Boli \& Thomas, 1999; Mehrpouya \& SallesDjelic, 2019).

Por ser vista como uma das principais estratégias para a aceitação/credibilidade institucional, a transparência do board já sofreu críticas e houve modificações ao longo do tempo (Bamber \& McMeeking, 2016; Botzem \& Dobusch, 2012; Yen, Hirst, \& Hopkins, 2007). Apesar disso, há sempre diferentes lados quando se fala em incremento da transparência. Ao mesmo tempo que é aclamada por trazer mais informação para o processo decisório, há vertentes que entendem que esse "aumento não obrigatoriamente leva a uma tomada de decisão de maior qualidade (Bamber \& McMeeking, 2016; Herbohn \& Herbohn, 1999).

Além da incerteza quanto ao surgimento do conceito da transparência e da sua constante reinvenção, há também uma incompletude desse conceito, sendo ele parcial e modificado ao longo do tempo (Mehrpouya \& Salles-Djelic, 2019), se considerarmos que a "transparência implica no acesso ilimitado de informações para o público (Hood \& Heald, 2006)" (Mehrpouya \& Salles-Djelic, 2019, p. 14).

Com isso, devemos questionar diversas premissas, como: quem é o público? Como é esse acesso? O que seria ilimitado? Com esses questionamentos e com base na teoria do discurso que emprego nesta tese (Laclau \& Mouffe, 1985), entendo a transparência como um 
significante vazio. Portanto, existe uma relação entre a transparência e a política (Laclau, 2007b) e considero que, mesmo aplicando ferramentas de transparência com relação ao processo normativo, essa prática não o torna apolítico (Gallhofer \& Haslam, 2007).

Com base nisso, diversos conceitos podem ser relacionados com a transparência, como o de iluminação, visibilidade, publicidade, evidência, tendo sempre em comum a vacuidade de significado. Suas mais diversas aplicações já ocorreram em diferentes organizações transnacionais, como o Banco Mundial, o FMI e a GRI (Dingwerth, 2007; Li, 2011; Mehrpouya \& Salles-Djelic, 2019).

Apesar da variedade de significados, a transparência também é vista como a principal estratégia de boa governança para aferir a qualidade do trabalho de alguns entes na contabilidade ( $\mathrm{Li}, 2011)$ : “A história recente da elevação da transparência em associação com a contabilidade, auditoria e boa governança é, em outras palavras, a história da problematização, responsabilização e transformação do local enquanto se empodera e exonera o global" (Mehrpouya \& Salles-Djelic, 2019, p. 27).

Botzem e Dobusch (2012) afirmam que, após críticas pontuais de mercados do G20 e de outros envolvidos, o discurso da transparência teve sua relevância aumentada nos mais diversos processos, objetivos e produtos do IASB. No caso do processo normativo, ela é vista como uma ferramenta que garantiria a imparcialidade das escolhas e decisões tomadas pelos membros do board, uma vez que todos os documentos seriam públicos (Burlaud \& Colasse, 2011).

Entretanto, como vimos na seção anterior (Figura 5), sua conceituação acaba por se mostrar pobre para o IASB e sem informações que sejam suficientes para entender o que o board entende pelo conceito, possibilitando, assim, a realização de críticas com base na prática corrente e levando a uma necessidade de pesquisas sobre o papel da transparência na regulação contábil, uma vez que esse é um conceito central na argumentação sobre governança e qualidade das normas (Mehrpouya \& Salles-Djelic, 2019).

Além de todos esses atributos, a transparência também pode ser vista como uma estratégia e controle democrático. Em pesquisa acerca da transparência no processo normativo da GRI, Dingwerth (2007) observou a quantidade de documentos que são disponibilizados pela internet e os esforços do órgão para disponibilização de informações e feedbacks de forma tempestiva. Entretanto, em uma linha mais crítica, o autor observa que a transparência também funciona como uma estratégia retórica de legitimação, uma vez que apenas os documentos finais são traduzidos para outras línguas. isso faz com que o processo normativo em si não seja 
transparente; ou ao menos podemos dizer que ele se limite a pessoas com mais expertise da língua inglesa. Isso exclui, exatamente, os atores que possuem menos poder institucional e financeiro (Dingwerth, 2007).

Além disso, apesar de haver disponibilização dos documentos, o processo de tomada de decisões se limita aos membros que compõem o corpo diretivo das entidades e essas decisões não necessitam de ampla justificativa tomando como base os comentários dos respondentes (o mesmo ocorre para o IASB). Ou seja, a transparência na apresentação dos documentos é apenas de caráter informativo, porém não há ferramentas de controle que façam com que essa informação seja conferida e cobrada. As decisões podem ser tomadas, portanto, sem levar em consideração os comentários. Essa não consideração não necessita nem de justificativa, uma vez que as estratégias de governança de representatividade se fazem "eficazes" mediante o voto desses membros, e não sobre o processo.

Já em pesquisa relacionada ao IASB, apesar da alegada transparência no processo normativo, Cortese e Irvine (2010) desenvolvem um framework de análise do processo e demonstram, de forma aplicada à construção da IFRS 6 (Exploration for and Evaluation of Mineral Resources), que a transparência também é uma ferramenta retórica e simbólica em que não há comprometimento efetivo e substantivo por parte do órgão (Bamber \& McMeeking, 2016). Para as autoras, a transparência existiria se os inputs visíveis de um processo levassem a outputs consistentes com tais inputs. Porém o que as autoras observam é que existe uma "caixa preta" em que os processos possuem outputs que muitas vezes são inconsistentes com os inputs visíveis e observáveis, o que leva ao entendimento de que há inputs não visíveis/observáveis e que eles possuem grande relevância no processo decisório, fazendo com que este, portanto, seja não transparente (Cortese \& Irvine, 2010).

Por fim, podemos ver que nessas entidades a transparência é muitas vezes associada com controles burocráticos e não efetivamente com a aplicação transparente e eficaz de medidas que atendam às demandas dos atores. Será que é esse o real interesse do que seria definido como transparência no processo decisório para o alegado “interesse público"? Essa pergunta continua sem resposta, porém abre caminhos para novas reflexões sobre o assunto e possibilidade de pesquisas empíricas que envolvam, também, o princípio da consulta completa e justa.

\subsubsection{Consulta Completa e Justa}

Os procedimentos de consulta, assim como a transparência, também representam uma das principais ferramentas de aceitação/credibilidade transnacional (Botzem, 2014), 
principalmente por incorporarem uma lógica de democracia participativa. $\mathrm{O}$ argumento é de que o processo participativo tende a aumentar o diálogo e o debate entre os diferentes interessados (J. Brown \& Dillard, 2015; Stirling, 2008).

Entretanto, já na década de 1990 se falava acerca da retórica da justiça no processo de consulta. A argumentação gira em torno do discurso construído do processo normativo do FASB, mostrando que "a genialidade do processo normativo do FASB é a cultivação da crença entre os constituintes de que suas contribuições exercem algum tipo de influência sobre o conteúdo final das normas" (Fogarty, 1994, p. 220).

Esse pensamento é ratificado ao se argumentar que a consulta funciona como um "procedimento que cria a impressão de transparência no qual todas as vozes são ouvidas" (Wingard et al., 2016, p. 10). Reparemos, portanto, na importância dessa aparência para o discurso normativo, pois ela é a ferramenta utilizada para o discurso de qualidade e independência das normas emitidas, uma vez que os envolvidos são levados ao entendimento de que as normas são fruto da melhor possibilidade neutra e técnica (Bamber \& McMeeking, 2016; Erb \& Pelger, 2015; McGregor, 2012; Weetman, 2001).

Seguindo esse modelo de participação, podemos dizer que a participação de atores pode representar diversos mecanismos discursivos para o normatizador, como: mecanismo de consentimento; mecanismo de controle; mecanismo de cooperação; mecanismo de accountability; mecanismo para o aumento da confiança; substituto da verdade; discurso para melhorar a justiça e mecanismo de governança corporativa (Greenwood, 2007).

A inclusão de outros atores, portanto, acaba por ser problemática para o próprio normatizador, momento em que podemos dizer que há um "trade-off entre a participação inclusiva/ampla e a lógica de decisão técnica da normatização" (A. J. Richardson \& Eberlein, 2011, p. 223). Considerando o discurso de tecnicidade e alta qualidade das decisões que envolve o processo normativo, muitos atores acabam por não apresentar tais características e são excluídos (Burlaud \& Colasse, 2011; A. J. Richardson \& Eberlein, 2011; Young, 2014). Além disso, a participação tende a acontecer mais com os normatizadores locais e entidades financeiramente relevantes, uma vez que a participação em entidades transnacionais envolve altos custos (A. J. Richardson, 2008; Samsonova-Taddei \& Humphrey, 2014). Seria isso justo? Seria isso uma consulta completa? Não seria o board capaz de consultar outros atores de forma ao menos a entender suas necessidades e queixas? Por "sofisticação" do processo, podemos dizer que o board acaba por preferir limitar a participação aos experts - que, no discurso, garantem a qualidade das normas - porém são estes experts os atores que estão diretamente 
envolvidos no financiamento do board ou já participam nas mais diversas fases do processo, entrando aqui a crítica quanto à independência (Botzem \& Quack, 2009; Martinez-Diaz, 2005; Pelger \& Spieß, 2017; A. J. Richardson \& Eberlein, 2011; Stirling, 2008).

O pensamento de inclusão é confirmado pelo argumento:

Uma vantagem dos procedimentos formalizados reside na abertura de caminhos para a consulta e participação. Embora os procedimentos participativos transmitam a impressão de abertura e inclusão, eles estão perfeitamente atrelados a um entendimento baseado na expertise do processo normativo que considera a abertura a argumentos técnicos uma qualidade inerente. (Botzem \& Hofmann, 2010, p. 24)

$\mathrm{O}$ argumento central, portanto, é de que a diferença entre os atores envolvidos também é um fator limitador do processo de consulta do IASB, pois atores considerados mais fortes possuem contato direto com a organização, procurando essa estratégia como forma de garantir que sua opinião será tratada. Embora possam se utilizar dos meios formais de consulta (principalmente comment letters), os atores com menos poder acabam tendo sua participação tratada de forma menos relevante (Botzem, 2014; Erb \& Pelger, 2015).

Por conseguinte, podemos entender que o processo de "consulta pública" não é realmente público (Erb \& Pelger, 2015), uma vez que não há acesso irrestrito a todos (Hopper et al., 2017; Humphrey et al., 2009). Nesse caso, como há diferenças nesse acesso, o processo normativo acaba por corroborar o oposto, em que a ausência da esfera realmente pública aumenta a desigualdade a medida que o acesso de atores mais influentes tende a elevar suas opiniões em detrimento de outras possíveis (Fraser, 1992).

Normalmente tendemos a entender a consulta como um exercício que envolve a participação e a aceitação dos resultados dessa consulta, porém, na análise do IASB devemos entender esses conceitos de forma separada, uma vez que os diversos atores não possuem poder direto no processo de decisão. Assim, "ao invés de ser um instrumento de participação, o due process é principalmente um exercício de consulta" aos principais atores de interesse (Botzem \& Dobusch, 2012, p. 751), cumprindo mais uma função comunicativa do que efetivamente uma consideração acerca das opiniões (Botzem, 2012; Erb \& Pelger, 2015). Devemos analisar, então, se o sucesso (de aceitação) que as normas internacionais apresentam a partir do século XX deve levar a questionamentos acerca da efetiva participação global de atores, ou seja, buscando uma efetiva participação democrática. Ou será que somente a consulta, sem a necessária justificativa acerca dos resultados do processo decisório é suficiente?

Isso quer dizer que, apesar de haver um processo de consulta, os resultados de tais consultas, ou seja, as comment letters e roundtables, não obrigam ou desobrigam o board a nada, inclusive os membros votantes do board não analisam diretamente tais consultas e 
recebem apenas seus dados de forma agregada. É função do staff técnico resumir e preparar os documentos resumo (comment letters sumaries) que efetivamente são alvo de discussões nas sessões públicas (Botzem \& Quack, 2009).

A qualidade da participação também pode ser levada a questionamento com base na constante "evolução" do discurso até se chegar em uma orientação exclusivamente voltada para o mercado e investidores. Essa limitação de escopo diminui, formalmente, a participação pública e deve ser foco de análise não como sendo um conceito abstrato, mas sim de forma individualizada durante todo o processo de normatização (Botzem \& Dobusch, 2012; Hopper et al., 2017).

Até mesmo a forma da escrita das questões que o IASB lança para comentários públicos pode ser questionada quando se fala em justiça e completude. As perguntas não são abertas, mas sim solicitação de concordância ou discordância, o que acaba por reafirmar que as decisões normativas já foram discutidas em algum momento anterior e, neste momento, busca-se espalhar essas ideias para o público (Botzem, 2014).

Complementando tal ideia, podemos criticar o momento em que as consultas são realizadas. Na maioria dos casos, a consulta formal ocorre em um momento já adiantado do processo normativo, em que as decisões já estão praticamente tomadas e as discussões, pesquisas e embasamentos teóricos já foram desenvolvidos. Isso leva a crer que o board, nesse processo de consulta, não busca uma abertura quando ao conteúdo da norma, mas sim uma validação das decisões tomadas (Botzem, 2014), indicando o uso da figura de linguagem conhecida como prolepse, em que há uma antecipação e preparação para argumentações futuras que possam vir a acontecer, mais comumente quando se quer antecipar algo que está contra o mainstream. "Isso coloca o IASB em uma posição forte ao poder escrever sua própria narrativa (Black, 2008) dos eventos, por exemplo, dando justificativas ex-post para suas decisões que não necessariamente têm semelhança com o processo atual" (Pelger \& Spieß, 2017).

Já que muitas das regras processuais do IASB são baseadas nas do regulador norteamericano (Gallhofer \& Haslam, 2007; Hopper et al., 2017), esse pensamento da prolepse também é dividido quando se analisa o FASB. Young (2003) argumenta que o processo de consulta por meio de comment letters na verdade funciona como um armamento do normatizador ao proporcionar os argumentos para que o board possa trabalhar de modo a desacreditá-los a tempo. A forma utilizada é já inserir nas normas argumentos que invalidem as opiniões dissidentes e, assim, valorizar as decisões tomadas pelo board. 
Portanto, o conceito de justiça em um processo de consulta se mostra um tanto quanto ilusório (Erb \& Pelger, 2015). Para ser justo, deveríamos tomar algumas premissas, como: (i) as negociações deve ser abertas e não devem existir sessões fechadas; (ii) deve envolver a barganha sempre por envolvidos com habilidades semelhantes; (iii) deve envolver posições de poder semelhantes; (iv) todos os lados devem possuir as mesmas informações; ( $v$ ) deve envolver os assuntos que são relevantes para todos os envolvidos; ( $v i)$ deve ocorrer sob normas que já foram negociadas entre todas as partes anteriormente (Lincoln \& Guba, 1986).

Em pesquisa de natureza crítica, Palea (2015) argumenta que, apesar da existência formal do processo de consulta e da transparência dada a ele, a efetividade dessa consulta tende a não ser justa e de acordo com as premissas elencadas anteriormente, à medida que é impossível para alguns stakeholders fazerem parte do processo de forma igualitária. Para a autora, a decisão final é do board e há uma tendência a valorização de opiniões do FASB e outros grupos importantes, priorizando a convergência acima da qualidade e da opinião da maior parte dos stakeholders (Palea, 2015).

Complementando tal argumento, e tendo como base tanto um paradigma mais positivista quanto um paradigma crítico, há a demonstração de que o processo de consulta realmente não é justo (real e percebido) (Bamber \& McMeeking, 2016) e há priorização de determinados stakeholders (Bamber \& McMeeking, 2016; Cortese et al., 2010; Fogarty, 1994; Georgiou, 2010; Hewa et al., 2018; Orens et al., 2011; Ram \& Newberry, 2013), assim como de atores de determinadas jurisdições (Bamber \& McMeeking, 2016; Hopper et al., 2017; Jorissen, Lybaert, Orens, \& van der Tas, 2013; Zeff, 2002).

A participação de stakeholders, portanto, além de ser ponto central para a aceitação do board (Botzem, 2014; Botzem \& Quack, 2009), também é o maior ponto de crítica quando se fala em processo de consulta (J. Brown \& Dillard, 2015). A partir do momento que entendemos que a participação realmente não é para todos, devemos levantar dois questionamentos: quem são os que participam? E quem são os que não participam? A primeira vista, podemos entender que os que participam são representantes de grandes empresas de auditoria e multinacionais (em sua maioria), sendo portanto, que esses representam, na realidade, a visão dos shareholders (apesar de serem considerados stakeholders quando se fala em processo normativo), e não devemos esquecer que os resultados das decisões normativas impactam diretamente seus lucros e distribuições (J. Brown \& Dillard, 2015).

Acerca da segunda pergunta, ela é crucial para a compreensão do fenômeno por representar uma redução na possibilidade de visão crítica por meio de perspectivas alternativas (J. Brown \& Dillard, 2015). Os que não participam também trazem capacidade informativa. 
Pode ser porque não se veja utilidade ou impacto direto daquela norma na sua empresa ou dia a dia, ou pode ser por impossibilidade de participação imposta principalmente pelas barreiras de acesso que são criadas quando se exige um expertise técnico diferenciado para que seus argumentos realmente sejam objetivo de consideração por parte do board. Essa não participação acaba por limitar as opções alternativas àquele tratamento e deixa evidente apenas a opção já apresentada e desejada pelo regulador e grandes entidades internacionais, ou seja, mesmo em um processo de consulta, há uma exclusão das perspectivas alternativas e um reforço da perspectiva dominante, sendo o discurso criado majoritariamente pelo normatizador (J. Brown \& Dillard, 2015).

Com base nessas críticas, a noção de justiça no processo de consulta, portanto, é amplamente criticada. Em resumo, não se pode dizer que é justo um procedimento de consulta que envolve as mais diversas barreiras, como: custos, tempo, ausência de votos por parte do público e conhecimentos técnico e linguísticos (Burlaud \& Colasse, 2011). A maioria das reuniões é realizada em países do norte e desenvolvidos, o que limita a participação dos demais países, tanto por questões de recursos, como por questões de acesso e linguísticas (Dingwerth, 2007; Hopper et al., 2017). Isso faz com que os normativos apresentem sempre um viés para economias que possuem um mercado de capitais mais desenvolvido (financialização), o que, inclusive, chega a limitar a aplicação de suas normas em países que não possuam características similares (Botzem \& Quack, 2009).

A completude, apesar de crescente, também é um conceito abstrato que funciona de forma simbólica na normatização contábil (Hopper et al., 2017; Weetman, 2001). De forma semelhante ao IASB, o GRI também é uma entidade privada transnacional que busca uma regulação dentro da contabilidade e busca atingir aceitação para aplicação de seus normativos. Além disso, o órgão também se ampara em uma lógica de participação ativa dos atores, onde argumenta que busca agregar a participação global de diversos stakeholders nos diversos níveis de seu processo normativo. O órgão ainda caracteriza seu processo como uma filosofia da inclusão (Dingwerth, 2007).

Assim como o IASB, esse processo possui qualidades e falhas. Dingwerth (2007) realiza uma pesquisa com o órgão e apresenta que, apesar de existir uma ampla participação de atores, a caracterização dada pelo GRI aos atores e, mais especificamente, aos stakeholders, é um tanto quanto limitada e arbitrária. A ideia é que participam do processo aqueles atores que possuem alguma forma de interesse direto naquela norma. Isso quer dizer que muitas vezes não temos a participação de membros da sociedade civil, associações profissionais e setoriais, sindicatos, 
empresas de menor porte, analistas financeiros e, também, acadêmicos, salvo aqueles com mais interesse em questões internacionais (Burlaud \& Colasse, 2011; Malsch, Gendron, \& Grazzini, 2011). Porém, mesmo não sendo "experts", esses atores devem ter voz e participação, uma vez que também são impactados pelas decisões (Dingwerth, 2007). Devemos entender que, conceder o "direito a participar" não é efetivamente melhorar a participação.

\subsubsection{Accountability}

O termo accountability se faz presente e institucionalizado nas mais diversas áreas do conhecimento e impacta vários sujeitos, instituições e organizações sociais (Black, 2008). Apesar dessa presença, seus conceitos também são constantemente reinventados e atualizados, assim como suas métricas de análise e mensuração. Mesmo com essa constante reinvenção, não há grandes desacordos com relação ao que se deseja e espera de um processo com accountability (Young \& Oakes, 2009), caracterizando-se, assim, como um significante vazio (Glynos \& Howarth, 2007; Howarth, 2000; Laclau, 2007b; Laclau \& Mouffe, 1985; Torfing, 1999).

Em resumo, podemos dizer que a accountability funciona como uma relação em que "se espera que uma parte preste contas de suas ações para outras partes" (P. F. Williams, 1987, p. 170), representando uma “obrigação de um agente (a uma pessoa ou grupo) de reportar suas atividades (explicar e justificar as condutas) e encarar as consequências (custos) que podem ser impostos pela pessoa ou pelo grupo” (A. J. Richardson \& Eberlein, 2011, p. 225).

A execução da accountability, de forma sintética e considerando um contexto de normatização transnacional, seria vista como a relação entre diferentes atores, em que um dos atores presta contas ao outro, que pode aceitar ou não tal informação. Ter accountability, portanto, seria "construir e apresentar uma narrativa de eventos ou ações passadas" (Black, 2008, p. 151). Apesar de existir no IASB, ela pode ser vista como limitada (A. J. Richardson \& Eberlein, 2011).

$\mathrm{Na}$ GRI, por exemplo, a transparência é vista como uma ferramenta prévia à accountability, ou seja, é condição necessária para que se possa haver uma accountability como ferramenta de controle de qualidade de um processo normativo (Dingwerth, 2007). Esse fenômeno é também visto em outras esferas da regulação da contabilidade, sendo a accountability vista como dependente da transparência para representar o modo de tomada de decisão mais "apropriado" (A. J. Richardson \& Eberlein, 2011). 
Normalmente a tomada de decisões e aplicação da accountability envolve a posição de que um sujeito exerce o poder de controle sobre o outro, podendo exclui-lo do processo e substituindo-o por outro. No contexto da regulação internacional tal fenômeno se torna mais difícil, uma vez que normalmente a aceitação dos membros Estado é feita mediante leis, e os atores de maior poder também fazem parte do board do IASB. Além disso, atualmente não há outro organismo internacional que realiza o mesmo trabalho do IASB e que busca tal posição (Dye \& Sunder, 2001; Hewa et al., 2018).

Devido a essa aceitação da retórica e da vacuidade do significante, a accountability também virou um termo institucionalizado nos campos de regulação e de regimes internacionais como sendo representante de uma boa governança (Mehrpouya \& Salles-Djelic, 2019).

[...] as estruturas políticas da accountability são fluidas e contestáveis; hierarquias não são rígidas (Djelic \& Sahlin-Andersson, 2006). Atores e alianças estão permanentemente em movimento, programas são constantemente redefinidos, como se estivesse em uma 'esteira da accountability' interminável (Boström \& Garsten, 2008, p. 242). (Mehrpouya \& Salles-Djelic, 2019, p. 14).

Uma das questões que são base para a normatização baseada em soft-law é levantada com relação aos principais atores e suas formas de prestação de contas. Nas organizações transnacionais, os detalhamentos de estruturas e de processos internos de tomada de decisões se fazem de interesse para diversos agentes externos (Black, 2008). Apesar da variedade de atores, as formas de accountability nessas organizações tendem a se apresentar em forma de monólogo, em que o agente transnacional "informa" os demais sem a presença de uma troca de informações efetiva entre os atores. Apenas entendendo as práticas de accountability de forma dialógica é que esse princípio poderia ser eficazmente aplicado (J. Brown \& Dillard, 2015).

Para Hopper et al. ( 2017) , a accountability das entidades transnacionais é "hipócrita" (p. 139) por representar um problema estrutural. Como se pode apresentar accountability quando se diz que o interesse é internacional, porém há um privilégio dos critérios dos países do norte? Como representar os mais diversos atores quando o financiamento é realizado por grandes empresas da auditoria? (Hopper et al., 2017). Apesar de a comunidade que possui influência no processo normativo ser considerada restrita, suas ideias possuem o poder de serem difundidas e aplicadas globalmente (Botzem, 2014).

Assim, devemos questionar as relações entre os estados, a economia e os sujeitos envolvidos: Quem governa? Quem está responsável pela emissão das normas? Quem está responsável pela aprovação das normas? O que pode ser observado do processo? O processo possui participação ativa? Quem possui poder nesse processo? (W. Brown, 2015), porém antes de discutirmos as perguntas básicas da accountability, devemos discutir o que as entidades 
transnacionais realizam e como respondem para se ter e justificar seus processos com accountability (Black, 2008).

Esses questionamentos podem ser observados por meio da desconstrução de discursos naturalizados sobre o funcionamento da contabilidade, ou seja, pela visão não pragmática dos fenômenos sociais que envolvem o contexto da regulação e a prestação de contas desta mesma regulação (Critchley, Derrida, Laclau, \& Rorty, 1996).

A visão e o discurso da contabilidade como sendo técnica, por exemplo, pode mascarar as formas de apresentação dos critérios de accountability. Isso porque há envolvimento direto nos processos de elaboração de normas se vistos como técnicos ou políticos. Os vistos como técnicos tendem a apresentar critérios de mensuração da accountability mais objetivos, por meio de informações padronizadas e verificáveis. Esse seria o caso de uma análise formal dos passos elencados no due process e os momentos em que deveria haver algum procedimento a ser realizado com objetivos a prestar contas aos envolvidos. Porém o processo normativo envolve diversos outros aspectos, como votações, financiamento, formação de agenda, tempestividade em posicionamentos emergenciais, composição de membros, assim como diversos aspectos de relacionamentos com terceiros (Gallhofer \& Haslam, 2007; Young \& Oakes, 2009).

\subsection{Pesquisas críticas e pós-estruturalistas sobre Regulação}

Como está sendo (e será) discutido ao longo de toda esta tese, as pesquisas críticas mostram um cenário distinto que tem mais relação com o grupo de pesquisadores que negam a possibilidade de separar a contabilidade da questão social, política, moral e ética (Young, 2003).

As pesquisas que se utilizam de paradigmas críticos ainda são minoria na área contábil. Nesta área, as mais comuns envolvem o tema de sustentabilidade (Voss, 2016; Warren et al., 2019). Além das publicações em journals, que são predominantemente positivistas, os estudos críticos também são minoria em nossos programas de pós-graduação em contabilidade. Isso pode ocorrer devido a diversos fatores, que não explorarei nessa tese, mas ressalto a importância de pontuar que pesquisas críticas e eventos dessa natureza já foram e estão sendo realizadas nos programas stricto sensu.

Nesta própria casa (USP) e Programa (PPGCC) já foram defendidas teses com a aplicação da mesma teoria aplicada na presente tese (Laclau \& Mouffe, 1985) na área gerencial (Nascimento, 2011), na área de educação e pesquisa em contabilidade (Aragão, 2016) e na área de contabilidade socioambiental (Voss, 2016). Há, também, pesquisa crítica na área de 
regulação contábil (Homero Junior, 2018), porém, diferentemente desta, com aplicação da teoria e de conceitos de Bourdieu.

As pesquisas críticas sobre regulação contábil são importantes, entre outros aspectos, para demonstrar a compreensão da contabilidade como mecanismo de controle social (Tinker, 1984). Esse poder dado à contabilidade, para Baker e Bettner (1997, p. 305), serve como ferramenta para "instituir valores, sustentar e legitimar mitos, mascarar conflitos e promover uma autoperpetuação da ordem”. A argumentação é de que a teoria funcionalista não cabe na explicação política dos fenômenos de regulação, uma vez que entendem a objetividade das estruturas sociais, o que leva à necessidade de compreensões sociológicas mais modernas (Fogarty, 1994).

Especificamente, as pesquisas pós-estruturalistas tendem a argumentar que o atual estágio da contabilidade, incluindo nele o modo de regulação das normas, não é algo sagrado e dado como certo na sociedade. Esse estágio é resultado de batalhas históricas que envolvem instrumentos de poder e criação de discursos que direcionam o funcionamento das instituições, da profissão e da própria área (Macintosh, 2002)

Considerando que as entidades transnacionais "não são tão transnacionais, nem tão privadas, e não tão próxima da governança descrita por muitos” (Graz \& Nölke, 2008, p. 242), ou seja, possuem diversas pontos de crítica com relação às suas reais independências, financiamentos e necessidade de apoio público, podemos entender que as pesquisas tendem a demonstrar seus lados de futuro sucesso. Entretanto, devemos observar também suas falhas, com uma visão mais crítica, de forma a contribuir ao debate acadêmico acerca dos limites da transnacionalidade e das estratégias para se manter tal hegemonia (Graz \& Nölke, 2008).

Apesar de uma constante e antiga alegação por parte dos reguladores contábeis de que suas normas apenas representam "as coisas como elas são" de forma neutra tanto pelo mensurador como da medida (Hines, 1991), há toda uma literatura crítica na contabilidade que procura demonstrar como a regulação, a contabilidade e a auditoria influenciam a (e são influenciadas pela) realidade organizacional (Bengtsson, 2011; Black, 2008; Botzem, 2012; J. Brown \& Dillard, 2015; Chapman et al., 2009; Erb \& Pelger, 2015; Hopwood, 1994; Hopwood \& Miller, 1994; Madsen, 2013; Palea, 2015; Warren et al., 2019; Young, 2003, 2014).

As normas contábeis e seus devidos processos de edição, além de procurarem agir com um discurso de comparabilidade internacional em decorrência do processo de globalização (Durocher \& Gendron, 2011; Hopper et al., 2017), devem ser entendidas como um "sistema de informações socialmente construídas” (Botzem \& Dobusch, 2012, p. 745) e, portanto, devem 
ser analisadas com uma base sociológica pertinente e relativa às suas práticas sociais (Chapman et al., 2009; Gallhofer \& Haslam, 2007; Hopwood \& Miller, 1994), utilizando-se não somente de teorias e racionais econômicos neoliberais, mas envolvendo uma gama de outras bases teóricas, como políticas, internacionais e sociais (Baudot, 2014; Chua \& Taylor, 2008; Posner, 2010; Warren et al., 2019).

Aplicando o conhecimento à tese, a regulação contábil é alvo de pesquisas com a utilização de teorias mais críticas quando se fala com relação aos órgãos que estão no topo da normatização internacional e, também, suas missões e seus produtos (Bengtsson, 2011; Botzem, 2008, 2012, 2014; Botzem \& Quack, 2009; Erb \& Pelger, 2015; Hoffmann \& Zülch, 2014; Müller, 2014; Pelger, 2016; Pelger \& Spieß, 2017; Rodrigues \& Craig, 2007; Warren et al., 2019; Young, 1994, 1996, 2003, 2006, 2014; Young \& Mouck, 1996; Young \& Williams, 2010).

A análise da missão do IASB, por exemplo, é criticada quando o board afirma que suas normas são desenvolvidas para o "interesse público", em que há a demonstração de que o interesse público não está nem próximo de ser o objetivo principal, uma vez que os atores que possuem recursos para participar da normatização contábil normalmente não têm suas opiniões ouvidas, ou seja, a missão do board seria menos retórica se deixasse claro o "interesse privado" (Botzem \& Quack, 2009; Gallhofer \& Haslam, 2007).

Considerando que já na missão e na estrutura do órgão há críticas, adentro mais ao processo normativo em si. O processo normativo também já foi analisado tomando como base os conceitos, com uma base crítica, de racionalidade e poder de Flyvbjerg (1998, 2001). O estudo se utilizou dos documentos públicos de um processo normativo, também conjunto entre FASB e IASB, e como houve a evolução até a marginalização do conceito de stewardship e as medidas políticas inseridas nos discursos e na mudança de tal conceito de forma a agradar os agentes mais poderosos. Demonstra, portanto, que os atores não possuem o poder que aparentam ter no discurso do órgão e, no final, a política prevalece em nome da sobrevivência do próprio normatizador (Pelger, 2016).

Esse ponto leva a necessidade de análises processuais que possam explicar como e por qual motivo aquela norma ficou de determinada forma, mostrando que é igualmente importante, portanto, a análise dos processos normativos e não somente dos conteúdos finais.

Uma das lógicas processuais é o discurso da dualidade política versus neutra/técnica que é discutida com viés crítico em Macintosh (2002), com aplicação ao papel dos Princípios Contábeis Geralmente Aceitos (nomenclatura norte-americana para os princípios da contabilidade). Com base em uma visão pós-estruturalista por meio de uma análise genealógica, 
os autores concluem que, embora a contabilidade esteja presa a tantos princípios, normas, regras, convenções, postulados e técnicas, "muito da contabilidade hoje é resultado de relações de poder e não uma questão de neutralidade que provê orientações para o reporte verdadeiro" (Macintosh, 2002, p. 121), sendo o posicionamento do profissional contábil limitado ao resultado final, mas com baixa atenção ao seu contexto geral.

Com isso, o autor procura discutir sobre como a contabilidade está além da mera aplicação dessas regras e princípios que é feita pelo profissional da área, sendo essa aplicação construída por meio de um discurso tecnicista (Porter, 2005). O espelhamento objetivo de conceitos contábeis, como por exemplo o conceito de "receita líquida", tende a ser mascarado como um “fato contábil” simples, já que a história de criação desse conceito não foi amplamente discutida e apresentada. Com base nisso, o contador seria apenas um "faz tudo" (bricoleur, nos termos do autor), ou seja, aquele que recebe diretrizes do que fazer em uma espécie de manual, e simplesmente as aplica (Macintosh, 2002).

Entretanto, por meio de análise genealógica e histórica, percebe-se que a criação de conceitos contábeis não é tão técnica e deve ser apresentada de forma a expor o processo, já que este é (e tende a ser) longo, árduo, envolvendo uma jornada agonística de disputas, alianças e politização (Macintosh, 2002, p. 125). Apesar de um possível conhecimento imediato dessa história, a memória do aplicador e dos usuários é apagada com o passar do tempo, muito em virtude do interesse pela comparabilidade dos resultados anuais. Isso faz com que a parte política da normatização (que ocorreu em diversas fases históricas) seja frequentemente esquecida e as normas sejam aplicadas sem uma lembrança desse processo, levando a um entendimento de que a contabilidade é realmente técnica e objetiva.

Para que o contador possa produzir sentidos, algo inerente ao subjetivismo, ele não deve ser, então, um replicador de normas (bricoleur) que tende a demonstrar o lado possivelmente objetivo da profissão. Assim, para produzir valor, o profissional deve participar e se envolver em etapas subjetivas. Macintosh (2002) argumenta que esta etapa concerne ao processo de criação das tais normas, em que sentidos podem ser criados e discutidos de forma a incrementar o valor da profissão e do seu produto.

Para chegar a tais conclusões, também houve a análise de um processo específico, que foi o de regulação das empresas de "óleo e gás" norte americanas. Assim como nesta tese, o autor procurou por significantes vazios que compõem o processo de criação de significados na contabilidade, encontrando que neste setor a "receita líquida" funciona como significante vazio, uma vez que sempre é utilizada para justificativas das mais diversas naturezas de regulação, 
porém é uma linha que os usuários tendem a não utilizar, principalmente os analistas (Macintosh, 2002). O funcionamento desse significante é muito semelhante ao que ocorre na normatização de leasing, uma vez que se argumenta com base na informação que é necessária para os analistas e investidores, sendo defendido que eles se preocupam com a capitalização do arrendamento e da qualidade da informação (IASB, 2016d), porém será que essa questão realmente possui "sentido" ou funciona como um significante vazio que agrega diferentes demandas, uma vez que estudos mostram que para os analistas a mudança na normatização não obrigatoriamente incorpora valor (no sentido econômico) às demonstrações? (Allini et al., 2018; Young, 2006).

Há, também, pesquisa crítica, de natureza pós-estruturalista e com a aplicação dos conceitos teóricos de "condensação, deslocamento e sobredeterminação" advindos da teoria do discurso de Laclau e Mouffe (1985) para análise dessa tecnicidade. A premissa da pesquisa é que devemos entender o processo de regulação sendo complexo e arbitrário e, por consequência, ele não pode ser técnico e objetivo (Warren et al., 2019). Como é necessário para a aplicação desses conceitos, Warren et al. (2019) realizam estudo empírico do caso da normatização de PME (Pequenas e Médias Empresas) pelo IASB e analisam discursos dos documentos internos e de entrevistas. Após isso, os autores reconstroem a narrativa do processo, focando em três momentos considerados como centrais na discussão normativa: definição de PME, título da norma, e publicação de um guia normativo.

Ao focar em três pontos considerados polêmicos e com o auxílio dos documentos que mostram as discussões internas, os autores foram capazes de descontruir o discurso final do board e mostrar suas inconsistências e conflitos. Com isso demonstram que o processo de tomada de decisões do IASB não é tão técnico como alegam e que a política e a barganha possuem mais força na normatização contábil do que critérios estritamente técnicos. Isso está de acordo com o comportamento esperado de organizações transnacionais, uma vez que elas dependem do apoio público para se manterem hegemônicas em suas atribuições (Warren et al., 2019). Por fim, os autores chamam os pesquisadores a desafiarem - nos mais diversos projetos, teorias e com diferentes métodos - esse discurso de tecnicidade defendido pelo board.

Em uma mesma linha de desconstrução dos discursos do board, Erb e Pelger (2015) analisam as inconsistências "técnicas" no discurso de mudança da característica qualitativa da confiabilidade para a representação fiel. Os autores demonstram, também por meio da narrativa histórica, o poder que membros do board e do staff possuem no processo de tomada de decisões, mesmo quando seus argumentos não são "técnicos e objetivos” (Erb \& Pelger, 2015). 
Além destas pesquisas, cabe ressaltar o trabalho da pesquisadora norte-americana Joni J. Young ${ }^{4}$ que será alvo das discussões no restante desta seção. Em Young (2003), a autora toma como premissa que o processo normativo contábil deve ser entendido como um exercício de persuasão, principalmente em decorrência da ambiguidade e da fluidez das categorias e classificações contábeis e da controvérsia técnico-política do processo em si. Com base nisso, apresenta como objetivo demonstrar os esforços de persuasão feitos pelo FASB em pronunciamentos específicos. A autora complementa que os textos das normas são formados por um ponto de vista muito específico do órgão que as edita, levando em consideração suas próprias conclusões sobre os eventos e fatos que ocorreram durante o processo normativo (Young, 2003).

Observa-se, aqui, semelhança com a presente tese no que concerne ao direcionamento da análise. A autora procura apresentar pontos no discurso que apresentam essa "estratégia argumentativa/persuasiva" como forma de mostrar que suas normas são as melhores possíveis na opinião do próprio normatizador. Não se preocupa, no artigo, em demonstrar momentos de maior neutralidade ou menor necessidade argumentativa. Apesar disso, a autora analisa momentos de silêncio como sendo um argumento.

Young (2003) também fala em aderência/consistência nos seus argumentos ao afirmar que o FASB se prende a uma aderência (nesse caso, formal) ao due process como forma de garantir o status de emissora de "boas" normas. Essa consistência é garantida por meio de uma descrição meticulosa dos documentos emitidos, prazos para comentários, número de comentários, número de apresentações públicas, task forces criadas e entidades consultadas. Para a autora, essa aderência e sua consequente descrição por parte do FASB resulta em uma estratégia retórica de argumentação com a finalidade de demonstrar que segue passos necessários que garantem a emissão de normas de qualidade. Assim, pode-se dizer que a autora não se prende à análise da consistência formal, mas também analisa a consistência dos argumentos do FASB (similar aos conceitos de (in)consistência e (in)completude utilizado na presente tese). Essa visão também é compartilhada em outros estudos de natureza crítica acerca da regulação (Burlaud \& Colasse, 2011; Hewa et al., 2018; A. J. Richardson, 2008; A. J. Richardson \& Eberlein, 2011; Wingard et al., 2016; Young, 2014).

\footnotetext{
${ }^{4}$ Joni J. Young é Full Professor da University of New Mexico. Além disso, é professora visitante da London School of Economics and Political Sciences (LSE) e da KPMG. Sua principal linha de pesquisa é em pesquisas críticas, com a aplicação de métodos de análise dos discursos e fundamentações linguísticas, relacionadas aos processos de regulação e normatização contábil e história da contabilidade, com publicações em diferentes journals, em sua maioria na Critical Perspectives on Accounting e Accounting, Organizations and Society.
} 
Outra premissa levada por Young (2003) é a de que a retórica é vista como um exercício de persuasão. Entende-se que, na escrita de um texto, não há como separar a forma argumentativa de seu autor, assim, a personalidade e as intenções do autor se passam por meio do texto decorrente das escolhas literárias utilizadas e outros efeitos advindos da argumentação. Além disso, deve-se considerar o público alvo daquele texto e o objetivo proposto pelo autor, que pode ser o de persuadir para a adoção de alguma política, aceitação de resultado de pesquisa e, até mesmo, implementação de normas contábeis (Young, 2003). Nesse sentido, a retórica pode ser vista como a "arte da persuasão, aquela que pode ser usada para garantir a aderência de outros a uma perspectiva particular" (Young, 2003, p. 624), sendo ela utilizada como forma de convencer o leitor das intenções e perspectivas do autor.

Outras pesquisas já analisaram a retórica no contexto contábil, porém em situações distintas, como a forma com a qual os pesquisadores da área tentam persuadir os leitores sobre a qualidade dos resultados, análise do comportamento das pessoas do mundo dos negócios e como a contabilidade pode ser útil para a economia (Arrington \& Schweiker, 1992; Gallhofer \& Haslam, 2007; Suddaby \& Greenwood, 2005). Apesar disso, uma quantidade mais restrita de pesquisas analisa como a utilização da retórica "contribui para a produção e alteração de práticas contábeis específicas” (Young, 2003, p. 623). Hoffmann e Zülch (2014), por exemplo, analisam a habilidade retórica para a aplicação de normas internacionais na Alemanha, porém em um cenário intrinsecamente político, e Young (2014) analisa a habilidade retórica em demonstrar uma separação da capacidade técnica aplicada ao ambiente do FASB.

Com base nisso, a autora demonstra aspectos argumentativos, os quais ela classifica como estratégias retóricas, que garantem ao normatizador certa qualidade. A qualidade, então, não é medida pela "pureza conceitual", mas sim por estratégias criadas, como: o próprio desenho das normas, argumentos de qualidade das normas, argumentos de que a realidade é um fator decisivo, argumentos de que usuários são autoridades de decisão, argumentos sobre consistência, evocação da prática profissional como justificativa e, em casos específicos, o silêncio se mostra como a melhor forma de argumento (Young, 2003). Madsen (2013) corrobora tal argumento ao afirmar que a qualidade, ao menos sob uma visão crítica, é amplamente simbólica, uma vez que não se pode mensurar tal conceito, até mesmo porque não há competidores do IASB no cenário global com emissão de normas que pudessem ser confrontadas (Dye \& Sunder, 2001; Sunder, 2011).

A mesma autora, em paper mais recente (Young, 2014), também se amparando em um paradigma crítico e no conceito de pureza de Douglas (1966), objetiva examinar os recursos retóricos utilizados para se construir uma fronteira entre os aspectos políticos e técnicos no 
processo de normatização do FASB que, conforme discuti, é uma das estratégias utilizadas pelos normatizadores para garantir credibilidade frente a seus participantes.

Para a autora, a forma como o órgão distingue o que é relevante do que é irrelevante para a normatização é justificada como uma decisão técnica, porém representa, na realidade, uma "caixa preta" emaranhada de decisões políticas e negociações. O processo decisório acaba sendo unilateral, o que privilegia os atores mais influentes. Esse argumento encontra consonância com Simmons (2001), ao analisar a posição americana no movimento de harmonização contábil.

Para argumentar tal ponto, Young (2014) selecionou um projeto considerado polêmico na história de normatização do órgão (pagamento baseado em ações) para análise dos discursos internos. Por meio da análise retórica, identificou a recorrente reafirmação do argumento da separação entre a capacidade técnica do órgão e a influência política sofrida, argumentando que a técnica gera qualidade e a política gera viés (discurso do board). Demonstra, também, retóricas de desmoralização dos discordantes e identificação do órgão como sendo detentor do conhecimento técnico contábil acima dos atores que optam por participar do processo.

Ela demonstra, por meio da desconstrução das práticas discursivas, as políticas de autoafirmação do regulador, a existência de grupos de interesses que pressionam os congressistas americanos, havendo um jogo político na aprovação de normas em que uns atores ganharão e outros perderão. Além disso, a autora levanta a discussão, com base nos resultados, sobre uma possível incoerência no discurso do normatizador quando analisados os discursos “apolíticos e anti-políticos", sendo encontradas inconsistências nas posições do órgão por meio dos argumentos apresentados (Young, 2014).

A autora possui outras pesquisas acerca do processo normativo, como Young (2006), que discute acerca da visão do FASB de utilizar o conceito naturalizado de usuários para garantir que suas propostas normativas sejam aceitas. Esse conceito não deveria ser naturalizado, pois o órgão se utiliza disso para construir as "necessidades normativas" com base nos interesses dos usuários (Young, 2006). O que se argumenta é que não é realidade no discurso o que se defende de que os interesses da regulação são para o benefício dos usuários, uma vez que eles, além de não possuírem influência significativa no processo, muitas vezes não necessitam das mudanças propostas.

A autora também possui estudo acerca da entrada na agenda dos reguladores, em especial o FASB (Young, 1994). Para ela, a entrada na agenda envolve inicialmente um discurso de criação da necessidade regulatória e, após isso, inclui na agenda como forma de 
construir os conceitos e regular da forma como o normatizador deseja. Essas decisões são resultantes de pensamentos institucionais (Young, 1996) como forma de construir e resolver problemas que antes não existiam, mas agora podem incorporar a institucionalização do órgão.

Todos esses pensamentos nas obras da autora ratificam o interesse da presente tese em demonstrar a necessidade de se compreender melhor as histórias e os discursos do processo de elaboração e normas e não somente as normas finais publicadas. Essa é uma ação vital para o crescimento da contabilidade como profissão e área de estudos que possui real influência nas questões sociais do dia a dia (Young \& Mouck, 1996). Por isso, a política deve fazer parte do nosso cotidiano e das nossas bases de pesquisa.

\section{$2.4 \quad$ Literatura sobre Leasing}

Para não perder a tempestividade das discussões sobre arrendamento optei, juntamente com meu orientador, pela publicação prévia de dois papers contendo revisões da literatura sobre o tema de leasing, um com um enfoque mais de revisão descritiva e de escopo (E. B. S. de Matos \& Murcia, 2019b) e outro com uma revisão de cunho mais bibliométrico (E. B. S. de Matos, Góis, Nasu, \& Murcia, 2020). Além destes, publicamos um paper de natureza mais objetiva, apresentando os critérios contábeis da IFRS 16 (E. B. S. de Matos \& Murcia, 2019a). Por esse motivo, esta seção acaba por ser mais reduzida e nela apresento apenas os principais achados dos estudos anteriores que publicamos e algumas referências recentes que apresentam a relação do arrendamento com o processo normativo internacional.

Além destas revisões que realizamos, podemos encontrar outras revisões da literatura sobre o tema, sempre com foco em alguma especificidade do arrendamento (Barone, Birt, \& Moya, 2014; Goodacre, 2003; Lipe, 2001; Morais, 2013; Spencer \& Webb, 2015). Ainda, por ser um tema amplamente debatido, diversos estudos com discussões conceituais foram realizados acerca das mudanças propostas (Bauman \& Francis, 2011; Biondi et al., 2011; De Martino, 2011; Dye, Glover, \& Sunder, 2015; Kabir \& Rahman, 2018; E. B. S. de Matos \& Murcia, 2019a; N. B. Matos \& Niyama, 2018).

Especificamente com relação à normatização, os estudos tendem a analisar algum dos passos que envolveram o processo normativo da IFRS 16, desde os documentos emitidos pelo G4+1 (The Group of Four Plus One) (Durocher \& Fortin, 2009; Largay III, 2001; Lipe, 2001; Monson, 2001; Ryan et al., 2001), passando pelo Discussion paper (Carmo et al., 2014), Exposure drafts (Biondi et al., 2011; Comiran \& Graham, 2016; Marcelino, Miguel, Rodrigues, \& Cariano, 2017; E. B. S. de Matos, 2013; E. B. S. de Matos \& Niyama, 2013) até a própria 
norma final (Morales-Díaz \& Zamora-Ramírez, 2018). Há, também, estudos que analisam mais de uma etapa do processo (Hussey, 2018; Mellado \& Parte, 2017).

Em sua ampla maioria, os estudos que analisam etapas do processo normativo são voltados para análises positivistas de comment letters, com a aplicação de modelos econométricos e que buscam analisar questões relacionadas com o lobbying ou grupos de interesses (E. B. S. de Matos \& Murcia, 2019b).

Nas revisões de literatura que publicamos antes desta tese, as amostras foram semelhantes, porém com enfoque de análise diferente. As amostras foram compostas pelos papers publicados nos 30 journals internacionais de contabilidade considerados como os mais relevantes de acordo com o ranking de Matherly e Shortridge (2009) e todos os periódicos nacionais que compõem a base da SPELL (Scientific Periodicals Electronic Library). No total, após a seleção por meio de palavras-chave, foram analisados 86 artigos (29 nacionais; 57 internacionais) publicados no período de 2000 a 2018 (E. B. S. de Matos et al., 2020; E. B. S. de Matos \& Murcia, 2019b).

Entre os resultados, observamos que a produção científica sobre leasing no campo da contabilidade apresentou relação direta com o processo normativo, sendo que os anos de maior produção foram aqueles em que os normatizadores apresentaram propostas de mudanças na norma original. Além disso, conforme pode ser observado na Tabela 1, a produção se concentra em três grandes grupos, sempre com enfoque mais positivista ou normativo: (i) Decisões/Ações da Administração (38\%); (ii) Avaliação de Riscos com base nas DFs (36\%); (iii) Normatização do arrendamento (26\%) (E. B. S. de Matos \& Murcia, 2019b).

Tabela 1 - Grupos de Subgrupos Temáticos da Produção Científica de Leasing

\begin{tabular}{|c|c|c|c|c|c|}
\hline Grupos & Quant & $\%$ & Subgrupos & Quant & $\%$ \\
\hline \multirow{4}{*}{$\begin{array}{l}\text { Normatização do } \\
\text { Arrendamento }\end{array}$} & \multirow{4}{*}{22} & \multirow{4}{*}{$26 \%$} & $\begin{array}{l}\text { Efeitos/Impactos e(ou) Descrição/Críticas } \\
\text { de mudanças normativas }\end{array}$ & 9 & $10 \%$ \\
\hline & & & Análise do processo normativo & 5 & $6 \%$ \\
\hline & & & Comparação de normas & 2 & $2 \%$ \\
\hline & & & Regras versus princípios & 6 & $7 \%$ \\
\hline \multirow{3}{*}{$\begin{array}{l}\text { Avaliação de Riscos } \\
\text { com base nas DFs; } \\
\text { Classificação dos } \\
\text { Arrendamentos }\end{array}$} & \multirow{3}{*}{31} & \multirow{3}{*}{$36 \%$} & $\begin{array}{l}\text { Usuários, risco e efeitos do (não) } \\
\text { reconhecimento do leasing }\end{array}$ & 14 & $16 \%$ \\
\hline & & & Qualidade de disclosure/auditoria & 10 & $12 \%$ \\
\hline & & & Indicadores contábeis e/ou covenants & 7 & $8 \%$ \\
\hline \multirow{3}{*}{$\begin{array}{l}\text { Decisões/Ações da } \\
\text { Administração }\end{array}$} & \multirow{3}{*}{33} & \multirow{3}{*}{$38 \%$} & Efeitos tributários & 10 & $12 \%$ \\
\hline & & & Gerenciamento de resultados/informações & 3 & $3 \%$ \\
\hline & & & $\begin{array}{l}\text { Determinantes. Decisão entre arrendamento } \\
\text { ou compra/venda. }\end{array}$ & 20 & $23 \%$ \\
\hline Total & 86 & $100 \%$ & Total & 86 & $100 \%$ \\
\hline
\end{tabular}

Fonte: Adaptado de Matos e Murcia (2019b) 
Entre esses grupos identificados, o que apresenta maior relação com o tema desta tese é o de "Normatização do arrendamento". Nesse grupo, os estudos se concentram em análises financeiras das mudanças propostas, análises do processo normativo em si, comparação descritiva das propostas e estudos que analisam efeitos e mudanças das regras e princípios (principalmente questões relacionadas com o off-balance das operações de acordo com a norma antiga - IAS 17).

Com base nesse primeiro artigo elaborado (E. B. S. de Matos \& Murcia, 2019b), observamos, durante a leitura dos papers, que mesmo as literaturas nacional e internacional apresentando semelhanças temáticas, havia uma diferença clara nas fundamentações e nos autores utilizados como bases teóricas. Por isso, surgiu a ideia de contribuir para essa literatura com o segundo paper (E. B. S. de Matos et al., 2020).

Esse segundo paper apresentou como objetivo "analisar, comparativamente, a utilização de citações e referências nos estudos nacionais e internacionais sobre arrendamento mercantil/leasing" (E. B. S. de Matos et al., 2020, p. 101). Com isso, tabulamos todas as citações utilizadas nos artigos, o que totalizou 2.889 referências. Com base na teoria normativa das citações (Merton, 1973) e com aplicação de técnicas bibliométricas acabamos constatando que realmente as referências utilizadas pela literatura nacional de leasing não se assemelham às utilizadas pela literatura internacional.

Se considerarmos que a literatura internacional se encontra em estágio mais avançado de desenvolvimento, constatamos que a literatura nacional pode estar embasando suas pesquisas em papers aparentemente de menor relevância científica, principalmente quando observamos que apenas três artigos nacionais utilizaram-se de alguma referência considerada "clássica do estado da arte" na literatura internacional.

Saindo dessa análise da literatura de leasing como um todo, cabe uma apresentação de uma pesquisa mais recente que alia a utilização de documentos do processo normativo de leasing como objeto de análise, uma visão baseada em uma epistemologia crítica e com a aplicação de técnicas de análise dos discursos (Stenka \& Jaworska, 2019). As autoras analisam as comment letters dos processos relacionados com o programa de normas do IASB que culminou na IFRS 16. Assim como nesta tese, o enfoque não é na norma e nos resultados contábeis dessa proposta, utilizando-se do processo dessa norma apenas como objeto de pesquisa. A pesquisa tem por objetivo verificar como o termo "usuários" é visto socialmente pelos diversos atores que participaram do processo (Stenka \& Jaworska, 2019).

Com base nessas análises empíricas, as autoras identificaram que não há padrão no uso do termo "usuários", corroborando argumentos de que este grupo é classificado de forma 
retórica (Young, 2003, 2006), uma vez que o termo é utilizado de forma genérica e como artificio para a validação de argumentos (Stenka \& Jaworska, 2019). Assim, não sabemos realmente quem são os "verdadeiros usuários", já que cada ator enxerga de forma diferente, inclusive internamente ao IASB. Esse conceito, portanto, não é fechado (Durocher \& Gendron, 2011; Suddaby \& Greenwood, 2005; Young, 2006). Utilizando a base teórica desta tese (Laclau \& Mouffe, 1985), o próprio conceito de usuários poderia ser visto como um significante vazio ou flutuante.

\subsection{Resumo do capítulo}

Como forma de demonstrar as lacunas na literatura e as contribuições que esta tese pode trazer para essa literatura sobre a normatização contábil, esta seção apresentou as principais características, discussões e pesquisas acerca do processo normativo na contabilidade, as principais estratégias utilizadas pelos normatizadores como forma de garantir a utilização e a aplicação de suas normas, com foco para o due process handbook, sendo este visto como uma das principais estratégias de normatização. Além disso, para argumentar acerca das literaturas similares, apresentei uma seção contendo pesquisas que envolvem o tema de normatização e com o foco crítico e pós-estruturalista. Por fim, também realizei uma breve discussão sobre pesquisas realizadas com o mesmo objeto de análise desta tese (leasing) e a mesma base metodológica (análise dos discursos).

A intenção é a de demonstrar que, apesar de ser de conhecimento que existe uma dualidade entre a técnica e a política na regulação contábil, sendo a técnica vista como algo bom para a elaboração de normas e a política como algo ruim e que traz viés (Young, 2014), as pesquisas positivistas tendem a aceitar essa visão técnica como premissa na visão do mundo social. Já nesta tese vejo a política como tal premissa base, sendo, portanto, necessária uma discussão crítica mais aprofundada acerca do tema.

Para isso, como apresentarei a seguir, utilizo-me da teoria pós-estruturalista do discurso como base da visão social (Laclau \& Mouffe, 1985) e procurei demonstrar as limitações teóricas que existem nas pesquisas atuais e como essa teoria poderia contribuir ao incremento da literatura, principalmente por meio da utilização do conceito de significantes vazios que pode ser incorporada na análise dos princípios do due process handbook, que são: transparência, consulta completa e justa e accountability. 
Esses princípios são, portanto, discutidos com base na sua aplicabilidade em diversos contextos e, especificamente na regulação contábil. Dessa forma, poderei demonstrar, utilizando-me dos achados já encontrados pela literatura e do conceito de significantes vazios, as limitações e inconsistências na aplicação desses princípios no processo do IASB, algo que pode contribuir tanto para a continuidade do debate acerca da política como ao debate acerca da própria visão do que seria qualidade no processo normativo. 


\section{VISÃO EPISTEMOLÓGICA}

A visão epistemológica de uma pesquisa deve apresentar estreita relação com premissas filosóficas sobre o conhecimento, o mundo empírico e a relação entre teoria e prática (Chua, 1986a; Crotty, 1998). Com base na ontologia social e na teoria do discurso aplicados nessa pesquisa, não se busca uma visão baseada no hipotético-dedutivismo ou no controle naturalístico (positivismo), mas sim um viés amparado em um paradigma crítico que possibilite compreensões mais subjetivas sobre os fenômenos empíricos em análise (Chua, 1986b; Laughlin, 1995).

Entendo que não existe o paradigma certo para cada pesquisa, mas sim aquele que se encaixa na forma de pensar de cada pesquisador, afinal, existe estreita relação entre a escolha do paradigma e a forma como o pesquisador vê o mundo (Burrell \& Morgan, 1979). Há pesquisadores que entendem não haver pontos positivos na aplicação positivista em cenários de discussões sociais e humanos, já que essa visão pressupõe uma ontologia de um cenário generalizável e objetivo a ser descoberto com base em uma teoria a ser testada (Baker \& Bettner, 1997). Aqui advogo que não julgo alguma base ontológica, epistemológica ou metodológica como superior à outra. Entendo, como Laughlin (1995), que todas possuem seus valores e qualidades mediante as premissas adotadas pelo pesquisador, assim como que nenhuma apresentará uma visão completa da realidade do cenário social, no caso: da contabilidade. Porém, com base no problema da presente tese, a visão crítica aqui aplicada, para mim, representa a melhor forma argumentativa da minha visão de mundo e social e, por não ser a mais tradicional na contabilidade, devemos acabar por explicar essa visão epistemológica de forma mais detalhada (Crotty, 1998).

\subsection{A Visão Crítica da (na) Pesquisa}

Ao enxergar a contabilidade como uma realidade socialmente construída e subjetiva (Baker \& Bettner, 1997), opto por uma abordagem diferente da naturalista na consecução da presente pesquisa. Portanto, utilizo-me da aplicação de um paradigma crítico (discutido nesta seção), mais especificamente, do pós-estruturalismo (próxima subseção).

Parto, nesta tese, da premissa de que não se faz necessário definir exatamente a pesquisa crítica, muito em decorrência da constante variação das fronteiras da pesquisa no tempo e no espaço, levando ao entendimento de que a pesquisa crítica não possui um sentido único 
(Gendron, 2018). Há diversas linhas de pensamento sobre a classificação epistemológica e ontológica das pesquisas, muitas delas até divergentes entre si.

Por exemplo, Burrell e Morgan (1979) não classificam a pesquisa como crítica ou não, mas sim discutem um framework para classificação de epistemologias em dois eixos, que são o da "objetividade/subjetividade" e o da "sociologia da mudança/sociologia da regulação". Com base nisso, as pesquisas são classificadas em quadrantes que possuem similaridades entre si.

Já Crotty (1998), também com origem na sociologia, não separa o processo de pesquisa em quadrantes por semelhança. Após descrever o processo ideal de pesquisa, que seria o de informar "epistemologia, perspectiva teórica, metodologia e métodos", o autor discute algumas perspectivas teóricas. Suas perspectivas teóricas, para outros autores, podem ser entendidas também como epistemologias. Porém, para Crotty (1998), a epistemologia é dividida entre objetivismo, subjetivismo e construcionismo. Em uma tentativa de classificação, poderíamos dizer que a pesquisa de natureza crítica estaria inserida tanto no construcionismo como no subjetivismo, sendo a lógica pós-estruturalista mais presente no construcionismo (Jørgensen \& Phillips, 2002). Apesar da diferença de compreensão geral da pesquisa, podemos ver semelhança com uma das categorias que formam os quadrantes de Burrell e Morgan (1979) no que se refere ao objetivismo e subjetivismo.

Já utilizando-me de pesquisadores da contabilidade, o fenômeno crítico é visto como uma alternativa ao funcionalismo instaurado nas pesquisas da área, possibilitando insights sobre um conhecimento menos regular na contabilidade (Roslender, 2006). É difícil encontrar definições claras sobre a pesquisa crítica nos autores da área de contabilidade, sendo que a maioria deles se embasa em pesquisadores da sociologia. Chua (1986) não define a pesquisa crítica, mas prefere discutir o mainstream na área contábil (positivismo e funcionalismo) com base nas principais características, visões da realidade social, do conhecimento e limitações. Em contraponto, a autora apresenta as mesmas categorias para a visão alternativa, nomeada por ela como "a alternativa crítica", ou seja, discute as principais características das diversas possibilidades de epistemologias, entre elas, a crítica.

Gendron (2018) também não define a pesquisa crítica por ele mesmo, mas baseia seus argumentos e desenvolvimentos em Laughlin (1999, p. 73), que a define como "uma compreensão crítica do papel dos processos, das práticas e da profissão contábil no funcionamento da sociedade e das organizações com a intenção de usar tal compreensão para procurar (quando apropriado) modificar tais processos, as práticas e a profissão". Ainda, podemos entender a pesquisa crítica como uma “inquietação acerca da adequação das 
descrições de contabilidade" que nos são apresentadas durante nossas carreiras, em que se fala que a contabilidade é uma "prática técnica que serve para espelhar alguma realidade econômica externa"(Young, 2018, p. 13).

Dillard (1991, p. 14) defende que todas as linhas de pesquisa crítica possuem como interesse "atingir um esclarecimento sobre a natureza humana, empoderamento e emancipação" de forma a interromper o ciclo de que um sistema dominante produz a contabilidade, reafirmando a contabilidade e assim mantendo-se como dominante.

Podemos perceber que muito da caracterização da pesquisa crítica em contabilidade se dá em contraponto ao que hoje é representado pelo positivismo e funcionalismo, ou seja, a pesquisa crítica em contabilidade seria o "anti-positivismo" descrito em Burrell e Morgan (1979). Assim, a pesquisa crítica é vista como a condução de um projeto "alternativo" que toma posições que fogem da objetividade (Parker \& Thomas, 2011).

Um potencial da pesquisa crítica é o de possibilitar uma maior reflexão com o objetivo de modificar pensamentos que estão enraizados em um discurso atual e que pode envolver indivíduos, grupos, organizações, políticos, governo e diversos outros atores. Assim, a pesquisa crítica nos oferece a possibilidade de procurar enxergar as situações pela visão de atores menos influentes, excluídos, minorias (Young, 2006, 2018). Essas visões podem ser chamadas de cenários alternativos ao que ocorreu na prática, sendo que esta prática normalmente é coordenada por instituições hegemônicas que produzem discursos, lógicas e ideologias que possuem efeito sobe diferentes participantes daquele ambiente (Gendron, 2018).

Com base nisso, devemos ter em mente que a pesquisa crítica possui uma função importante de não apenas seguir o status quo, mas sim de questioná-lo e demonstrar exclusões e como se chegou até aquela situação (Gendron, 2018; Young, 2018). A pesquisa crítica envolve questões sobre "dominação, exploração e contradições estruturais" (Chua, 1986a, p. 609). Análises históricas e não apenas de produtos finais se tornam grandes aliadas da contribuição dessa visão de pesquisa, pois o tempo colabora na demonstração de como um processo que sofreu alterações no seu desenvolvimento (Chua, 1986a; Young, 2003). Essa análise como processo possibilita a argumentação sobre questões retóricas, mitos e contradições argumentativas (Young, 2003) e, com isso, a demonstração dos objetivos desta tese em apresentar (in)consistências e (in)completudes na construção de discursos da regulação.

O projeto crítico na contabilidade tende a "desafiar a maneira como a contabilidade tem convenientemente privilegiado as questões técnicas e os conhecimentos em detrimento do pensamento de que a contabilidade não é criada em um vácuo social e que resulta de algo que 
pode ser altamente contestado" (Roslender, 2006, p. 247). Assim, intenta-se, no projeto crítico, que independentemente da teoria e metodologia utilizada, sejam explorados silenciamentos e lacunas que não são vistas pela pesquisa convencional (Cooper \& Hopper, 1987; Gallhofer \& Haslam, 2007).

A lógica crítica, como já argumentado, pode ser vista como uma base epistemológica. Young $(2018$, p. 13) realiza um contraponto interessante sobre a rigidez exigida em alguns momentos acerca dessa relação entre a epistemologia, metodologia e teoria ao afirmar que:

ser crítico não é sobre achar a teoria ou seguir a metodologia correta. Ao contrário, aqueles que produzem trabalhos críticos reconhecem a incompletude e a parcialidade de qualquer teoria ou método e as potenciais contribuições advindas da diversidade teórica e metodológica para o enriquecimento e à compreensão que podem emergir de agendas de pesquisa, assim como à contribuição para a formação de novas agendas de pesquisa (Young, 2018, p. 3).

A afirmação de Young (2018) vai ao encontro do pensamento geral desenvolvido em (Feyerabend, 2011), em que não há (nem deve haver) uma "camisa de força” nas escolhas epistemológicas, teóricas e, principalmente, metodológicas. Para o autor, deve haver uma congruência entre as lógicas gerais. A pesquisa deve estar repleta de escolhas por parte do autor, pois a realização de pesquisas sob um enfoque fixo que deve ser seguido sem modificações limita a capacidade contributiva dos trabalhos e, inclusive, de novas descobertas e argumentos (Feyerabend, 2011).

Assim, devemos aceitar a ausência de neutralidade na pesquisa científica (Feyerabend, 2011; Williams, 2014), pois ela já não existe desde a vida pregressa do pesquisador, ao seu histórico de estudos, à escolha do tema, ao método e às teorias, entre outros pontos que influenciam a consecução da pesquisa científica, ou seja, qualquer ponto que envolva socialização já caracteriza a inclusão de determinado viés (Chua, 1986a; Cox, 1981; Gendron, 2018; Williams, 2014). O que deve ser observado, portanto, é a congruência entre a lógica dos pensamentos a serem aplicados (Feyerabend, 2011). Mais sobre esse ponto será desenvolvido ao longo da tese, quando as demais premissas adotadas forem sendo apresentadas.

Como temos diferentes entendimentos da pesquisa crítica e suas subclassificações, optei não por definir, mas sim por apresentar as características gerais que levam uma pesquisa a ser crítica. A aparência de neutralidade das definições vem acompanhada, naturalmente, de declarações políticas e da promoção de interesses e visões particulares (Gendron, 2018). Podemos interpretar tal afirmação, de forma análoga, com relação aos objetivos da tese, uma vez que o órgão analisado realiza definições, das mais diversas no campo da contabilidade, alegando ser elas “técnicas”, "neutras” e não políticas (Laughlin \& Puxty, 1983; Young, 2014). 
Assim, vê-se a natureza desta pesquisa como crítica, também em decorrência do fato de procurar, sob um paradigma "alternativo", "encorajar formas de pensamento [...] que tomam posições, de alguma forma, contra a hegemonia das instituições consagradas" (Gendron, 2018, p. 2).

Por fim, podemos ver que apresentei diversas características das pesquisas críticas, mas ressalto que não obrigatoriamente uma pesquisa crítica deve apresentar todas essas características em conjunto. Pode haver maior ou menor foco em alguma abordagem ou característica, a critério do pesquisador e sempre tomando como base os objetivos da pesquisa.

\subsubsection{Pós-estruturalismo}

Como vimos anteriormente, há uma amplitude de abordagens críticas. Dentro do que poderia ser classificado como pesquisa crítica, podemos encontrar diversas subdivisões, como marxismo, pós-colonialismo, gênero, teoria crítica e pós-estruturalismo, entre outros (Lincoln, Lynham, \& Guba, 2018).

Classifico esta pesquisa como pós-estruturalista devido às características que apresentarei e por ser uma visão de pesquisa que apresenta constantemente questionamentos às estruturas e às tradições (J. Williams, 2013). Diversos pensadores são classificados como pósestruturalistas (ou possuem obras com esse viés), como Michel Foucault, Gilles Deleuze, Jacques Derrida, Jean-François Lyotard, Ernesto Laclau e Chantal Mouffe, entre outros (Glynos, Howarth, Norval, \& Speed, 2009; Howarth, 2010, 2013). Por mais que ideias desses autores permeiem a lógica da tese, optei pela aplicação da teoria do discurso desenvolvida por Laclau e Mouffe (Laclau \& Mouffe, 1985) como base para a visão dos fenômenos sob análise.

O pós-estruturalismo tem sua origem com base na virada linguística, na qual os pensadores entendem que a linguagem (em suas diversas formas) influencia as vidas e as organizações (Macintosh, 2002). Essa linguagem não se limita ao consumo de textos, mas de diferentes materiais, inclusive objetos imateriais, como imagens, signos e comportamentos, entre outros.

Mas qual o sentido da análise ligada à linguagem e contabilidade? Se entendemos a contabilidade como uma linguagem dos negócios, ou seja, uma ferramenta para transmissão de informações para a sociedade, as teorias (ou pensamentos) pós-estruturalistas se mostram como ferramentas consistentes para a compreensão e análise de fenômenos de forma a poder 
contribuir por meio de um "sentido" diferente (Macintosh, 2002). Além disso, não podemos esquecer que a própria contabilidade é uma ciência social.

Assim como no que seria a pesquisa crítica, não podemos dizer que há um entendimento pleno e consensual sobre o que seria o pós-estruturalismo (J. Williams, 2013). Inclusive, definições fixas e consensos não são consistentes com o próprio pensamento pós-estruturalista, que toma a contingência como premissa do funcionamento do mundo.

Mas o que faz essa pesquisa ser pós-estruturalista? Além do fato de utilizar-me de uma teoria do discurso claramente classificada como pós-marxista e pós-estruturalista pelos próprios autores (Jørgensen \& Phillips, 2002; Laclau \& Mouffe, 1985; Marchart, 2014; Norval, 2014), discuto premissas e características que são aplicáveis a essa linha de pensamento e à tese, conforme detalharei a seguir.

Consoante com a lógica crítica da pesquisa, no pós-estruturalismo não se estruturam argumentos que tomem como base essencialismo, determinismo e naturalismo (Dillard, 1991; J. Williams, 2013). Uma das diferenças para o estruturalismo é que no pós não se tem uma limitação à linguagem como subsidiária a uma estrutura fixa maior (Jørgensen \& Phillips, 2002; Macintosh, 2002; J. Williams, 2013) e sob essa ótica não se possui como objetivo principal analisar as grandes eventos e revoluções por meio de reflexões teóricas abstratas, mas sim uma ênfase em um mundo empírico e no conceito de mudanças, vinculado às aplicações práticas por meio de uma estrutura que varia o sentido em relação a outros sentidos (Jørgensen \& Phillips, 2002). Assim, há a possibilidade de desconstruir, transformar e mostrar exclusões presentes em discursos (J. Williams, 2013).

Nesse caso, devemos entender, com base na lógica pós-estruturalista, que a mudança aqui analisada da normatização de leasing não surgiu sem contexto. Ao aceitar que as questões contábeis não surgem naturalmente, compreendemos que as realidades são construídas como problemas pelos membros daquele espaço (Pelger \& Spieß, 2017) e o pós-estruturalismo surge para questionar tal discurso e mostrar que ele não surgiu sem contexto, mas sim como resultado humano (Macintosh, 2002). A linguagem, portanto, não é retroativa às mudanças, ou seja, não é apenas uma forma de comunicação. A linguagem é proativa. Por meio da mudança de discursos é que se realizam mudanças nos cenários sociais (Jørgensen \& Phillips, 2002).

Uma síntese que demonstra os principais pontos a serem discutidos aqui foi apresentada em Williams (2013, p. 222), ao afirmar que o pós-estruturalismo

\footnotetext{
trabalha dentro do que ele sucede, não para destruí-lo em nome de algo melhor e diferente, mas para trazer à tona sua máxima capacidade de abertura à mudança, em linha com seus valores mais altos. Essa abertura é política. É um convite a experimentar com novos modos de pensar a diferença e os limites do conhecimento. É também um desafio a todos os modos de pensar calcados em valores e identidades fixas. Nada permanece o mesmo ao longo do tempo ou dentro de limites espaciais, e, quando nos agarramos à
} 
ilusão dessa mesmice, nós impomos os valores de uma falsa identidade sobre o que difere dela. (J. Williams, 2013, p. 222)

Devemos acreditar, portanto, que nenhum conceito é absoluto (J. Williams, 2013), inclusive aqueles que são alvo de críticas, análises e conclusões. Essa é mais uma das premissas do pós-estruturalismo. Assim, não há uma rejeição por completo das coisas/conceitos, mas sim um esforço contínuo de desconstruir as verdades construídas por meio de discursos ao longo do tempo, desfazendo "seus postulados exclusivistas de verdade e pureza" característicos de um pensamento de "senso comum" (J. Williams, 2013, p. 23).

Podemos dizer, também, que por meio da desconstrução existente no pós-estruturalismo pesquisas e pesquisadores também são políticos (Dillard, 1991; Gendron, 2018), já que procuram, por meio de uma lógica de análise articulatória, analisar e desconstruir processos a fim de expô-los sob um diferente ângulo e, se possível, contribuir para seu desenvolvimento. Devemos entender, ainda, que esse desenvolvimento não suscita na criação de novos processos (mais evoluídos) que se configurem em uma nova norma, valores ou verdades. Isso seria contrastante exatamente com o que defendemos que é a ausência de uma verdade absoluta final e da presença da contingência em todas as instancias de análise (Derrida, 2013; Laclau \& Mouffe, 1985; J. Williams, 2013).

Muitas vezes as obras pós-estruturalistas são acompanhadas da palavra radical, mas seu sentido tende a ser mal interpretado. Primeiramente, devemos entender que o pósestruturalismo tende a ser uma epistemologia pós-marxista, mas não deixa de trabalhar com conceitos discutidos por Marx (Howarth, 2000, 2013; Jørgensen \& Phillips, 2002; Torfing, 1999; J. Williams, 2013). A ideia do radicalismo refere-se ao anseio de sobrevivência da democracia por parte dos pós-estruturalistas e, para isso, procuram compreender melhor fatos ligados ao poder e à dominação. Assim, a democracia (ou processos democráticos) deve estar sempre aberta para a transformação e revitalização, sendo esta a visão do radical, ou seja, relacionado com a abertura à mudança (J. Williams, 2013). Inclusive a mudança é o ponto central das análises de reconstrução que são foco dos pós-estruturalistas (Burke, 2012).

Mais uma das premissas comuns aos adeptos do pós-estruturalismo é a de que o pensamento vai além das proposições claramente articuladas por argumentos aparentemente válidos e consensuais. $\mathrm{O}$ argumento pode, ao mesmo tempo, ser claro e não definir o pensamento, ou seja, pode haver um argumento explícito, porém ele não demonstrar a prática articulatória por trás do que se objetiva como resultado final, o que leva o pensamento não a 
uma verdade, mas sim a um encadeamento de mudanças (Laclau \& Mouffe, 1985; J. Williams, 2013).

Com base nisso, as análises, principalmente aquelas mais ligadas à desconstrução de Derrida (Derrida, 2013), são estruturadas com base na coerência articulatória, procurando observar nos textos e nas ações os argumentos centrais e as derivantes desses argumentos, ou seja, uma análise das cadeias articulatórias (Laclau \& Mouffe, 1985) As cadeias articulatórias tendem a ser analisadas com um olhar para as exclusões, silenciamentos e vieses de naturalidade e neutralidade impostos, entre outros (Gallhofer \& Haslam, 2007; J. Williams, 2013). Assim, abandonamos a obrigação de encontrar políticas neutras, já que são vistas como inexistentes e utópicas e passamos a uma análise dos vieses propriamente ditos (Critchley et al., 1996).

Por mais que pareça ser uma epistemologia essencialista, esta crítica deve ser defendida como não real, uma vez que os pesquisadores tendem a justificar e demonstrar seus pontos de vista e compreensão com base em evidências empíricas sobre determinado assunto, mas deve ser ressaltada a natureza humanística de tal lógica, uma vez que não pode ser substituída por algoritmos ou fórmulas matemáticas (J. Williams, 2013).

Mais uma vez, o que seria esse pós-estruturalismo aplicado à contabilidade? Podemos dizer que uma das vantagens da lógica pós-estruturalista a ser utilizada na contabilidade é que ela pode trazer uma gama de discussões não tão presentes na área, porém que possuem grande relevância ao questionar pontos atualmente vistos como naturais e rotineiros, além de a contabilidade ser uma área que possui impacto e é útil para diferentes interações sociais (Macintosh, 2002). Nesse sentido, enxergo a contabilidade mais como uma ferramenta de poder do que como uma ferramenta de eficiência econômica (Wickramasinghe, 2006).

Se não começarmos aceitar a dimensão política e social na contabilidade, não evoluiremos como área, pois apenas aceitar a contabilidade como um conjunto de normas e procedimentos começa a apresentar limitações. Os pesquisadores pós-estruturalistas em contabilidade tendem a não consagrar o que já existe na área, mas sim trazer pontos de relevância que podem auxiliar no desenvolvimento e no conhecimento dos diversos impactos que a contabilidade apresenta e pode apresentar.

Por fim, concluo com um trecho que descreve tanto um aspecto do pós-estruturalismo como desta tese: "o pós-estruturalismo envolve uma crítica da política utópica e uma reflexão sobre como manter o desejo por um mundo melhor sem uma imagem fixa do que este mundo deveria ser" (J. Williams, 2013, p. 41). 


\subsection{A Busca pela Verdade}

Apesar da existência de certo pragmatismo em alguns momentos do pós-estruturalismo, muito em decorrência da análise prática de cenários específicos, há, nesta epistemologia, um compromisso com a visão crítica e construtivista, sem que haja compromisso com "quaisquer verdades definitivas" (J. Williams, 2013, p. 20).

Podemos dizer, portanto, que no pós-estruturalismo não há verdades absolutas ou resultados finais (Macintosh, 2002). Essa noção da verdade (absoluta) é inconsistente com o conceito de contingência (Laclau \& Mouffe, 1985) presente na teoria do discurso, isso porque há uma abertura constante ao novo por meio da crítica. A verdade, portanto, passa de uma análise absoluta para uma análise de regimes de verdades, que são relacionados com a coerência/consistência argumentativa e histórica das situações empíricas (Macintosh, 2002).

Mas então, se ciência e verdade normalmente caminham juntas, o que seria verdade para o pós-estruturalismo? A resposta é que, "para o pós-estruturalismo, a verdade se torna uma questão de perspectiva ao invés de uma ordem absoluta" (J. Williams, 2013, p. 31), por isso há, mais uma vez, a rejeição ao determinismo, ao objetivismo e ao naturalismo (Macintosh, 2002). O que se evita no pós-estruturalismo é exatamente essa verdade final, já que ela seria uma violência ao que se vê como pensamento crítico e oportunidades criativas (J. Williams, 2013).

Essa alegada verdade (completude) existente no mundo naturalista é a principal fonte de crítica, portanto, do pós-estruturalismo (e desta tese), pois acreditamos que em todas as instâncias há uma expressão de estilo por meio da individualidade. Esse estilo é o que diferencia os indivíduos e as instituições, que, em decorrência exatamente da particularidade, comunicam a individualidade "sem lhe impingir transparência absoluta, já que isso seria recair na ilusão da comunicação perfeita e das verdades universalmente acessíveis” (J. Williams, 2013, p. 31).

Por mais que se utilize de análises empíricas, algo presente em diversas linhas da ciência, o pós-estruturalismo se diferencia ao entender que a ciência não é encarregada por ser o juízo final de verdades, ou seja, por ser a palavra de verdade carregada por um método neutro. Portanto, toda verdade é subjetiva e passível de críticas e contingenciamento, o que contribui ao manter o caráter evolutivo e reformador das compreensões de mundo naturais da ciência (Laclau \& Mouffe, 1985; J. Williams, 2013). 


\subsection{Visão de Reflexividade}

Após discutirmos sobre pesquisa crítica, paradigma pós-estruturalista e a relação com as noções de verdade e ciência, falta apresentarmos algo com relação à reflexividade nessa pesquisa. Por mais que essa discussão esteja presente em toda a leitura do texto, reservei essa seção para uma apresentação clara de como esse conceito é visto na tese. A discussão sobre reflexividade também poderia estar situada nos procedimentos metodológicos, porém optei por apresentar aqui os conceitos gerais, já que se relacionam com toda a lógica paradigmática da pesquisa e as "aplicações" da reflexividade ao longo da tese.

A reflexividade é vista como "o processo de refletir criticamente o ser como um pesquisador" e seu papel como instrumento na pesquisa (Lincoln et al., 2018, p. 248). Para introduzir a questão de uma forma epistemológica, devemos entender que somos pesquisadores de um campo e, por estar nesse campo de estudos,

o analista de discursos está sempre ancorado em uma estrutura discursiva. Mesmo a análise dos discursos sendo afastada desses discursos e tentando mostrá-los 'como eles são', nesse tipo de teoria não há esperança de escapar desses discursos e mostrar a verdade pura, sendo a própria verdade uma construção discursiva. (Jørgensen \& Phillips, 2002, p. 49).

Devemos entender que a ciência é uma construção social que não é fixa, nem objetiva nem desvinculada dos indivíduos. A necessidade de conceituação da reflexividade, portanto, é mais presente em pesquisas que sigam uma epistemologia subjetivista e métodos qualitativos (Gibbs, 2007), sendo a reflexividade aqui nesta tese vista como a "relação entre conhecimento e sociedade e/ou pesquisador e sujeito, focando na reflexão contínua dos atores sociais em si mesmos e seu contexto social" (Giddens \& Sutton, 2017, p. 63).

Por isso, devemos levar em consideração as mais diversas perspectivas, tanto do objeto que se estuda como de quem estuda, mantendo, sempre que possível, clara a perspectiva em análise (Gadamer, 1997). Ao adotar a perspectiva crítica, entendo que a pesquisa e o pesquisador não devem ser vistos como neutros, nem mesmo os instrumentos por nós utilizados (Baker \& Bettner, 1997).

Por mais que não tenha como meta a mudança imediata do status quo, nas pesquisas críticas buscamos uma reflexão sobre tal situação, assim como formas de demonstrar que mudanças são necessárias (Dillard, 1991; Gendron, 2018). Assim, devemos saber que toda pesquisa possui a própria interpretação do pesquisador, que naturalmente é baseada nas suas próprias experiências, presas em seu tempo-espaço, assim como sua visão - decorrente de suas 
vivências e posições - de conceitos importantes, como minoria, poder e exclusão, entre outros (Cox, 1981).

Toda essa visão interpretativa e nossa forma de observar os fenômenos é decorrente da nossa história e de nossa constante socialização (Gendron, 2018) e devemos procurar ser o mais explícitos possíveis com relação a todos esses aspectos sociológicos, críticos, sociais e éticos que envolvem o processo da pesquisa (Glynos \& Howarth, 2007).

O meu pensamento como pesquisador surgiu em decorrência do fato de também compor uma minoria. Isso não quer dizer que apenas minorias podem ser pesquisadores críticos, mas auxilia no processo de "ressignificação" do senso comum (Roslender, 2006), principalmente ao trazer um "lugar de fala" para o pesquisador. Confesso que minha carreira foi construída com base em um pensamento hegemônico na contabilidade, com passagem por empresas de capital aberto e auditoria em big4. Foi apenas durante o doutorado que fui apresentado à pesquisa crítica como alternativa ao que é mais praticado na contabilidade e que eu, apesar de compreender, não desejava fazer nessa fase da minha vida.

Aplicando essa realidade à pesquisa, no decorrer do doutorado passei por uma ressignificação da contabilidade, o que me levou a tentar entender as práticas contábeis por meio de uma visão diferente da que é tradicionalmente pregada. Busquei uma reflexão crítica para o senso comum que era a aceitação das normas como ferramentas totalmente técnicas que trazem bons efeitos, como globalização, qualidade, comparabilidade e melhores resultados econômicos globais. Com isso, houve um empoderamento próprio por meio de uma compreensão reflexiva sobre as diferentes práticas ocorridas nos diversos cenários (Roslender, 2006) e passei a dar mais importância às vitórias sociais que às econômicas.

Por essa história, busquei novas epistemologias e me encontrei o pós-estruturalismo que, como disse anteriormente, não busca derivantes do objetivismo. Considero como objetividade a noção de que existe verdade e sentido nos objetos independentemente de fatores externos e da consciência (Crotty, 1998). Esse objetivismo seria assumir a existência de "relações de causalidade, livres de contexto podem ser especificadas por meio de observações sistemáticas" (Dillard, 1991, p. 11). Ao contrário, reconhecemos e devemos informar a parcialidade no papel crítico da análise (Macintosh, 2002; Roslender, 2006; J. Williams, 2013).

Essa parcialidade não deve ser vista como algo não científico, mas sim como a presença de interpretações contextuais de cada pesquisador, tomando como base todo esse histórico que podem influenciar suas visões de mundo e de pesquisa (Cox, 1981; Jackson, 2011). Ser parcial, portanto, não é um demérito da pesquisa pós-estruturalista. É exatamente o contrário. O que 
traz a qualidade é demonstrar onde essa parcialidade está presente e o que levou para o entendimento de cada interpretação (Gibbs, 2007).

Após esta exposição, fica claro que na pesquisa crítica existe uma participação mais ativa do pesquisador como sujeito daquele espaço. Negar essa participação seria fazer algo semelhante ao que critico no discurso do IASB, que é o de se promover por meio da aparente "neutralidade" da tecnicidade (nesse caso, da neutralidade do pesquisador enquanto analista). Isso, portanto, nos leva para uma discussão acerca da ausência, do "controle" ou da aceitação dos vieses na pesquisa. O posicionamento do pesquisador, principalmente ontológico, precisa ser apresentado. É sempre um risco fazer o diferente, porém, se não fizesse, não seria eu mesmo.

\subsection{Resumo do Capítulo}

O conceito do que é a regulação em contabilidade e quais são as suas funções podem ser vistos por meio de diversos paradigmas e epistemologias. Mais comumente, um paradigma de natureza funcionalista ou positivista - em que não se considera a existência de conflitos e há uma visão da sociedade como regulada (Burrell \& Morgan, 1979) - tende a observar a contabilidade como uma tecnologia (Dillard, 1991). Essa visão parte da premissa de que a capacidade técnica da área é desassociada de questões relacionadas com a moral e ética. Assim, sob esse paradigma, em essência, a contabilidade produz (e é produto de) um contexto livre de vieses, sendo essa tecnologia algo separado de influências políticas e culturais (Dillard, 1991; Gendron, 2018; Young, 2018).

Ao considerar que a visão dominante desta área do conhecimento é a funcionalista e positivista, podemos argumentar que a função crítica é vista como uma "oportunidade de romper o ciclo em que o sistema social dominante produz contabilidade, assim como a contabilidade reproduz e reifica o sistema social dominante" (Dillard, 1991, p. 9). O que argumento, portanto, é que a própria visão da contabilidade/regulação como sendo de natureza amplamente técnica é nada mais que uma construção social. Com base nisso, se não for analisada sob uma diferente ótica, inclusive sob um "espelho ideológico" distinto do funcionalista, diferentes realidades sociais nunca serão construídas e a contabilidade será sempre o mesmo sistema social hegemônico uma vez construído (Chua, 1986a; Dillard, 1991).

Mesmo havendo diversas vertentes de pesquisas e teorias críticas que podem ser aplicadas em estudos científicos, suas premissas podem ser vistas como complementares. Nesse sentido, podemos dizer que a ciência social crítica busca uma explicação de algo de modo que essa explicação seja: científica, crítica, prática e não-idealista (Dillard, 1991). Para isso, é 
necessário que tenhamos uma compreensão pluralista dos conceitos utilizados e de suas aplicações nos mais diversos cenários.

Nesta tese vejo a contabilidade e a regulação como construções sociais e políticas (Hopwood, 1994; Hopwood \& Miller, 1994). Mais especificamente, além de serem resultado de uma construção social, também geram um contexto social próprio (Tinker, 1984) derivante da criação de discursos. Para isso, me baseio no paradigma pós-estruturalista.

O paradigma pós-estruturalista nos permite analisar o contexto social de forma a procurar explicações aos fenômenos, porém enxergando que não existe apenas uma verdade. A verdade também é uma construção discursiva, sendo ela, portanto, contingente e situacional (Jørgensen \& Phillips, 2002). A missão é, portanto, a de demonstrar alternativas a visão naturalizada pelo status quo.

Para essas explicações, há a necessidade de se entender o próprio contexto social do pesquisador, já que este não é neutro no processo e as explicações são derivantes de suas experiências. Diversos fatores do pesquisador e de sua vida influenciam na análise e devem ser apresentados de forma a ser o mais justo possível com o leitor para que este possa compreender as explicações e entender a noção de verdade ali produzida (Cox, 1981; Guba \& Lincoln, 1994). 


\section{REFERENCIAL TEÓRICO E CONCEITUAL}

A visão de teoria, no pós-estruturalismo, é amplamente ligada à prática. Nesse sentido, muitas teorias emergem da própria prática, ou seja, não se espera uma teoria prévia existente que seja apresentada, aplicada a algum cenário e, após isso, testada. Isso explica a empiria dessa lógica de pensamento, uma vez que há conceitos base a serem utilizados, mas as considerações emergem das situações reais (J. Williams, 2013).

Em consonância com essa visão epistemológica, a teoria do discurso de Laclau e Mouffe (Laclau \& Mouffe, 1985) deve ser vista como uma teoria a ser pesquisada com base em uma abordagem orientada por problemas (problem-driven) (Shapiro, 2002). Podemos dizer que esse tipo de pesquisa "envolve construção de problemas particulares em contextos históricos específicos" (Glynos et al., 2009, p. 9). Na presente pesquisa, parte-se de uma problematização de um fenômeno empírico (processo normativo contábil aplicado à norma de leasing e a dicotomia discursiva criada da tecnicidade versus a política), porém, apesar de ser orientada por problemas, não há intenção de solução de problemas (Cox, 1981).

Para tanto, nesta seção serão apresentados os aspectos teóricos, conceituais e ontológicos que direcionarão a discussão dos problemas elencados na introdução da pesquisa. Nesse sentido, procuro sempre levar em consideração como a teoria do discurso, que contempla uma ampla gama de teorias críticas, pode colaborar à compreensão de como os discursos institucionais podem ser avaliados e criticados (Glynos et al., 2009).

Há uma dificuldade em caracterizar a teoria do discurso (Laclau \& Mouffe, 1985) exatamente como uma teoria, método ou framework (Glynos et al., 2009). O que podemos dizer é que os autores (Laclau \& Mouffe, 1985) buscam realizar um compêndio de conceitos que possuem premissas ontológicas e epistemológicas com congruência entre si (Torfing, 1999), tomando como base noções de diversos campos científicos, em especial sociologia, linguística, psicologia e ciência política (Howarth, 2000). Para isso, os autores norteiam seus pensamentos a se caracterizarem como pós-marxistas, tendo uma quebra do essencialismo marxista ao justificarem sua lógica em pensadores como Gramsci, Foucault, Derrida, Lacan, Žižek e Saussure, entre outros (Glynos \& Howarth, 2007).

Esse pós-marxismo se caracteriza muito em decorrência de os autores tomarem como base a crítica à noção de materialismo histórico e da divisão em classes fixas que correspondem aos proprietários, capitalistas e trabalhadores (Burke, 2012). Portanto, há uma crítica ao essencialismo marxista que reduz as relações sociais ao antagonismo do capital e trabalho, ou seja, em classes econômicas fixas (Mendonça \& Rodrigues, 2014; Norval, 2014). Para a teoria 
do discurso, os antagonismos não são presos a classes e envolvem um jogo social e político mais complexo (Glynos et al., 2009), conforme veremos nas seções a seguir.

\subsection{Visão Ontológica}

A visão ontológica deve ser compreendida como a base firme de uma abordagem teórica que será aplicada nas pesquisas. Nesse sentido, podemos dizer que a ontologia da teoria política do discurso concebida com base na obra de Laclau e Mouffe (1985) e obras posteriores desses autores é uma resposta às abordagens positivistas que são, pelos autores aqui utilizados, consideradas como essencialistas. Essa consideração se dá no fato de o positivismo priorizar análises com viés naturalista baseadas na causalidade em detrimento da compreensão mais ampla do fenômeno; e por considerar como premissa leis gerais (às vezes imutáveis) em detrimento do pensamento baseado na contingência (Burrell \& Morgan, 1979; Glynos et al., 2009).

Alguns autores classificam o próprio pós-estruturalismo como uma ontologia (Glynos \& Howarth, 2007). Entretanto, as premissas básicas do pós-estrutualismo, nesta tese, foram discutidas em uma seção específica dentro do capítulo da epistemologia (ver seção VISÃO EPISTEMOLÓGICA). Nesta seção de visão ontológica, dedico-me a discutir conceitos relacionados com a própria visão de mundo com base na teoria política do discurso (Laclau \& Mouffe, 1985).

A principal premissa da teoria pós estruturalista do discurso diz respeito ao político como categoria ontológica (Glynos et al., 2009; Mouffe, 2015). Além desta, entre as principais categorias ontológicas, estão: "a contingência, a precariedade, a indeterminação e o paradoxo" (Mendonça \& Rodrigues, 2014, p. 48), todos conceitos relacionados com a formação dos discursos e a visão dos fenômenos sociais. Portanto, discutirei cada um desses conceitos e, após isso, adentraremos na discussão da teoria propriamente dita.

$\mathrm{Na}$ teoria do discurso entendemos que todo sujeito (individual e coletivo) é político, assim como as ações por ele realizadas, isto porque política é uma categoria ontológica. Seguindo uma visão pós-gramsciana (Jørgensen \& Phillips, 2002), não podemos separar qualquer área do conhecimento social da política, sendo essa uma categoria central (Laclau, 1990). Portanto, não podemos separar as diversas áreas que esta tese pode abordar da visão política reforçando, ainda, que a análise do político não pode ser compreendida sob um paradigma positivista com visão baseada no racionalismo liberal (Mouffe, 2015). Por esse 
motivo, para a análise de eventos sociais, faz-se necessária a leitura por meio de teorias sociais e políticas e a análise estritamente econômica da superestrutura é abolida (Jørgensen \& Phillips, 2002).

Inicialmente vale explicar as diferentes visões da política e do político. Os conceitos se complementem e não se excluem. Há diferenças temporais em que um leva ao outro e isso é desenvolvido por Mouffe (2015)

\footnotetext{
'a política' se refere ao nível 'ôntico', enquanto 'o político' tem a ver com o nível 'ontológico'. Isso significa que o ôntico tem a ver com as diferentes práticas da política convencional, enquanto o ontológico refere-se precisamente à forma em que a sociedade é fundada. [...] entendo por 'o político' a dimensão de antagonismo que considero constitutiva das sociedades humanas, enquanto entendo por 'política' o conjunto de práticas e instituições por meio das quais uma ordem é criada, organizando a coexistência humana no contexto conflituoso produzido pelo político. (Mouffe, 2015, p. 8).
}

Embora a tese seja desenvolvida em uma crítica mais ao nível ôntico, ou seja, à política, nos padrões de Mouffe (2015), devemos ter em mente o conceito do político, ao nível ontológico, pois ele é a base para o entendimento do social. Ao contrário do pensamento estritamente marxista, por exemplo, que entende o social como classes e com uma superestrutura econômica, para a teoria do discurso (Laclau \& Mouffe, 1985) o político é a categoria ontológica central da compreensão do social.

Portanto, entendemos que é um problema a "negação da dimensão do político e a crença de que o objetivo da política [...] é estabelecer o consenso a respeito de um modelo único, impedindo, assim, a possibilidade de um dissenso legítimo" (Mouffe, 2015, p. 81).

Em resumo, para Laclau e Mouffe (1985) o político não é um fim a ser atingido com os argumentos, mas sim a base dos argumentos. Ou seja, parte-se de um cenário político para que possamos explicar a criação de sentidos. O político, portanto, é ontologia para os autores, uma vez que é a base da visão de mundo (Glynos et al., 2009). Qualquer momento de mudança deve ser analisado de forma política (Laclau, 2013). Isso não significa que o político seria apenas a "superestrutura" do sistema que rege os demais fenômenos sociais. O político tem primazia, mas, além de influenciar os demais fenômenos, também é influenciado por eles (Jørgensen \& Phillips, 2002).

Mesmo assim, há diversas formas de entendermos a política, mas não devemos restringila ao senso comum do conceito, que é aquele vinculado aos cenários que envolvem parlamentares e modelos de governo. A política é um conceito mais abrangente em que há uma constante constituição de sociais e a exclusão de outros (Jørgensen \& Phillips, 2002). Assim, todos os processos políticos que visam a fixação de uma visão e a exclusão das demais é vista como um material a ser analisado com base na política pela teoria do discurso. 
Para iniciar a discussão de premissas ontológicas, e podendo se encaixar em diversos momentos desta tese, a articulação de discurso é essencial para a compreensão do social. Diversas são as definições de discurso a depender da teoria, da visão ontológica, epistemológica e metodológica. Discurso é um termo não muito claro, pois há diferentes visões do que ele é e de como é conceituado, o que pode levar a problemas de argumentação e interpretação (Burke, 2012). Muitas vezes a palavra discurso é utilizada sem sua conceituação ou a devida explicação do que é visto como discurso na pesquisa (Jørgensen \& Phillips, 2002). Por esse motivo, devemos discutir aqui o que é discurso tomando como base a teoria de Laclau e Mouffe (1985).

O discurso, na teoria de Laclau e Mouffe (1985), não é uma categoria descritiva ou empírica, como em muitas abordagens, mas sim uma categoria ontológica (Glynos et al., 2009), uma vez que é por meio dos discursos que há a construção e compreensão dos fenômenos sociais (Burity, 2014; Laclau \& Mouffe, 1985).

Para essa vertente do pós-estruturalismo, o discurso é visto como a união de diversos elementos para formar sentidos (Laclau \& Mouffe, 1985). Consideramos, ainda, que as realidades sociais dependem da produção de sentidos por meio dos discursos, ou seja, o sentido é parte integrante da construção social (Burity, 2014). O discurso não é totalizado por meio da fala e escrita, mas estas compõem o conceito, entre outras práticas (Mendonça, 2014). Isso quer dizer que o discurso não se reduz apenas ao conteúdo semântico ou pragmático da linguagem, mas sim a toda uma prática social (Laclau \& Mouffe, 1985), ou seja, não é algo restrito ao texto escrito, mas algo que envolve, além de textos: falas, comportamentos, ações e práticas das mais diversas organizações (Critchley et al., 1996; Jørgensen \& Phillips, 2002; Laclau, 1994; Laclau \& Mouffe, 1985; Mendonça \& Rodrigues, 2014).

Consideramos que o social deve ser analisado e compreendido com base na lógica do discurso. A prática social, portanto, é entendida como uma construção discursiva, sendo o discurso materialmente analisável (Laclau \& Mouffe, 1985).

Os discursos merecem atenção pois, como já argumentado, não são fixos e possuem uma natureza de possíveis alterações. Essa essência de modificações, adaptações e mudanças nos discursos representam o trabalho da política e abrem margem para as mais diversas análises (Glynos et al., 2009; Southwell, 2014). O discurso, portanto, é uma fixação parcial de sentido como consequência das práticas hegemônicas de articulação (Torfing, 1999). Com base nisso, além das premissas ontológicas, esse conceito voltará a ser discutido nas seções seguintes.

Outra premissa ontológica para a teoria do discurso é a aplicação do conceito de contingência. Para a teoria, tudo é contingente. Isso porque nossas ações e as construções 
políticas são vistas como contingentes, à medida que representam uma fixação temporária de sentidos que produz mudanças na organização da sociedade (Jørgensen \& Phillips, 2002). Por isso, entendemos a contingência como o conceito necessário para a eliminação da objetividade discursiva e para a existência de hegemonia, sendo ela sempre parcial (Laclau \& Mouffe, 1985). A contingência é, portanto, a visão de que as construções sociais são "possíveis, porém não necessárias" (Jørgensen \& Phillips, 2002).

Apesar de considerarmos todos os discursos como contingentes, entendemos também que há objetividade nos discursos já sedimentados. Por esse motivo deve haver um certo receio quando se há a naturalização/objetividade de um discurso. A naturalização de conceitos e visões de mundo tende a mascarar esses discursos de forma que elimina a possibilidade, ao menos naquele momento, de uma visão alternativa, uma vez que existe um "senso comum" objetivo. A hegemonia pode levar a tal naturalização, porém devemos entender que, mesmo já sendo amplamente aceitos e não questionados, os conceitos e as visões de mundo são sempre sujeitos a mudanças e devemos sim tentar mudar conceitos e práticas sedimentadas.

Também devemos entender o conceito de precariedade utilizado como base ontológica para a teoria do discurso. A precariedade representa que, mesmo o discurso sendo hegemônico, ele não será eterno, ou seja, em algum momento discursos antagônicos se tornarão hegemônicos no lugar do anterior. Percebemos, portanto, que os conceitos ontológicos de contingência e precariedade são relacionados entre si e fazem com que os discursos sejam vistos de forma a não fixar conceitos e ideias (Laclau \& Mouffe, 1985).

A indeterminação também é uma visão essencial para a teoria. O sujeito é visto como sobredeterminado, ou seja, "à multiplicidade de determinações, determinação recíproca e a fusão de distintas contradições que conservam a sua especificidade" (Southwell, 2014, p. 145). Assim, podemos entender que há uma multiplicidade de articulações possíveis dentro de um mesmo discurso, mostrando que o sujeito também não é fixo e construído previamente, mas é resultado das diferentes articulações presentes no discurso hegemônico (Laclau \& Mouffe, 1985).

$\mathrm{Na}$ visão social entendemos que os fenômenos sociais e humanos são sobredeterminados. Isso quer dizer que há diversas explicações possíveis para um mesmo fenômeno, exatamente por lidarmos com questões amplamente humanas, não naturais e não exatas. A sobredeterminação envolve, portanto, além de diferentes formas de abordar um problema, diferentes formas de descrever e explicar (Burity, 2014), cabendo a congruência ao argumento e à articulação e não se limitando à relação linguística entre significante e significado. 
Por isso, entendemos que o sujeito é também construído pelo discurso, assim como suas posições e identificações (Howarth, 2000). O sujeito é posicionado pelos diversos discursos conflitantes e, quando não há esse conflito aparente, podemos entender que é um sujeito hegemônico, que é quando possibilidades alternativas são excluídas (precariamente) e essa construção do sujeito é naturalizada (Jørgensen \& Phillips, 2002). Além disso, o próprio sujeito pode se identificar (e ser identificado) de formas diferentes em situações distintas.

O sujeito normalmente é visto como individual, mas para Laclau e Mouffe (1985) e para a teoria pós-estruturalista do discurso como um todo, o sujeito também pode ser representado por um grupo ou coletivo (J. Williams, 2013). Isso quer dizer que os mesmos princípios de análise de identidades individuais também podem ser utilizados para análises de sujeitos coletivos, como, por exemplo, o IASB. Referendando o que já vem sendo discutido na tese, qualquer formação de grupos (como o IASB) é política, desde sua criação até seus mais diversos desenvolvimentos, devendo ser alvo de uma visão com base em teorias políticas (Jørgensen \& Phillips, 2002).

Ainda, para entendermos os grupos e os coletivos, devemos também entender o conceito de representação. A representação é quando uma voz representa um grupo na ausência de outro. O grupo só existe quando alguém o representa. Com relação ao IASB e ao seu processo normativo, diversos sujeitos atuam como representantes do grupo, como os membros do board (votações), o staff técnico (documentos formais) e o DPOC (processo normativo).

Por fim, ainda para a formação de um discurso, devemos discutir o conceito de paradoxo. Esse conceito possui relação com a noção de antagonismo social, que é representado pela batalha de discursos que se excluem entre si (Jørgensen \& Phillips, 2002). O antagonismo é, portanto, o conflito entre diferentes discursos em uma ordem de discurso. Aqui devemos entender que Laclau e Mouffe (1985) veem o antagonismo como o excesso de significado de determinado discurso, porém não o limitam a algum campo específico (Jørgensen \& Phillips, 2002). Para mim, nesta tese, levarei o antagonismo como o excesso de discurso, porém entendendo que seria um excesso em discursos relacionados entre si. Por exemplo, considero um discurso antagônico ao IASB aquele que fala sobre possibilidade de não regulação da contabilidade, mas não considero um discurso de física como antagônico, uma vez que não faz parte do mesmo sistema discursivo. 
Podemos dizer que a principal obra que funciona como marco da teoria do discurso (Laclau \& Mouffe, 1985) é, também, uma das primeiras obras em que o pensamento pósestruturalista foi "extensivamente empregado como uma 'ferramenta' para a análise política no sentido estrito" (Marchart, 2014, p. 10). Por causa disso, Laclau e Mouffe (1985) também funciona como uma das principais fontes para a aplicação de estudos pós-estruturalistas empíricos que levam em consideração a perspectiva de discurso da Escola de Essex (Marchart, 2014).

A teoria originada com base nos pensamentos de Ernesto Laclau e Chantal Mouffe encontra-se presente nas mais diversas literaturas e, como ela não é nomeada pelos próprios autores como uma teoria, pode ser descrita, nas mais diferentes pesquisas, como teoria do discurso, teoria política do discurso, teoria do discurso político, teoria do discurso de Laclau e Mouffe, teoria pós-estruturalista do discurso, entre outros (Glynos \& Howarth, 2008; Howarth, 2000, 2010, 2013; Rear \& Jones, 2013; Torfing, 1999).

De forma geral, a teoria objetiva auxiliar no entendimento do "social como uma prática discursiva em que, em princípio, todos os fenômenos sociais podem ser analisados utilizando-se de ferramentas analíticas de discurso" (Jørgensen \& Phillips, 2002, p. 24), tendo em mente que os fenômenos sociais nunca estão completos e totalizados, sendo constante a batalha pela criação de "sentidos" (Mendonça, 2009). Esses sentidos, por sua vez, são fixados e desafiados por meio de convenções, negociações e conflitos que ocorrem por meio da lógica de diferenças e equivalências (Jørgensen \& Phillips, 2002). Pretende-se, a longo prazo, que a teoria seja considerada uma teoria política geral, trazendo a política como uma ontologia para a análise do social e cabível nas mais diversas áreas do conhecimento (Burity, 2014).

Para discutirmos a teoria pós-estruturalista do discurso (Laclau \& Mouffe, 1985) devemos começar, além dos aspectos ontológicos já apresentados, com a relação entre três termos, que são: poder, política e hegemonia. Há inter-relação entre esses termos na teoria e, também, nas análises que serão realizadas nesta tese. O poder e a política levam ao conceito de hegemonia, que é a posição atual do discurso normatizador internacional, possibilitando-o de realizar certas ações. Nesse sentido, critico algumas dessas ações com base na lógica crítica e pós-estruturalista de análise, principalmente utilizando-me do conceito laclauniano de significantes vazios. Nesta tese veremos o poder não no sentido de sua microfísica, conforme proposto por Foucault, mas em um sentido mais ligado com a hegemonia. 
Devemos entender que o poder é um lugar vazio (Mouffe, 2015). Isso quer dizer que não há um sujeito fixo e ocupante eterno daquela posição. Para se exercer o poder, o sujeito deve ter habilidade para se manter naquela posição, principalmente quando falamos em modelos democráticos. O poder, portanto, não é algo que se detém, mas sim algo que participa da construção do social. Então podemos entender que é o poder que cria conhecimentos, identidades e relações, sendo todos esses contingentes. Com isso, a criação de conceitos, visões de mundo e sujeitos, assim como a exclusão de possibilidades alternativas, é efeito do poder (Jørgensen \& Phillips, 2002).

A figura dos sujeitos é importante para a teoria, pois muitas das decisões e articulações políticas são tomadas como forma de construir as identidades desses sujeitos. Os sujeitos/atores são criados por meio de discursos (Jørgensen \& Phillips, 2002). O sujeito não é, portanto, aquela identidade fixa e centrada, mas emerge de diferentes formas nos discursos e os discursos acabam por posicionar tais sujeitos (Laclau \& Mouffe, 1985). Com base nisso podemos dizer que os sujeitos são posições no discurso e, como dito, podem representar mais de uma posição ao mesmo tempo.

Está aí a importância entre o universalismo e o particularismo na teoria do discurso. Os discursos hegemônicos tendem a criar os papeis dos diferentes atores sociais dentro de um discurso universal que agregue as mais diversas demandas em "sensos comuns", que são representados por demandas plurais dos mais diversos segmentos e atores. Esse papel é operacionalizado por meio de discursos homogeneizantes, o que limita, portanto, a ação dos atores de forma a se rebelar contra estruturas, mesmo que precárias e contingentes. Afinal, quem seria, por exemplo, contra discursos universais como: democracia, transparência, consulta, accountability,...?

Assim, podemos dizer que poder e política são conceitos interrelacionados, uma vez que poder é a participação na construção de objetos e sociedades e a política é a contingência presente nessa construção (Jørgensen \& Phillips, 2002).

A hegemonia já é considerada a habilidade de se conseguir sucesso na construção de um campo discursivo que agregue diferenças antagônicas em seu interior (Laclau \& Mouffe, 1985). Essa construção política envolve o conflito e a ocupação, naquele momento, de um discurso com maior representatividade. Isso quer dizer que, sob a ótica da teoria do discurso, não se acredita na visão pós-política de uma globalização marcada pelo consenso e pela ausência de adversários (representados pelo antagonismo) (Mouffe, 2015), mas sim em 
momentos que conseguem representar uma totalidade. Entretanto, essa totalidade é temporária e é denominada de relação hegemônica (Laclau \& Mouffe, 1985).

Para entender a hegemonia, a teoria do discurso usa como fonte a lógica de Gramsci, com adaptações ao contexto pós-marxista dos autores (Torfing, 1999). Assim, há um entendimento de que a para obter hegemonia a classe governante necessita, além da força, da persuasão como principal estratégia de governo (Young, 2003). A hegemonia, na lógica Gramsciana, depende da aceitação dessa persuasão por parte dos subordinados (Burke, 2012). Hegemonia seria, portanto, a capacidade de um sistema em estabelecer relações de ordem e discursos sistematizadores. Em termos linguísticos, seria a capacidade de um discurso unir diversos elementos de forma organizada, mesmo que precária e contingente (Mendonça \& Rodrigues, 2014).

Não se confunde hegemonia com o significado mais corriqueiro de noção topográfica, como aquela relacionada com a supremacia ou de poder absoluto. Ou seja, na teoria do discurso não se entende que hegemonia é uma posição fixa no topo que transmite efeitos a partir dela, mas sim uma relação política derivante da prática articulatória que resulta de um processo de negociação de interesses e demandas (Laclau \& Mouffe, 1985). A hegemonia é, portanto, similar ao discurso no sentido de que ambos procuram transformar elementos em momentos discursivos (Jørgensen \& Phillips, 2002). Hegemonia, para Laclau e Mouffe (1985), é representada pela dominação de uma perspectiva particular, sendo que a teoria do discurso necessita de uma situação de hegemonia para fazer sentido como teoria política.

O que se acredita é que a hegemonia depende de diferenças de opiniões. Então podemos dizer que a articulação é central para a hegemonia. Há duas formas principais de articulação hegemônica que são as lógicas da equivalência e diferença. Para se construir uma hegemonia, deve-se conseguir criar uma nova cadeia de equivalências (lógica da equivalência) que agregue essas diversas lutas democráticas (Laclau \& Mouffe, 1985). Para exercer esse objetivo, existem as figuras dos significantes vazios e flutuantes. Dizemos, portanto, que a articulação de significantes vazios e flutuantes é que permite a existência de práticas hegemônicas (Sales Jr., 2014).

A hegemonia atinge um "sucesso" (sempre parcial) quando o discurso defendido domina e os antagônicos são silenciados. Assim, a intervenção hegemônica torna um discurso dominante com base na fixação de sentidos e esse processo de transformação de discursos hegemônicos é a base que a teoria do discurso investiga. Além disso, com base em um pensamento mais crítico, também faz parte do arcabouço da teoria de Laclau e Mouffe (1985) 
a demonstração de fragilidades nesses discursos e em seus elementos base como a criação de sentidos (Jørgensen \& Phillips, 2002).

O sentido deriva das diferenças que ocorrem no sistema linguístico, isso quer dizer que os sentidos são construídos de acordo com o que não são. Assim, os sentidos são diferenciais, não substantivos (Macintosh, 2002). Na teoria pós-estruturalista do discurso entende-se que a maneira de apresentar os discursos não reflete o mundo neutro, mas sim o constitui e o modifica (Jørgensen \& Phillips, 2002).

Toda fixação de sentido é contingente, ou seja, é possível, mas não necessária e final e é exatamente nessa ausência de fixação de sentido (uma diferença da teoria pós-estruturalista para a linguística estruturalista) que a análise dos discursos ganha relevância ao poder demonstrar que sentidos que às vezes são tomados como naturais e óbvios são meras convenções aceitas, mas podem ser criticados e antagonizados (Jørgensen \& Phillips, 2002).

Para essa criação de sentidos e cadeias hegemônicas, há que se deixar um momento particularista para utilizar-se de um discurso coletivo que se utilize de verdades e princípios gerais que agreguem diversas demandas. Argumento aqui que os princípios do processo normativo exercem essa função para o discurso da "normatização contábil internacional de qualidade", juntamente com o discurso da "convergência".

A identidade das organizações hegemônicas (como o IASB) que constroem tais discursos coletivos procura a completude de significados e sentidos, porém, esta é impossível em decorrência da contingência e precariedade dos discursos. Assim, entendemos o conceito de falta constitutiva, ou seja, que as identidades, mesmo hegemônicas, são sempre incompletas e em busca de aprimoramento e incorporação de novos sentidos aos seus discursos (Mendonça \& Rodrigues, 2014). Isso pode ser observado quando vemos as mudanças na aplicação dos princípios do handbook sendo realizadas, assim como a criação de novas definições, práticas e fronteiras para a aplicação desses princípios.

Por fim, outro interesse da teoria do discurso é o de entender discursos que limitam a ação de indivíduos nas mais variadas formas, como, por exemplo: desvalorização de atores, valorização própria por meio do conhecimento e criação de significantes vazios e flutuantes (Jørgensen \& Phillips, 2002). Isso faz com que os sujeitos, em diversos momentos, tenham suas ações de resistência limitadas por poderes e barreiras a eles impostos que muitas vezes não são percebidos em um primeiro momento, principalmente em decorrência de barreiras impostas discursivamente. 
Como já apresentei na Revisão da Literatura, uma das formas de identificar essa limitação de comportamento dos sujeitos ocorre por meio de argumentações baseadas na prolepse, que é a antecipação dos argumentos dos sujeitos de forma a descredibiliza-los antes mesmo de serem realizados. Assim, o discurso hegemônico consegue se valorizar e, ao mesmo tempo, desvalorizar os discursos antagônicos.

Levando em conta tal funcionamento hegemônico, podemos explicar o processo normativo contábil com base nos diferentes conceitos discutidos na teoria do discurso. Isso faz com que o processo normativo se encaixe como um processo político e que pode ser analisado com base nessa teoria.

Podemos entender, por exemplo, que o processo normativo contábil neutro e técnico é uma construção hegemônica com base em diferentes articulações discursivas, portanto, não podemos separar a tecnicidade e a neutralidade da política. Por esse motivo, a teoria do discurso é uma ferramenta importante para a análise de processos normativos contábeis, uma vez que com base nela entendemos essa construção como política. Assim, considerando que todos os sujeitos são políticos no sentido ontológico (Laclau, 1990). Em momentos de mudanças há uma necessidade maior de interpelação que geram possíveis confrontações políticas e discursivas (Southwell, 2014) e, por isso, além de uma visão geral do processo normativo, analisaremos um processo específico que envolveu diversas mudanças, que é o de leasing. Mais informações sobre essa escolha serão discutidas na seção "Escolha do Caso: Processo normativo de Leasing (IFRS 16)".

\subsection{Esquematização do Funcionamento da Teoria do Discurso de Laclau e Mouffe}

Após a explicação de aspectos gerais do posicionamento ontológico e teórico da teoria do discurso (Laclau \& Mouffe, 1985), discutirei, nesta seção, os principais conceitos e suas interrelações que auxiliam na compreensão de tal posicionamento, que tem como premissa a centralidade da política, do discurso e do poder (Mendonça \& Rodrigues, 2014).

Devido ao alto nível de presença do contingente e da precariedade na teoria do discurso, é perigoso tentar esquematizar todo o arcabouço teórico de conceitos desenvolvidos e articulados por Laclau e Mouffe (1985) e obras posteriores dos autores, pois, além da discussão de diversos conceitos, suas organizações podem ocorrer das mais diversas formas dentro da teoria.

Porém, há certa dificuldade na compreensão dos termos de forma não articulada, portanto, optei por realizar tal esquematização e ressalto a necessidade de entender que essa 
seria uma das possíveis formas de desenvolvimento do arcabouço teórico. A ideia foi de realizar uma simplificação da complexidade geral dos conceitos para tentar demonstrar suas interrelações. Isso não é uma desculpa, mas uma explicação para não incorrer no risco de supersimplificar e subdimensionar a complexidade e a qualidade da teoria. Assim, a esquematização tem como objetivo relacionar os conceitos antes linguísticos e demonstrar como normalmente um discurso pode ser formado para seus mais diversos impactos nos ambientes sociais, conforme Figura 6.

Figura 6 - Esquematização dos conceitos-chave da Teoria do Discurso (Laclau \& Mouffe, 1985)

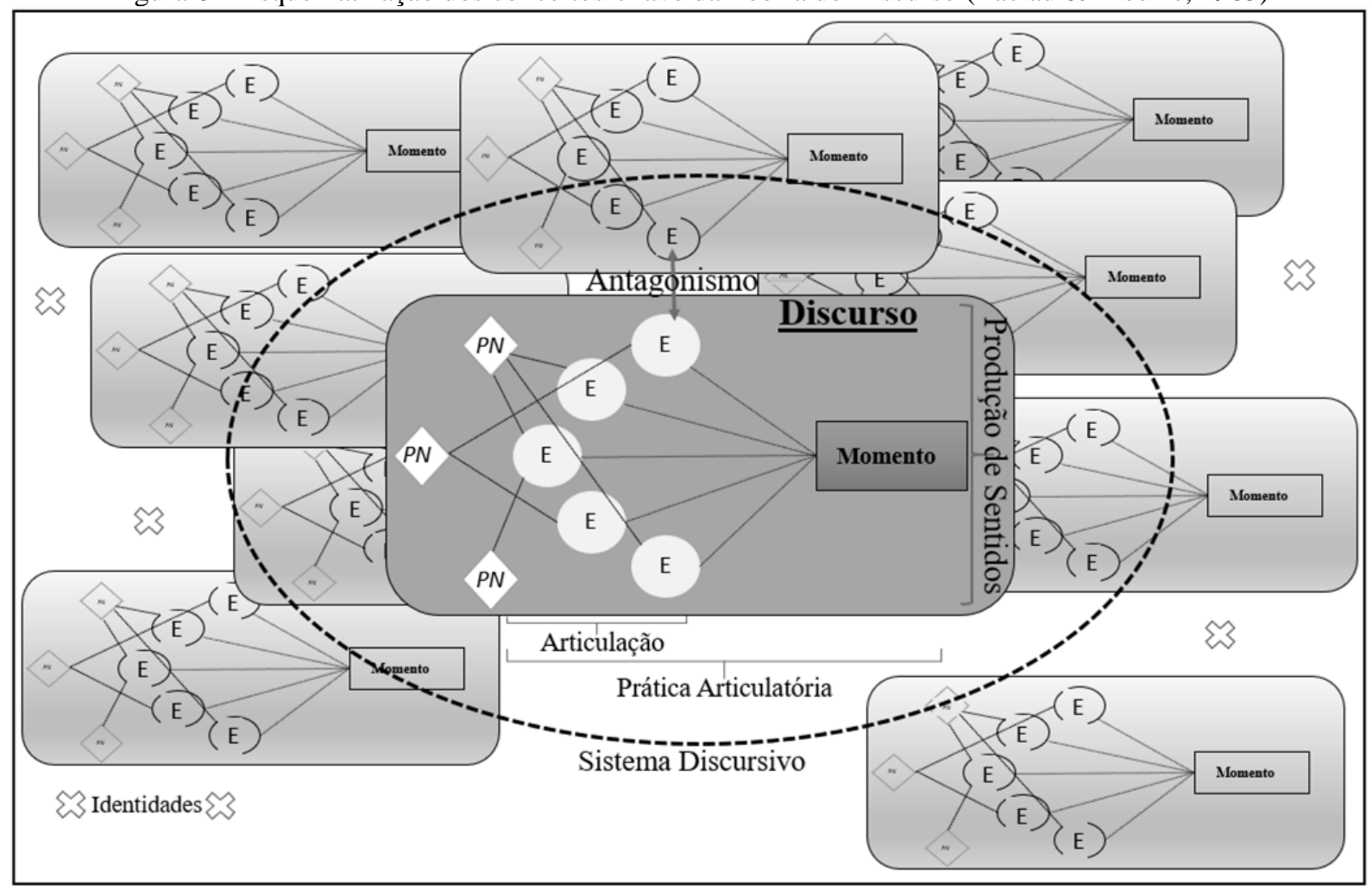

Legenda: (E) Elemento; (PN) Ponto Nodal Fonte: Elaborado pelo autor.

Diversos são os possíveis pontos de partida para a compreensão das relações entre os termos e conceitos da teoria do discurso em um mesmo espaço. Inicialmente, explico que na Figura 6 podemos observar diferentes discursos, representados pelas caixas. Os discursos são compostos, principalmente, porém não exclusivamente, pela relação entre pontos nodais, elementos e momentos, sendo esta transformação nomeada de "produção de sentidos".

Os pontos nodais possuem uma função importante dentro do discurso, já que representam uma base de ordenação dos diversos elementos. Por meio deles, cristalizam-se os sentidos, então servem como uma base de sentidos (Jørgensen \& Phillips, 2002). Seria, por exemplo, um unificador de sentidos dentro de diversas possibilidades de outros sentidos. Por 
exemplo, necessita-se de um ponto nodal que dê coerência para o que seria "transparência" em cada discurso, uma vez que esse elemento pode possuir diversos sentidos, como o sentido físico, sentido de apresentar de forma clara os dados, sentido de personalidade, entre outros. O ponto nodal, portanto, aparece como uma função de fixar o sentido para aquele discurso específico. Isso faz com que o discurso seja uma redução de sentidos e possibilidades, uma vez que o discurso se reafirma por meio da diferença com outros discursos antagônicos e concorrentes (Laclau \& Mouffe, 1985).

Podemos entender, portanto, que os pontos nodais são centrais às lógicas da equivalência e da diferença. Eles são os resultados da lógica das diferenças e o início da lógica das equivalências, conforme compreendidas na teoria do discurso (Laclau \& Mouffe, 1985). Esse é o ponto de vacuidade dos significados particulares em prol dos significados universais. Isso quer dizer que o conteúdo particular que antes estava espalhado pelo sistema discursivo é tão esvaziado que consegue se transformar em um conteúdo universal dentro de um discurso específico. Essa transformação dos pontos nodais é o que dá origem aos elementos. A transformação do particular em universal é de grande importância para as discussões sobre significantes vazios, que será realizada na seção seguinte.

Após essa explicação, devemos entender a esquematização de forma mais geral, para, após isso, adentrar nos conceitos específicos. A esquematização apresenta a rivalidade entre diferentes discursos dentro de um campo da discursividade, ou sistema discursivo. Esse sistema é o sentido dado aos elementos fora de um discurso específico. Seria, portanto, os significados diferentes daqueles limitados pelos pontos nodais e diferenciação do discurso em questão, ou seja, o "sentido extra". Ele é importante, pois com base nessa diferenciação é que os discursos se tornam hegemônicos e os sentidos são construídos de forma a criar significantes vazios, ou seja, são as exclusões dadas naquele discurso (Jørgensen \& Phillips, 2002).

O sistema discursivo é a maior crítica à teoria do discurso, uma vez que críticos afirmam que na teoria de Laclau e Mouffe (1985) o discurso sempre será criado com relação ao que se exclui por meio do campo da discursividade (Jørgensen \& Phillips, 2002). Os autores não negam que há tal exclusão, mas ela se torna necessária uma vez que enxergam o campo da discursividade como todos os sentidos possíveis que não estão naquele discurso, como, por exemplo, falar-se sobre o sentido de transparência da água em um discurso de transparência como princípio contábil. Apesar de ser o mesmo signo, a transparência da água está no campo da discursividade quando se fala em discurso normativo contábil, uma vez que essa possibilidade de significado é excluída do discurso contábil. 
Isso ocorre para demonstrar, mais uma vez, a importância do conceito de elementos na formação de um discurso, já que eles são os responsáveis por “excluir" essas possibilidades de sentido que não se encaixariam naquele discurso. Os elementos (isoladamente) representam conceitos que podem ser antagônicos. Por isso, os elementos ainda não são momentos fixados , portanto, flutuam sobre múltiplos sentidos de forma a levar a um momento daquele discurso e, após isso, serem capazes de ser articulados em um momento que formaria o discurso. Essa é a real intenção do discurso. Para que haja essa transformação dos elementos em momentos deve ser observada a existência de algum ponto em comum entre esses elementos por meio da prática articulatória.

O que podemos ver, portanto, é que o campo da discursividade é importante para que os elementos possam sofrer articulações e excluir os múltiplos possíveis sentidos que poderiam ser alocados naquele discurso. Esse processo todo obtém sucesso de articulação se os elementos conseguirem se configurar em significantes vazios, uma vez que seriam capazes de agregar a maior quantidade de demandas em um elemento específico. Essa transição, porém, nunca é finalística, uma vez que existe todo um campo da discursividade ao redor que agrega as mais diversas demandas e discursos antagônicos, daí a noção de Laclau e Mouffe (1985) de ausência de uma totalidade e universal, pois os sentidos nunca serão completos e finais em decorrência da multiplicidade de sentidos no campo da discursividade.

Podemos dizer, portanto, que há um sucesso no discurso quando ele consegue parcialmente fixar o sentido dos elementos, porém devemos ter atenção que é sempre parcial e o processo de articulação daquele discurso hegemônico acaba por ser contínuo. Demonstrar essas articulações e como os sentidos são transformados ao longo do tempo é uma das grandes vantagens das análises realizadas com base na teoria do discurso (Laclau \& Mouffe, 1985).

a formação de um discurso é o resultado contingente de uma série de articulações. Articulação é a 'prática que estabelece relações entre elementos de maneira que suas identidades sejam modificadas como resultado da prática articulatória' (LACLAU; MOUFFE, 1987, p. 105). As práticas articulatórias tendem a organizar o discurso em torno de uma série de pontos nodais. Os pontos nodais cumprem o papel de significados mestres capazes de unificar uma superfície discursiva entrelaçando uma variedade de identidades diferentes em torno de um nó de significados. (Southwell, 2014, p. 139)

A articulação representa a prática de estabelecer relações entre os elementos e modificá-los. Após essa modificação, os elementos já relacionados por meio da articulação podem se transformar em momentos. Esse processo completo é nomeado de prática articulatória, sendo seu resultado o próprio discurso (Laclau \& Mouffe, 1985). A articulação, portanto, depende do sistema discursivo para fazer com que os elementos possam ter sentidos diferenciados naquele discurso. 
Após entendermos esses conceitos, conseguimos perceber que os pontos nodais e os elementos são significantes flutuantes até que sejam articulados dentro de um sistema de diferenciação e dentro de um mesmo discurso. Esses pontos, por serem vazios, são pontos privilegiados para a prática política, uma vez que podem sofrer inúmeras articulações de forma a agregar demandas. Toda a articulação e prática articulatória que ocorre dentro de um discurso, incluindo a transformação de pontos nodais em elementos e momentos, é nomeada de produção de sentidos de um discurso, sendo esse o resultado da hegemonia discursiva (Torfing, 1999), mas devemos lembrar que esse resultado é precário e contingente, ou seja, não existe um "fim da história" (Mendonça \& Rodrigues, 2014).

Esse fim não existe em função dos discursos antagônicos, que representam o impedimento da formação completa de identidades, ou seja, a objetividade e a totalidade de discursos de forma plenamente transparente (Mendonça \& Rodrigues, 2014). Os discursos antagônicos, então, corroboram a visão de precariedade da teoria de Laclau e Mouffe (1985)

Essa objetividade (temporária) trazida pelas práticas articulatórias em torno de elementos anteriormente deslocados em diversas identidades é vista como o mito. Um mito construído com sucesso representa a hegemonia (Laclau \& Mouffe, 1985). Embora utilizem-se do conceito de mito, Laclau e Mouffe (1985) não o desenvolvem como Barthes (1972), mas acabam por relacionar o mito com o que é a hegemonia.

De forma simplificada, podemos tentar resumir a relação entre os termos da seguinte forma:

o discurso objetiva remover ambiguidades pela transformação de elementos em momentos por meio de um fechamento. Mas esse objetivo nunca é completado com sucesso à medida que as possibilidades de sentidos que os discursos substituem do sistema discursivo sempre ameaçam desestabilizar a fixação do sentido. Assim, todos os momentos permanecem potencialmente polissêmicos, o que significa que os momentos são sempre potencialmente elementos. E devido a essa potencial polissemia perceptual, toda expressão verbal e escrita (e toda ação social [...]) é também, em algum nível, uma articulação ou inovação. (Jørgensen \& Phillips, 2002, p. 29. grifo do autor).

Após discutirmos os diversos conceitos utilizados na teoria do discurso, podemos entender que o discurso é uma prática política "que transforma, mantém e estabelece as relações de poder e as entidades coletivas em que tais relações se colocam, havendo, portanto, uma competição para fixar sentidos” (Marques, 2014, p. 120), porém esses sentidos, como já vimos, são constantemente negociados em decorrência da contingência e precariedade dos discursos, sendo necessário um esforço continuo de articulação para a manutenção das entidades hegemônicas (Laclau \& Mouffe, 1985).

$\mathrm{O}$ que podemos concluir, com base no entendimento da teoria do discurso, é que o significado dado ao significante depende do social, uma vez que pode ser diferente para cada 
sujeito e ambiente discursivo. Isso nos permite afirmar que a linguística é parte integrante do social, e não o contrário. Aplicar conceitos da linguística por si só, portanto, não faz o estudo ser considerado um estudo linguístico (Howarth, 2000).

Assim, entendemos a teoria do discurso como uma visão modificada da estrutura fixa de Saussure, pois na teoria de Laclau e Mouffe (1985) não se acredita no fechamento total e final do sentido, sendo o discurso, portanto, temporário e as articulações para sua formação, contingentes. Isso abre margens para análises que envolvem lutas e exclusões, uma vez que o sistema discursivo é aberto. Para a análise dessas exclusões e parcialidades, o foco deve ser dado nas expressões, elementos e momentos, pois é neles que todo o discurso é centralizado para ser construído.

\subsection{Os Significantes Vazios e a Lógica da Equivalência}

Ao entendermos que a sociedade se estrutura em torno de articulações políticas, tendemos a ver diferentes lutas ideológicas nos mais diversos cenários. Como forma de representar certa pluralidade dentro de um cenário, aparecem os significantes vazios, sendo que estes tendem a não ser fixados em uma articulação (Laclau, 2007a) e, em decorrência das diversas articulações, assumem um papel de vacuidade de conteúdo. Essa vacuidade é que permite a influência política, uma vez que se houver fixação, não há discussão (Southwell, 2014).

A visão dos significantes vazios é central para a teoria do discurso (Laclau \& Mouffe, 1985), já que a hegemonia e a construção de discursos dependem da articulação de significantes vazios que funcionem como significantes universais (Laclau, 2007a). Devido a importância desse conceito, Laclau dedicou um ensaio (Laclau, 2007b) para discuti-lo, sendo ele a principal fonte para essa seção. Para o autor, "o significante vazio, estritamente falando, é um significante sem significado" (Laclau, 2007b, p. 36) que possui como função a de silenciar diferenças (Laclau \& Mouffe, 1985).

Além de possuírem um espaço de destaque dentro da teoria do discurso e das análises políticas em geral (Mendonça \& Rodrigues, 2014), os significantes vazios representam uma ferramenta importante para a criação de antagonismos sociais, principalmente naqueles casos em que os discursos se formam por meio de "sensos comuns" (Burity, 2014), em que há diversos significados para esses significantes, porém nenhum com um sentido claro e definido, possibilitando, assim, diferentes articulações por meio desses significantes. 
O conceito acaba por se confundir com o de significantes flutuantes, porém os flutuantes são os significantes que ocorrem em processos articulatórios distintos, em que um mesmo significante possui dois significados diferentes (a depender do sistema discursivo) e até contraditórios entre si (Torfing, 1999). Já os vazios também podem estar em diferentes processos articulatórios, porém possuem como principal função a de agregar demandas, então não são contraditórios entre si (Howarth, 2000).

Os significantes vazios, portanto, não significam muita coisa até que articulados por meio da lógica de equivalências e diferenças e combinados a outros signos a fim de criar sentidos (Jørgensen \& Phillips, 2002), por isso, trabalham no limite da significação, encontrando o ponto de interseção (diferença e equivalência) a partir dos pontos nodais para que possam agregar os mais diversos interesses (Laclau, 2007b).

Para entender sobre a diferença, voltemos ao início da significação linguística de Sartre e Saussure, em que a produção de significados ocorre por meio da diferença com outros objetos. A explicação dos significantes vazios parte, portanto, dessa visão linguística, ao demonstrar que tais significantes possuem uma ausência de diferenciação para que represente uma totalidade (o universal):

A divisão de cada unidade de significação que o sistema tem que construir como o locus da indecibilidade no qual tanto a lógica da diferença quanto a lógica da equivalência operam. É somente privilegiando a dimensão da equivalência ao ponto em que sua diferenciação é praticamente apagada isso é esvaziar a natureza diferencial - que o sistema pode se significar como uma totalidade. (Laclau, 2007b, p. 39).

Tendo como base essa noção do vazio, podemos entender que ele é sempre inalcançável (Laclau, 2007b), o que o torna uma importante ferramenta e estratégia política no processo de significação e hegemonia. Uma das formas de identificação de batalhas políticas se dá pela identificação e antagonização dos significantes vazios com vistas a mostrar seu uso no "preenchimento por sentidos particulares" (Burity, 2014, p. 70). Como entendemos que a hegemonia é construída por meio dessas significações e que ela é contingente, a crítica serve para trazer que essa construção é meramente particular e não universal como se intenta.

Assim, como forma e estratégia de agregar diversas demandas particulares de diferentes indivíduos, utiliza-se de uma estratégia de esvaziar o significado dos signos. Com isso, são agregadas diversas demandas, mesmo que diferentes, em função da identificação não com as demandas, mas sim com os sentidos que são esvaziados, sejam por proposição de mudanças ou por sensos comuns pouco debatidos, mas aceitos. Portanto, para a manutenção da hegemonia e tentativa de perpetuação contra os antagonismos, a criação de discursos em torno de 
significantes vazios se mostra como uma ferramenta presente e muito utilizada nos mais diversos contextos sociais (Laclau \& Zac, 1994).

Entendemos que, com base na teoria pós-estruturalista do discurso, os sistemas de significação correspondem a uma rede de significantes que podem apresentar relações não determinadas entre si, formando discursos com base em diferentes tipos de significantes (vazios ou flutuantes), que se articulam em forma de pontos nodais de forma a trazer a articulação política necessária para o discurso hegemônico (Macintosh, 2002).

Apesar disso, esses significantes também são sempre inadequados, uma vez que carecem de representação direta e significativa. Essa carência demonstra uma falsa totalização, uma vez que o significante não espelha uma particularidade específica e esse discurso é exatamente o que chamamos de discurso hegemônico (Laclau, 2007b). Assim, podemos dizer que "a classe ou grupo é considerado hegemônico quando não está fechado em uma perspectiva corporativista restrita, mas se apresenta como realizador de objetivos mais amplos de emancipação ou garantindo a ordem para massas mais amplas da população" (Laclau, 2007b, p. 43).

Mais uma vez, reitero que para a existência dessa hegemonia e para a agregação de demandas, faz-se necessária a construção de significantes vazios. Outra função política e estratégica é que os significantes vazios acabam por ajudar a impedir revoluções dos sujeitos, uma vez que procuram estabelecer sensos comuns variáveis que funcionam de diferentes maneiras para cada indivíduo. Isso é possível por meio da lógica de equivalências criada. Assim, grupos hegemônicos particulares conseguem identificar uma camada maior da população (Laclau \& Mouffe, 1985) ao "apresentar uma particularidade de um grupo como a encarnação de um significante vazio que se refere a ordem da comunidade como uma ausência, uma realidade não preenchida" (Laclau, 2007b, p. 44).

A criação de significantes vazios é extremamente conveniente como estratégia política, pois esses significantes tendem a caber nos mais diversos discursos e interessados. Isso quer dizer que esses significantes podem possuir os mais diversos sentidos de acordo com a interpretação dos agentes sociais. Assim, devemos trazer esse conceito para o debate na criação de normas contábeis, uma vez que representariam estratégias retóricas para a criação de valor ao processo normativo e possíveis garantias de qualidade. Entretanto, como vimos, não há totalidade na visão de Laclau e Mouffe, o que leva a crer que tais significantes merecem ser criticados e expostos de forma a desmistificar o que é tido como real, total e garantido em um processo organizacional. 
Com base nisso, o significante vazio funciona como um instrumento de luta à medida que consegue garantir a união de diversas identidades e atores com interesses sociais distintos e, por natureza, a articulação desses significantes é uma ferramenta política. Argumento nesta tese que os princípios do processo normativo do IASB (transparência, consulta completa e justa e accountability) são significantes vazios, uma vez que agregam interesses retóricos e míticos. Afinal, o que é ser transparente? Como se realiza uma consulta completa e justa? O que é accountability na elaboração de normas? Esses termos são significantes flutuantes, a princípio, pois não representam conceitos contrastantes e antagônicos em outros sistemas discursivos, porém são vazios uma vez que não se há uma visão única sobre o que representam, ou seja, trazem instabilidade e ambiguidade nas suas aplicações (Laclau, 2007b).

Em uma analogia com a discussão sobre ordem feita por Laclau (2007b), podemos argumentar que em ambientes democráticos há uma necessidade de prestação de contas por parte dos representantes de tal movimento. Assim, há uma necessidade de apresentação de estratégias de boas práticas de governança (Hopper et al., 2017), como os princípios do due process. Com isso, e o conteúdo das normas acaba por ser secundário nesse processo de prestação de contas demandado pela democracia. Os princípios, por si só, não possuem conteúdo, pois somente existem nas várias formas em que são aplicados e sua ausência pode não ser percebida. Assim, se tornam um significante vazio.

Faz sentido, portanto, analisar esses significantes vazios? Nesta tese argumento que sim, uma vez que as decisões (de conteúdo e de processo) são realizadas com base nesses significantes que, por serem vazios, possibilitam diversas rearticulações de discursos hegemônicos. Procuro demonstrar tal ausência de significado e articular que essa estratégia política deve ser contestada para que haja sempre uma evolução de conceitos e uma visão política do processo. Esses conceitos, portanto, por serem subjetivos e vazios em suas essências, devem ser alvo de desconstruções que mostrem suas fragilidades, obrigando que haja constante rearticulação por parte da hegemonia discursiva e mantendo-se, assim, a democracia no processo normativo contábil.

A crítica desse instrumento de luta (criação de princípios como significantes vazios que “suportam" condições de boas práticas de governança ao processo normativo) representa, portanto, uma crítica pós-estruturalista indireta ao discurso criado pelo IASB de qualidade técnica apolítica. 


\subsection{Resumo do Capítulo}

Com base na teoria pós-estruturalista do discurso (Laclau \& Mouffe, 1985), entendemos que o discurso constrói os sentidos sociais, sendo que esses sentidos nunca serão permanentemente fixos (Jørgensen \& Phillips, 2002), pois estão permeados pelos conceitos de contingência e precariedade (Mendonça \& Rodrigues, 2014). Assim, na lógica de Laclau e Mouffe (1985), não há uma interpretação finalística, ou seja, a compreensão idealista de um cenário final, real e verdadeiro, principalmente em decorrência da existência do antagonismo. O que é possível é a realização de análises e compreensões que auxiliam naquele cenário específico, para aquele momento, com base em ferramentas discursivas para a compreensão e crítica do social, mas nunca uma totalidade.

Podemos dizer que o discurso e a política fazem parte da ontologia, ou seja, da visão do "ser enquanto ser" (Laclau, 2014) e compreendem, além dos aspectos linguísticos, aspectos extra-linguísticos, que envolvem os diversos fenômenos sociais (Glynos et al., 2009; Howarth, 2000; Jørgensen \& Phillips, 2002; Torfing, 1999).

Os discursos são uma forma de tentar estruturar signos como se fossem permanentes e não-ambíguos e nós, como atores sociais, também tentamos entender a realidade dessa forma estruturada (Jørgensen \& Phillips, 2002). A teoria de Laclau e Mouffe (1985) vem exatamente argumentar que essa estrutura não pode ser totalmente fixada e demonstrar que não há essa pretenciosa objetividade quando se fala em análises sociais, muito em decorrência de sua visão de mundo baseada na contingência, precariedade e sobredeterminação do sujeito (Torfing, 1999).

Para se atingir um discurso que alcance o status de hegemônico, faz-se necessária a construção de um campo discursivo que construa significantes vazios, sendo este o ponto mais político do processo (Laclau, 2014). Para isso, é necessária a criação de totalizações e universalizações que agreguem, por meio da lógica de equivalência, demandas antes tidas como diferentes, mas que se unem por um objetivo particular em comum. Com isso, temos um mito que, quando institucionalizado, representa a hegemonia do discurso (Laclau \& Mouffe, 1985).

Nessa teoria entendemos que o discurso não pode ser totalizado e final, sendo que sempre haverá discursos conflitantes e antagônicos na busca de espelhar uma realidade social diferente. Com essa batalha de discursos, alguns se tornam hegemônicos e são vistos com mais naturalidade e uma "pseudo incontestabilidade". Apesar disso, essa objetividade de um discurso e consequente naturalização também é contingente e precária e pode ser questionada, sendo 
sempre necessária a reformulação dos discursos para que se mantenham como momentos articulados (Jørgensen \& Phillips, 2002; Laclau \& Mouffe, 1985).

Em resumo, devemos entender que: ( $i$ ) o social é discursivamente significado; (ii) a teoria do discurso é uma teoria das diferenças; (iii) toda construção discursiva é contingente e precária; (iv) toda constituição discursiva é antagônica; (v) o discurso é efeito, ou resultado, de uma prática articulatória; (vi) a teoria do discurso é uma teoria da hegemonia (Mendonça, 2009, pp. 167-168).

De forma aplicada à tese, o objetivo teórico, portanto, é o de desconstruir a objetividade e a naturalidade de conceitos e trazê-los ao entendimento político, sem considerar, assim, que as informações, argumentos e conceitos são taken for granted (Young \& Oakes, 2009). Devemos enxergar esses conceitos "naturais" como meras convenções aceitas que podem (e devem) ser antagonizadas (Jørgensen \& Phillips, 2002).

As visões que adoto na tese de (in)completude e (in)consistência estão baseadas na noção de que os discursos estão sempre em transformação e que essa fixação de sentido é parcial, podendo a "qualidade" da consistência flutuar ao longo do tempo ou até mesmo em diferentes processos normativos, mas é fato, com base na teoria do discurso, que não há consistência e completude "total", pois os conceitos são sempre temporários, contingentes, precários e parciais, e, por isso, podem mudar.

A função desta tese é, portanto, representar um discurso antagônico de forma a mostrar que os princípios, ora vistos como momentos, podem ser criticados e retornarem ao status de elementos, caracterizando-os, portanto, como significantes vazios e que cabem em diversos contextos. Com isso, demonstro que eles não representam totalidades e universalidades. Isso dificulta a realização de críticas e discursos antagônicos, uma vez que sempre há potencial para a reinvenção e rearticulação desses elementos/momentos, porém, ao mesmo tempo, valoriza as críticas ao representarem exatamente essa necessidade de rearticulação. 


\section{ESTRATÉGIAS E VISÕES METODOLÓGICAS}

Assim como os desenhos das organizações atuais não são os mesmos do passado, as pesquisas também estão evoluindo para obter melhores formas e metodologias para analisar esses novos modelos organizacionais, principalmente ao partir para análises mais "efêmeras" de aspectos que antes não eram considerados relevantes (Phillips \& Hardy, 2002). A lógica pósestruturalista discutida nesta tese possui o mesmo pensamento, em que deixa de basear as análises em totalizações e estruturas fixas da constituição organizacional e passa para uma compreensão da pesquisa e dos fenômenos sociais de forma mais parcial e emaranhada, daí surgem conceitos, como pontos nodais, significantes flutuantes e outros (Laclau \& Mouffe, 1985).

Inicialmente é importante destacar que uma das críticas ao pós-estruturalismo é com relação à alegada carência de "cientificidade". Já a visão dos seguidores desta lógica é exatamente o oposto, de que devemos "resistir ao predomínio do modelo das ciências e do conhecimento científico" (J. Williams, 2013, p. 33) não a fim de se opor à cientificidade, mas sim por entender que essa característica defendida é aplicável às ciências naturais. Com base nisso, não se busca uma verdade final; e métodos fixos e absolutos que "trazem uma verdade" ficam sob suspeita (L. Richardson, 1994).

Não se consagra impulso por interesses metodológicos "rebeldes", mas sim tem-se como objetivo o desenvolvimento uma desconstrução diferente dos "fatos científicos (positivistas)" (J. Williams, 2013). Assim, entendo que "no pós estruturalismo a vida não deve ser definida apenas pela ciência, mas pelas camadas de história e criações futuras capturadas em sentidos amplos da linguagem, do pensamento e da experiência" (J. Williams, 2013, p. 34) e, para tanto, não se pode restringir as pesquisas pós-estruturalistas a uma visão ou metodologia, nem mesmo à visão de ciência como isenta de valores e neutra.

Com base nisso, mesmo as pesquisas pós-estruturalistas apresentando uma empiria (Baker \& Bettner, 1997; Chua, 1986a; Macintosh, 2002; J. Williams, 2013), nesta seção desenvolverei argumentos com relação às estratégias metodológicas, mas não à aplicação exata de uma metodologia já existente e claramente definida. Essa prática está de acordo com o que foi proposto por Feyerabend (2011), em que as descobertas nas ciências sociais muitas vezes são limitadas pelo método científico. Nas palavras do metodólogo, "tudo vale", pois prenderse a um método pode restringir os achados e levar a ciência a estagnação. Considero, portanto, 
que por mais que me utilize de métodos de análise existentes, não há um engessamento, sendo que realizo ajustes de acordo com as necessidades articulatórias da pesquisa.

\subsection{Relação Metodológica com a Teoria e com a Epistemologia}

Devo dizer que possuo visão semelhante a de Ahrens e Chapman (2006), em que não vejo o processo de pesquisa como sendo linear, ou seja, começando pelo problema e terminando pela conclusão. Isso tende a ser a estrutura formal após a pesquisa estar finalizada, porém "o problema, a teoria e os dados influenciam um ao outro durante o processo de pesquisa" (Ahrens \& Chapman, 2006, p. 836). Não diferentemente disso, esta pesquisa foi fruto de uma constante revisitação e modificação dos seus elementos ao longo de seu desenvolvimento.

Corroborando tal pensamento, com relação à estrutura metodológica da tese e sua relação com as teorias suporte, concordo com Feyerabend (2011, p. 19) quando afirma que "os eventos, os procedimentos e os resultados que constituem as ciências não têm uma estrutura comum".

Nenhuma teoria jamais está de acordo com todos os fatos em seus domínios; contudo, a culpada nem sempre é a teoria. Os fatos são instituídos por ideologias mais antigas, e um conflito entre fatos e teorias pode ser uma prova de progresso. Tal conflito constitui também um primeiro passo em nossa tentativa de encontrar os princípios implícitos em noções observacionais familiares. (Feyerabend, 2011, p. 67)

O foco das análises com base na desconstrução pós-estruturalista da teoria do discurso (Laclau \& Mouffe, 1985) é na descrição e na interpretação de cenários específicos, não sendo objetivada sua classificação. Para isso, busca-se leitura de textos ou interpretação de cenários que tragam à tona quesitos como: coerência interna, implicações, estilos, significados e argumentos das situações linguísticas e extralinguísticas (Glynos \& Howarth, 2007; Glynos et al., 2009; Howarth, 2000, 2013; Laclau \& Mouffe, 1985; Macintosh, 2002; Torfing, 1999; J. Williams, 2013).

Considerando o aspecto da contingência aqui empregado, esse exercício de desconstrução e análises são contínuos, ou seja, não se chega a um resultado final sobre determinado fenômeno, mas sim a conclusões compatíveis com aquele momento e àquela análise (J. Williams, 2013).

Com essa visão pós-estruturalista, estratégias como a desconstrução e a lógica de explicações críticas auxiliam no entendimento central de determinados "sentidos linguísticos" (Glynos \& Howarth, 2007). Uma leitura com base nessas lógicas epistemológicas e metodológicas, além de ser uma estratégia política em sentido estrito, também colabora com a 
compreensão de sistemas de pensamento por detrás de estruturas políticas e sociais construídas por meio de práticas discursivas (Macintosh, 2002).

A compreensão de práticas discursivas com base no pós-estruturalismo tende a envolver a discussão de pontos que envolvem retórica (Durocher \& Gendron, 2011; Macintosh, 2002; Young, 2003), criação de mitos (Baker \& Bettner, 1997; Hoffmann \& Zülch, 2014; Meyer \& Rowan, 1977), purificação de conceitos (Durocher \& Gendron, 2011; Young, 2014) e poder (Bengtsson, 2011; J. Brown \& Dillard, 2015; Chua \& Taylor, 2008; De Lange \& Howieson, 2006; Stenka \& Jaworska, 2019), entre outros. Nesse sentido, temos como proposta "desenvolver, estender e aprimorar nosso conhecimento e compreensão sobre o mundo. Entretanto, o objetivo desse conhecimento não é desenvolver teorias preditivas ou de controle" (Young \& Oakes, 2009).

Essas formas leitura das práticas discursivas têm como objetivo trazer à tona as contradições, as ambiguidades, a dominação, os conflitos e os jogos de palavras e poder (Burke, 2012; Burrell \& Morgan, 1979). No pós-estruturalismo, a união entre metodologia e teoria se faz interessante para conseguir, por meio de ferramentas pertinentes, trazer uma abordagem crítica para a desconstrução do conhecimento que é tomado como legítimo e válido como verdades em determinados cenários (Jørgensen \& Phillips, 2002).

Especificamente, a aplicação da teoria do discurso (Laclau \& Mouffe, 1985) desperta o interesse, entre outros, em "revelar" sentidos e percepções com base na percepção do pesquisador, mostrando possíveis visões distintas daquelas usualmente praticadas pelos diversos participantes daquela prática (Torfing, 1999). Assim, busca-se uma aplicação da análise dos discursos de forma não estruturada, ou seja, sem seguir padrões fixos de classificação e categorização, mas sim por meio de um entendimento pessoal do pesquisador e de sua forma de visão dos fenômenos (Crotty, 1998; Feyerabend, 2011).

A abordagem metodológica, portanto, não necessita ser fixa, precisa e nem com base em técnicas e procedimentos exatos (Feyerabend, 2011), devendo ser aberto ao pesquisador o uso de diferentes formas de análise, ou até mesmo de formas inovadoras adaptadas de algo já existente como técnica de análise (Jørgensen \& Phillips, 2002).

Apesar de a teoria do discurso ser compatível com diferentes ferramentas de análise dos discursos, os autores (Laclau \& Mouffe, 1985) não demonstram ferramentas metodológicas específicas para a aplicação de sua teoria geral (Jørgensen \& Phillips, 2002), mas entendem que "a análise de uma prática discursiva focaliza os processos de produção, consumo e mudança 
textual, o que exige referências aos ambientes econômicos, políticos e institucionais particulares nos quais o discurso é gerado" (Marques, 2014, p. 119).

A análise com base na teoria do discurso (Laclau \& Mouffe, 1985) possui estreita relação com as mudanças sociais, isto é, as mudanças (nas mais diversas naturezas) representam um forte arcabouço para análises com base na teoria do discurso, isto porque há uma possibilidade de uma diversidade de análises políticas advindas dessas mudanças, assim como ferramentas discursivas utilizadas na articulação de tais mudanças (Jørgensen \& Phillips, 2002; Laclau \& Mouffe, 1985).

As mudanças representam um momento para a análise de discrepâncias entre o discurso formal e as práticas, pois muitas vezes o discurso hegemônico se institui por meio de conteúdos democráticos, porém a aplicação não obrigatoriamente os segue, já que não há um determinismo constitucional, mas sim uma construção de comportamentos por meio de práticas (Laclau \& Mouffe, 1985). Por isso, a aplicação metodológica segue os padrões de análise da Lógica da Explicação Crítica (Glynos \& Howarth, 2007), que busca unir tanto a visão metodológica da desconstrução como a teoria aplicada (Laclau \& Mouffe, 1985).

Considerando que a "hegemonia é a articulação contingente de elementos em um terreno de indecibilidade e a desconstrução é a operação que mostra que a intervenção hegemônica é contingente - que os elementos poderiam ter sido combinados de forma diferente" (Jørgensen \& Phillips, 2002, p. 48), buscarei demonstrar exatamente as falhas do discurso com a união desses conceitos teóricos e metodológicos. Apesar disso, não há necessidade de aprimorar tais discursos ou uma tentativa de destruição do discurso hegemônico.

Ao rejeitar o determinismo, mesmo que os discursos tenham sido criados pelas instituições hegemônicas para serem interpretados de certa maneira, os indivíduos e pesquisadores podem (e devem) critica-los e demonstrar que esses discursos podem ser “decodificados” de uma maneira diferente (Jørgensen \& Phillips, 2002). Essa prática possui uma relação com a aceitação/não aceitação dos argumentos de uma ideologia dominante, já que por meio da análise e interpretação de discursos de forma distinta daquela latente é uma forma de resistência à hegemonia e às ideologias dominantes (Laclau \& Mouffe, 1985). Isso não quer dizer que a interpretação diferente seja uma "verdade superior" àquela defendida em algum discurso, apenas informa uma "verdade diferente", uma vez que entendemos não haver "verdades absolutas".

Em resumo, unindo as lógicas epistemológicas, teóricas e metodológicas, procurarei demonstrar que ocorrem discrepâncias entre o que se diz e o que se faz e os discursos são formados com base nisso, pois compõem, como já discutido, toda a prática social. Nesse 
sentido, o IASB, assim como outros órgãos detentores de poder, justifica suas práticas sociais com base em quesitos democráticos (como a aplicação dos princípios na normatização), porém apesar dessa formalidade, a prática demonstra falhas que não são naturalmente percebidas, uma vez que não são constantemente questionadas (Gallhofer \& Haslam, 2007).

\subsection{Trustworthiness}

Como já discuti, não entendo que a ausência de juízo de valor possa, nem seja, possível nas pesquisas em ciências humanas (Lincoln \& Guba, 1985, 1986), sendo este um condicionante chamado de "obstáculo epistemológico". Este é o principal limitador que leva a estagnação das pesquisas (Bachelard, 1996). Em resumo, podemos entender que alegar estrito rigor em pesquisas em ciências sociais e humanas, especialmente em contabilidade, é um mito que deve ser reconstruído (Williams, 2014). A ausência daquele rigor exato não significa demérito à pesquisa, mas apenas uma forma diferente de se realizar pesquisa.

Pesquisas com uma visão mais construcionista desafiam os paradigmas dominantes que se baseiam nas ciências naturais e na objetividade. Também se evita a utilização de nomenclaturas positivistas, mesmo que similares, para que os demais paradigmas possam criar suas próprias identidades (Ahrens \& Chapman, 2006; Chua, 1986a; Harrison, MacGibbon, \& Morton, 2001; Lincoln \& Guba, 1985; L. Richardson, 1994, 1997). Assim, com a visão de verdade subjetiva e contingente, não se fala mais em generalização, objetividade, neutralidade e independência do pesquisador (Crotty, 1998; Phillips \& Hardy, 2002).

Como as diversas epistemologias geram visões sobre pressupostos do mundo, da ciência e do conhecimento distintas, os critérios para avaliação das pesquisas também devem ser diferentes e cada um compatível entre si (Lincoln \& Guba, 1985). Por exemplo, não seria justo avaliar sob uma lente objetivista, que exige a definição clara das variáveis, uma pesquisa que por natureza entende as variáveis como subjetivas.

Há diversas formas de se discutir a qualidade metodológica de uma pesquisa. Por exemplo, Smith (2003) se baseia no acrônimo NIRD (novo, interessante, replicável e defensável) para essa discussão de forma a demonstrar a "validade" de uma pesquisa, porém o próprio autor já limita a aplicação do conceito de replicabilidade para alguns métodos e visões epistemológicas. Guba (1981) e Lincoln e Guba (1985) propõem os critérios de credibilidade, transferibilidade, dependência e confirmação (credibility, transferability, dependability, confirmability). Os mesmos atores, em momento posterior, também propuseram os critérios de 
autenticidade: justiça, ontológica, educativa, catalítico e tático (Guba \& Lincoln, 1989; Lincoln \& Guba, 1986).

Além destes, há a noção de qualidade e validade na pesquisa proposta por Richardson (1994, 1997) e Ahrens e Chapman (2006), em que se vê a avaliação de qualidade não como uma triangulação, mas sim por meio do "exame das propriedades de um cristal no sentido metafórico" (Lincoln et al., 2018, p. 244). Os autores defendem ser esta uma métrica condizente com a análise da qualidade de pesquisas pós-estruturalistas, já que nesta epistemologia não se busca a verdade absoluta, mas sim a congruência de sentido entre os argumentos.

A lógica da cristalização foi pensada com base no pós-estruturalismo e é mais ligada ao relacionamento ético e epistemológico na (com a) ciência (Lather, 1993; Lincoln et al., 2018), em que o pesquisador informa suas decisões, já que a pesquisa pode envolver uma "variedade de configurações, substâncias, transmutações, multidimensionalidades e ângulos de abordagens", assim como um cristal reflete luz (L. Richardson, 1997, p. 92). Portanto, a qualidade da pesquisa é mensurada por meio da informação e da congruência.

Em suma, as propostas de visualização da qualidade da pesquisa qualitativa não positivista - ou seja, que não enxerga o mundo e o conhecimento de forma objetiva, mas sim como um emaranhado de agentes sociais - propõem ações de avaliação que exigem do pesquisador uma apresentação das decisões e explicações acerca das escolhas tomadas ao longo da pesquisa.

Com base nessa ideia de trazer identidade para as pesquisas críticas e qualitativas e amparado na cristalização (L. Richardson, 1994, 1997), utilizo como critério de qualidade a lógica de trustworthiness e plausibility (confiabilidade e plausibilidade) (Ahrens \& Chapman, 2006; Guba \& Lincoln, 1994; Lincoln \& Guba, 1985; Lincoln et al., 2018), isso porque os resultados são interpretações, e não verdades (Crotty, 1998). Essa discussão encontra-se em diversas partes desta tese. Ao defender alguma escolha, documento, técnica ou argumento, a qualidade da pesquisa está em jogo e a argumentação funciona como forma de garantir ou defender tal qualidade de acordo com a visão do pesquisador, do paradigma, da teoria ou da metodologia.

A trustworthiness, portanto, é vista como "os meios pelos quais trabalhamos para cumprir os critérios de validade, credibilidade e confiabilidade de nossas pesquisas" (Harrison et al., 2001, p. 324). Isso inclui diversas premissas, como as citadas anteriormente e que incorporam critérios de qualidade. Portanto, nesta seção, indico os principais pontos que garantem a qualidade e a congruência ética e metodológica da tese. 
Considerando as diferentes visões, também podemos dizer que todos os critérios que possam trazer trustworthiness também são contingentes e provisórios (Lincoln \& Guba, 1985), assim como na teoria do discurso (Laclau \& Mouffe, 1985). Por mais persuasiva que uma pesquisa seja, ela sempre apresentará um sistema aberto com possibilidade de críticas, afinal, não acreditamos na completude e na verdade absoluta.

Entre esses critérios, a confiabilidade e a validade da pesquisa pós-estruturalista advém do poder da argumentação empregado na escrita do texto (Macintosh, 2002; Roslender, 2006). Com a aplicação de bases teóricas, há um poder de trazer um framework conceitual que possibilita uma melhor compreensão de fenômenos sociais que envolvem a contabilidade e, com base nessa aplicação, a argumentação surge com a utilização de materiais empíricos (Roslender, 2006). Outro ponto que aumenta a qualidade é o pesquisador refletir sobre o seu papel como pesquisador e como pessoa. Esse ponto já foi discutido na seção "VISÃO EPISTEMOLÓGICA".

Nesse modo de pesquisa, podemos dizer que algo é "aceito como uma explicação válida somente se produz insights e maior iluminação de acordo com critérios que podem ser publicamente articulados, critérios relativos à evidência, consistência, exaustão e assim por diante" (Glynos \& Howarth, 2007, p. 38). Isso não quer dizer que não possa haver contestação da explicação. A mensagem que deixo é que, sob essa base epistemológica, não há neutralidade nem rigor estrito, e sim uma concepção de que a explicação pode ser flexível (Glynos \& Howarth, 2007).

Outro pesquisador, portanto, pode se utilizar das mesmas técnicas e documentos e chegar a outra conclusão. Esse pensamento acaba por ter uma base axiomática, pois nas metodologias qualitativas e críticas não se espera a replicação exata por parte de outro investigador, mas sim que o argumento seja capaz de fazer sentido para os demais, já que a interação dos pesquisadores com os fenômenos sempre serão diferentes (Lincoln \& Guba, 1985).

Por analisar um processo específico de uma instituição hegemônica no meio contábil (Botzem, 2012), pode-se subentender que há generalização para demais processos. Entretanto, utilizo-me do conceito adaptabilidade da pesquisa (Lincoln \& Guba, 1985). Ou seja, pontos levantados também podem ser válidos para aplicação em demais processos conduzidos pelo órgão por meio da lógica de semelhança de família de Wittgenstein (Jackson, 2011). Essa noção não se confunde com o conceito de generalização mais presente nas pesquisas positivistas, que 
seria quando o pesquisador acredita e busca que, além de o "mundo empírico" ser objetivo, ele é também totalmente conhecido e apresenta relações de interesses constantes (Chua, 1986).

Como pesquisadores, também buscamos que a questão da pesquisa seja nova e interessante. Com isso enxergo qualidade em pesquisas que buscam responder ou discutir pontos, às vezes já discutidos, sob um novo paradigma, se amparando em uma teoria diferente ou com a aplicação de um método distinto do já aplicado anteriormente.

Então, para garantir a trustworthiness, devemos buscar descrever claramente os fenômenos e as decisões tomadas, de forma a demonstrar que observamos as possibilidades explicativas, as exceções, o engajamento do pesquisador com o tema e as checagens dos dados de forma a garantir a melhor forma de persuasão e credibilidade (Lincoln \& Guba, 1985). Entretanto, não necessariamente devemos unir todas essas informações em um só lugar, mas podemos também ir mostrando-as ao longo das discussões. O importante é explicar e justificar.

\subsection{Análise dos Discursos}

Com base na teoria pós estruturalista do discurso (Laclau \& Mouffe, 1985), devemos selecionar os métodos e as técnicas a serem aplicadas na análise empírica de acordo com a forma como foi realizada a problematização do objeto (Glynos et al., 2009). Quando procuramos analisar fenômenos políticos e sociais, uma das técnicas centrais são os estudos de discurso com um amparo linguístico e social (Glynos \& Howarth, 2007).

Há uma necessidade crescente na pesquisa crítica de demonstração de opiniões ditas como "alternativas" por meio da diminuição da aceitação de discursos hegemônicos. Nesse sentido, a análise dos discursos sob pontos de vista diferentes dos principais da área é incentivada (Gendron, 2018).

Aqui falo de análise dos discursos em um sentido mais amplo, que será vista em consonância com a "lógica da explicação crítica" (Glynos \& Howarth, 2007). De forma geral, podemos ver a análise dos discursos não como uma técnica específica e claramente definida, mas como uma série de abordagens metodológicas que podem ser utilizadas para analisar diferentes contextos sociais (Jørgensen \& Phillips, 2002).

Por mais que técnicas de análise dos discursos possam ser aplicadas às mais diversas áreas, devemos levar em consideração que essas técnicas não existem e não devem ser utilizadas de forma separada das perspectivas teórica e epistemológica. Assim, como já discutido nas seções anteriores desta tese, a congruência entre os aspectos filosóficos da pesquisa, em especial a visão ontológica e epistemológica são de grande importância, pois será por meio delas que 
nós pesquisadores poderemos informar nossas visões e compreensões sobre a linguagem e seu funcionamento (Jørgensen \& Phillips, 2002).

Como já discutido, "discurso" é um conceito que, sozinho, não diz muita coisa em decorrência da sua amplitude de significados (Burke, 2012). Por isso, ressalto que na visão pósestruturalista consideramos discurso como uma ferramenta de construção social (Laclau \& Mouffe, 1985; J. Williams, 2013), representada pela união de textos (que envolvem diversas formas, como textos escritos, falas, símbolos, figuras, entre outros) e as "práticas de sua produção, disseminação e recepção" (Phillips \& Hardy, 2002, p. 3), envolvendo, portanto, aspectos linguísticos e extralinguísticos (Howarth, 2000). Com base nisso, as interações sociais necessitam da análise de discursos para que sejam observados os elementos de sentidos. Nossa função como analistas do discurso é a de "exploração da relação entre o discurso e a realidade" (Phillips \& Hardy, 2002, p. 3).

Consideramos, também, que as ferramentas discursivas não produzem sentido sozinhas, mas sim por meio de uma cadeia de documentos e práticas que possibilitam essa criação articulação. Assim, a análise dos discursos pode ser vista como uma ferramenta que possibilita o pesquisador a visualizar, por meio de uma coletânea de documentos e práticas, "situações incompletas, ambíguas e discursos contraditórios que produzem uma realidade social que vivenciamos como sólida e real" (Phillips \& Hardy, 2002, p. 1).

A análise dos discursos pode ter diversas intenções por parte dos pesquisadores, mas de acordo com a lógica pós-estruturalista, não se pode objetivar dizer o que é certo e errado, nem qual é a realidade concreta por detrás dos discursos ou as reais intenções de um interlocutor; isso porque a realidade, nessa epistemologia, não é observável fora dos discursos, tornando, portanto, os discursos as principais fontes de análise para observação e crítica dos fenômenos desejados (Jørgensen \& Phillips, 2002). Há uma rejeição a noção de que a linguagem é neutra, dando-se maior relevância para os diferentes discursos (Marques, 2014).

Com base na teoria aqui aplicada, "um dos objetivos da análise dos discursos é o de identificar e analisar mitos de uma sociedade como sendo uma realidade objetiva que está implícito na fala e nas ações” (Jørgensen \& Phillips, 2002, p. 40), sendo o mito o termo que tenta representar a totalidade dos significantes flutuantes (Laclau, 1990).

Por meio da análise de tais mitos e discursos, faz-se possível o mapeamento de processos que envolvem a tentativa de fixação de sentidos de forma que se auxilia na visão alternativa àquela naturalizada e convencionalizada como sendo a correta e normal daquele processo (Jørgensen \& Phillips, 2002). Assim, pretendo mostrar que os princípios ligados à elaboração 
de normas contábeis pelo IASB não são totalizantes e sofrem uma restrita gama de críticas, já que funcionam como coadjuvantes no processo, sendo que sua função não deveria ser coadjuvante.

Por fim, o que devemos levar em consideração é que, nesta tese, a análise dos discursos não é um método, mas sim uma metodologia. Aliada com a visão ontológica, teórica e epistemológica, a análise dos discursos pode fazer uso de diferentes técnicas qualitativas de análise de dados sobre diferentes tipos de informações (Phillips \& Hardy, 2002). Essa necessidade de tentar aliar dados, contexto e discursos em uma análise se torna uma tarefa complexa e, naturalmente, o pesquisador deve limitar a quantidade de dados e informações analisadas de forma a tornar a pesquisa factível, conforme será discutido em mais detalhes na seção "Documentos Analisados".

Se a análise dos discursos funciona, nesta tese, como uma metodologia no sentido amplo, então como aplicarei os conceitos da teoria do discurso (Laclau \& Mouffe, 1985) para o atingimento dos objetivos aqui propostos? Essa será a discussão da próxima seção, onde apresento a estratégia metodológica da "Lógica da Explicação Crítica" (Glynos \& Howarth, 2007).

\subsection{Lógica da Explicação Crítica}

A lógica da explicação crítica, assim como a teoria política do discurso (Laclau \& Mouffe, 1985), foi desenvolvida por pesquisadores da Universidade de Essex. O pensamento geral está apresentado em Glynos e Howarth $(2007$, 2008) e busca ser uma estratégia metodológica para ser aplicada juntamente com a teoria política do discurso de forma a superar os pensamentos da lógica causal que se baseia na predição e dedução (Glynos et al., 2009).

A visão central é a visualização de que os discursos são constitutivos das práticas sociais. Como forma de trazer operacionalização e aplicabilidade à teoria do discurso (Laclau \& Mouffe, 1985), essa estratégia (LEC) “é baseada na articulação da ontologia social que leva em conta a contingência radical e a incompletude estrutural de todos os sistemas de relações sociais" (Glynos \& Howarth, 2008, p. 6).

Com base nessa estratégia, partimos de uma problematização e desconstrução de textos, práticas e organizações para analisar com base na política - no sentido ontológico - os diversos fenômenos que fazem parte de comportamentos sociais de organizações hegemônicas. Assim, procuro analisar como as entidades foram capazes de realizar ou aplicar aquele conjunto de normas sob tais conjunturas (Laclau \& Mouffe, 1985). A desconstrução acaba por ser a 
demonstração de que a relação entre elementos para formar momentos e significados é contingente e não fixa (Southwell, 2014). Assim podemos dizer que a prática da

desconstrução se caracteriza por destacar um elemento do discurso analisado cuja ambiguidade, contraditoriedade ou oscilação de sentido revelaria a abertura de sentido do discurso, assim como a arbitrariedade da decisão tomada pelo sujeito (individual ou coletivo) na tentativa de controlar o deslizamento de sentido, ou seja, a instabilidade semântica de seu próprio discurso, sempre sujeito a ambiguidades, mal-entendidos, mal-ditos, não ditos... (Sales Jr., 2014, p. 174)

Apesar de a desconstrução ter uma origem mais forte nos pensamentos de Derrida, ela é presente na lógica de análise do social com base nos discursos laclaunianos, principalmente com a função de demonstrar as oscilações de sentido e ambiguidades presentes nos sujeitos políticos (Torfing, 1999).

A prática do desconstrução auxilia, também, na análise dos deslocamentos de sentidos, uma vez que podem ser demonstrados os momentos de ruptura do significante universal representado por um ponto nodal por meio de suas contradições (Torfing, 1999; Warren et al., 2019). Porém ela não funciona sozinha. Na LEC entendemos que vamos além da desconstrução: para uma "avaliação crítica das normas e estruturas políticas e morais" (Glynos \& Howarth, 2007, p. 5)

Para começar com a aplicação da LEC devemos entender que ela é composta de passos que compõem desde a identificação inicial do problema até os objetivos finais de explicação dos fenômenos (Glynos et al., 2009). Apresento na Figura 7 uma esquematização que envolve: as abordagens da explicação dos fenômenos sociais, passando pela LEC; a forma como os conceitos dessa estratégia é representada; e como serão aplicados na presente tese, tendo como base a análise do processo normativo de leasing.

Figura 7 - Modelo de Construção da Estratégia Metodológica

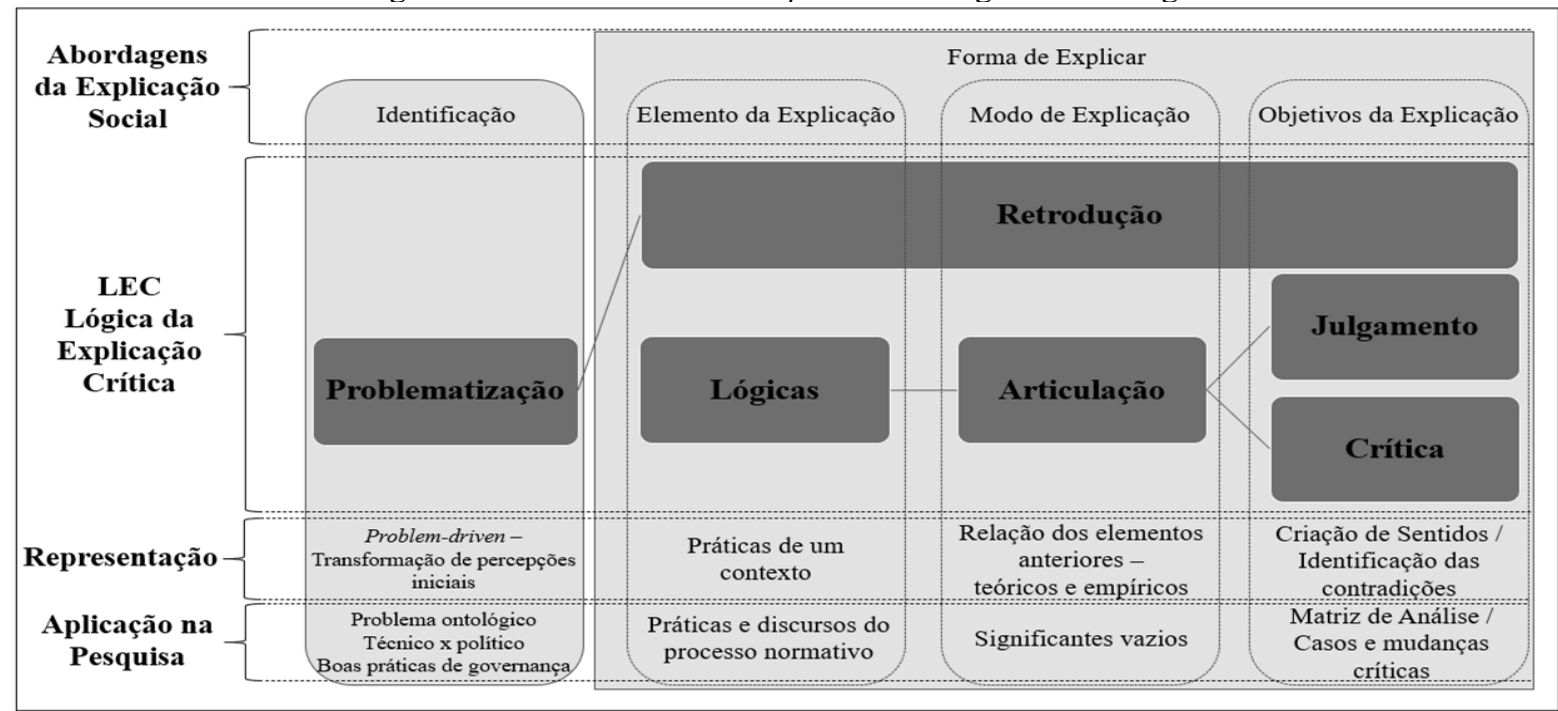

Fonte: Elaboração própria. 
Como primeiro passo temos a problematização, que é a constituição de um objeto em um problema como a base da pesquisa, ou seja, a pesquisa parte de um problema e não da necessidade de aplicação de um método. Essa deve possuir certo nível de complexidade e abstração; e resulta de uma mudança da percepção inicial do pesquisador sobre algum fenômeno que normalmente envolve conceitos que tomamos como garantidos/naturais (taken for granted) em um processo (Glynos et al., 2009; Howarth, 2010). Nosso papel como pesquisadores é, portanto, criticá-los de forma a que não sejam mais tão "óbvios" como pareciam ser. Para isso, devemos identificar algum fenômeno que se mostre viável e digno de contestação (Glynos \& Howarth, 2007).

Nesta tese, a aplicação da problematização se deu pela própria premissa ontológica levada em consideração pela teoria pós-estruturalista do discurso, que é a base da visão dos fenômenos sociais por meio da política. A problematização, portanto, envolve a dualidade do discurso técnico-político do IASB tomado como pressuposto para a necessidade de convergência internacional das normas de contabilidade. Neste discurso, tenta-se trazer a compreensão "naturalizada e retórica" de que trabalhos técnicos representam bons produtos (normas) e trabalhos políticos representam impureza no processo (Young, 2014). Considerando que a política é a base ontológica da teoria, qual a viabilidade da separação de tais conceitos?

Como a teoria do discurso (Laclau \& Mouffe, 1985) e a LEC (Glynos \& Howarth, 2007) exigem a análise de situações específicas e empíricas, escolhi a aplicação no processo normativo da IFRS 16 para a articulação prática, uma vez que esse processo envolveu diversas mudanças no conteúdo da norma e isso me possibilita partir dessas mudanças para construir um framework que envolva a descrição, explicação, avaliação e crítica dos fenômenos sociais (Glynos \& Howarth, 2007, 2008).

A LEC enxerga a "retrodução" como a principal forma de explicação dos fenômenos. Essa retrodução representa um antagonismo às epistemologias hegemônicas que trabalham com os conceitos de dedução ou indução (Glynos \& Howarth, 2007). "Enquanto a ciência baseada na dedução propõe provar o caso, e a baseada na indução objetiva aproximar ao caso, a retrodução conjectura o caso" (Glynos \& Howarth, 2007, p. 26).

Com isso, não buscamos uma explicação causal ou interpretativa. Como categoria de explicação, podemos entender que retrodução, por ser ligada ao contexto sob análise, é mais voltada a um contexto de justificação dos eventos. Ela representa um círculo que vai da problematização para a justificação e da justificação para a problematização por meio de lógicas. Por isso, estamos em constante problematização e reconstrução dos fenômenos, levantando pontos como (in)consistência, credibilidade e persuasão (Glynos \& Howarth, 2007). 
Nesse momento de retrodução, me questiono nessa tese os fatores que levaram o IASB à construção e à finalização da norma de leasing com sucesso. Considero sucesso aqui não o conteúdo, mas a possibilidade de editar uma norma e de fazê-la aplicável nos mais diversos cenários que constituem o escopo do board.

Para podermos apresentar um fator explicativo com base na LEC, esse círculo da retrodução leva a necessidade de iniciar uma explicação daquela problematização para que ela se torne alvo da epistemologia crítica/pós-estruturalista. Entra nesse cenário os elementos iniciais de explicação, que são as lógicas sociais, políticas e fantasmáticas que,

\footnotetext{
quando articuladas conjuntamente, constituem o esquema explicativo da abordagem pós-estruturalista para a explicação crítica. Esse complexo de lógicas nos fornece recursos teóricos para caracterizar as práticas e os regimes, para considerar sua relação dialética, e para explicar como e porque elas modificam ou resistem à mudança (Glynos \& Howarth, 2007, p. 106).
}

"O conceito de lógica possui um sentido bastante particular, que procura capturar as razões, regras, e pressuposições ontológicas que fazem com que uma prática ou regime seja possível, inteligível e vulnerável" (Glynos et al., 2009, p. 11). As lógicas, portanto, nos auxiliam a compreender "como as entidades devem ser para tornar suas regras possíveis" (Butler, Laclau, \& Žižek, 2000, p. 284).

Essas lógicas possuem um ordenamento. As primeiras são as lógicas sociais, que funcionam como forma de caracterizar as práticas de alguma organização ou contexto social por meio de uma gramática ou regras, sendo que essas regras espelham os objetivos, as formas e os conteúdos das práticas sociais. Assim, as lógicas sociais são diretamente ligadas com as regras de funcionamento (não necessariamente escritas e explícitas) do fenômeno social sob análise (Glynos \& Howarth, 2007), mas não se limitam ao que o nome traduz (social) e podem incluir as mais diversas práticas, como econômica, cultural e políticas (Howarth, 2010).

Em seguida, as lógicas políticas, como o próprio nome já diz, estão mais relacionadas com a dimensão política e com as lógicas (equivalência e diferença) trabalhadas pela teoria do discurso (Laclau \& Mouffe, 1985) no contexto de mudanças. Na lógica política temos os pontos em que as práticas originais são rearranjadas de forma a garantir a manutenção do discurso hegemônico, ou seja, pela limitação dos antagonismos. Seria a consecução da demandas individuais em projetos mais amplos (lógica da equivalência), ou o desmembramento de projetos amplos em demandas mais particulares e gerenciáveis (lógica das diferenças) (Glynos et al., 2009). Com isso, ela nos ajuda a compreender a forma como as práticas surgiram, como são operacionalizadas, questionadas e transformadas (Glynos \& Howarth, 2007). Essas lógicas possuem uma aplicação especial nesta tese, uma vez que se relacionam diretamente com a ideia 
de mudanças sociais em nome de "princípios ou ideais". Ela nos permite explicar e criticar a emergência dessas mudanças em um contraponto com tais princípios gerais (Howarth, 2010).

Por fim, as lógicas fantasmáticas mostram como as práticas das lógicas anteriores limitam a ação dos sujeitos por meio da "construção de novos sentidos, práticas e identidades", ou seja, mostram porque as práticas sociais modificaram ou se mantiveram (Glynos \& Howarth, 2007, p. 15). Essa lógica tende a responder: por qual motivo aquela prática resistiu ou se modificou ao longo do tempo? Qual o papel de aceitação ou revolução dado ao sujeito? Com isso, a lógica fantasmática visa uma teorização mais voltada ao sujeito, em que "objetiva capturar a maneira como os sujeitos são cúmplices no acobertamento sobre a contingência radical ou sobre as irregularidades das relações sociais" (Glynos et al., 2009, pp. 11-12).

As lógicas representam o marco central para a aplicação da LEC. Mas será que essa estratégia metodológica é aplicável à regulação e documentos formais? Argumento que sim, pois nada no cenário de regulação se diferencia de cenários sociológicos. Além disso, entendo que nesse cenário de regulação os discursos são constituintes da realidade (Remling, 2018). Para auxiliar na análise dessas lógicas adaptei uma proposta de perguntas que podem ser realizadas em cenários de regulação, conforme pode ser visto na Figura 8.

Figura 8 - Aplicação das Lógicas na Pesquisa

\begin{tabular}{|c|c|c|c|}
\hline Lógica & $\begin{array}{c}\text { Função } \\
\text { Explicativa }\end{array}$ & $\begin{array}{l}\text { Pergunta } \\
\text { geral }\end{array}$ & Perguntas empíricas \\
\hline Sociais & $\begin{array}{c}\text { Revela regras } \\
\text { e normas } \\
\text { aceitas. }\end{array}$ & $\begin{array}{l}\text { Quais são as } \\
\text { regras e } \\
\text { normas? }\end{array}$ & $\begin{array}{l}\text { - O que caracteriza a normatização (de leasing) do IASB? } \\
\text { - Em que "fatos" esse discurso se ampara, por exemplo, o } \\
\text { que aparece como "natural" ou "dado"? } \\
\text { - Quais tipos de normas são reproduzidos, quais valores } \\
\text { ‘contam'? } \\
\text { - Quais são as expectativas implícitas e as regras que } \\
\text { devem respeitar, ou seja, como as respostas devem } \\
\text { parecer para serem aceitáveis? }\end{array}$ \\
\hline Políticas & $\begin{array}{c}\text { Revela o } \\
\text { aparecimento } \\
\text { e a instalação. }\end{array}$ & $\begin{array}{l}\text { Por que e } \\
\text { como elas } \\
\text { surgiram? }\end{array}$ & $\begin{array}{l}\text { - Como é construída a lógica explicativa abrangente? } \\
\text { - Quais estratégias discursivas (equivalência/diferença) } \\
\text { criam o discurso e como é estabelecida a coerência entre } \\
\text { os diferentes elementos? } \\
\text { - Com o que a normatização (leasing) está associada e } \\
\text { como? } \\
\text { - Quais significados e cursos de ação são apresentados ou } \\
\text { excluídos? } \\
\text { - Onde são traçadas as fronteiras e quais ideias foram } \\
\text { fechadas ou marginalizadas no processo? }\end{array}$ \\
\hline Fantasmáticas & $\begin{array}{l}\text { Revela pontos } \\
\text { que engajam, } \\
\text { controlam, } \\
\text { convencem e } \\
\text { governam os } \\
\text { sujeitos. }\end{array}$ & $\begin{array}{l}\text { Como elas } \\
\text { são } \\
\text { sustentadas? }\end{array}$ & $\begin{array}{l}\text { - Como esse discurso é sustentado, o que o faz } \\
\text { "funcionar"? } \\
\text { - Como o entendimento da normatização (leasing) é } \\
\text { justificado e explicado, e como ele tenta "conquistar o } \\
\text { público"? } \\
\text { - Quais resultados são prometidos ou alertados? } \\
\text { - Qual o trabalho ideológico as políticas realizam e com } \\
\text { que finalidade? }\end{array}$ \\
\hline
\end{tabular}

Fonte: Traduzido e Adaptado de Remling (2018, p. 5). 
Com a análise das lógicas por meio das perguntas empíricas, somos capazes de reconstruir os cenários e demonstrar as contingências e os antagonismos neles presentes, podendo, assim, realizar uma avaliação normativa e ética das práticas realizadas. Com isso, temos como modo de explicação dos fenômenos a articulação, em que unimos a visão da problematização e das lógicas teóricas com o contexto empírico de forma a oferecer a explicação crítica.

Essa articulação nada mais é do que a explicitação da forma como devemos entender a pesquisa e sua condução por meio das ciências sociais (Glynos \& Howarth, 2007). Nesta tese a articulação se deu por meio da análise dos princípios do processo normativo, que nos termos da teoria do discurso (Laclau \& Mouffe, 1985) representam significantes vazios com uma pluralidade política de significados.

Juntamente com essa articulação, entramos no objetivo final da explicação crítica, que envolve o julgamento e as críticas propriamente ditas. A ação de articulação exige a atividade de julgamento por parte do pesquisador, atividade que ocorre por meio da dedicação e imersão do pesquisador ao contexto em análise. O julgamento e a crítica, portanto, são "quando o pesquisador [...] adquire e aceita sua capacidade para conectar um conceito a um objeto, ou 'aplica' a lógica a uma série de processos sociais dentro de um framework teórico contingente e contestável" (Glynos \& Howarth, 2007, p. 184).

A crítica, além do julgamento, envolve a prática de "tornar visíveis" fenômenos antes não observados que envolvam lados de dominação e subordinação por meio da demonstração de inconsistências e contradições nos discursos. Com isso, por meio da crítica - principalmente normativa - realizamos uma "contestação pública" de práticas sociais sempre levando em consideração os valores democráticos (Glynos \& Howarth, 2007, 2008; Glynos et al., 2009), sendo este o produto da LEC.

A crítica normativa deve envolver questões de dominação e de diferentes posições dos sujeitos. Assim, essa forma de crítica deve demonstrar essas relações de dominação de modo a poder desafiar as práticas atuais, tomadas como garantidas, em defesa de uma nova visão com base em valores alternativos ou novos princípios (Glynos et al., 2009). Porém devemos ter a noção de que "ao tomarmos como garantidos valores e premissas que sustentam as práticas e as instituições contábeis, nós somos continuamente relembrados que esses (e todos os outros constructos humanos) não devem ser considerados fixos, finais e imutáveis" (Young \& Oakes, 2009). 
Por fim, cabe ressaltar que a estratégia metodológica da LEC (Glynos \& Howarth, 2007) representa uma ferramenta para a aplicação da teoria do discurso (Laclau \& Mouffe, 1985). Considerando que tal teoria trabalha com as bases ontológicas da contingência e precariedade, as explicações dadas por essa estratégia não tendem a representar uma resposta única e verdade final. Ela representa possibilidades da compreensão da prática de articulação realizada em um cenário que se considera o político (no nível ontológico) como categoria central. Por mais que o julgamento e as críticas apresentem as inconsistências discursivas, essas críticas também são contingentes e temporárias, já que a democracia nos permite a atualização das visões exatamente por meio desses antagonismos.

\subsection{Escolha do Caso: Processo normativo de Leasing (IFRS 16)}

As pesquisas de natureza pós-estruturalista tendem a selecionar casos e não analisar dados agregados de forma generalizável e abstrata. O interesse envolve reflexões de situações empíricas específicas que, primordialmente, apresentam mudanças na ordem prática dos fatos (Mendonça \& Rodrigues, 2014; J. Williams, 2013). Isso porque o caso particular envolve diversas especificidades que podem revelar aspectos do mecanismo social que possuem algum vício (Burke, 2012). Ainda com base no pós-estruturalismo, consideramos que textos, ações e discursos dependem da comunidade em que estão situados para fazer sentido (Macintosh, 2002), o que justifica análises empíricas de um processo específico e sob uma mesma comunidade (contábil).

A escolha de uma situação de análise, portanto, não é uma limitação da pesquisa, mas sim uma necessidade teórica e epistemológica (Glynos et al., 2009; Jørgensen \& Phillips, 2002; Macintosh, 2002; Torfing, 1999; J. Williams, 2013). Esse ponto é justificado tendo em vista que as questões não surgem sem discursos, portanto as necessidades de mudanças são discursivamente criadas (Pelger \& Spieß, 2017). A construção de discursos não ocorre em um momento específico, mas como o próprio nome diz, os discursos são construídos por meio de diversas estratégias e envolvem tempo e diferentes práticas para se tornar hegemônico, portanto, a análise de um processo completo tende a suprir tal necessidade na análise de discursos.

As mudanças envolvem, naturalmente, tomadas de decisões. As decisões possuem papel fundamental na análise de desconstrução laclauniana (Laclau, 2013), pois são esses os momentos em que há a realização de formações discursivas e as tentativas de formações hegemônicas. Nos cenários em que encontramos mudanças e tomadas de decisões, também encontramos lutas, pois diferentes sujeitos tentam fazer com que seus pontos de vista 
prevaleçam. Com base na lógica utilizada na tese, essa situação de conflito e mudanças é um material importante e que necessita de análises de casos empíricos específicos e não situações de contexto geral (Jørgensen \& Phillips, 2002).

Além de não representar uma limitação, escolher um caso pode ser uma contribuição ao contexto geral, ou outros casos, por meio da lógica de semelhança de família de Wittgenstein (Burke, 2012; Howarth, 2013). Entender uma situação de forma profunda pode auxiliar na observação de incoerências de sistemas maiores, uma vez que podem ser analisadas em outros cenários de mesma natureza (Burke, 2012). De forma mais ambiciosa, podemos dizer que a crítica ao "todo" somente pode ser realizada se criticado, anteriormente, o "particular" (Glynos \& Howarth, 2007).

Além destes, diversos outros pontos podem ser motivadores para a escolha de um caso específico de análise em uma pesquisa. Essa motivação pode ser em função daquele caso representar a "miniatura de uma situação" em que o pesquisador já imagina ter a existência do fenômeno que ele procura (Burke, 2012, p. 71); em função daquele caso representar uma “excepcionalidade e por revelar mecanismos sociais que não funcionam” (Burke, 2012, p. 72); ou por propiciar "um lugar privilegiado para se observarem as incoerências de grandes sistemas sociais e culturais, as brechas, as fendas na estrutura" (Burke, 2012, p. 73); entre outros.

Outras pesquisas (críticas) que analisam processo normativo dos reguladores também foram aplicadas em processos específicos de forma a argumentar e desconstruir os conceitos tomando como base contextos e análises mais pormenorizadas de casos, como: passivos (Morley, 2016); instrumentos financeiros (Bamber \& McMeeking, 2016; Hewa et al., 2018; Young, 1996); PME (Ram \& Newberry, 2013, 2017); recursos minerais (Cortese \& Irvine, 2010; Cortese et al., 2010); combinação de negócios (Hughes et al., 2017); estrutura conceitual (Pelger, 2016); receitas (Baudot, 2018) e formação da agenda (Pelger \& Spieß, 2017).

Considerando que a maior parte dos estudos analisa algum resultado final de norma (Chiapello \& Medjad, 2009; Mehrpouya \& Salles-Djelic, 2019; Pelger \& Spieß, 2017; Walker \& Robinson, 1993); e que as análises de processo normativo tendem a envolver diversas etapas, acabei por analisar a construção de discurso em um processo do início ao fim. Com isso, optei pela análise do processo normativo de leasing (que culminou na edição da IFRS 16 - Leases,). Como o pós-estruturalismo possui um foco na lógica de mudança como motivador de análise (Burke, 2012; Laclau, 2013), a norma de leasing se mostra como um objeto coerente de análise para a teoria do discurso, uma vez que apresenta, além de mudanças de conteúdo, mudanças 
em impactos, impactados, assim como em aplicação de conceitos e argumentos (E. B. S. de Matos \& Murcia, 2019b).

Embora iniciados os estudos preliminares em 1996, pelo G4+1, apenas em 2006 o tema “leasing" entrou na agenda do órgão. Em consequência desse espaço temporal, críticas ao processo apareceram desde antes da sua entrada na agenda pelos mais diversos atores, como: acadêmicos, práticos, usuários e representantes de normatizadores locais (Beattie, Goodacre, \& Thomson, 2006; Biondi et al., 2011; Morales-Díaz \& Zamora-Ramírez, 2018; Reither, 1998). Após 10 anos, a norma final (IFRS 16) foi emitida.

Além da relevância de seu processo, a norma de leasing possui a criticada figura das transações off-balance (Biondi et al., 2011). As normas contábeis que envolvem esse "reconhecimento" são relacionadas como um dos principais produtos contábeis responsáveis pela crise financeira iniciada nos anos de 2007/08 (Botzem, 2014). Com base nisso, órgãos econômicos mundiais solicitaram urgente tratativa do IASB com relação às normas que possuíam tal figura, inclusive relacionando o off-balance com falta de transparência (G20, 2008), muito em decorrência dos impactos financeiros que essas mudanças poderiam trazer ao mercado mundial.

Apesar desse processo ter envolvido a normatização conjunta do FASB e IASB e já se encontrar finalizado, as normas finais editadas pelos boards contêm diferenças decorrentes de pontos de desacordo ao longo do processo. A análise da convergência entre FASB e IASB como um todo é um tanto quanto precoce, tendo em vista que poucos foram os projetos já finalizados, porém a crítica de processos específicos já pode aumentar os insights acerca do futuro da convergência entre os boards (Baudot, 2014; Camfferman \& Zeff, 2018).

Por fim, considero que a análise de um caso específico possui comprometimentos quanto a generalização (sendo que este não é meu objetivo, como descrito na seção “Trustworthiness"), porém argumento que, dado que o projeto analisado foi conduzido e teve participação de diversos membros que também participaram de outros projetos do IASB, o mesmo processo social analisado nesta tese pode auxiliar na compreensão e na explicação de outros projetos (Morley, 2016).

\subsection{Documentos Analisados}

Como o "pós-estruturalismo é uma prática" (J. Williams, 2013, p. 20), optei por uma análise empírica, como já dito, de um processo específico e dos diversos documentos que o compõem. Para a condução de estudos empíricos sobre política, há uma necessidade de 
restrição dos dados e documentos a serem analisados. Isso porque a quantidade de atores e informações deve ser algo gerenciável para o pesquisador (Phillips \& Hardy, 2002). Assim, a escolha dos documentos e informações deve ser aquela que o pesquisador tenha classificado como as mais relevantes para analisar determinado objeto dentro de um fenômeno maior, ou seja, os documentos que sejam capazes de transmitir o pensamento político acerca de determinada prática (Bevir \& Rhodes, 2003).

Apesar de haver tal seleção, é função do pesquisador informar onde esses dados e documentos se localizam no contexto mais amplo e quais as posições dessas informações no contexto geral da análise (Phillips \& Hardy, 2002), ou seja, como esses documentos auxiliam na verificação da constelação de informações, atores e outros conhecimentos que estejam no escopo do objetivo da pesquisa (Baudot, 2014; Mehrpouya \& Salles-Djelic, 2019).

Para a escolha de documentos e práticas a serem analisados sob uma ótica da teoria pósestruturalista do discurso (Laclau \& Mouffe, 1985), deve-se ter como base o pensamento comparativo. Não apenas a comparação entre documentos para ver similaridades e diferenças, mas documentos, ações e práticas que possam ter suas visibilidades demonstradas, isto é, formas de demonstrar com base histórica e por meio da desconstrução: as contingências de determinadas organizações e os antagonismos internos. Essa é uma forma de demonstrar questões políticas que são obscuras quando regras e normas regulam as ações de determinada organização, pois regras tendem a ser imutáveis (Glynos \& Howarth, 2007, 2008; Laclau, 1994).

A categoria de discurso do pensamento de Laclau e Mouffe não se restringe àquele discurso popularmente conhecido, como pronunciamentos de figuras políticas, presidentes de empresas ou sindicalistas, mas também ao discurso organizacional e das mais diversas formas de pronunciamento público que envolve mais do que textos e falas (Burity, 2014; Laclau \& Mouffe, 1985). Por isso, análises de organizações na formação de discursos também se enquadram no contexto da teoria do discurso aqui discutida.

Como já argumentei, os discursos contemplam tanto aspectos linguísticos como extralinguísticos (Howarth, 2000; Torfing, 1999; J. Williams, 2013), o que leva a diversas possibilidades de documentos e informações que podem ser utilizadas em pesquisas dessa natureza. A visão é que representam, normalmente, fontes primárias de dados e contemporâneas com o "período" analisado (May, 2011).

Os documentos, lidos como sedimentações das práticas sociais, têm o potencial de informar e estruturar as decisões que as pessoas tomam diariamente e a longo prazo; eles também constituem leituras particulares de eventos sociais. Eles nos falam sobre as aspirações e intenções dos períodos a que se 
referem e descrevem lugares e relações sociais em uma época em que talvez não tivéssemos nascido ou simplesmente não estivéssemos presentes (May, 2011, pp. 191-192).

A maior parte dos estudos sobre regulação busca analisar documentos externos ao IASB, principalmente as comment letters ou questionários com possíveis atores envolvidos (Gipper et al., 2013), porém, mais recentemente outros documentos, principalmente aqueles gerados internamente ao board, passaram a ser alvo de mais pesquisas (Bamber \& McMeeking, 2016; Baudot, 2014; Camfferman \& Zeff, 2018; Cortese \& Irvine, 2010; Erb \& Pelger, 2015; Morley, 2016; Pelger, 2016; Warren et al., 2019).

Isso não representa um demérito para pesquisas que se utilizam de documentos gerados externamente ao board, porém nestes estudos obtém-se mais informações sobre os atores do que sobre o próprio IASB. Tudo varia de acordo com os objetivos da pesquisa. Como o objetivo desta se relaciona com análises do discursos do próprio IASB, optei pela escolha de documentos internos, já que "esses documentos fornecem informações nas políticas presentes nas IFRSs [...] e contextualizam o projeto para permitir um maior entendimento dessas políticas presentes" (Warren et al., 2019, p. 131).

Em minhas análises e estudos sobre o board, percebi que "a comunicação escrita com as partes interessadas é o coração do due process" (Botzem, 2014, p. 945) do IASB. Por isso, escolhi analisar o discurso partindo dos mais diversos documentos formais emitidos pelo IASB e tentando realizar suas relações com as ações que envolveram o processo normativo de leasing. Com base nesses documentos, apliquei técnicas de análise do discurso e lógica da explicação crítica. Isso não quer dizer que esses são os únicos documentos que poderiam ser alvo de análise em um trabalho que analisa questões políticas em normatizadores. Há diversas outras fontes de informação e técnicas metodológicas que ainda podem ser incorporadas no futuro por outras pesquisas e pesquisadores que podem contribuir de forma relevante ao debate sobre o assunto. Escolhi os formais pois são esses os documentos que os interessados em geral possuem acesso.

A comunicação escrita e formal do board envolve vários dados, como já apresentado na Figura 3. Esses dados possuem como base o próprio due process handbook, que descreve quando e como devem ser feitas as comunicações formais, sendo essas comunicações o ponto central do handbook (Botzem, 2014). Com isso, podemos dizer que a aplicação dos princípios do handbook é uma estratégia chave na elaboração dos documentos.

O IASB propriamente dito não escreve qualquer documento nem realiza qualquer ação, mas sim seus "funcionários". Posso dizer que os responsáveis pela escrita da maior parte das formalidades são os membros do staff técnico, porém o que é publicado representa o 
posicionamento organizacional. $\mathrm{Na}$ análise dos discursos entendemos as identidades coletivas sob os mesmos parâmetros da análise de identidades individuais (Jørgensen \& Phillips, 2002).

Dada a importância do staff técnico no processo de normatização contábil e a pouca atenção ao seu papel e atuação (Botzem, 2012; Erb \& Pelger, 2015; Georgiou, 2004; Hoffmann, 2011; Howieson, 2009; Morley, 2016; Pelger \& Spieß, 2017; Wingard et al., 2016), analisarei, nesta tese, principalmente os documentos emitidos por esse grupo de profissionais, até porque são eles que (teoricamente) influenciam as ações diretas de tomadas de decisões, que são as votações dos membros votantes do board (Pelger, 2016).

Esses documentos foram emitidos por diferentes órgãos da IFRS Foundation, entre eles: Accounting Standards Advisory Forum, Capital Markets Advisory Committee, Due process Oversight Committee, Effects Analysis Consultative Group, Global Preparers Forum, IFRS Advisory Council, International Accounting Standards Board, e The Trustees of the IFRS Foundation.

Considerando o objetivo da presente tese, apresento os principais documentos que foram analisados por entender que representam a essência das escolhas feitas. Em complemento, apresento no Apêndice B todos os documentos que compuseram o processo normativo da IFRS 16 e que estão publicamente disponíveis. Ressalto que todos eles fizeram parte da análise. A diferença é que os documentos apresentados na Figura 9 são aqueles que estão disponíveis como “documentos emitidos", ou seja, são os documentos formais distribuídos ao público acerca do projeto de norma. Os demais documentos referem-se a partes do processo, como gravações de reuniões, porém, apesar de haver acesso, nem todos os observam, já que não estão registrados como emissões formais da visão do board, mas sim representam a disponibilização de etapas para cumprimento "formal" da transparência.

Por esse motivo, vejo a análise dos discursos dos documentos formais (Figura 9) como aquela que pode ser contrastada com as práticas (observado por meio das mudanças normativas e dos demais passos que são disponibilizados no Apêndice B) para a desconstrução e crítica dos discursos. 
Figura 9 - Principais Documentos Analisados na Pesquisa

\begin{tabular}{|c|c|c|}
\hline $\begin{array}{l}\text { Etapa do } \\
\text { Processo }\end{array}$ & Documento Público Emitido & Citação \\
\hline \multirow{2}{*}{$\begin{array}{c}\text { Fase Pré } \\
\text { Agenda }\end{array}$} & \begin{tabular}{l|l} 
Jul 1996 & Accounting for Leases: A New Approach \\
\end{tabular} & (McGregor, 1996) \\
\hline & \begin{tabular}{l|l} 
Feb 2000 & Leases: Implementation of a New Approach \\
\end{tabular} & (Nailor \& Lennard, 2000) \\
\hline \multirow[b]{2}{*}{ Agenda } & \begin{tabular}{|l|l|l|} 
Jul 2006 & AP9A: Agenda proposal_Leasing \\
\end{tabular} & (IASB, 2006a) \\
\hline & $\begin{array}{l}\text { Jul 2006 | International Accounting Standards Board meeting | AP9: } \\
\text { Leasing }\end{array}$ & $(\mathrm{IASB}, 2006 \mathrm{c})$ \\
\hline \multirow{2}{*}{ DP/2009/1 } & \begin{tabular}{|l|l|} 
Mar 2009 & Discussion paper: Leases Preliminary Views \\
\end{tabular} & (IASB, 2009a) \\
\hline & \begin{tabular}{l|l} 
Mar 2009 & Snapshot: DP: Leases-Preliminary Views \\
\end{tabular} & (IASB, 2009b) \\
\hline $\begin{array}{l}\text { DP/2009/1 } \\
\text { Feedback }\end{array}$ & Sep 2009 | IASB meeting | 6A: Comment letter Summary & (IASB, 2009c) \\
\hline \multirow{4}{*}{$\mathrm{ED} / 2010 / 9$} & \begin{tabular}{|l|l|} 
Aug 2010 & Press release
\end{tabular} & $(\mathrm{IASB} \& \mathrm{FASB}, 2010)$ \\
\hline & \begin{tabular}{|l|l|} 
Aug 2010 & Exposure draft: Leases \\
\end{tabular} & (IASB, 2010b) \\
\hline & \begin{tabular}{l|l} 
Aug 2010 & Exposure draft: Leases: Basis for Conclusions \\
\end{tabular} & (IASB, 2010a) \\
\hline & \begin{tabular}{l|l} 
Aug 2010 & Snapshot: Exposure draft: Leases \\
\end{tabular} & (IASB, 2010c) \\
\hline $\begin{array}{l}\text { ED/2010/9 } \\
\text { Feedback }\end{array}$ & $\begin{array}{l}\text { Jan } 2011 \mid \begin{array}{l}\text { IASB meeting | 5A: Comment letter summary - main } \\
\text { issues }\end{array} \\
\end{array}$ & $(\mathrm{IASB}, 2011)$ \\
\hline \multirow{4}{*}{$\mathrm{ED} / 2013 / 6$} & May 2013 Press release & (IASB \& FASB, 2013) \\
\hline & May 2013 Revised Exposure draft: Leases & (IASB, 2013c) \\
\hline & May 2013 1 Revised ED Leases: Basis for Conclusions & (IASB, 2013b) \\
\hline & May 2013 Snapshot: Exposure draft: Leases & (IASB, 2013d) \\
\hline $\begin{array}{l}\text { ED/2013/6 } \\
\text { Feedback }\end{array}$ & $\begin{array}{c}\text { Nov } 2013 \mid \text { IASB meeting |3A: Summary of Feedback on the } 2013 \\
E D\end{array}$ & (IASB, 2013a) \\
\hline \multirow{5}{*}{ IFRS 16} & \begin{tabular}{|l|l|} 
Jan 2016 & Press release \\
\end{tabular} & $(\mathrm{IASB}, 2016 \mathrm{f})$ \\
\hline & \begin{tabular}{l|l} 
Jan 2016 & IFRS 16 Leases \\
\end{tabular} & (IASB, 2016e) \\
\hline & \begin{tabular}{l|l} 
Jan 2016 & IFRS 16 Project Summary and Feedback Statement \\
\end{tabular} & (IASB, 2016d) \\
\hline & \begin{tabular}{l|l} 
Jan 2016 & IFRS 16 Leases: Basis for Conclusions \\
\end{tabular} & (IASB, 2016b) \\
\hline & \begin{tabular}{l|l} 
Jan 2016 & IFRS 16 Leases: Effects Analysis \\
\end{tabular} & $(\mathrm{IASB}, 2016 \mathrm{c})$ \\
\hline
\end{tabular}

Fonte: Elaborado pelo Autor.

A análise das normas e de suas propostas mostra-se relevante e necessária, pois estas são "artefatos" que resumem o ocorrido durante um processo normativo, levando em conta o resultado final após envolver diferentes atores e conteúdos (Young, 2003). Ainda, pode-se dizer que os textos apresentados representam a opinião dos normatizadores, naquele momento, sobre o tema, demonstrando aonde eles tentarão persuadir os leitores para o convencimento do assunto (Young, 2003).

Além das normas, os principais documentos emitidos em um processo normativo normalmente envolvem as fases Discussion paper e Exposure drafts; isso porque são nessas fases em que as mudanças normativas são realizadas e há maior possibilidade de discussões públicas (Pelger, 2016). Inicialmente, os documentos analisados referem-se às normas (e propostas), suas apresentações, press releases e snapshots. Esses documentos, inclusive, foram a base para a elaboração dos requisitos contábeis apresentados no Apêndice A.

O próprio IASB afirma que as comment letters representam o principal documento do consulta de seu processo normativo (IFRS Foundation, 2016b), sendo que elas também são publicadas nas fases que envolvem DPs e EDs. Como as CLs já são alvo de diversas pesquisas 
e acabam por representar as opiniões externas ao board, nesta tese trabalho com os Comment letters Summaries como os principais documentos de análise, já que estes, além de representarem o trabalho do staff técnico e serem as bases para as discussões dos membros votantes, representam as respostas aos documentos tidos como os principais do processo (CLs).

Nesses summaries há a categorização e argumentação direta acerca do que os "atores" afirmam e eles funcionam como a principal ferramenta de prestação de contas do board para com seus participantes. Uma das funções da análise dos discursos é exatamente a de verificar como os sujeitos são caracterizados pelos discursos hegemônicos, já que essa categorização pode afetar as diversas possibilidades de ação por parte dos sujeitos (Jørgensen \& Phillips, 2002).

Nos comment letters sumaries, a estrutura normalmente é a de resumir as opiniões recebidas pelos usuários, assim como demonstrar a opinião do órgão sobre pontos recebidos e questionados. O órgão estrutura esses documentos de acordo com as perguntas que encaminhou para o público e tende a apresentar resumos para todas elas.

Como os comment letters sumaries são feitos em resposta aos comentários recebidos dos usuários da contabilidade (comment letters), toma-se como premissa que: quem pergunta deve levar em consideração as respostas a serem recebidas, sendo que as perguntas são encaminhadas para pessoas que têm condições de respondê-las. Se algum desses pontos não for real, podemos dizer que há intenções implícitas por parte do questionador inicial (Brandão, 2012). Esse é um fato presente no IASB, que ao limitar as perguntas ao alto conhecimento técnico, acaba por restringir a participação no processo.

Vejo que esses documentos representam, para o IASB, um instrumento formal de aprimoramento dos seus princípios, uma vez que o órgão os vê como um aumento da transparência do processo normativo, que resulta em uma melhoria baseada no princípio da consulta completa e justa e gera accountability ao justificar suas decisões. Assim, há a possibilidade de diversas análises e desconstruções que levem em consideração conceitos críticos, como a existência de silenciamentos e prolepses e a desconstrução dos principais argumentos e ações realizadas tomando como base os princípios do handbook.

Além dos summaries, destaco que a análise será realizada levando-se em consideração os relatórios emitidos pelo Due Process Oversight Committee, conforme apresentado na Figura 10. Eles serão base de análises subsidiárias, pois neles há informações sobre os passos formais de condução do processo e a visão do órgão quanto à sua aderência (de direito). Além disso, o 
DPOC recebeu críticas por parte de atores externos acerca do processo de leasing e é formalmente responsável pelas respostas e acompanhamentos desses pontos.

Figura 10 - Documentos Emitidos pelo Due Process Oversight Committee

\begin{tabular}{|c|c|}
\hline Documento Público Emitido & Citação \\
\hline Apr $2011 \mid$ DPOC paper 2(ii): Correspondence with global leasing industry representatives & (DPOC, 2011) \\
\hline Jan 2012 DPOC meeting paper 3E(iv): Correspondence with ACCOR et al & (DPOC, 2012c) \\
\hline $\begin{array}{l}\text { Jan } 2012 \text { DPOC meeeting paper 3C-appendix 2: Correspondence with ACTEO, AFEP } \\
\text { and MEDEF }\end{array}$ & $(\mathrm{DPOC}, 2012 \mathrm{a})$ \\
\hline $\begin{array}{c}\text { Jan } 2012 \mid \text { DPOC meeting paper } 3 D(\text { ii) appendix 1: Updating the IASB's procedures in } \\
\text { response to the DPOC protocol: Leases example }\end{array}$ & $(\mathrm{DPOC}, 2012 \mathrm{~b})$ \\
\hline \begin{tabular}{l|l} 
Jul 2012 & IASB meeting paper $3 H:$ Leases: Due process \\
\end{tabular} & (DPOC, 2012e) \\
\hline $\begin{array}{l}\text { Jul } 2012 \mid \text { IASB meeting paper } 3 G: \text { Leases: Exposure draft comment period and permission } \\
\text { to begin the balloting process }\end{array}$ & $(\mathrm{DPOC}, 2012 \mathrm{~d})$ \\
\hline May 2013 Memo to DPOC: Leases: Issue of revised Exposure draft: Due process & $(\mathrm{DPOC}, 2013)$ \\
\hline \begin{tabular}{l|l|l} 
Oct 2014 & AP3C: Leases-Feedback on leases due process \\
\end{tabular} & $(D P O C, 2014 a)$ \\
\hline \begin{tabular}{l|l} 
Oct 2014 & AP3C(i): Leases-Project update \\
\end{tabular} & $(D P O C, 2014 b)$ \\
\hline \begin{tabular}{l|l} 
Oct 2014 & Trustees meeting summary October 2014
\end{tabular} & $(D P O C, 2014 c)$ \\
\hline $\begin{array}{c}\text { Mar 2015 | IASB Meeting paper 3A: Leases: Due process, re-exposure and permission to } \\
\text { ballot }\end{array}$ & $(\mathrm{DPOC}, 2015 \mathrm{c})$ \\
\hline Mar 2015 Staff e-mail to DPOC & $(\mathrm{DPOC}, 2015 \mathrm{e})$ \\
\hline Apr 2015 | AP3C: Leases: Due process 'lifecycle' review & $(D P O C, 2015 a)$ \\
\hline Apr $2015 \mid$ AP3C(i): Leases: Due process paper to the IASB & $(D P O C, 2015 b)$ \\
\hline \begin{tabular}{l|l} 
Oct 2015 & IASB Meeting paper 3B: Leases: Effective Date \\
\end{tabular} & $(\mathrm{DPOC}, 2015 \mathrm{~d})$ \\
\hline Oct 2015 Staff e-mail to DPOC & (DPOC, 2015f) \\
\hline \begin{tabular}{|l|l|l} 
Jan 2016 & AP3D: Quality control: The process from permission to ballot to publication \\
\end{tabular} & $(D P O C, 2016)$ \\
\hline
\end{tabular}

Fonte: Elaborado pelo Autor.

Ressalto, ainda, que outros documentos e relatórios internos não diretamente relacionados ao processo normativo de leasing foram utilizados para a argumentação em questões pontuais, mas não representam os documentos principais da pesquisa. Entre esses documentos, cito relatórios de reuniões dos trustees e com participantes do mercado. Nesses documentos, informações também podem ser obtidas sobre as opiniões do board naquele momento e confrontadas com decisões tomadas durante o processo e os princípios do handbook.

Por fim, um dos diferenciais é a análise longitudinal de documentos que compõem diversas fases do processo normativo (Baudot, 2014). Nesse caso, podemos observar a vantagem de uma análise singular ao longo do tempo, já que incorpora explicações contextuais sobre o fenômeno e não somente uma análise voltada para efeitos genéricos, o que contribui para as compreensões de desconstruções baseadas nas mudanças ao longo do processo e auxiliando na construção narrativa das ambiguidades observadas. 
5.7 A Criação de um Framework de Análise do Processo Normativo

Cada ambiente possui os seus próprios mecanismos de funcionamento - como os valores, as regras, os procedimentos e os rituais - e esses mecanismos servem como base para o comportamento dos envolvidos naquele ambiente (Macintosh, 2002). As instâncias de poder também demonstram quem são os responsáveis por transformar esses mecanismos em verdades, ou seja, aqueles que possuem o poder dado para ser o transmissor da mensagem, da "verdade" (Macintosh, 2002). No caso em questão, esse é o papel dado ao IASB que, por meio do processo de regulação, apresenta estratégias de boa governança como mecanismo de verdade para a consecução do seu processo normativo.

O framework de análise crítica, portanto, foi criado com base em diversos estudos críticos sobre regulação na contabilidade (Bamber \& McMeeking, 2016; Beisheim \& Dingwerth, 2008; Burlaud \& Colasse, 2011; Erb \& Pelger, 2015; Herbohn \& Herbohn, 1999; Hewa et al., 2018; Hughes et al., 2017; Pelger, 2016; Pelger \& Spieß, 2017; A. J. Richardson, 2008; A. J. Richardson \& Eberlein, 2011; Warren et al., 2019; Wingard et al., 2016), em especial os realizados por Joni J. Young (Young, 1996, 2003, 2006, 2014; Young \& Williams, 2010) e Sebastian Botzem (Botzem, 2008, 2012, 2014; Botzem \& Dobusch, 2012; Botzem \& Hofmann, 2010; Botzem \& Quack, 2006a, 2006b, 2009). E também sempre buscando amparo na teoria pós-estruturalista do discurso (Critchley et al., 1996; Howarth, 2010; Laclau, 1994, 2007b; Laclau \& Mouffe, 1985; Laclau \& Zac, 1994; Mouffe, 2015; Torfing, 1999).

Para se criar uma análise com base na teoria de Laclau e Mouffe (1985), discuti os conceitos que embasam as análises empíricas, como:

\footnotetext{
- Pontos nodais, significantes mestres e mitos, que são nomeados coletivamente como significantes chave em um discurso organizacional.

- O conceito de cadeia de equivalência que se refere ao investimento dos significantes chave em um sentido.

- Conceitos relacionados com a identidade: formação de grupos, identidade e representação; e

- Conceitos para análises de conflitos: significantes flutuantes, antagonismo e hegemonia (Jørgensen \& Phillips, 2002, p. 50).
}

A operacionalização partiu desses conceitos para uma análise e criação de um framework de análise em um cenário específico. Como a teoria é mais uma visão do mundo político do que diretrizes claras e detalhadas, a construção de frameworks de análise acaba por ser individual a cada pesquisador e a cada projeto (Jørgensen \& Phillips, 2002).

Para montar um framework geral (Figura 11), utilizo-me do cruzamento de constructos (retóricos) de inclusão, deliberação e controle democrático, representados por meio dos princípios do handbook - transparência, consulta completa e justa, e accountability - 
(Beisheim \& Dingwerth, 2008; A. J. Richardson \& Eberlein, 2011; Young, 2003, 2014); e de elementos e procedimentos de análise empírica voltados às dimensões da criação de normas de órgãos transnacionais, que são: atores envolvidos, processo organizacional e conteúdo da norma (Botzem, 2012).

Figura 11 - Framework de Análise Crítica dos Pontos de (in)consistências e (in)completudes

\begin{tabular}{|c|c|c|c|}
\hline $\begin{array}{c}\text { Bases de } \\
\text { Análise/Princípios }\end{array}$ & Transparência & Consulta completa e justa & Accountability \\
\cline { 1 - 1 } Conteúdo da Norma & POntOS de \\
\cline { 1 - 2 } $\begin{array}{c}\text { Processo } \\
\text { Organizacional }\end{array}$ & $($ in $)$ Consistências e \\
\cline { 1 - 2 } Atores Envolvidos & $($ in) completudes \\
\hline
\end{tabular}

Fonte: Elaboração própria.

Em cada situação empírica, uma forma de análise pode ser desenvolvida e aplicada de forma a discutir acerca da negociação e imposição desses conceitos em determinados contextos (Jørgensen \& Phillips, 2002; Laughlin, 1995; Young \& Oakes, 2009). Por isso, a elaboração do framework de análise (Figura 11) é, nesta seção, geral, podendo ser preenchida internamente de acordo com os cenários alvo de análise. Com isso, sugiro que esse framework geral também possa ser utilizada para aplicação em outros processos do IASB ou em normatizadores similares que possam vir a surgir, sendo diferenciado apenas o seu preenchimento. Com base nesse framework de análise, portanto, as demais pesquisas podem partir para a criação das críticas específicas a cada projeto.

Ao mesmo tempo que existe essa subjetividade na aplicação dos princípios e dos passos de análise, existe também uma burocratização que é verificável empiricamente (Botzem \& Hofmann, 2010). Porém devemos deixar claro que a constante aplicação dos conceitos dos princípios, principalmente por meio de sua vacuidade, leva tais princípios a representarem uma visão de "meios" e não "fim”, justificando análises do termo que se voltam para elementos dos processos e não para resultados finais (P. F. Williams, 1987). Ainda, após a finalização (votação e emissão da norma final), não há participação pública e presença de estratégias de accountability e transparência com relação à decisão tomada. Isso, portanto, demonstra que o interesse na "aplicação dos princípios" é durante o processo, e não sobre o resultado final (Pelger, 2016). 


\subsubsection{Criação do Eixo Vertical - Elementos do Processo Normativo}

Inicialmente descrevo a construção dos mecanismos de análise relacionados com os elementos do processo normativo. A criação dos constructos de análise se deu conforme a Figura 12.

Figura 12 - Constructo de Análise do Processo Normativo

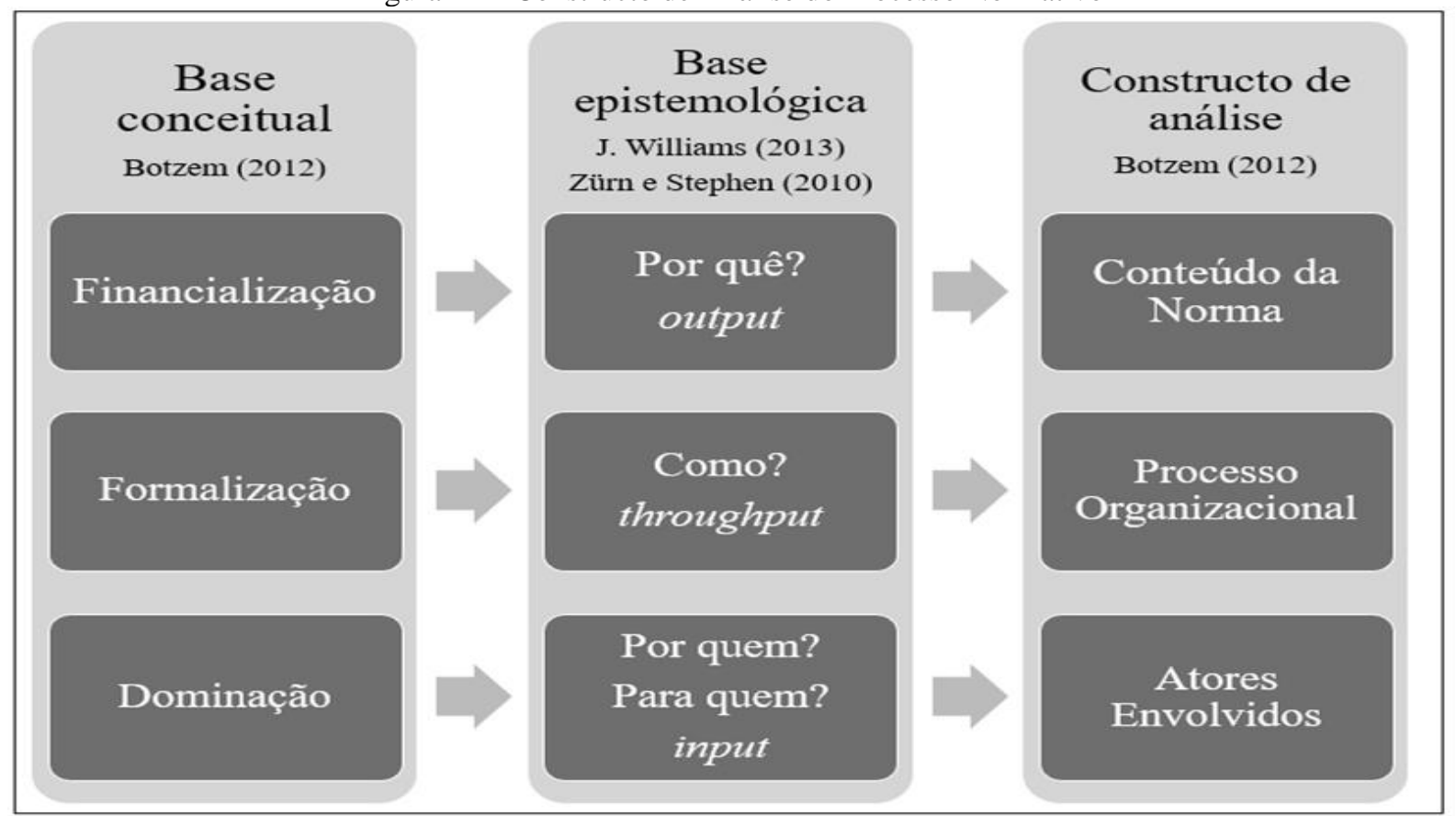

Fonte: Elaboração própria

As organizações consideradas novos agentes no mercado, como é o caso dos órgãos transnacionais, além de serem novas instituições, também formulam novas políticas, que possuem como cerne mecanismos institucionais como: "financialização", formalização e dominação. Estes direcionam seu funcionamento e qualificação, sendo a teorização de Botzem (2012) a de que o processo normativo circula em torno dos seguintes conceitos:

(i) “Financialização": "a sucessiva exclusão de princípios alternativos leva a uma orientação que abastece e resguarda a lógica distributiva do mercado de capitais" (p. 178).

(ii) Formalização: "com respeito aos ajustes organizacionais contínuos e à formalização dos processos normativos, a ênfase na transparência e em passos

\footnotetext{
${ }^{5}$ Esse conceito, no sentido utilizado pelo autor, representa a questão do conteúdo das normas contábeis editadas pelo IASB possuírem um claro direcionamento para o mercado, ou seja, um direcionamento para a "financialização".
} 
responsivos indica que a lógica processual é o bloco principal na institucionalização transnacional"' (p. 178).

(iii) Dominação: "a dominação de atores centrais, individuais e organizações envolve a inclusão estratégica de gatekeepers, enquanto ao mesmo tempo, marginaliza e exclui os stakeholders sociais mais fracos" (p. 178).

Esses conceitos possuem consonância com algumas perguntas que geralmente são levantadas em análises pós-estruturalistas, como: (i) "por quê?”, (ii) “como?”; e (iii) "por quem?/para quem?” (J. Williams, 2013). Podemos argumentar que (i) refere-se à financialização, em que as normas são realizadas para suprir a visão financeira do mercado de capitais; (ii) teria uma relação com a formalização, em que os processos são mecanismos de explicação e direcionamento da construção das normas; e (iii) possui uma relação com a dominação, em que temos atores mais influentes que mesmo sendo formalmente apresentados como constituintes, possuem tanto poder que se tornam alicerces que direcionam a normatização.

Apesar de não utilizar diretamente na tese teorias de legitimidade, há uma relação desses constructos com as três dimensões da legitimidade voltadas para a tomada de decisões. Podemos dizer que a análise da dimensão input se relaciona com as pessoas envolvidas na tomada de decisão e seus interesses. A análise da throughput envolve questões relacionadas com a processo da tomada de decisões. Por fim, a dimensão output é fundamentada na qualidade da decisão (A. J. Richardson \& Eberlein, 2011; Zürn \& Stephen, 2010).

Após essa relação entre a base conceitual da organização dos processos normativos (Botzem, 2012; Botzem \& Dobusch, 2012) e a base epistemológica (J. Williams, 2013; Zürn \& Stephen, 2010), cheguei aos constructos finais, que são os mesmos propostos por (Botzem, 2012) como sendo os mais relevantes para análises de processos normativos, em especial do IASB. O autor afirma que a maior parte dos estudos analisa apenas um desses constructos de forma separada, sendo relevante a realização de estudos críticos que observem mais relações entre esses elementos (Botzem, 2012). O que observo é que muitas vezes esses constructos também se misturam, pois um influencia o outro.

Falando especificamente das categorias, o conteúdo da norma possui relação clara com o processo normativo, uma vez que o conteúdo acaba por ser o resultado político das decisões dos normatizadores, que envolve objetos de interesse, barganha, negociação e política (Botzem \& Quack, 2009; Fogarty, 1994; Pelger, 2016; Young, 2014). 
Com base nisso, podemos dizer que o conteúdo da norma não é dependência factual da opinião do próprio IASB. Isso ocorre principalmente por ser uma instituição que possui membros votantes que cumprem mandatos; e os processos, muitas vezes, são mais longos do que a permanência dos membros no órgão. Assim, é importante a capacidade do staff em manter suas opiniões e posicionamentos, uma vez que o conteúdo pode sofrer relutâncias em decorrência da entrada/saída de membros votantes e da participação dos atores de acordo com seus interesses (Pelger, 2016).

Outra estratégia que influencia o conteúdo é a de aproximar a contabilidade internacional da contabilidade dos países que possuem um mercado maior e considerado mais desenvolvido (Hopper et al., 2017). Isso se deu com a aproximação dessas normas às anglosaxãs (Botzem \& Quack, 2009; Camfferman \& Zeff, 2006; Gallhofer \& Haslam, 2007) por meio do conceito de financialização, levando ao argumento de que essa visão traz maior qualidade (Arnold, 2012; Chiapello, 2016; Hopper et al., 2017). Com isso temos uma relação direta também entre a qualidade e a própria convergência. A qualidade seria medida pela consistência aos conceitos desenvolvidos na estrutura conceitual e a convergência ao nível de aceitação das normas do board (Burlaud \& Colasse, 2011; Street, 2006). Quando o board se deparar com uma dúvida entre os dois, qual ele priorizará?

Quando falo em conteúdo da norma, é difícil dizer que estou avaliando a qualidade da norma em si, já que as premissas contábeis tendem a ser subjetivas e ainda há uma grande incerteza sobre o que seria uma norma de alta qualidade. Além disso, as premissas de qualidade de uma norma contábil são avaliadas pelos mesmos experts que a escreveram e que estão no mesmo contexto científico (Madsen, 2013). Apesar disso, perceberemos que esse é um dos principais argumentos dados como justificativa para as mudanças de conteúdo.

Nos casos como o de leasing, em que há duas partes contratuais diretamente afetadas, os momentos de conflito podem ser observados, principalmente quando se impacta o lado econômico desses sujeitos. Esses sujeitos tentam influenciar a normatização para que os beneficie, levando a uma constelação de atores envolvidos no processo normativo.

Os atores tendem a atuar sob três principais motivações, que são: interesses, razão e paixões (Mouffe, 2015). Quando há disputas por significados, podemos entender que há diferentes atores tentando construir um sentido, porém, ainda, atores hegemônicos tendem a construir certa naturalidade no discurso, de forma a denotar que não há outras alternativas possíveis (Jørgensen \& Phillips, 2002). Isso mostra a habilidade de atores poderosos em criar 
discursos estratégicos e limitar a participação e o espaço dos atores com menos poder, principalmente por meio de silenciamentos e prolepses (Phillips \& Hardy, 2002).

Por exemplo, entre esses atores poderosos (e que possuem razões, interesses e paixões) estão as grandes empresas multinacionais de auditoria. Negar a influência das Big4 é um tanto quanto ingênuo. Sua influência o transforma em um dos principais atores na condução do processo e seu papel é participativo desde a parte financeira, até a emissão do que é conhecimento expert e relevante para a normatização (Botzem, 2008; Shafer \& Gendron, 2005).

Já entre os atores internos e passíveis de análise, nos vêm à cabeça os membros votantes do board e os membros do staff técnico. Apesar da dita independência desses membros, muito em decorrência da alegada variedade de backgrounds profissionais (auditores, acadêmicos, mercado e reguladores nacionais) e geográficos, podemos perceber que a maioria carrega semelhanças nos backgrounds educacionais e, inclusive, profissionais. A maioria possui educação com base em conceitos e visões anglo-saxãs da contabilidade e tiveram suas experiências em empresas de auditoria, mesmo que no final de suas carreiras estivessem em outras áreas (Burlaud \& Colasse, 2011). Além disso, por já terem feito parte dos altos escalões dessas empresas, há uma condição moral crítica na análise dos atores envolvidos e possíveis vieses de interesse (Botzem \& Quack, 2009). Aqui podemos demonstrar a mesma relação já descrita acerca do conteúdo da norma, em que pode ser visualizada uma dicotomia entre qualidade e convergência. O que esses atores priorizariam?

A participação no board de forma a ter representação geográfica, por exemplo, é uma ferramenta de governança explícita. Apesar de haver "representatividade" geográfica e de setores econômicos entre os membros do board, a participação de constituintes de mercados menores, como América Latina e África, é bastante restrita (Camfferman \& Zeff, 2006)

Quando falamos em "atores" na regulação contábil, devemos ter como base de que esse conceito é relacionado com o de "usuários" constante nos mais diversos documentos do IASB. Esses usuários são entendidos, com base na literatura crítica, como a representação retórica de grupos que são interessados nas normas contábeis, sendo "eles" o principal elemento na justificativa das decisões normativas (Hopwood, 1994; Stenka \& Jaworska, 2019; P. F. Williams \& Ravenscroft, 2015; Young, 2003, 2006).

A contabilidade possui uma grande variedade de atores que podem ser impactados. Naturalmente, pensamos em participantes do mercado, como entidades industriais, comerciais, instituições financeiras, analistas de mercado, auditores e investidores, porém há diversos outros, como cidadãos comuns e diversos países com baixa representatividade no mercado financeiro (Palea, 2015). Isso porque muitas decisões de políticas públicas podem advir de 
dados contábeis, influenciando na empregabilidade e nos mais diversos direitos. Com isso, podemos afirmar que há um claro desbalanceamento quando pensamos em atores envolvidos no processo (Botzem \& Quack, 2009), o que nos leva a incluir essa categoria para verificarmos até que ponto há inclusão/exclusão de determinados atores com base nos princípios.

Por fim, o processo organizacional já foi discutido junto com os outros constructos, uma vez que representa o elo que une tanto os atores quanto o conteúdo. As organizações transnacionais se utilizam do discurso de que, a fim de manter sua credibilidade, devem possuir estruturas organizacionais claras (Black, 2008) que funcionem como centro limitador das ações durante a processo de elaboração de uma norma.

\subsubsection{Criação do Eixo Horizontal - Princípios do Handbook}

Após a realização dos constructos do processo normativo, verifiquei no documento base da pesquisa (handbook) a presença de itens que representassem conceitos políticos da teoria do discurso (Laclau \& Mouffe, 1985). Considerando que a busca pela hegemonia é a tentativa de transformação de conteúdos particulares em universais, ou seja, aceitos em sua plenitude (mesmo isso sendo impossível em decorrência do conceito de falta constitutiva) (Laclau, 1990; Laclau \& Mouffe, 1985), a busca dos pontos de (in)consistências e (in)completudes foi por significantes vazios/flutuantes e que sua visualização no sistema discursivo pudesse ser percebida como uma batalha ontológica e epistemológica entre a totalização e a contingência. Isso porque, nesses significantes poderei perceber uma "pseudototalização" que sempre será ameaçada pela contingência e pela precariedade, sendo que essa contingência e precariedade seriam as representações factuais do antagonismo por meio das críticas. Além disso, são conceitos naturalizados que, para Glynos e Howarth (2007, p. 131), expressam o comando para pesquisadores: “deixe a procura começar. Eu te garanto que há algo a ser encontrado!”.

Como já afirmei em diversos momentos desta tese, há uma tendência a observar a contabilidade sob um panorama de que ela representa algo objetivo, neutro e que produz resultados independentemente da realidade social externa. Para justificar tal movimento, são realizadas estratégias que produzem normas esteticamente neutras e objetivas e essas estratégias envolvem a discussão de postulados e princípios, que estão presentes desde a elaboração de normas até suas aplicações (Macintosh, 2002). Assim, o outro eixo que fará parte do framework de análise é representado pelos princípios do due process handbook (Figura 13), que são apresentados como os polos fundamentais para a criação de normas contábeis de "qualidade" 
pelo IASB. Esses princípios, em suas essências, funcionam como significantes vazios com base na teoria do discurso (Laclau \& Mouffe, 1985).

Figura 13 - Constructo de Análise do Handbook

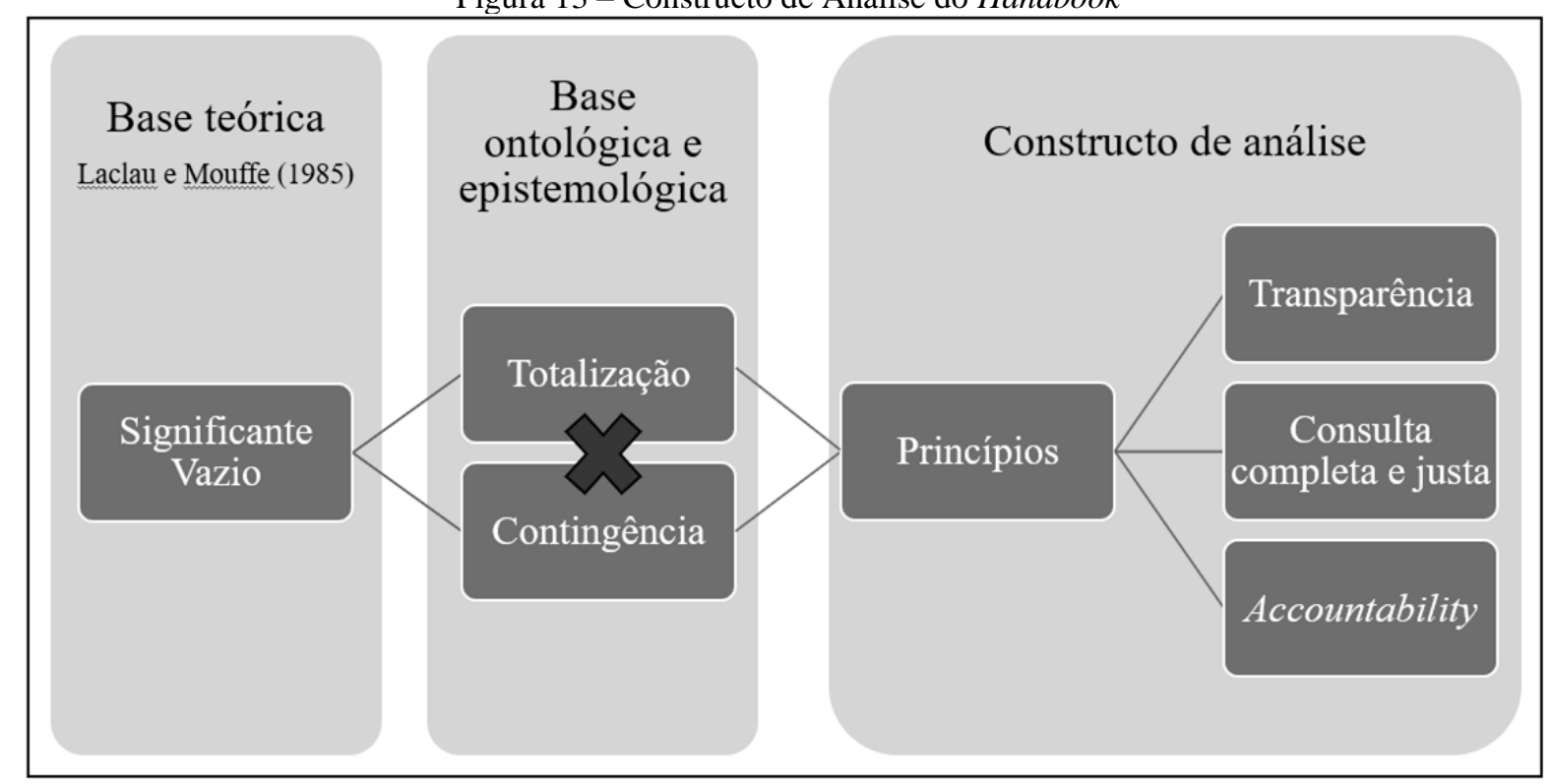

Fonte: Elaboração própria

O significante vazio possui uma função importante nas estratégias políticas, muito em decorrência de agrupar diversos agentes que se sentem representados por aquela universalidade, porém que não se questionam se tal universalidade uma hora será representada pela particularidade do agente com maior poder (Laclau, 2007b) A totalidade é uma entidade imaginária (Jørgensen \& Phillips, 2002), portanto, eu objetivo demonstrar que os princípios não são totais - (in)completude - e são construções discursivas que funcionam como significantes vazios.

"Nós agimos na sociedade como se existisse uma totalidade, e verbalizamos como se fosse uma totalidade" (Jørgensen \& Phillips, 2002, p. 39). De forma semelhante ao que Hopwood (1994) argumenta acerca da perspectiva dos usuários, podemos dizer que os princípios são vistos como tão óbvios que não necessitam nem de uma manifestação física nem de uma apelação à bases de evidências convencionalmente aceitas" (p. 249), porém existem formas de criticar esse óbvio quanto a não aplicação dos princípios em determinados contextos (Gallhofer \& Haslam, 2007). Mas me sinto no dever de informar que, mesmo criticando a aplicação dos princípios, nunca um processo será perfeito e total.

Devido às possíveis ambiguidades advindas da totalidade quando encarada com a contingência, os princípios não podem ser medidos sob uma ótica objetiva em que temos um tamanho único (one-size fits all) (Young \& Oakes, 2009). Com base nisso, devemos nos utilizar 
de técnicas e conhecimentos que auxiliem na explicação, mas que não deem tal compreensão objetiva.

Mas como analisar esses princípios? Minha sugestão é que seja pelos pontos de (in)consistências e (in)completudes. Esses pontos podem ser demonstrados por meio dos próprios documentos internos emitidos. Por exemplo, quando se possui acesso aos documentos de comunicação externa de uma organização, a transparência e a accountability deixam de ser algo abstrato para se tornar algo observável. Assim, tais formas de comunicação se tornam dados e bases de análise. Nesse sentido, o interesse seria o de verificar se a narrativa construída por meio da comunicação com os agentes externos faz sentido e se existe congruência nas articulações ao longo do tempo (Black, 2008). Para isso, existe o ferramental crítico baseado na desconstrução.

Considerando a teoria suporte desta pesquisa (Laclau \& Mouffe, 1985), podemos entender que as "relações de accountability são interações discursivas com suas próprias lógicas que recorrem e, assim, reproduzem estruturas particulares de significado" (Black, 2008, p. 152). A narrativa construída por meio da accountability é efeito de decisões da organização, ou seja, constituída pela entidade, porém ela não constitui as normas e práticas. Por ser reativa, a "narrativa pode ser falsa de forma a servir aos próprios interesses da organização" (Black, 2008, p. 151). Assim, por esses exemplos, as ações diretas de accountability podem ser observadas por meio dos mais diversos procedimentos articulatórios de uma organização em confronto direto com suas práticas. Esse representou um dos modos de análise dos princípios de forma a utilizar-se de ações observáveis. Para continuidade desse pensamento, desenvolvo nos resultados os pontos de análise de forma aplicada ao caso da normatização de leasing.

\subsection{Resumo do Capítulo}

A metodologia e as estratégias metodológicas devem possuir relação estreita de congruência com as visões ontológica, teórica e epistemológica da pesquisa, sendo que cada um desses elementos deve ser explicitado quando da realização de pesquisas, principalmente aquelas que se amparam em paradigmas diferentes do mainstream da área. Por se amparar em um paradigma diferente, as nomenclaturas também variam e merecem ser explicadas (Chua, 1986b; Guba \& Lincoln, 1994; Lincoln et al., 2018).

Inicialmente, devemos entender que entre as premissas metodológicas estão aquelas ligadas à trustworthiness. Os critérios de trustworthiness são de preocupação para o autor, na 
forma de explicar todas as escolhas realizadas e para o leitor de uma pesquisa, seja como forma de avaliá-la, utilizá-la como base para alguma outra pesquisa ou desenvolver seus modelos e teorias. Assim, acabam por ser critérios avaliados pelo leitor como forma de identificar a qualidade da pesquisa e é responsabilidade do autor dar informações suficientes para essa análise do usuário (Lincoln \& Guba, 1985). Cabe ao autor, portanto, realizar uma pesquisa que apresente congruência interna entre seus diversos elementos, informando sobre as premissas e escolhas utilizadas nas mais variadas etapas de realização da pesquisa (Lincoln \& Guba, 1986).

Como discutimos, nesta pesquisa não anseio dizer se algo é verdadeiro ou falso, mas sim verificar qual o papel dos discursos na criação de verdades. Isso nos permite montar um ferramental de análise e argumentação que procura explicar de forma narrativa como verdades são criadas por meio de discursos, ou seja, como processos discursivos são montados para dar a impressão de criação de uma verdade e realidade social estável (Jørgensen \& Phillips, 2002).

Para isso, utilizo como metodologia a lógica de análise dos discursos e da desconstrução, mais especificamente a estratégia metodológica da LEC desenvolvida por Glynos e Howarth (2007, 2008) e especialmente aplicável a estudos que se utilizam da teoria do discurso (Laclau $\&$ Mouffe, 1985).

A LEC é dividida em passos e apresenta como intuito descrever as práticas discursivas e sociais com base em conceitos da teoria do discurso, ou seja, funciona como uma forma de explicação social. Para seu desenvolvimento, parte-se desde a identificação de uma problematização até as explicações críticas dos fenômenos sob análise. Para isso, são realizados os passos conforme a Figura 7, que envolvem: problematização; retrodução; lógicas (sociais, políticas e fantasmáticas); articulação; e julgamento e crítica (Glynos \& Howarth, 2007).

Consoante com este pensamento e sob uma ótica de desconstrução, a visualização dos discursos é realizada “deslindando suas contradições, dirigindo a atenção às suas ambiguidades ou jogos de palavras e lendo-os contra si mesmos e seus autores" (Burke, 2012, p. 261). A análise de debates internos é uma ferramenta que auxilia na desconstrução e visualização dessas contradições e tensões (Suddaby \& Greenwood, 2005).

Para a consecução da LEC e da teoria do discurso, faz-se necessária a análise empírica de fenômenos e, para isto, selecionei o processo normativo que finalizou com a publicação da IFRS 16 (Leases) e foi conduzido de 2006 a 2016. Esse processo foi selecionado por ter envolvido diversas mudanças de conteúdo durante seu andamento e por mimetizar possíveis relações de poder, política, atores e discursos.

Para a análise deste processo foram utilizados os principais documentos internos emitidos pelo board, como as normas, summaries, effects analysis e press releases, em especial 
os comment letters summaries. Esses documentos representam os discursos do board naquele momento quanto às mudanças propostas e os possíveis caminhos para a conclusão do processo normativo.

Por fim, como forma de direcionar a análise crítica e os julgamentos, elaborei um framework de análise, que compreende dois eixos conceituais. No eixo vertical temos os principais elementos de um processo normativo (atores envolvidos, processo organizacional e conteúdo da norma) e no eixo horizontal temos os significantes vazios presentes no processo do IASB, representados pelos princípios do handbook (transparência, consulta completa e justa e accountability). Com a união desses constructos, que podem ser utilizados ainda em outros processos do board, espero poder articular os conceitos e demonstrar, conforme o objetivo da pesquisa, os pontos de (in)consistências e (in)completudes do processo que impedem a totalização dos conceitos apresentados no framework de análises. 


\section{EXPICAÇÃO CRÍTICA: APLICAÇÃO NO PROCESSO DA IFRS 16}

Nesta seção apresento uma descrição narrativa dos processos e das práticas relacionadas à normatização do leasing. O foco é na discussão histórica acerca das mudanças e suas principais justificativas e articulações, trazendo à tona o cenário da discussão da tese. A partir dessa etapa, consigo descrever melhor o cenário analisado para que possa apresentar as (in)consistências e (in)completudes observadas na análise.

Primeiro, defendo que o IASB pode ser considerado um sistema sedimentado de discursos, já que possui o poder de "parcialmente fixar regras, normas, recursos, práticas e subjetividades que são relacionadas entre si de forma particular" (Howarth, 2010, p. 312). Por isso, podemos considera-lo para análise com amparo na teoria pós-estruturalista do discurso (Laclau \& Mouffe, 1985).

Uma das formas de se iniciar um estudo que tome como base teórica e metodológica a teoria pós-estruturalista do discurso (Laclau \& Mouffe, 1985) é pela identificação da posição do sujeito no discurso, ou seja, é um sujeito individual ou coletivo? No caso da presente tese, estudamos um sujeito coletivo, que é a formação do grupo do IASB. Com base nisso, devemos identificar as principais representações no discurso e como os pontos nodais são preenchidos com significados por esses representantes (Jørgensen \& Phillips, 2002).

Aplicado no âmbito contábil, os documentos emitidos por órgãos reguladores devem ser vistos como a opinião do board como um todo, levando em consideração sua posição como regulador no âmbito analisado (Young, 2003). Assim, documentos dos boards representam uma opinião "monolítica", mesmo o board sendo composto por diferentes membros e representado por um sujeito coletivo (Young, 2003).

Considerando tais pontos, problematizo o fenômeno da normatização contábil internacional tomando como base parâmetros de construções discursivas de sentido observadas. Após essa problematização, discuto as diferentes lógicas (social, política, fantasmática) propostas pela LEC (Glynos \& Howarth, 2007) e que representam um ferramental empírico de análise baseada nas premissas da teoria pós-estruturalista do discurso (Laclau \& Mouffe, 1985). Essa análise empírica é exatamente o resultado das observações dos fenômenos de mudanças normativas que geraram novas construções discursivas hegemônicas. Finalizo com uma sugestão de preenchimento do framework de análise crítica do processo que também pode ser utilizada na aplicação de pesquisas similares. 


\subsection{Descrição do Processo de Leasing}

Leasing, assim como sua normatização, é um dos temas mais polêmicos da contabilidade e sobre os relatórios financeiros (Nailor \& Lennard, 2000). Em pesquisa realizada com acadêmicos, reguladores e práticos, identificou-se que, dentre as normas do FASB, a de leasing foi votada como sendo a menos preferida (Reither, 1998).

Em complemento, pode-se dizer que, desde o início das tentativas de normatização contábil, as propostas de normas para leasing são as que mais sofreram alterações e possuem maior quantidade (Wolk, Dodd, \& Rozycki, 2008). Monson (2001) demonstra tal fato ao afirmar que, mesmo já existindo a SFAS 13, o FASB ainda realizou nove emendas, seis interpretações, 12 boletins técnicos e inúmeros consensus do $\mathrm{EITF}^{6}$.

Como forma de apresentar as diversas normas emitidas, apresento na Figura 14 a evolução normativa do leasing nos EUA e internacionalmente.

Figura 14 - Evolução e modificações das Normas de Leasing Americanas e Internacionais

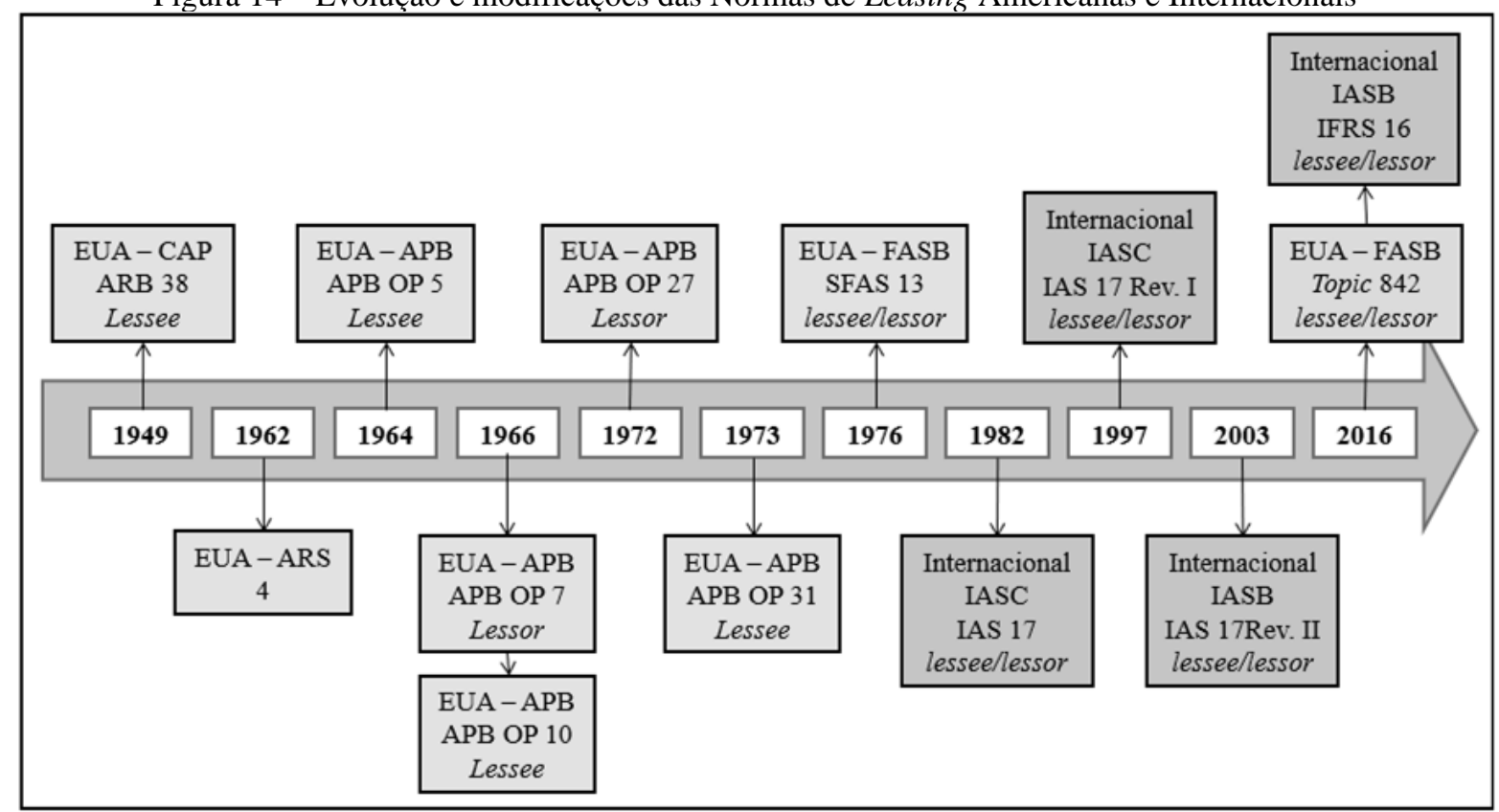

Fonte: Adaptado e atualizado de Matos (2013).

Nesses cenários, a primeira norma sobre o tema foi editada nos EUA, em 1949, com foco apenas em regular questões contábeis relacionadas aos arrendatários. Diversos

\footnotetext{
${ }^{6}$ EITF (Emerging Issues Task Force) é um grupo do FASB que tem como missão auxiliar o board na melhoria das informações contábeis por meio da identificação tempestiva, discussão e resolução de questões contábeis dentro do escopo do FASB.
} 
pronunciamentos e interpretações foram emitidos ao longo dos anos, até a emissão da SFAS 13, que foi atualizada pelo Topic 842 .

A partir da próxima seção, focarei nas discussões relacionadas com a normatização do arrendamento de forma internacional, que é o objetivo da presente tese.

\subsubsection{Formalidade processual da IFRS 16}

Internacionalmente, a primeira norma de leasing foi a IAS 17, editada em 1982, pelo IASC, já com foco tanto em critérios para contabilização do arrendador como do arrendatário. A IAS 17, como apresentei na Figura 14, sofreu diversas atualizações e foi substituída pela IFRS 16, lançada em 2016, com vigência a partir de 2019. Apresento as etapas desse processo na Figura 15.

Figura 15 - Etapas do processo normativo da IFRS 16 - Leases

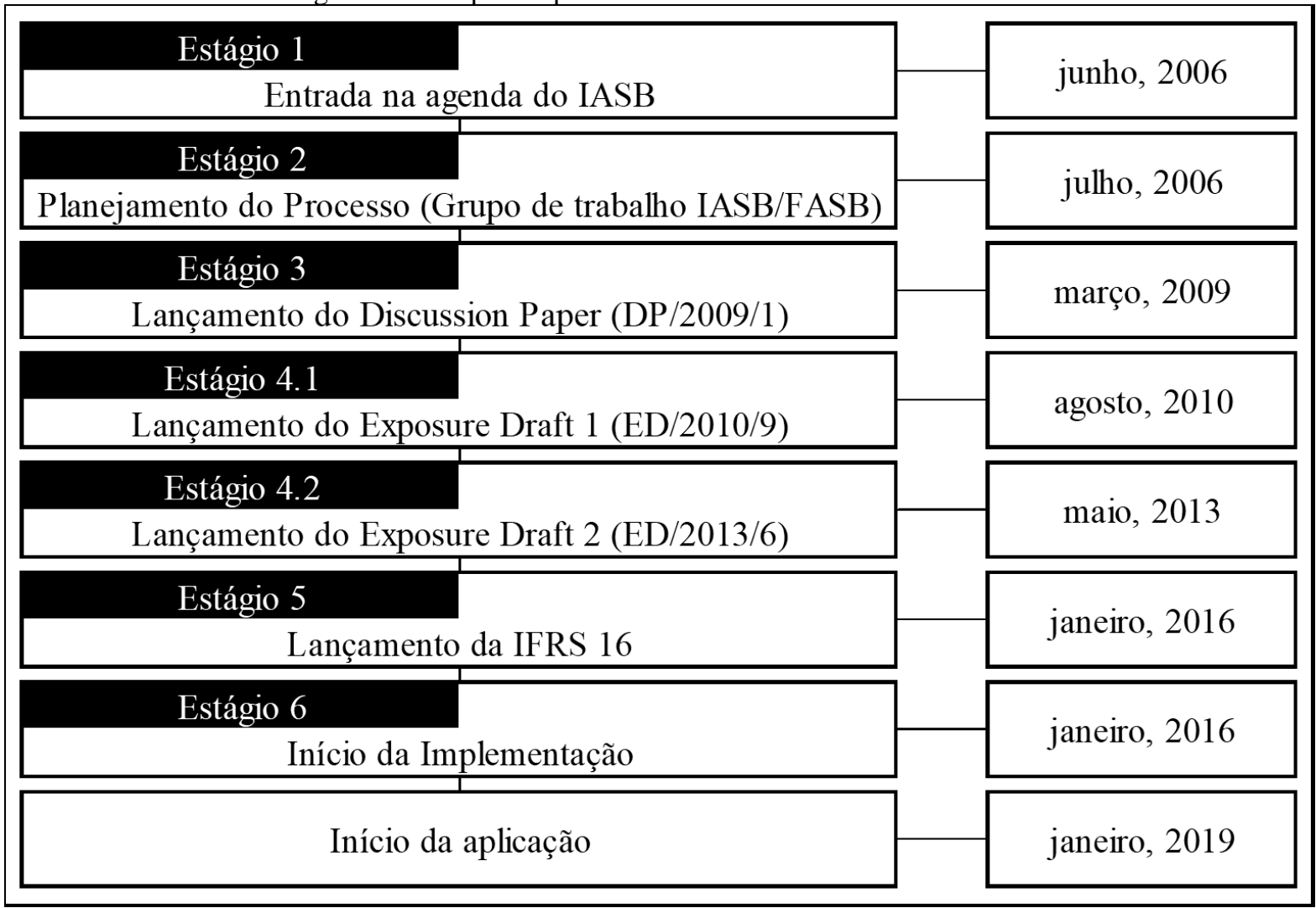

Fonte: Elaborado pelo autor.

O processo normativo de edição da IFRS 16, conforme pode ser observado na Figura 15, teve início em 2006 e, após 10 anos, culminou na norma final - IFRS 16. A título de comparação, a norma anterior, IFRS 15 (Receitas) entrou na agenda do IASB em 2001 e a 
norma final foi emitida em 2015 (14 anos) e a posterior, IFRS 17 (Contratos de seguros), teve seu discussion paper editado em 2007 e sua publicação final em 2017 (10 anos).

Ressalta-se que, antes mesmo do processo formal ter iniciado, o órgão informa que norteou sua decisão de reexaminar a norma de leasing tendo como base dois documentos de estudos emitidos pelo G4+1 (McGregor, 2012): Accounting for Leases: A New Approach (McGregor, 1996) e Leases: Implementation of a New Approach (Nailor \& Lennard, 2000). Isso ocorreu, principalmente, porque os primeiros membros votantes do board do IASB eram, também, alguns dos membros do G4+1 (Street, 2006). O primeiro documento, de natureza mais teórica, representa um estudo que critica a IAS 17 e a SFAS 13, alegando serem essas normas falhas para a representação dos contratos de leasing existentes. Já o segundo, de natureza mais prática, propõe lógicas contábeis para uma possível nova norma e apresenta os modelos de contabilização que poderiam ser realizados para cada condição contratual esperada.

Além disso, o processo já envolveu uma consulta prévia às empresas de auditoria (Big4). Warren McGregor, ex-membro votante do board e que participou da criação do IASB, afirma que, antes mesmo de iniciar o processo, o órgão elaborou um documento com uma proposta e encaminhou às empresas de auditoria na intenção de angariar apoio e saber se a proposta envolveria algo realmente auditável (McGregor, 2012). Apesar da possível ingenuidade no comentário, podemos perceber que o processo, desde seu início, foi desenvolvido por meio de interesses políticos, afinal, se realmente o board é independente, qual o motivo da consulta prévia? Se as propostas do board realmente envolvem a "melhor opção técnica", não seria a auditoria que deveria se adaptar às normas, e não o contrário?

Quando se comparam os passos de um processo normativo com base no handbook (Figura 2) e os passos efetivos que foram realizados no processo da IFRS 16 (Figura 15) percebe-se que, formalmente, todas as etapas foram cumpridas, inclusive a elaboração de um discussion paper - etapa 3 - que não é obrigatória.

Entretanto, o projeto apresentou atraso com relação ao programado. Em 2008, na fase do programa de pesquisa, o IASB definiu que realmente seria necessária a edição de uma nova norma, sendo planejado seu lançamento para o ano de 2011 (IASCF, 2009). Ainda quando da emissão do primeiro ED (ED/2010/9), em agosto/2010, o board planejava emitir a norma final em meados de 2011, porém, conforme Matos (2013), que realizou pesquisa sobre o ED/2010/9, em decorrência do alto nível de críticas e discordâncias com relação ao modelo contábil proposto nesse documento, principalmente com relação aos arrendadores, foi necessária a emissão de um segundo ED (ED/2013/6), o que fez com que o IASB não conseguisse cumprir 
o prazo anteriormente pretendido e informasse que o órgão estava trabalhando com um plano de redeliberação sobre a norma. Após a emissão desse documento, não mais foi formalizada uma data para a emissão da norma final, porém esperava-se que saísse a qualquer momento, o que efetivamente ocorreu em janeiro de 2016, cinco anos após o planejado inicialmente.

Ressalto também que o processo, inicialmente, foi conduzido como um projeto conjunto entre o FASB e o IASB que, ao final, por apresentarem diferenças em seus entendimentos, apresentaram normas diferentes (IFRS 16 para o IASB e Topic 842 para o FASB). Como o objetivo de pesquisa relaciona-se com o processo normativo do IASB, o desenvolvimento da norma do FASB não será discutido, sendo ressaltadas, quando pertinente, suas diferenças contábeis e outros entendimentos do processo.

\subsubsection{Base Conceitual das propostas normativas}

A base conceitual representa um ponto que também apresenta divergências na prática e na literatura. Existem diversas convenções que servem como justificativas "técnicas" e conceituais para escolhas contábeis que, por natureza, são escolhas sociais e subjacentes a forças políticas de negociação. Entretanto, para defender a qualidade das normas emitidas, já desde antes da existência da atual estrutura conceitual, havia uma criação de conceitos que justificassem as "boas práticas" as quais as entidades deveriam seguir. A questão é que são diversas as práticas, que hoje foram transformadas em estrutura conceitual e características qualitativas, e que esses pontos podem ser inconsistentes entre si a depender da visão adotada pelo praticante, porém são utilizados na argumentação "técnica" pela escolha dos procedimentos contábeis de uma norma (Laughlin \& Puxty, 1983).

Nesta seção apresento os principais pressupostos contábeis levados em consideração nas propostas normativas realizadas e que culminaram na emissão da IFRS 16. Como forma de auxiliar na compreensão dos documentos, apresento, na Figura 16, as propostas normativas, assim como os órgãos emissores.

Ressalto que há outras normas sobre leasing, como a norte americana e até mesmo versões anteriores da IAS 17, porém, para esta tese, interessa mostrar o desenvolvimento das normas internacionais, partindo-se, portanto, da IAS 17 e chegando na IFRS 16. Optei, também, por apresentar uma discussão conceitual dos estudos de McGregor (1996) e Nailor e Lennard (2000), por terem sido eles os motivadores para as novas propostas normativas de leasing. 
Figura 16 - Relação dos documentos descritos, órgão emissor e citação

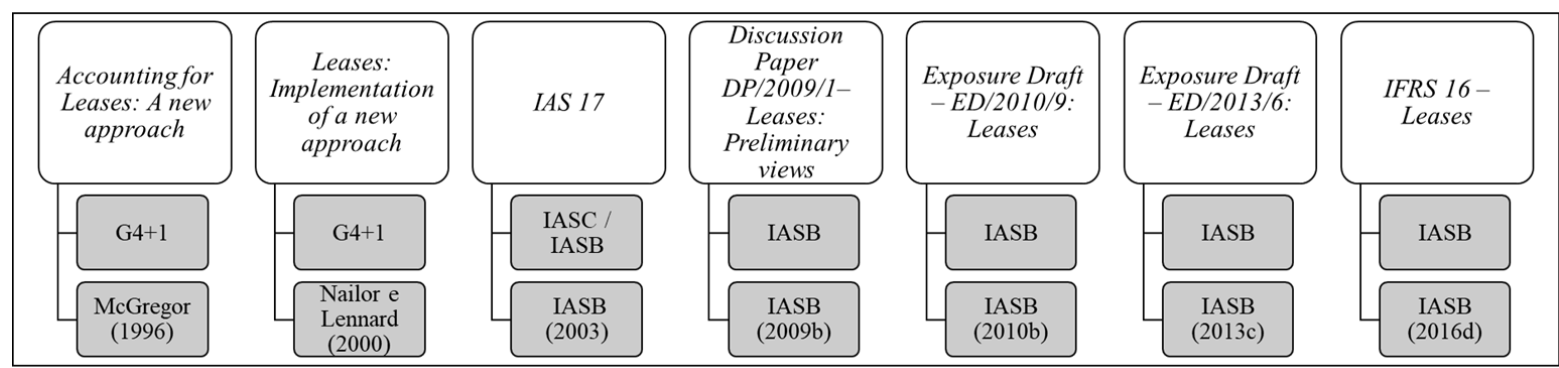

Fonte: Elaborado pelo autor

Muito se criticava quanto a atualidade, relevância e complexidade da IAS 17 na representação das práticas mais atuais de leasing realizadas nos diversos mercados (Monson, 2001). A IAS 17 é baseada na classificação das operações (financeiro e operacional) de acordo com o nível de exposição aos riscos e benefícios de cada uma das partes do contrato, também conhecido como modelo de propriedade. Essa classificação é criticada por diversas razões e, também, é o motivo da maior parte da produção acadêmica contábil relacionada a leasing (Matos \& Murcia, 2019b; Monson, 2001). Biondi et al. (2011) afirmam que "infelizmente" a IAS 17 está "infestada" de brechas que fazem com que as entidades não sigam os reais interesses da norma. Entre as críticas realizadas, fala-se em:

(i) Knife-edged accounting ${ }^{7}$ : Pontos em que pequenas mudanças em transações levam a diferenças na contabilização, fazendo com que transações similares sejam contabilizadas de forma diferente, como é o caso de classificação dos arrendamentos (Biondi et al., 2011);

(ii) Bright-line tests ${ }^{8}$ : Em conjunto com o knife-edged accounting, representa as regras muito específicas que determinariam a classificação do arrendamento. Essas regras estão mais claramente presentes na SFAS 13 (FASB, 1976) quando, por exemplo, afirma que se classifica como financeiro quando "o valor presente é igual ou maior que $90 \%$ do valor justo da propriedade”. (Biondi et al., 2011);

(iii) Arbitrariedade: Ponto mais presente na IAS 17 (IASB, 2003) e em normas com maior necessidade de julgamento, como a exigência de avaliar o que seria "substancialmente todos os riscos e benefícios" para a classificação (Biondi et al., 2011);

\footnotetext{
${ }^{7}$ Expressão que, traduzida literalmente, seria “contabilidade ponta de faca”. Refere-se a uma situação delicada em que o resultado é incerto.

8 Também chamado de "bright-line rules". Expressão que, traduzida literalmente, seria "testes (regras) de linhas brilhantes". Refere-se à existência de regras objetivas que deixam pouco espaço para interpretações e julgamentos.
} 
(iv) Estruturação das transações: Tendo como base os itens (i), (ii) e (iii), as entidades podem estruturar contratos como forma de obter o tratamento/resultado contábil desejado (prevalência da forma sobre a essência da operação) (Biondi et al., 2011; Morales-Díaz \& Zamora-Ramírez, 2018);

(v) Baixa comparabilidade e alta complexidade: Devido a existência de dois modelos distintos, a comparabilidade entre empresas fica prejudicada. Há, também, complexidade que envolve diferentes possibilidades de tratamentos e custos de sistemas (Biondi et al., 2011);

(vi) Comportamento oportunista de gestores: Possibilidade de classificações com tratamentos contábeis distintos possibilita que gestores estruturem as operações como forma de obter os resultados contábeis mais convenientes para eles (Biondi et al., 2011);

(vii) Apresentação off-balance e não reconhecimento de passivos: A classificação como arrendamento operacional abre a possibilidade de não reconhecimento dos ativos e, principalmente, dos passivos oriundos das operações (Biondi et al., 2011; Franzen, Cornaggia, \& Simin, 2009);

(viii) Comportamento dos analistas: Devido a diferença de classificação e possibilidade de apresentação conforme item (vii), analistas tendem a subavaliar a relevância na informação reconhecida e efetuam ajustes de forma a incluir todas as operações nos números contábeis, uma vez que estes afetam os riscos das entidades (Biondi et al., 2011);

(ix) Falta de simetria: Diferença de tratamentos contábeis entre arrendadores e arrendatários, que podem reconhecer a mesma transação de forma distinta, diminuindo a comparabilidade e a consistência (Biondi et al., 2011);

(x) Brechas: Exclusões que podem fazer com que empresas não apliquem a norma, ou pontos que geram interpretações diversas, como a consideração (ou não) dos contratos de serviços e executórios (Biondi et al., 2011; Jamal \& Tan, 2010; Ryan et al., 2001).

Os pontos de crítica referem-se à questão da necessidade de classificação dos arrendamentos em uma das duas categorias possíveis. Essas críticas, portanto, são os principais argumentos utilizados pelos normatizadores como justificativa para a necessidade de uma atualização da norma de leasing (IASB, 2009a, 2010b, 2013c, 2016e; McGregor, 1996; Nailor \& Lennard, 2000). 
Com base nessas supostas necessidades e nas desatualizações da IAS 17, o G4+1 apresentou estudos (McGregor, 1996; Nailor \& Lennard, 2000) que propuseram novos tratamentos para as operações de arrendamento mercantil, com maior foco nos critérios e nas características contábeis que impactam os arrendatários. Assim como os demais estudos que esse grupo lançou, o principal argumento era de que as mudanças seriam necessárias para se trazer maior comparabilidade para os usuários (Street, 2006). Apesar disso, essa é uma estratégia meramente retórica para trazer um conceito, que representa um significante vazio, à tona que normalmente não é criticado e é visto como sendo algo positivo para o mercado neoliberal que toma como premissa argumentativa as soluções de competição de mercado, a transparência e a accountability (Durocher \& Gendron, 2011; Glynos \& Howarth, 2008).

McGregor (1996) é o primeiro estudo publicado sobre o tema de leasing pelo G4+1. Nele defende-se que há uma falha no modelo de representação da IAS 17 , em que não se reconhecem todos os ativos e passivos oriundos de operações classificadas como leasing operacional. Nesse sentido, observa-se a preferência do grupo para o reconhecimento de todas as operações no balanço. Esse estudo, de natureza mais teórica e chamado de "uma nova abordagem" (a new approach), procura demonstrar a significância das operações de arrendamento e, por consequência, a necessidade da atualização e manutenção de uma norma específica sobre o assunto. Para tanto, os autores criticam as normas anteriores e propõem o fim das classificações de leasing como forma de determinar o reconhecimento ou não das informações. Apesar de afirmar ser necessário levar em consideração também a mudança contábil para arrendadores, o estudo apenas cita alguns efeitos, sem propostas teóricas para modificação de tal modelo.

Entende-se, portanto, que os participantes do G4+1 urgem a necessidade de mudanças, principalmente para manter a utilização do conceito (também retórico) da essência sobre a forma. Além disso, os autores entendem que a contabilidade possui uma função posterior à negociação de operações, e não deve ser determinante nas escolhas de negócios (standard driven transactions). Esse fato pode ser observado no caso do leasing, em que empresas realizam contratos para suprir os requisitos contábeis desejados (McGregor, 1996), o que pode impactar diretamente na comercialização desses produtos (Kam, 1990), ou seja, as exigências da norma contábil estão influenciando as escolhas de negócios das empresas.

Esse primeiro estudo (McGregor, 1996), entretanto, não apresenta propostas contábeis diretas que levam em conta a escrituração contábil, mas sim uma visão mais teórica do que seria desejado para a norma. Já em um estudo mais aplicado, também realizado pelo G4+1, Nailor e 
Lennard (2000) partem de McGregor (1996) e afirmam que a principal conclusão do estudo anterior é a de que a norma é "arbitrária e insatisfatória" (p. 11). Assim, demonstram de forma prática novos critérios contábeis para as operações de leasing por meio da demonstração de possíveis modelos de escrituração contábil. O estudo apresenta propostas mais consolidadas para arrendatários, e apenas questões preliminares sobre a contabilização dos arrendadores, já afirmando ser necessária a simetria entre as partes da operação. Além disso, nesse relatório os autores já apresentam tratamentos para questões pontuais de contratos, como valor residual garantido, aluguéis contingentes e outras opções contratuais.

Justifica-se, durante o estudo, a necessidade de um novo raciocínio contábil para o aumento da qualidade dos relatórios financeiros por meio da diminuição da realização de julgamentos subjetivos, além do aumento da comparabilidade das informações. Para tanto, propõem um modelo sem requisito de classificação entre contratos de leasing, ou seja, um modelo único em que todas as operações que suprissem a definição de arrendamento seriam tratadas de forma semelhante.

Em resumo, os autores propõem o reconhecimento, no início do prazo do arrendamento, do valor justo dos direitos e obrigações, sendo que esse valor deve ser mensurado com base nos pagamentos mínimos e não-canceláveis a serem feitos pelo arrendatário (Nailor \& Lennard, 2000).

Essas propostas não ficaram somente no âmbito dos normatizadores. No ambiente acadêmico, a Accounting Horizons, por meio do seu editor Largay III (2001), convocou pesquisadores e profissionais da área para realizar estudos para a composição de uma edição especial com comentários sobre Nailor e Lennard (2000). Essa edição apresentou as obras de Monson (2001), Ryan et al. (2001) e Lipe (2001). Destes, apenas um (Ryan et al., 2001) realiza discussões conceituais relacionadas aos critérios normativos. Os demais se relacionam mais com discussões teóricas sobre a necessidade de mudança, impactos ou a apresentação da literatura acadêmica sobre o tema.

Ryan et al. (2001) foi escrito por nove pesquisadores da área de contabilidade financeira e surgiu após uma reunião desses pesquisadores no Comitê de Normas Contábeis da AAA (American Accounting Association). Nele os autores realizam uma breve revisão das pesquisas sobre leasing e, após isso, levantam suas críticas e opiniões com relação a alguns critérios propostos no relatório do G4+1. Para tanto, procuram responder algumas perguntas, conforme apresentado na Figura 17. 
Figura 17 - Pontos de Diferenças e Semelhanças entre Nailor e Lennard (2000) e Ryan et al. (2001)

\begin{tabular}{|c|c|c|c|}
\hline Tema & Pergunta & $\begin{array}{l}\text { G4+1 - Nailor e } \\
\text { Lennard (2000) }\end{array}$ & Ryan et al. (2001) \\
\hline $\begin{array}{l}\text { Data de } \\
\text { reconhecimento }\end{array}$ & $\begin{array}{l}\text { Os arrendamentos devem ser } \\
\text { reconhecidos nas demonstrações no } \\
\text { momento da assinatura do contrato } \\
\text { ou da entrega do ativo? }\end{array}$ & Entrega do Ativo & Assinatura do contrato \\
\hline $\begin{array}{l}\text { Pagamentos } \\
\text { opcionais }\end{array}$ & $\begin{array}{l}\text { Os pagamentos que são opcionais ou } \\
\text { contingentes, mas prováveis em } \\
\text { decorrência dos termos do contrato, } \\
\text { devem ser reconhecidos como ativos } \\
\text { e passivos? }\end{array}$ & $\begin{array}{l}\text { Varia de acordo com o } \\
\text { tipo de pagamento }\end{array}$ & $\begin{array}{l}\text { Critério da probabilidade } \\
\text { para todos os pagamentos } \\
\text { opcionais }\end{array}$ \\
\hline $\begin{array}{l}\text { Valores de } \\
\text { reconhecimento }\end{array}$ & $\begin{array}{l}\text { Os ativos e passivos reconhecidos } \\
\text { devem ser pelos valores brutos ou } \\
\text { líquidos? }\end{array}$ & Valores Líquidos & Valores brutos \\
\hline $\begin{array}{l}\text { Natureza do } \\
\text { ativo }\end{array}$ & $\begin{array}{l}\text { A natureza do ativo subjacente ou do } \\
\text { tempo do arrendamento devem afetar } \\
\text { a capitalização? }\end{array}$ & \multicolumn{2}{|c|}{$\begin{array}{l}\text { Natureza do ativo e tempo do contrato não devem } \\
\text { influenciar no tratamento contábil. Deve-se ter como } \\
\text { critério a materialidade }\end{array}$} \\
\hline Simetria & $\begin{array}{l}\text { A contabilização deve ser simétrica } \\
\text { entre arrendadores e arrendatários? }\end{array}$ & \multicolumn{2}{|l|}{ Deve haver simetria } \\
\hline Valor Justo & $\begin{array}{l}\text { A mensuração a valor justo dos } \\
\text { recebíveis e dos passivos é algo } \\
\text { desejado? }\end{array}$ & Custo Histórico & $\begin{array}{l}\text { Deve usar valor justo nos } \\
\text { mesmos modelos dos } \\
\text { instrumentos financeiros }\end{array}$ \\
\hline
\end{tabular}

Fonte: Elaborado pelo autor.

Há semelhança de opinião apenas nos critérios "Natureza do ativo" e "Simetria". Em todos os demais, Ryan et al. (2001) apresentam opiniões diferentes daquelas apresentadas em Nailor e Lennard (2000). Os dois estudos possuem a opinião concreta de que é necessário o fim da classificação dos arrendamentos em financeiro e operacional, levando, portanto, à efetiva capitalização das operações de arrendamento e ao fim da existência de off-balance para essas transações. Apesar disso, com base nas diferenças demonstradas na Figura 17, percebese que o momento do reconhecimento, os itens reconhecidos e a forma de mensuração são diferentes, o que levaria a modelos contábeis distintos.

Enquanto Nailor e Lennard (2000) justificam suas decisões com base na comparabilidade e na qualidade das demonstrações financeiras aos usuários, Ryan et al. (2001) argumentam suas decisões com base na teoria e nos conceitos utilizados para todos os itens. Portanto, tem-se como mensagem que o estudo de Ryan et al. (2001) é uma das primeiras críticas do ponto de vista acadêmico para as decisões tomadas pelos normatizadores contábeis sobre as propostas lançadas pelo G4+1. No desenvolvimento das propostas de normas, perceber-se-á que esses pontos foram modificados diversas vezes.

Apesar de haver a crítica sobre a existência de dois modelos distintos (financeiro e operacional) na IAS 17 e de se afirmar a necessidade de um modelo único para o incremento da comparabilidade, Nailor e Lennard (2000) propõem algo que, para Monson (2001), permite dois possíveis modelos contábeis. O primeiro, "modelo de componentes financeiros" (financial 
componentes approach), levaria a um reconhecimento proporcional do ativo arrendado como ativo intangível. No segundo, "modelo do ativo completo" (whole asset approach), todo o ativo arrendado seria reconhecido na categoria contábil a que ele pertence. Os efeitos nas demonstrações contábeis são apresentados e o autor argumenta que, em ambas as propostas, os usuários ainda precisariam ancorar suas decisões em notas explicativas e, por esse motivo, justificar a decisão do modelo contábil com base na necessidade dos usuários (como fala o G4+1) seria incorreto. Tomando como base a comparabilidade e as características da informação contábil segundo a estrutura conceitual, o autor demonstra preferência pela apresentação mais realística do bem, que seria pelo "modelo do ativo completo".

Com base no apresentado, observa-se que o relatório de Nailor e Lennard (2000) foi base para o início do processo de normatização contábil de leasing do FASB e do IASB. Após esses estudos, a IAS 17, que já existia, ainda sofreu uma nova revisão, gerando uma norma atualizada em 2003. Apesar disso, as mudanças referem-se mais a aspectos relacionados com outras normas, sem modificações relevantes nos critérios de classificação, reconhecimento, mensuração e apresentação das operações de arrendamento.

Após a apresentação dos estudos preliminares que direcionaram o processo normativo da IFRS 16, apresento a seguir os critérios contábeis, as visões conceituais e os modelos de contabilização das propostas normativas. A organização da apresentação dar-se-á da seguinte forma: (1) resumo dos principais pressupostos levados em consideração nas normas, como as definições e os escopos dos projetos e; (2) apresentação das possibilidades de classificação de leasing de forma comparativa entre as propostas normativas.

O primeiro pressuposto a ser comparado refere-se ao "escopo/alcance" dos documentos (Figura 18). Nessa seção da norma são delimitadas as aplicações, o público, os setores ou alguma condição que deve ser observada em outra norma que não aquela apresentada. Faz-se importante conhecer as modificações do escopo, uma vez que pode haver resistência de impactados ou modificações relevantes de aplicações, já podendo ser observados certos jogos de inclusões/exclusões das normas de forma a beneficiar algum público (Biondi et al., 2011; Jamal \& Tan, 2010). Jamal e Tan (2010), em experimento realizado com a norma de leasing americana, observaram que o escopo é uma das formas utilizadas pelos gestores para encontrar brechas e estruturar operações com o objetivo de obtenção dos resultados contábeis desejados. 
Figura 18 - Descrição do Escopo/Alcance das (propostas de) normas

\begin{tabular}{|c|c|}
\hline Documento & Escopo/Alcance \\
\hline $\begin{array}{l}(\mathrm{IASB}, 2003, \mathrm{p} . \\
6)\end{array}$ & $\begin{array}{l}\text { [...] deve ser aplicado na contabilização de todas as operações de arrendamento mercantil } \\
\text { (leasing) que não sejam: } \\
\text { (a) arrendamentos mercantis para explorar ou usar minério, petróleo, gás natural e recursos } \\
\text { similares não regeneráveis; e } \\
\text { (b) acordos de licenciamento para itens tais como fitas cinematográficas, registros de vídeo, } \\
\text { peças de teatro, manuscritos, patentes e direitos autorais (copyrights). } \\
\text { Este Pronunciamento, entretanto, não deve ser aplicado como base de mensuração para: } \\
\text { (a) propriedade detida por arrendatário que seja contabilizada como propriedade de } \\
\text { investimento; } \\
\text { (b) propriedade de investimento fornecida pelos arrendadores sob a forma de arrendamentos } \\
\text { mercantis operacionais; } \\
\text { (c) ativos biológicos detidos por arrendatários sob a forma de arrendamentos mercantis } \\
\text { financeiros; } \\
\text { (d) ativos biológicos fornecidos por arrendadores sob a forma de arrendamentos mercantis } \\
\text { operacionais. }\end{array}$ \\
\hline $\begin{array}{c}\text { DP/2009/1 } \\
(\mathrm{IASB}, 2009 \mathrm{a})\end{array}$ & $\begin{array}{l}\text { A opinião inicial é a de que o alcance da nova norma deve ser baseado no das normas já } \\
\text { existentes. }\end{array}$ \\
\hline $\begin{array}{c}\text { ED/2010/9 } \\
(\mathrm{IASB}, 2010 \mathrm{c}, \\
\text { p. 17) }\end{array}$ & $\begin{array}{l}\text { [...] deve aplicar [...] a todos os arrendamentos, incluindo arrendamentos de ativos de } \\
\text { direito de uso em subarrendamento, exceto para: } \\
\text { (a) arrendamentos de ativos intangíveis; } \\
\text { (b) arrendamentos para explorar ou usar minerais, petróleo, gás natural e recursos não } \\
\text { renováveis similares; } \\
\text { (c) arrendamentos de ativos biológicos; } \\
\text { (d) arrendamentos entre o "início do arrendamento" e o "começo do prazo", se suprida a } \\
\text { definição de contrato oneroso. }\end{array}$ \\
\hline $\begin{array}{l}(\mathrm{IASB}, 2013 \mathrm{c}, \\
\quad \text { p. 13) }\end{array}$ & $\begin{array}{l}{[\ldots] \text { deve aplicar [...] a todos os arrendamentos, incluindo arrendamentos de ativos de }} \\
\text { direito de uso em subarrendamento, exceto para: } \\
\text { (a) arrendamentos de ativos intangíveis para arrendadores; } \\
\text { (b) arrendamentos para explorar ou usar minerais, petróleo, gás natural e recursos não } \\
\text { renováveis similares; } \\
\text { (c) arrendamentos de ativos biológicos; } \\
\text { (d) acordos de concessão de serviços; } \\
\text { Oarrendatário não precisa aplicar essa minuta de pronunciamento para arrendamentos de } \\
\text { ativos intangíveis. }\end{array}$ \\
\hline $\begin{array}{l}\text { (IASB, 2016e, } \\
\text { p. 9) }\end{array}$ & $\begin{array}{l}\text { [...] deve aplicar [...] a todos os arrendamentos, incluindo arrendamentos de ativos de } \\
\text { direito de uso em subarrendamento, exceto para: } \\
\text { (a) arrendamentos para explorar ou usar minerais, petróleo, gás natural e recursos não } \\
\text { renováveis similares; } \\
\text { (b) arrendamentos de ativos biológicos e Produto Agrícola mantidos por arrendatário; } \\
\text { (c) acordos de concessão de serviço; } \\
\text { (d) licenças de propriedade intelectual concedidas por arrendador; e } \\
\text { (e) direitos detidos por arrendatário previstos em contratos de licenciamento para itens } \\
\text { como: filmes, gravações de ví́deo, reproduções, manuscritos, patentes e direitos autorais. } \\
\text { O arrendatário pode, mas não é obrigado a, aplicar este pronunciamento a arrendamentos de } \\
\text { ativos intangíveis. }\end{array}$ \\
\hline
\end{tabular}

Fonte: Elaborado pelo autor

A IAS 17 apresenta uma separação na descrição do escopo, uma vez que possui dois modelos de classificação (financeiro e operacional). Assim, seu escopo se divide em "contabilização" e "mensuração". Essa separação não aparece nos demais documentos analisados. 
A exclusão de alguns itens do escopo se deu em mais de um dos documentos, como “ativos biológicos" e "concessões”, já que esses temas possuem normas específicas. O principal ponto de diferença no escopo, entretanto, refere-se aos "intangíveis".

Com relação aos intangíveis, na IAS 17 não se falava desses ativos de forma específica, tendo este item aparecido como exclusão de escopo no ED/2010/9 (exclusão total). Já no documento seguinte $(\mathrm{ED} / 2013 / 6)$ o tratamento foi diferente. Houve um entendimento de que para arrendadores esse item deveria ser excluído e, para arrendatários a exclusão dos intangíveis seria discricionária. Na IFRS 16, manteve-se o posicionamento de discricionariedade para os arrendatários, e não se fala mais em exclusão de intangíveis para arrendadores, o que leva ao entendimento de que intangíveis, neste documento, devem ser parte integrante daqueles aplicáveis na norma.

A justificativa para a exclusão dos intangíveis no ED/2010/9 é a de deixar a norma consistente com a prática, mesmo o board não tendo nenhuma justificativa conceitual para tal exclusão (IASB, 2010a). Questiono aqui o argumento utilizado, uma vez que o órgão afirma tomar suas decisões com base nas questões técnicas e conceituais do Handbook e da estrutura conceitual. Nesse sentido, apenas o delineamento de que a prática ocorre de tal forma não justificaria a decisão, principalmente quando se observa que o board propõe normas de alta qualidade acima dos efeitos para a convergência (IFRS Foundation, 2014).

Já no ED/2013/6, a justificativa para a exclusão dos intangíveis para arrendadores, e a permissão para arrendatários, é a mesma do ED/2010/9 (ressalta-se que o tratamento do intangível do documento anterior era diferente). Ou seja, exclusão/não obrigatoriedade dos intangíveis também é afirmada como não tendo respaldo conceitual (IASB, 2013b). Há, ainda, a inclusão do argumento de que a norma de intangível deve ser revista.

Na IFRS 16, apesar de o tratamento continuar diferente dos documentos anteriores, os argumentos foram os mesmos dos anteriores (IASB, 2016b), sem qualquer citação do motivo de não se falar sobre intangíveis de arrendadoras. Ressalto, aqui, que há diferenças entre os escopos das normas do IASB e do FASB e, além disso, essas modificações impactam diferentes empresas e setores, uma vez que cada setor pode ter (ou não) preponderância do uso de certos tipos de ativos, como intangíveis. Nesse sentido, mantém-se o questionamento das razões pelas quais tais modificações foram realizadas, criticando-se a carência de argumentações para tais decisões.

O segundo pressuposto a ser comparado é a própria definição dada pelos documentos para o que seria arrendamento mercantil, conforme apresentado na Figura 19. 
Figura 19 - Definições de Arrendamento Mercantil apresentadas nas (propostas de) normas

\begin{tabular}{|c|c|}
\hline Documento & Definição de Arrendamento Mercantil \\
\hline $\begin{array}{l}\text { IAS 17 } \\
(\mathrm{IASB}, 2003, \text { p. 6) }\end{array}$ & $\begin{array}{l}\text { Arrendamento mercantil é um acordo pelo qual o arrendador transmite ao arrendatário } \\
\text { em troca de um pagamento ou série de pagamentos o direito de usar um ativo por } \\
\text { um período de tempo acordado. }\end{array}$ \\
\hline $\begin{array}{c}\mathbf{E D / 2 0 1 0 / 9} \\
(\mathrm{IASB}, 2010 \text { b, p. 39) }\end{array}$ & $\begin{array}{l}\text { Arrendamento é o contrato que transfere o direito de uso de um ativo específico } \\
\text { (ativo subjacente) por um período de tempo em troca de contraprestação. }\end{array}$ \\
\hline $\begin{array}{c}\mathbf{E D} / \mathbf{2 0 1 3 / 6} \\
(\mathrm{IASB}, 2013 \mathrm{c}, \text { p. 36) }\end{array}$ & $\begin{array}{l}\text { Arrendamento é o contrato que transfere o direito de uso de um ativo específico } \\
\text { (ativo subjacente) por um período de tempo em troca de contraprestação. }\end{array}$ \\
\hline $\begin{array}{c}\text { IFRS 16 } \\
(\mathrm{IASB}, 2016 \mathrm{e}, \text { p. 26) }\end{array}$ & $\begin{array}{l}\text { Arrendamento é o contrato, ou parte do contrato, que transfere o direito de usar um } \\
\text { ativo (ativo subjacente) por um período de tempo em troca de contraprestação. }\end{array}$ \\
\hline
\end{tabular}

Fonte: Elaborado pelo autor

Com relação à definição, observamos que não há mudanças significativas no conceito de arrendamento, havendo, porém, mudanças em terminologias utilizadas. Na definição da IFRS 16, é explícito que o arrendamento pode ser "parte do contrato", para que fique claro que, havendo contrato com diversos direitos e deveres (bens e serviços), este deve ser desmembrado para que seja reconhecida apenas a parte que concerne ao ativo arrendado. Biondi et al. (2011) criticam tal questão, pois entendem que, se um contrato de arrendamento incorpora outros pontos de forma conjunta (serviços, por exemplo), todos devem ser reconhecidos com base na norma de arrendamento para, assim, evitar estruturação de transações com o objetivo de não reconhecer possíveis ativos e passivos.

O conhecimento da definição é importante para a tese, uma vez que seus critérios são determinantes na escolha do que reconhecer. Ainda, ressalto que o órgão apresenta a definição, mas sempre se refere ao application guidance para a decisão do que é ou não um arrendamento. Nesse documento há fluxogramas explicativos do que poderia ser, ou não, classificado como arrendamento.

O terceiro e último pressuposto apresentado nesta etapa é a definição do prazo do arrendamento (Figura 20). Essa definição é o principal critério para que as empresas saibam o que compõe o arrendamento e a forma de mensuração dos contratos. 
Figura 20 - Definições de "Prazo do Arrendamento" apresentadas nas (propostas de) normas

\begin{tabular}{|c|c|}
\hline & Definição do prazo do arrendamento (lease term) \\
\hline (IASB, 2003, p. 7) & $\begin{array}{l}\text { Prazo do arrendamento mercantil é o período não cancelável pelo qual o arrendatário } \\
\text { contratou o arrendamento mercantil do ativo juntamente com quaisquer prazos } \\
\text { adicionais pelos quais o arrendatário tem a opção de continuar a arrendar o ativo, } \\
\text { com ou sem pagamento adicional, quando no início do arrendamento mercantil for } \\
\text { razoavelmente certo que o arrendatário exercerá a opção. }\end{array}$ \\
\hline $\begin{array}{c}\text { DP/2009/1 } \\
\text { (IASB, 2009a) }\end{array}$ & $\begin{array}{l}\text { Os boards consideram três possibilidades para a determinação do prazo específico do } \\
\text { arrendamento: } \\
\text { (a) limites de probabilidade; } \\
\text { (b) a avaliação qualitativa do prazo do arrendamento; } \\
\text { (c) o prazo mais provável de ocorrer. }\end{array}$ \\
\hline $\begin{array}{c}\text { ED/2010/9 } \\
\text { (IASB, 2010b) }\end{array}$ & $\begin{array}{l}\text { Prazo do arrendamento é o maior prazo possível que é mais provável (do que não) de } \\
\text { ocorrer. }\end{array}$ \\
\hline (IASB, 2013c, p. 37) & $\begin{array}{l}\text { Prazo do arrendamento é o prazo não cancelável durante o qual o } \\
\text { direito de usar o ativo subjacente, juntamente com duas das seguin } \\
\text { (a) períodos cobertos por opção de prorrogar o arrendamento, s } \\
\text { possuir incentivo econômico significativo de exercer essa opção; } \\
\text { (b) períodos cobertos por opção de rescindir o arrendamento, se } \\
\text { possuir incentivo econômico significativo de não exercer essa opç }\end{array}$ \\
\hline (IASB, 2016e, p. 27) & $\begin{array}{l}\text { Prazo do arrendamento é o prazo não cancelável durante o qual o arrendatário tem o } \\
\text { direito de usar o ativo subjacente, juntamente com: } \\
\text { (a) períodos cobertos por opção de prorrogar o arrendamento, se o arrendatário } \\
\text { estiver razoavelmente certo de exercer essa opção; e } \\
\text { (b) períodos cobertos por opção de rescindir o arrendamento, se o arrendatário estiver } \\
\text { razoavelmente certo de não exercer essa opção. }\end{array}$ \\
\hline
\end{tabular}

Fonte: Elaborado pelo autor

Em todas as propostas (exceto no ED/2010/9) há, inicialmente, a definição de prazo do arrendamento como sendo o "prazo não cancelável”. As diferenças surgem após a determinação desse prazo. Na IAS 17 fala-se em incluir prazos adicionais (opções) caso sejam razoavelmente certos. O DP/2009/1, documento este que possui uma natureza exploratória de apresentação das ideias, oferece três opções distintas de avaliação do prazo, incorrendo todas em avaliações consideradas subjetivas e que necessitam de capacidade de julgamento por parte da empresa. Apesar das diferenças, as propostas favorecem a questão da "probabilidade de ocorrência", sendo esta considerada mais interessante para o board por possibilitar menos estruturação dos contratos e ser menos complexa (IASB, 2010a). Porém devemos lembrar que, probabilidade é extremamente subjetiva e alvo de especulações. Seria, portanto, esse conceito redutor de subjetividades como o board argumenta?

O documento seguinte - ED/2010/9 - é o que apresenta a definição mais contrastante com as demais, ao definir como o "maior prazo possível que é mais provável de ocorrer". Mesmo possuindo natureza subjetiva, ele levaria a uma mensuração de prazos mais longos. Os demais documentos também trabalham com a probabilidade de ocorrência, aplicada de forma a identificar o que é razoavelmente certo (ou não) de ocorrer no momento do início do contrato. 
Observa-se, portanto, que há poucas diferenças na definição que fariam com que as bases de reconhecimento e mensuração fossem contrastantes entre si, ou seja, as definições são mais amplas, apenas como delineador geral do contrato. Para discussões sobre esses critérios de forma mais aplicada à IFRS 16, ver Matos e Murcia (2019a).

Entretanto, as diversas propostas normativas realizadas durante o processo apresentaram, também, propostas contábeis distintas, principalmente no que se refere aos modelos de classificação do arrendamento, lembrando que esse era o ponto central de crítica da IAS 17. Portanto, discuto tais modelos na seção a seguir.

\subsubsection{Histórico de Classificação do Arrendamento}

Entre as críticas mais presentes durante o processo normativo, estavam as propostas para reconhecimento das operações, sendo que esse reconhecimento é derivado da classificação dos arrendamentos. Apresento na Figura 21 os diferentes modelos de classificação e seus critérios nas normas e propostas de normas analisadas, tanto para arrendatárias quanto para arrendadoras.

Figura 21 - Classificações dos arrendamentos

\begin{tabular}{|c|c|c|}
\hline Documento & Arrendatária & Arrendadora \\
\hline $\begin{array}{c}\text { IAS } 17 \\
(\mathrm{IASB}, 2003) \\
\end{array}$ & $\begin{array}{l}\text { - Leasing Financeiro } \\
\text { - Leasing Operacional } \\
\text { Critério: Exposição aos Riscos e Benefícios }\end{array}$ & $\begin{array}{l}\text { - Leasing Financeiro } \\
\text { - Leasing Operacional } \\
\text { Critério: Exposição aos Riscos e Benefícios }\end{array}$ \\
\hline $\begin{array}{c}\text { DP/2009/1 } \\
(\text { IASB, 2009a) }\end{array}$ & - Modelo único (Direito de Uso) & $\begin{array}{l}\text { - Performance Obligation Approach } \\
\text { - Derecognition Approach } \\
\text { Critério: Exposição aos Riscos e Benefícios }\end{array}$ \\
\hline $\begin{array}{c}\text { ED/2010/9 } \\
(\mathrm{IASB}, 2010 \mathrm{~b})\end{array}$ & - Modelo único (Direito de Uso) & $\begin{array}{l}\text { - Performance Obligation Approach } \\
\text { - Derecognition Approach } \\
\text { Critério: Exposição aos Riscos e Benefícios }\end{array}$ \\
\hline $\begin{array}{c}\mathbf{E D} / \mathbf{2 0 1 3 / 6} \\
(\mathrm{IASB}, 2013 \mathrm{c}) \\
\end{array}$ & $\begin{array}{l}\text { - Tipo A } \\
\text { - Tipo B } \\
\text { Critério: Natureza do ativo arrendado }\end{array}$ & $\begin{array}{l}\text { - Tipo A } \\
\text { - Tipo B } \\
\text { Critério: Natureza do ativo arrendado }\end{array}$ \\
\hline $\begin{array}{c}\text { IFRS } 16 \\
(\mathrm{IASB}, 2016 \mathrm{e}) \\
\end{array}$ & - Modelo único (Direito de Uso) & $\begin{array}{l}\text { - Leasing Financeiro } \\
\text { - Leasing Operacional } \\
\text { Critério: Exposição aos Riscos e Benefícios }\end{array}$ \\
\hline
\end{tabular}

Fonte: Elaborado pelo Autor.

Assim, as primeiras propostas de modificação da IAS 17 (DP/2009/1 e ED/2010/9) trouxeram um modelo único para arrendatárias, ou seja, todas as operações seriam classificadas da mesma maneira. Os boards intentavam, com esse modelo, suprir as críticas apontadas com relação à possibilidade de classificação dada na IAS 17 (IASB, 2009a, 2010b).

Já para as arrendadoras, o DP e o ED1 continuaram com a classificação baseada na exposição aos riscos e benefícios, porém diferente da divisão “financeiro/operacional” presente 
na IAS 17. Em IASB (2010b) afirma-se que, mesmo havendo uma classificação dupla, em nenhum dos modelos propostos há a situação de não reconhecimento de ativos e passivos oriundos da transação, sendo que este era o problema conceitual da IAS 17. Com relação à opinião dos respondentes sobre os modelos para arrendadoras, ao contrário da opinião para arrendatárias, Matos e Niyama (2013) observaram um nível de concordância de apenas 16\%.

Portanto, com relação à classificação inicial da proposta do DP/2009/1 e do ED/2010/9, já surge a crítica quanto a falta de simetria entre arrendador e arrendatário, em que afirma-se haver uma inconsistência entre as classificações das partes (Biondi et al., 2011), sendo que este foi um dos principais argumentos para a mudança normativa. Os autores ainda contrastam tal ponto da norma com o discurso de comparabilidade e consistência das informações contábeis que tem sido adotado pelo IASB nos últimos anos.

Outro ponto criticado nessas propostas é o fato da diferença de classificação possuir impacto significativo nos indicares contábeis e de desempenho das entidades (Cornaggia, Franzen, \& Simin, 2013, 2015; Franzen et al., 2009; Fülbier, Silva, \& Pferdehirt, 2008). Nesse sentido, gestores podem se beneficiar de tal fato para a obtenção dos indicadores desejados, o que também seria uma desvirtuação dos objetivos da norma e poderia afetar usuários menos preparados (Biondi et al., 2011).

Com relação ao modelo único para arrendatárias apresentado no DP/2009/1 (IASB, 2009a), Carmo, Ribeiro e Carvalho (2014) analisaram a opinião de 260 comment letters válidas e constataram que 62\% (38\%) eram favoráveis (contrárias) ao modelo. Resultados similares foram encontrados na análise das cartas encaminhadas como resposta ao ED/2010/9. Matos e Niyama (2013), ao analisarem 262 documentos, observaram que 65\% concordaram com a proposta.

Em uma análise geral dos modelos de classificação e reconhecimento propostos no ED/2010/9, há um nível de 36\% de aceitação dos usuários (Matos \& Niyama, 2013). Assim, em decorrência das diversas críticas e da baixa aceitação recebida, o IASB emitiu o ED/2013/6 (IASB, 2013c) com uma proposta de classificação, tanto para arrendadoras quanto para arrendatárias, baseada na natureza do ativo arrendado, e não mais nos riscos e benefícios inerentes à propriedade do bem.

Mesmo havendo maior nível de concordância por parte dos usuários com relação aos critérios para arrendatárias, os boards decidiram modificar tais critérios e propuseram uma nova metodologia no ED/2013/6. Em pesquisa de natureza similar às anteriores e com análise de 248 cartas, percebeu-se que nessa proposta normativa o nível de discordância foi maior, em que 
$70 \%$ (30\%) discordaram (concordaram) com a mudança de critérios e inserção de modelo duplo de capitalização, tanto para arrendadoras como para arrendatárias (Visoto, 2018).

O ED/2013/6 (IASB, 2013c) propõe a classificação dos arrendamentos em Tipo A e Tipo B. O Tipo A engloba os arrendamentos em que o ativo subjacente não é um imóvel (nonproperty) e o Tipo B os arrendamentos em que o ativo subjacente é um imóvel (property). A intenção dessa separação é justificada não unicamente por envolver o tipo de ativo, mas também pelo consumo daquele ativo durante o contrato. O órgão entende que arrendamentos em que se consome grande parte do bem devem ser reconhecidos de forma distinta daqueles em que se consome parte insignificante do ativo, como seria o caso de imóveis, que possuem vida útil mais longa que a de equipamentos, por exemplo.

Por mais que a proposta seja diferente, pode-se dizer que as críticas são semelhantes às da proposta anterior, uma vez que o problema era relacionado com a existência de duas categorias distintas de classificação que poderiam gerar falta de simetria na contabilização de arrendadoras e arrendatárias e inconsistência de tratamentos, abrindo margem para estruturações de operações e demais pontos de crítica apresentados.

Por fim, percebe-se que tal proposta não foi bem aceita e a norma final, a IFRS 16 (IASB, 2016e), foi emitida novamente com mudanças nos modelos de classificação. Para as arrendatárias o modelo de classificação voltou a ser aquele apresentado no DP/2009/1 e no ED/2010/9, baseado em um modelo único de "direito de uso". Para as arrendadoras, surpreendentemente, o modelo voltou a ser semelhante ao da norma já vigente (IAS 17), com a classificação em dois tipos de arrendamentos (financeiro e operacional). Assim, nenhum dos modelos apresentados na IFRS 16 foi novo, mas sim reapresentações de modelos já existentes em alguma etapa anterior, podendo-se dizer, portanto, que as críticas são as mesmas daquelas já apresentadas. Para maiores detalhes acerca da escrituração contábil e premissas de cada proposta normativa, ver Apêndice A.

\subsection{Problematização do Processo normativo (de Leasing)}

Para que o IASB atingisse status de hegemonia como normatizador internacional, alguns conceitos políticos e linguísticos se tornam relevantes. A retórica, vista como a "arte da persuasão" (Young, 2003), é um conceito chave para a compreensão do fenômeno. O modo de escrever, de argumentar, as escolhas literárias e a formalidade argumentativa representam 
estratégias que se encaixam nesse âmbito da retórica regulatória (Arrington \& Schweiker, 1992; Suddaby \& Greenwood, 2005).

Como já apresentei em diversos momentos desta tese, o IASB é uma organização transnacional que funciona sob a lógica de soft law. Isso quer dizer que não há um caráter jurídico punitivo claramente delineado para os aplicadores das normas. Esse caráter dependerá dos governos nacionais regularem se o país deve ou não seguir os padrões do IASB.

A partir desse cenário, o board necessita construir uma base argumentativa que o torne relevante e que atraia os países a não só aderirem às suas normas, como também manterem o interesse na sua aplicação. Surgem, portanto, construções discursivas que tentam trazer uma tecnicidade em nível ontológico, contrastando a técnica com a política, e articulações que circulam em torno da defesa de boas práticas de governança.

O objetivo alegado do IASB é trazer convergência às informações contábeis. Para isso, o board se ampara em diferentes discursos que possam garantir o interesse de países na adesão ao projeto de normatização. Por exemplo, há um discurso relacionado à estrutura do board, autoafirmando-se como independente, que busca o interesse público. Há também o discurso acerca dos seus produtos (as normas contábeis - IFRSs), que se relaciona com normas de alta qualidade, que trazem comparabilidade e um maior poder de competição para países de diversos níveis financeiros, uma vez que as informações são similares e podem ser interpretadas por diferentes interessados, não só os locais. Por fim, existe o discurso que direciona a aceitação processual para garantir que essas alegadas normas realmente sejam de alta qualidade. Esse discurso é representado pela existência do handbook, que funciona como um manual de boas práticas para a elaboração de normas.

Dentro desses processos de aceitação, podemos destacar alguns discursos mais específicos que funcionam como agregativos de opiniões e criam esse sentido de normas de alta qualidade que não beneficiam ninguém. Inicialmente temos o discurso retórico/fictício de “essência sobre a forma" (Pelger, 2016), que atualmente é o discurso que defende que o board direciona o processo de escolhas contábeis para o que é mais fidedigno - mas, vejamos bem, não deixam de ser escolhas. Como o IASB pode afirmar que as próprias escolhas realmente são as melhores? Ele mesmo se avalia? Falando em autoavaliação, há também o discurso de que o board prioriza a qualidade das normas sobre a necessidade de convergência. Mas são eles mesmos que dizem o que é qualidade e convergência.

Especificamente com relação à condução processual, temos o discurso (que argumento ser ilusório) de "controle" de qualidade trazidos pelo handbook por meio da tecnicidade. Para 
mim, esse é o principal discurso do board: o da criação da contradição entre técnica e política. A partir desse discurso, todos os demais são justificados e delineados durante o processo.

Para a condição de um processo considerado justo e técnico, o board articula os princípios da transparência, consulta completa e justa e accountability como o cerne do processo, o que garante qualidade ao processo de emissão de normas e, consequentemente, às normas propriamente ditas. Porém, como esse discurso é conduzido e empoderado? Quais as lógicas sociais e políticas que os mantêm? Há relações de dominação e silenciamento? Os atores possuem poder para verificar a aplicação prática desses princípios ou são silenciados? Já que as práticas compõem o discurso, esses discursos "escritos" são confrontados com a prática processual? A criação de sentidos é realmente técnica e exclui a dimensão política do processo?

Muitas das pesquisas já realçam questões relacionadas com a estrutura organizacional ou a análise de normas já prontas de forma a mostrar suas limitações (Burlaud \& Colasse, 2011; Camfferman \& Zeff, 2018; Danjou \& Walton, 2012; Dye \& Sunder, 2001; Gipper et al., 2013; Kabir \& Rahman, 2018; Larson \& Kenny, 2011; Madsen, 2013; McGregor, 2012; Morley, 2016; Whittington, 2008; Zeff, 2002, 2012). Portanto, para contribuir com essa literatura, proponho a análise desses critérios relacionados com a aceitação do processo de elaboração das normas, sob um paradigma distinto do mais aplicado e com o estudo de critérios específicos do handbook, e não de forma generalizada.

As críticas das pesquisas atuais possuem maior foco no "discurso completo" de qualidade do board. Nesse sentido, a qualidade seria medida pela previsibilidade do mercado de capitais. Porém, não se pesquisam muito os "micro discursos" inseridos nesse contexto geral de qualidade. Como os elementos internos do discurso funcionam para incrementar o discurso central de convergência? Quais as relações de equivalência e diferença presentes nesse processo?

Além de auxiliar o preenchimento dessa lacuna da literatura, há uma contribuição para as demais análises críticas das normas, já que elas não são “objetividades do mundo”, mas sim construídas por esse processo normativo que avalio como político. Mas de onde parte essa objetividade que devemos demonstrar não ser real? Argumento que essa objetividade parte do discurso dual entre técnica e política no processo. Esse discurso envolve tanto aspectos institucionais quanto processuais e de aplicação das normas emitidas pelo IASB. Por isso, devemos estudar como as estratégias de governança do handbook funcionam para garantir a perpetuação desse discurso e, por consequência, da hegemonia do discurso da convergência presente na normatização contábil. 
Apesar de o conceito de "obstáculo epistemológico" ter sido desenvolvido para a crítica quanto ao progresso do conhecimento científico (Bachelard, 1996), podemos adaptá-lo para a realidade do processo normativo. Os obstáculos epistemológicos apresentam como característica o fato de trazer estagnação por meio da criação de barreiras interpretativas, isto é, da criação de rotulações que limitam o avanço do conhecimento e da discussão acerca das realidades sociais.

A fim de superar essa limitação, devemos desconstruir a ideia de que há qualquer dicotomia envolvida nas discussões sobre processo normativo. Além disso, devemos trazer o idealismo de que essas barreiras conceituais do dicotomismo podem ser discutidas de forma mais ampla, o que pode conferir acessibilidade aos possíveis participantes com menos poder, por meio do fim das exigências de expertise ou características restritas a determinados participantes para a contribuição. Os obstáculos epistemológicos tendem a simplificar as discussões ao "encaixotar" conceitos e dicotomias em pontos "bons ou ruins", mas isso é uma forma um tanto quanto superficial de ver nossa realidade. Devemos sair dessa dicotomia a fim de encontrar discussões que analisam os cenários de forma mais abrangente, mas como podemos fazer isso? Respondo que isso deve ser feito por meio da abertura para discussões e desconstruções acerca da posição dos diversos discursos dicotômicos no cenário de análise.

Mostrar que a dualidade técnico-política é um discurso criado para aceitação é exatamente essa desconstrução do status quo. A forma de demonstrar isso é pelas inconsistências de discursos não técnicos. Argumento que, por natureza, decisões são políticas e geram viés no processo, o que é natural e não precisaria ser mistificado. Para isso, a principal base de análise é feita por julgamentos e críticas que demonstram limitações entre decisões e práticas relacionadas com os princípios do handbook.

Em resumo, podemos dizer que o "problema da normatização contábil internacional" gira em torno do discurso de separação da capacidade do IASB da dos demais membros da contabilidade, o que afasta a noção dos menos poderosos de que poderiam alcançar aquele nível e que não seriam capazes de contribuir ao discurso já sedimentado da convergência, ou que sua contribuição deve ser marginal. Isso diferencia o board e exclui os demais, criando uma relação de poder, de conflito e de dominação que é mascarada pelo discurso de "boas práticas de governança" que leva a noção ilusória de justiça, de tecnicidade e de pensamento coletivo. 


\subsection{As Lógicas da Normatização Contábil Internacional}

De forma simplificada, posso dizer que na discussão das lógicas o objetivo é o de entender as regras do jogo (social - o quê), como essas regras são botadas em prática (política - como) e a forma como elas se mantêm (fantasmática - por quê).

A lógica social da regulação tende a ser a de se criar um problema (até então não existente e sequer questionado). Esse problema é criado por meio de diversas críticas e estratégias de credibilização/aceitação tomando como base a influência e o poder. Após o problema existir, temos então as possibilidades de solução, que são apresentadas pelos mesmos agentes que criaram o problema e, por meio da lógica da equivalência, acabam por agregar diversas demandas e aprovam suas normas sem grande resistência.

Como resultado das análises do processo normativo do IASB (em geral) e do processo de arrendamento (de forma específica), identifiquei as lógicas apresentadas na Figura 22.

A construção das lógicas é a efetiva teorização social desta tese. Portanto, discuto-as em seus pormenores nas próximas subseções. Para contribuir ao debate, também apresento, no apêndice $\mathrm{C}$, uma breve descrição de todas as lógicas teorizadas. Para isso, consulte as lógicas sociais, na Figura 56; as lógicas políticas na Figura 57; e as lógicas fantasmáticas na Figura 58. Ressalto que essas não são as únicas lógicas possíveis, mas são as que identifiquei e que podem contribuir para a análise e desconstrução tomando como base o objetivo da tese e a teoria do discurso (Laclau \& Mouffe, 1985).

Figura 22 - Relação das Lógicas Identificadas no Processo Normativo Contábil

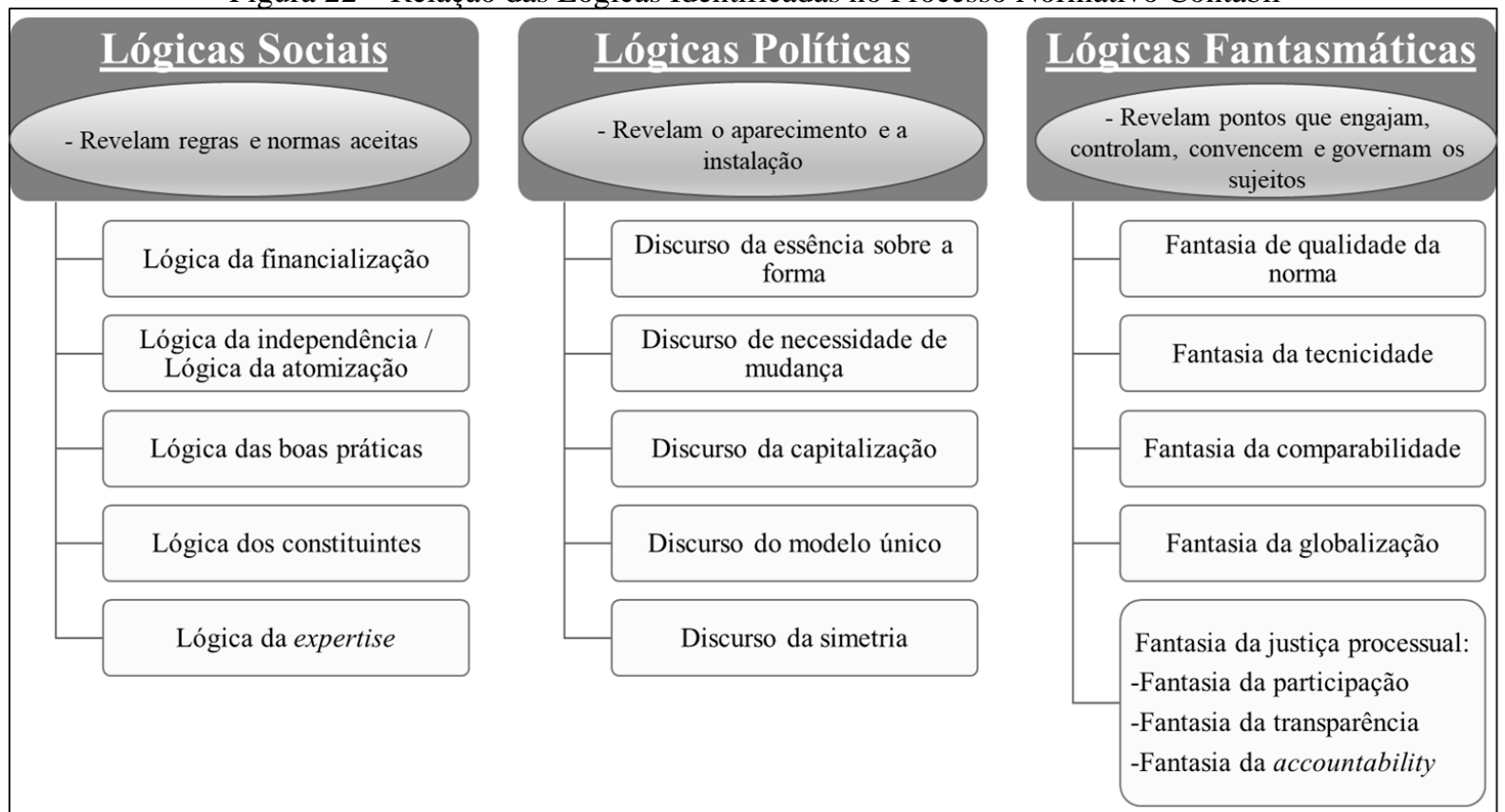

Fonte: Elaboração própria. 
Ressalto também, em caráter de sugestão, que entendi a leitura e a discussão das lógicas de forma distinta. Nas lógicas sociais e fantasmáticas fui capaz de sintetizar de uma forma que elas se encaixam para os mais diversos processos normativos do board. Já nas lógicas políticas, por mais que possam se encaixar em outros projetos, apresentei-as com uma aplicação ao processo de arrendamento. Elas dependem disso, já que tendem a demonstrar a instalação da situação específica. Entretanto, em algumas delas há como extrapolar para outros processos. Por esse motivo, na argumentação a seguir, busco discutir as lógicas de forma geral e, na articulação, é que eu efetivamente as discuto sobre o caso de arrendamentos.

\subsubsection{Lógicas Sociais}

As lógicas sociais visam a demonstrar uma reconstrução de práticas sociais de forma a revelar as regras e normas implícitas ao processo. Para isso, realizei o questionamento "Quais são as regras e normas?" (ver Figura 8). Elas funcionam como forma de mostrar os "sensos comuns" do ambiente sob análise. No caso do processo normativo do IASB, essas lógicas possuem relação direta com a visão das estratégias organizacionais, em que se leva em consideração um "sistema socialmente construído de normas, valores, crenças e definições" (Suchman, 1995, p. 574). Diversas são as lógicas sociais que podem ser elencadas com relação ao processo normativo internacional e a principal função da discussão é a de apresentar como esse evento é dado e como ele ocorre. Portanto, aqui almejo desenvolver as lógicas de funcionamento do processo normativo do IASB de acordo com a minha releitura dos eventos ocorridos com base na normatização de leasing e tomando como base a criação da dualidade técnico-política.

Inicialmente, pontuo a lógica da financialização, relacionada com a premissa de que as normas e os produtos do IASB são resultantes de demandas da economia neoliberal que prega o livre mercado e a valorização do mercado financeiro. Essa lógica representa a substância do "viés" do IASB para a criação de normas levando em consideração conceitos econômicos relacionadas com o mercado financeiro e com os investidores, principalmente pelos shareholders, com base em uma visão da situação da empresa pelos proprietários.

Por mais que o IASB não se utilize do termo "financialização" diretamente, durante a leitura e análise dos documentos constatei que a normatização contábil é caracterizada e se faz reproduzir por meio desse discurso. Ressalto aqui que o resultado de demonstrar que a lógica da financialização é uma das lógicas sociais para a reconstrução do processo normativo internacional não possui relação com minha opinião acerca dessa lógica ser ou não a correta 
para a aplicação em normas contábeis, mas sim ser a que representa a essência da prática normativa do board.

Essa lógica não advém da prática da contabilidade, já que não resulta de necessidades “técnicas" da profissão. É o contrário, ela surge por necessidades da própria regulação (e talvez da academia/teoria), que impõe a financialização para a prática por meio da demanda existente por parte dos usuários externos "relevantes" (o movimento não é de dentro da profissão para os seus usuários, mas sim dos usuários para dentro da profissão). Isso acaba levando a profissão contábil e os aplicadores da contabilidade (os contadores em geral) a uma passividade na condução das próprias regras "ditas técnicas e neutras" que regem seus trabalhos.

Por esse motivo, é interessante notarmos que a visão prática da financialização leva a uma compreensão da contabilidade como mais voltada para a teoria do proprietário, porém o IASB tem como discurso, de forma contraditória, que suas normas tendem a refletir um padrão misto entre as teorias da entidade e do proprietário, mesmo não explicitando tal pensamento na estrutura conceitual (Müller, 2014). Nesta, o board se limita ao compromisso de informação acerca da "entidade que reporta", mas ao mesmo tempo leva em conta o interesse para além dos proprietários ao afirmar que "as informações fornecem dados úteis para as decisões sobre a oferta de recursos a uma entidade" (IFRS Foundation, 2018a, p. A24). Esse movimento de informações, portanto, resulta em um compromisso com aspectos da entidade, porém com interesse em fornecer tais informações para a tomada de decisões de terceiros ("oferta de recursos a uma entidade") e não para a tomada de decisões pela entidade (na figura de seus gestores).

Demonstro, Figura 23, esse caminho da necessidade da regulação por meio da financialização. Ao entendermos que as demandas partem de usuários externos e da própria regulação, compreendemos a natureza política desse quesito. Como forma de se isentar desse arcabouço político, o discurso é de que as mudanças na regulação são derivantes da necessidade de evolução da prática profissional. Assim, alterações regulatórias decorreriam de uma “ideologia dos praticantes", uma forma de representar aqueles que aplicam as técnicas da contabilidade em seus ambientes de trabalho para o reconhecimento, a mensuração e a apresentação de operações contabilmente relevantes.

Entretanto, a fim de possuir uma natureza mais "técnica", apesar de eu ver isso como algo utópico, o movimento das necessidades de mudança deveria ser o contrário: a partir do interior da figura para o seu exterior. Assim, será que haveria uma necessidade da financialização se a regulação fosse baseada diretamente nas necessidades dos stakeholders e 
não dos shareholders? Nesse questionamento não devemos confundir a necessidade de informação com as demandas de outras áreas de contabilidade (como contabilidade gerencial). É necessário indagar sobre o motivo pelo qual as necessidades dos contadores não são levadas em consideração na hora de regular o produto de seus trabalhos no lugar da prevalência da necessidade de usuários externos à profissão. Com base nessa visão, claramente temos a interferência política nos produtos da contabilidade e não podemos mais falar em tecnicidade das decisões.

Figura 23 - Necessidade da Lógica Social da Financialização

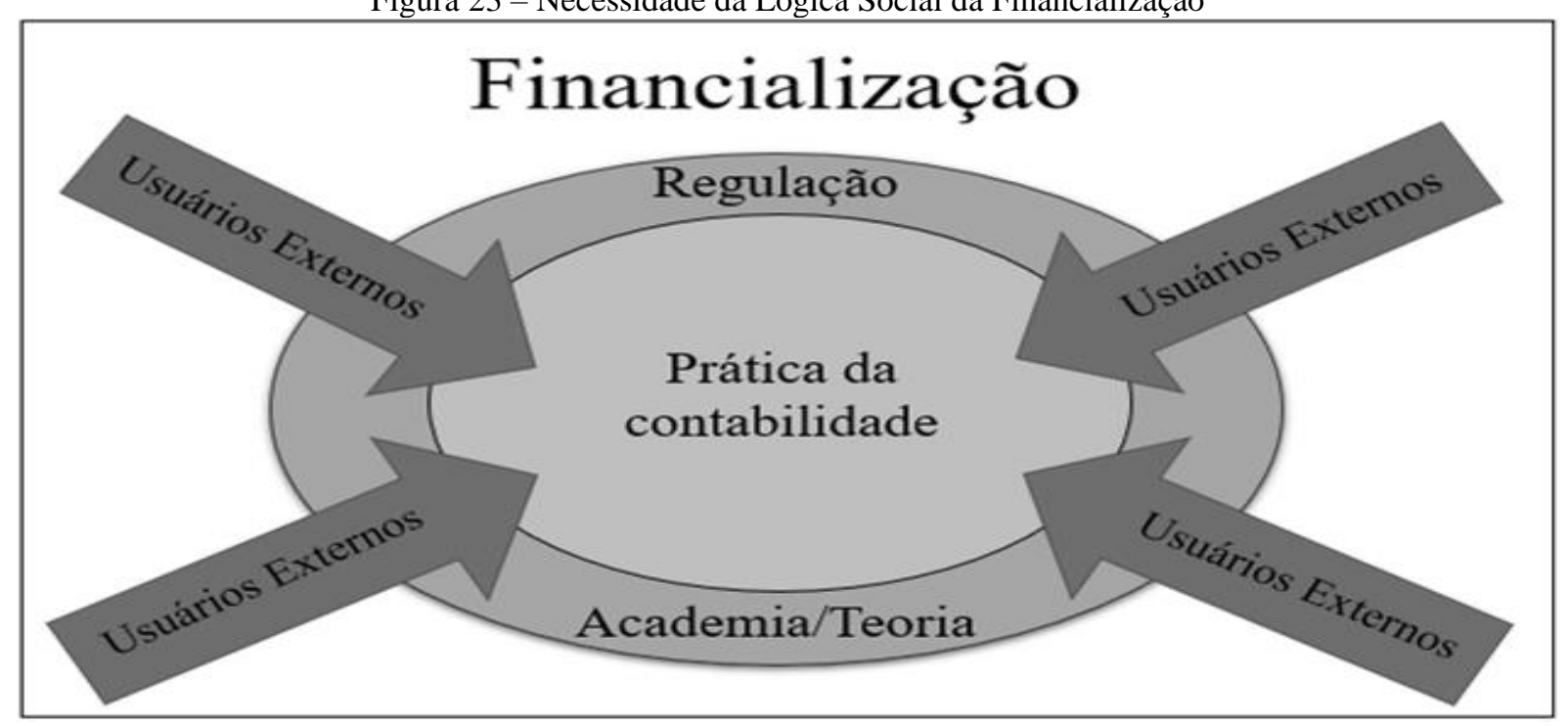

Fonte: Elaboração própria.

O projeto de arrendamento é um exemplo da aplicação da Figura 23, de modo a demonstrar que a regulação e a teoria/academia, juntamente com a demanda dos usuários, guiam ativamente o conteúdo das normas e a prática da contabilidade. Para isso, há uma articulação por meio da defesa de "estudos neutros" por parte do G4+1 (isso já na década de 1990). Por se basear na opinião de normatizadores de países com natureza amplamente voltada para o mercado de capitais e com um viés mais desenvolvido, as visões daqueles relatórios envolviam aspectos que satisfaziam diretamente às necessidades desses usuários. Em razão disso, o ambiente "regulatório" do G4+1 criava necessidades de mudanças normativas não com base em questionamentos e solicitações de contadores de empresas, mas sim com base na necessidade dos investidores/reguladores e demais usuários do mercado de capitais.

A necessidade de mudança e a entrada na agenda tomando como base a vontade dos usuários mostra-se, na verdade, como a imposição disfarçada da vontade dos "investidores" (institucionais e qualificados). O handbook vigente quando da entrada do processo de arrendamento na agenda do IASB definia como regra: “o IASB considera se o projeto endereça 
necessidades dos usuários de diferentes jurisdições" (IASC Fountarion, 2006, p. 8). Primeiro, entendemos que apenas jurisdições com mercado de capitais desenvolvido são as que possuem investidores com nível de realização de ajustes contábeis dessa magnitude. Ainda, apesar de informarem "usuários", todas as justificativas partem da necessidade dos investidores em "precificar" as empresas e tomar decisões de investimentos.

Essa demanda dirigida à contabilidade (como área) para modificação do trabalho contábil (da própria área) por terceiros (que podem ou não ser da área) é, inclusive, uma retirada de poder da área em se autorregular. Com a importância dada na regulação aos investidores, suas demandas acabam virando normas e conceitos contábeis e isso leva a um viés normativo que, além de privilegiar certo grupo, retira a autonomia da área (profissional e científica) da contabilidade. Isso limita, inclusive, o caráter científico das "ciências" contábeis. Afinal, os conceitos e as necessidades são os definidos pelas pesquisas contábeis (partindo dos próprios contadores) ou por demandas externas?

Atualmente, podemos dizer que a lógica social (financialização) continua a mesma (partindo de necessidades de usuários externos). Recentemente houve a incorporação de um discurso aplicado ao "chamamento" da academia para o processo de elaboração de normas, tentando valorizar as decisões com base em respaldos "científicos/teóricos". Apesar disso, há evidências que demonstram que esse chamamento não obrigatoriamente impacta nas decisões normativas, sendo que o maior poder concentra-se nos próprios reguladores envolvidos no processo (Michele et al., 2016).

Mas o que é, na prática, a lógica da financialização? Ela sempre existiu? Apesar de ser aceita atualmente como um "senso comum" na regulação, cabe ressaltar que a normatização contábil nem sempre foi representada por essa lógica social como cerne do conteúdo das normas. A financialização representa uma "revolução", uma mudança de paradigma acerca da essência das normas (Müller, 2014). A financialização representa uma lógica que caracteriza a normatização contábil do IASB e não de seus antecessores, ou seja, com efeitos relevantes principalmente a partir do ano de 2001, amplamente embasada nos relatórios e posicionamentos do G4+1. Essa mudança ocorreu exatamente para trazer mais poder ao normatizador por meio da sua aceitação de partes "poderosas", como auditoria e participantes relevantes do mercado financeiro, ambos impulsionados por apoio de entidades ligadas à regulação, como a IOSCO (International Organization of Securities Commissions). Essa lógica é exatamente a visão de trazer conceitos das finanças para que as informações contábeis reflitam o interesse de análise dos investidores e tragam informações que sejam úteis, principalmente, para a tomada de 
decisão desse público. Sua aplicação pode ser observada na condução do processo de elaboração das IFRSs sob diversas formas de cálculos, estimativas e "avaliação de riscos"; principalmente quando há uma substituição do custo histórico pelo valor justo, sendo este último exatamente o representante dos interesses dos investidores ligados a um mercado baseado no liberalismo econômico. Pontos em que houve tal situação serão apresentados de forma aplicada com decisões tomadas na condução do processo normativo de leasing.

Esse processo é bastante observado como prática social presente nas decisões normativas do IASB que resultam na justificativa das demandas de cumprimento dos financial reporting das entidades. A financialização não é apenas uma regra contábil de escrituração, mas toda uma prática de valores e crenças que tomam como base a penetração da lógica das finanças para dentro das entidades (Aglietta \& Rebérioux, 2005). A aplicação normativa clara para esse direcionamento é a existência da "estrutura conceitual para relatório financeiro" (IFRS Foundation, 2018a), que funciona discursivamente como o limitador da elaboração das normas e o documento base para as justificativas tomadas. Por ser ampla e de aplicação subjetiva, defendo que a maioria das escolhas normativas tomadas, mesmo que antagônicas, podem ser justificadas com base nesse documento. Isso faz com que o board possa argumentar suas decisões (com viés) se amparando numa "pseudológica" de neutralidade da estrutura conceitual. Ressalto que já houve diversas estruturas conceituais na história do IASC e do IASB e, portanto, reafirmo que a lógica da financialização nem sempre foi presente com base tais documentos.

Entretanto, as estruturas conceituais mais recentes apresentam essa lógica, tomando como principal premissa a limitação dos usuários (IFRS Foundation, 2018a), quando se afirma que seu objetivo é

O objetivo do relatório financeiro para fins gerais é fornecer informações financeiras sobre a entidade que reporta que sejam úteis para investidores, mutuantes e outros credores, existentes e potenciais, na tomada de decisões quanto à oferta de recursos à entidade. Tais decisões envolvem a compra, venda ou manutenção de instrumentos de patrimônio e de dívida e a oferta ou liquidação de empréstimos e outras formas de crédito. (IFRS Foundation, 2018a, p. A23)

Com base nesse trecho, observamos claramente o viés normativo para os usuários externos, como investidores e demais interessados na avaliação da situação financeira da entidade para a tomada de decisões. Isso ratifica as decisões com base nas necessidades do mercado. Apesar de "poderem” compartilhar desses interesses, diversos usuários são excluídos dos interesses da normatização do IASB, como usuários internos e até mesmo outros usuários externos, como governos e a própria sociedade civil. Esse é exatamente o viés que argumento ser caracterizado pela lógica social da financialização. 
Além dessa limitação aos usuários, o próprio due process handbook demonstra a importância da estrutura conceitual no processo de elaboração de normas ao defender que "o IASB deve considerar quando alguma norma deve ser revisada de forma a refletir as premissas da estrutura conceitual" (IFRS Foundation, 2016b, p. 23). Portanto, temos dois documentos que, além de caracterizarem a normatização contábil por meio da financialização, também servem como limitadores formais para a aplicação de visões diferentes, que são: a estrutura conceitual (IFRS Foundation, 2018a) e o due process handbook (IFRS Foundation, 2016b).

Em resumo, com relação à financialização, podemos responder as perguntas elencadas na Figura 8 (na seção Lógica da Explicação Crítica), em que temos essa lógica social como forma que "caracteriza a normatização contábil do IASB". Com base na estrutura conceitual e no movimento que a informação contábil tomou após 2001, essa lógica é dada como natural/fato por parte do mercado financeiro (principalmente por esse ser o principal beneficiado com esse movimento). Assim, essa lógica reproduz exatamente os valores do capitalismo neoliberal ao priorizar os valores de "mercado/justos" das entidades, muitas vezes até intangíveis e baseados em "estimativas".

Isso quer dizer que a informação contábil é sim voltada para um determinado público e com determinado viés, então vejo que não há motivos para se auto justificar como tomador de decisões técnicas e que possuem neutralidade, pois, ao priorizar certos usuários, perde-se claramente a neutralidade na elaboração das informações e ganha-se a inserção da política já desde o início do processo.

Possuindo relação com a lógica anterior, porém também representando aspectos próprios, outra lógica social que identifiquei como presente e condutora do processo normativo internacional é a lógica da independência, diretamente relacionada com uma lógica da atomização social e, por isso, as discutirei de forma conjunta.

De forma adaptada ao conceito de lógica da atomização social já descrito em Glynos e Howarth (2008), vejo a lógica com base no termo que surge das ciências naturais, em que um processo de atomização representa a fragmentação de um corpo em unidades menores. É um processo de transformação que envolve o conceito central de átomo (sistema neutro), que possui um núcleo hierárquico e partículas representadas pelos elétrons. Um sistema completo, que envolve a união de diferentes átomos, forma as moléculas que, se sofrerem modificações em seus átomos, afetam as propriedades da substância. Então, no processo social, a atomização seria o processo contrário ao de formação da molécula, ou seja, seria a segregação de elementos de uma molécula de forma a criar átomos únicos e diferentes dos demais. Essa criação, no caso 
do IASB, é representada por um discurso (ou lógica) da independência, em que o board se diz separado de todo e qualquer interessado, o que o tornaria socialmente neutro e diferenciado de outros possíveis concorrentes. Inicialmente já posso destacar a inconsistência dessa lógica com a lógica da financialização, entretanto, ambas são dadas como justificativas nas mais diversas estratégias do processo normativo do IASB.

Entendo que a atomização funciona como fenômeno de se criar individualidade (e diferenciação) para uma identidade específica. Para isso, a lógica da atomização funciona como um fenômeno hierarquizante, sendo que essas hierarquias podem ser visíveis ou invisíveis. A atomização ligada à regulação internacional representa o fenômeno que "naturalmente" cria padrões identitários comuns em sistemas amparados na "globalização" como justificativa para as ações, mas que, ao mesmo tempo, traz individualidade a mecanismos sociais que funcionam como átomos e possuem características próprias. A "globalização" seria a identidade geral de uma molécula, que possui diversos átomos na sua composição. Como esses átomos são individuais, qualquer modificação nas suas estruturas cria um novo mecanismo geral. Entre os átomos, temos os agentes do discurso da globalização, como os reguladores, os estados-nações, a comparabilidade e o neoliberalismo econômico voltado para a internacionalização de bens e serviços, entre outros. Assim, temos a criação de hierarquias invisíveis amparadas na diferenciação do board por meio dos discursos citados.

Esse pensamento neoliberalista é de grande valia para a análise de questões políticas no cenário atual. Nas bases da teoria do discurso, entendemos que o "liberalismo precisa negar o político em sua dimensão antagonista" (Mouffe, 2015, p. 9). Isso porque questões políticas necessitam de escolhas entre alternativas conflitantes, porém, na interpretação liberalista temos uma visão fictícia de que "vivemos num mundo em que existe, de fato, um grande número de pontos de vista e valores, e que, devido às limitações empíricas, eles nunca poderão ser adotados em conjunto, mas que, ao serem reunidos, constituem um conjunto harmonioso e não conflitante" (Mouffe, 2015, p. 9). Vejamos, o discurso social de independência é exatamente a aplicação ilusória dessa ausência de conflitos, em que se argumenta que existe um ente independente e atomizado do seu meio social capaz de realizar decisões "técnicas" sem a interferência de conflitos e, portanto, sem a existência de política.

A partir do ponto em que há essa atomização (processo discursivo de desconstrução e criação de diferenciações - algo similar ao que é discutido pela linguística de Jean-Paul Sartre -, há a presença de uma hierarquia invisível, afinal temos um ente que discursivamente não é comparável a qualquer outro, sendo ele "superior" e único quando comparado às possíveis alternativas já existentes ou que possam ser criadas. Além disso, há um desejo de 
universalização de seus interesses, de forma a tratar as possíveis demandas individuais por seu próprio viés ideológico, sem que haja um controle sobre tais ações. Essa diferenciação decorre da lógica de criação do seu status de independência, já que todo o processo normativo é justificado com base na premissa de tecnicidade advinda da independência do board.

Está aqui o ponto ligado ao IASB. Para ser considerado independente (o que no seu discurso naturaliza a garantia de decisões técnicas), há que se atomizar o board, ou seja, há que se criar discursos que o diferenciam dos demais de forma a garantir que ele seja a melhor opção possível quando se fala no discurso de globalização da regulação contábil. A independência e a atomização no IASB, portanto, funcionam como lógicas sociais que caracterizam toda a base argumentativa da organização. Uma das principais formas de defesa do board é exatamente pelo discurso de que, por ser um órgão independente, suas decisões são neutras e de qualidade, o que lhe confere uma diferenciação como "único e melhor" normatizador internacional possível. Esse fato pode ser questionado, o que ocorre em diversos estudos, porém, atualmente, após anos de experiência e aceitação do board por mais de uma centena países, a diferenciação como "melhor regulador, com melhor processo para a tomada de decisões técnicas" passou ao status de regras do jogo, amplamente aceito (hegemônico), principalmente pela prática profissional, que tende a não questionar suas normas ao subentendê-las como independentes, daí forma-se o status quo da regulação. Lembro, ainda, que esse status é conferido por uma "auto-avaliação", já que estamos falando de um processo de auto-regulação.

Mas como ser independente se os usuários da informação (discutidos na lógica da financialização) são exatamente aqueles que fornecem os estudos, a mão de obra e os recursos financeiros para o board? Devemos entender que o board necessita da aprovação de terceiros para que atinja um nível de autoridade substantiva e, para isso, não basta aprovação apenas por parte de usuários em geral, preparadores, auditorias, instituições financeiras e agências de investimentos. O board também necessita de aprovação por parte de "agentes públicos" de forma a conduzir a autoridade em níveis nacionais. Para atingir tal status, vejo que o board se ampara na independência e na atomização como as melhores opções (diferenciada) de discurso, que foi construído e condensado como senso comum ao longo dos anos, sendo que esse poder discursivo é apresentado desde a constituição do board, em que se afirma ser um órgão independente com produção de normas de alta qualidade. Além disso, o que reitera a alegada independência é o discurso do "interesse público", que direciona a compreensão dos atores, no sentido de que o board atende a todos de forma igualitária, algo que também já apresentei não ser real na discussão da lógica da financialização. 
Esses valores acabam por, atualmente, passarem inquestionados pela prática profissional. Posso dizer, então, que, em consonância com o que representa uma lógica social, tanto a independência como a atomização no contexto do IASB caracterizam o processo de normatização e são questões dadas como naturais. Os participantes acabam por aceitar tais conceitos sem questioná-los, como se fossem expectativas implícitas ao board e à condução do processo.

A fim de trazer a atomização e a independência para o cenário da regulação contábil, esforços discursivos foram realizados de forma a institucionalizar tais discursos. Entre esses esforços, posso descrever mais três lógicas sociais relacionadas, conforme Figura 24.

Figura 24 - Interrelação das Lógicas da Independência, das boas práticas, dos constituintes e da expertise

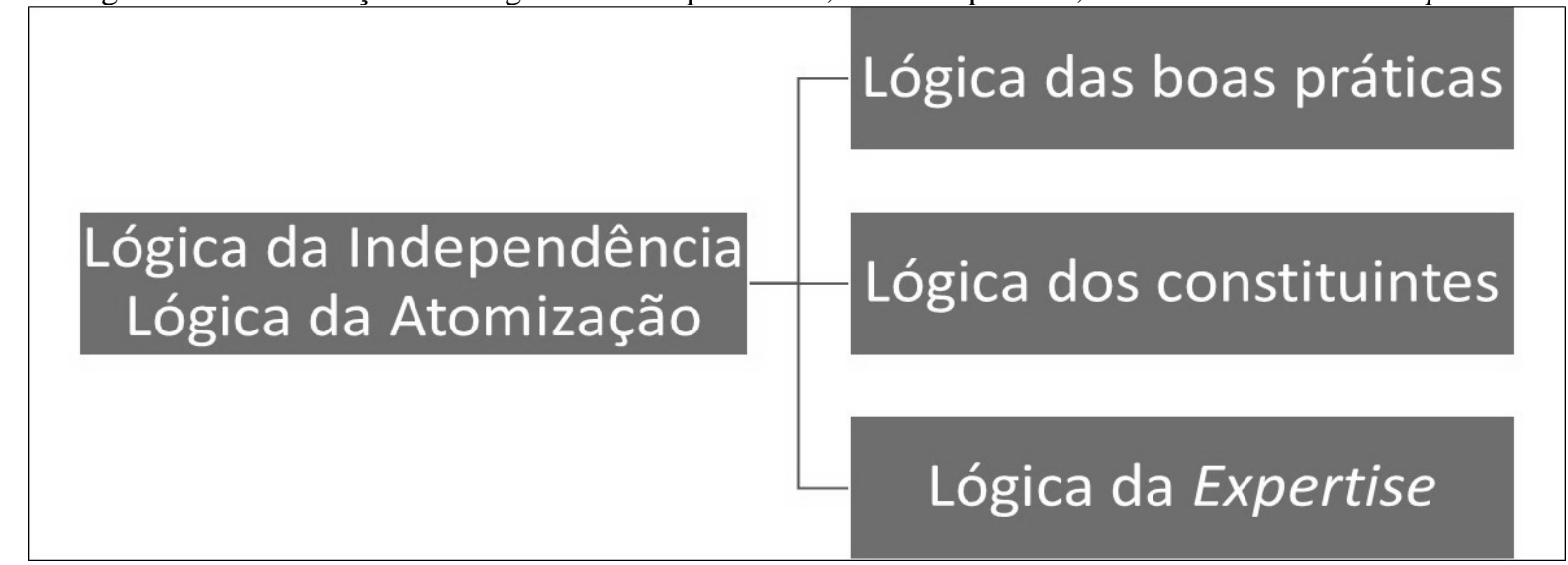

Fonte: Elaboração própria.

Vejo que as três principais lógicas utilizadas para reafirmar as lógicas da independência e da atomização são: lógica das boas práticas; lógica dos constituintes; lógica da expertise. Com auxílio delas, o discurso hegemônico das "normas sociais" foi construído para a regulação de forma a caracterizá-lo e trazer naturalidade ao sistema, formando regras implícitas ao jogo normativo. Perceba que essas três lógicas possuem relação com os pilares que discuto ao longo da tese (processo organizacional, atores envolvidos e conteúdo da norma).

A lógica das boas práticas de governança - que pode ser apresentada com uma aplicação da interseção da figura dos princípios do processo normativo (em especial a transparência) com o processo organizacional - funciona como pilar de sustentação da normatização de forma a caracterizar o discurso de qualidade da regulação. Essas boas práticas se amparam na hegemonia do discurso geral da normatização para, ilusoriamente, demonstrar a modernidade do IASB na elaboração de suas normas, porém, com base no objetivo da tese, questiono: será que essas boas práticas realmente ocorrem na prática ou se mantêm no campo do discurso escrito? 
Essas boas práticas acabam por caracterizar o processo normativo, ao menos na teoria. Exemplos envolvem a publicidade dada aos documentos, a tentativa de trazer uma governança em redes, com participação pública, a diminuição do status do próprio regulador em prol do "amplo debate" e a tentativa de justificativa das decisões tomadas, entre outros. Esses exemplos reforçam a ideia de naturalidade da qualidade das decisões tomadas, uma vez que há a impressão de haver ferramentas que envolvem os valores de controle, de participação e de avaliação. Esse alto rigor exigido em um due process traz um valor simbólico ao processo de forma a moldar os valores levados em consideração na elaboração de normas.

Apesar disso, há sempre um porém entre a "teoria e a prática" do processo. Posso dizer que essas boas práticas, no caso do IASB, funcionam como a estratégia geral e acabam por caracterizar o processo normativo contábil internacional, já que grande parte da argumentação das normas, das decisões e da necessidade de mudanças se justifica com base nos princípios gerais do due process. Em razão disso e da limitação real na "fiscalização" do processo, esses princípios são naturalizados como pontos "dados" no processo. Ou seja, a ausência de críticas advindas da hegemonia já conquistada reafirma a não necessidade de articulação em torno dos conceitos e das suas aplicações. Isso, por consequência, garante certa pacificação na utilização dos conceitos sem a necessidade de aplicação prática ou, com a aplicação prática limitada aos interesses e à relação de custo versus benefício avaliada pelo agente ativo do discurso hegemônico. Entretanto, a minha função aqui é exatamente a de mostrar que essa lógica social pode ser questionada e que qualquer conceito naturalizado pode ser trazido à discussão para aprimoramento da qualidade discursiva. Esse aperfeiçoamento pode ser realizado por meio da ruptura entre o elo da produção dos sentidos, materializado pelos elementos sendo transformados em momentos, de acordo com a teoria pós-estruturalista do discurso.

Relacionada com a lógica anterior, temos a lógica dos constituintes (partes interessadas/usuários), que está ligada com a categoria dos "atores envolvidos" e traz à tona o discurso de que os "constituintes" são partes integrantes do processo de construção de normas do IASB.

Inicialmente devemos refletir sobre o uso do termo "constituintes". Se olharmos a natureza do conceito de "constituintes", ele se refere a agentes que participam de forma (ativa) na elaboração de constituições. Podemos ampliar esse conceito para um uso mais moderno, em que se referiria a agentes que participam da elaboração/construção de documentos, normas, regras e (ou) informações. Ressalto que não podemos confundir o termo original em inglês com 
seu uso "mais corriqueiro" na língua portuguesa, já que o IASB se comunica formalmente em inglês e os participantes recebem as informações originalmente nessa língua.

O termo "constituents" na língua inglesa é definido como "someone who lives in a particular constituency" (Cambridge, 2020). Quando traduzimos, devemos entender que “constituency", presente na definição, não se refere a um "local", mas sim algo similar a “círculo/distrito eleitoral”. Ao incluirmos a noção de "eleitoral” na compreensão, isso quer dizer que "constituents" deveria envolver poder de decisão ou de participação ativa nos processos. Em termos democráticos, seria o direito a voto, ou seja, a capacidade de representar um peso positivo na relação "numerador/denominador" do processo decisório.

Em uma analogia com a estrutura formal da IFRS Foundation e, em especial do IASB, os constituintes, à luz do conceito da palavra, seriam os membros votantes, que possuem o poder de tomada de decisão acerca do conteúdo das normas editadas. Além deles, há os trustees da IFRS Foundation, que possuem o poder de elaboração e voto dado pela constituição do IASB. Nessa realidade, nem mesmo os membros do staff técnico seriam considerados constituintes, uma vez que apenas participam do processo normativo (mesmo tendo funções extremamente relevantes na sua condução), porém não possuem o poder decisório final e tampouco "assinam" os documentos finais.

Em um contraponto com o que se espera, o conceito de constituintes, nos diversos documentos do IASB, apresenta certa similaridade com o conceito de usuários (ou participantes/atores do processo) e não com os efetivos tomadores de decisões. Apesar disso, ressalto não encontrei a palavra "constituinte (constituent)" nos dois principais documentos que regem a estrutura da IFRS Foundation e do IASB (a constituição e o due process handbook, respectivamente). Essa estratégia é interessante, uma vez que o termo não aparece nos documentos "base" de um processo, não comprometendo formalmente a um uso inadequado do termo nem a uma definição clara. Entretanto, nos diversos documentos formais que são emitidos ao longo do processo e que possuem poder informativo, o termo aparece com similaridade ao conceito de "usuários/respondentes", como por exemplo:

"O board perguntou aos constituintes se a proposta de norma deve excluir arrendamentos de ativos não operacionais ou de curto prazo" (IASB, 2009c, p. 7).

"a maioria dos constituintes apoia o derecognition approach para a contabilidade das arrendadoras na maioria dos arrendamentos" (IASB, 2010a, p. 14).

"Em adição às respostas recebidas por constituintes do FASB e constituintes do IASB de países que adotam as IFRSs desde 2005, as respostas foram [...]” (IASB, 2011, p. 3).

"Esses requerimentos são familiares para muitos constituintes, o que fará com que a aplicação seja mais fácil e consistente" (IASB, 2013b, p. 83).

"os constituintes necessitarão de algum tempo para avaliar o impacto da proposta revisada" (DPOC, 2012d, p. 3) 
O termo (constituinte) aparece principalmente quando o board se refere às etapas de consultas. Se fizermos uma análise dos documentos, a consulta é um dos princípios do due process e tem como objetivo angariar opiniões de uma "ampla maioria das partes interessadas e afetadas, sendo este o garantidor da qualidade das IFRSs" (IFRS Foundation, 2016b, p. 14). Com isso, percebemos que há um uso equivocado (que não posso afirmar se é intencional ou não) do termo constituintes não só pelo IASB, mas também pelos diversos órgãos da estrutura da IFRS Foundation. O que posso afirmar é que o uso equivocado pode levar à compreensão incorreta da forma de funcionamento do processo normativo, o que dá a entender que a lógica dos constituintes seria a lógica dos usuários, isto é, os usuários e as partes interessadas possuiriam poder de decisão, o que não é verdade. Seu "poder" está apenas no fato de "poder ser" consultado.

Já argumentei que o IASB “mimetiza” uma lógica de democracia representativa, em que sua constituição estabelece que deve haver representantes de variadas "regiões" e de variados "conhecimentos de negócios". Entretanto, digo que é uma "mimetização" a partir do momento que é uma estratégia de disfarce. Vejamos, por mais que haja essa ilusão de variedade representativa nos membros do board, eles possuem mandatos que não são conferidos por parte das regiões/usuários que representam, mas sim por parte dos trustees da IFRS Foundation. Ou seja, o "povo" regulado não possui poder para a escolha de seus representantes e, por não cumprirem um mandato formalmente político, esses membros não possuem a necessidade de votar e de defender os interesses de tal "povo". Essa estratégia, portanto, confere o poder de constituinte a um membro, porém ele não possui o papel de representante legítimo de determinados "usuários".

Devemos ter esse ponto em evidência nas diversas análises que fazemos do board, pois a representação dada na constituição do IASB, sob esse enfoque, tende a ser retórica de forma a garantir uma ilusória qualidade com base em boas práticas de governança representativa. Em um paper anterior de minha autoria com demais pesquisadores (Matos, Gonçalves, Niyama, \& Marques, 2013), inclusive, identifiquei que não há relação observável de defesa de interesses da população representada por parte dos membros votantes quando se fala em decisões tomadas durante seu processo normativo.

Com base nessa noção de democracia e da própria episteme do termo "constituintes", trago um questionamento relacionado com a lógica social em questão: Quem efetivamente são os constituintes? Mesmo sem sabermos quem são os que influenciam e os que são de "real interesse" por parte do board, aceitamos, de forma naturalizada, que o processo é justo a ponto 
de incluir todos os constituintes (ou seria usuários/partes interessadas?). Devemos, portanto, entender que todo modelo de democracia mascara relações de poder/dominação e é nossa função como pesquisadores deixar com que elas não passem despercebidas e sejam naturalizadas.

Quando discuti acerca da financialização, mostrei que os principais "usuários" (veja bem, no handbook e na constituição o IASB não os pontua como constituintes), são aqueles que estão diretamente ligados com as demandas atuais de visões econômicas neoliberalistas. Refirome neste ponto principalmente aos usuários ligados ao mercado financeiro em sua forma de funcionamento atual, que são investidores (em especial os qualificados e institucionais) e entidades financeiras e de avaliação de mercado. Considerando que os votos dos membros do board não tendem a apresentar grande divergência entre si (Matos et al., 2013) e também são regidos pela constituição do IASB que delimita esses usuários, podemos entender que os membros também representam esses mesmos interesses. Aqui cabem mais dois questionamentos, que são: se o IASB deixa claro seu viés com usuários do mercado financeiro e a economia neoliberal em prol do mercado de capitais, por qual motivo sempre reafirmam que seu processo de consulta é amplo e justo para atender a todas as demandas? Isso não apresenta uma realidade ilusória, para entes menos esclarecidos e que não conheçam a constituição, porém que aplicam as normas, de amplitude e justiça?

Entendo, portanto, que por lógica dos constituintes há a representação de uma estratégia ilusória que tende a naturalizar os conceitos, que não são aprofundados e acabam por serem tomados como "dados" por parte dos mais diversos participantes. Essa falsa ilusão ocorre por meio do pensamento de que os "usuários" possuem poder efetivo de decisão sobre o processo normativo e até mesmo sobre o conteúdo final das normas editadas.

Essas estratégias de naturalização de conceitos com base em uma constante replicação e utilização em documentos formais acabam por transformá-los em conceitos aceitos por parte dos mais diversos atores que possam estar envolvidos com o trabalho do IASB. Essa criação do discurso dos constituintes, portanto, funciona como uma lógica social que auxilia na compreensão do processo normativo do IASB como sendo de ampla participação e poder dos mais diversos usuários envolvidos. Por ser um conceito já naturalizado, não é comum surgirem críticas quanto ao seu uso. Normalmente as críticas se referem a quem teve poder ou influência nos processos, porém o conceito em si é tanto utilizado ampla e internamente, por meio dos documentos oficiais, quanto aceito pelos agentes externos. A estratégia é tão efetiva que percebi que eu mesmo, durante a escrita da tese, utilizei-me do termo "constituintes" quando queria me referir a "usuários em geral", "atores" ou "partes relacionadas" ao processo. Após a escrita dos 
resultados por meio desconstrução do termo, voltei em toda a tese para verificar a correta utilização do termo.

Assim, posso finalizar a lógica social dos constituintes por meio da argumentação de que são reproduzidos constantemente os valores de inclusão dos atores, o que acaba por auxiliar na garantia da "qualidade" das normas e na aceitação do trabalho do IASB. Ao incluir essa utilização de constituintes de forma enviesada com seu conceito efetivo, contribui-se para a ilusão de independência, conforme constructo desenhado na Figura 24.

Como última, porém não menos importante, lógica social a ser discutida, apresento a lógica da expertise que, ao mesmo tempo, é uma representante das categorias de análise do “conteúdo da norma", dos “atores envolvidos" e do próprio "processo organizacional”. Ressalto ainda que enxergo a expertise como sendo a lógica social capaz de dar significado para a lógica da atomização. Uma vez que a atomização representa a diferenciação do agente perante os demais, a expertise se torna uma lógica que representa, de fato, essa diferenciação, ao menos discursivamente, dos demais agentes, garantindo um lugar de destaque no que se refere à "detenção" do conhecimento.

A lógica social da expertise caracteriza de forma basal o processo normativo do IASB e apresenta diversos efeitos sobre as práticas tidas como naturalizadas nesse processo, por exemplo, a "capacidade técnica", a "ampla participação", a "experiência prática" e a "visão de mercado". Por isso, classifico a expertise como um discurso básico utilizado na regulação contábil com a função de não apenas limitar ações externas, como também ser o discurso central para a aceitação dos produtos normativos por parte desses mesmos agentes que têm suas participações tolhidas.

Primeiramente, demonstro o que entendo por diferenciação e atomização por meio da expertise. Esse discurso representa a premissa neoliberalista do laissez-faire, que nos remete à "necessidade" da existência de um agente regulador da contabilidade externo às forças estatais. Trata-se aqui da necessidade de um agente privado que possua "conhecimento diferenciado" para a condução da normatização de forma parcimoniosa e que implique uma alegada "qualidade técnica/neutra" na emissão de normas. Complemento tal visão com o discurso de que a expertise representaria utopicamente "um esforço contra influências externas, como a negociação política. [Nesse discurso, haveria uma] proteção à autonomia profissional e à consolidação do conhecimento reconhecido" (Botzem \& Hofmann, 2010, p. 22).

A expertise seria uma estratégia que traz prestígio e credibilidade (Abbott, 1988; Willmott, 2000) e diferencia o órgão (e seus participantes) para que este atinja uma posição de 
poder para exercer uma determinada função. No caso do IASB, a expertise funciona como estratégia que garante a posição para editar as normas internacionais e a atomização trazida pela expertise assegura o poder na normatização de forma que a posição do órgão seja respeitada pelos mais diversos países (mesmo que não possuam influência nessa normatização). Podemos dizer que, no caso do IASB, a expertise é exercida por meio de seus membros e do staff que se diferenciam dos demais agentes ao se auto avaliarem como os representantes de uma ampla experiência profissional e com conhecimento técnico superior.

Qualquer processo de atomização/diferenciação, por passar a impressão de "superioridade", segrega (no sentido negativo do isolamento) atores que acabam por se sentirem incapazes de contribuir com algo que já aparenta ser tão diferenciado. A expertise do IASB (e de seus membros) cumpre esse papel ao integrar os atores de visões similares acerca das premissas de financialização da regulação, em uma gama de procedimentos de tomadas de decisões bem articulados. Essa característica do órgão acaba por excluir visões alternativas, seja porque são justificadas como não "condizentes” com as missões da regulação, seja porque não estão, segundo o IASB, em conformidade com as premissas implícitas de participação com qualidade no processo de regulação.

Assim, há uma exclusão silenciosa daqueles que não possuem o status social desejado ao debate nem alguma forma de poder entre os envolvidos. Isso se contrapõe à apresentação formal do IASB como órgão amplamente inclusivo; que leva em consideração os posicionamentos das diferentes regiões, usuários e interessados. Se observarmos a realidade, qual parcela dos possíveis interessados realmente possui uma participação ativa e realmente considerada inclusiva no processo? Não há grande variedade de participação e os atores também se resumem a experts no assunto, como preparadores de grandes corporações, auditorias, reguladores, acadêmicos e associações de empresas/profissionais.

Mas como isso ocorre se todos possuem "acesso" ao conhecimento? Por entender que “conhecimento é um fato político" (J. Brown \& Dillard, 2015), posso dizer que poder e conhecimento estão intimamente ligados, sendo que um reforça o outro (J. Brown \& Dillard, 2015; Gallhofer \& Haslam, 2007). Assim, a argumentação de expertise reforça um lugar diferenciado no discurso, que é o de locus of knowledge (Botzem, 2012; Dillard \& Ruchala, 2005; Suddaby et al., 2007; Warren et al., 2019). Reitero, portanto, que além de uma lógica social que caracteriza a regulação contábil, a expertise é uma característica política por envolver uma limitação de acesso ao conhecimento (quem dita o que é expertise?), sendo que esse ponto é amplamente contraditório com a visão técnica alegada pelo board no processo de tomada de decisões. 
Esse locus of knowledge cria uma fronteira invisível de autoridade bastante baseada em características que discursivamente são articuladas como pertencentes apenas ao normatizador e a um seleto grupo que o interessa na regulação. Os critérios que determinam quem estaria nesse grupo, ou no locus, são articulações construídas, que se tornam naturalizadas no processo de regulação. Afinal, quem não gostaria de ser regulado por um órgão que apresenta características - em teoria - de neutralidade, tecnicidade, qualidade técnica, experiência na área e ampla democracia no processo decisório?

Durante a compreensão do fenômeno da normatização, percebi essa diferenciação diretamente presente no discurso do IASB como forma de justificar seus posicionamentos. Para isso, a apresentação recorrente de um embasamento teórico (seja por meio da estrutura conceitual, ou por meio da tecnicidade, da experiência/aceitação global e da recorrente (auto)avaliação da sua qualidade, entre outros) faz com que se garanta, por meio do discurso de detentor do conhecimento contábil, como agente possuidor de poder estrutural no mercado, salvaguardando sua posição como normatizador internacional. O amparo das grandes empresas de auditoria colabora com tal situação, uma vez que essas empresas estão sempre ligadas aos preparadores da informação e fazem parte do conhecimento contábil nas diversas esferas da profissão, como na educação, na carreira e no poder financeiro entre os profissionais da área.

Mas será que o board realmente leva em consideração apenas esses aspectos técnicos decorrentes do conhecimento, de maneira a garantir a objetividade e a supremacia do conhecimento na elaboração das normas? Na minha visão, essas alegadas objetividade e detenção do conhecimento funcionam como ferramentas que escondem e mascaram o poder, fazendo com que as construções políticas sejam esquecidas (Laclau, 1990). Isso acaba por se transformar em uma regra social naturalizada que caracteriza a normatização contábil ao trazer a tecnicidade como status quo, o que confere ao board e aos demais participantes ativos do processo a posição de que realmente possuem o conhecimento necessário (e superior ao dos demais) para a consecução do processo de regulação.

\subsubsection{Lógicas Políticas}

Ao descrever as lógicas políticas, procuro mostrar como se deu a institucionalização da normatização de leasing, com ênfase nos discursos que possuem fundamentos políticos em detrimento da dualidade com o discurso técnico apresentado como lógica social. 
As demais lógicas já descritas nesta tese também possuem vinculação com a normatização de leasing, pois foi com base nesse processo normativo que elas foram observadas. Entretanto, para maior contribuição da tese, principalmente quando penso na replicação das premissas aqui desenvolvidas para a análise de outros projetos de normas, desenvolvi as lógicas de forma a serem aplicadas aos processos normativos do IASB em geral, por meio da semelhança de família. Dessa forma, reservei a discussão específica da normatização de leasing para ocorrer na seção de articulação. No caso das lógicas políticas, não foi possível construí-las de modo que possam ser aplicadas genericamente, uma vez que essas lógicas devem se referir a uma institucionalização concreta. Ainda assim, as evidências empíricas de aplicação das lógicas políticas também serão apresentadas na seção da articulação, de forma a desconstruir a história do projeto de elaboração da norma do leasing. Nesta seção apresento, portanto, os principais discursos e como foram importantes para a condução das mudanças que ocorreram no processo de leasing.

Vários discursos podem ser apresentados como lógicas políticas ao longo do desenvolvimento do processo normativo de leasing. Isso se deve principalmente ao fato de que o processo passou por mudanças significativas de atores envolvidos, de conteúdo da norma e do próprio procedimento que exigiu a publicação de mais documentos do que se costuma fazer em outros processos. As alterações realizadas por si só constituem um dos principais pontos que tornam necessária a análise dos discursos e são premissas para análises com base na teoria pós-estruturalista do discurso, o que pode ser melhor observado em Laclau e Mouffe (1985) e Laclau (2013). Devemos falar então dos discursos observados desde o início do processo até a sua finalização com base principalmente nas mudanças, pois é nelas que a capacidade articulatória se mostra mais necessária para a manutenção do discurso hegemônico.

Inicialmente destaco um dos principais discursos das lógicas políticas, utilizado nos processos normativos do board em geral, principalmente como estratégia de criação de lógicas de equivalências que tornam o projeto politicamente viável: o discurso da essência sobre a forma (ou discurso da substância econômica).

O discurso da essência sobre a forma é crucial como modo de institucionalizar a lógica social da financialização no projeto de leasing, uma vez que funciona como elemento que direciona a tomada de decisão no sentido de "modificar a norma". Esse discurso se baseia na noção de "substância econômica" dos eventos e fatos em detrimento da noção jurídica (do direito). É mais uma dicotomização política criada com base na prática articulatória de que as práticas contábeis baseadas na essência econômica seriam boas/atuais enquanto aquelas baseadas na forma jurídica seriam ruins/antiquadas. 
Nos termos específicos da normatização, "ao avaliar se um item atende à definição de um ativo, passivo ou patrimônio líquido, deve-se atentar para a sua essência subjacente e realidade econômica e não simplesmente à sua forma legal” (IFRS Foundation, 2018a, p. A36). Interessante essa comparação com o direito como sendo o representante da "forma", sendo que, em muitos cenários, assim como a contabilidade, o direito é muito mais principiológico do que formal e amplamente baseado em hábitos e costumes acima das formalidades do ato. Mas é realmente mais interessante trabalhar com a supersimplificação de cenários por meio do uso de dicotomias, pois assim há mais chances de se criar antagonismos contra o cenário indesejado para o discurso hegemônico.

Além de possuir relação com a noção de financialização e de informações voltadas para os investidores, a essência sobre a forma ratifica a defesa do board pela constante utilização do "valor justo". Ela representa a busca argumentativa do board de defender normas mais "principiológicas" (por mais que isso possa ser questionado) em detrimentos de normas mais regradas. Esse argumento, além de gerar uma noção de modernidade dos anseios normativos do IASB, acaba por também desmerecer as normas do principal possível rival na regulação, que é o FASB. Ao argumentar sobre a realidade econômica, O IASB utiliza-se da noção de que a economia e as operações do mercado são dinâmicas e "a complexidade da contabilidade é um reflexo da crescente complexidade da realidade econômica" (Hoogervorst \& Prada, 2015, p. 7).

Podemos perceber na argumentação do board que, quando se fala em reconhecimento de eventos econômicos, há a defesa de uma visão contábil mais baseada nos accruals. Trata-se de um conceito de reconhecimento visto como "moderno", que desvincula o reconhecimento de resultados/desempenho do reconhecimento financeiro: "a essência da contabilidade de accruals é aquela em que os eventos econômicos são reconhecimentos independentemente de quando a transação de dinheiro ocorrerá" (Hoogervorst \& Prada, 2015, p. 6). Esse argumento está inserido em um debate acerca da reafirmação do regime de competência e da extinção do princípio da prudência na estrutura conceitual do board.

Interessante notar que, paralelamente à defesa do board acerca da necessidade de uma visão mais subjetiva da realidade econômica ao se afirmar que "as normas contábeis objetivam descrever a realidade econômica da forma mais confiável e neutra possível” (Hoogervorst \& Prada, 2015, p. 5), exclui-se o princípio da prudência ao argumentar-se que falta "precisão e é aberto a muita interpretação" (Hoogervorst \& Prada, 2015, p. 6). Mas, no discurso das IFRSs, não deveria ser priorizada a capacidade de julgamento dos profissionais contábeis? Enfim, esse discurso específico não cabe muito a esta tese, porém é importante destacá-lo a fim de 
demonstrar que há possíveis incoerências no discurso interno e na defesa dos conceitos que interessam ao regulador. Isso quer dizer que tudo depende da capacidade articulatória do board, e não do conceito em si, já que justificativas semelhantes podem ser utilizadas para se defender ou atacar um conceito.

O discurso da essência sobre a forma também possibilita maior capacidade de julgamento, uma vez que apresenta maior subjetividade quando comparado ao discurso da forma jurídica. Por um lado, o board apresenta a essência como mais relevante para a tomada de decisões dos investidores, entretanto, essa essência pode ser vista de diferentes maneiras a depender da entidade e do usuário. Isso acaba, na opinião do board, por aumentar a fidedignidade da representação dos eventos econômicos e, por mais que possua diferentes possibilidades de reconhecimento e mensuração, aumentaria a fantasia da comparabilidade. $\mathrm{O}$ discurso da forma, por outro lado, seria mais fixo, sem grandes possibilidades de variação no que concerne ao reconhecimento ou à mensuração das operações.

O que cabe nessa diferenciação é que politicamente o discurso da essência é mais interessante, uma vez que viabiliza maior utilização da lógica das equivalências em decorrência da sua subjetividade e possibilidade de totalização/agregação de demandas, enquanto o discurso da forma não possibilita unir demandas diferentes. Com base na teoria pós-estruturalista do discurso (Laclau \& Mouffe, 1985), as lógicas políticas se amparam em conceitos que podem representar diversas demandas por meio da articulação de lógicas de equivalências. Nessa articulação, os agentes políticos utilizam-se de pontos nodais e significantes vazios que apresentam a capacidade de reunir tais demandas por meio da identificação de diversos sujeitos ao discurso da essência. Assim se cria o discurso da essência sobre a forma, que resulta na agregação de diversas demandas que entendem a normatização anterior como antiquada e buscam uma mudança. $\mathrm{O}$ antagonismo se mostra presente com o andamento da normatização, nos momentos em que temos diferentes interesses dentro de um mesmo discurso da essência sobre a forma.

O discurso da essência sobre a forma funciona também como a base para a criação do discurso de necessidade de mudança. Uma vez que houve a construção hegemônica de que as normas devem se basear na substância econômica, abre-se espaço para a crítica à normatização antiga, que, na articulação do board, era baseada na forma jurídica. Com isso, o que era antes um antagonismo ao discurso vigente se transforma no discurso hegemônico. A necessidade de mudança de uma norma no contexto internacional, portanto, se constrói por meio de reiteradas críticas ao modelo normativo anterior, mostrando suas falhas, e como elas 
não se enquadram mais ao modelo atual de negócios com base nas fantasias da globalização, da comparabilidade e da qualidade.

Nas propostas de mudanças normativas, o agente ocupante da posição de poder, quando não consegue inserir demandas específicas na sua argumentação por meio de alguma lógica da equivalência, cria o discurso de encaixar tais demandas em uma lógica das diferenças. Essa narrativa criada não apresentaria características suficientes para modificar a intenção do board.

Por exemplo, ao criar a lógica de diferenças com base na "necessidade de mudanças", temos a inserção nesse discurso de qualquer vontade de mudança de qualquer ator, mesmo que com demandas antagônicas. A partir daí, o board ratifica sua necessidade de realização de uma nova norma, principalmente por meio de críticas ao modelo normativo existente. As críticas são contundentes e envolvem diversas partes relacionadas de forma a agregar as demandas que antes se encontravam voltadas, cada uma delas, para um cenário específico distinto. Há o início da articulação por meio da lógica das diferenças, ou seja, a união de diversas demandas muitas vezes antagônicas ao redor da "vontade de mudança".

Todavia, com o andamento do processo, decisões são tomadas em favor de uma mudança específica, o que faz com que surjam agentes não representados por aquela particularidade. Ou seja, os agentes se enquadram na vontade de mudança (mesmo que pela diferença), porém não concordam com a mudança efetivamente proposta após a já aceitação de mudança geral. Nesse momento, entretanto, o projeto já foi iniciado tomando como base a noção de que "algo" deveria mudar na norma. Há aqui uma ruptura do momento hegemônico, que é sempre temporário e contingente, e constrói-se um problema de equivalência em que o significado perde seu sentido dado em determinado tempo-espaço, já que os discursos foram modificados, particularizam-se, e agora não mais agregam as mesmas demandas.

Apesar disso, há um fenômeno que possibilita a diminuição do poder de argumentação antagônica por parte dos "não representados", já que demais agentes se sentem representados e os "não representados" apoiaram tal projeto inicialmente. Mas para obter sucesso na continuidade articulatória e na transformação dos momentos, há a necessidade de constante articulação por parte do discurso hegemônico. A hegemonia é exatamente esse poder de construir um campo que agregue diferentes demandas de um sistema discursivo em torno de uma mesma prática articulatória.

Quando dessa atuação política (momento em que se defende mudança), é possível que o board já possua suas preferências de conteúdo da norma, o que permitiria a antecipação das necessidades articulatórias que surgiriam a partir do ponto em que as diferenças fossem 
realçadas por meio de alguma particularidade. Eventual antecipação facilitaria a construção hegemônica mais duradoura que criaria, além das diferenças, equivalências de forma a manter o discurso a longo prazo sempre coerente. Na prática regulatória, seria a construção de críticas iniciais que levaram à "vontade de mudança" que realcem exatamente a visão de conteúdo que o board deseja para a norma final. Isso quer dizer que, somente após ter esse interesse (ideia de norma futura), poder-se-ia começar as articulações para a criação da necessidade de mudança.

Assim, apesar de cronologicamente (para o público externo) e simbolicamente ocorrer primeiro a necessidade de mudança com base em críticas ao modelo anterior para depois disso se definir o conteúdo da futura norma seguindo-se um processo normativo, argumento que o processo é na prática o inverso.

Primeiro, o board possui uma intenção de conteúdo de norma e, após isso, cria a articulação que agregue as diversas diferenças para que se atraiam por essa necessidade de mudança. Seria muito arriscado para qualquer agente político propor uma mudança sem ter projetada qual mudança se deseja, porém no primeiro momento se apresenta apenas a vontade de mudar e, após isso, são inseridos os outros elementos ao processo. Assim, há a defesa de coerência do processo com os princípios que o norteiam, de participação, transparência e accountability, pois se constrói o discurso de que a norma foi editada com ampla participação e por meio das demandas populares e democráticas. Isso acaba por simbolicamente excluir o viés político do board e as opiniões que demonstram esse interesse acabam por ser marginalizadas.

Após concretizada a necessidade de mudança (que no caso da normatização representa uma lógica de diferença) e a institucionalização de que contabilmente é mais interessante tratar os números contábeis com base na essência econômica dos fatos e eventos, criam-se os discursos baseados no conteúdo da norma propriamente dita. Entre eles, temos o discurso da capitalização. Esse discurso é diretamente ligado ao de mudança normativa do arrendamento e é defendido desde os primeiros relatórios do então IASC/G4+1 quando se falava em mudança normativa do arrendamento, como em McGregor (1996) e Nailor e Lennard (2000).

No momento inicial, utilizando-se da lógica da diferença da "necessidade de mudança", o discurso da capitalização foi desenvolvido por meio da articulação de que esta era a melhor opção para o reconhecimento das operações de arrendamento tomando como base a essência econômica do que efetivamente representa um arrendamento. Nesse ponto, havia uma lógica bem articulada e hegemonicamente construída que fazia com que as partes relacionadas concordassem com a mudança da normatização contábil dos arrendamentos. 
Após isso, constrói-se o discurso específico da mudança. No caso do arrendamento foi o de capitalização de todas as operações de arrendamento. O ponto nodal torna-se, portanto, a “capitalização". Aí a lógica da diferença encontra problemas referentes à particularização da visão de mudança, limitando a capacidade de transformação dos elementos e pontos nodais em momentos. A produção de sentidos, que antes girava em torno do discurso da necessidade de mudança, passa a orbitar a definição de qual mudança deveria ser efetivada. A capitalização de todas as operações de arrendamento claramente não agrada a todas as partes relacionadas e que antes apoiavam mudanças na norma. Com isso, novas equivalências devem ser produzidas para a manutenção do discurso hegemônico.

A questão é que, se o arrendamento deve representar a essência das operações, partes relacionadas enxergam tais operações de formas distintas. Quando falo nessas partes relacionadas posso me referir a diferentes países, diferentes mercados, diferentes partes na operação do arrendamento ou diferentes setores de negócios. Cada uma seria impactada de maneira desproporcional a depender de como as operações de arrendamento funcionam nos seus nichos. Em razão disso, grupos começam a não se sentir mais representados por aquele discurso anterior que funcionava como significante vazio de mudança e há a reconstrução da relação hegemônica dos discursos, em que as totalizações temporárias são constantemente articuladas de forma a tentar sempre agregar demandas para aquele momento.

Com a realidade de antagonização, as batalhas políticas envolvem exatamente a identificação das forças antagônicas de forma a preencher os sentidos particulares. Daí surge a necessidade de que discursos de conteúdo da norma sejam articulados no campo discursivo para a condução do processo. A capitalização sozinha possibilita ainda diversas visões de reconhecimento e mensuração. Por esse motivo, funciona como discurso político, pois ainda possui a capacidade de agregar diferentes demandas dentro do escopo desse discurso mais universal.

Porém, em dado um momento é necessária a particularização. Ainda com relação ao conteúdo da norma e sendo uma extensão do discurso da capitalização, temos o discurso do modelo único. O modelo único envolve exatamente a aplicação das principais críticas que ocorriam à norma anterior de arrendamento e segue a articulação baseada na fantasia da comparabilidade para o aumento da qualidade dos negócios internacionais. A crítica era a de que poderia haver estruturação de operações com base na possibilidade de classificações existentes (operacional e financeiro). 
O modelo único "supre" tais críticas e acaba por agradar o público que demandava tal mudança. Como forma de articulação, já que esse modelo representa uma particularização do discurso da capitalização, une-se ao discurso mais universal de que "resolve" as críticas anteriores. Porém, como forma de trazer validade, esse discurso aparece excluindo agentes que demandam uma proposta diferente. Como isso é feito? Há uma tentativa de demonstrar viés político em interesses individuais.

A articulação de modelo único, então, é capaz de flutuar mediante significantes como comparabilidade, necessidade de simplificação e custos versus benefícios. Além disso, flutua sobre o argumento de que esses significantes são de interesse primário dos investidores. Entretanto, há certa incoerência na argumentação de que um modelo único baseado nos critérios de simplificação seria o ideal, tomando como premissa que a argumentação inicial dada para o discurso da necessidade de mudança é exatamente a de que o modelo anterior necessitava de ajustes, porque não espelhava a complexidade e a variedade das operações de leasing existentes no mercado internacional.

Toda essa variedade foi exatamente a justificativa para a mudança da norma com base no discurso da "essência sobre a forma", que deveria ser capaz de espelhar tal variedade. Mas será possível espelhar a alegada variedade de visões do arrendamento nos diversos mercados com um modelo único? Algum desses discursos necessita de aprimoramento para trazer maior coerência com relação à noção técnica. Aqui, claramente podemos enxergar que existe política na argumentação. Assim conseguem marginalizar as diferentes visões e críticas por meio do argumento de que esses antagonismos acabam virando "políticos" e, por isso, não caberiam na ilusão do processo técnico. Essa constante reafirmação acaba por criar uma "verdade" politicamente criada.

Por fim, ainda envolvendo conteúdo da norma, porém também diretamente as partes relacionadas, temos a instalação de outra lógica política ao processo. Por representar uma forma de contrato que apresenta, no mínimo, duas partes, a norma deve traçar ao menos a visão contábil para essas duas partes e, dessa maneira, surge o discurso que flutuou e foi bastante antagonizado em sua articulação (no caso de arrendamento): o discurso da simetria.

As normas internacionais mais atuais procuram espelhar como as transações seriam reconhecidas e mensuradas sob os diversos participantes das operações, então esse discurso não é restrito à norma de arrendamento, mas foi nessa norma que ele sofreu mais antagonismos e flutuações durante o processo. Na articulação geral, para defender a tecnicidade e demonstrar o simbolismo de que não se privilegia nenhuma das partes frente às escolhas contábeis, 
argumenta-se que deve haver simetria entre as contabilizações, evitando dupla contagem de itens contábeis.

Nesse sentido, a articulação segue até um senso comum e algo que, no geral, se esperaria de modelos contábeis. Por isso, seria de certa maneira simples marginalizar visões antagônicas que trouxessem de forma mais evidente aspectos políticos privilegiadores de algum grupo de interesse para a decisão normativa. Entretanto, devemos entender que em ambos os lados das operações podemos ter partes relacionadas com certo nível de poder; o que torna esse discurso político de certa forma difícil de encaixar e agradar. Assim podem ser gerados antagonismos com potencial de "prejudicar a tecnicidade" do processo e, por consequência, gerar críticas não só com relação ao conteúdo da norma, mas também ao processo normativo em si. Essas críticas incluem possíveis visões de presença política e "rompimento" das lógicas social e fantasmática criadas em torno da tecnicidade do processo.

Apesar das possíveis dificuldades durante o processo, principalmente com relação aos atores, o discurso da simetria funciona como uma lógica construtiva geral e abrangente aos processos de elaboração das IFRSs e acaba por criar uma lógica da equivalência em torno da dicotomia técnico-política do processo, servindo esta equivalência como uma estratégia de defesa da fantasia tecnicista que traz, teoricamente, coerência ao discurso normativo geral. Essa fronteira técnico-política compõe, além de uma lógica política por meio dos discursos que apresentei, o discurso central da normatização contábil internacional de qualidade e serve como ponto de marginalização dos demais discursos antagônicos. Além disso, reafirma o board como o único detentor da expertise, porém "aberto" a críticas por meio do processo de consulta, mesmo que essas críticas acabem por ser desacreditadas em virtude da própria fantasia da tecnicidade e da própria lógica social da expertise.

\subsubsection{Lógicas Fantasmáticas}

Durante toda a tese, discuto pontos relacionados com o poder. Embora esse conceito possa ser visto de diferentes formas a depender da posição ontológica e epistemológica adotada pelo pesquisador, podemos ter como base que o poder depende da existência de duas ou mais figuras. Na regulação, podemos relacionar as questões sobre poder com o termo "autoridade" e, assim como o poder, a autoridade também depende de duas ou mais figuras. Nesse contexto, autoridade/poder somente existem se também existirem atores que ocupem as posições de quem emite ordem e de quem as cumpre. Por isso, há um pensamento de que quem segue as "ordens" 
é que dá o poder/autoridade para quem as emite, ou seja, quem segue é quem possibilita o exercício do poder.

Com base nisso, as entidades que desejam essa posição de autoridade acabam por dedicar parte de suas estratégias para atingir exatamente essas formas de condução do poder. Uma das exigências dessa posição é a limitação das ações por parte dos agentes que recebem as "ordens". Por isso, temos a análise das lógicas fantasmáticas, que acabam por revelar "pontos que engajam, controlam, convencem e governam os sujeitos" (Remling, 2018, p. 5).

Nas lógicas fantasmáticas podemos dizer que há a criação de adversários de forma que a organização (prática social) em análise oferece o melhor cenário - o cenário final de qualidade. Por meio dessas lógicas, podemos ver como o agente social dominante “"sobrevive’ aos diversos testes institucionais" (Glynos \& Howarth, 2008, p. 26) a ele impostos por necessidade de aceitação.

No IASB, a base para as fantasias aqui analisadas é relacionada com seu due process. Considerando que este due process seja de alta qualidade, todas as premissas por ele elencadas garantem também a qualidade dos demais itens sob sua alçada e, por essa diferenciada qualidade, temos uma ferramenta que tanto afasta como limita as críticas.

Por falar nessa necessidade de qualidade, a primeira lógica fantasmática a ser discutida é a da fantasia de qualidade da norma. Essa lógica envolve argumentações de qualidade processual, de conteúdo e de atores envolvidos. Isso quer dizer que a argumentação da qualidade final da norma é amplamente baseada nas qualidades dadas ao processo normativo, amparadas nas alegadas boas práticas de governança. Assim, temos uma relação dessa fantasia com as lógicas sociais que já apresentei. A fantasia de qualidade da norma procura criar um discurso que sustenta a necessidade de ser o IASB, especificamente, o regulador internacional, uma vez que ele argumenta possuir todas as características necessárias para a criação do melhor cenário internacional possível para a prática da contabilidade (Barth, 2006).

Um dos pilares de sustentação é o de que a qualidade (técnica) da norma está acima de qualquer interferência política, até mesmo da funcionalidade de "convergência" das informações contábeis de forma a atingir o (alegado) interesse público (Hoogervorst \& Prada, 2015; Nobes, 2013). Além disso, o discurso faz com que os agentes se sintam envolvidos na construção dessa qualidade.

Os conceitos de qualidade da norma e de convergência encontram-se conectados no discurso do IASB. Eles não obrigatoriamente são correlacionados de forma positiva, ou seja, um aumento da "qualidade" leva a um aumento da "convergência", ou vice versa. Para o board, “embora a convergência [...] seja muito importante, a qualidade não deve sofrer para alcançar 
tal harmonização" (IFRS Foundation, 2014, p. 3). Aqui podemos observar, portanto, que teoricamente, quando há conflitos entre qualidade e convergência, a prioridade deveria ser a qualidade, ao menos no discurso formal. Entretanto, considerando que a qualidade seria o requisito máximo para a elaboração de normas, como podemos justificar as diversas abordagens que demonstram haver lobbying e defesa de interesses particulares no processo de normatização? Esse é um argumento para demonstrar que o processo não é "naturalmente técnico" de forma a priorizar sempre o que seria "qualidade".

Formalmente, o objetivo do IASB envolve a edição de normas de "alta qualidade" (IFRS Foundation, 2016b). Ao mesmo tempo, temos como requisitos para a entrada de um projeto na agenda a necessidade de que "o tema aumentará a convergência internacional" e a possível "qualidade da norma a ser desenvolvida" (IFRS Foundation, 2020). Aqui entro na "retoricidade" do termo "qualidade" como significante vazio, uma vez que representa diversas possibilidades de significados e, ao mesmo tempo, nenhuma especificamente. Assim, não somos capazes de dizer com certo nível de confiabilidade o que seria (alta) qualidade para o IASB, configurando esse significante vazio como um mito e interferindo na transição dos sentidos em momentos com base na teoria do discurso (Laclau \& Mouffe, 1985).

Porém, ao mesmo tempo, somos capazes de demonstrar momentos em que possa não ter havido a relação de qualidade sendo superior às necessidades de convergência e comparabilidade. Apesar de sermos capazes de desmistificar essa relação e demonstrar que não necessariamente a qualidade é respeitada na prática, o discurso naturalizado continua sendo o de qualidade como requisito para a edição ou modificação de normas. No caso específico de leasing, demonstrarei pontos em que os esforços de convergência com o FASB foram discutidos como necessários acima do que o próprio board acreditava ser o de maior qualidade.

A qualidade da norma se torna uma fantasia, portanto, por ser uma das bases argumentativas na normatização contábil para justificar e explicar a necessidade de mudanças nas normas e, ao mesmo tempo, "conquistar o público" de forma a mostrar que há sempre incremento dessa qualidade (imensurável e vazia). Dessa maneira, o board promete essa qualidade ao público, porém ela se torna ideológica ao ponto de ser uma estratégia política como forma de garantir a credibilidade e a aceitação de seus produtos.

Mas a fantasia da qualidade da norma não aparece sozinha. Para que ela exista, temos outras fantasias relacionadas. Entre elas, a fantasia da tecnicidade. Essa fantasia está presente nas mais diversas discussões desta tese e a tecnicidade se comporta como principal argumento do board para sua aceitação, para a garantia da qualidade, da neutralidade, da independência e 
das mais diversas estratégias de boas práticas de governança. A tecnicidade muitas vezes aparece atrelada a noções de objetividade e se configura como premissa também para paradigmas de pesquisa que não levam em consideração esses fatos citados, como a independência, e acabam por não quantificar tais fenômenos em suas análises.

Argumento que a tecnicidade, no contexto do processo normativo do IASB, é uma fantasia. A visão de tecnocracia, na realidade, é uma visão politicamente construída. Podem coexistir diferentes visões "técnicas" que possuem embasamentos, embora sejam contraditórias entre si. Em algum momento se faz necessária a existência de uma decisão, e aí entra o processo político. A escolha de uma decisão técnica, portanto, é uma escolha política.

Essa é uma característica das ciências humanas. Não existe a dicotomia criada por discursos ilusórios da decisão técnica correta e da decisão política errada. Veja como exemplo esta tese: aqui tenho uma leitura de um processo com embasamento teórico e científico, porém com uma visão política clara. Entretanto, existem diversas outras possibilidades de leituras desse mesmo processo, que também são políticas e seguem técnicas científicas, com leituras distintas da que aqui apresento. Uma leitura não invalida outra. O mesmo ocorre com a decisão “técnica”. Há mais de uma possibilidade e a política é exatamente a escolha de qual será a aplicada (não somente a escolha, mas a escolha é o observável).

Considerando que até vertentes científicas tomam como garantida a naturalização da tecnicidade na normatização contábil internacional, extrapolo que tal compreensão também ocorre com as mais diversas partes interessadas nesse processo. Além disso, as partes menos conhecedoras, como outras áreas do conhecimento, acabam por ter essa noção técnica da profissão contábil, trazendo essa noção da tecnicidade não somente ao processo, mas também a toda a profissão.

Além de alguns paradigmas de pesquisa se ampararem nessa neutralidade e tecnicidade, há o caminho inverso também realizado pelo IASB. Nesse caminho, temos o amparo do board em uma visão de cientificidade (positivista ou naturalista), baseada na comprovação empírica (não refutação) de hipóteses formuladas, demonstrando uma neutralidade e ausência de viés no processo decisório. Assim, cria-se uma dicotomia em que há a cientificidade (tecnicidade) versus política. Como consequência, passa-se a impressão de que as decisões técnicas são amparadas em quesitos científicos e por isso são de melhor qualidade e maior neutralidade.

Como forma de valorizar suas decisões por meio da participação da ciência (que traria maior resguardo de que as decisões são técnicas), o board inclusive inclui em suas etapas a consulta a estudos científicos e um programa de pesquisa que leva em consideração posicionamentos da academia. Apesar disso, poucas são as vezes que estudos científicos são 
utilizados como forma de justificar as escolhas realizadas durante os processos de edição de normas e, quando utilizados, tendem a adotar premissas de um paradigma positivista de visão do mercado e dos contextos organizacionais.

Contudo, o que devo deixar registrado nessa fantasia da tecnicidade é que existe a figura formal de participação acadêmica e de que suas contribuições seriam levadas em consideração no processo de tomada de decisões. A existência dessa formalidade auxilia no convencimento de partes relacionadas que, se não investigarem, levam a premissa da tecnicidade como algo garantido no processo por meio de referendo científico.

A fantasia de tecnicidade não se reafirma apenas pela cientificidade acreditada pelo discurso acadêmico, mas também por outros meios. O discurso técnico aparece desde o início, já nas necessidades de "conhecimento técnico" para participação no board, seja como membro votante, seja como staff (IFRS Foundation, 2016a), e segue presente em quase todos os documentos do IASB. No handbook (IFRS Foundation, 2016b), por exemplo, a palavra "technical" é a sétima palavra com maior número de aparições, totalizando 124 citações. A diversidade de contextos nas aparições acaba por tornar esse conceito um significante vazio no âmbito do IASB e a constante reafirmação do termo funciona como uma estratégia fantasmática de "conquista do público", uma vez que a tecnicidade é vista como positiva nesse ambiente.

A repetição, portanto, funciona como uma maneira de controle que, ao longo do tempo, mascara o poder exercido por meio da aceitação e do esquecimento. Esse pensamento é ratificado quando se vê que "a repetição de afirmações até que tenham efeito é a principal estratégia na racionalização do poder e na forma como o poder define a realidade" (Flyvbjerg, 1998, p. 113). A partir disso e fundamentado na visão pós-estruturalista que adoto na tese, posso dizer que a repetição é uma estratégia eficiente na internalização e institucionalização de determinadas ideias, uma vez que pelo poder linguístico constroem-se os discursos e com base nele as realidades são moldadas (Laclau \& Mouffe, 1985).

A tecnicidade, além de sempre reafirmada, também possui relação discursiva com o discurso de objetividade. Vejamos a visão de presidentes do board acerca do tema:

reconhecemos que a contabilidade geralmente envolve julgamento e que não é uma disciplina puramente técnica e objetiva. Por esse motivo, trabalhamos duro para visualizar questões contábeis complexas sob diversos ângulos e evitar uma abordagem ideológica da contabilidade. No entanto, mesmo que reconheçamos que os padrões contábeis não podem atingir 100\% de objetividade e precisão, nosso objetivo é chegar o mais próximo possível desse ideal. (Hoogervorst \& Prada, 2015, p. 5).

Apesar de não afirmarem que objetividade e técnica são a mesma coisa, deixam clara a visão de que a subjetividade levaria a uma abordagem ideológica (talvez queiram dizer a possível politização do processo?). A questão é, se temos toda uma normatização baseada em 
princípios, isso já não seria uma ilusão da objetividade? Se buscam o máximo de objetividade, não deveriam ter padrões fixos e sem margens para variações que os princípios (pela própria natureza da palavra) possibilitam? Ainda que afirmem buscar a objetividade e o embasamento técnico, a política é condição ontológica para esse discurso, ou seja, ela sempre existirá.

Mas o discurso de objetividade quando aliado ao de embasamento técnico é uma estratégia fantasmática que, mais uma vez, conquista o público por meio dessa ilusão de neutralidade. Esse discurso também é uma ideologia. Não podemos nos limitar a dizer que ideologia apenas ocorre quando há interferências políticas claras. Qualquer construção discursiva, por mais objetivamente embasada, também compõe uma ideologia, talvez de natureza mais conservadora, porém não deixa de ser uma ideologia. Isso porque, com base em Žižek e semelhante à visão de discurso de Laclau e Mouffe (1985), "ideologia é uma doutrina, um conjunto de ideias, crenças, conceitos destinados a nos convencer de uma "verdade", mas, na verdade, serve a algum inconfesso interesse particular de poder" (Costa, 2020). Com isso, existem ideologias inclusive que possuem como contexto o de silenciar a política e a dominação nela presente em prol de um discurso de "ruptura" que traz à tona significantes vazios como a tecnicidade neutra, justa e apolítica. Esse é o caso do discurso geral do IASB e da normatização contábil internacional.

A sustentação do discurso de tecnicidade no processo normativo, portanto, possui diversas frentes e age para engajar, controlar e governar os sujeitos que se utilizam de alguma forma dos produtos da normatização contábil. Revoluções com relação a esse conceito são de difícil realização, uma vez que a profissão muitas vezes encontra-se mais preocupada em aplicar as normas finais e menos preocupada nos seus processos de construção. Isso faz com que tenhamos, como área, uma perda na noção de como as normas foram influenciadas politicamente e passemos apenas a reproduzir pensamentos internalizados como se neutros fossem.

A fantasia da tecnicidade existe para trazer a alegada independência (lógica social) para o discurso da fantasia da comparabilidade. A comparabilidade seria o atributo que a normatização contábil atingiria por meio da fantasia das normas de alta qualidade aliada à fantasia da tecnicidade. Por meio da hipotética realização dessas duas fantasias, encontraríamos o "santo graal" da comparabilidade das informações contábeis, o que traria supostos benefícios para empresas, para o mercado e para a distribuição de riqueza pelo mundo. Considerando esse discurso dos benefícios da comparabilidade, deparamo-nos com uma outra fantasia, que é a fantasia da globalização. Por isso, discutirei essas duas fantasias de forma conjunta. 
A comparabilidade, assim como a fantasia da qualidade, já aparece na constituição da IFRS Foundation ao se afirmar, em seu objetivo, que as normas devem possuir alta qualidade e serem comparáveis com a finalidade de auxiliar, principalmente, os investidores (IFRS Foundation, 2016a). Também está presente no handbook (IFRS Foundation, 2016b), ao defender que a comparabilidade é requisito necessário para a avaliação de accountability da norma. Desse modo, torna-se premissa do órgão, na teoria, avaliar o incremento da comparabilidade para verificar os possíveis efeitos daquela norma.

A comparabilidade já é vista por outros pesquisadores como historicamente relevante para a defesa dos reguladores (Durocher \& Gendron, 2011; Young, 2006). No caso dos processos normativos do IASB, a comparabilidade funciona bem nesse contexto ao ser retoricamente relembrada nas justificativas das mudanças nas normas. Ao observarmos as articulações, seremos capazes de identificar que o aumento da comparabilidade (para os investidores) é sempre uma das principais premissas que justificam as mudanças.

O mito do interesse público se junta à comparabilidade quando o board argumenta que o aumento da comparabilidade interessa aos investidores, que poderão realizar decisões econômicas mais bem embasadas. Já dizia Montesquieu que "os interesses particulares fazem esquecer facilmente os interesses públicos". Se temos partes relacionadas com interesse nessa regulação que são "priorizadas", temos claramente a noção fantasiosa, ilusória e retórica do interesse público. Com a comparabilidade advinda das normas internacionais e com a aplicação dessas normas pelos mais diversos países, os investidores seriam capazes de investir em entidades localizadas em países com mercados menos desenvolvidos, pois haveria nesses locais empresas utilizando as mesmas normas dos demais mercados. Assim, pelo argumento do board, haveria um incremento da função "social" da contabilidade no auxílio aos mercados emergentes e menos desenvolvidos, que poderiam competir com os mercados do considerado "primeiro mundo".

A questão é que são muitos os pontos que diferenciam esses mercados, inclusive a capacidade da profissão contábil em aplicar as normas internacionais, que exigem uma habilidade maior de julgamento por parte dos contadores. A comparabilidade, portanto, pode ser vista mais como uma estratégia de convencimento do que como um incremento à globalização. A globalização também funciona como uma fantasia nesse cenário, uma vez que se construiu um status quo acerca das suas vantagens e da necessidade de um mundo globalizado. 
A comparabilidade é, então, um ideal da globalização que atende aos usuários sofisticados do mercado de capitais internacional. Esse ideal é construído de forma a persuadir os usuários a entenderem que a comparabilidade é sempre crescente com as normas internacionais e que ela é sempre vantajosa. Mas ao mesmo tempo em que sabemos que o ideal da comparabilidade pode ser de interesse dos usuários, principalmente investidores, devemos entender que esses agentes não possuem uma real influência sobre o processo normativo, ainda que possam idealizar serem atores ativos em decorrência do discurso dos usuários e dos possíveis benefícios do discurso da comparabilidade.

Ambas as fantasias, então, acabam por sustentar o discurso da normatização contábil, mostrando um cenário ilusório em que as informações são dadas aos investidores de forma a beneficiá-los e também a beneficiar as diversas nações. Essas fantasias fazem com que a normatização contábil internacional funcione sem que haja grandes críticas por parte da comunidade, justamente por internalizar o conceito da comparabilidade como sempre crescente e vantajoso. Ou seja, promete-se que entidades e países que adotem as normas apresentarão menores dificuldades de inserção no mercado internacional em decorrência da comparabilidade de suas informações, trazendo uma simplificação ideológica dos termos de forma a qualificar ambas as características apenas por seus aspectos positivos. Como a própria comparabilidade e as vantagens que ela traria são de difícil testagem e comprovação, os usuários reproduzem o status quo e, a partir disso, cria-se um mecanismo que tem o poder de governar os pensamentos dos sujeitos acerca da qualidade normativa do board e da sua necessidade para a continuidade da globalização dos mercados financeiros.

Considerando que existe essa compreensão da globalização como presente nos mais diversos discursos do IASB, devemos discutir o que esse processo "globalizatório" carrega como necessidade para sua existência. Quando utilizamos esse conceito, pensamos em diferentes atores e diferentes demandas e, com isso, surge a fantasia que garante o discurso central de todas as lógicas anteriores elencadas, que é o discurso da fantasia da justiça processual, que aparece acompanhado das fantasias travestidas de princípios: fantasia da participação, fantasia da transparência e fantasia da accountability. Essas fantasias também poderiam funcionar como lógicas políticas por institucionalizarem o processo normativo em geral. No entanto, escolhi sua aplicação como lógicas fantasmáticas por tomar como premissa na tese de que os princípios são retoricidades utilizadas com a finalidade de trazer a ilusão/fantasia de um processo de qualidade e, dessa maneira, convencer as partes relacionadas e os diversos usuários a utilizarem as normas internacionais sem maiores questionamentos. 
Essas fantasias estão conectadas com os princípios do processo normativo, que são de análise primária nesta tese. Para discutir essas fantasias, entra no cenário uma visão de complexidade do fenômeno por meio da opressão (Howarth, 2010). Considerando a existência de um discurso hegemônico que coordena a articulação desses princípios e que é conduzido por uma entidade que se credibilizou por meio da lógica da diferenciação pela atomização social, limitam-se as críticas ao processo por meio da articulação de princípios gerais que não podem ser modificados, isso porque se aceita o status quo de que esses princípios são inequívocos e totalizantes. E quem limita a visão desses princípios? O próprio agente que os cria e acaba por deter o poder nesse discurso.

Mas, para entrar especificamente nas fantasias dos princípios, devemos discutir a fantasia que as guia, que é a fantasia da justiça processual. Inicialmente, entendo que a alegada justiça processual é mais uma justiça com relação aos entes comerciais e profissionais, e não realmente um fórum aberto a todo e qualquer público que possa vir a ser influenciado. Essa justiça, portanto, é a defesa "formal" de que todas as vozes serão ouvidas e de que o processo é conduzido de forma neutra sem beneficiar algum público específico e levando-se em consideração as missões do board na edição de normas de "alta qualidade" e de "interesse público". Essa justiça é caracterizada pelo discurso técnico/neutro e apolítico do board. Apesar disso, minha visão é de que o processo justo e aberto a todos ocorre de forma simbólica, ao "possibilitar", ao menos formalmente, a participação de todos. Para isso, o board se resguarda por meio dos princípios do due process.

Outro ponto da fantasia da justiça processual é a vantagem de servir de precaução à possibilidade de agentes se sentirem não representados. Para isso, o agente de poder (board) cria estratégias que silenciam os demais agentes ao longo do tempo. Quando falamos nessas estratégias, falamos da fantasia da participação. Mas como ela ocorre atualmente? Principalmente por meio da inclusão meramente "formal" da participação pública dos mais diversos atores, pois para a real ocorrência dessa inclusão encontramos entraves que limitam a mobilização de atores em posições de menor poder. Por mais diversas que sejam as formas de consulta, a modificação (ou não) de conteúdos depende exclusivamente do board, então na realidade esse processo de participação se torna retórico de forma a poder limitar coalisões de atores que não se sintam representados determinada escolha. A argumentação é de que a

\footnotetext{
${ }^{9}$ Ressalto que aqui trago o termo "defesa formal" principalmente por entender que não posso afirmar "defesa discursiva", já que enxergo o discurso não só como algo escrito, mas sim como toda uma prática social. Por isso, não podemos cair no engano de nos referir ao escrito como discurso. $O$ objetivo desta tese é exatamente demonstrar que o que está "formalmente escrito" pode não estar sendo seguido na prática, caracterizando, portanto, a (in)consistência e (in)completude do discurso.
} 
consulta foi feita, porém com requisitos técnicos as escolhas realizadas foram " $\mathrm{X}$ " (conforme opinião do board) e não "Y" (conforme solicitações nos processos de consulta).

Ao se juntar essa questão técnica com a lógica da expertise, não há outras ferramentas de argumentação e, como não há concorrentes do IASB, resta ao ator submeter-se à decisão aceitando-se que o processo foi conduzido de forma justa. Isso porque considero que o discurso de aceitação do próprio IASB é hegemônico. O próprio presidente do board entende que o processo de consulta exige "expertise técnico", ou seja, admite a não completude e (in)justiça de tal processo.

Em nossa consulta pública, tentamos garantir um feedback equilibrado de todas as partes relevantes. Geralmente, não temos problemas em obter feedback das empresas, porque elas têm um grande interesse em nossas normas e têm os recursos e a experiência técnica para escrever cartas de comentários. (Hoogervorst \& Prada, 2015, p. 11).

Ainda que as empresas não sejam o principal público do board, conforme sua constituição, que trata os investidores e os tomadores de decisões como principais usuários, elas são consideradas como os "usuários" que possuem capacidade (talvez habilidade) de participar nos processos de consulta por meio das comment letters. O presidente complementa seu argumento dizendo que os demais usuários interessados (como investidores, ou seja, minimiza a participação do principal usuário de acordo com sua estrutura conceitual) recebem documentos "menos técnicos" como snapshots, para que possam ter suas opiniões formadas: "sempre que publicamos grandes propostas, também produzimos resumos de "snapshots" de alto nível, escritos para um público geral de negócios" (Hoogervorst \& Prada, 2015, p. 11). Aqui também limitam. Já deixam claro que os snapshots são de "alto nível”, ou seja, também exigem conhecimento amplo, limitando a sua compreensão a públicos muito específicos.

Vemos aqui a retoricidade do processo de consulta "completa e justa" e o mito da fantasia da participação na sua essência. O agente menos esclarecido "acha" que houve ampla participação e que seus representantes foram ouvidos. Contudo, se a principal forma de consulta limita a participação para um grupo de partes interessadas que formalmente nem são vistas como os principais usuários, temos limitações à completude e à justiça em diversas frentes. Inicialmente, a limitação é no público que é considerado como parte interessada e na limitação de suas participações ao conhecimento técnico necessário. Além disso, temos a limitação na forma de participação de agentes menos esclarecidos. Estes recebem relatórios ditos como nãotécnicos (snapshots) e são esperados que contribuam de modo não formal (não por meio de comment letters), já que não possuem o alegado conhecimento técnico. 
Apesar disso, o próprio board afirma que as CL (comment letters) representam a principal forma de consulta (IFRS Foundation, 2016b). Então, seria válido contribuir por outras frentes "menos formais"? Como elas seriam tratadas? Seria justo segregar a participação a determinados agentes? Afirmar que o processo é aberto a todos, portanto, é uma estratégia retórica que garante apenas uma sustentação à participação meramente formal. Na prática, temos uma incoerência: de um lado, o "anseio" de participação pública, de outro, incentivos de participação concreta apenas àqueles que interessam ao board. Embora os demais possam participar porque o processo é aberto, não devem fazê-lo visto que não possuem as características desejadas para configurarem uma boa participação. Será que se participarem sem o alegado conhecimento teriam suas opiniões consideradas da mesma forma que as dos demais? Será que, se as participações ocorressem de forma anônima, teríamos alguma mudança nas interpretações e considerações do board?

A limitação mascarada pela fantasia da participação leva a limitação das outras duas fantasias baseadas nos princípios, que são: fantasia da transparência e fantasia da accountability (ambas com relação ao processo normativo e não especificamente ao conteúdo da norma). Lembrando: nesse caso, a transparência seria relacionada com a evidenciação de todas as decisões, documentos, discussões e qualquer outra informação que se relacione com o processo normativo. Usando termos contábeis, não se limita à “apresentação", mas sim a uma evidenciação que possibilite uma carga analítica pelas partes relacionadas. Apenas apresentar os documentos muitas vezes é até mais uma limitação, já que não podemos presumir que as partes relacionadas possam efetivamente interpretar. Já a accountability seria a explicação das decisões tomadas, os racionais por trás do processo de tomada de decisão e suas justificativas para que aquela seja considerada a "melhor decisão técnica/neutra" para a norma.

Essas fantasias, assim como a da participação, também são referendadas pelos presidentes, inclusive com uma união das três fantasias na citação a seguir:

Todas as cartas de comentários são publicadas com igual destaque na seção do projeto do site do IASB, enquanto a consideração do IASB sobre esse feedback está sujeita a uma trilha de auditoria completa. [...]. No final do projeto, o IASB normalmente também publica uma Declaração de Feedback que explica como respondeu aos grandes temas recebidos durante a consulta. (Hoogervorst \& Prada, 2015, p. 11).

Apesar de realmente darem publicidade às cartas comentário, essa publicidade por si só não possibilita um rastro completo de auditoria, uma vez que as métricas de análise por parte do staff técnico são obscuras e não são demonstradas em documentos formais do processo. $\mathrm{O}$ próprio presidente afirma que apenas os "grandes temas" são respondidos no comment letters summaries, o que leva a crer que as críticas recebidas não são tratadas de forma homogênea. 
Além disso, como apresentei, há outras formas de consulta "menos formais", que teoricamente compõem os summaries. No entanto, nada se fala nos documentos acerca da forma como essas consultas foram tratadas e analisadas, nem qual o peso é dado a elas, já que representam consultas com o alegado público-alvo do board. O summary apresenta as informações selecionadas pelo próprio staff técnico e de forma agregada. Há ainda a noção de que esses summaries representam a fonte de informação dada pelo staff técnico para que os membros votantes do board possam tomar suas decisões.

Aqui temos uma limitação tanto da transparência como da accountability, reforçando o argumento de que são estratégias simbólicas e fantasmáticas que envolvem o processo de tomada de decisões. A partir do momento em que trabalhamos com informações agregadas e sem um devido "controle de qualidade", temos uma limitação da transparência, em que não podemos afirmar acerca da fidedignidade de tais dados e até mesmo se há silenciamentos ocultos na preparação desses documentos.

Além disso, considerando que a accountability é a prestação de contas para a tomada de decisões, temos uma limitação dupla: (i) os membros votantes do board, se limitarem suas análises e discussões apenas aos summaries, poderão estar se embasando em documentos incompletos para a decisão do voto; (ii) as justificativas dadas para as respostas são limitadas ao não haver um controle se todos os argumentos foram compreendidos no documento e se os argumentos realmente são condizentes com o que as partes relacionadas demandaram.

Em uma analogia com as "afirmações da auditoria", teríamos limitações: da "integridade" (se todos as críticas recebidas foram analisadas e respondidas); da "existência" (se todos respostas dadas referem-se a críticas efetivamente recebidas); da "precisão/valorização" (se são adequadas as tratativas dadas às críticas); e da "apresentação" (se as críticas e as respostas foram apresentadas de forma adequada).

Com base nisso, temos uma possibilidade formal de conferência das informações, dado que as comment letters são disponibilizadas, porém não poderíamos, como argumentado pelos presidentes, realizar uma trilha de auditoria dos dados, visto que não são evidenciados os critérios de análise nem os pontos de consultas informais realizadas pelos membros do staff.

Ainda com relação às fantasias da transparência e da accountability, o board defende que o controle de accountability é realizado pelo DPOC. Contudo, argumento que esse controle também é alvo de crítica por ser componente de "conquista do público" característico da lógica fantasmática. Essa figura de controle com uma estrutura "independente" de governança exercida pelo DPOC é ressaltada pelos presidentes como uma estratégia moderna de governança para que o processo seja conduzido da forma como previsto. 
todo o processo devido é então sujeito a uma revisão abrangente e completa do ciclo de vida pelo Trustees' Due process Oversight Committee, antes que a norma final possa ser emitida pelo IASB. Preocupações sobre supostas ofensas ao devido processo são extremamente raras. (Hoogervorst \& Prada, 2015, p. 11).

A figura de controle de accountability sobre o processo é exercida formalmente pelo DPOC de diversas maneiras, mas não pode ser vista como "completa", uma vez que revisa requisitos formais do processo, como cumprimento de prazos, se todos os documentos necessários foram emitidos e votos, entre outros. Ou seja, não há um controle efetivo e proativo de "qualidade" não formal, por exemplo, se os usuários estão sendo ouvidos e se as decisões são realmente as melhores opções (se é que podemos dizer o que seria melhor).

Além disso, a ação do DPOC muitas vezes é reativa às denúncias recebidas e os presidentes afirmam que essas denúncias são raras. Com relação a essas denúncias, portanto, posso fazer dois questionamentos para podermos analisar se existe controle efetivo por parte do DPOC ou se seria somente mais uma estratégia fantasmática: Essas denúncias são raras porque as possíveis partes interessadas sequer conhecem o órgão e sabem sua função na estrutura formal? Ou essas denúncias são raras porque o processo realmente é visto como coerente e seguido à risca por parte do IASB?

Daí a importância das questões relacionadas ao processo e não somente ao conteúdo final, uma vez que, com o passar do tempo, os antagonismos ocorridos durante a elaboração da norma tendem a ser silenciados e esquecidos, e sua aplicação passa a ser realizada sem qualquer resistência. Esse fenômeno só seria relembrado quando da intenção do ator com poder (no caso o board ou os atores que estão por trás de sua existência) decidir pela mudança naquela proposta regulatória. Aí sim todas as forças antagônicas anteriores serão revisitadas como forma de justificar a necessidade de mudanças.

Essa é a intenção das lógicas fantasmáticas: a de criar narrativas que prometem uma "pseudocompletude" de interesses e, por consequência, limitar obstáculos futuros. As lógicas fantasmáticas, nesse caso concreto, portanto, representam um mito (no seu conceito mais simples) da inclusão e garantem a detenção do poder por meio da limitação moral à apresentação de antagonismos por parte dos atores dominados.

Por que essas lógicas são criadas e sustentadas? Porque essa é a forma de sobrevivência de tais atores. Os agentes que dominam devem constantemente criar (e manter) tais discursos hegemônicos e limitarem os antagonismos, uma vez que o poder é um conceito relacional na estrutura de dominação (Howarth, 2010). Isso leva à necessidade de sempre se manter (e até mesmo se antecipar) firme nas possíveis lutas. 
Em suma, afirmo que as lógicas desenvolvidas nesta seção sustentam o discurso da regulação técnica/apolítica, justificando a neutralidade e a qualidade do board na edição de normas internacionais de forma a "convencer o público" de que suas promessas de qualidade são as melhores possíveis para a manutenção de uma contabilidade a nível global, criando-se uma ideologia simbólica de que a regulação é participativa e voluntária.

\subsection{Articulação, Julgamentos e Críticas ao Processo}

A articulação tem como principal função a de desconstruir os discursos e demonstrar empiricamente possíveis inconsistências na construção do sistema de produção de sentidos. Essa produção de sentidos funciona como uma estratégia política para a fixação de discursos hegemônicos. "Realçar a dimensão política de uma prática implica apontar os aspectos daquela prática que buscam gerar, manter, controlar ou resolver a contestação pública de uma norma social" (Howarth, 2010, pp. 327-328).

Ressalto que na articulação não tenho como objetivo contar toda a história e todos os andamentos do processo normativo de leasing. Questionamentos podem surgir, como: "mas o pesquisador não citou isso ou aquilo". Entretanto, meu objetivo com a desconstrução é o de demonstrar momentos em que a articulação do normatizador se mostrou inconsistente ou paradoxal dentro do seu próprio discurso. Desse modo, somos capazes de enfatizar a natureza contingente e política dos discursos.

Por esse motivo apresentei as lógicas na seção anterior, pois elas representam a direção para a articulação: a forma de leitura do processo. Após a apresentação das lógicas, a articulação demonstra as inconsistências desse status quo dicotomizado da contabilidade, sendo que ele deve ser questionado e não pode ser naturalizado de forma a mostrar que as únicas boas opções são aquelas permitidas pelo regulador internacional.

As críticas não possuem a finalidade de destruir ou descontinuar a elaboração de normas contábeis. Devemos levar em consideração que "o mercado financeiro e seus reguladores, incluindo questões relacionadas ao financial reporting, não são forças da natureza, mas sim criações humanas. São meios para serem modificados, redesenhados, melhorados e em algumas ocasiões delimitados de acordo com o sistema de ideais politicamente vigentes" (Palea, 2015, p. 13).

Como a base central argumentativa gira em torno dos princípios, devo deixar registrado que não devemos esperar que haja "princípios ou qualidades puras". Isso é sempre uma estratégia retórica de ilusão frente à argumentação necessária para a sobrevivência em um 
determinado contexto social. Daí entendemos a (in)completude. Por ser retórica, sua contraposição com situações empíricas tende a demonstrar a tal falha nesse discurso totalizante do "ideal purificado". Exatamente por não acreditar nesse conceito ideal é que surgiu a motivação da tese para a desmistificação dos princípios presentes na normatização como sendo os pilares completos de um processo de elaboração de normas na contabilidade.

Para a desconstrução discursiva devemos entender qual seria a visão do IASB/DPOC para a importância do próprio processo normativo. Para eles: "ao considerar a finalização de uma IFRS, o objetivo do devido processo [due process] é garantir que o IASB esteja satisfeito por ter realizado consultas e análises suficientes para justificar suas decisões" (DPOC, 2015c, p. 1), ou seja, apesar de possuir um caráter formal de independência e neutralidade, o board entende que o processo normativo serve para que ele mesmo se assegure de que tomou as decisões tendo como base todas as informações relevantes disponíveis. Para isso, há os princípios que norteiam esse processo e, nesta seção, desconstruo o mito de que as informações são disponíveis para todos de forma transparente, por meio de consulta completa e justa e com accountability. Posteriormente, demonstro a (in)completude dos princípios por meio da apresentação das (in)consistências na sua articulação e na relação entre o discurso formal e a efetiva prática discursiva.

\subsubsection{Análise dos Principais Discursos de Mudanças: Explicitação das Contradições}

Para análises de inconsistências no sistema discursivo, principalmente quando falamos em comparações entre discurso escrito e discurso prático, o principal cenário empírico é aquele que envolve mudanças. Já que "mudança” representa uma palavra importante tanto para a teoria do discurso quanto para o próprio projeto de leasing, a primeira tarefa foi elencar os principais estágios que representaram mudanças no processo em uma lógica histórica:

(i) a criação da necessidade do projeto: a mudança da norma propriamente dita. Nesse estágio constrói-se a necessidade de mudança da norma.

(ii) a criação de uma base conceitual ideal e de alianças políticas: ocorrência da primeira mudança proposta no conteúdo da norma, momento em que alianças de projeto de convergência também são realizadas. 
(iii) as consequentes reestruturações conceituais e de alianças: diversas mudanças de conteúdo ocorreram ao longo do processo, modificando também impactos e impactados.

(iv) o silenciamento da base conceitual e das alianças para finalização do projeto: após as diversas mudanças, alianças se mostraram frágeis e houve silenciamento de decisões tomadas que antes eram tidas como indesejadas.

Podemos relacionar as fases do processo elencadas anteriormente com as subseções deste capítulo. Para a articulação da criação da necessidade do projeto, apresento na subseção 6.4.1.1 momentos discursivos relacionados com a criação da necessidade de mudança da norma propriamente dita. Em seguida, quando falo em "criação de uma base conceitual ideal e de alianças políticas", apresento, na subseção 6.4.1.2, as articulações que ocorreram como forma de criar o racional para o reconhecimento das operações pelas arrendatárias. Após isso, na subseção 6.4.1.3, articulo sobre a questão da simetria entre as partes do contrato, para explicar o fenômeno da reestruturações conceituais e silenciamentos do processo. Por fim, discuto brevemente sobre a aliança entre o FASB e o IASB no projeto de arrendamento (subseção 6.4.1.4) a fim de compor a argumentação sobre silenciamentos para a finalização do projeto.

Para explicar os pontos que envolvem as lógicas, tento realizar uma articulação tomando como base a cronologia dos eventos que envolveram a norma e nos pontos acima elencados, porém adianto que isso nem sempre foi possível. Durante o processo de arrendamento, houve muito "vai e vem" que envolveu mudanças de opiniões, de articulações, de posicionamentos e até mesmo de posturas frente aos conteúdos, atores envolvidos e ao próprio processo organizacional.

Destaco que todas as etapas que descrevi envolvem fases do processo que representaram rupturas ou produção de sentidos que foram importantes durante a elaboração da IFRS 16. Em todas elas temos o elemento comum que permeou a maior parte das discussões do arrendamento, que é o das críticas que envolvem o registro contábil de operações antes reconhecidas como off-balance. Mais uma vez afirmo que esses podem não ser todos, mas representam passos importantes em que posso demonstrar o objetivo da tese e discuto-os de forma a mostrar inconsistências acerca da dicotomização técnico-política. 


\subsubsection{A Necessidade de uma Mudança Normativa para Leasing}

O discurso em torno do significante vazio da "mudança" é presente não somente na esfera da regulação contábil internacional, mas inclusive em questões políticas de nossas vidas quotidianas, como em cenários eleitorais para cargos políticos. Falar em mudança traz à tona a lógica da equivalência/diferença que insatisfaz as diversas partes interessadas e acaba por angariar um público tendente a apoiar a causa vazia da "mudança”, mesmo sem saber qual é a mudança propriamente dita.

Aplicando ao processo de arrendamento conduzido pelo IASB, posso dizer que, formalmente, conforme documento de entrada na agenda (IASB, 2006a), as bases para o início da argumentação acerca da necessidade de mudança normativa do leasing foram os relatórios do G4+1 em que se criticava o modelo existente (McGregor, 1996) e se propunha uma nova forma de reconhecimento e mensuração dessas operações (Nailor \& Lennard, 2000). Por mais que o G4+1 não seja o IASB propriamente dito (na época dos relatórios, IASC), o grupo era coordenado por membros do IASB/IASC e refletia as opiniões do board.

Nesses dois relatórios do G4+1 foi lançada a lógica política por meio do discurso da "necessidade de mudança" normativa, tomando como base a também lógica política da "essência sobre a forma". Ambos os discursos se ampararam em uma visão da lógica social da financialização, da expertise e dos constituintes, resguardados pelas fantasias da qualidade da norma, tecnicidade, comparabilidade e globalização, conforme esquema da Figura 25.

Figura 25 - Relação das lógicas sobre o tema da "Necessidade de Mudança"

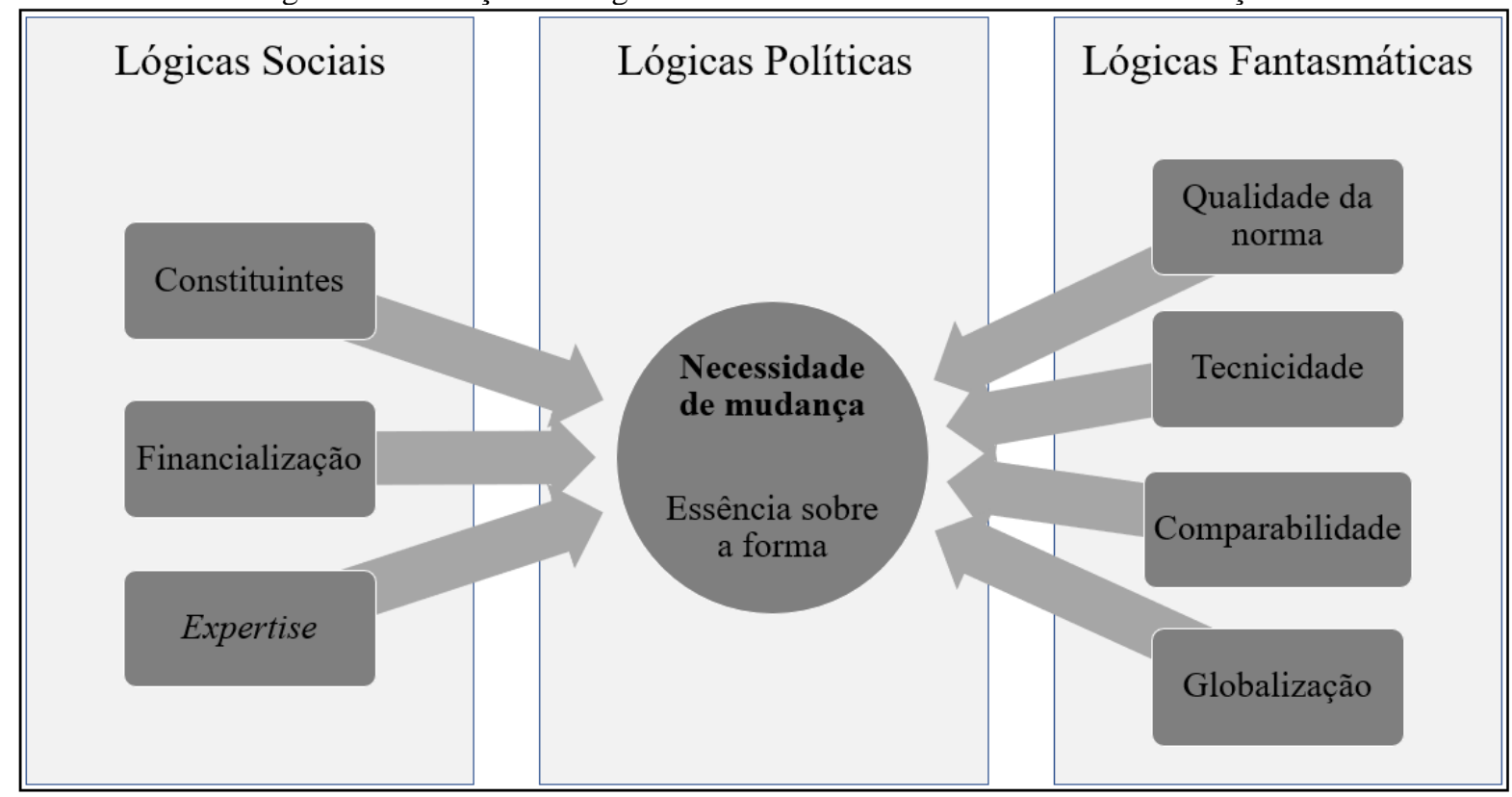

Fonte: Elaboração própria. 
Com base nessa relação entre as diversas lógicas, entendo que há como desenvolver um posicionamento crítico acerca do discurso de necessidade mudança criado pelo board. Para justificar a necessidade de mudança na norma de leasing, deve-se primeiro "convencer" o normatizador a incluí-lo na agenda. Esse convencimento, entretanto, é realizado pelo próprio órgão, por meio de argumentações do staff técnico, ou seja, a necessidade de mudança e a inclusão na agenda ${ }^{10}$ são de iniciativa e aprovação pelo próprio IASB.

Para observação dessa estratégia de convencimento, elaborei a Figura 26 que relaciona, à época, os critérios para a entrada na agenda, de forma geral, e as articulações defendidas pelo board para o processo de arrendamento, de forma específica. A principal linha de defesa consistiu nos seguintes argumentos:

Figura 26 - Argumentos do IASB para a entrada do projeto na agenda

\begin{tabular}{|c|c|}
\hline $\begin{array}{c}\text { Critérios } \\
\text { (IASC Fountarion, 2006) }\end{array}$ & $\begin{array}{c}\text { Argumentos do IASB } \\
(\text { IASB, 2006a, 2006c) }\end{array}$ \\
\hline $\begin{array}{l}\text { Relevância para os usuários } \\
\text { das informações e a } \\
\text { confiabilidade das } \\
\text { informações que serão } \\
\text { fornecidas }\end{array}$ & $\begin{array}{l}1 \text { - As operações de arrendamento são importantes globalmente, envolvendo } \\
\text { grande quantidade de participantes e valores monetários. } \\
\mathbf{2} \text { - Muitas são as críticas às normas anteriores (IAS } 17 \text { e SFAS 13), que não } \\
\text { representam o melhor modelo dos negócios, entre elas: separação entre financeiro } \\
\text { e operacional; subjetividade; testes bright-line; estruturação de operações; } \\
\text { arrendamentos devem ser vistos como financiamentos; diferenças de escopo entre } \\
\text { a norma de arrendamento e as normas mais modernas e atuais; inadequação dos } \\
\text { critérios para arrendadoras. } \\
\mathbf{3} \text { - Modificando a norma e trazendo a harmonização entre os boards, os } \\
\text { problemas das críticas anteriores seriam resolvidos e haveria mais confiabilidade } \\
\text { das informações. }\end{array}$ \\
\hline $\begin{array}{l}\text { Existência de guias ou } \\
\text { estudos anteriores }\end{array}$ & $\begin{array}{l}1 \text { - Apesar de existirem, nada se justifica com base em algum estudo prévio já } \\
\text { existente. Os argumentos giram em torno da necessidade de mudança em } \\
\text { decorrência da inadequação da norma aos critérios atuais da estrutura conceitual. }\end{array}$ \\
\hline $\begin{array}{l}\text { Possibilidade de aumento } \\
\text { da convergência }\end{array}$ & $\begin{array}{l}1 \text { - Justifica que a qualidade da norma deve estar acima das necessidades de } \\
\text { convergência. Entende que a maioria dos reguladores nacionais apoiam as } \\
\text { mudanças propostas pelo IASB. } \\
2 \text { - Apesar de entender que a qualidade deve estar acima da convergência, vê como } \\
\text { sendo essencial a convergência com o FASB. }\end{array}$ \\
\hline $\begin{array}{l}\text { Qualidade da norma a ser } \\
\text { desenvolvida }\end{array}$ & $\begin{array}{l}1 \text { - Haverá aumento da comparabilidade e da compreensibilidade ao se retirar } \\
\text { a arbitrariedade e incluir um modelo único; } \\
2 \text { - Para incremento da qualidade, a norma deve necessariamente possuir } \\
\text { consonância com os conceitos desenvolvidos em outras normas/projetos, em } \\
\text { especial: "combinação de negócios", "estrutura conceitual", "reconhecimento de } \\
\text { receitas", "instrumentos financeiros" e "provisões, passivos contingentes e ativos } \\
\text { contingentes"; } \\
\text { 3 - A qualidade da norma depende de um balanço entre os custos e os benefícios. }\end{array}$ \\
\hline Restrições de recursos & 1 - Há recursos para a condução do projeto. \\
\hline
\end{tabular}
Fonte: Elaborado pelo autor com base em IASB (2006a, 2006c).

Dentre os pontos da Figura 26, duas são as principais justificativas dadas para a entrada do projeto na agenda: críticas à norma anterior e necessidade dos usuários. Ambas em

\footnotetext{
${ }^{10}$ Atualmente esse processo passa por uma consulta para revisão, porém a transparência do processo ainda é limitada e demandas podem surgir internamente ao board sem ter havido sugestão externa formal.
} 
decorrência de trabalhos de "capitalização indireta" que esses "usuários" devem realizar durante o processo de análise das demonstrações financeiras das empresas em decorrência da possível brecha para arbitrariedade gerada pela norma.

\footnotetext{
"Os boards decidiram por adicionar o projeto em suas agendas à luz das críticas ao modelo existente para arrendamentos" (IASB, 2009a, p. 12)

"O modelo atual de contabilização dos arrendamentos tem sido criticado por falhar em atender a necessidade dos usuários das demonstrações financeiras. [...] usuários rotineiramente ajustam os valores reconhecidos com a intenção de reconhecer aqueles ativos e passivos [de arrendamento] e refletir os efeitos dos contratos de arrendamento nos lucros e prejuízos. Apesar disso, a informação disponível para os usuários nas notas explicativas das demonstrações financeiras é insuficiente para que eles realizem os ajustes de reconhecimento de forma confiável”. (IASB, 2009a, p. 14).

"tem havido um pedido antigo de muitos usuários das demonstrações financeiras e outros para alterar os requisitos de contabilidade para que os arrendatários sejam obrigados a reconhecer esses ativos e passivos". (IASB, 2013c, p. 5).
}

Quais seriam os problemas nas normas anteriores para que demandassem uma nova norma de "maior qualidade"? Vejamos, a primeira justificativa (críticas) possui um tom mais conceitual, em que se demonstram possíveis falhas ao modelo até então vigente. Já a segunda (usuários) apresenta um discurso mais voltado à lógica dos constituintes, em que estes são alçados à posição de demandantes das mudanças.

Com relação às críticas à norma anterior, a principal é articulada é a que se relaciona com o reconhecimento (ou não) de transações off-balance e o board. No ambiente regulatório, essa crítica normalmente se ampara em um relatório da SEC relacionado à norma norteamericana em que demonstra que informações off-balance podem ser responsáveis pela incompreensão das informações contábeis (IASB, 2006a; SEC, 2005). Esse modelo (de classificação com possibilidade de reconhecimento ou não), entretanto, já havia sido visto como o modelo que propunha mudanças e era inovador com relação ao leasing. No início das normas sobre o assunto, afirmava-se que "as normas contábeis [da década de 1970] foram elaboradas para superar as deficiências da contabilidade com relação aos efeitos das transações de arrendamento" (McGregor, 1996, p. iii). Da mesma forma como atualmente, propunha-se uma mudança em decorrência das "falhas das normas vigentes em se espelhar as transações de arrendamento" (McGregor, 1996, p. iii).

Interessante notarmos que a articulação que antes era a inovação, atualmente é o problema. Isso em si não é uma incoerência, uma vez que o modelo de negócios das entidades evolui e se adapta às diversas necessidades ao longo do tempo, mas a argumentação é a mesma: a de que a norma não mais espelha o modelo de negócios corrente. Há aqui uma ratificação da teoria do discurso no que concerne ao conceito da contingência e precariedade. Com base nessas articulações dadas, podemos reafirmar a teoria no que se refere à contingência e constante 
necessidade de mudança das articulações políticas necessárias para as diversas situações. Mesmo tendo objetivos de normas distintos, a articulação por meio do significante vazio da "mudança” é a mesma.

A questão nessa mudança recente é a reafirmação do funcionamento da lógica social da financialização, em que temos a necessidade de mudança partindo de críticas acerca da forma como os usuários são capazes de "identificar" as transações de arrendamento nas entidades. Isso quer dizer que a normatização do arrendamento parte de críticas dos "usuários" (que não são descritos) e, dessa maneira, constrói-se a ideia de incorreção da teoria por trás da norma e a necessidade de mudança na regulação do tema. Com base nisso, podemos observar uma incoerência com o que se prega acerca da qualidade teórica que guia a necessidade de mudanças do processo. Seria a qualidade teórica atrelada às demandas dos usuários externos? Essas demandas não representam um ponto de vista da informação que possui o viés na precificação das entidades?

A própria necessidade de capitalização do leasing surge a partir de demandas do mercado financeiro/auditorias e não das empresas. Percebe-se a aplicação direta da lógica social da financialização quando se privilegia a informação voltada para as demandas dos stakeholders em detrimento daquela voltada para os shareholders. Isso resulta em um maior controle dos passivos, uma vez que a solvência financeira é de interesse dos potenciais investidores externos, representados por analistas de mercado. Para que a articulação possa ocorrer, a demanda desses stakeholders é transformada em um discurso conceitual, que é o da essência sobre a forma. Ou seja, o mercado cria um discurso de que para eles, é mais interessante a divulgação dessa forma, mesmo que isso gere aumento de passivos e de custos que impactam diretamente os shareholders.

Já nos relatórios iniciais, por mais que já houvesse um processo de "harmonização" existente com as IAS, argumenta-se que uma nova norma seria necessária para incrementar essa fantasia por meio da aplicação mais principiológica dessa essência. Ainda no início, como forma de incluir as partes relacionadas no processo e de reafirmar sua independência, afirmase que a necessidade de mudanças não parte dos reguladores, mas sim dos "usuários" que encontram-se insatisfeitos com a IAS: "as normas contábeis de arrendamento atuais são vistas por muitos observadores como insatisfatórias" (McGregor, 1996, p. 3).

Ressalto aqui que o IASB afirma que a necessidade parte de demanda dos usuáriosinvestidores para que não tenham que capitalizar manualmente as informações, porém ele não exemplifica tais investidores. Há uma vasta possibilidade de tipos de investidores e cada um possui diferentes poderes de influência no mercado financeiro. Apesar disso, entendo que esses 
investidores são aqueles com mais poderes (financeiros e de expertise), já que nem todo o público tem a capacidade de capitalização manual dos arrendamentos.

Em estudo acadêmico, realmente percebe-se que essa norma é uma das menos "bem quistas" por parte dos aplicadores da contabilidade, entretanto, a argumentação desses aplicadores não demonstra ser em decorrência da ausência de comparabilidade ou qualidade, mas sim em decorrência da complexidade da norma (Reither, 1998). Ou seja, é mais uma dificuldade em aplicar a norma do que uma crítica à qualidade conceitual/“técnica” da norma. Isso nos leva a questionar a fantasia da comparabilidade, em que parece ser mais uma necessidade do próprio regulador do que dos aplicadores e usuários da contabilidade. Apesar disso, essa fantasia funciona durante todo o processo normativo como uma das principais necessidades para a troca da norma.

Apesar de justificar com base na comparabilidade, até mesmo em citação utilizada pelo próprio G4+1 acerca da necessidade com base na demanda dos usuários (sem especificar) não se fala em comparabilidade, mas sim na complexidade da aplicação. E mesmo assim a citação refere-se à normatização de leasing pelo FASB (SFAS 13), que é diferente da norma internacional (IAS 17) no que concerne às regras.

Todos nós lutamos para entender a grande quantidade de regras detalhadas que direcionam a contabilidade para arrendamentos. Algumas vezes achamos que as únicas pessoas que têm motivações suficientes para estudar as suas particularidades são aquelas que precisam escrever os contratos de arrendamento para que produzam os resultados esperados. Sabemos que os critérios para distinção entre arrendamentos operacionais e de capital [financeiros] editados pelo [FASB] Financial Accounting Standard no. 13 e seus suplementos são arbitrários e sua aplicação normalmente é voluntariamente caprichosa. (Knutson, 1993 como citado em McGregor, 1996, pp. 4-5).

Portanto, temos uma certa incongruência acerca da justificativa fantasmática da comparabilidade, que é amplamente baseada na lógica social dos constituintes. A comparabilidade, teoricamente, traria a pureza desejada da tecnicidade ao processo. Apesar de se argumentar que o principal motivo é aumentar a comparabilidade em decorrência da necessidade dos usuários (principalmente investidores/analistas), esses usuários sequer criticam a comparabilidade, mas sim a complexidade da norma. $\mathrm{O}$ aumento da comparabilidade, portanto, seria um "benefício" secundário da norma, mas não uma demanda explícita dos usuários realizada pelos canais formais.

Outro discurso político que ampara a mudança é o da substância econômica. Apesar de dizer que a norma deve ser modificada por espelhar a forma jurídica, o próprio G4+1 entende que a norma anterior (IAS 17) deveria ser interpretada por meio da substância econômica. Além disso, o G4+1 não vê a norma como incorreta do ponto de vista teórico, mas sim do ponto de 
vista da aplicação. Nesse caso, se teoricamente ela estaria coerente e já representava a substância econômica, qual o motivo de modificá-la ao invés de aumentar o controle e o enforcement sobre o uso e aplicação das normas?

\footnotetext{
Apesar do dever de basear o julgamento na substância da operação, ou seja, quando substancialmente todos os riscos e benefícios associados à propriedade do arrendamento estão com o arrendador ou com o arrendatário, na prática o critério quantitativo tem tipicamente sido percebido como regras precisas e aplicados com limiares absolutos. (McGregor, 1996, p. 9).
}

Mais uma vez argumenta-se que a forma é utilizada como base em decorrência das regras (conhecidos como bright-line tests). Entretanto, essa figura não está presente na IAS 17 exatamente em decorrência da possibilidade de estruturação de operações formalmente. Apesar de essa ser uma condição da norma norte-americana (SFAS 13), ela é utilizada como argumento para mudança da norma internacional, que sequer possui formalmente essa característica. Nesse trecho também podemos observar que o "problema" não seria a norma em si, mas sim sua aplicação. Nesse caso, há uma questão ética por parte dos aplicadores e uma limitação metodológica dos testes de auditoria para a verificação da representação fidedigna da norma, não da norma em si. No final do relatório, há um sumário do principal "problema" da norma que levaria à necessidade de mudança, porém em nenhum momento se fala em comparabilidade ou reclamação dos usuários (investidores). O problema, mais uma vez, seria resultante da complexidade e da falta de coerência na aplicação por parte dos aplicadores (entidades/preparadores).

Aqui há outra inconsistência. No discurso do board, as normas não são editadas exclusivamente para a previsão de valores do mercado, mas sim buscando uma congruência com os conceitos exigidos pela estrutura conceitual, devendo-se priorizar a qualidade sobre a convergência ("o primeiro motivador para esse projeto é a evolução da qualidade da norma existente e não a convergência" (IASB, 2006a, p. 7)). Porém, o caso de modificar uma norma para satisfazer a capacidade preditiva do mercado não necessariamente cumpriria tal requisito, pois ele pode estar acima da referida qualidade quando se comparar a norma com a estrutura conceitual. Essa questão é uma incoerência para qual somente vejo solução caso se assuma a ausência de neutralidade e a real visão de que os objetivos das normas seriam o de auxiliar a previsão da tomada de decisões por parte dos investidores. Apesar de esse ser um dos objetivos, ele não pode ser contemplado dentro de uma visão estritamente técnica e neutra. Por isso, há inconsistência: existir um usuário específico como público-alvo é abdicar da neutralidade. No leasing o usuário seria o investidor, mesmo sem que se comprove sua real demanda pelo assunto. Apesar de seu possível benefício, outros usuários também seriam beneficiados, como 
as auditorias; e usuários diretamente impactados acabaram por não se sentir satisfeitos, como as próprias arrendadoras e arrendatárias.

Embora o objetivo deste projeto seja principalmente melhorar as normas existentes em vez de convergência, a remoção das diferenças existentes entre diferentes normas nacionais de leasing e as IFRS aumentará a comparabilidade e reduzirá a necessidade dos usuários de realizar ajustes estimados na análise de entidades em diferentes jurisdições. Além disso, isso reduzirá os custos para as entidades que relatam em mais de um padrão contábil. (IASB, 2006c, p. 11).

No que se refere à fantasia da globalização, argumenta-se que a existência simultânea de diferentes modelos constitui uma crítica à norma, pois essa diversidade geraria custo. Contudo, as respostas aos procedimentos de consulta mostram que o aumento de custos advém, na verdade, da nova proposta normativa, que exige um controle excessivo e uma reavaliação de todos os contratos da entidade que poderão se enquadrar na norma de arrendamentos a partir do novo modelo. A lógica fantasmática da qualidade da norma e sua relação com a fantasia da globalização se mostram internalizadas por parte dos respondentes, que argumentam que "não apoiam a convergência se a qualidade da norma contábil for comprometida para que se atinja essa convergência" (IASB, 2009a, p. 26). Nesse sentido, o board afirmar que os diversos interessados apoiam a mudança pela redução de custos pode ser relacionado com a vontade de convergência apenas vinculada à qualidade?

Quando se fala na mudança, o board defende que ela deve ser similar ao que já se propõe em estudos preliminares, isso porque seria "familiar aos constituintes. [...] mais fácil para os constituintes entenderem e implementarem" (IASB, 2009a, p. 19). Aqui percebo um argumento mais voltado para a possível satisfação de constituintes (não se citam quais), ou seja, talvez priorizando aspectos de aplicabilidade e convergência acima daquele prometido de norma técnica, sem vieses e de maior qualidade possível. Devemos ter em mente, portanto, que os atores envolvidos compõem o principal argumento e concedem a validade necessária para a atualização normativa.

Isso traz ao debate o segundo ponto que guia a necessidade de mudanças: a necessidade dos usuários. Apesar de nos documentos que justificam a entrada na agenda o staff informar que os usuários enxergam o aumento do disclosure das normas atuais como suficiente para suprir suas necessidades, no documento formal de feedback que possui maior circulação pública - comment letters summary -, o staff diminui tal relevância ao afirmar que "outros apoiam a melhoria da contabilidade do arrendatário [...] melhorando os requisitos de divulgação, ao invés de alterar os requisitos de reconhecimento e mensuração" (IASB, 2013a, p. 5). O uso de "outros" leva a um entendimento de minoria e nós, que acompanhamos o processo a uma certa distância, porém somos diretamente impactados, não sabemos efetivamente o que houve na 
opinião do público. Logo em seguida informa que apenas "alguns" (some) acham o aumento simples do disclosure seria uma decisão não otimizada. Fica incerto, então, se há um entendimento por parte dos usuários de que o aumento do disclosure seria suficiente para suas necessidades ou não.

Mas parece que essa incerteza é exatamente a intenção do discurso como forma de se resguardar quanto às contingências e antagonismos que possam ocorrer. $\mathrm{Na}$ teoria, todos os discursos estão sujeitos à contingência nas articulações, então a incompletude ou ambiguidade nos argumentos acaba por fazer com que os mais diversos discursos antagônicos sejam representados, aumentando a capacidade de perpetuação do discurso intentado pelo board. Desse modo, passa-se a ilusão de que os mais diversos usuários estão representados no processo de forma justa.

Veja, então, que a lógica social dos constituintes/usuários está presente como justificativa central no discurso da necessidade de mudança. Nesse discurso, articula-se que os usuários reinterpretam a informação contábil a fim de ajustar os números. Esse ajuste seria o de “incluir" os arrendamentos operacionais nas demonstrações financeiras das arrendatárias. Aqui ocorre um momento em que a necessidade de regulação (no caso de mudança da regulação) não partiu da "teoria", mas sim de uma prática dos usuários externos que apresenta como objetivo a precificação de empresas. Seria esse o objetivo principal da informação contábil?

“A capitalização manual dos arrendamentos operacionais [...] pelos analistas de investimentos e outros usuários [...] parece ser o padrão, o que sugere que o tratamento contábil atual dos arrendamentos operacionais não é o mais relevante" (Nailor \& Lennard, 2000, p. 5).

"investidores devem estimar os efeitos dos arrendamentos operacionais sobre o passivo e receitas. Se as arrendatárias reconhecerem os ativos e passivos que derivam desses contratos, os investidores entenderão melhor a atividade de arrendamento" (IASB, 2010c, p. 2)

O elemento que representa a insatisfação dos usuários com a informação recebida se transforma, então, no momento articulatório que reforça a antiga incompletude da informação e cria a necessidade de um melhor tratamento contábil para a tomada de decisões dos usuários. Entretanto, temos limitações em relação a que usuários são esses. Usuários com capacidade de capitalizar de forma indireta os arrendamentos tendem a ser aqueles usuários mais institucionais, representados por analistas e investidores qualificados. $\mathrm{O}$ privilégio dado às necessidades de tais usuários é incongruente com a própria missão do board que é direcionada aos usuários, "em especial investidores", porém sem segregar tais investidores em grupos menores. O investidor “comum", entretanto, não possui tal expertise nem outras condições que o capacitariam para tal capitalização. 
Ainda utilizando-me do argumento do próprio board, os usuários por ele defendidos apenas não conseguiriam realizar tal capitalização em decorrência da falta de informações. De acordo com tal articulação, um simples aumento de exigência de disclosure resolveria tal problema, sendo que, inclusive, essa era a demanda principal de acordo com as respostas (IASB, 2013f, 2013e). Seria necessária, então, a mudança da norma por meio de major amendments?

Cabe ressaltar que o board, quando justifica a demanda dos "usuários", não especifica quais são esses usuários, por exemplo: “os usuários se queixam que as demonstrações financeiras não retratam claramente o efeito dos arrendamentos operacionais" (IASB, 2009b, p. 2). Subentendo que tais usuários são os investidores e analistas qualificados, que possuem condições de realizar tais ajustes para suas análises. Os demais usuários, inclusive as entidades que possuem operações de arrendamento, estariam no discurso dos usuários que solicitam mudanças, porém, em decorrência do que pode ser observado nos comentários nos momentos de consulta público, posso afirmar que essa não é uma demanda que partiu desse público. $\mathrm{O}$ silenciamento da descrição detalhada dos usuários é uma limitação de transparência com relação aos atores envolvidos no processo. Esse silenciamento acaba por criar um entendimento aparentemente consensual e totalizante em termos discursivos, além de funcionar como uma articulação hegemônica para a justificativa de mudança da norma.

Podemos perceber, portanto, que a questão conceitual relacionada às críticas à norma antiga fica em um segundo plano quando o foco maior é exatamente na demanda dos usuários. Diminui-se a importância do problema que levaria a norma a um possível aumento da qualidade e prioriza-se um problema naturalmente político. Nesse momento, com o objetivo de mitigar antagonismos por meio da ilusão da inclusão dos mais diversos atores ao processo, o board reforça os aspectos da teoria do discurso (Laclau \& Mouffe, 1985) ao demonstrar a sua vontade de diminuição das contingências. Porém, ao mesmo tempo, perdem o foco no argumento central do processo normativo como um todo. Renuncia-se ao status quo da neutralidade e justiça processual para atender à demanda de usuários específicos (poucas vezes descritos). $\mathrm{O}$ atendimento de pleitos de partes relacionadas é uma tomada de posição que elimina a possibilidade ilusória da independência do processo.

Voltando à necessidade dos usuários como fonte da necessidade de mudanças, o board parte da premissa de que esses usuários dispõem de tempo e recursos para analisar as informações de arrendamentos. No entanto, ignora-se o aumento dos custos envolvidos aos preparadores, que, de forma oposta, despenderão mais tempo e recursos para a adaptação à nova 
norma. Lembro ainda que, conforme apresentei na Figura 26, um dos argumentos para a modificação da norma é a "grande quantidade de usuários envolvidos".

Nota-se uma preferência por justificar a necessidade de mudanças com base no suprimento de demandas dos usuários externos e na sua diminuição de custos para análises. Mais uma vez, questiono: quem efetivamente são esses usuários que possuem a capacidade de realizar as análises de forma tão qualificada? De forma contraditória, apesar de os usuários externos (em especial investidores institucionais) serem os principais interessados na mudança da norma, compõem um grupo de participantes nos processos de consulta menos relevantes. $\mathrm{O}$ próprio staff afirma:

Embora as respostas dos usuários tenham sido limitadas, os membros do board e o staff concentraram grande parte de seus esforços de divulgação nesses grupos para garantir que suas opiniões pudessem ser incluídas nas redeliberações dos boards sobre o projeto. (IASB, 2011, p. 3)

Ao consultarmos a participação dos usuários no ED1, vemos que os usuários externos estão nos grupos menos representados, a frente apenas dos "reguladores", da "academia" e de "outros". Infelizmente não podemos afirmar nada sobre o percentual ou quantidade, pois o gráfico disponibilizado pelo board não contém essas informações. No ED2, o comportamento de ausência de informações continua similar. Embora o staff afirme que a participação dos usuários tenha ocorrido em "mais de 20 cartas", ao se observar o gráfico de representatividade, o grupo figura entre aqueles com menos participação. Considerando 20 cartas em um total de 638, a representatividade desse grupo foi de aproximadamente $3 \%$.

Se o grupo de usuários realmente é tão interessado (e não possui poucos participantes, já que envolve investidores em geral), por qual motivo não tiveram uma participação mais ativa no processo para defender seus interesses? Será que o custo de "interpretarem" as informações de arrendamento é menor do que o custo de participação no processo? Será que realmente podemos dizer que o processo é acessível a todos de forma a justificar a "consulta completa e justa"? Uma coisa é fato: o interesse do board com esses usuários se mostra tão diferenciado que, ainda que eles não tivessem participado por vontade própria, o board afirma que foi atrás desses usuários para levantar suas opiniões. Seria isso neutro e justo? Ou o processo é inacessível, ou não é uma demanda tão relevante na visão dos próprios usuários.

A questão que fica é que, por mais que seja uma demanda dos usuários, parece ser a demanda de um grupo muito restrito dentro desse público tão amplo. Se entendermos que o pleito por mudança parte daqueles usuários que realizam a capitalização dos arrendamentos de forma manual para obter uma alegada representação mais completa das entidades, chegaremos à conclusão de que apenas um restrito grupo realiza tal processo: aqueles investidores com 
perfil mais sofisticado que dispõem de mais recursos para a realização das análises. Nesse sentido, embora o board se utilize de uma argumentação de que a demanda é de todo um grupo, a demanda e a participação no processo, na realidade, se restringem a um restrito subgrupo que se encontra inserido na nomenclatura maior dos usuários. Já argumentei aqui sobre a ilusão gerada pela lógica dos constituintes e esse fato vem reforçar tal argumento. A representação mitológica do que seriam os usuários tem a função de significante flutuante na medida em que se utiliza tal conceito da forma mais conveniente em cada cenário. Além disso, não há uma fixação concreta de quem são os efetivos usuários que possuem interesse no processo normativo contábil e, em especial, na modificação da norma de arrendamentos.

Cabe ressaltar que os "usuários" que realizam ajustes o fazem apenas para os casos em que consideram as atividades de arrendamento operacional como relevantes ("a maioria dos usuários que forneceram feedback já fazem ajustes no balanço patrimonial relatado pelo arrendatário para capitalizar os arrendamentos operacionais quando os arrendamentos operacionais são significativos para o arrendatário" (IASB, 2013a, p. 6)). Isso quer dizer, assim como já defendi nesta tese, que nem todos os setores possuem impactos semelhantes e até mesmo os maiores beneficiários com essa informação reconhecem tal fato.

Outro ponto que devemos lembrar é sobre a característica qualitativa da relevância, que se refere a informações que possam modificar a tomada de decisão dos usuários. O próprio board argumenta que usuários capacitados apenas realizam ajustes em alguns casos. Será que as informações de arrendamento são realmente relevantes (no conceito de característica qualitativa) a ponto de precisarem de major amendments para satisfazer a essa demanda tão restrita? Ressalto que, no argumento do board, essa demanda não é restrita, porém, na minha análise dos documentos, chego à conclusão de que essa demanda é, além de restrita, vinculada a um grupo específico de demandantes.

Como podemos saber, então, quais os "usuários" aos quais o board se refere quando diz que eles "clamam" pela mudança da norma, conforme argumento na tese? Em um documento mais próximo do final do processo e escrito por uma das diretoras técnicas do IASB que conduziu o processo de arrendamento, fala-se claramente que são os investidores. A diferença deste documento para os demais é que este é mais voltado para distribuição ao mercado, com maior circulação entre os investidores, e citar este público diretamente é uma forma de agradar uma audiência que já possui privilégios no processo. A distinção de postura é clara: "por muitos anos temos sido informados que o modelo contábil de arrendamentos não satisfaz as necessidades dos usuários” (Lloyd, 2016, p. 1). A passividade nesse documento é algo que não 
observei nos demais. Será que o board modifica sua postura frente à possibilidade de documentos com maior circulação e maior acesso público?

Na norma final (IFRS 16), que já é um documento que circula entre uma gama maior de usuários, principalmente preparadores, que são os principais impactados, o board volta ao discurso de "necessidade dos usuários" (IASB, 2016e, p. 6), sem a citação de que esses usuários são os investidores. Esse comportamento reforça a necessidade do board de aceitação frente aos mais diversos impactados. Então não citar diretamente é um silenciamento que possibilita uma lógica de equivalências em que diversos públicos podem se sentir representados.

Continuando na discussão desses usuários e da sua "demanda" pela capitalização, o board informa que esses usuários, quando consultados diretamente, "apoiam o modelo do direito de uso em princípio" (IASB, 2011, p. 7). Para um processo que possui como pilar a prestação de contas, esse "em princípio" é um tanto quanto inconclusivo. O que seria concordar com um modelo em princípio? Na continuidade desses argumentos dos usuários, o staff informa que os próprios usuários alegam que, mesmo havendo o reconhecimento contábil dos ativos e passivos, eles continuarão realizando ajustes, ou seja, qual a necessidade de mudanças por parte do IASB se a principal justificativa continuaria ocorrendo? O board complementa informando que já existem técnicas consolidadas entre os analistas para a realização dos ajustes.

\footnotetext{
A maioria daqueles que ajustam os arrendamentos operacionais estimam o ativo e o passivo de arrendamento "ausentes" do balanço do arrendatário multiplicando a despesa anual de arrendamento operacional por um múltiplo - o múltiplo mais comum usado é 8 , mas varia de 5 a 12 . Relativamente poucos estimam o ativo do arrendamento e o arrendamento passivo usando as divulgações das notas explicativas de arrendamento operacional. [...]. Alguns investidores e analistas [...] escolhem o número mais alto como ativo e passivo de arrendamento estimados ou calculam um número combinado.

Alguns investidores e analistas não fazem ajustes para arrendamentos operacionais. Alguns observaram que isso ocorre porque não consideram os arrendamentos operacionais significativos para as empresas nas quais investem. Em algumas partes do mundo, entretanto, os ajustes não são normalmente feitos mesmo para setores da indústria que têm arrendamentos operacionais significativos (por exemplo, varejo e transporte). (IASB, 2013e, pp. 2-3)
}

Nesse ponto, devemos nos questionar: até que ponto esses usuários realmente se importam com a informação contábil? Mesmo ajustando o modelo contábil para satisfazê-los, eles ainda não utilizarão a informação em sua íntegra?

Por fim, vamos pensar em um caso específico de mudança que é o de arrendamentos de curto prazo. Inicialmente o board não possuía uma opinião final se deveria criar algum critério específico para esses arrendamentos, embora já tivesse a compreensão de que criar exceções levaria a norma a aspectos de menor qualidade muito em decorrência dos mesmos argumentos que são utilizados para a mudança da norma. Além disso, defendia que conceitualmente os arrendamentos de curto prazo poderiam ser simplificados, mas deveriam sim ser registrados nos ativos e passivos das entidades (IASB, 2010c). 
Em complemento, como forma de esquivar-se da potencial discordância dos respondentes com relação ao modelo proposto pelo board, em momentos o argumento era articulado de forma a silenciar tal discordância. Veja: "quase todos os respondentes apoiam os esforços do board em prover uma simplificação para a contabilização dos arrendamentos de curto prazo" (IASB, 2011, p. 22). O board afirma que há um apoio para a simplificação, mas se silencia em relação à opinião dos respondentes acerca do modelo proposto.

O board reconhece que, se abrir exceções, poderá criar um novo viés na norma que manteria o "reconhecimento off-balance" que, no agregado, pode ser material para as entidades. Além disso, o próprio board estaria encorajando estruturação de operações por meio de redesenhos dos contratos existentes, criando uma nova arbitrariedade, sem incremento para a comparabilidade (IASB, 2009a). Esses são os mesmos argumentos que motivam as críticas que justificam a necessidade de mudanças da norma como um todo. Estaria o board então disposto a abrir uma exceção que leva em conta exatamente aquilo que eles condenam?

Desde o summary do DP, o staff não deixa claro como é o comportamento dos respondentes com relação às exceções. Ele não direciona sequer com os pronomes se houve maioria ou não que concorda com a exclusão dos arrendamentos de curto prazo, por exemplo. O staff limita-se a dizer que a maioria dos respondentes que comentaram sobre esse ponto concordam, porém não há indícios sobre a quantidade de respondentes que comentaram sobre o assunto. Quando apresenta o argumento contrário, ou seja, daqueles que não concordam, apenas informa que "respondentes que não concordaram". A ausência até mesmo dos pronomes deixa o interessado externo ao board completamente limitado de capacidade interpretativa sobre o fato.

Após deliberações, foi exatamente isso que ocorreu. A IFRS 16 traz duas exceções, que são os arrendamentos de curto prazo e de baixo valor. A mensagem que passa é a de que as “exceções” desacreditam a própria articulação criada em torno da lógica política da necessidade de mudanças, criando uma inconsistência difícil de defender. A criação de exceções é exatamente a criação de "categorias" de arrendamento que possibilitam contabilizações offbalance e, por consequência, essas exceções podem gerar uma reestruturação dos contratos, levando às críticas iniciais da norma: reestruturação de operações, modificação da comercialização e criação de dois modelos distintos. Para tentar diminuir as críticas, esses contratos são vistos como "exceções", mas agora resta ao tempo dizer se na prática serão apenas isso. 
6.4.1.2 O Reconhecimento das Operações de Leasing: temos uma métrica conceitual?

As decisões acerca do reconhecimento das operações de arrendamento nas arrendatárias e as diversas modificações ocorridas durante o processo levam a um questionamento sobre a alegada expertise do board, assim como sobre a qualidade técnica tanto do board quanto das decisões. Inicialmente, ressalto minha visão de que algumas decisões do board parecem ser imutáveis desde o momento da entrada na agenda. A articulação dos elementos em momentos já era clara quando o board afirmava que a nova norma deveria "garantir que todos os ativos e passivos derivados de um contrato de arrendamento serão contabilizados nas demonstrações financeiras" (IASB, 2010b, p. 5). Todo o andamento do processo confirmou essa questão e demonstra que há pontos da norma que parecem ser inegociáveis. Qualquer outra visão que não considere a eliminação do modelo duplo de classificação das arrendadoras e a capitalização dos arrendamentos parece ser excluída do sistema discursivo por meio do argumento de que não é conceitualmente correto. Isto é, a lógica dos constituintes se mostra limitada pela lógica da tecnicidade e da financialização. Mas se isso realmente ocorre, então qual seria a razão da consulta?

A pergunta anterior é respondida por meio da análise das próprias lógicas da explicação crítica. Como já disse, desde a necessidade de mudança da norma o processo de consulta funciona como uma ferramenta retórica de reafirmação da qualidade ilusória das boas práticas de governança e na fantasia da justiça processual, além de qualidade baseada na "democracia participativa". O ponto é que a participação dos “constituintes" é limitada ao recebimento de tais posições, mas não ao direcionamento efetivo do conteúdo da norma.

Para melhor desenvolvimento das lógicas, apresento na Figura 27 a relação observada das lógicas de forma aplicada ao processo de arrendamento e ao tema de reconhecimento dos arrendamentos pela arrendatária. 
Figura 27 - Relação das lógicas sobre o tema do "Reconhecimento das operações de arrendamento"

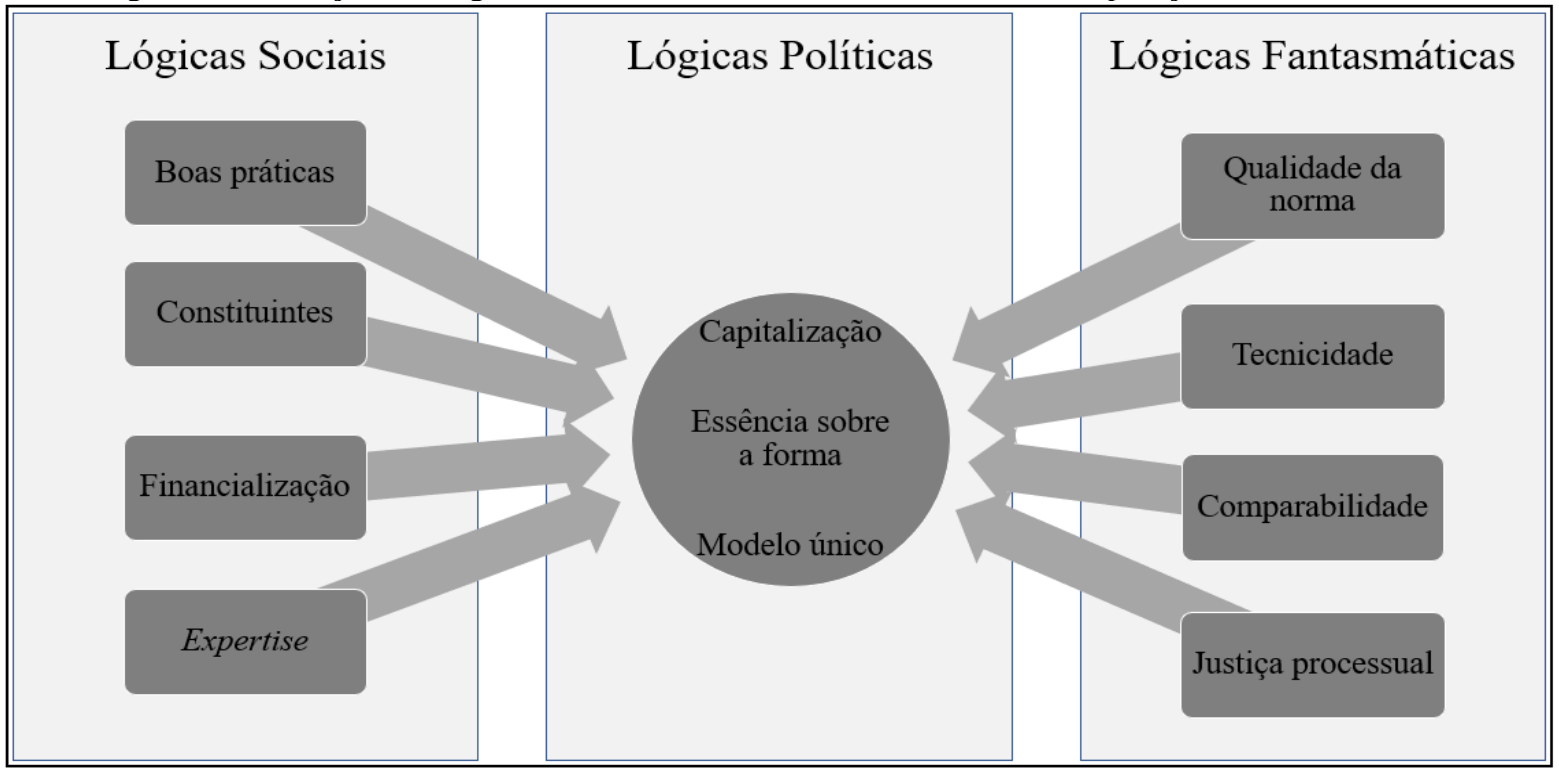

Fonte: Elaboração própria.

A base conceitual do projeto já foi apresentada anteriormente, mas vale relembrar que ela foi criada amplamente em uma lógica de diferenças/equivalências amparada em uma ideia de desatualização do modelo até então vigente e na proposta de um modelo único de contabilização que aumentaria a comparabilidade das informações contábeis. Além disso, também foi amparada em uma pseudo lógica dos constituintes, em que na verdade envolvia demanda de grupos específicos e não dos atores como um todo.

Com base nas lógicas sociais, podemos perceber que as propostas normativas de leasing relacionadas com a capitalização dos arrendamentos representam a aplicação direta do que se vê como financialização.

A financialização pode ser descrita como o desenlace da forma monetária do capital e seu retorno ao domínio. [...]. As economias [...] são canalizadas menos para a formação de capital fixo no setor corporativo e mais para ativos financeiros e/ou para os bolsos de investidores [...]. No nível agregado, vemos coisas como taxas mais altas de capitalização do mercado de ações para PIB ou uma parcela crescente dos lucros que é apropriada pelo setor financeiro. (Müller, 2014, p. 547)

Esse conceito de financialização acaba por ser predominante inclusive na normatização de leasing, uma vez que a necessidade dos investidores, por vezes, contrasta com a necessidade que era do usuário mais comum nos anos 1990 (que eram as instituições financeiras). Os investidores buscam informações, mesmo que fictícias e que não se envolvam diretamente com ativos em "substância física" para a mensuração do capital. A informação acaba por necessitar ser mais "tempestiva", já que as carteiras de investimentos tendem a ser mais flexíveis e mutáveis do que aquela relacionada com as instituições financeiras (que precisam de informações mais a longo prazo para mensurar a capacidade de pagamento das entidades). Essa 
necessidade de informações mais atuais para fins especulativos fez com que o board defendesse a capitalização dos arrendamentos como forma de agradar o mercado financeiro.

Esse modelo gera uma nova forma de competição entre as entidades. Antes existia uma competição operacional tomando como base dados contábeis como receitas, despesas e lucros. Além destes, existia a competição com dados administrativos, como market-share, recursos humanos, qualidade dos produtos e inovação. Entretanto, o modelo de financialização traz uma nova visão de competição ligada diretamente com o estudo das finanças, que é a competição no mercado financeiro. A mudança de leasing traz uma alteração clara na estrutura de capital das entidades e, por isso, devemos observar que essa mudança possui relação com esses dados e influenciam no mercado de capitais. Isso quer dizer que, por mais que não haja mudança nos contratos e nas suas formas de negociação, os dados contábeis sofrerão alterações e influenciarão a visão do mercado de capitais, mesmo não havendo influência similar nos quesitos de competitividade administrativos.

No relatório inicial (McGregor, 1996), os arrendamentos são comparados a contratos executórios. Os contratos executórios possuem uma visão atualmente consolidada acerca de suas formas de contabilização na contabilidade e justificariam a visão de capitalização das operações de arrendamento. Entretanto, com as mudanças propostas durante o processo normativo, esse argumento tenderia a demonstrar incoerência com as decisões tomadas e, com isso, esse argumento acabou por ser silenciado ao longo dos documentos. Foi, aliás, citado em Nailor e Lennard (2000) como não sendo um contrato executório. Isso faz com que não haja uma vinculação da proposta normativa com visões contábeis já existentes. Após essas visões contrastantes, as citações e comparações aos contratos executórios são silenciadas, sendo que esse silenciamento auxilia na prática do esquecimento e da desarticulação de possíveis antagonismos que viessem a ser criados.

Após as diversas mudanças nos critérios de contabilização e a inconsistência entre os modelos (de classificação) das arrendadoras e arrendatárias, uma preocupação inicial do staff virou a questão final: esperava-se que "houvesse pesquisas suficientes que garantiriam que não surgiriam questões que enfraqueceriam o modelo desenvolvido" (IASB, 2006c, p. 12). Entretanto, a alta quantidade de mudanças traz à tona a percepção de que falta aos usuários certa condição de apurar a qualidade das decisões do board. Assim, entra o questionamento: o board sabe a decisão que está tomando ou está tentando por meio de tentativa e acerto?

A crítica à existência de um modelo com diferentes possibilidades de classificação é a de que arrendamentos semelhantes podem ser classificados de forma distinta, gerando a estruturação de operações. Entretanto, o board reconhece que há mais de um tipo de modelo de 
operação de leasing (figura claramente observável nas diversas propostas ao longo do processo e da manutenção de dois modelos para as arrendadoras). Partindo dessa visão, criando um modelo único temos o problema inverso. Operações bastante diferentes serão contabilizadas de forma semelhante. Nesse sentido, qual seria o incremento para a comparabilidade e o alegado benefício aos usuários? A mudança de filosofia gera o seguinte raciocínio (Figura 28):

Figura 28 - Críticas/Inconsistências dos argumentos à classificação ou não de operações de arrendamento

\begin{tabular}{|c|c|c|}
\hline Proposição & Crítica & Questionamentos velados \\
\hline $\begin{array}{l}\text { Modelo com } \\
\text { classificação }\end{array}$ & $\begin{array}{l}\text { Estruturação de } \\
\text { operações. Operações } \\
\text { similares podem ser } \\
\text { contabilizadas de } \\
\text { forma diferente. }\end{array}$ & $\begin{array}{l}\text { - Seriam as entidades/profissionais limitados para ter capacidade } \\
\text { de julgamento para decisão da melhor forma de espelhamento da } \\
\text { operação? } \\
\text { - Haveria falta de competência moral para contadores seguirem } \\
\text { uma norma principiológica? } \\
\text { - A auditoria não seria capaz de testar os diferentes modelos de } \\
\text { reconhecimento frente à operação em questão? } \\
\text { - Teriam as normas internacionais baixa capacidade de } \\
\text { enforcement, ou seja, o board não consegue garantir a efetividade } \\
\text { da sua norma? }\end{array}$ \\
\hline $\begin{array}{l}\text { Modelo único / } \\
\text { sem classificação }\end{array}$ & $\begin{array}{l}\text { Diminuição da } \\
\text { comparabilidade. } \\
\text { Operações diferentes } \\
\text { serão contabilizadas } \\
\text { de forma similar. }\end{array}$ & $\begin{array}{l}\text { - Se a ideia é aumentar a comparabilidade, o modelo único espelha } \\
\text { a amplitude de operações de arrendamento? } \\
\text { - Seriam os contadores/entidades incapazes de analisar o melhor } \\
\text { cenário contábil que espelha a operação e, por isso, é melhor } \\
\text { limitar? } \\
\text { - Seria um modelo único a representação da essência da transação? } \\
\text { - Mais fácil limitar opções do que possibilitar o julgamento? } \\
\text { Limitar aumenta a comparabilidade e a qualidade? }\end{array}$ \\
\hline
\end{tabular}

Fonte: Elaboração própria.

Parece ser claro o que o board desejava como norma final. Não digo todos os requisitos de reconhecimento, mensuração e apresentação, porém a essência do fim da classificação dos arrendamentos e a incorporação do conceito de direito de uso para todas as operações sim. Apesar de propor em algumas etapas modelos diferentes, era evidente que o board defendia um modelo único de classificação dos arrendamentos e, por isso, realizava duras críticas ao modelo duplo, inclusive com um apelo que, em alguns momentos, não compunha a realidade normativa de arrendamento. Por exemplo, é injusto (para não dizer imoral) em um documento do IASB falar-se em bright-line tests, uma vez que a norma internacional (IAS 17) em suas versões mais atuais já trazia uma classificação baseada na essência e não em regras como no FASB.

Apesar disso, esse argumento compôs um dos principais pontos de crítica à norma anterior que justificava a necessidade de mudanças. Por exemplo: “a distinção bright-line entre arrendamentos financeiros e operacionais inevitavelmente leva a reconhecimentos muito diferentes de ativos e passivos em transações que economicamente são muito similares" (IASB, 2006d, p. 4). O board se refere ao IASB e não ao FASB, sendo este segundo o que possui os alegados bright-line, já que no FASB o leasing financeiro é chamado de leasing de capital. 
Além disso, nesse momento em que o documento foi elaborado, o projeto conjunto entre os boards ainda não estava aprovado, logo, era um documento de autoria exclusiva do IASB.

No mesmo documento em que se faz a crítica aos testes bright-line (objetividade que gera a estruturação de operações) presentes na SFAS 13, o board também critica a subjetividade para a classificação da IAS 17, mesmo sendo esse o direcionamento das normas internacionais, no sentido de privilegiar o julgamento profissional por meio de normas mais principiológicas e subjetivas.

Para ter sucesso na articulação, desde o início da intenção de normatização do leasing, o IASB já buscava apoio de atores relevantes como as Big 4. A intenção era convencer as partes interessadas que uma norma amplamente baseada em princípios poderia ser realizada e seria aplicável às mais diversas entidades. Esse seria um argumento para que a normatização do IASB fosse vista como superior à americana e, assim, aumentar sua credibilidade e validade globalmente (McGregor, 2012).

Com base nessa lógica da essência sobre a forma sob o amparo "conceitual" das auditorias, a decisão do arrendamento já é utilizada como exemplo na própria estrutura conceitual do board. Veja:

Dessa forma, por exemplo, no caso de arrendamentos financeiros, a essência e a realidade econômica são que o arrendatário adquire os benefícios econômicos do uso do ativo arrendado pela maior parte da sua vida útil em troca da aceitação de uma obrigação de pagar por esse direito um valor próximo do valor justo do ativo e o respectivo encargo financeiro. Portanto, o arrendamento financeiro origina itens que atendem à definição de um ativo e um passivo e são reconhecidos como tais no balanço patrimonial do arrendatário. (IFRS Foundation, 2018a, p. A36).

Ao determinar a existência de um ativo, o direito de propriedade não é essencial; desse modo, por exemplo, o imóvel detido em um arrendamento é um ativo se a entidade controlar os benefícios que se espera fluam do imóvel. (IFRS Foundation, 2018a, p. A36).

Mas aqui cabem diversos questionamentos. A decisão sobre o reconhecimento dos arrendamentos não é algo que é dúvida para o board, porém este encaminha o processo de consulta como se a decisão ainda estivesse completamente em aberto. Outro ponto é que a estrutura conceitual não deveria ser um guia geral para a elaboração de normas? Então seria coerente inserir esse exemplo claro de decisão tomada pelo board nesse documento?

Com base nisso, o modelo financeiro/operacional é articulado como inconsistente desde o início do projeto, sendo necessário o seu fim para o aumento da qualidade: "a redução dessas inconsistências representará uma grande melhoria na qualidade do reporte financeiro" (IASB, 2006c, p. 11). Já no estudo inicial do G4+1 e nas primeiras propostas normativas do IASB propunha-se como a única alternativa plausível para a fantasia da comparabilidade e para a utilidade da informação globalmente o "reconhecimento como ativos e passivos de todos os 
direitos e obrigações materiais que derivam de contratos de arrendamento" (McGregor, 1996, p. 4).

O staff técnico afirma que, apesar de haver algumas preocupações acerca da implementação do modelo, é unanimidade entre os "respondentes que são usuários das demonstrações contábeis" (IASB, 2009a, p. 3) o apoio ao modelo do direito de uso. Primeiro, conforme discuti na lógica dos constituintes, o conceito de "usuários/constituintes" é utilizado pelo board de forma conveniente nos mais diversos momentos. Se utilizarmos a lógica de usuários internos e externos, temos aí todos os respondentes sendo usuários, porém, ao que parece, o board nesse momento se refere a outros usuários mais específicos. Quando observo a tabela inicial do summary do DP, por exclusão tendo a entender que esses são os usuários investidores (qualificados e institucionais), já que o relatório segrega diversos potenciais usuários. Em complemento a essa análise, percebo que o board classifica apenas cinco respondentes nesse grupo.

Com base nisso, parto para as inconsistências e tendências de construção articulatória enviesada (ou seja, com posicionamento político antagonista com a alegada tecnicidade e neutralidade na análise das informações). Se o board defende que o usuário investidor é seu principal interesse como normatizador e o usuário que mais demanda a mudança no reconhecimento do arrendamento operacional de forma única, como pode apenas cinco terem efetivamente comentado a proposta normativa? Tratar cinco respostas como unanimidade é um direcionamento discursivo que ilude os mais diversos participantes do processo, principalmente porque para encontrar essa informação não é tão simples. Além disso, em momentos o board afirma que consulta esses usuários de forma a obter suas participações por outros meios, porém não os sumariza. A informação clara dada ao mercado ocorre por meio de snapshot ou pequenas matérias, que sempre reforçaram a "alta" quantidade de cartas e participações recebidas no processo de arrendamento. Assim, há desinformação direcionada ao interessado, que entende que houve unanimidade de aprovação com base em "diversas" opiniões, com a ilusão de que a participação pública apoia a mudança.

Outros pontos de desconstrução são os próprios estudos que analisam a participação dos usuários no processo normativo de leasing. Em contraponto com o dito pelo staff no summary do DP de que a totalidade (unanimidade) dos usuários concorda com a proposta do direito de uso, há estudo científico que categorizou as respostas dessas mesmas cartas e chega ao resultado de um nível de $38 \%$ de respondentes contrários à proposta. Em uma análise pormenorizada do grupo de "usuários investidores", esse nível de discordância seria de 57\% (Carmo et al., 2014). 
Outros estudos que analisaram a opinião dos respondentes também não encontram níveis próximos dessa unanimidade alegada pelo staff em nenhum grupo de usuários respondentes (Marcelino et al., 2017; de Matos, 2013; Matos \& Niyama, 2013; Visoto, 2018).

Um dos motivadores dados pelo staff para a mudança no modelo de capitalização é representado por argumentos de que a norma anterior trazia complexidade desnecessária ao processo contábil. Entretanto, em diversos momentos da proposta normativa o board afirma que os respondentes entendem os modelos propostos como extremamente complexos. Por exemplo, ele complementa o argumento de que a unanimidade dos usuários das demonstrações financeiras apoiam o direito de uso com: "a maioria dos respondentes que suportam o modelo do direito de uso expressam, em princípio, preocupações com a complexidade do modelo" (IASB, 2009a, p. 3). Justifica, então, que mais estudos devem ser feitos de forma a simplificar o modelo.

Cabe aqui uma reflexão: a maioria de cinco respondentes seria três respondentes. Isso é, para o board, uma quantidade significativa que justifica mudanças na norma de forma a demonstrar que é neutro e sem viés político-ideológico com relação aos atores envolvidos? Se analisarmos o cenário mais amplo, o próprio staff argumenta que "a maioria dos respondentes que não concordaram com os princípios propostos no discussion paper são preparadores e organizações industriais" (IASB, 2009a, p. 3). Ora, se observarmos, no mesmo relatório os preparadores e as organizações industriais representam 65\% das respostas (187 cartas). Esse número, tanto percentualmente quanto quantitativamente, é significativamente superior ao de "usuários". Argumento, ainda, que os preparadores e as organizações industriais representam, também, usuários das demonstrações financeiras, pois essas entidades (normalmente os respondentes são entidades de grande porte e com grande diversificação de portifólios) representam investidores institucionais e operam no mercado financeiro internacional.

$\mathrm{O}$ argumento, não coincidentemente, é o mesmo para os diversos usuários, acerca da complexidade e dos custos dessa mudança normativa, observando que os custos podem não superar os benefícios da informação (inclusive usuários do mercado financeiro argumentando isso). Digo não coincidentemente pois os investidores institucionais sabem que custos dados aos preparadores por novas necessidades regulatórias serão repassados para eles, já que investem nessas entidades e elas terão suas despesas aumentadas para modificação de processos que já são analisados por eles de forma mais simplificada.

Esses argumentos anteriores demonstram uma limitação da accountability relacionada não com o conteúdo da norma, mas sim com o processo normativo em si. Argumentos contraditórios e contestáveis com relação aos vieses na exposição das cartas demonstram que a 
prestação de informações acerca da análise das cartas comentários pode não ser tão relevante como se defende no handbook quando se fala que a consulta é um dos principais pilares do processo normativo.

Defender que o público interessado pode conferir tais informações por meio da transparência pela disponibilização das cartas acaba por tornar o processo mais fictício ainda. Conto aqui uma experiência própria. Em minha dissertação de mestrado, analisei 262 cartas enviadas ao IASB em resposta ao ED/2010/9. Essas cartas representavam 33\% do total de cartas enviadas naquela etapa. Em uma dedicação exclusiva à análise dessas cartas e tendo um foco na análise (não precisava interpretar todos os pontos), demorei seis meses para a formação do banco de dados. Nesse sentido, que tipo de interessado no processo teria esse tempo, disponibilidade de recursos e expertise para realizar tais análises? Principalmente tomando como base que não se previa um processo de arrendamento tão demorado, ou seja, poderia nem existir um prazo tão longo para a edição da norma final. Poderia acontecer, portanto, a situação em que a norma estaria editada e discutida antes do interessado ter terminado a análise. Isso leva ao entendimento de que até mesmo uma estratégia defendida como um pilar da transparência não é efetivamente transparente, sendo mais simbólica e ilusória do que efetiva para o interessado externo ao processo.

Não posso deixar de citar a flutuação conceitual que ocorreu nos modelos de classificação/reconhecimento do arrendamento. De forma geral, foi o modelo já decidido quando da entrada na agenda que acabou sendo aprovado ao final do processo da IFRS 16 para as entidades arrendatárias, conforme pode ser observado na Figura 29.

Figura 29 - Modificações nos critérios de reconhecimento das arrendatárias durante o processo

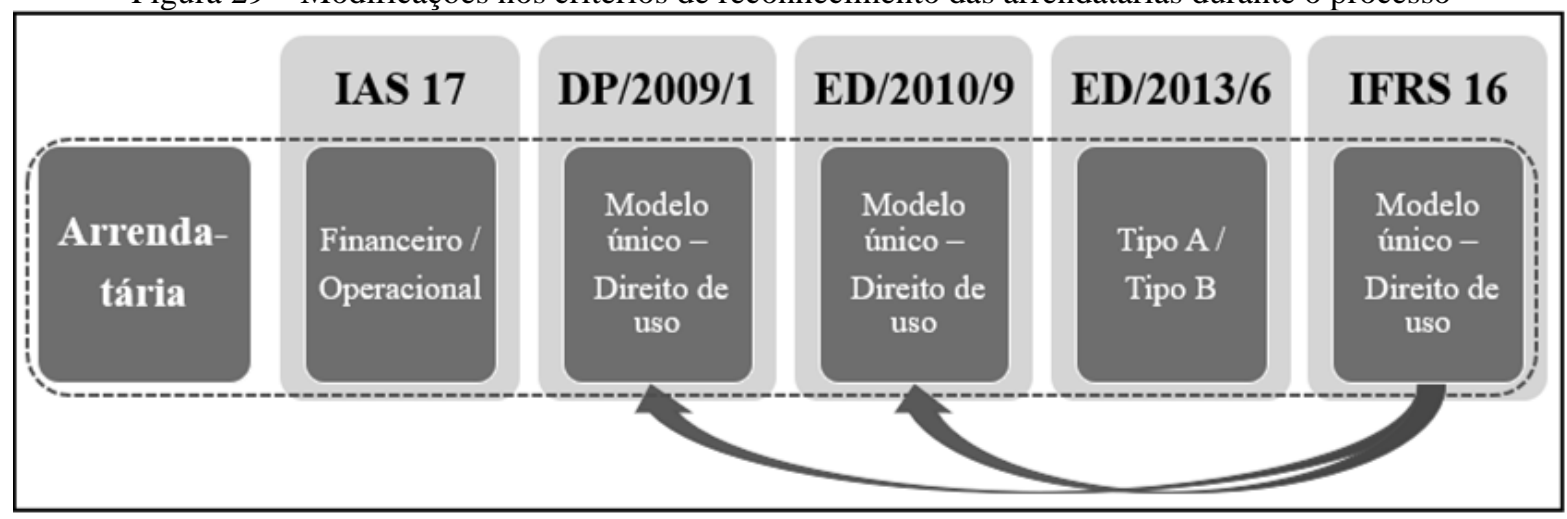

Fonte: Elaboração própria.

Apesar do modelo final ter sido consistente com o inicial proposto, a flutuação da articulação dos discursos parece ter ocorrido principalmente como forma de se defender dos 
antagonismos e produzir um sentido discursivo de que mesmo realizando ajustes solicitados, o modelo proposto inicialmente continuava sendo a melhor opção. Essa visão é perpetuada ao longo de toda a argumentação e ao final do processo, quando se defende que "as IFRS, especialmente após as melhorias na contabilidade do arrendamento, garantem que o balanço patrimonial reflita com precisão a extensão total dos passivos de uma empresa" (Hoogervorst \& Prada, 2015, p. 6). Melhorias (improvements), inclusive, é uma palavra bastante presente no discurso do IASB que leva ao entendimento de que, mesmo com as flutuações, as novas propostas eram superiores às anteriores.

O DPOC afirma que "a decisão de re expor [re exposure] é evidência de que o IASB está seguindo os procedimentos do due process" (DPOC, 2012a, p. 6). Aqui devemos questionar se realmente é uma evidência. Re exposure significa que se adicionou uma fase que não é obrigatória ao processo, mas não que se segue o processo corretamente. Seria a intenção dizer que re expor o ED seria seguir o processo porque o ED teve um alto nível de reclamações? Nesse caso estaria assumindo-se que a re exposição de documentos ocorreria em decorrência de pedidos de participantes e não por necessidades "teóricas", já que no segundo ED também houve alto nível de reclamações e o documento final (IFRS) veio diferente de qualquer proposta anterior (ver Figura 29). Inclusive, para arrendatárias o documento final veio semelhante ao primeiro ED, o qual o DPOC afirma, conforme citação anterior, que foi re exposto para seguir o processo. Portanto, seria incoerente voltar ao modelo que defendiam como não correto naquele momento.

Os argumentos da re-exposição (ED2) circulam e torno do fato de que o board reconhece que há diversas substâncias para os contratos formais de arrendamento; e de que houve uma demanda dos stakeholders (DPOC, 2012d). Esses argumentos vão de encontro aos anteriores, em que se entendia que, mesmo podendo haver diversas formalidades, no fim todos os contratos trariam a necessidade de reconhecimento total do direito de uso nos ativos. Além disso, anteriormente argumentava-se que os "usuários" desejavam um modelo único (fato este que já questionei na tese).

Devemos entender que pode haver mudança na opinião do board. O que é inconsistente é que o modelo do ED2 retorna com uma "classificação" dos arrendamentos. Essa classificação traz à tona todos os motivos argumentados para a necessidade de mudanças, em que haveria possibilidade de estruturação de operações.

A questão é que, para a qualidade da norma, o board entendia que deveria haver a extinção do modelo de classificação e o reconhecimento do modelo único baseado no direito de uso. Mas, neste momento, o board abriu mão dessa qualidade dizendo entender que 
realmente há mais opções e que esse modelo é necessário para incremento da qualidade e comparabilidade da norma. Além disso, afirma que o modelo único para todos os arrendamentos "não é apropriado". Essa afirmação, no momento do ED2, não é tão problemática, porém, após o processo estar finalizado, podemos questionar: por qual motivo o board terminou na IFRS 16 propondo um modelo que ele mesmo, categoricamente, afirmou não ser apropriado?

Após as diversas modificações, entendíamos que o modelo já estava mais próximo do final, porém tudo mudou novamente e voltou ao modelo único, ignorando os argumentos anteriores de que há mais substâncias nas operações de leasing. Essa quantidade de mudanças leva os impactados a uma sensação de impotência perante o processo e a uma sensação de falta de independência e do alegado expertise que o board prega possuir. Daí nos questionamos: será que o board sabe o que está fazendo? Essa quantidade de mudanças é realmente um espelhamento de mudanças técnicas e neutras ou houve interferências no processo? Se houve interferências, quem seriam os beneficiados? Ou seja, todas as mudanças, que contradizem argumentos anteriores, acabam por colocar em xeque as políticas que funcionam como pilares de defesa do board, como independência, qualidade, expertise e tecnicidade. Isso ocorre principalmente porque não são somente mudanças, são retornos a modelos propostos anteriormente e que foram tratados como "incorretos" pelo próprio board ao modificá-los e, pior, o board opta por não explicar tal ponto e simplesmente silenciá-lo.

Curioso notar que entre o ED/2010/9 e o ED/2013/6 também se fala em melhoria, afinal, de acordo com o handbook, somente se emite um novo draft com outra proposta se esta for considerada superior à anterior no quesito de qualidade. Porém logo após, na norma final, tivemos um retorno à proposta anterior. Seria então o retorno uma "melhoria", mesmo a proposta descartada tendo já sido uma melhora?

Vejamos isso de forma prática. Se o board afirma que as mudanças de conteúdo do ED1 para o ED2 são resultantes de estudos que demonstram que o modelo proposto no ED1 não é o melhor e que o modelo do ED2 aumentará tanto a comparabilidade quanto a qualidade da norma (IASB \& FASB, 2013), por qual motivo a norma final (IFRS 16) acabou voltando ao que era proposto no ED1 (ver Figura 29)? Não desenvolvo muito esse argumento por considerar que ficaríamos em um círculo vicioso e sem grandes conclusões, mas cabe a reflexão acerca do que realmente é um aprimoramento do modelo e de qual é a métrica de avaliação para julgar tal aprimoramento. 
Outro ponto de destaque com relação às mudanças envolve a participação no processo. A lógica dos constituintes funciona como uma das principais bases para a justificativa de um processo normativo de qualidade que traz transparência para as decisões do board, mas ela também já foi questionada ao DPOC: “estamos preocupados de que as mudanças nas decisões dos boards durante o período de redeliberação seja um indicativo de que os comentários dos constituintes estejam sendo negligenciados e questionamos quais as implicações disso na área da transparência e no respeito ao due process" (DPOC, 2012a, p. 2).

No momento do DP, quando o board propunha o modelo único do direito de uso, o staff, após análise das comment letters, afirma que "quase todos os respondentes” (nearly all) (IASB, 2009a, p. 11) concordam com uma mensuração inicial por meio do custo. Ao mesmo tempo, "vários" (several) acham que deveria ser pelo valor justo. Já temos uma dificuldade de interpretação pelo uso dos pronomes de forma a não determinar com exatidão (nem mesmo com proximidade) uma suposição acerca do "nível” de suporte para cada visão. Seria "nearly all" mais "several" igual a 100\% dos respondentes? Parece um tanto quanto estranha a soma desses dois pronomes, sendo que ambos indicariam uma "maioria". Outro ponto de desconstrução da alegada transparência e consequente ausência de accountability é que o staff argumenta, em parágrafos anteriores, que "aproximadamente metade dos respondentes" (IASB, 2009a, p. 8) concordou que um contrato de arrendamento gerava ativos e passivos para a arrendadora, ou seja, gerava necessidade de reconhecimento. Como um externo (e até mesmo os board members) pode entender que metade dos respondentes não enxerga que o contrato de arrendamento gera ativos e passivos, mas mesmo assim "quase todos" os respondentes são a favor da mensuração desses ativos e passivos pelo custo? É possível mensurar sem reconhecer?

Temos outras inconsistências dessa mesma natureza, como o fato de "vários" concordarem com a mensuração do ativo a valor justo, porém "a maioria" discorda que os passivos sejam mensurados a valor justo ao defenderem que essa técnica diminui a comparabilidade. Em seguida, o board afirma que "mais da metade" (IASB, 2009a, p. 15) concorda com a reavaliação dos ativos e passivos, mas como isso ocorreu se apenas “aproximadamente metade dos respondentes" (IASB, 2009a, p. 8) concordou com a metodologia proposta?

Após a exemplificação, retorno ao questionamento enviado ao DPOC: "estamos preocupados de que as mudanças nas decisões dos boards durante o período de redeliberação seja um indicativo de que os comentários dos constituintes estejam sendo negligenciados e questionamos quais as implicações disso na área da transparência e no respeito ao due process" (DPOC, 2012a, p. 2). O DPOC alega não intervir em decisões técnicas, mas aqui, além de 
questões técnicas, temos uma denúncia sobre o processo, que é sobre a negligenciação das participações. Nesse ponto, o DPOC, que é o responsável pela qualidade do processo, silenciase e não informa detalhes.

Por fim, temos um paradoxo que envolve as atitudes de escolhas normativas do board (principalmente quanto à classificação e reconhecimento dos contratos de arrendamento). Há dois discursos paradoxais nesse caso: (i) o discurso de que a normatização deve prover a informação mais completa ao usuário; (ii) o discurso de representação fiel das informações.

Mediante as diversas propostas normativas, fica evidente que não há um modelo único de arrendamento e que a proposta de mudança pode ter sido motivada por um anseio de satisfazer aos investidores. Mas devemos questionar a função da regulação contábil. Seria priorizar um determinado público ou seria a de seguir as características qualitativas da estrutura conceitual e a alegada neutralidade/tecnicidade nas suas decisões?

Caso realmente se acredite na viabilidade de mais de um tipo de arrendamento e se proponha a existência de um modelo único, cria-se um impedimento à comparabilidade, já que os valores capitalizados tornam-se incomparáveis por representarem um amontoado de operações distintas, o que impossibilita a comparação de itens que podem apresentar naturezas distintas entre as entidades. As vezes devemos entender que a necessidade de "capitalização" dos usuários é diferente do que os aspectos conceituais na contabilidade dizem, assim como os próprios interesses dos investidores. Não devemos perder de vista que o IASB, ao mesmo tempo que alega realizar normas de interesse público, tem os investidores como principais usuários, demonstrando a inconsistência do discurso de justiça na regulação com a prática que privilegia necessidades de usuários específicos. Aqui a discussão é maior do que a regulação de leasing em si. É com relação a todo o processo de regulação.

Ao mesmo tempo em que temos toda uma argumentação de que as IFRSs devem dar maior capacidade de julgamento e autonomia para as entidades serem capazes de espelhar suas operações da forma mais "fiel" possível aos usuários, temos o discurso contraditório da "objetividade". Podemos dizer que há uma purificação da objetividade, sendo ela o que se deseja nas informações contábeis, porém o argumento de subjetividade que, nesta lógica, seria uma impureza, também é visto como a purificação por meio da modernização da contabilidade por meio da possibilidade de julgamentos, pela diminuição de regras e pelo aumento da noção principiológica das normas contábeis. Afinal, qual seria o posicionamento ideal por parte do board quando falamos em "estilos" de normas? 
Já no caso aplicado à normatização dos arrendamentos, devemos entender as técnicas contábeis como interligadas. Quero dizer, os critérios para reconhecimento e mensuração se conectam e a discussão de apenas um deles acaba por ser tornar superficial se forem levadas sem articular também as falhas que estão corrigindo.

Durante as análises, percebi uma visão externa que traz outra visão advinda de uma denúncia e que deve ser levada em consideração: "seria inaceitável impor uma nova norma motivada por preocupações anti-abusivas sem conseguir demonstrar que a base conceitual é sólida, sua abordagem é prática e a informação que provê é a melhor combinação do custo para os preparadores e do benefício para os usuários" (DPOC, 2012a, p. 2). Isso contrasta exatamente com a justificativa para uma nova norma. Estaria a norma sendo elaborada porque o tratamento dado atualmente pelos aplicadores é abusivo na escolha entre a classificação (financeiro/operacional) ou por que realmente enxergam a base conceitual da norma como sendo falha?

Em razão disso, entendo que a discussão da estruturação de operações (principal crítica à IAS 17) acaba por ser perversa e culpar a norma contábil, enquanto poderia circular em torno do possível comportamento não ético dos agentes ao efetivamente estruturar operações. Esse pensamento é ratificado pela constante mudança argumentativa do board acerca da essência das operações de arrendamento e do mito da qualidade da norma.

\subsubsection{Arrendadoras: Onde foi parar a simetria?}

Assim como ocorreu com as arrendatárias e apresentei na seção anterior, o "vai e vem" na opinião dos boards acerca da normatização dos critérios contábeis para as arrendadoras é bastante notório e relevante na condução do processo normativo de arrendamentos, principalmente no que concerne à simetria. Veja, na Figura 30, uma breve explicação dos movimentos, em que podemos observar questões relacionadas com a simetria.

Os estágios de desenvolvimento da norma caminharam, ao menos formalmente, de forma distinta para os critérios relacionados com o arrendador ou com o arrendatário. Nos documentos formais a ideia de capitalização para arrendatários ocorre desde o início do processo, sendo a ideia já apresentada de forma desenvolvida na fase do DP. Já para arrendadores, a fase do DP foi a fase de consulta para ideias acerca de sua contabilização. Mesmo assim, já se falava na simetria como necessária para incremento da qualidade da norma (IASB, 2009b). 
Figura 30 - Modificações nos critérios de reconhecimento durante o processo

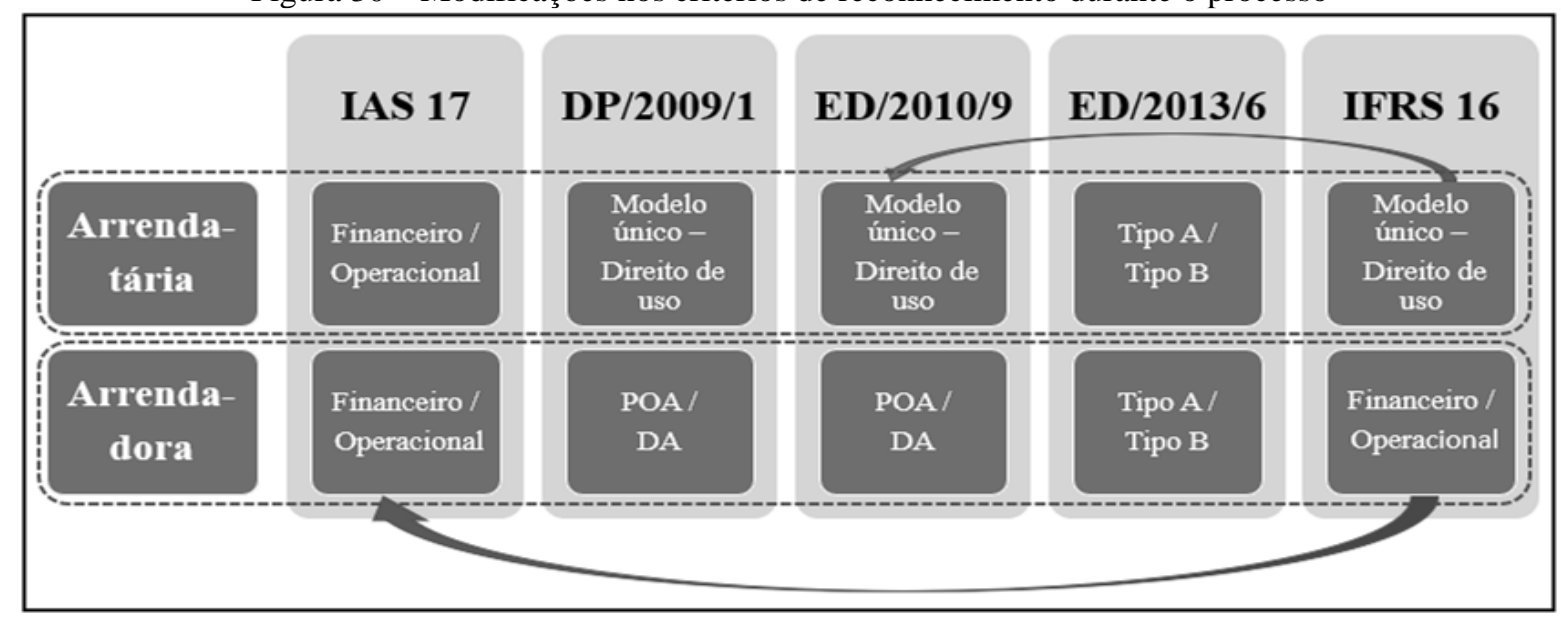

Fonte: Elaboração própria.

Os arrendadores sempre ganharam seções de menos destaque nos documentos formais. Apesar disso, o board mantinha a argumentação da sua necessidade de mudanças. Entretanto, nos documentos mais do final do processo, os arrendadores passaram a não ganhar seção alguma, havendo destaque apenas para os arrendatários e um completo silenciamento dos arrendadores.

O silenciamento tem a intenção oposta da repetição. Quando falamos em repetição, temos um interesse tanto imediato quanto de longo prazo na manutenção de uma visão. Isso ocorreu no processo de leasing principalmente quando havia a repetição da necessidade de mudança e da proposta da capitalização do arrendamento. Já no silenciamento, apesar de trazer críticas no curto prazo, acaba por ser esquecido no longo prazo simplesmente pela ausência de informação. O silenciamento, portanto, pode ser visto como uma intervenção hegemônica para fixação de um sentido (Jørgensen \& Phillips, 2002). Por isso, a transparência e a accountability são requisitos tão importantes a qualquer processo normativo.

Outra diferença de comportamento do board com relação aos arrendadores e arrendatários é que a proposta de arrendador, por mais que justificadas como menos importantes, variaram mais. Como argumentei, com relação ao arrendatário parece que a capitalização já era decidida e imutável desde o início do processo.

Para diminuir as críticas e trazer a validação necessária ao processo, ao não emplacar a simetria que era argumentada como necessária para que a norma tivesse incremento de qualidade, o board justifica sempre se colocando de forma passiva e expondo a "razão" dos problemas (ou da inabilidade de ação) para os atores. Quando citado, o IASB vira um agente passivo e "respeitador" do processo de consulta. Mesmo afirmando durante todo o processo que seria necessária uma mudança nos arrendadores para manter um modelo simétrico, sendo essa 
simetria necessária para a edição de uma norma de qualidade, afirma-se: "fomos informados que o modelo contábil das arrendadoras da IAS 17 não estava "quebrado"” (Lloyd, 2016, p. 2).

Vejamos, então, a argumentação dada nas diversas fases do projeto.

(i) No momento da entrada na agenda, optou-se que a nova norma englobaria as mudanças para as duas partes do contrato, devendo ser simétricas; isso seria condição para o incremento da qualidade da norma.

(ii) Logo em seguida, no momento do Discussion paper, os boards decidiram direcionar mais estratégias para as arrendatárias e pouco espaço se destinou para as arrendadoras. A decisão é que as arrendadoras seriam menos importantes.

(iii) Após o Discussion paper, o board "entendeu", novamente, que tratar ambas as partes do contrato e primar pela simetria seria critério necessário para a qualidade da norma. Tratar ambas as partes seria importante para se compreender a substancia econômica da transação e é uma demanda recorrente dos respondentes (IASB, 2010d).

(iv) Já no primeiro Exposure draft, manteve-se a opinião de que as arrendadoras, com base na opinião dos respondentes, eram parte importante e integrante dos contratos de arrendamentos e, por isso, a norma deveria ser consistente entre as partes e apresentar consonância com o que o board prega acerca da qualidade das normas. Fica evidente, neste momento, que o board sabe das inconsistências derivantes do modelo das arrendadoras:

Embora muitos dos problemas associados aos padrões de arrendamento existentes se relacionem com o tratamento dos arrendamentos operacionais nas demonstrações financeiras dos arrendatários, manter os padrões de arrendamento existentes para arrendadores seria inconsistente com a proposta abordagem à contabilidade do arrendatário. Também seria inconsistente com a abordagem proposta pelos boards para reconhecimento de receita, descrita em sua minuta de exposição Receita de Contratos com Clientes. (IASB, 2010b, p. 5)

(v) No segundo Exposure draft, o board retorna com a argumentação de que as partes devem ter contabilizações simétricas e consistentes, mas abandona a visão de modelo único. Para o board, a essência da transação deve ser levada em consideração e a simetria é necessária. Juntos, compõem os critérios necessários para normas de qualidade. "Os boards mudaram a contabilidade do arrendador proposta para conseguir refletir mais de perto como um arrendador precifica seus arrendamentos em resposta ao feedback recebidos no ED 2010” (IASB, 2013d, p. 8). Além disso, o board utiliza o mesmo argumento que descrevi no ED1, com o seguinte complemento 
manter o modelo existente para arrendadores [...] resultaria em um aumento da complexidade dos relatórios financeiros. Além disso, os boards decidiram que será benéfico considerar a contabilidade para arrendadoras ao mesmo tempo que desenvolvem a proposta para o reconhecimento de receitas. (IASB, 2013c, p. 5).

(vi) Na IFRS 16 qualquer argumento de mudança para arrendadores é silenciado. A norma apresentada não fala em simetria entre as partes, sendo a do arrendador semelhante aos critérios que já existiam na norma anterior, com mudanças apenas em disclosure.

Com base nessas movimentações, as lógicas que envolvem o discurso da simetria são apresentadas na Figura 31.

Figura 31 - Relação das lógicas sobre o tema do "Simetria entre arrendadoras e arrendatárias"

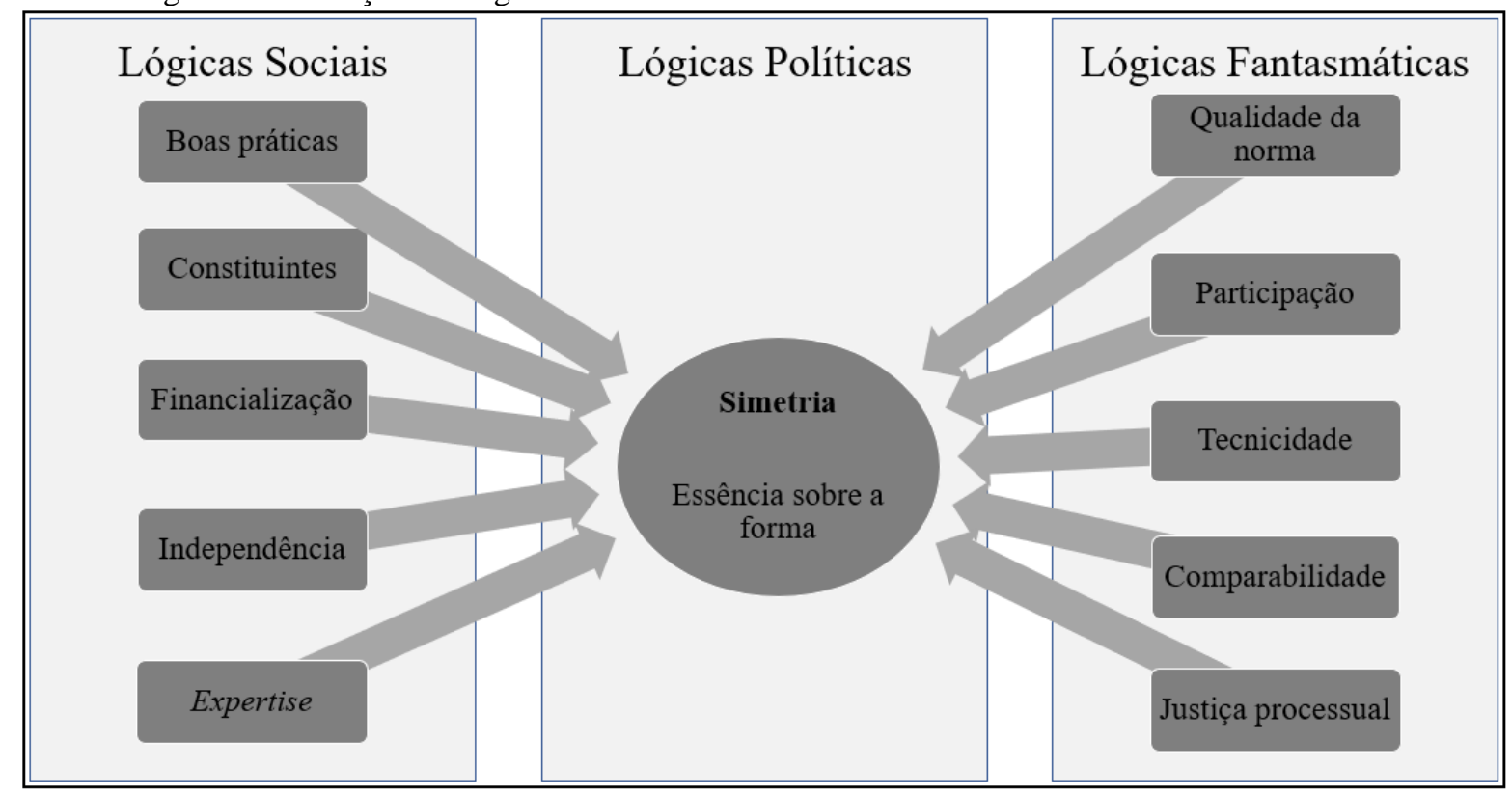

Fonte: Elaboração própria.

No momento em que se decidiu sobre a entrada na agenda (IASB, 2006c), os boards chegaram à conclusão de que "o projeto deve reconsiderar todos os aspectos da contabilidade de arrendamentos" (p. 1), o que inclui questões relacionadas tanto com as arrendadoras quanto com as arrendatárias. Ainda, acreditam que "não é possível melhorar significativamente a contabilidade de arrendamentos por meio de ajustes pequenos ao modelo atual” (IASB, 2006c, p. 1). Isso porque a não simetria afrontaria diretamente contra a verificabilidade.

Concluímos que não se considerava, portanto, realizar uma proposta assimétrica. Desse modo, a proposta nas discussões para a entrada na agenda, em ambos os boards, era a de que deveria ser sinalizado que o projeto de leasing não seria feito por partes, mas sim de forma a 
“sinalizar aos constituintes que o IASB e o FASB estão sérios na missão de endereçar um projeto completo acerca da contabilização dos arrendamentos” (IASB, 2006b, p. 5). O board entendia, também, que para o projeto ser relevante ele deveria envolver todas as facetas do arrendamento:

cobrindo a contabilidade para arrendatárias, arrendadoras e o arrendamento de bens imóveis, o projeto proposto deve reconsiderar todos os aspectos da contabilização de arrendamentos. [...] entende-se que não é possível melhorar significativamente a contabilidade para contratos de arrendamento por meio de ajustes menores no modelo atual. (IASB, 2006a, p. 1).

Esse é, inclusive, um dos critérios para a entrada na agenda de novas propostas normativas e não apenas ajustes em normas já existentes, ou seja, para uma nova norma, a ideia é que se realizem ajustes que mudem de forma substancial a já existente. Teria então o projeto de arrendamento cumprido essa exigência?

A promessa era de que o projeto deveria trazer uma informação completa e compreensível em (para) ambas as partes de um contrato de arrendamento. O projeto, portanto, seria finalizado quando essas metas, que fazem parte das exigências para a entrada de um projeto de mudança de norma na agenda, fossem cumpridas. Isso garantiria a alegada qualidade normativa das normas que deve estar acima da convergência em si.

Como nesta seção estou falando de todo um lado da operação e não de algum evento específico, resolvi separar as articulações por assunto. As inconsistências com o discurso da arrendadora vão além da simetria, porém todas aquelas podem ser relacionadas com esta. Alguns argumentos dados pelo board em detrimento para a normatização dos aspectos relacionados com as arrendadoras acabam por serem contraditos ao longo do processo.

i. A maior parte dos problemas e demandas dos usuários ocorre nas arrendatárias; poucos questionamentos às arrendadoras (ver Figura 32);

ii. A consideração de ambos os lados da operação atrasaria a norma final (ver Figura 33);

iii. A contabilização das arrendadoras se relaciona com outros projetos em andamento pelo IASB (ver Figura 34);

iv. Qualquer mudança sobre arrendadoras deverá envolver uma diferenciação para propriedades para investimentos, e essa norma é bastante diferente entre as IFRS e US GAAP (ver Figura 35).

Como disse, na flutuação de opiniões do board acerca da modificação da parte da norma voltada às arrendadoras, o board inicialmente via a mudança de ambas as partes do contrato 
como necessária, porém já no DP surgiu com a argumentação amplamente baseada nos constituintes, conforme Figura 32.

Figura 32 - Principais articulações que envolvem mudanças nas arrendadoras - Parte 1

\begin{tabular}{|c|c|c|}
\hline \multicolumn{2}{|c|}{$\begin{array}{c}\text { Articulação Inicial } \\
\text { (DP/2009/1 - parágrafo 1.21) }\end{array}$} & $\begin{array}{l}\text { A maior parte dos problemas e demandas dos usuários o } \\
\text { arrendatárias; poucos questionamentos às arrendadoras. }\end{array}$ \\
\hline \multicolumn{2}{|c|}{ Lógicas sociais relacionadas } & \\
\hline \multicolumn{2}{|c|}{ Lógicas políticas relacionadas } & Discl \\
\hline \multicolumn{2}{|c|}{$\begin{array}{c}\text { Lógicas fantasmáticas } \\
\text { relacionadas }\end{array}$} & \\
\hline & \multicolumn{2}{|c|}{$\begin{array}{l}\text { O board afirma que os problemas existem em decorrência de questionamentos externos, em } \\
\text { uma tentativa de reafirmar que a lógica dos constituintes é direcionadora do processo. Porém } \\
\text { os questionamentos são apresentados em termos de quantidade (maior parte dos } \\
\text { questionamentos), o que realmente era de se esperar que ocorresse com arrendatárias, já que } \\
\text { são mais diversas. A lógica da financialização está presente quando se defende que as críticas } \\
\text { estão voltadas para a criação de modelos voltados aos usuários externos. Desse modo, constrói- } \\
\text { se o discurso de necessidade de mudança por demanda dos constituintes para a construção de } \\
\text { uma capitalização por parte dos próprios preparadores. Por fim, a fantasia de qualidade da } \\
\text { norma se revela como ilusória a partir do momento que a mudança é defendida para } \\
\text { arrendatárias e não arrendadoras, criando a falta de simetria que o próprio board defende como } \\
\text { necessária para uma norma de qualidade e comparável (outra fantasia). Nesse ponto, a } \\
\text { comparabilidade é defendida para entidades similares (arrendatárias), porém não a } \\
\text { comparabilidade entre as duas partes da operação. A fantasia da tecnicidade dá lugar à política, } \\
\text { já que a demanda não partiu de questões conceituais e há uma decisão, mesmo que em } \\
\text { detrimento da qualidade, de não modificação das arrendadoras (fato este que mudou nas } \\
\text { diversas etapas normativas). Por fim, a ilusão da participação cria uma fantasia de que todos } \\
\text { os públicos usuários seriam beneficiados, principalmente ao defender a participação } \\
\text { quantitativa das arrendatárias. Nesse ponto, a participação deve ser medida em termos } \\
\text { quantitativos, diminuindo a relevância dos que necessitam da informação das arrendadoras? } \\
\text { Isso faria com que existisse a justiça processual defendida pelo board? }\end{array}$} \\
\hline
\end{tabular}

Fonte: Elaboração própria.

Já no início do processo havia uma visão dos respondentes a favor da simetria, argumentando (quase todos os respondentes - almost all respondents) que o arrendador deveria reconhecer um ativo decorrente do direito de recebimento das parcelas do arrendamento (IASB, 2009a). Havia, portanto, um apoio inicial dos respondentes dos momentos de consulta no sentido de editar um projeto simétrico e simultâneo para as duas partes da operação.

Antes mesmo da entrada do tema na agenda, a simetria dos modelos de contabilização entre arrendadores e arrendatários já era argumentada como sendo condição para haver normas de alta qualidade. Sob essa visão, a contabilização dos arrendadores deveria necessariamente derivar de forma simétrica aos critérios das arrendatárias de forma a evitar dupla contagem de bens ou o contrário, que o bem não esteja reconhecido em lugar algum (Nailor \& Lennard, 2000).

"Considerando a abordagem da contabilização dos arrendamentos[...] em que não há distinção entre arrendamento financeiro e operacional, o objetivo deve ser o de atingir simetria 
entre a contabilização dos arrendadores e arrendatários" (McGregor, 1996, p. 24). Essa visão de simetria é presente desde a primeira versão da IAS 17. Mesmo com a separação entre financeiro e operacional, espera-se que na prática as arrendadoras e arrendatárias trabalhem com a mesma classificação entre elas, mas com a figura de um modelo único, essa necessidade se torna mais evidente e é argumentada desde o início como condição essencial para a boa aplicação da norma e para a coerência teórica das propostas.

A simetria, portanto, aparece como discurso desejado, que une quase todas as lógicas que descrevi na seção anterior. O discurso da simetria utiliza-se de todas as fantasias para trazer sua validade como discurso político e se ampara nas lógicas sociais para também validar as práticas normativas existentes. A presença desse discurso aparece tanto diretamente, por meio do uso do termo "simetria", como indiretamente, quando o board compara/vincula (ou cria dependências de) técnicas de reconhecimento e mensuração entre as partes do contrato, por exemplo: "Os resultados reportados como ativos para os arrendadores serão, em geral, convertidos por meio dos valores reconhecidos como passivos pelos arrendatários" (Nailor \& Lennard, 2000, p. xiii).

Não podemos esquecer que a falta de simetria, inclusive, era uma das críticas existentes aos modelos anteriores de arrendamento (IAS 17 e SFAS 13). Entretanto, tendo dificuldades de convergência do modelo internacional e do norte-americano, o IASB acabou por finalizar o projeto sem trazer mudanças significativas nos critérios para os arrendadores e por afirmar que a contabilidade dos arrendadores não está defasada e não necessita de mudanças urgentes pela baixa demanda dos usuários.

Ora, realmente a demanda dos usuários externos por mudanças para arrendadores é menor em termos representativos, uma vez que essas empresas são quantitativamente muito menos relevantes que as arrendatárias. Apesar disso, não podemos esquecer os discursos de mudança propostos; nem mesmo aceitar o silenciamento acerca da simetria sem questionamentos. Essas eram promessas de qualidade que justificavam a atualização da norma como um projeto principal. Se consultarmos o projeto de leasing na página do IASB, poderemos ver que o projeto se encontra como finalizado (completed projects). Considerando que um projeto somente é completado quando se entende que a norma final possui os incrementos necessários para o aumento relevante da qualidade e que grandes ajustes (major amendments) não são mais necessários, como podemos interpretar essa mudança na filosofia do que seria qualidade para as companhias arrendadoras? Teria o board privilegiado a aceleração da convergência apenas para uma parte da operação, agradando assim um grupo de usuários externos, em detrimento de uma real atualização "completa" da norma? 
Partindo para o argumento do board apresentado na Figura 32 e sua relação com a fantasia da participação: nas fases iniciais (DP), a visão dos respondentes (e reconhecida pelo staff) era a de que postergar (ou não modificar) a parte da transação de arrendamento, além de ser conceitualmente falho, seria uma afronta ao próprio processo normativo do board, em que abriria mão da qualidade em detrimento da própria competência do board em conseguir um modelo condizente com a realidade (IASB, 2009a). De acordo com o summary, "quase todos os respondentes que comentaram sobre postergar a decisão da contabilização das arrendadoras discordam com essa decisão" (IASB, 2009c, p. 4). De modo contrastante, com o andamento do processo, o board afirma que a opinião passou a ser a oposta. No summary do ED2 o staff informa que a "maioria dos constituintes" discorda do modelo proposto e acha que a norma das arrendadoras não deve ser modificada. O que levou a tal mudança de opinião? Será que os respondentes entenderam que o board não seria capaz de trazer um bom modelo para as arrendadoras?

Aqui cabe uma crítica que contrasta os pronomes, sendo essa uma falha de (in)completude que gera (in)consistência na aplicação dos princípios. Esses pontos serão discutidos em mais detalhes na seção seguinte. Mas veja, ao mesmo tempo em que argumenta que "nearly all" (quase todos) discordaram em adiar a decisão para arrendadoras, o relatório comenta que "several" (vários) concordaram em adiar a decisão. Logo em seguida, argumentaram que a visão dos usuários sobre esse assunto está "mixed" (misturada). Bem, parece haver uma inconsistência com o uso de termos nos relatórios, levando a uma subjetividade que impossibilita qualquer capacidade interpretativa por parte de algum interessado externo. Como "quase todos" discordam e mesmo assim podemos afirmar que a visão dos usuários é "misturada"? Seria possível "quase todos" discordarem e mesmo assim "vários" concordarem com uma mesma decisão?

A divergência na opinião dos usuários é resultante da flutuação na condução do próprio processo normativo. No primeiro ED, o board entende que haveria um problema conceitual em não modificar a norma para arrendadoras, tanto do ponto de vista de comparabilidade da transação quanto em relação a problemas conceituais com outras normas. Esses são dois dos principais critérios que resultariam na alegada qualidade da norma, que seria o aumento da comparabilidade e a essência sobre a forma. O board afirma, ainda, que os problemas acerca das arrendatárias são mais presentes/relevantes. Se não pensarmos em quantidade de impactados (isso naturalmente é mais relevante para arrendatárias porque essas companhias são quase todas do mercado, enquanto as arrendadoras são mais restritas), ao assumirmos que existe 
um problema para arrendadoras e, considerando que para ter qualidade devemos ter critérios simétricos entre as partes contratuais (já que a transação é a mesma e sua essência também), não deveria existir um lado com problemas mais presentes ou não. Uma norma que busca critérios conceituais deve entender que a existência de um problema impacta ambos os lados. Nessa argumentação do board, fica evidente que o interesse é satisfazer determinado grupo de atores e isso demonstra a ausência da alegada neutralidade do processo.

Entretanto, aqui há um dilema diretamente ligado ao discurso base que guiou o processo normativo de arrendamentos, que é o da essência sobre a forma. O board decide manter um modelo que não retrata, na sua própria visão, a essência da transação. Esse não retratamento fica justificado como uma visão financialista para a lógica dos constituintes, que não demandaram a mudança. O board, entretanto, afirma possuir a expertise para regular, mas limita sua expertise à demanda? Por essa inconsistência entre a visão social do processo normativo e as atitudes tomadas, defendo que a tecnicidade, a necessidade de comparabilidade, a priorização da qualidade da norma acima da convergência e a justiça processual desempenham lógicas fantasmáticas no processo. Trata-se de papéis ilusórios e retóricos utilizados apenas como forma de garantia da independência do board na edição de normas contábeis.

O staff, que na própria visão do IASB é a esfera mais técnica do projeto, argumenta que existe interconexão entre arrendadoras e arrendatárias, sendo que modificações em um dos modelos leva a novas visões no outro: "o staff acredita que a consideração do modelo de contabilidade do arrendador e possíveis simplificações de escopo podem ser relevantes ao tomar decisões sobre o modelo de contabilidade do arrendatário" (IASB, 2013f, p. 3).

A justificativa dada de que o projeto será revisitado novamente mais tarde acaba por se mostrar inconsistente com toda a lógica do processo normativo do IASB e com a tecnicidade alegada pelo staff. Se o projeto já demonstra que deverá ser revisitado, pois há falhas conceituais no modelo geral proposto, ele não deveria ser considerado finalizado. Ao ser finalizado, a revisitação necessitará de uma nova entrada na agenda e os critérios para entrada na agenda além de envolverem aspectos políticos - estão mais restritivos. Atualmente informa-se que a entrada se dá mediante a necessidade dos usuários, por meio de procedimentos de consulta. Considerando que os usuários investidores em arrendadoras são mais limitados quantitativamente, uma vez que essas companhias são menos presentes e, muitas vezes, são representadas por instituições financeiras de grande porte, será que haveria "demanda" dos usuários pela mudança desses critérios? 
Em complemento, se considerarmos que os usuários externos comumente participativos no processo normativo são os investidores/analistas institucionais, vemos que eles podem fazer parte de grandes instituições financeiras ou possuir alguma parte relacionada. Nesse ponto, não seria necessário, para eles, as mudanças dos critérios das arrendadoras, além de incorporar os custos da nova norma aos preparadores, o que indiretamente poderia influenciá-los negativamente. Se não houver a tal "demanda popular", a norma pode não precisar entrar novamente na agenda e conviveremos com uma norma que conceitualmente é inconsistente, segundo o próprio board.

Tendo em vista a subjetividade dos julgamentos ocorridos durante o processo e as mudanças na opinião do board e dos respondentes acerca da atualização (ou não) dos critérios para as arrendadoras, o DPOC analisa o processo e contradiz exatamente a sua própria argumentação acerca dos respondentes. Em um momento mais final do processo, ao revisar se as principais fases foram seguidas de acordo com o due process, o board informa que "quase todos os respondentes que comentaram sobre a contabilidade do arrendador discordaram da proposta dos boards de adiar a consideração da contabilidade do arrendador e solicitaram que o projeto de arrendamento considerasse a contabilidade do arrendatário e do arrendador" (DPOC, 2015c, p. 3).

Com essa variedade de informações, fica impossível para o "interessado comum” saber a realidade do processo. Para eles, é difícil compreender tanto os motivos que efetivamente levaram às reviravoltas nos critérios do IASB quanto a opinião dos respondentes. A falta de transparência e de accountability de forma a justificar as mudanças é clara e o silenciamento das contradições do processo também. Quero dizer que, quando havia modificações, os relatórios de maior circulação não davam destaque ao que era modificado e aos racionais, mas simplesmente apresentavam a nova proposta, defendendo suas qualidades. Um usuário comum pode nem perceber que essa modificação veio de uma contradição, mas sim entender o modelo proposto como sendo o mais relevante por acreditar na qualidade do processo.

$\mathrm{O}$ que concluo sobre tal argumento é que a argumentação de que a demanda por mudanças para a arrendatária é maior que a demanda por mudanças para a arrendadora é objetivamente inconsistente. Digo "objetivamente" porque ao pé da letra é uma verdade, uma vez que as arrendatárias são mais representativas em termos quantitativos e em questões de interesses para uma maior variedade de usuários interessados. Mas analisar e justificar mudanças com base nesse argumento é inconsistente por ser uma análise injusta e que simplifica cenários em prol da defesa do argumento desejado. Dessa maneira, utiliza-se da lógica da 
demanda dos constituintes por meio da demanda por informações com um viés para usuários externos (financialização) para não se seguir os discursos principais do processo normativo, que são os de necessidade de mudança e o da essência sobre a forma.

Dando continuidade aos argumentos do board acerca da arrendadora, há o argumento que leva em consideração o prazo da norma, diretamente relacionado com aspectos associados ao processo organizacional, conforme apresento na Figura 33.

Figura 33 - Principais articulações que envolvem mudanças nas arrendadoras - Parte 2

\begin{tabular}{|c|c|c|}
\hline \multicolumn{2}{|c|}{$\begin{array}{c}\text { Articulação Inicial } \\
\text { (DP/2009/1 - parágrafo 1.21) }\end{array}$} & A consideração de ambos os lados da operação atrasaria a norma final. \\
\hline \multicolumn{2}{|c|}{ Lógicas sociais relacionadas } & Lógic \\
\hline \multicolumn{2}{|c|}{ Lógicas políticas relacionadas } & Discurso de necessidade de mudança; discurso da simetria \\
\hline & \\
\hline & \multicolumn{2}{|c|}{$\begin{array}{l}\text { Após a articulação anterior, outro ataque dado às arrendadoras é de que a modificação atrasaria } \\
\text { a norma final, sendo isso inconsistente com a lógica das boas práticas prometida pelo board } \\
\text { como critério para edição de normas de qualidade. Nessas boas práticas, a neutralidade seria } \\
\text { um quesito que deveria prevalecer no momento de tomada de decisões e a própria entrada na } \\
\text { agenda como major project já prevê uma mudança completa da norma. Assim, priviligia-se, em } \\
\text { detrimento da neutralidade, determinado grupo de atores que demanda a mudança por meio de } \\
\text { uma ilusão da participação. O discurso de simetria foi reforçado e silenciado ao longo de todo } \\
\text { o processo, demonstrando o interesse momentâneo do board. Por isso, reforça-se a fantasia de } \\
\text { que a qualidade da norma (que seria vista como a simetria entre as partes) não é tão relevante a } \\
\text { ponto de comprometer a convergência. Do mesmo modo, a justiça processual representada } \\
\text { pelos princípios é comprometida a medida que a consulta realizada é restritiva ao público } \\
\text { dominante, não se dá a devida transparência quanto ao real interesse do board no processo nem } \\
\text { a devida explicação quanto às mudanças propostas e seus vieses, principalmente quanto ao } \\
\text { benefício de determinados atores. }\end{array}$} \\
\hline
\end{tabular}

Fonte: Elaboração própria.

No início do projeto não era cogitada uma norma sem a reconsideração dos critérios para as arrendadoras: "[a contabilidade das arrendadoras] necessitará de uma reconsideração completa" (IASB, 2006c, p. 12). Considera-se impensável a existência de mais de um modelo para arrendadoras e arrendatárias, tendo em vista que a crítica é exatamente a de arbitrariedade por parte dos aplicadores. Isso demandaria um modelo único que acabaria por "omitir qualquer inconsistência conceitual” (Nailor \& Lennard, 2000).

A regulação dos critérios para as entidades arrendadoras passou por momentos de pausa e momentos de aceleração. Inicialmente o projeto parte de relatórios mais voltados para as arrendatárias, porém, na entrada na agenda, o board entendia que os projetos para arrendadoras e arrendatárias deveriam ser conduzidos conjuntamente, principalmente para manter a simetria. No momento do DP, a proposta das arrendatárias continuou mais desenvolvida quando comparada a das arrendadoras. O board assume que "não discutiram a contabilização para arrendadoras em detalhes" (IASB, 2009a, p. 97) e argumenta que decidiu por "adiar as 
considerações sobre a contabilização das arrendadoras para que sejam resolvidos os problemas relacionados com a contabilização das arrendatárias o mais rápido possível" (IASB, 2009b, p. 3). Com relação ao conteúdo, o board apresenta a visão de que o modelo de direito de uso proposto é inconsistente com o modelo antigo de classificação (financeiro/operacional), no aspecto tanto conceitual quanto de escopo, e relação com as demais normas contábeis.

O board entende que "a entidade é requerida a aplicar, avaliar e pesar todos os aspectos de um contrato para determinar a substância da transação" (IASB, 2009a, p. 118). Nesse sentido, é um tanto quanto incongruente afirmar que, para arrendatárias, o board compreendeu a essência da transação de arrendamento a ponto de conseguir ser capaz de modificar a norma com qualidade, porém para a arrendadora isso não foi possível. Para compreender a essência da transação se faz necessário que o board compreenda a transação em si, ou seja, as diferentes formas de arrendamento que são possíveis nos mais variados cenários. Ao compreender a transação, o board deveria ser capaz de compreender os dois lados da operação, senão ele não teria de fato compreendido a situação do arrendamento.

Com relação a essa incongruência da condução do processo normativo, o DPOC recebeu uma denúncia externa que afirmava: "se a contabilidade das arrendatárias será modificada, a contabilidade das arrendadoras deve ser tratada de uma maneira que seja consistente com as revisões das arrendatárias" (DPOC, 2012a, p. 4). Aqui há uma crítica ao que se chama de consistência interna do próprio processo. Entretanto, a visão do DPOC foi a de consultar o staff e defender que o projeto estava seguindo todos os requisitos formais exigidos.

Há, ainda, outra denúncia que demonstra que, mesmo atrasando o processo, esse seria o correto a ser feito.

sem a reexposição do ED de arrendamentos, há um risco significativo de que os boards emitam um novo padrão que não foi bem pensado e dá origem a consequências, o que implica que mudanças adicionais na contabilidade do arrendamento podem ter que ser feitas no curto prazo. Isso representaria uma oportunidade perdida de desenvolver um projeto internacional de alta qualidade padrão contábil para arrendamentos, algo que apoiamos integralmente. (DPOC, 2011, p. 4).

Nesse caso, o projeto passou por uma condução que durou 10 anos. O mercado financeiro já aguardava os efeitos da norma, mas não se encontra presente no handbook qualquer defesa de aceleração do projeto ou exclusão de partes do projeto para que ele fosse finalizado de forma mais rápida. Se olharmos por esse ponto, o projeto deveria ter sido mais célere ainda, uma vez que a visão final para as arrendadoras foi a mesma presente no DP e no ED1. Argumentar que arrendadoras atrasariam o processo é diminuir a capacidade técnica advinda da própria expertise e técnica que o board defende possuir. Afinal, seria uma decisão 
técnica apresentar uma norma em que se assume haver deficiência conceitual em função do tempo? Seria essa uma decisão que privilegia a qualidade acima da convergência?

A impressão que passa é que não houve consenso entre os boards e, para evitar diferenças mais relevantes entre IFRS e USGAAP, optou-se por manter essa parte da norma sem alterações. Entretanto, essa decisão vai de encontro ao que se alega como justiça processual, principalmente no que concerne à falta de transparência e accountability, diminui a comparabilidade e resulta na perda da alegada neutralidade nas decisões. $\mathrm{O}$ tempo, no handbook, não é um quesito para a finalização de algum projeto e já houve projetos mais longos que o de arrendamentos na história do IASB. Mesmo assim, essa foi uma das justificativas para a edição da norma de forma não simétrica.

Como terceira justificativa do board acerca das decisões para as arrendadoras, há questões relacionadas com o escopo da norma e de outros normas que por ventura estejam relacionadas, conforme apresentado na Figura 34.

Figura 34 - Principais articulações que envolvem mudanças nas arrendadoras - Parte 3

\begin{tabular}{|c|c|c|}
\hline \multicolumn{2}{|c|}{$\begin{array}{c}\text { Articulação Inicial } \\
\text { (DP/2009/1 - parágrafo 1.21) }\end{array}$} & \\
\hline \multicolumn{2}{|c|}{ Lógicas sociais relacionadas } & Lógica das boas práticas; lógica da independência \\
\hline \multicolumn{2}{|c|}{ Lógicas políticas relacionadas } & Discurso da essência sobre a forma \\
\hline \multicolumn{2}{|c|}{$\begin{array}{c}\text { Lógicas fantasmáticas } \\
\text { relacionadas }\end{array}$} & \\
\hline & \multicolumn{2}{|c|}{$\begin{array}{l}\text { A contabilização das arrendadoras, assim como a das arrendatárias, possui relação com outras } \\
\text { normas. Por exemplo, as arrendatárias podem ser relacionadas à contabilização de contratos } \\
\text { executórios, ou seja, a relação com outras normas não é uma particularidade das arrendadoras. } \\
\text { De toda sorte, esse fato já havia sido observado na entrada na agenda e os projetos são discutidos } \\
\text { em conjunto. O discurso da essência sobre a forma é exatamente reforçando que, mesmo tendo } \\
\text { relação com outras normas, vale-se a essência da transação e o escopo das normas pode ser } \\
\text { sempre discutido. Entretanto, mesmo a norma de arrendamentos tendo sido editada } \\
\text { posteriormente às demais que possuem relações (como a norma de receitas), os critérios para } \\
\text { arrendamento são incondizentes com a lógica da norma de receitas; fato este reconhecido pelo } \\
\text { board. Mais uma vez, entra-se em uma fantasia ilusória de que a qualidade da norma deve estar } \\
\text { acima de outros quesitos, principalmente por amparar-se em uma fantasia da tecnicidade. Nesse } \\
\text { sentido, temos uma tomada de decisões não técnica que levou a um reconhecimento de menor } \\
\text { qualidade. Negligencia-se, também, a fantasia da comparabilidade ao defender, em diversos } \\
\text { momentos, que a simetria seria critério necessário para a comparabilidade entre empresas, } \\
\text { porém decide-se pela norma final "não comparável". Por fim, a justiça processual também é } \\
\text { ilusória ao decidir por um processo em que não são seguidas as exigências de accountability e } \\
\text { transparência acerca das decisões tomadas sobre o escopo da norma. }\end{array}$} \\
\hline
\end{tabular}

Fonte: Elaboração própria.

A justificativa para mudar ambos os lados e considerar as demais normas na realização da proposta de arrendamento é simples: “empresas [...] seriam requeridas a aplicar uma abordagem baseada em regras no lado do arrendador e uma abordagem baseada em princípios no lado do arrendatário" (DPOC, 2011, p. 3). Isso leva a uma "incoerência” não apenas interna 
da norma como também com a estrutura conceitual do board e as demais normas e práticas defendidas pelo IASB.

Como já discuti, o modelo de classificação para as arrendadoras é uma crítica desde o início do processo, sendo inclusive caracterizado pelo board como um dos principais motivadores para a mudança e como uma das críticas à evolução da qualidade das IFRSs, principalmente no que diz respeito à congruência com o escopo das demais normas: "a contabilização das arrendadoras é baseada em conceitos de diferimento e correspondência/competência que são bastante diferentes das abordagens de mensuração de ativos/passivos para o reconhecimento de receitas que sustentam o desenvolvimento das normas do IASB” (IASB, 2006a, p. 5).

Além da questão da simetria, o próprio board, portanto, assumia já na entrada do processo na agenda que os critérios para arrendadores apresentavam conflitos com normas mais modernas que estavam sendo editadas (principalmente receitas) e conceitos utilizados nessas mesmas normas, como: desreconhecimento, diferimento e reconhecimento/mensuração de ativos e passivos (IASB, 2006c). Isso demonstra uma inconsistência não apenas da simetria entre as partes, mas também com uma questão de escopo que vai ao contrário do que o board prega acerca da estrutura conceitual e da qualidade das normas com base em um handbook de alta qualidade.

Para o board existe um vínculo entre as normas, já que todas se baseiam em uma mesma estrutura conceitual. Mudanças em uma norma que impactam em outra devem ser tratadas dentro do processo normativo: "quando uma nova norma [...] é editada ela deve trazer emendas em outras normas que são consequências dos novos requisitos" (IFRS Foundation, 2016b, p. 31). Esse ponto de inconsistências entre as normas de arrendamento e reconhecimento de receitas, por exemplo, foi levantado inclusive em denúncias ao DPOC, porém ao final do processo esse ponto foi silenciado ao manter os critérios da norma anterior.

Desde 2009 alguns respondentes alertam o DPOC e o board acerca desse problema com relação aos critérios das arrendadoras. Em denúncia realizada afirma-se:

a indústria de arrendamentos já expressou suas preocupações com relação ao processo normativo que está sendo seguido para as arrendadoras. Apesar disso, a consideração da contabilidade do arrendador ainda parece ser de relativamente baixa prioridade para os boards [IASB e FASB] e, com os boards trabalhando para um prazo-alvo oficial de junho de 2011, existe o risco de que a contabilidade do arrendador seja negligenciada, ou mesmo abandonada no último minuto. (DPOC, 2011, p. 3).

Mesmo alertando, foi exatamente o que ocorreu. Por não chegar a um modelo considerado ideal, o board optou por não modificar os critérios das arrendadoras, assumindo 
que há inconsistências entre a proposta antiga (que virou atual) e normas mais modernas, como a IFRS 15 que havia sido recentemente lançada.

Desse modo, percebemos a necessidade de uma norma que agrade ao mercado de capitais, em ambos os lados das operações. Entretanto, ao concretizar tal fato, temos a negligenciação do discurso da essência sobre a forma - que foi silenciado para as arrendadoras - e do próprio handbook, que prevê que novas normas devem ser condizentes com normas vigentes do IASB e com a estrutura conceitual. Certamente esse ponto de crítica, caso o IASB deseje manter seu status de regulador internacional, será utilizado como forma de desvalorização das decisões tomadas pelo board e de reafirmação da fantasia da qualidade e da tecnicidade do processo normativo internacional.

Além da IFRS 15, que é constantemente citada pelos respondentes, temos a estrutura conceitual. No documento final (IFRS16), afirma-se que "o objetivo é assegurar que arrendadores e arrendatários ofereçam informação relevantes de uma maneira que represente com fidedignidade as transações de arrendamento" (IASB, 2016e, p. 6), sendo estas características qualitativas fundamentais da estrutura conceitual.

Afirmar isso logo no início de uma norma passa certa incoerência: $(i)$ afirmar a relevância e representação fiel para ambas as partes do contrato dá a entender que ambas foram modificadas e atualizadas, o que não foi o caso; (ii) não apresentar a limitação na mudança das arrendadoras e ao mesmo tempo afirmar representação fidedigna para esse lado da operação é temerário frente ao que o board argumentou durante todo o processo.

Com relação ao item (i), o próprio board havia afirmado anteriormente que se não realizasse mudanças em ambas as partes a informação não seria nem fiel nem relevante (IASB, 2006b, 2006a). Se isso não ocorresse, não haveria "melhora significativa" na norma (IASB, 2006a, p. 1). Bem, se utilizarmos, portanto, a própria argumentação do board, podemos concluir que não houve (para arrendadoras), nem a aplicação das características qualitativas fundamentais nem melhora significativa do modelo.

Parto para uma análise mais profunda da afirmação (ii). Sabemos que a representação fidedigna é uma característica qualitativa fundamental, de acordo com a estrutura conceitual básica. Essa característica, entretanto, é voltada para o preparador da informação quando de sua elaboração. Mas seria possível haver a aplicação da representação fiel sendo que o processo teve influências políticas que diretamente afetaram as escolhas que representariam a lógica política da "essência sobre a forma" da transação? O que quero dizer é: o board entendia que a simetria seria necessária para a qualidade da norma e para a representação da substância econômica da transação. Isso se justifica no fato de que a transação é a mesma (para ambas as 
partes), sendo diferente apenas a parte no contrato, o que levaria a necessidade de simetria entre as partes. Essa seria a premissa para a representação fiel. Lembro ainda que a representação fiel é uma característica fundamental. Isso quer dizer que, em teoria, não deveria ser restrita pelo "custo". Porém, é essa a justificativa que acaba ocorrendo: "o custo de realizar mudanças substanciais para a contabilização das arrendadoras superaria os benefícios no presente momento" (Lloyd, 2016, p. 2). Se fossemos por essa lógica, entre os principais argumentos contrários à mudança da norma para as arrendatárias deveria estar o aumento substancial dos custos que a norma traria aos preparadores - arrendatários - (E. B. S. de Matos, 2013; Visoto, 2018), então esse modelo, nessa visão, não deveria ter sido alterado.

Sabendo de tal contingência na articulação do processo normativo, o board acaba por silenciar tal questão e limitar as justificativas dadas quanto ao ponto dos arrendadores, explicando apenas que "ambos os boards decidiram por não modificar substancialmente a contabilização dos arrendadores" (IASB, 2016e, p. 7). Isso é um tanto quanto minimizador perto da quantidade de articulações realizadas com relação a tal assunto. Há um viés também quando afirmam que não modificaram ao menos alguma quantidade. Isso dá a entender que modificaram algo, mas o que houve foi apenas um aumento de disclosure. Contabilmente não houve modificações. Porém, em um argumento contraditório, para as arrendatárias "aumentar o disclosure não é suficiente" (IASB, 2016d, p. 3).

Por um lado, devemos lembrar que há a tendência de que a norma em si mantenha sua relevância e circulação ao longo dos anos. Por outro, os documentos do processo acabam por perder sua relevância para o grande público e a norma permanece como documento que resume todo esse processo. Ao simplificarmos e silenciarmos os eventos, no longo prazo, os pontos de conflitos na elaboração da norma e as intervenções políticas desaparecem e a norma passa a ser vista como estritamente técnica.

Por fim, a última justificativa do board com relação às decisões tomadas para as arrendadoras diz respeito à convergência das IFRS com os US GAAP, conforme Figura 35. 
Figura 35 - Principais articulações que envolvem mudanças nas arrendadoras - Parte 4

\begin{tabular}{|c|l|}
\hline $\begin{array}{c}\text { Articulação Inicial } \\
\text { (DP/2009/1 - parágrafo 1.21) }\end{array}$ & $\begin{array}{l}\text { Qualquer mudança sobre arrendadoras deverá envolver uma } \\
\text { diferenciação para propriedades para investimentos, e essa norma é } \\
\text { bastante diferente entre as IFRS e US GAAP. }\end{array}$ \\
\hline Lógicas sociais relacionadas & Lógica da independência; Lógica das boas práticas; Lógica da expertise \\
\hline Lógicas políticas relacionadas & Discurso da essência sobre a forma \\
\hline $\begin{array}{c}\text { Lógicas fantasmáticas } \\
\text { relacionadas }\end{array}$ & $\begin{array}{l}\text { Fantasia da qualidade da norma; fantasia da tecnicidade; fantasia da } \\
\text { comparabilidade; fantasia da globalização; fantasia da justiça processual }\end{array}$ \\
\hline $\begin{array}{l}\text { A independência do board, quando afirma que suas decisões são pautadas em critérios técnicos } \\
\text { e levando em consideração a qualidade acima da convergência é posta em xeque quando se } \\
\text { afirma que a mudança nas arrendadoras não será realizada tomando como base que há grandes } \\
\text { diferenças entre os padrões IFRS e USGAAP no que se refere às propriedades para } \\
\text { investimentos. Considerando que as boas práticas também defendidas pelo board relatam a } \\
\text { necessidade de neutralidade no processo normativo e que o board defende possuir a expertise } \\
\text { diferenciada para a tomada de decisões acerca do conteúdo normativo, por qual motivo nesse } \\
\text { observada }\end{array}$ & $\begin{array}{l}\text { caso decide por não mudar, mesmo considerando necessário, apenas tomando como base que } \\
\text { outro board é diferente? Minha explicação é que as lógicas sociais do processo normativo são } \\
\text { construções meramente retóricas com a finalidade de apresentar um discurso formal e escrito } \\
\text { convincente, porém na prática não seria seguido, limitando o alegado discurso de que a essência } \\
\text { deve ser a base das escolhas normativas. Todas as fantasias anteriores estão presentes nesse } \\
\text { momento de articulação, com a inclusão da fantasia da globalização. Seria condizente com esse } \\
\text { discurso a não realização de uma parte da norma em decorrência de diferenças com outro } \\
\text { normatizador, sendo que esse outro normatizador, além de não aplicar as IFRSs, somente possui } \\
\text { poder normativo nos EUA? }\end{array}$ \\
\hline
\end{tabular}

Fonte: Elaboração própria.

Com relação a essa justificativa do board, eu, como pesquisador externo, tenho até dificuldades de desconstruir devido à ausência de explicações formais e ao completo silenciamento desse movimento. O que podemos questionar envolve a relação defendida na fantasia da qualidade da norma de que a qualidade está acima da convergência nas decisões do board.

O processo normativo foi amplamente incentivado, tanto internamente no IASB como externamente, a ser conduzido de forma conjunta pelos boards. Naquele momento, já era sabido que as normas de propriedades para investimentos das duas entidades possuíam diferenças relevantes que seriam refletidas nas decisões de arrendamentos.

Se considerarmos o discurso da essência sobre a forma e a lógica social da independência, encontramos aqui uma inconsistência das práticas discursivas com as reais práticas adotadas no processo. Apesar de ser um projeto conjunto, deve haver a priorização da qualidade da norma e essa qualidade está atrelada à representação econômica da transação. Se o board entende que a representação econômica dos arrendadores é afetada pela propriedade para investimentos, ele sequer deveria argumentar que no FASB essa visão é diferente, mas sim defender a visão que ele entende ser a mais adequada. Quero dizer que a diferença entre normas do board não poderia servir como justificativa para a não alteração, pois esta atitude demonstra a priorização da convergência acima da qualidade. Seria, portanto, o board realmente 
independente? Essa argumentação reforça meu argumento acerca das posturas políticas no processo, não técnicas e da fantasia ilusória do que seria "qualidade" em um ambiente de autorregulação.

Por fim, com base na teoria do discurso e nas diversas lógicas aqui articuladas, considero que as arrendadoras foram excluídas do sistema discursivo da norma. O silenciamento sobre a ausência de mudanças na norma final e a ausência explicações de caráter "tecnicista" como o board alega acerca das mudanças que ocorreram durante o processo reforçam que o board tomou uma decisão política pela diminuição da qualidade da norma, mesmo essa atitude sendo inconsistente com o que prega o handbook.

Durante o processo, portanto, houve a tentativa de rearticulações e de discursos no intento de transformar o elemento dos arrendadores em momentos mais consolidados que abrangesse uma maioria de interessados a favor. Entretanto, essa articulação aparenta não ter tido sucesso e a construção de um discurso hegemônico se tornou limitada, o que obrigou a prática articulatória do processo a silenciar e construir um novo sentido para ausência de necessidade de mudanças nos critérios das arrendadoras. Veja que é o comportamento oposto ao que ocorreu com as arrendatárias. Nas arrendatárias presenciamos uma constante reafirmação e repetição da necessidade de mudanças. Essa era a prática discursiva que ocorria com as arrendadoras, porém, em certo momento, essa prática foi trocada pelo silenciamento, de forma que o resultado foi uma pseudo hegemonia no discurso do board. Em consequência, as decisões aparentaram, principalmente a longo prazo, ter um caráter técnico, neutro e sem grandes antagonismos.

\subsubsection{Projeto Conjunto: e o FASB?}

Argumento aqui acerca da sobredeterminação e precariedade do sujeito. Quando falamos em IASB e na sua relação com o FASB, não devemos entender o próprio IASB como agente hegemônico central. Nesse momento, ele passa de uma posição de sujeito com poder perante os atores do processo para um sujeito que necessidade de uma negociação política mais clara, principalmente por envolver a relação com outro regulador com características semelhantes, porém com visões às vezes contraditórias acerca das modificações contábeis nos contratos de arrendamento.

Desde o início do projeto, no momento de discussão de sua entrada na agenda dos boards (FASB e IASB), a dúvida era acerca da condição, principalmente do FASB, em 
despender tempo e recursos nesse projeto (IASB, 2006b). Era consenso que sozinhos não conseguiriam conduzir um projeto considerado de alta complexidade e por isso decidiram por um projeto conjunto (IASB, 2006c). Além disso, também no momento inicial, o IASB justificava como essencial a convergência com o FASB: "é essencial que qualquer norma final [de arrendamento] seja desenvolvida de forma conjunta com o FASB” (IASB, 2006c, p. 8). Esperava-se um “consenso" entre os boards (IASB, 2006c).

Para o IASB, a importância do projeto em conjunto seria a de trazer critérios harmonizados entre o FASB e o IASB e os demais normatizadores locais: "embora a IAS 17 e as normas nacionais de arrendamento sejam baseadas em princípios semelhantes, eles têm variações que resultam em diferenças contábil significantes, tanto no momento do reconhecimento das despesas quanto nas receitas e como eles são classificados" (IASB, 2006c, p. 6). Essa é a uma das principais premissas justificadas para a entrada do projeto na agenda e como argumento de que essa harmonização deve ser feita para que a relevância da informação seja aumentada e, assim, a confiabilidade.

Em diversos documentos, havia uma ênfase de que o projeto era conjunto e benéfico para a convergência da contabilidade. Inclusive, o board demonstra que há interesse dos respondentes e dos diversos participantes da contabilidade em apoiar tal convergência, como "muitos dos constituintes apoiam o objetivo do projeto de desenvolver uma norma completa e convergida entre os modelos IFRS e USGAAP” (IASB, 2013a, p. 5).

A ideia do projeto conjunto era a de chegar, portanto, a uma norma final semelhante, sem grandes diferenças nos principais critérios contábeis de reconhecimento, mensuração e apresentação. Isso seria de fato um incremento à convergência. No início do processo os boards já entendiam haver diferenças em algumas visões sobre o assunto, entretanto, tomando como base a alegada importância da consulta e da opinião dos atores sobre o processo, havia um comprometimento em que os boards "resolveriam essas diferenças a luz dos comentários recebidos no discussion paper" (IASB, 2009a, p. 11).

Apesar de tudo parecer positivo acerca da condução do projeto em conjunto, a visão sobre este fato, entretanto, foi sendo modificada ao longo do tempo até a edição final de normas diferentes entre os boards. Entretanto, a não concordância dos boards sobre determinados tópicos tendeu ao silenciamento durante o processo e à diminuição de relevância.

Até mesmo quando o projeto já estava com decisões diversas, o board focava em demonstrar que o processo foi iniciado como um "joint project" (IASB, 2016e, p. 6), sem explicar que durante as discussões esse projeto foi finalizado de forma separada. O board utilizou, inclusive, números norte americanos como justificativa para as mudanças em seu 
último press release (IASB, 2016f), porém eles não seriam aplicáveis, já que as empresas dos EUA não utilizam as IFRS. As diferenças entre as normas acabam por ficar, portanto, em segundo plano no documento de maior circulação do processo, que é a norma propriamente dita. Com essa ausência de citação, no futuro a tendência é de nem mesmo haver dúvida acerca da convergência, pois há qualquer registro que prove o contrário.

Esse ponto não passou despercebido pelos participantes do processo. Questionamentos surgiram durante o processo quanto à habilidade de boards com visões normativas, por vezes, contrastantes conduzirem um projeto de tamanha complexidade e variação de visões de forma conjunta. Inclusive tal ponto foi levado ao DPOC por diferentes denúncias, como: "Essas mudanças individuais nas direções nos levam a uma grande preocupação de que os dois boards não possuem uma visão clara ou um entendimento comum dos objetivos desse projeto" (DPOC, 2012a, p. 2).

Apesar disso, esses pontos eram minimizados e o DPOC se restringiu a afirmar que não participa de decisões técnicas. Efetivamente começar um projeto de forma conjunta e terminar com normas diferentes não é uma violação ao handbook. O que critico é a ausência de transparência e de divulgação quanto ao fato. É importante aos impactados saber claramente as razões que levam os dois maiores boards responsáveis pela regulação contábil a discordar de pontos de uma norma tida como uma das mais importantes atualmente. Essa é uma atitude que traria transparência e accountability sobre o processo e ajudaria os impactados a entender os motivos que levaram à não convergência.

Mais uma vez reforço, minha missão aqui não é a de desvendar todos os pontos de inconsistências discursivas, mas sim realçar as inconsistências existentes, principalmente por meio da articulação das lógicas descritas nesta tese. Ou seja, principalmente nesse assunto acerca do projeto em conjunto, apenas consigo demonstrar falhas nos discursos que mostram essa inconsistência do discurso ocupante do status quo.

Com base nisso, apresento as principais lógicas que auxiliaram na identificação das inconsistências entre os discursos da relação FASB versus IASB, conforme Figura 36. 
Figura 36 - Relação das lógicas sobre o discurso do projeto conjunto entre FASB e IASB

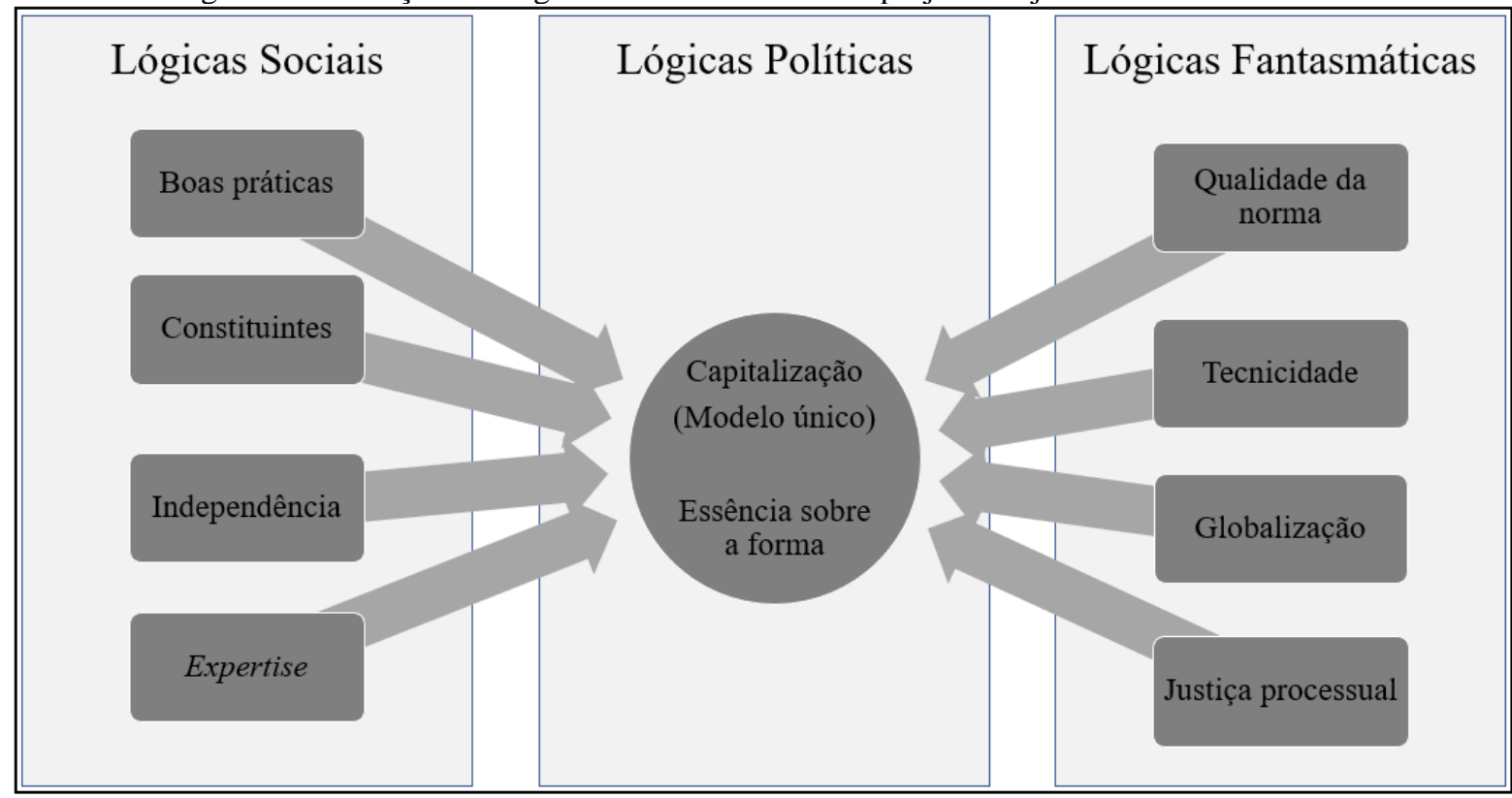

Fonte: Elaboração própria.

Para subsidiar a análise das lógicas, vejamos, portanto, de uma forma simples, a modificação no uso de palavras à medida que o projeto avançava. Para isso, utilizo-me das press releases. Temos três principais notas a imprensa durante o processo. PR1 ocorreu na divulgação do ED/2010/9, PR2 na divulgação do ED/2013/6 e PR3 na divulgação da IFRS 16.

PR1: O IASB e o FASB, dos Estados Unidos, publicaram hoje para comentários públicos proposta conjunta [joint Project] para melhorar os relatórios financeiros de contratos de arrendamento. As propostas são um dos principais projetos incluídos no Memorando de Entendimento dos conselhos. (IASB \& FASB, 2010).

PR2: o IASB e o FASB iniciaram um projeto conjunto [joint Project] para melhorar os relatórios financeiros de atividades de arrendamentos de acordo com as IFRSs e os U.S. GAAP. (IASB \& FASB, 2013).

PR3: o IASB (the Board) emitiu hoje um novo padrão contábil, denominado IFRS 16 Arrendamentos. O IASB também trabalhou em estreita colaboração [close collaboration] com o FASB no desenvolvimento da nova Norma. Os dois Conselhos estão alinhados quanto à questão central de trazer os arrendamentos aos balanços e à definição de um arrendamento e como os passivos do arrendamento devem ser mensurados. (IASB, 2016f).

Nas notas à imprensa, que eram sempre emitidas em conjunto, os boards faziam questão de ressaltar o esforço conjunto e destacar que pequenas mudanças ocorriam entre os board apenas por questões de regramentos específicos, mas que eram "quase idênticas" (IASB \& FASB, 2013). Entretanto, com a discordância dos boards acerca do conteúdo final da norma, não se explicou a interrupção do projeto em conjunto, mas simplesmente, silenciou-se tal fato.

O primeiro ponto a se notar é que os boards começam emitindo documentos em conjunto e utilizando-se das palavras "joint project" (projeto conjunto). Ao longo do tempo e do aumento das divergências, passa-se a utilizar working together" (trabalhando juntos) (IASB, 2015, p. 2) até os últimos documentos, em que observamos “close colaboration" (colaboração 
próxima) e "alinhamento" (IASB, 2016f). Esse achado parece pouco, porém as palavras utilizadas são escolhidas de forma objetiva com o intuito de silenciar que houve um afastamento dos boards durante a condução do projeto.

Esse silenciamento pode ter diversas funções dentro do discurso, desde realmente tentar esconder o que estava acontecendo até deixar tal informação despercebida ou mesmo iludir os leitores. Quem não acompanha de forma próxima não consegue identificar a diferença nos termos, porém ao acompanhar de modo mais próximo, percebemos que passou de um estágio de emitir uma mesma norma para os dois boards para um trabalho entre "colegas".

Uma das diferenças identificadas relaciona-se ao reconhecimento de despesas. Em resumo, no modelo do IASB, as despesas de arrendamento das arrendatárias são separadas em despesas financeiras e despesas de depreciação/amortização. Jó no modelo do FASB, todas as despesas de arrendamento compõem um grupo único de despesas operacionais.

Próximo à data de edição da norma, o board ainda argumentava que a "convergência sempre foi uma prioridade tanto para o IASB quanto para o FASB durante o projeto de arrendamentos" (DPOC, 2015c, p. 7). Para não atingir a convergência, o board argumenta que "um modelo completo de convergência depende que a solução seja de alta qualidade" (DPOC, 2015c, p. 9). Com isso, o board reafirma a fantasia da qualidade da norma.

Considerando que a norma final não foi igual para os boards, entendemos, com base no trecho anterior, que o IASB considera que a proposta do FASB não cumpre os requisitos de alta qualidade. Entre esses requisitos, está a alegada tecnicidade do processo. Porém, o IASB editou uma norma diferente argumentando que:

com base no feedback recebido de investidores e analistas, o IASB concluiu que um modelo que apresenta separadamente juros e amortização para todos os arrendamentos reconhecidos no balanço patrimonial forneceria informações que são mais úteis para a mais ampla gama de investidores e analistas. Embora os investidores e analistas expressem opiniões divergentes sobre alguns aspectos do projeto, a maioria dos consultados considera que os arrendamentos criam ativos e passivos "semelhantes a dívidas". (DPOC, 2015c, p. 10).

A justificativa para a escolha do modelo do IASB é com base no feedback recebido por investidores e analistas. Já ressaltei em diversos momentos desta tese a insignificância quantitativa da participação desses "usuários" da informação contábil, muito embora esse mesmo grupo de usuários tenha tido o poder de direcionar uma decisão normativa em sentido contrário ao alegado principal interesse do board: a convergência. Aqui não argumento que o modelo do FASB é o correto, todavia demonstro a incoerência na relação entre a tecnicidade, neutralidade, convergência, comparabilidade, globalização, justiça processual e qualidade da norma (todas estas vistas como lógicas fantasmáticas nesta tese). 
O que devemos entender é que essa não é uma diferença pequena. No intuito de diminuir essa diferença, que é relevante e impacta diretamente nos indicadores de desempenho das entidades, já que envolve diferença no reconhecimento de despesas, o board se utiliza do discurso político da capitalização, uma ferramenta já decidida no início do processo. É até de certa forma ludibrioso argumentar que os boards "estão alinhados quanto à questão central de trazer os arrendamentos aos balanços" (IASB, 2016f). Isso demonstra o interesse intencional de diminuir a diferença focando a atenção nos pontos de convergência.

Porém, como também já defendi, esses pontos de convergência já estavam acordados desde o início do processo normativo e da decisão do projeto em conjunto.

Um tempo considerável foi dedicado a discutir o status e as opções em relação ao projeto de arrendamentos. Houve um apoio substancial de que os arrendamentos criam ativos e passivos que devem ser refletidos no balanço do arrendatário. Na verdade, haveria uma enorme decepção se o projeto não atingisse esse desenvolvimento. Houve forte endosso de que, embora a convergência com o US GAAP seja muito importante, a qualidade não deve ser prejudicada para se obter tal harmonização. Coerente com esta perspectiva foi o desejo expresso de concluir o projeto, mesmo que isso resulte em não convergência. [...] $\mathrm{O}$ board reconheceu o papel positivo que pode desempenhar na sensibilização para a necessidade de alterações na contabilidade da arrendamentos e os méritos de uma informação mais transparente sobre os contratos de locação. (IFRS Foundation, 2014, pp. 3-4).

Os diversos andamentos da norma e da relação FASB e IASB demonstram, mais uma vez, a presença das lógicas fantasmáticas e da qualidade da norma. Mesmo contra o handbook e o discurso formal do board, houve momentos em que se priorizaram escolhas em prol da convergência. Um desses momentos é a não modificação dos critérios das arrendadoras que discuti na seção anterior.

Nessa relação entre possíveis conflitos FASB x IASB com relação a determinados conteúdos da norma, há um posicionamento do DPOC após denúncia acerca do possível viés do IASB para agradar ao FASB. Tal posicionamento reitera o discurso formal do board em priorizar a qualidade acima da convergência:

O DPOC acredita que a qualidade das normas deve continuar como o principal condutor. Para ajudar a garantir que o IASB cumpra com seu compromisso com a qualidade e com um processo normativo adequado, o DPOC aumentou seu relacionamento com o IASB. Agora estamos nos encontrando mensalmente com o IASB para discutir o status da convergência com o FASB. (DPOC, 2011, p. 5).

Entretanto, apesar de haver essa afirmação citada, não encontrei relatórios do DPOC com a devida transparência acerca desses encontros mensais e de demais tratativas sobre a questão da convergência com o FASB e o IASB.

Essa possível relação de conflito de interesses envolvida entre o "incremento da convergência", advindo de uma globalização, e a "qualidade da norma" é uma ferramenta amplamente política e não técnica, já que envolve duas partes com interesses que, por vezes, 
são dicotômicos. No final, um sai ganhando e outro perdendo. Ou então podemos encontrar contrastes de discursos de forma a modificar significados anteriormente construídos.

Quando analisamos relações entre dois órgãos que possuem o poder de construir discursos hegemônicos em seus respectivos campos, devemos entender o movimento de produção de sentidos com relação à sua independência, que seria atrelada à tecnicidade. A construção de articulações que podem ser dicotômicas entre entes de poder gera antagonismos e contingências difíceis de contrapor ao movimento de produção de sentidos. Por isso, uma estratégia é o silenciamento e a defesa velada apenas das propostas do próprio board, sem atacar diretamente as visões antagônicas do FASB.

Com base nessas análises e nas inconsistências apresentadas, levanto alguns questionamentos: há como ter independência nas decisões desses órgãos? Ou, se o projeto é em conjunto, naturalmente algum lado deve ceder em determinados momentos? Se ambos possuem expertise para avaliar a essência sobre a forma e chegam a conclusões distintas, por qual motivo não apresentam claramente (e com a alegada técnica) os motivos que levaram a cada decisão e deixar a avaliação por parte dos participantes do processo? A globalização e o interesse na convergência, portanto, são na prática mais importantes que a justiça processual fantasmática e a qualidade da norma?

\subsubsection{Análise da Aplicação dos Princípios do Processo Normativo Internacional}

Após a análise do processo normativo de arrendamentos tomando como base as lógicas sociais, políticas e fantasmáticas, continuo utilizando-me do caso específico para propor um framework geral de análise dos processos do IASB com base em seus princípios. Devo deixar claro que os princípios analisados não se referem aos atributos da norma exigidos para os preparadores, mas sim aos atributos do processo normativo.

Dividi essa análise em duas seções. Inicialmente preenchi o framework de análises que iniciei a construir nas visões metodológicas - com questionamentos que servem de auxílio para a análise dos princípios frente ao processo normativo. Com isso, na seção seguinte, realizei a análise propriamente dita com a evidenciação dos momentos de (in)completude e (in)consistências na aplicação dos princípios do due process handbook.

A proposta de framework de análise encontra-se nos resultados por ser um dos produtos desta tese e que se originou após a análise inicial das lógicas da explicação crítica de Glynos e Howarth (2007). Por meio desse arcabouço analítico, outras pesquisas podem ser realizadas 
analisando outros processos conduzidos pelo board e seu aprimoramento será constante. Esse framework foi desenvolvido, portanto, tomando como base os resultados da pesquisa e, por isso, na metodologia apenas apresentei sua visão geral metodológica de sua idealização, com o efetivo preenchimento sendo apresentado na presente seção.

\subsubsection{Desenvolvendo o Framework de Análise do Processo}

Considerando que o sentido, na ótica pós-estruturalista, nunca será fixado e totalizado de forma definitiva, o framework de análise que proponho parte da investigação dos conceitos que se enquadram na definição de significantes vazios e podem ser criticados de forma a demonstrar sua não totalização.

São exatamente esses conceitos que nunca estão completamente fixados e universalizados, ainda que muitas vezes pensemos neles como algo natural e inquestionável. Esses significantes vazios representam o ponto de partida para a análise de discursos que visam à estabilização do poder e à criação de discursos hegemônicos (Jørgensen \& Phillips, 2002).

A partir do momento em que se têm poder, tem-se, também, a validade social para criar conhecimento (Jørgensen \& Phillips, 2002). Essa criação de conhecimentos limita os sentidos "válidos" e exclui as possibilidades alternativas. Considerando, então, que a análise dos discursos é uma ferramenta de análise da batalha entre sentidos, a pergunta a ser feita é: "quais potenciais sentidos são excluídos?” (Jørgensen \& Phillips, 2002, p. 22). Por isso, para a construção interna de análise específica do caso do framework, realizei as perguntas tomando como base os "momentos em que tal característica não foi realizada", assim posso analisar momentos de exclusão de sentidos na batalha pela naturalização de conceitos.

Com base no framework de análise proposto na Figura 37, podemos observar uma relação do eixo vertical que se refere ao processo normativo com estratégias de governança utilizadas pelo IASB. Quando falamos em conteúdo da norma, verificamos uma relação com o discurso de expertise e locus of knowledge. Quando falamos em processo organizacional, verificamos questões com o discurso de justiça procedimental, principalmente por meio da estratégia de existir um handbook burocrático. Quando falamos em atores envolvidos, além de relacionarmos com os atores internos, também relacionamos com a estratégia de inclusão e participação aberta (Pelger \& Spieß, 2017; Quack, 2010; A. J. Richardson \& Eberlein, 2011). 
Figura 37 - Modelo de Interpretação do Framework de Análise Crítica ${ }^{11}$

\begin{tabular}{|c|c|c|c|}
\hline & Transparência & $\begin{array}{c}\text { Consulta completa } \\
\text { e justa }\end{array}$ & Accountability \\
\hline $\begin{array}{c}\text { Atores } \\
\text { Envolvidos }\end{array}$ & $\begin{array}{l}\text { - Quem são? Informou? } \\
\text { - Ganhadores/perdedores são } \\
\text { descritos? }\end{array}$ & $\begin{array}{l}\text { - Quem participou? } \\
\text { Informou? } \\
\text { - Condições de acesso são } \\
\text { semelhantes? }\end{array}$ & $\begin{array}{l}\text { - Os atores externos } \\
\text { conseguirão aplicar? } \\
\text { - Quem foram os } \\
\text { impactados? Eles } \\
\text { participaram? } \\
\text { - Quais os custos e } \\
\text { benefícios que envolvem os } \\
\text { atores? }\end{array}$ \\
\hline $\begin{array}{c}\text { Processo } \\
\text { Organizacional }\end{array}$ & $\begin{array}{l}\text { - Como as justificativas de } \\
\text { mudanças no processo foram } \\
\text { dadas? } \\
\text { - Podemos observar } \\
\text { subjetividades? } \\
\text { - Disponibilização de } \\
\text { documentos é de fácil e } \\
\text { irrestrito acesso? }\end{array}$ & $\begin{array}{l}\text { - Como a consulta chegou a } \\
\text { todos? } \\
\text { - Como o resultado da } \\
\text { consulta chegou a todos? }\end{array}$ & $\begin{array}{l}\text { - Como os resultados do } \\
\text { processo foram tratados? } \\
\text { - Foi adequado para levar } \\
\text { informação precisa, neutra e } \\
\text { técnica? } \\
\text { - A participação do DPOC } \\
\text { foi efetiva? }\end{array}$ \\
\hline $\begin{array}{r}\text { Conteúdo } \\
\text { da Norma }\end{array}$ & $\begin{array}{l}\text { - As mudanças de conteúdo } \\
\text { foram justificadas? Por que } \\
\text { não? } \\
\text { - Por que o conteúdo } \\
\text { mudou? }\end{array}$ & $\begin{array}{l}\text { - Quais as opiniões } \\
\text { dissidentes? } \\
\text { Justificaram? Por que não? }\end{array}$ & $\begin{array}{l}\text { - Quais os racionais para as } \\
\text { mudanças de conteúdo? } \\
\text { - Há ambiguidades? } \\
\text { - Críticas anteriores não } \\
\text { foram resolvidas? }\end{array}$ \\
\hline
\end{tabular}

Fonte: Elaboração própria.

Devemos entender a retoricidade e a política no processo como um todo. Porém, para a análise dos pontos levantados no framework, utilizei-me, principalmente, dos principais documentos de circulação pública do processo de arrendamento. Isso porque entendo que o uso articulatório dos principais documentos é um filtro para a visão que o board deseja passar para a sociedade. Em especial para demonstrar que não podemos acreditar em tudo que lemos e entender que há muito por trás de discursos e das palavras escritas.

Os documentos não possuem o mesmo destaque e a mesma qualidade de acesso. Muitos dos processos e documentos não são conhecidos do público e a evidência maior é dada aos documentos que necessitam de participação pública. Essa evidência é a disponibilização dos documentos na página principal do projeto. Os documentos de reuniões, atas e até mesmo os summaries dos feedbacks dos respondentes normalmente possuem um acesso mais dificultado e diversos possíveis interessados sequer sabem da existência de tais informações. Durante o

${ }^{11} \mathrm{Na}$ análise dos resultados, atentar para as nomenclaturas utilizadas para a simplificação da descrição das
interseções discutidas. Cada interseção entre princípios versus elementos de análise foi caracterizada com um
código, conforme figura abaixo.
\begin{tabular}{|c|c|c|c|}
\hline & Transparência & Consulta completa e justa & Accountability \\
\hline Atores Envolvidos & A 1 & B 1 & C1 \\
\hline Processo Organizacional & A 2 & B 2 & C 2 \\
\hline Conteúdo da Norma & A 3 & B 3 & C 3 \\
\hline
\end{tabular}


projeto de arrendamento o site passou por uma modernização e, apesar de o layout ser mais moderno, o acesso se tornou mais complicado, necessitando de informações mais precisas para encontrar a informação desejada. Desse modo, apesar de não haver "limitação" de acesso, há mais barreiras para o acesso.

Faço um adendo de uma observação que surgiu durante a análise dos documentos públicos e sua limitação quanto à transparência. Apesar da disponibilização desses documentos, eles acabam por funcionar como uma cortina de fumaça para justificar a transparência ilusória do processo. Se sabemos que o trabalho em grande parte é realizado pelo staff técnico, ou seja, se as discussões e as propostas de rumos normativos são feitas com base no trabalho do staff, por que os documentos públicos são os de reuniões de apresentação do staff aos board members? Os documentos de discussões propriamente ditos seriam as discussões que o staff realiza antes da elaboração das propostas normativas.

Destaco que temos a seguinte lógica normativa: (1) discussões internas do staff $\rightarrow$ (2) elaboração de propostas $\rightarrow$ (3) apresentação dessas propostas aos board members $\rightarrow$ (4) decisões dos board members e futuros andamentos. Os documentos públicos representam as etapas (3) e (4). Entretanto, nesses momentos as propostas já estão feitas e somente são apresentadas. Para uma real transparência, deveríamos ter acesso aos passos (1) e (2), que são quando as discussões propriamente ditas são realizadas e aí sim podemos observar melhor a habilidade política do processo. Contudo, essa etapa não é apresentada em momento algum, sendo essa atitude uma estratégia silenciosa de dirimir os antagonismos ao processo e apresentar apenas informações mais consolidadas.

Já falando de forma mais aplicada aos documentos disponíveis, não posso dizer que há casualidade na escolha de palavras/construção de discursos nos mais diversos documentos e nas variações dessas palavras e articulações entre documentos com maior ou menor circulação pública. O que posso dizer é que há intenções. O processo de edição de normas contábeis não foge a esse padrão, mostrando que há politização. Contudo, a política presente nesse processo não necessariamente é algo prejudicial e pode, inclusive, elevar o nível do debate. O prejuízo é negar a presença de tal política e referendar todo um processo com base em uma técnica que se mostra como uma ferramenta retórica e ilusória.

Por fim, as críticas realizadas com base no framework são apresentadas na próxima seção e representam um antagonismo às normas sociais não contestadas por meio dos princípios do handbook. Essas críticas buscam demonstrar a lógica política da regulação contábil, neste caso a aplicada ao processo de leasing. O objetivo é o de mostrar que não há completude na 
aplicação dos princípios do handbook. Para a análise, efetuei o confronto desses princípios com três principais pilares do processo normativo do IASB.

\subsubsection{A (In)completude dos Princípios: Críticas com base no Framework de Análise}

Inicio as análises com a compreensão prévia de que quando se envolve interesses e relações de dominação, devemos entender que a representação dos fatos nunca será totalmente transparente ou completa (Howarth, 2010).

A reconstrução de conceitos "naturalmente" positivos em terminologias de mercado, como "qualidade", "excelência", "profissionalismo", conhecimento", "transparência", "consulta", "accountability" e "inclusão", entre outros, é a estratégia que se faz presente para a articulação da lógica da equivalência via significantes vazios e flutuantes. Dessa maneira, os agentes conseguem se qualificar exatamente pela não fixação desses significados, de forma que normalmente não são “desnaturalizados” por representarem conceitos "óbvios”. Minha missão aqui é mostrar exatamente essa incompletude, que faz com que seja necessária uma pressão para a formalização das necessidades essenciais para cumprimento dessas características.

Limitar-se a requisitos formais de apresentação desses conceitos é mais uma estratégia de fácil atingimento, todavia até que ponto essa informação pode ser dada sem comprometer a hegemonia desses órgãos?

Com base nisso e visando ser uma voz de antagonismo (não de inimizade), apresento as críticas com base no framework por linhas (1-2-3). A vacuidade dos significantes do framework dificulta, em alguns momentos, análises muito delimitadas de caixas específicas (por exemplo: A3; B2; C1) e, muitas vezes, elas se misturam e uma análise pode incorporar outra.

\subsection{Relação dos Atores Envolvidos com os Princípios}

Abro a articulação pela linha 1: atores envolvidos. Quando falo em atores envolvidos, falo de todo e qualquer impactado no(pelo) processo normativo. Em alguns momentos, o próprio board influencia na interpretação de quem seriam os atores por meio de classificações subjetivas, retóricas e que funcionam como significante flutuante. $\mathrm{O}$ uso incorreto da palavra “constituintes" por parte do board, conforme já discuti na lógica social dos constituintes, leva a um uso igualmente incorreto por parte dos participantes do processo normativo. Não são apenas aqueles participantes menos esclarecidos que, porventura, se equivocariam. São 
participantes do mercado e que possuem poder. Inclusive participantes que são ativos no processo e realizam denúncias ao DPOC. Embora o fato de realizar denúncias ao DPOC demonstre conhecimento do processo e das suas instâncias, isso não impede a captura pelo significante flutuante (constituintes) que pode apresentar diversas funções: "Também estamos preocupados com o fato de que o ritmo das re-deliberações está tornando-o extremamente difícil para a grande maioria dos constituintes seguir e compreender decisões e analisar suas implicações potenciais" (DPOC, 2011, p. 2).

Com relação aos atores, deixo aqui um trecho de bastante importância para a visão das inconsistências no discurso do IASB, com relação à transparência, à consulta e à accountability.

Conforme explicado pelo Presidente Tweedie, durante o estágio do devido processo, o IASB recebe novas ideias porque a consideração de diversos pontos de vista e preocupações melhora a qualidade de um padrão de contabilidade; melhorando o julgamento do normatizador (IASB, 2003). No entanto, para participar efetivamente no devido processo do IASB, os constituintes devem perceber que o IASB não responderá àqueles que se opuserem à reforma e ao desenvolvimento de novos padrões internacionais que resultem em maior transparência. O lobbying de interesse especial servirá apenas para impedir o desenvolvimento e aceitação de padrões globais de alta qualidade. (Street, 2006, p. 124)

Essa fala do então presidente do IASB demonstra, ao mesmo tempo, uma vontade de apresentar um processo técnico e neutro e uma exclusão de atores com a reafirmação de impureza da figura política. Como venho argumentando nesta tese, se entendermos a política como algo impuro, devemos tratar o próprio IASB sob o mesmo enfoque da impureza, já que ressalto que ele é um órgão político. Aí está a inconsistência. Quem seriam esses atores intencionalmente excluídos por meio do lobbying? Se formos considerar tal ponto, o board deveria se autoexcluir do processo, pois ele realiza estratégias de argumentação (que poderiam ser estratégias de lobbying) para defender seus pontos de vista. Além disso, ele inclui intencionalmente atores políticos no processo, como as big4, a EFRAG (European Financial Reporting Advisory Group) e o FASB.

Outro ponto a questionar é com relação a como essas informações foram excluídas. Em minhas análises não vi qualquer posicionamento do board referente a exclusões de opiniões devido a atividades de lobbying ou defesa de interesses. Apesar disso, há evidências de que essas atividades ocorreram no projeto de arrendamentos (Carmo et al., 2014; E. B. S. de Matos \& Niyama, 2013; Visoto, 2018). Se isso aconteceu, falta transparência em apresentar, falta accountability em explicar e falta a consulta "completa e justa" que acaba por excluir atores. Outro ponto é: estaria o board excluindo antagonismos e limitando o debate ao "entender" que são atividades de interesses? Se partirmos do pressuposto de que a participação envolve custos, entendemos que ela somente ocorre quando há interesses que trazem benefícios superiores ao interessado. Por esse racional, todas as opiniões deveriam ser excluídas. 
Falta, portanto, transparência (A1) com relação a quem os atores efetivamente são quando o board se posiciona. Nos raros momentos em que citam os setores de algum respondente, percebemos que o motivo não é o aumento da transparência do processo de forma a realmente informar a visão do setor, mas o objetivo tende a ser o de qualificar/desqualificar alguma posição. Por exemplo, temos a citação que fala que "quase todos os analistas de empresas aéreas ou de transportes concordam [...]” (IASB, 2013a, p. 12). Esse grupo de analistas de empresas de transportes, em teoria, está inserido entre os respondentes caracterizados como "usuários". Considerando tal fato e uma citação anterior, todo o grupo de usuários totalizava 20 respondentes. É de se esperar que esses analistas concordem, uma vez que receberão um maior nível de informação, mas o que devemos questionar é: quantos são esses analistas que merecem tamanho destaque no relatório, enquanto outros respondentes mais representativos (em termos quantitativos) não têm suas respostas citadas?

Há uma argumentação até excessiva de que os usuários externos, principalmente os investidores institucionais e analistas, aprovam o aumento das informações a serem fornecidas sobre os arrendamentos por meio das notas explicativas. A repetição acaba por ter um papel de reforço importante nessa opinião, que é um tanto quanto esperada. Para os usuários externos, não há custos diretos com o aumento da informação e eles só tendem a ser beneficiados em suas análises. Portanto, não teriam motivos para se oporem.

Assim como o silenciamento, a repetição também tem seu papel político na regulação. A repetição e defesa da qualidade, da independência, da tecnicidade e da expertise acaba por se tornar também uma estratégia que deixa o IASB em um status de autoridade (Warren et al., 2019), principalmente por não ser tão publicamente criticado ou possuir algum "concorrente" para a edição de normas.

Entretanto, a priorização desses usuários, mesmo sendo mais restrita sua participação no processo, gera um viés no alegado processo neutro e objetivo que pode incomodar outras camadas de participantes. Observe que, apesar de alegar que "muitos constituintes discordam das propostas de disclosure do ED 2013" (IASB, 2013a, p. 53), o foco e defesa do board (inclusive aparecendo antes no documento) é sustentar que "a maioria dos usuários expressou visões que apoiam a proposta [de aumento do disclosure]" (IASB, 2013a, p. 52). Contudo, os usuários correspondem a 20 (das 628) cartas recebidas nessa etapa. Os demais constituintes, mesmo sendo maioria, portanto, foram sumarizados como "muitos", enquanto os usuários como “a maioria”. A informação pode até ser verídica (e imagino que seja), no entanto, fazer uso desses pronomes sem proximidade com os quantitativos absolutos demonstra uma vontade de 
criar um discurso articulatório a favor do que o próprio board anseia. Assim, desmerecem a transparência e a "maioria" das opiniões, trazendo a tona problemas relacionados com a consulta "justa".

Ainda no A1, quando falamos em atores envolvidos e transparência, o próprio board os relaciona com ganhadores e perdedores em termos de custos. "um novo modelo de arrendamento [...] produzirá 'ganhadores' e perdedores"” (IASB, 2006a, p. 11). Apesar de entender que essa relação existe, o board, nas justificativas, tende a silenciar quem seriam os ganhadores/perdedores ou mesmo os mais impactados pelas mudanças normativas. Percebi durante a leitura dos documentos que há um receio do board em citar setores e essas citações são bastante restritas nos documentos, limitando-se a documentos oriundos de reuniões públicas, pois nelas há um questionamento direto. Já no grupo dos principais documentos do processo, essas referências são mais restritas.

Até mesmo quando o board se propõe da falar dos afetados, não há informação relevante: Após a realização do questionamento (feito por ele mesmo) "quem será afetado pela proposta?", o board responde que "a proposta irá afetar qualquer entidade que entrar em uma transação de arrendamento" (IASB, 2013c, p. 5). Essa resposta é um tanto quanto óbvia e carece de capacidade informativa para os interessados. Nesse momento, nós interessados queremos saber os principais setores, mercados e entidades que serão impactados e como esses impactos se refletirão nas informações contábeis das entidades. Essa informação não é presente nem no snapshot, que possui a função de ser um relatório para o mercado.

Já com relação a B1 (relação atores envolvidos/consulta completa e justa) podemos perceber que a importância/falta de importância conferida aos diversos usuários durante o processo normativo é dada de acordo com os próprios interesses do board. Historicamente, em todos os momentos de consulta do projeto de arrendamento (DP, ED1 e ED2), os tipos de usuários que mais participaram foram os preparadores e as organizações industriais. Isso tende a ser natural, uma vez que são as empresas as que mais terão impactos de custos, de aumento/adaptação de controles e de modificações das suas estruturas de capital.

Entretanto, como a maior parte desses usuários era contrária à mudança da norma, eles não são trazidos ao debate nas etapas de feedback das consultas ou, quando trazidos, são citados como exceções que possuem viés em seus interesses. O board opta por trazer ao debate um grupo que representa cinco cartas na etapa do DP para justificar a necessidade de mudança, mas poucas são às citações ao grupo que compõe mais da metade de respondentes. Em resumo, podemos dizer que em momentos de discordância, os preparadores são tratados como minoria e "viés". Veja: "alguns outros constituintes, principalmente os preparadores, questionam" 
(IASB, 2013a, p. 10). Aqui podemos observar uma diminuição do papel do grupo que, representativamente, é o mais relevante entre os respondentes. Porém, como é de se esperar, manifestam-se contra a proposta. Então, quando não silenciados, são diminuídos no debate. Apesar disso, eles representam a ponta da contabilidade, ou seja, os que diretamente serão impactados pelas mudanças normativas.

Já quando os preparadores são de opinião semelhante à do board, eles aparecem no debate. Um exemplo é quando se defende a indicação de exceções na norma (principalmente arrendamentos de curto prazo). Por exemplo, apesar de reconhecer inconsistências conceituais com relação à essência da transação, aí sim os demais usuários são incluídos no debate incorporando todo o grupo de "respondentes".

As mudanças são sutis quando usuários são excluídos de algum debate de forma a articular o argumento favorável ao board. Os "respondentes", que são todos, passam a ser os "respondentes que concordam", "os respondentes que discordam", "os respondentes interessados no mercado financeiro", "os respondentes que comentaram sobre esse tema”. Há uma sutil limitação desses respondentes que, muitas vezes, passam despercebidas pelo leitor e cria mais uma subjetividade, já que não se sabe quem são esses respondentes limitados pelo discurso.

Entretanto, a capacidade informativa quando os usuários são descritos e suas opiniões articuladas seria de grande valia aos interessados, uma vez que a transparência dos resultados da consulta poderia ser mais efetiva por meio do aumento da compreensão dos leitores. O que quero dizer é que, sabendo como os tipos específicos de respondentes pensam, podemos compreender os motivos desses pensamentos. Por exemplo, à época das discussões sobre o modelo de reconhecimento de despesas, o board informou uma visão diferente entre as empresas de contabilidade e normatizadores quando comparada à visão dos preparadores e indústrias. Isso demonstra que, do ponto de vista da disponibilização da informação, os preparadores veem que os custos não superam os benefícios, enquanto usuários externos da informação prefeririam o modelo mais detalhado (já que não envolveria custos para eles). Isso é importante para que o participante externo do board possa formular melhor sua opinião, tendo em vista que entende os vieses das respostas dadas. Assim, pode-se avaliar até que ponto tal informação seria realmente válida ou não sob os mais diversos panoramas.

Tomando como base a diferenciação dada aos diferentes participantes do processo nos momentos de feedback, argumento que essa diferenciação também se dá no processo de consulta em si, desde o acesso dos usuários até mesmo seu tratamento. O princípio utiliza-se da 
retórica da "consulta completa e justa". Já argumentei que essa retórica, por si só, já vai de encontro ao que tomamos como premissa da construção discursiva na teoria pós-estruturalista (Laclau \& Mouffe, 1985), isso porque entendemos que não há totalização de conceitos, porque existe a contingência, ou seja, sequer podemos caracterizar o que seria completude e justiça no sentido da consulta do board.

Apesar de não podermos definir, podemos entender o que seria uma contradição à completude e à justiça. O staff afirma, nos documentos de feedback, que buscou apoio e sugestões (antes mesmo dos documentos com as propostas normativas serem lançados) de dois principais participantes: auditorias (por meio das big4) e investidores institucionais. Seria isso justo? Se entendermos que esses usuários tiveram acesso aos documentos antes dos demais e antes de os documentos serem encaminhados para a consulta pública, onde podemos ver a justiça (e até mesmo a necessidade) dos processos de consulta do board? Alguns usuários possuem o direito (para não dizer poder) de influenciar os rumos das propostas antes mesmo de serem públicas.

Além desse ponto acerca da facilitação do acesso para usuários específicos, temos a dificuldade de acesso de outros usuários, muitos deles representando a ponta da contabilidade, ou seja, os que realmente aplicarão as normas nos seus trabalhos e empresas (preparadores). O acesso se restringe a respondentes de língua inglesa, respondentes que possuem certa capacidade financeira de participação e respondentes que possuem a "expertise" que o board exige com suas formalidades. Então eu concluo aqui mostrando que, mesmo não podendo definir o que seria completude e justiça no processo normativo, podemos dizer que esses conceitos não são coerentemente aplicados e funcionam como estratégias ilusórias e fantasmáticas de uma consulta inclusiva e participativa.

Quando falamos na relação atores envolvidos e accountability (C1), argumento que o board insiste em defender que, com a nova norma, os usuários não mais precisarão realizar ajustes de forma a reconhecer valores off balance nas demonstrações financeiras das entidades arrendatárias. Entretanto, o board não delimita tais usuários, não diz quem serão os privilegiados nem mesmo aqueles que realmente realizam os ajustes nas DFs. Assim, temos um grupo beneficiado com uma alegada diminuição de custos, enquanto os preparadores possuem o aumento de custos para beneficiá-los e não há uma defesa explícita desse primeiro público beneficiado, ainda que ele tenha representado o argumento da força motriz para a mudança da norma.

São poucos os momentos em que, nas prestações de contas acerca da opinião dos respondentes, o staff descreve algum tipo de respondente. Porém essa descrição mais detalhada 
seria de grande valia tanto para o interessado externo quanto para os membros do board subsidiarem suas opiniões. É natural, por exemplo, que setores mais impactados por determinada decisão, seja por efeitos financeiros, seja por aumento de cargas de trabalho e de controle, discordem das mudanças. Então, é interessante ter essa noção para que as análises não se baseiem em opiniões genéricas e agregadas e acabem por se distanciar das discussões conceituais e se embasando em números fíctícios e ilusórios.

Em alguns casos o staff decidiu por evidenciar o setor, como, por exemplo, "quase todas as empresas de investimento imobiliário que responderam" (IASB, 2009a, p. 24). Entretanto, a capacidade analítica continua restrita. Se voltamos ao início do relatório, quando quantificam o tipo de usuário respondente, não temos o grupo de empresas de investimento imobiliário, sendo impossível, com as informações disponíveis no relatório, saber a quantidade de empresas e se sua participação é relevante perante o total.

Com base nessas articulações, podemos observar uma certa limitação do produto contábil ao interesse dos atores que se caracterizam como investidores, em especial os institucionais e qualificados. Nesse sentido, continuo a defender que essa limitação de atores demonstra (in)consistências conceituais com os princípios do handbook.

\subsection{Relação do Processo Organizacional com os Princípios}

Passando para a linha 2 do framework (processo organizacional), tenho pontos a levantar principalmente no que concerne à efetiva qualidade do processo e de sua condução. Quando falamos em processo organizacional, naturalmente devemos pensar no handbook e no trabalho do DPOC. Se entendemos que o DPOC é o "guardião" do handbook, temos uma crítica quanto ao seu restrito trabalho reativo com relação ao processo. Em suma, seus relatórios demonstram solicitações de prestações de contas por parte do staff que ocorrem de forma posterior aos eventos. Raros são os eventos em que o DPOC participa.

Demonstrei nas articulações sobre os momentos de mudanças no processo de arrendamento (seção 6.4.1 e suas subseções) que o DPOC não se posicionou de forma a corrigir qualquer denúncia recebida, respondendo com pareceres padrões, e, quando não havia possibilidades, informou que conversaria com os membros do board. Apesar disso, as informações pertinentes a tais “conversas" não tiveram a devida divulgação. Portanto, defendo sua função retórica na validação de um processo por meio da apresentação teórica de boas práticas de governança. 
Além disso, cabe um receio com relação a sua correta atualização no processo normativo. Seus membros possuem outras funções corporativas na organização e a dedicação não é integral, ou seja, o DPOC é um acúmulo de funções de pessoas que já estão inseridas na hierarquia da IFRS Foundation. Dito isto, defendo que questões relacionadas ao acompanhamento acabam por se demonstrar falhas. Por exemplo, no relatório de acompanhamento posterior ao DP, que serve de base para autorizar o IASB a seguir o processo de emissão do ED (IASB, 2010d), o staff utilizou como base para a análise um handbook que, naquela época, já representava uma versão desatualizada. Durante todo o relatório da IASB meeting, cita-se que o staff seguiu o solicitado pelo handbook de 2006, porém em 2010 já havia o handbook de 2008 com emendas aprovadas sobre o handbook de 2006. Identifiquei tal ponto ao verificar os parágrafos que o documento cita (IASB, 2010d). Apesar de não haver grandes diferenças entre os documentos, é relevante notar a citação incorreta, uma vez que o staff pode acabar por se espelhar em documentos ultrapassados, o que demonstra falta de zelo com o próprio processo normativo. O DPOC autorizou, com base nesse relatório, a continuidade do processo sem qualquer ressalva desse tipo.

A análise das comment letters envolve outro passo importante do processo normativo, sendo inclusive integrante dos passos de "cumprir ou explicar" (comply or explain). Esses passos representam aqueles que o board enxerga como mais relevantes e que, se não cumpridos, devem ter o racional do não cumprimento claramente explicado. Entre as obrigações dessa etapa, temos uma que esteve ativa durante todo o processo de arrendamento, que é: "estabelecer os procedimentos para a revisão dos comentários realizados dentro de um prazo razoável" (IASC Fountarion, 2006; IFRS Foundation, 2016b).

O staff afirma e promete que os documentos de feedbacks apresentarão descrições detalhadas das opiniões dos usuários de forma a possibilitar não só a tomada de decisões por parte dos membros votantes do board, bem como o acompanhamento por parte de qualquer interessado. Inclusive após a emissão desses documentos, ele defende o nível de detalhamento:

Consulte o Documento da Agenda 3D da reunião do conselho de janeiro de 2014 e o Documento da Agenda 3A da reunião do conselho de março de 2014 para uma descrição detalhada do feedback recebido sobre o modelo de contabilidade do arrendatário e as razões do IASB para decidir sobre um único modelo de contabilidade do locatário. (DPOC, 2015c, p. 11).

Alguns comentários para desconstruir tal visão já foram demonstrados nesta tese, principalmente a limitação desse "detalhamento" dado que impossibilita, na maior parte dos casos, a capacidade analítica por parte dos interessados. Além disso, esses documentos de feedback, de acordo com as práticas do board, são apenas documentos técnicos que espelham 
resumos das opiniões e não apresentam racionais do board para as decisões tomadas. Como poderiam, então, demonstrar razões para as escolhas?

Esses procedimentos vão além do cumprimento de um prazo. Referem-see a procedimentos a serem realizados que devem ter seu efetivo esclarecimento. Entretanto, além de não haver uma explicação do racional para a análise realizada, diversas foram as críticas já apresentadas nesta tese com relação a inconsistências nesses documentos e a falta de transparência e accountability. Dentre os procedimentos, há a conferência do DPOC, que se mostra extremamente formal, dos seguintes pontos (IASB, 2016a, pp. 8-9):

Passo: - Times dos projetos analisam e sumarizam as cartas-comentários do "request for information" para a consideração do IASB.

- O sumário dos comentários é postado no website.

Métrica de evidência: - Análise dos comentários foi apresentada ao IASB em reunião pública;

- Cartas recebidas foram postadas no website do IASB.

- O IASB considerou os comentários e os ponderou em uma abordagem para o projeto.

Evidência dada ao DPOC: - O IASB relatou o progresso como parte de seu relatório trimestral nas trustee meetings. (IASB, 2016a, pp. 8-9).

Mais uma vez, há destaque ao processo de análise das cartas comentário, compondo um dos passos obrigatórios de um processo normativo e de controle do DPOC, apresentando métricas e evidências para análise do cumprimento. Entretanto, como argumento, o trabalho do DPOC, além de formal, é reativo (intempestivo), atende principalmente sob denúncias e acaba sendo mais simbólico do que efetivo.

Ainda que haja uma obrigação de análise das cartas e da elaboração dos resumos, uma das métricas de evidências é a necessidade de ponderar as abordagens e os comentários recebidos, sendo a evidência apenas uma explicação geral do fato. Considerando que as cartas representam, no discurso formal do board, uma das principais etapas do processo, seriam essas métricas subjetivas suficientes para a comprovação de uma análise de qualidade, que realmente possa subsidiar a tomada de decisão por parte dos membros votantes? Aliás, se é necessário ponderar as opiniões com uma abordagem clara, ouso dizer que o staff, além de não tê-la realizado no caso de arrendamento, também não explicou. Não houve uma efetiva ponderação. A crítica recorrente acerca do uso dos pronomes indefinidos se encaixa aqui também. Não há uma ponderação compreensível e, portanto, não há cumprimento das métricas de evidência. Apenas disponibilizar dados não os torna transparentes.

Especificamente sobre a relação do processo organizacional com a transparência (A2), argumento que a constante subjetividade apresentada nos summaries e demais relatórios do staff acaba por descredibilizar o processo normativo como um todo. Afirma-se, em diversos 
momentos, que o staffé o responsável por resumir e que os membros votantes do board recebem esses relatórios para a tomada de decisões. Como relatórios tão subjetivos e com os diversos vieses que apresentei podem subsidiar decisões que influenciam diversos tipos de usuários nos mais diversos países do mundo?

A subjetividade, ao mesmo tempo que naturalmente contrasta com o discurso constante de tecnicidade do IASB, também pode ser vista como uma forma de contraste ao argumento da transparência. Todavia, afirmo que essa "disparidade" deve ser analisada com cautela. Primeiro, no discurso naturalizado, a subjetividade é uma "porta de entrada" para interferências políticas e, por questões de manutenção da neutralidade, o board preferiria alternativas que levassem à compreensão da objetividade nas escolhas como ponto central para a garantia de decisões técnicas e neutras. Essa é a constatação natural para o conceito em questão.

Apesar disso, proponho uma análise da subjetividade em contraponto com a transparência. A partir do momento em que "esperamos" decisões objetivas, há pontos de entrada subjetivos no processo, de modo que tais pontos devam ser melhor justificados e que seja dada "mais transparência" (se é que é possível trazermos a lógica de "advérbio de intensidade" para um termo que se propõe como completo) aos documentos e a qualquer informação envolvida no processo de tomada de decisão. Isso porque o órgão deveria "garantir" sua objetividade ao mostrar que as "entradas" subjetivas no seu processo foram realizadas com o maior zelo possível, a fim de assegurar as fantasias da qualidade processual e da transparência. Mas será que as entradas subjetivas no due process (que são muitas) possuem uma carga de justificação condizente com o esperado?

Não é de grande interesse da lógica pós-estruturalista a análise e quantificação de palavras utilizadas, mas nesse caso, devo ressaltar que minha análise dos pronomes indefinidos não recai sobre a palavra em si, mas sim sobre a inconsistência nos seus usos. No caso, podemos observar argumentos de opiniões contraditórias que utilizam pronomes distintos, conforme Figura 38. 
Figura 38 - Usos dos pronomes indefinidos nos documentos formais de feedback de consulta

\begin{tabular}{|c|c|c|}
\hline Opinião que concorda & Opinião contrária & Citação \\
\hline $\begin{array}{l}\text { Quase todos os respondentes disseram } \\
\text { (nearly all respondents said) }\end{array}$ & $\begin{array}{l}\text { Vários respondentes suportaram } \\
\text { (several respondents suported) }\end{array}$ & $\begin{array}{l}\text { (IASB, 2009a, } \\
\text { p. 12) }\end{array}$ \\
\hline $\begin{array}{l}\text { A maioria dos respondentes suportou } \\
\text { (the majority of respondents supported) }\end{array}$ & $\begin{array}{l}\text { Vários respondentes não suportaram } \\
\text { (several respondents did not supported) }\end{array}$ & $\begin{array}{l}\text { (IASB, 2009a, } \\
\text { p. 13) }\end{array}$ \\
\hline $\begin{array}{l}\text { Mais da metade dos respondentes suportam } \\
\text { (more than half of respondents sopported) }\end{array}$ & $\begin{array}{l}\text { Alguns respondentes se opuseram } \\
\text { (some respondentes opposed })\end{array}$ & $\begin{array}{l}\text { (IASB, 2009a, } \\
\text { p. 15) }\end{array}$ \\
\hline $\begin{array}{l}\text { A maioria dos respondentes suportou } \\
\text { (most respondents supported })\end{array}$ & $\begin{array}{l}\text { Alguns respondentes argumentaram } \\
\text { (some respondents argued) }\end{array}$ & $\begin{array}{l}\text { (IASB, 2009a, } \\
\text { p. 15) }\end{array}$ \\
\hline $\begin{array}{c}\text { Muitos respondentes discordam } \\
\text { (many respondentes disagree) }\end{array}$ & $\begin{array}{l}\text { A maioria dos respondentes concordou } \\
\text { (the majority of respondentes agreed) }\end{array}$ & $\begin{array}{l}\text { (IASB, 2009a, } \\
\text { p. 16) }\end{array}$ \\
\hline $\begin{array}{l}\text { Quase todos os usuários ajustam } \\
\text { (almost all users make adjustments) }\end{array}$ & $\begin{array}{c}\text { Alguns usuários não ajustam } \\
\text { (some users do not make adjustments) }\end{array}$ & $\begin{array}{l}\text { (IASB, 2011, } \\
\text { pp. 7-8) }\end{array}$ \\
\hline $\begin{array}{l}\text { A minoria dos respondentes suporta } \\
\text { (the minority of respondents supported) }\end{array}$ & $\begin{array}{l}\text { Quase todos os respondentes expressaram } \\
\text { preocupações } \\
\text { (almost all respondents expressed concerns) }\end{array}$ & $\begin{array}{l}(\mathrm{IASB}, 2011 \\
\quad \text { p. } 24)\end{array}$ \\
\hline $\begin{array}{l}\text { Muitos daqueles consultados concordam } \\
\text { (many of those consulted agree) }\end{array}$ & $\begin{array}{c}\text { Alguns analistas imobiliários levantaram } \\
\text { preocupações } \\
\text { (some equity analysts noted concerns) }\end{array}$ & $\begin{array}{l}(\mathrm{IASB}, 2013 \mathrm{e}, \\
\text { p. } 4)\end{array}$ \\
\hline $\begin{array}{l}\text { Muitos constituintes, incluindo a maioria } \\
\text { dos investidores e analistas, concordam } \\
\text { (many constituints, including the majority of } \\
\text { investors and analysts, agree) }\end{array}$ & $\begin{array}{l}\text { Muitos outros constituintes discordam } \\
\text { (many other constituents disagree) }\end{array}$ & $\begin{array}{l}(\mathrm{IASB}, 2013 \mathrm{f}, \\
\text { p. } 2)\end{array}$ \\
\hline $\begin{array}{l}\text { Muitos constituintes suportam } \\
\text { (most constituents support) }\end{array}$ & $\begin{array}{l}\text { Uma maioria dos constituintes, entretanto } \\
\text { (a majority of constituents, however) }\end{array}$ & $\begin{array}{l}\text { (IASB, 2013f, } \\
\text { p. 5) }\end{array}$ \\
\hline $\begin{array}{l}\text { A maioria dos constituintes discorda } \\
\text { (the majority of constituents disagree) }\end{array}$ & $\begin{array}{l}\text { Alguns constituintes apoiam modificar } \\
\text { (some constituents support changing) }\end{array}$ & $\begin{array}{l}\text { (IASB, 2013a, } \\
\text { pp. 5-17) }\end{array}$ \\
\hline $\begin{array}{c}\text { Muitos constituintes concordam } \\
\text { (many constituents agree) }\end{array}$ & $\begin{array}{l}\text { Muitos outros não comentaram } \\
\text { (many others did not comment) }\end{array}$ & $\begin{array}{l}\text { (IASB, 2013a, } \\
\text { p. 8) }\end{array}$ \\
\hline $\begin{array}{l}\text { Muitos constituintes apoiam com a decisão } \\
\text { do board } \\
\text { (many constituents support the boards' } \\
\text { decision) }\end{array}$ & $\begin{array}{l}\text { Uma maioria dos constituintes discorda } \\
\text { (a majority of constituents disagree) }\end{array}$ & $\begin{array}{l}\text { (IASB, 2013a, } \\
\text { pp. 12-13) }\end{array}$ \\
\hline $\begin{array}{l}\text { A maioria dos constituintes levantaram } \\
\text { pontos } \\
\text { (the majority of constituents had concerns) }\end{array}$ & $\begin{array}{l}\text { A maioria dos constituintes apoia } \\
\text { (the majority os constituents support) }\end{array}$ & $\begin{array}{l}\text { (IASB, 2013a, } \\
\text { pp. 19-21) }\end{array}$ \\
\hline $\begin{array}{c}\text { Muitos constituintes suportam } \\
\text { (many constituents support) }\end{array}$ & $\begin{array}{l}\text { Muitos constituintes discordam } \\
\text { (many constituents disagree) }\end{array}$ & $\begin{array}{l}\text { (IASB, 2013a, } \\
\text { p. 35) }\end{array}$ \\
\hline
\end{tabular}

Fonte: Elaboração própria.

A análise desses pronomes é falha principalmente quanto à transparência. É notória a presença do uso de pronomes indefinidos quando se sumarizam os comentários do board, sem que saibamos quais os "pesos" de cada medida dada pelo board, nem mesmo se eles sabem os pesos dessas medidas ou não. Por exemplo, temos diversos trechos com os seguintes termos: aproximadamente metade dos respondentes; o restante dos respondentes; a maioria dos respondentes; muitos respondentes; um número de respondentes; quase todos os respondentes; alguns respondentes; outros respondentes.

Ressalto que o uso dos pronomes indefinidos apresenta limitações do processo normativo com todos os princípios do handbook (A2, B2, C2). O primeiro ponto a se criticar quanto ao uso dos pronomes é sua inconsistência interna. Não há qualquer métrica de comparação entre eles, sendo impossível ao leitor ter vestígios efetivos da direção das opiniões 
dos respondentes. Na Figura 38 apresento diversos momentos em que pronomes iguais são utilizados de modo diferente nos mais diversos contextos e a ambiguidade na utilização dos pronomes que "contrastam" opiniões. Ao analisar tal ponto, reafirmo a baixa qualidade dos relatórios de feedback do processo e levanto preocupação, pois estes são os documentos que o staff formalmente encaminha aos membros votantes do board para que esses membros tomem suas decisões acerca dos rumos do projeto. Seriam essas informações, subjetivas e ambíguas, suficientes para a tomada de decisões?

Ao imaginarmos que existe uma lógica em seu uso, mais uma vez percebemos que não. Ao observar a figura anterior, podemos pensar que, ao contrastar as opiniões, teríamos um percentual total de $100 \%$. Isso seria dizer que se "somássemos" os pronomes que concordam com os que discordam, teríamos a totalização das respostas. Entretanto, a miscelânia no uso desses pronomes impede tal fato, já que diversas vezes combinações de pronomes dos que concordam e discordam são inconsistentes entre si. Outro ponto a se observar na Figura 38 é a criação de valores ao utilizar, em certos momentos, o tipo de usuário ou trazer como "mixed" posições em que a divergência com o board é aparentemente superior.

É ilusório e ingênuo pensarmos que não é possível quantificar as opiniões de forma a aumentar a transparência e a accountability dos processos de consulta. Além de possuir um staff para a realização desse trabalho, o board, em momentos, realiza essa quantificação. Por exemplo: "analistas de duas agências de crédito estão interessados" (IASB, 2013a, p. 9). O interessante desse raro momento de quantificação é que ele acompanha um argumento que o board não considerava incluir na norma. Assim, ao citar que apenas dois usuários demandaram aquele ponto, há uma desvalorização da demanda. Não se sabe qual é o objetivo dos momentos de quantificação, já que são escassos, mas tanto a escassez de objetividade quanto os momentos de subjetividade nos levam a crer que isso auxilia no processo de articulação em prol dos anseios do próprio staff.

Outro exemplo em que o board adota a subjetividade, diminuindo a possibilidade de transparência, por exemplo: "aproximadamente 45 reuniões"; "aproximadamente 25 trabalhos de campo". Vejamos, esses são dados que a entidade possui. O staff sabe quantas reuniões e trabalhos de campo foram realizados formalmente. Por qual motivo não cumprir a exigência de transparência do processo normativo e informar o número exato?

Perceba que o meu ponto de crítica acerca do uso de subjetividades por meio dos pronomes indefinidos vai além da falta de transparência e accountability da informação, mas sim leva ao questionamento: como uma informação tão incerta, contraditória e inconsistente pode servir para subsidiar a tomada de decisões de um passo de consulta que é considerado o 
mais importante do processo e que dá toda a validação "externa" do próprio processo organizacional?

Ainda falando em subjetividades, interessante notar que há uma grande crítica (do próprio IASB) que motiva a demonstração de defeitos da IAS 17 exatamente em torno a subjetividade na classificação:

A norma [IAS 17] define um arrendamento financeiro como aquele em que se transferem 'substancialmente todos os riscos e benefícios oriundos da propriedade'. Apesar de a norma definir alguns indicadores de quando o arrendamento é financeiro, ela não provê testes objetivos na determinação do ponto em que o critério do 'substancialmente todos' é cumprido. (IASB, 2006a, p. 6).

$\mathrm{O}$ argumento realmente é válido, porém ao mesmo tempo em que há a crítica à subjetividade na norma, há utilização das mesmas palavras durante o processo, replicando, portanto, essa mesma subjetividade ao processo que, como eles dizem, deveria ser auditável por todo e qualquer interessado. A subjetividade dos pronomes indefinidos não é observada apenas quando se fala acerca da opinião dos “usuários". Em diversos documentos formais não há o comprometimento do board e as palavras utilizadas são subjetivas de forma a não delimitar as ações do board, por exemplo: "é possível desenvolver uma norma completa sobre leasing dentro de um prazo razoável" (IASB, 2006d, p. 5).

Com isso, ao falar sobre a relação consulta completa e justa e processo organizacional (B2), defendo que quando o board afirma que "considerará todos os feedbacks" (IASB, 2010c, p. 11) recebidos ele está sendo demagogo por vários enfoques. Primeiro, o board tende a silenciar os questionamentos ou comentários que são realizados e que não seriam respostas diretas aos questionamentos que ele mesmo realiza. Segundo, apresentar informações agregadas e com restrita capacidade analítica por parte de agentes externos não representa uma discussão "completa" como se afirma. Terceiro, o próprio board afirma que realiza reuniões informais (IASB, 2009a, p. 10), porém não há registros das discussões. Seria isso transparente? Além disso, seria isso justo? Realizar reuniões informais com grupos específicos não os privilegiaria?

Já quando falamos da relação accountability e processo organizacional (C2), a técnica é uma palavra que representa bem esta etapa, pois, na opinião do board, seu processo envolve neutralidade e expertise na condução das decisões. A técnica, portanto, é articulada como um signo que garante qualidade ao processo (Macintosh, 2002) e pode ser chamada de "ideologia prática" no mundo contábil, algo que o mercado valoriza e entende como a melhor forma para realizar normas para os diversos públicos (Botzem \& Quack, 2009). 
Contudo, a técnica demonstra algumas inconsistências com decisões do processo normativo. Primeiro devemos entender o papel social da contabilidade no contexto dos negócios e, principalmente, o papel da regulação nesse mesmo contexto. Seria a contabilidade uma ferramenta a ser considerada ativa na forma como os negócios são dirigidos? Ou seria ela mais importante para a análise tempestiva, porém posterior, aos eventos oriundos das operações tradicionais do mercado? Encontramos uma presença da definição do objetivo da contabilidade mais semelhante ao que se questiona na segunda pergunta.

Entretanto, um dos pontos de crítica com relação à accountability do processo de arrendamentos é com relação aos efeitos que essa norma pode ter no modelo de comercialização dessas operações. Na justificativa para a mudança normativa, o IASB informa que os arrendamentos representam operações significantes no mercado internacional, em especial na Europa e nos EUA. Em alguns momentos do processo normativo, há críticas que direcionam ao entendimento de que a mudança normativa do arrendamento da forma como se propõe pode modificar a estrutura das operações de arrendamento, como: "muitos arrendadores expressaram preocupações que arrendatários irão adquirir ao invés de arrendar ativos, especialmente arrendatários de alta qualidade de crédito" (IASB, 2013a, p. 63).

Nesse caso, a contabilidade passa de um papel reativo de informar eventos para o papel de direcionar as forças de mercado e os modelos de comercialização. Apesar dessa crítica, que está inclusive em desacordo com o objetivo do próprio board quando fala em regulação, não há pronunciamento formal nos documentos de arrendamento acerca do papel do IASB nesse cenário. Entretanto, se pensarmos de forma menos contemporânea, no momento da regulação da SFAS 13 e IAS 17, ao haver possibilidade de um modelo duplo de contabilização, a contabilidade também acabou por exercer um papel ativo, direcionando a forma contratual dos arrendamentos para que os arrendatários pudessem classificar as operações da forma mais conveniente. Com isso, percebemos que a proposta normativa está apenas replicando algo que a norma do mesmo tema já fez no passado e que, na opinião do board, não deu certo por gerar a estruturação das operações. No entanto, o que garante que não haverá estruturações de novas operações para suprirem aos critérios da nova norma?

Portanto, o questionamento é: mesmo mudando o modelo, o board continua com o padrão de editar uma norma que terá efeitos sobre a comercialização daquela operação e, como efeito, as empresas tenderão a estruturar as operações de forma a esquivar dos efeitos negativos dessa norma. Por qual motivo persistir no mesmo comportamento? Essa resposta não tivemos no processo de leasing, em que não há pronunciamento, ao menos nos documentos formais, acerca do papel que o board pode trazer para essas operações. Há, inclusive, a apresentação por 
parte de respondentes, de pesquisas que demonstram que as operações de arrendamento serão amplamente impactadas (Biondi et al., 2011). Considerando uma possível diminuição da relevância dessas operações no mercado, o board entraria em contradição, uma vez que um dos argumentos para a mudança da norma é exatamente a relevância dessas operações nos mais diversos mercados. Infelizmente, não houve accountability em tal ponto.

Aliás, a accountability do processo organizacional deveria funcionar como a estratégia de prestação de contas do processo normativo em si. Nesse sentido, os documentos públicos formais seriam os que melhor representam essa etapa de análise, em especial os summaries das etapas de participação pública, já que, em teoria, resumem a opinião dos respondentes de forma a subsidiar as decisões do board e a justificar o processo como sendo mais participativo e inclusivo.

No processo de arrendamentos temos três principais summaries, que são os resumos das etapas dos: DP/2009/1, ED/2010/9 e ED/2013/6. À primeira vista, a crítica vem em formato da falta de tecnicidade que o board tanto prega de forma ilusória. Esses relatórios representam o alegado arcabouço técnico elaborado pelo technical staff. Os membros votantes do board não realizam a leitura e análise de todas as cartas recebidas e possuem uma função mais comercial de apresentar o IASB internacionalmente. A função mais operacional é direcionada ao staff técnico, que deve prover os membros com a informação mais técnica possível para a tomada de decisões. Por tecnicidade, entendemos uma informação completa, fidedigna e neutra que espelhe exatamente os reflexos do processo de consulta.

Entretanto, observamos summaries sem essa alegada tecnicidade e caracterizados por serem genéricos sem aprofundamento das opiniões obtidas na consulta. Por exemplo, além das subjetividades já citadas, temos incertezas sobre a origem dos membros, o cruzamento de setores com localidades dos respondentes e sobre efetivamente o nível de concordância/discordância acerca dos critérios propostos. Não se pode alegar que há disponibilização das comment letters, pois elas, principalmente no projeto de leasing, foram quantitativamente muito relevantes, o que inviabiliza que qualquer interessado possa efetivamente analisar as cartas. A disponibilização, então, representa apenas um critério de transparência, porém sua função efetivamente é mais a de cumprir o critério do que prover informação aos interessados. Isso faz com que a disponibilização seja, na prática, uma retórica e uma estratégia simbólica de representação das boas práticas de governança.

Considerando, portanto, que os summaries possuem essa função de efetivamente conferir a transparência às cartas que não é dada por sua mera disponibilização, a importância 
daqueles se torna maior na prestação de contas (accountability) do processo, o que exigiria uma boa qualidade de informação aos interessados. Entretanto observamos falhas nessa prestação de informações. Inicialmente, de acordo com o handbook, as opiniões que compõem os summaries representam opiniões das cartas recebidas e de outros processos de consulta (até mesmo informais) que possam ter sido realizados pelo board. Apesar disso, em nenhum momento dos summaries essa informação é dada, nem mesmo se há a incorporação de outras etapas de consulta no processo nem qual o peso dado a essas etapas. No caso de arrendamento, os summaries começam apresentando a quantidade de comment letters por setor recebidas e suas orientações geográficas, sem qualquer cruzamento de informações. Após isso, já começam análises das respostas e não sabemos se envolvem outras consultas ou não.

Será que apenas esse tipo de informação genérica já satisfaz as necessidades dos membros do board para tomar uma decisão "técnica" e "neutra" baseada na efetiva opinião dos respondentes? Além disso, a não segregação de posicionamentos por setores é algo limitador, principalmente para arrendamentos, em que cada setor é impactado de forma diferente. Caso alguma segregação a mais seja feita aos membros do board, isso estaria em desacordo com o que se fala no handbook. A informação genérica é exatamente o que o board critica na norma anterior de leasing, dizendo que não pode continuar por ser subjetiva, arbitrária, artificial e que cria possibilidades de estruturação de compreensões.

Além do uso de pronomes indefinidos, o board ainda possui outros condicionantes para a análise de interessados externos. Por exemplo: "a maioria dos respondentes que comentaram sobre a exclusão de arrendamentos de curto prazo" (grifo pelo autor) (IASB, 2009c, p. 7). A limitação apenas aos respondentes "que" comentaram traz mais subjetividade, pois não sabemos quantos são os que comentaram e fica ainda mais difícil prever o significado de "maioria", sendo que essa maioria pode ser extremamente não representativa da população.

Outro ponto é que não se explica como os respondentes efetivamente construíram suas cartas. Pessoas com maior conhecimento do processo ou que já analisaram as cartas compreendem a complexidade dessa análise. O board solicita respostas a perguntas específicas, sem grande abertura para opiniões mais diversas. Entretanto, diversas são as variações que podem ser encontradas nas respostas, como por exemplo: cartas que não possuem resposta a todas as perguntas; cartas que não respondem perguntas, mas realizam um tex to contínuo; cartas com críticas ao próprio board; entre outros. Em suma, falta uma informação efetiva que limita a transparência e a accountability da análise no que diz respeito a como essas cartas foram tratadas e analisadas. 
Por fim, ainda sobre accountability e processo organizacional (C2), argumento sobre a ferramenta de controle "técnico" de qualidade do processo, que é o DPOC. Quando falo em processo organizacional, relaciono com o próprio processo normativo. Além da burocratização existente que deve ser acompanhada pelo DPOC, temos itens de menos formalidade, mas que constituem o processo. Para quem acompanhou o projeto juntamente com seu andamento, houve diversos ajustes em seus cronogramas e atrasos das mais diversas naturezas. Entretanto, ao se consultar os documentos disponíveis atualmente no website, verifica-se que os cronogramas foram suprimidos (normalmente com o texto: "omitido das notas aos observadores" (IASB, 2006c)). Essa edição e omissão da informação diminui a transparência e pode levar o interessado a diferentes conclusões, como a de que o processo não teve atrasos.

Sabemos que houve atrasos na edição da norma, que era prevista para ser editada em 2011, porém somente foi editada em 2016. Isso por si só não é um problema nem uma inconsistência, uma vez que o processo sofreu mais críticas externas do que o esperado. Entretanto, o fato de silenciar tal fato traz à tona a questão relacionada com a transparência. Contemporâneos desse processo entendem que houve diversas modificações e conflitos, sem um consenso acerca de conceitos e do andamento político do processo, mas e daqui uns anos? Os profissionais da contabilidade saberão o contexto de criação da norma ou apenas a replicarão sem habilidade crítica e sem questionar a validade efetiva da norma com o desenvolvimento das operações de arrendamento?

Após citar em alguns momentos as denúncias encaminhadas ao DPOC, devemos refletir sobre a retoricidade do seu funcionamento que pode ser observada por meio das respostas. Apesar de ser um órgão teoricamente independente na estrutura da IFRS Foundation, podemos observar um certo corporativismo por parte dos membros acerca do tratamento das denúncias, já que formalmente não se pode observar nenhuma medida tomada acerca da denúncia a um dos princípios do due process. A resposta normalmente inclui um tom personalístico ao órgão de promessas que não podem ser verificadas, inclusive mitigando a transparência e accountability do processo: "Eu quero assegurá-los de que os Trustees recebem atualizações regulares acerca do projeto de arrendamentos. Eu sei que os membros do IASB levam a sério suas responsabilidades de empreender e comunicar uma análise completa e ponderada" (DPOC, 2012c, p. 6).

Devo lembrar que o DPOC funciona como estratégia de aceitação que visaria a aumentar a qualidade do processo normativo, inclusive fazendo parte como lógica social de boas práticas, 
mas as justificativas práticas são muito simplistas perto do que o órgão se propõe a ser como agente de controle.

A incompletude do processo de aplicação dos princípios também é perigosa quando nos restringimos ao acesso aos documentos principais (normas finais) em que tendemos a acreditar nos argumentos gerais lá apresentados. Acreditamos porque aceitamos os normatizadores como “soluções ótimas" para a regulação e não questionamos o escrito. No final do processo o board insiste em dizer que a nova norma passou por "extenso e completo processo de consulta" (IASB, 2016d, p. 6) e que diversos feedbacks foram recebidos. Além disso, afirma que a "nova norma de arrendamentos foi submetida a múltiplas mesas redondas com consulta pública e extensivo processo de deliberação do conselho, todos tendo sido conduzidos de forma pública e por meio de webcasts" (IASB, 2016f, p. 2).

Primeiro devemos entender que a participação nessas mesas redondas, webcasts e em alguns processos de consulta do board é paga, o que retira o caráter público propriamente dito da palavra. Podemos dizer que pode haver ampla ou diversa participação, mas pública é perigoso. Além disso, muitas das consultas são realizadas com públicos específicos e de forma não rastreável. Algumas dessas seções possuem atas, mas outras não. Em segundo lugar, realizar ampla consulta e receber múltiplos feedbacks por si só não garante que essa consulta tenha sido respeitada e que os feedbacks tenham sido atendidos. Então há uma valorização do processo amplamente formal e que não obrigatoriamente se mostra efetiva na prática. Isso é temerário, uma vez que os usuários gerais não tendem a questionar o fato de terem sido limitadamente informados pelo board. Esse é um impacto direto da (in)completude ao princípio da accountability no processo.

\subsection{Relação do Conteúdo da Norma com os Princípios}

A relação final, que é a do conteúdo da norma com os princípios (linha 3), envolve os aspectos já discutidos anteriormente. Por exemplo, quando falei sobre o uso de pronomes indefinidos nas respostas dos summaries, indiretamente estou falando do conteúdo, já que as respostas são com relação ao conteúdo. Além disso, as análises das inconsistências que envolvem conteúdo foram detalhadas na seção anterior (6.4.1- Análise dos Principais Discursos de Mudanças: Explicitação das Contradições).

Nas análises desta tese, identifiquei que, enquanto a ferramenta de valorização dos atores envolvidos implica "consulta participativa aos constituintes" e a ferramenta do processo implica "tecnicidade", a ferramenta valorização do conteúdo da norma é a "expertise". Alegar 
expertise é uma forma de se diferenciar e demonstrar que seus produtos são exclusivos e outra organização não seria capaz de alcançar, ou seja, a estratégia de auto diferenciação se torna eficiente quando se fala na criação de conteúdos (Shafer \& Gendron, 2005).

Aliar a expertise à articulação com base na tecnicidade e na objetividade faz com que, ao menos naquele momento, não haja uma condição de críticas quanto a outros pontos de vista, uma vez que aqueles conceitos foram construídos no intuito de demonstrar que apenas o "detentor do discurso" seja capaz de compreender e construir tal lógica (Laclau, 2007a). Assim, surge a argumentação política também baseada na expertise (Warren et al., 2019). Entretanto, no caso da regulação contábil, essa expertise é reiterada por meio de uma prática de autorregulação, que, por sua vez, envolve o fato de que o próprio board avalia sua própria expertise.

Há ainda um discurso poderoso que é o de transformar a própria profissão contábil em tecnocrata. Ao silenciar as discussões sobre conteúdo da norma do processo, a mensagem que os contadores (que são os que realmente aplicam a norma, ou seja, os reais práticos da profissão) recebem é a de que a norma final é a melhor opção; que não há discussão e que ela deve ser aplicada sem vieses. Transformar essa ponta da profissão em tecnocracia auxilia no processo político ao evitar uma quantidade de demandas, críticas e antagonismos políticos que poderiam existir em uma população mais crítica. Essa é a premissa argumentada por Mouffe (2015) como estratégia de organizações com uma visão mais liberal que tentam perpetuar seus discursos por meio da criação de ilusões de tecnicidade de forma a silenciar a política e amparar as bases técnicas como sendo em prol de todos.

Quando falamos em transparência (A3) e consulta (B3), devemos pensar que as propostas de conteúdo trazem a visão oposta, vista como "opiniões dissidentes" pelo board. A escolha de racionais para a prestação de contas da opinião dos usuários também possui seu viés. Quando as opiniões são alinhadas à opinião dos boards, há sempre a defesa de que "a maioria concorda", ou "muitos concordam". Já em momentos contrários, percebam a diferença na argumentação: "a minoria dos respondentes suporta os conceitos relacionados com o modelo contábil das arrendadoras, notando que essa abordagem é: (a) razoavelmente consistente [...]; (b) apropriadamente baseada em uma avaliação em que os arrendadores possuem exposição aos riscos [...]" (IASB, 2011, p. 24). O board desmerece os respondentes que discordam do modelo na medida em que sequer os cita. Prefere citar que "a minoria" concorda do que citar que a "maioria discorda". Além disso, acaba enfatizando as opiniões dos que concordam e mostrando os pontos positivos elencados por esses respondentes. 
Esse direcionamento para a interpretação, além de representar uma estratégia incoerente com as práticas de transparência e accountability prometidas, enviesa qualquer interpretação, inclusive a daqueles membros que possuem o poder de voto para a decisão normativa. Ressaltar pontos de concordância, mesmo que em minoria, e discutir os pontos positivos apresentados por essa minoria (na contramão do que é realizado quando há concordância) é uma clara presença da ausência de neutralidade e da influência de interesses políticos sombrios no processo.

De acordo com o handbook, é obrigação do IASB apresentar toda e qualquer opinião dissidente. Entretanto, a mudança de critérios nessa apresentação desfavorece a maioria que discordou de tal ponto. Em seguida, o documento (IASB, 2011, p. 24) afirma que "quase todos [almost all] os entrevistados expressaram preocupações em relação à abordagem proposta". Veja a diferença. Normalmente o board afirma as opiniões dissidentes (quando minoria) como “alguns discordam", "a minoria discorda", ou seja, utiliza a palavra discorda que, juntamente com pronomes indefinidos que remetem a um "pequeno grupo", valoriza o próprio board. Já nesse caso, que houve maior discordância, o board preferiu utilizar "expressam preocupações", um tom que ameniza as discordâncias e faz a dissidência parecer apenas uma preocupação (veja a diferença no uso das descrições na Figura 38). Todavia, o uso das palavras é muito diferente. Preocupações demandam esclarecimentos, discordância demanda mudança.

Esses pontos foram recorrentes nas argumentações sobre: (i) a necessidade de uma mudança normativa para leasing; (ii) o reconhecimento das operações de leasing; (iii) simetria na contabilização das arrendadoras e arrendatárias; já discutidos em seção anterior.

Além desses pontos citados, demonstro apenas uma simples ambiguidade de accountability do conteúdo (C3). O board reitera nos documentos, inclusive na norma final (IFRS 16), que abordagem decidida para as arrendatárias na norma foi a de que todos os arrendamentos são vistos como aquisição de um direito de uso. Entretanto, como já demonstrei, há exceções. Ainda assim, o board insiste em utilizar os termos "all lease contracts". Esse uso incorreto do "todos" gera uma ambiguidade que não existe. Se há exceções, não são todos. E as exceções não são pequenas. Se considerarmos que os antigos arrendamentos operacionais têm uma natureza, na essência, que pode envolver trocas de equipamentos para a manutenção tecnológica dos arrendatários, por exemplo, grande parte dos arrendamentos seria classificada nas exceções (curto prazo e valor imaterial).

Essas exceções, portanto, geram um confronto com a principal crítica à norma anterior (IAS 17), que é a possibilidade de estruturação de operações. Mesmo estando ciente dessas possibilidades e da rearticulação do mercado de arrendamentos para se aproveitar da nova 
brecha da norma, o board não destaca tal ponto e insiste em criar a ambiguidade de afirmar que todos os contratos de arrendamento serão capitalizados. Isso é feito para que se mantenha o discurso político da capitalização, que era a argumentação central para a entrada na agenda e criação de uma nova norma de arrendamentos.

Não há uma economia em afirmar que o modelo atual é inconsistente com outras normas/projetos em desenvolvimento: "a norma atual [IAS 17] oferece informações que são inconsistentes com normas mais recentes e não oferece ao usuário uma informação transparente e útil” (IASB, 2006c, p. 13). Essa era uma crítica anterior, acerca do modelo de classificação, que foi modificada. Entretanto, para as arrendadoras voltou ao estágio inicial, que era inconsistente com outras normas. Nesse sentido, a accountability falhou em explicar o motivo de tal inconsistência não ter sido tratada com relação ao conteúdo da norma.

Já em relação ao conteúdo em si - não tanto ao processo - devemos entender que a inconsistência entre a visão de subjetividade versus objetividade também se faz presente. $\mathrm{O}$ board diz que prefere objetividade nas decisões, por isso busca normas mais claras, porém, ao mesmo tempo, a subjetividade que leva a uma habilidade do julgamento profissional é uma das premissas das IFRSs para se afastar do padrão de normas baseadas em regras. Entretanto, assim como nas respostas dadas aos argumentos das comment letters, o board possui tais subjetividades, como: virtually certain, reasonably certain, probable e more likely than not.

O próprio board entende que não há um conceito claro que delimita tais "métricas". Visão semelhante pode ser dada aos pronomes indefinidos. Assim, não temos a base de transparência nem de accountability com relação à opinião dos respondentes quanto ao conteúdo da norma.

Portanto, mesmo havendo mudanças, críticas que eram norteadoras para o discurso da necessidade de mudanças não foram tratadas de forma a serem dirimidas. Dessa maneira, temos um silenciamento de tais pontos no intuito de não desvalorizar as mudanças que foram realizadas. Assim, quando o board apresentou racionais e teve sucesso nas mudanças, defendeu tais racionais. Naqueles em que retornou ao estágio inicial, a algo semelhante ao modelo e às críticas anteriores, o silenciamento e a criação de ambiguidades sobre o conteúdo da norma tomou lugar, criando um discurso político acima da ilusão e fantasia da qualidade da norma, que é amplamente pregada na defesa do processo do board. 


\section{CONSIDERAÇÕES FINAIS}

“Não comemore as palavras por antecipação, aguarde as ações. ” (Carpinejar)

Inicialmente gostaria de apresentar um pensamento, que circundou a elaboração desta tese, acerca da nossa função como pesquisadores sociais, em que nos ausentamos

e nos tornamos cúmplices em relação às reformas sociais, especialmente quando elas são associadas com ideais de maior transparência ou accountability, nos levando a sentimentos de culpa e vergonha se nos opomos ou somos transgressivos. Isso, por consequência, age de forma a 'conter' nosso impulso por protestar. (Glynos \& Howarth, 2007, p. 177)

Com base nesse pensamento, entendo esta pesquisa como sendo um antagonismo ao status quo de aceitação direta das normas internacionais editadas pelo IASB e à naturalização de sua qualidade inquestionável, completa, neutra, justa e que representa as demandas dos mais diversos atores envolvidos na normatização contábil internacional. Por isso, durante a pesquisa objetivei, além de descrever o processo normativo do IASB com base em lógicas sociais, políticas e fantasmáticas, analisar momentos em que há (in)completude e (in)consistências na aplicação dos princípios do due process handbook durante a condução deste processo.

Esse antagonismo, ao demonstrar pontos de (in)completude e (in)consistências, pode ser visto, como citei anteriormente, como uma transgressão ou uma simples crítica opositiva. Entretanto, argumento que é exatamente nesse ponto que contribuo com um trabalho que analisa o processo normativo contábil internacional sob um paradigma distinto do mainstream. Com essa visão epistemológica distinta temos a capacidade de enxergar o fenômeno sob uma ontologia também distinta e, a partir disso, realizar críticas que são vistas como naturalizadas em um processo de análise. Nesse caso, ao questionar a construção discursiva do processo do IASB, somos capazes de desconstruir os discursos e analisar se a prática realmente aplicou os momentos construídos por meio de discursos formais.

Resumo bem este esforço realizado na tese com o pensamento pós-estruturalista. Nesta tese, portanto, “não há uma rejeição por completo das coisas/conceitos, mas sim um esforço contínuo de desconstruir as verdades construídas por meio de discursos ao longo do tempo, desfazendo 'seus postulados exclusivistas de verdade e pureza' característicos de um pensamento de "senso comum"' (J. Williams, 2013, p. 23).

Como pesquisadores de paradigmas mais críticos devemos entender que, por mais que haja oposição, é nosso papel discutir práticas sociais que, muitas vezes, são vistas como naturais, porém envolvem a política tanto em nível ontológico como ôntico (Mouffe, 2015). Para a consecução da pesquisa por meio desse nível ôntico, utilizei-me de conceitos 
desenvolvidos pela teoria pós-estruturalista do discurso (Laclau \& Mouffe, 1985) - em especial o de significantes vazios e os das lógicas sociais, políticas e fantasmáticas - como fio condutor da análise do processo normativo do IASB.

Quando se constrói um significante vazio, podemos dizer que há um momento de condensação e sobredeterminação de sentido. Como consequência, diversas demandas se encaixam num mesmo sentido, ainda que antagônicas. Após a prática, pode acontecer a ruptura, ou seja, um momento em que as demandas particulares não se sentem mais representadas pela universalização do significante vazio. A partir disso, a construção de lógicas fantasmáticas por parte do agente hegemônico se torna uma ferramenta de grande importância. Isso é o que procuro mostrar na tese: momentos em que houve escolhas nas quais as demandas não se encaixavam numa sobredeterminação construída e estratégias para garantir a hegemonia, mesmo após tais momentos de ruptura. Dito de outra forma, particularidades que não cabiam mais no universal do significado dos princípios e estratégias de defesa de tais particularidades. Essa é a lógica da não fixação dos significados, já que eles devem ser constantemente rearticulados de forma a agregar as demandas particulares.

Com o amparo em uma ontologia que enxerga a política como essencial e intrínseca nos mais diversos fenômenos, utilizo-me da Lógica da Explicação Crítica (LEC) para explicar o fenômeno da normatização do IASB. Por meio dessa visão metodológica, somos capazes de demonstrar a ilusão da dicotomia entre a alegada tecnicidade - vista como pureza em um processo neutro - e a política - vista como uma impureza. A explicação se torna mais efetiva se realizada de modo empírico. Então selecionei o projeto normativo da IFRS 16, principalmente por envolver grande quantidade de mudanças e polêmicas nos dez anos em que foi formalmente discutido. As mudanças são essenciais para que se possa desconstruir discursos políticos de forma a mostrar possíveis (in)consistências.

$\mathrm{Na}$ minha explicação crítica, trato como as principais problematizações a dicotomia do discurso técnico-político e o amparo na alegada expertise atingida por meio de um discurso de atomização e independência do IASB como regulador internacional. Para isso, cumpri a primeira parte do objetivo ao reconstruir o processo por meio das lógicas sociais da financialização, atomização/independência, boas práticas, constituintes e expertise. Para auxiliar nessa explicação e aplicando ao processo da IFRS 16, identifiquei os cenários de mudanças que funcionam como lógicas políticas, que são os discursos: da essência sobre a forma; da necessidade de mudança; da capitalização; do modelo único; e da simetria. Por fim, as lógicas fantasmáticas e ilusórias foram (des)construídas, como a fantasia: da qualidade da 
norma; da tecnicidade; da comparabilidade; da globalização; e da justiça processual. Essas lógicas representam a minha principal teorização de leitura do processo normativo do IASB.

Para a análise desta tese, vale a ressignificação do papel da dicotomia imposta nas relações sociais por meio do conceito de "obstáculo epistemológico" na pesquisa científica discutido por Bachelard (1996). Nessa ressignificação, a dicotomia da normatização na contabilidade é dada pela regulação como sendo estritamente política ou técnica. Portanto, com base em uma análise da problematização por meio das lógicas elencadas, somos capazes de contribuir com um novo modelo de análise dos processos do IASB que foge da simplificação dicotômica criada neste ambiente regulatório.

A partir daí, realizei a construção de um framework de análise que me auxiliou na construção das críticas, articulações e julgamentos que representa uma contribuição desta tese para a literatura e que possibilita a análise de outros processos normativos levando em conta a lógica da semelhança de famílias. Não quero defender aqui a irrestrita generalização dos meus resultados, mas sim que os instrumentos construídos servem como base para a análise de outros processos, sempre levando em consideração as especificidades de cada cenário.

$\mathrm{Na}$ articulação da segunda parte do objetivo, que envolve a demonstração das (in)consistências e (in)completudes dos discursos, a análise do processo da IFRS 16 foi importante por trazer um cenário propício de discussões amparadas em idealismos e ideologias de qualidade técnica.

A (in)completude já é um conceito ontologicamente presente na teoria do discurso que aplico na tese. Isso principalmente por entendermos a contingência, a precariedade e a sobredeterminação como essenciais em qualquer fenômeno social e de construção de discursos. Apesar de já ser presente na teoria, avanço ao trazer essa (in)completude para a análise empírica com base nos conceitos idealizados de democracia participativa, o que, sob o senso comum, levaria à neutralidade do processo. Isso foi possível por meio da desconstrução dos princípios no processo normativo.

A (in)completude é presente pela aplicação de conceitos impossíveis de serem totalizados. O processo se ampara nos princípios do due process handbook que já se apresentam como incompletos por representarem subjetividades idealizadas por meio de construções que se amparam como significantes vazios dentro de um sistema discursivo. Apesar de serem naturalmente incompletos, são acolhidos sem questionamentos por grande parte dos envolvidos. Assim, demonstro que, mesmo sem se amparar na busca de "maior aplicação possível" desses princípios, há momentos em que eles servem apenas como justificativas para a fantasia da alegada justiça processual, porém não há evidências de uma busca efetiva pelo seu 
cumprimento. Isso pôde ser observado por meio da negligenciação de comentários de atores, pela priorização de determinados públicos no processo, pela ausência de documentos que trouxessem uma capacidade analítica aos envolvidos e pelos diversos silenciamentos de antagonismos como forma de blindar o processo normativo de críticas.

O framework desenvolvido trouxe a relação desses princípios (transparência, consulta completa e justa e accountability) com os principais pontos de um processo normativo (atores envolvidos, processo organizacional e conteúdo da norma). Dessa forma, consegui articular desconstruções dos discursos do IASB de forma a demonstrar as (in)consistências nos argumentos utilizados para determinadas decisões ou andamentos do processo.

Assim, as (in)consistências são observadas por meio da análise conjunta das mudanças no processo e das (in)completudes na aplicação prática dos princípios. Essas inconsistências representam diferenças entre os discursos escritos e os discursos práticos. Lembro que, com base na teoria do discurso, enxergamos que o processo de construção do sistema discursivo envolve aspectos formais, informais, escritos e práticos. Portanto, essa separação entre o discurso escrito e a efetiva prática aplicada ao processo de arrendamentos é meramente analítica para conseguir construir essas falhas e inconsistências. Contudo, ressalto que toda a análise constitui um mesmo discurso de regulação que procura ser totalizante e hegemônico.

Não tive como objetivo descrever todas as mudanças e selecionei como foco de análise os cenários de construção da necessidade de mudanças, da capitalização total dos arrendamentos, da simetria entre arrendadoras e arrendatárias e do projeto conjunto entre o FASB e o IASB. Nesses cenários consigo mostrar que a articulação de tecnicidade não passa de um simbolismo para garantir a aceitação necessária para um regulador que mantém seu poder por meio de uma aplicação soft-law.

Argumento, também, que o processo normativo funciona com base em outros discursos políticos amparados em lógicas fantasmáticas. Isso me leva à conclusão de que o processo funciona como uma replicação de mitos e retóricas para a construção de um discurso hegemônico. Considerando que esse discurso capta os envolvidos se tornando o status quo da regulação, questiono até que ponto a transparência, a consulta e a accountability possuem alguma função efetiva no processo, além do simbolismo de boas práticas de governança. Falo isso porque os próprios participantes do mercado são captados por essa construção discursiva e investem recursos nessa participação de forma a ter uma ilusão de que seus posicionamentos serão considerados de forma neutra e justa. Nesse sentido, argumento que nós estamos apenas reproduzindo essa retórica geral do processo. 
Dessa maneira, acabo argumentando que as etapas formais de consulta, incluindo as comment letters, funcionam mais de forma simbólica como um mito de aplicação de boas práticas de governança, de modo a trazer credibilidade (fictícia) ao processo normativo.

Devemos entender que essas visões contribuem para um outro antagonismo, que se relaciona com as pesquisas realizadas sobre os produtos do processo normativo. Com base nos estudos e resultados desta tese, entendo que a visão sob diferentes paradigmas é interessante e contributiva para o desenvolvimento científico. Por esse motivo, sugiro que passemos a analisar menos os fenômenos da normatização contábil internacional (e seus produtos) sob a ótica positivista e econômica da regulação e passemos a utilizar outros paradigmas e teorias políticas propriamente ditas. Isso porque devemos passar a compreender a regulação contábil como um fenômeno intrinsecamente político e não como um fenômeno técnico, neutro e controlável.

Entre os motivadores desta tese, destaquei logo no início o ditado "faça o que eu digo, mas não faça o que eu faço". Ele me motivou no início das leituras dos documentos do IASB quando eu via um discurso moralista (purificador) baseado na lógica das boas práticas de governança, em especial nos princípios retóricos de um processo de qualidade. Nesse momento inicial eu ainda desconhecia a teoria do discurso de Laclau e Mouffe (1985) e vários fundamentos do paradigma pós-estruturalista de pesquisa. A partir da apresentação desses conceitos fui compreendendo mais a função do discurso na construção do ditado citado e percebendo que não era só um achismo, mas que poderia cientificamente demonstrar inconsistências discursivas entre falas e atitudes do normatizador internacional. Agora nas considerações finais, destaco uma frase que convenientemente li durante a escrita desta seção: "Não comemore as palavras por antecipação, aguarde as ações". Ela reforça o pensamento desta tese de que devemos ser céticos com o que lemos e as críticas podem ser úteis no alerta contra o status quo ao demonstrar possíveis inconsistências entre o que se fala e o que se faz.

Ressalto que em todas as análises da tese e na apresentação dessas considerações finais não almejo ser a única possibilidade de verdade ou de leitura do processo normativo internacional. Embora a minha contribuição ocorra por meio de uma leitura feita a partir de um paradigma distinto, isso não significa que ela seja a única opção cientificamente válida.

Outras contribuições dessa pesquisa foram elencadas durante seu desenvolvimento, mas gostaria de ressaltar a expansão na literatura com algumas bases de escolhas que foram distintas das mais usuais. Por exemplo, os documentos analisados para que se chegasse às articulações da pesquisa envolveram as construções discursivas internas ao board. Normalmente, nas pesquisas que analisam o processo normativo há um forte amparo em documentos externos, como comment letters, porém pouca atenção é dada aos trabalhos de articulações internos. E 
são nessas articulações que somos capazes de demonstrar possíveis falhas nos discursos. Além disso, há uma contribuição simbólica com um amparo metodológico, epistemológico, teórico e ontológico pouco comum na área da contabilidade.

Procuro também, já de forma ambiciosa, contribuir ao cenário nacional de pesquisa e da própria prática profissional ao apresentar o processo normativo a um público mais distante da regulação contábil internacional. Ainda que haja no Brasil a aplicação das normas internacionais por meio das traduções do CPC (Comitê de Pronunciamentos Contábeis), grande parte dos impactados pelas normas contábeis sequer conhece como é o processo de construção de normas e acaba por se amparar no mito de perfeição, pureza, independência e qualidade técnica irrestrita do IASB. Fomos apresentados às normas internacionais como sendo o grande avanço da globalização e as aceitamos sem grandes críticas. Aqui não desqualifico tal concepção, mas evidencio que estamos aceitando normas sem realizarmos nossos próprios questionamentos quanto às suas possíveis (in)consistências. Por meio dessa lógica, espero poder trazer certa luz ao cenário nacional no sentido de que possamos ter um papel mais crítico no acolhimento das normas internacionais.

Mesmo não sendo o objetivo central da tese, por meio da pesquisa crítica também podemos contribuir para a mudança e não somente demonstrá-la. Posso argumentar que, por mais que haja discursos com ambições totalizantes, o processo normativo do IASB não é universalmente justo, nem transparente, nem com total accountability. Essa já era uma premissa argumentada desde a introdução e nesta tese demonstrei isso de forma empírica. Com base em uma visão crítica normativa, também posso sugerir mudanças com vistas a aprimorar tal processo, lembrando que nunca haverá, partindo da teoria do discurso, a totalização ou a universalização dos princípios de forma a "completar" a normatização para todo e qualquer sujeito.

Entre as melhorias a serem sugeridas, foco principalmente na diminuição de discursos simbólicos e na possibilidade de realmente incrementar a prática da normatização. Assim, melhorar-se-ia o processo caso o board buscasse não novos procedimentos para o aumento da qualidade na aplicação dos princípios, mas sim a real aplicação desses princípios no que é possível. Ser justo com o usuário é demonstrar o viés das decisões e os racionais que levam a pensar o motivo que realmente encaminhou alguma mudança. Não basta criar barreiras amparadas em boas práticas de governança que qualificariam o processo como justo por meio de participação pública, afinal, essa participação é limitada. Cria-se, assim, a ilusão de que a participação é variada, mas não é. 
Então, sugiro que o board seja mais real nas explicações das escolhas, na diminuição da utilização de subjetivismos nas defesas de vieses (exemplo: utilizar menos pronomes indefinidos e ser objetivo quanto às participações), na explicação dos impactados e no viés para o mercado (isso inclusive está na constituição do IASB, mas no processo, reforça-se que as decisões são neutras e sem benefício de usuários específicos). Considerando a função social da regulação, defendo que a disponibilização de informações primárias também não é suficiente para trazer transparência ao processo. Devem ser construídos documentos formais que objetivem as participações, os antagonismos e os reais racionais (políticos) para as tomadas de decisões. Isso traria a alegada justiça, transparência e accountability. Com os silenciamentos atuais e a criação desse discurso técnico ilusório, me arrisco a dizer que o processo não carece da aplicação dos princípios discutidos (ou seja, falta de justiça, falta de transparência e falta de accountability), mas sim se torna injusto, não transparente e sem accountability. Esforços pequenos (e teóricos) acabam por não se sobrepor à prática atual, que acaba por descredibilizar os resultados.

Dito isto, argumento que os pontos de (in)completude e (in)consistências do processo podem ser trabalhadas de forma a tornar o real mais próximo do discurso pregado. As próprias (in)consistências e (in)completudes apresentadas funcionam como uma possibilidade de mudança crítica por parte do board. Mostrar esses pontos acaba por contribuir ao desenvolvimento de saídas melhores para a normatização. Para isso, deve-se ter a intenção de mudar e, para mudar, deve-se assumir a natureza política da normatização e o papel também político do board. Diminuir a criação do obstáculo da purificação da "técnica" e passar a explicar os vieses políticos. Em resumo: ser político não é ser ruim. Ser político é habitar e assumir sua função social no meio em que se vive.

Assim como todo trabalho científico, esta tese também possui limitações/delimitações. Entre elas destaco o fato de amparar as discussões nos documentos formais que estão disponíveis pelo IASB. Considerando que, entre os princípios do processo normativo do órgão, temos a transparência e a accountability, acredito que todos os documentos foram disponibilizados. Possíveis negociações informais ou que possam ter ocorrido fora do ambiente regulatório acabam não sendo levadas em consideração nesta pesquisa. Entretanto, esses pontos apenas aumentariam a possibilidade de críticas realizadas e não impossibilitaram a demonstração de inconsistências discursivas mesmo dentro dos documentos constantes no escopo de análise.

Ressalto também que a tese é um mapa aberto, ou seja, funciona como um guia, mas que não necessariamente será (nem deve) ser seguida e aplicada em estudos futuros de forma 
engessada e irrestrita. Deve ser questionada, aprimorada e novas visões sobre o fenômeno são bem-vindas. A escolha de uma epistemologia específica direciona minha leitura científica e acaba por limitar visões antagônicas. Com isso, deixei de enxergar o fenômeno de análise tomando como base diversas outras leituras científicas igualmente válidas. Além disso, vale ressaltar que a construção do framework de análise está em constante aprimoramento e, mesmo que aplicado da forma atual, as interpretações e os achados podem variar sob o amparo do paradigma crítico. O que quero dizer é que ele não é uma regra absoluta. Há a possibilidade de replicação, por meio da aplicação de semelhança de família de Wittgenstein, principalmente na coleta e no tratamento dos dados, porém os resultados analíticos podem variar e, por sua vez, acabam por ser bastante importantes para o aprimoramento da ferramenta aqui desenvolvida.

Outro ponto que deve ser levado em consideração é que procurei não incorrer exatamente naquilo que critico no processo do IASB: a tentativa de apresentar um discurso técnico. Não poderia ser diferente. Eu não poderia criticar a fantasia da tecnicidade e da neutralidade do IASB e realizar uma tese em que não me posicionasse. Isso seria uma falha ontológica sobre minha visão de mundo.

Apesar de não me posicionar diretamente se sou favorável ou não à mudança da norma de arrendamentos, não poupo a apresentação de posicionamentos claramente com "juízos de valor" acerca do processo e de suas (in)completudes e (in)consistências. Não me posiciono acerca da necessidade de mudança porque entendo que minha pesquisa contribui ao objeto da regulação, ou seja, à análise do processo normativo em si. Apesar do conteúdo da norma ser um importante fundamento do processo, nesta pesquisa demonstro inconsistências deste conteúdo por meio dos cenários discursivos construídos e não se esse conteúdo é o correto ou não.

Posso resumir as contribuições desta tese em duas grandes frentes. Academicamente, as contribuições giram em torno da união da visão ontológica, epistemológica e metodológica para a leitura de um fenômeno relacionado com a regulação internacional. De forma mais objetiva, a contribuições dessa leitura de materializou por meio da construção do framework de análise, gerando assim um ferramental que possibilita o crescimento da literatura e que tomou como base premissas científicas para sua construção. Há também as contribuições da tese para a área contábil. Neste ponto, vejo que uma leitura questionadora das práticas contribui para aumentar a capacidade analítica da profissão e dos produtos gerados pela área. Além disso, contribui-se ao possibilitar uma maior leitura por parte dos usuários de forma a compreender melhor o 
funcionamento da regulação contábil e, com isso, aumentarem a qualidade e a possibilidade de suas participações de forma a influenciar diretamente sobre as normas editadas.

De forma aplicada ao processo de arrendamentos, trago alguns questionamentos ainda não respondidos. A principal crítica referente ao modelo anterior acaba por ser menos conceitual e mais prática. Nas críticas citadas nos documentos formais, destaca-se a que defende que o modelo da IAS 17 possibilita uma estruturação de operações oriunda da possibilidade de classificação em operacional e financeiro. Entendo a intenção, porém devemos dizer que essa estruturação é oriunda de uma prática antiética das entidades, de uma ausência de controle por parte dos normatizadores, de uma inabilidade das auditorias em verificar tais situações ou até mesmo de uso vantajoso de possibilidades regulatórias? Para complemento, argumenta-se em benefício da informação ao usuário. Nesse caso, sem argumento principal derivando de necessidades conceituais ou até mesmo de inconsistências com a estrutura conceitual, deveríamos pensar em uma modificação da norma?

Por fim, registro aqui meu anseio e sugestão de que cada vez mais tenhamos um amparo em teorias de naturezas críticas para a avaliação e para a compreensão do processo normativo contábil internacional. Tanto as teorias críticas quanto as teorias políticas podem nos auxiliar, como área, à compreensão diversa dos fenômenos sociais que nos envolvem e, por consequência, ao desenvolvimento científico do campo. Com essas visões, podemos questionar eventos que estão naturalizados e passam despercebidos em nossas pesquisas, contribuindo, assim, tanto para a academia e quanto para a profissão contábil. Devemos questionar não apenas as métricas contábeis, mas sim como elas são desenvolvidas e como os "bastidores" desse desenvolvimento podem modificar o comportamento da área contábil. 


\section{REFERÊNCIAS}

Abbott, A. (1988). The system of professions. An essay on the division of expert labor. Chicago: The University of Chicago Press.

Abbott, K. W., \& Snidal, D. (2001). International "standards" and international governance. Journal of European Public Policy, 8(3), 345-370. https://doi.org/10.1080/13501760110056013

Aglietta, M., \& Rebérioux, A. (2005). Corporate Governance Adrift: A Critique of Shareholder Value. Journal of Chemical Information and Modeling (Vol. 53). Cheltenham: Edward Elgar Pub.

Ahrens, T., \& Chapman, C. S. (2006). Doing qualitative field research in management accounting: Positioning data to contribute to theory. Accounting, Organizations and Society, 31(8), 819-841. https://doi.org/10.1016/j.aos.2006.03.007

Allini, A., Aria, M., Macchioni, R., \& Zagaria, C. (2018). Motivations behind users' participation in the standard-setting process: Focus on financial analysts. Journal of Accounting and Public Policy, 37(3), 207-225.

https://doi.org/10.1016/j.jaccpubpol.2018.04.002

Álvarez, I., Calvo, J. A., \& Mora, A. (2014). Involving academics in the accounting standard setting process: an application of the Delphi methodology to the assessment of IASB proposals. Journal of Management \& Governance, 18(3), 765-791.

https://doi.org/10.1007/s10997-012-9244-3

Aragão, I. R. B. N. (2016). Hegemonia do discurso científico contábil no Brasil. Universidade de São Paulo, São Paulo. https://doi.org/10.11606/T.12.2016.tde-25072016-164253

Arnold, P. J. (2012). The political economy of financial harmonization: The East Asian financial crisis and the rise of international accounting standards. Accounting, Organizations and Society, 37(6), 361-381. https://doi.org/10.1016/j.aos.2012.05.001

Arrington, C. E., \& Schweiker, W. (1992). The rhetoric and rationality of accounting research. Accounting, Organizations and Society, 17(6), 511-533. https://doi.org/10.1016/0361-3682(92)90011-G

Bach, D., \& Newman, A. L. (2010). Transgovernmental networks and domestic policy convergence: Evidence from insider trading regulation. International Organization, 64(3), 505-528. https://doi.org/10.1017/S0020818310000135

Bachelard, G. (1996). A formação do espírito científico: Contribuição para uma psicanálise do conhecimento. (Tradução de Estela dos Santos Abreu). Rio de Janeiro, RJ: Contraponto.

Baker, C. R., \& Bettner, M. S. (1997). Interpretive and Critical Research in Accounting: A Commentary on its Absence from Mainstream Accounting Research. Critical Perspectives on Accounting, 8(4), 293-310. https://doi.org/10.1006/cpac.1996.0116 
Ball, R. (2016). IFRS - 10 years later. Accounting and Business Research, 46(5), 545-571. https://doi.org/10.1080/00014788.2016.1182710

Bamber, M., \& McMeeking, K. (2016). An examination of international accounting standardsetting due process and the implications for legitimacy. British Accounting Review, 48(1), 59-73. https://doi.org/10.1016/j.bar.2015.03.003

Barone, E., Birt, J., \& Moya, S. (2014). Lease Accounting: A Review of Recent Literature. Accounting in Europe, 11(1), 35-54. https://doi.org/10.1080/17449480.2014.903630

Barth, M. E. (2000). Valuation-based accounting research: Implications for financial reporting and opportunities for future research. Accounting and Finance, 40(1), 7-32. https://doi.org/10.1111/1467-629X.00033

Barth, M. E. (2006). Research, Standard Setting, and Global Financial Reporting. Foundations and Trends® in Accounting, 1(2), 71-165. https://doi.org/10.1561/1400000002

Barth, M. E., \& Schipper, K. (2008). Financial Reporting Transparency. Journal of Accounting, Auditing \& Finance, 23(2), 173-190. https://doi.org/10.1177/0148558X0802300203

Barthes, R. (1972). Mythologies. New York: The Noonday Press.

Baudot, L. (2014). GAAP convergence or convergence Gap: unfolding ten years of accounting change. Accounting, Auditing \& Accountability Journal, 27(6), 956-994. https://doi.org/10.1108/AAAJ-03-2013-1297

Baudot, L. (2018). On Commitment Toward Knowledge Templates in Global Standard Setting: The Case of the FASB-IASB Revenue Project. Contemporary Accounting Research, 35(2), 657-695. https://doi.org/10.1111/1911-3846.12396

Bauman, M. P., \& Francis, R. N. (2011). Issues in Lessor Accounting: The Forgotten Half of Lease Accounting. Accounting Horizons, 25(2), 247-266. https://doi.org/10.2308/acch10021

Beach, D., \& Pedersen, R. B. (2013). Process- Tracing Methods : Foundations and Guidelines. USA: The University of Michigan Press.

Beattie, V., Goodacre, A., \& Thomson, S. J. (2006). International lease-accounting reform and economic consequences: The views of U.K. users and preparers. International Journal of Accounting, 41(1), 75-103. https://doi.org/10.1016/j.intacc.2005.12.003

Beisheim, M., \& Dingwerth, K. (2008). Procedural legitimacy and private transnational governance. Are the good ones doing better? (No. 14). SFB-Governance Working Paper Series. Berlin.

Bengtsson, E. (2011). Repoliticalization of accounting standard setting-The IASB, the EU and the global financial crisis. Critical Perspectives on Accounting, 22(6), 567-580. https://doi.org/10.1016/j.cpa.2011.04.001

Beresford, D. R. (1997). How to succeed as a standard setter by trying really hard. Accounting 
Horizons, 11(3), 79-90.

Bertomeu, J., \& Magee, R. P. (2015). Political pressures and the evolution of disclosure regulation. Review of Accounting Studies, 20(2), 775-802.

https://doi.org/10.1007/s11142-014-9312-9

Bevir, M. (2010). Democratic Governance. Woodstock, Oxfordshire: Princeton University Press.

Bevir, M., \& Rhodes, R. A. W. (2003). Interpreting British Governance. London: Routledge.

Biondi, Y., Bloomfield, R. J., Glover, J. C., Jamal, K., Ohlson, J. A., Penman, S. H., ... Jeffrey Wilks, T. (2011). A perspective on the joint IASB/FASB exposure draft on accounting for leases. Accounting Horizons, 25(4), 861-871. https://doi.org/10.2308/acch-50048

Biondi, Y., Glover, J., Jamal, K., Ohlson, J. A., Penman, S. H., Sunder, S., \& Tsujiyama, E. (2012). Some conceptual tensions in financial reporting. Accounting Horizons, 26(1), 125-133. https://doi.org/10.2308/acch-50087

Black, J. (2008). Constructing and contesting legitimacy and accountability in polycentric regulatory regimes. Regulation \& Governance, 2(2), 137-164. https://doi.org/10.1111/j.1748-5991.2008.00034.x

Boli, J., \& Thomas, G. M. (1999). Constructing World Culture: International Nongovernmental Organizations since 1875. Stanford, California: Stanford University Press.

Boström, M., \& Garsten, C. (2008). Organizing Transnational Accountability. Chentelham, UK: Edward Elgar Publishing.

Botzem, S. (2008). Transnational expert-driven standardisation: Accountancy governance from a professional point of view. In J.-C. Graz \& A. Nölke (Eds.), Transnational Private Governance and its Limits. New York, NY: Routledge.

Botzem, S. (2012). The politics of Accounting Regulation: organizing transnational standard setting in financial reporting. Cheltenham, UK: Edward Elgar Publishing Limited.

Botzem, S. (2014). Transnational standard setting in accounting: Organizing expertise-based self-regulation in times of crises. Accounting, Auditing \& Accountability Journal, 27(6), 933-955. https://doi.org/10.1108/AAAJ-04-2013-1301

Botzem, S., \& Dobusch, L. (2012). Standardization Cycles: A Process Perspective on the Formation and Diffusion of Transnational Standards. Organization Studies, 33(5-6), 737-762. https://doi.org/10.1177/0170840612443626

Botzem, S., \& Hofmann, J. (2010). Transnational governance spirals: The transformation of rule-making authority in Internet regulation and corporate financial reporting. Critical Policy Studies, 4(1), 18-37. https://doi.org/10.1080/19460171003714948

Botzem, S., \& Quack, S. (2006a). Contested rules and shifting boundaries: International standard-setting in accounting. In M.-L. Djelic \& K. Sahlin-Andersson (Eds.), 
Transnational Governance: Institutional Dynamics of Regulation (pp. 266-286).

Cambridge, UK: Cambridge University Press.

Botzem, S., \& Quack, S. (2006b). Contested rules and shifting boundaries: International standard-setting in accounting. In M.-L. Djelic \& K. Sahlin-Andersson (Eds.), Transnational Governance: Institutional Dynamics of Regulation. Cambridge, UK: Cambridge University Press.

Botzem, S., \& Quack, S. (2009). (No) Limits to Anglo-American accounting? Reconstructing the history of the International Accounting Standards Committee: A review article. Accounting, Organizations and Society, 34(8), 988-998. https://doi.org/10.1016/j.aos.2009.07.001

Brandão, H. H. N. (2012). Introdução à Análise do Discurso (3rd ed.). Campinas, SP: Editora da Unicamp.

Broadbent, J. (1998). The Gendered Nature of "Accounting Logic": Pointers to an Accounting that Encompasses Multiple Values. Critical Perspectives on Accounting, 9(3), 267-297. https://doi.org/10.1006/cpac.1997.0158

Bronner, S. E. (2002). Of Critical Theory and its Theorists (2nd ed.). New York, NY: Routledge.

Brown, J., \& Dillard, J. (2015). Dialogic Accountings for Stakeholders: On Opening Up and Closing Down Participatory Governance. Journal of Management Studies, 52(7), 961985. https://doi.org/10.1111/joms.12153

Brown, W. (2015). Undoing the Demos: Neoliberalism's Stealth Revolution. New York, NY: Zone Books.

Burity, J. A. (2014). Discurso, política e sujeiro na teoria da hegemonia de Ernesto Laclau. In D. de Mendonça \& L. P. Rodrigues (Eds.), Pós-estruturalismo e teoria do discurso: em torno de Ernesto Laclau0 (2nd ed.). Porto Alegre, RS: Editora Universitária da PUCRS.

Burke, P. (2012). História e Teoria Social (2nd ed.). São Paulo, SP: Editora Unesp.

Burlaud, A., \& Colasse, B. (2011). International Accounting Standardisation: Is Politics Back? Accounting in Europe, 8(1), 23-47. https://doi.org/10.1080/17449480.2011.574412

Burrell, G., \& Morgan, G. (1979). Sociological Paradigms and organisational analysis. London: Heinemann Educational.

Butler, J., Laclau, E., \& Žižek, S. (2000). Constructing Universality. In Contingency, Hegemony, Universality: Contemporary Dialogues on the Left (pp. 281-307). London: Verso. Retrieved from papers2://publication/uuid/11D104A2-9944-4D0D-9EF2E530A08346B1

Cambridge Dictionary. (2020). Cambridge University Press. Retrieved from https://dictionary.cambridge.org

Camfferman, K., \& Zeff, S. A. (2006). Financial Reporting And Global Capital Markets: A 
history of the International Accounting Standards Committee, 1973-2000. Norfolk, UK: Oxford University Press.

Camfferman, K., \& Zeff, S. A. (2018). The Challenge of Setting Standards for a Worldwide Constituency: Research Implications from the IASB's Early History. European Accounting Review, 27(2), 289-312. https://doi.org/10.1080/09638180.2017.1296780

Carmo, C. H. S. do. (2014). Lobbyng na regulação contábil internacional: uma análise do processo de elaboração da norma sobre reconhecimento de receitas. Universidade de São Paulo. (Tese de Doutorado, Programa de Pós Graduação em Controladoria e Contabilidade, Universidade de São Paulo). https://doi.org/10.11606/T.12.2014.tde14072014-185506

Carmo, C. H. S. Do, Ribeiro, A. M., \& Carvalho, L. N. G. de. (2014). Influência dos Grupos de Interesse no Processo de Normatização Contábil Internacional: o Caso do Discussion Paper sobre Leasing. Revista Contabilidade Vista \& Revista, 25(2), 98-118.

Chapman, C. S., Cooper, D. J., \& Miller, P. B. (2009). Accounting, Organizations \& Institutions: Essays in Honour of Anthony Hopwood. Oxford: Oxford University Press.

Chiapello, E. (2016). How IFRS Contribute to the Financialization of Capitalism. In D. Bensadon \& N. Praquin (Eds.), IFRS in a Global World: International and Critical Perspectives on Accounting (pp. 71-84). New Yotk: Springer International Publishing. https://doi.org/10.1007/978-3-319-28225-1_6

Chiapello, E., \& Medjad, K. (2009). An unprecedented privatisation of mandatory standardsetting: The case of European accounting policy. Critical Perspectives on Accounting, 20(4), 448-468. https://doi.org/10.1016/j.cpa.2008.09.002

Chua, W. F. (1986a). Radical Developments in Accounting Thought. The Accounting Review, 61(4), 601-632. https://doi.org/10.2307/247360

Chua, W. F. (1986b). Theoretical constructions of and by the real. Accounting, Organizations and Society, 11(6), 583-598. https://doi.org/10.1016/0361-3682(86)90037-1

Chua, W. F., \& Taylor, S. L. (2008). The rise and rise of IFRS: An examination of IFRS diffusion. Journal of Accounting and Public Policy, 27(6), 462-473. https://doi.org/10.1016/j.jaccpubpol.2008.09.004

Collier, S. J. (2009). Topologies of Power. Theory, Culture \& Society, 26(6), 78-108. https://doi.org/10.1177/0263276409347694

Comiran, F., \& Graham, C. M. (2016). Comment letter activity: A response to proposed changes in lease accounting. Research in Accounting Regulation, 28(2), 109-117. https://doi.org/10.1016/j.racreg.2016.09.010

Cooper, D. J., \& Hopper, T. M. (1987). Critical studies in accounting. Accounting, Organizations and Society, 12(5), 407-414. https://doi.org/10.1016/03613682(87)90028-6

Cornaggia, K. J., Franzen, L. A., \& Simin, T. T. (2013). Bringing leased assets onto the balance sheet. Journal of Corporate Finance, 22(1), 345-360. 
https://doi.org/10.1016/j.jcorpfin.2013.06.007

Cornaggia, K. J., Franzen, L. A., \& Simin, T. T. (2015). Managing the Balance Sheet with Operating Leases. SSRN Electronic Journal, (August), 1-48. https://doi.org/10.2139/ssrn.2114454

Cortese, C. L., \& Irvine, H. (2010). Investigating international accounting standard setting: The black box of IFRS 6. Research in Accounting Regulation, 22(2), 87-95. https://doi.org/10.1016/j.racreg.2010.07.003

Cortese, C. L., Irvine, H. J., \& Kaidonis, M. A. (2010). Powerful players: How constituents captured the setting of IFRS 6 , an accounting standard for the extractive industries. Accounting Forum, 34(2), 76-88. https://doi.org/10.1016/j.accfor.2008.11.003

Costa, E. B. da. (2020, July 16). Ideologia do discurso anti-ideologização no Brasil. Le Monde Diplomatique Brasil. Retrieved from https://diplomatique.org.br/ideologia-do-discursoanti-ideologizacao-no-brasil/

Cox, R. W. (1981). Social Forces, States and World Orders: Beyond International Relations Theory. Millennium: Journal of International Studies, 10(2), 126-155. https://doi.org/10.1177/03058298810100020501

CPC. (2010). Pronunciamento Técnico CPC 06(R1) - Operações de Arrendamento Mercantil. Brasília. Retrieved from http://static.cpc.aatb.com.br/Documentos/163_CPC_06_R1_rev 08.pdf

Critchley, S., Derrida, J., Laclau, E., \& Rorty, R. (1996). Deconstruction and Pragmatism. (C. Mouffe, Ed.). London: Routledge. Taylor \& Francis Group.

Crotty, M. J. (1998). The Foundations of Social Research: Meaning and Perspective in the Research Process. St Leonards, Austrália: Allen \& Unwin.

Dahl, R. A. (1958). A Critique of the Ruling Elite Model. American Political Science Review, 52(2), 463-469. https://doi.org/10.2307/1952327

Danjou, P., \& Walton, P. (2012). The Legitimacy of the IASB. Accounting in Europe, 9(1), 1-15. https://doi.org/10.1080/17449480.2012.664396

De Lange, P., \& Howieson, B. (2006). International accounting standards setting and U.S. exceptionalism. Critical Perspectives on Accounting, 17(8), 1007-1032. https://doi.org/10.1016/j.cpa.2005.08.011

De Martino, G. (2011). Considerations on the subject of lease accounting. Advances in Accounting, 27(2), 355-365. https://doi.org/10.1016/j.adiac.2011.08.007

Derrida, J. (2013). Gramatologia. São Paulo, SP: Editora Perspectiva.

Dick, W., \& Walton, P. (2007). The IASB Agenda - A Moving Target. Australian Accounting Review, 17(42), 8-17. https://doi.org/10.1111/j.1835-2561.2007.tb00438.x

Dillard, J. F. (1991). Accounting as a Critical Social Science. Accounting, Auditing \& Accountability Journal, 4(1), 09513579110143849. 
https://doi.org/10.1108/09513579110143849

Dillard, J. F., \& Ruchala, L. (2005). The rules are no game: From instrumental rationality to administrative evil. Accounting, Auditing \& Accountability Journal, 18(5), 608-630. https://doi.org/10.1108/09513570510620475

Dingwerth, K. (2007). The New Transnationalism: Transnational Governance and Democratic Legitimacy. New York, NY: Palgrave Macmillan.

Djelic, M.-L., \& Sahlin-Andersson, K. (2006). Transnational Governance: Institutional Dynamics of Regulation. Cambridge, UK: Cambridge University Press.

Douglas, M. (1966). Purity and Danger: an analysis of the concepts of pollution and taboo (ARKEdition). New York: Routledge.

DPOC. (2011). DPOC paper 2(ii): Correspondence with global leasing industry representatives. London. Retrieved from http://archive.ifrs.org/DPOC/Documentationand-Correspondence/Pages/Leases.aspx

DPOC. (2012a). DPOC meeeting paper 3C-appendix 2: Correspondence with ACTEO, AFEP and $M E D E F$. London. Retrieved from http://archive.ifrs.org/DPOC/Documentation-andCorrespondence/Pages/Leases.aspx

DPOC. (2012b). DPOC meeting paper 3D(ii) appendix 1: Updating the IASB's procedures in response to the DPOC protocol: Leases example. London. Retrieved from http://archive.ifrs.org/DPOC/Documentation-and-Correspondence/Pages/Leases.aspx

DPOC. (2012c). DPOC meeting paper 3E(iv): Correspondence with ACCOR et al. London. Retrieved from http://archive.ifrs.org/DPOC/Documentation-andCorrespondence/Pages/Leases.aspx

DPOC. (2012d). IASB meeting paper 3G: Leases: Exposure Draft comment period and permission to begin the balloting process. London. Retrieved from http://archive.ifrs.org/DPOC/Documentation-and-Correspondence/Pages/Leases.aspx

DPOC. (2012e). IASB meeting paper 3H: Leases: Due Process. London. Retrieved from http://archive.ifrs.org/DPOC/Documentation-and-Correspondence/Pages/Leases.aspx

DPOC. (2013). Memo to DPOC: Leases: Issue of revised Exposure Draft: Due process. London. Retrieved from http://archive.ifrs.org/DPOC/Documentation-andCorrespondence/Pages/Leases.aspx

DPOC. (2014a). Agenda Reference 3C: Feedback on Leases Due Process. (p. 11). Cidade do México: IFRS Foundation.

DPOC. (2014b). Agenda Reference 3C(i): Leases: project update. (p. 15). London: IFRS Foundation.

DPOC. (2014c). Summary of the conclusions of the IFRS Foundation Trustees' meeting. (p.

6). Cidade do México: IFRS Foundation.

DPOC. (2015a). Agenda Reference 3C: Leases: due process 'lifecycle' review. (p. 16). 
Toronto: IFRS Foundation.

DPOC. (2015b). Agenda Reference 3C(i): Leases: due process paper to the IASB. (p. 39). Toronto: IFRS Foundation.

DPOC. (2015c). IASB Meeting paper 3A: Leases: Due process, re-exposure and permission to ballot. London.

DPOC. (2015d). IASB Meeting paper 3B: Leases: Effective Date. London. Retrieved from http://archive.ifrs.org/DPOC/Documentation-and-Correspondence/Pages/Leases.aspx

DPOC. (2015e). Staff e-mail to DPOC. London. Retrieved from http://archive.ifrs.org/DPOC/Documentation-and-Correspondence/Pages/Leases.aspx

DPOC. (2015f). Staff e-mail to DPOC. London. Retrieved from http://archive.ifrs.org/DPOC/Documentation-and-Correspondence/Pages/Leases.aspx

DPOC. (2016). Agenda Reference 3D: IFRS 16 Leases: Quality control - the process from permission to ballot to publication. (p. 10). London: IFRS Foundation.

Durocher, S., \& Fortin, A. (2009). Proposed changes in lease accounting and private business bankers' credit decisions. Accounting Perspectives, 8(1), 9-42. https://doi.org/10.1506/ap.8.1.2

Durocher, S., \& Gendron, Y. (2011). IFRS: On the Docility of Sophisticated Users in Preserving the Ideal of Comparability. European Accounting Review, 20(2), 233-262. https://doi.org/10.1080/09638181003687869

Dye, R. A., Glover, J. C., \& Sunder, S. (2015). Financial Engineering and the Arms Race Between Accounting Standard Setters and Preparers. Accounting Horizons, 29(2), 265295. https://doi.org/10.2308/acch-50992

Dye, R. A., \& Sunder, S. (2001). Why Not Allow FASB and IASB Standards to Compete in the U.S.? Accounting Horizons, 15(3), 257-271. https://doi.org/10.2308/acch.2001.15.3.257

Eaton, S. B. (2005). Crisis and the Consolidation of International Accounting Standards: Enron, The IASB, and America. Business and Politics, 7(3), 1-18. https://doi.org/10.2202/1469-3569.1137

Eaton, S. B., \& Porter, T. (2008). Globalization, Autonomy, and Global Institutions: Accounting for Accounting. In L. W. Pauly \& W. D. Coleman (Eds.), Global Ordering: Institutions and Autonomy in a Changing World (pp. 125-143). Vancouver: UBC Press.

Erb, C., \& Pelger, C. (2015). "Twisting words"? A study of the construction and reconstruction of reliability in financial reporting standard-setting. Accounting, Organizations and Society, 40, 13-40. https://doi.org/10.1016/j.aos.2014.11.001

FASB. (1976). Statement of Financial Accounting Standards No. 13: Accounting for Leases. (p. 77). Norwalk, CT: Financial Accounting Standards Board.

Ferguson, J. (1990). The Anti-Politics Machine: Development, Depoliticization, and 
Bureaucratic Power in Lesotho. Cambridge, UK: Cambridge University Press.

Feyerabend, P. K. (2011). Contra o Método (2nd ed.). São Paulo, SP: Editora Unesp.

Flyvbjerg, B. (1998). Rationality and power. Chicago: The University of Chicago Press.

Flyvbjerg, B. (2001). Making Social Science Matter: Why social inquiry fails and how it can succeed again. Cambridge: Cambridge University Press.

Fogarty, T. J. (1994). Structural-Functionalism and Financial Accounting: Standard Setting in the US. Critical Perspectives on Accounting, 5(3), 205-226.

https://doi.org/10.1006/cpac.1994.1012

Franzen, L., Cornaggia, K. R., \& Simin, T. T. (2009). Capital Structure and the Changing Role of Off-Balance-Sheet Lease Financing. SSRN Electronic Journal, (April 2008). https://doi.org/10.2139/ssrn.1452971

Fraser, N. (1992). Rethinking the Public Sphere: A Contribution to the Critique of Actually Existing Democracy. In C. Calhoun (Ed.), Habermas and the Public Sphere (pp. 109142). Cambridge, MA: MIT Press.

Fülbier, R. U., Silva, J. L., \& Pferdehirt, M. H. (2008). Impact of Lease Capitalization on Financial Ratios of Listed German Companies. Schmalenbach Business Review, 60(2), $122-144$.

G20. (2008). Declaration of the Summit on Financial Markets and the World Economy. Washington. Retrieved from http://www.g20.utoronto.ca/2008/2008declaration1115.html

Gadamer, H.-G. (1997). Verdade e Método (3rd ed.). Petrópolis, RJ: Editora Vozes.

Gallhofer, S., \& Haslam, J. (1997). Beyond Accounting: the Possibilities of Accounting and "Critical” Accounting Research. Critical Perspectives on Accounting, 8(1-2), 71-95. https://doi.org/10.1006/cpac.1996.0087

Gallhofer, S., \& Haslam, J. (2003). Accounting and Emancipation: Some critical interventions. Routledge Studies in Accounting. London: Routledge. Taylor \& Francis Group.

Gallhofer, S., \& Haslam, J. (2007). Exploring social, political and economic dimensions of accounting in the global context: the International Accounting Standards Board and accounting disaggregation. Socio-Economic Review, 5(4), 633-664. https://doi.org/10.1093/ser/mwm012

Gallhofer, S., Haslam, J., \& van der Walt, S. (2011). Accountability and transparency in relation to human rights: A critical perspective reflecting upon accounting, corporate responsibility and ways forward in the context of globalisation. Critical Perspectives on Accounting, 22(8), 765-780. https://doi.org/10.1016/j.cpa.2011.07.002

Gendron, Y. (2018). On the elusive nature of critical (accounting) research. Critical Perspectives on Accounting, 50, 1-12. https://doi.org/10.1016/j.cpa.2017.11.001 
Georgiou, G. (2002). Corporate non-participation in the ASB standard-setting process.

European Accounting Review, 11(4), 699-722.

https://doi.org/10.1080/0963818022000001028

Georgiou, G. (2004). Corporate Lobbying on Accounting Standards: Methods, Timing and Perceived Effectiveness. Abacus, 40(2), 219-237. https://doi.org/10.1111/j.14676281.2004.00152.x

Georgiou, G. (2010). The IASB standard-setting process: Participation and perceptions of financial statement users. British Accounting Review, 42(2), 103-118. https://doi.org/10.1016/j.bar.2010.02.003

Gerboth, D. L. (1972). "Muddling Through" with the APB. Journal of Accountancy, Maio, $42-49$.

Gibbs, G. R. (2007). Analyzing Qualitative Data. London: SAGE Publications.

Giddens, A., \& Sutton, P. W. (2017). Conceitos essenciais da Sociologia (2nd ed.). São Paulo, SP: Editora Unesp.

Gieryn, T. F. (1995). Boundaries of Science. In S. Jasanoff, G. E. Markle, J. C. Petersen, \& T. Pinch (Eds.), Handbook of Science and Technology Studies (Revised, pp. 393-443). Thousand Oaks, California: Sage Publications, Inc. https://doi.org/10.4135/9781412990127

Gillis, P., Petty, R., \& Suddaby, R. (2014). The transnational regulation of accounting: insights, gaps and an agenda for future research. Accounting, Auditing \& Accountability Journal, 27(6), 894-902. https://doi.org/10.1108/AAAJ-07-2014-1757

Gipper, B., Lombardi, B. J., \& Skinner, D. J. (2013). The politics of accounting standardsetting: A review of empirical research. Australian Journal of Management, 38(3), 523 551. https://doi.org/10.1177/0312896213510713

Glynos, J., \& Howarth, D. (2007). Logics of Critical Explanation in Social and Political Theory. Abingdon: Routledge.

Glynos, J., \& Howarth, D. (2008). Critical Explanation in Social Science: A logics approach. Swiss Journal of Sociology, 34(1).

Glynos, J., Howarth, D., Norval, A., \& Speed, E. (2009). Discourse Analysis: varieties and methods. Retrieved from http://repository.essex.ac.uk/4026/

Goodacre, A. (2003). Assessing the potential impact of lease accounting reform: a review of the empirical evidence. Journal of Property Research, 20(1), 49-66.

https://doi.org/10.1080/0959991032000051962

Graz, J.-C., \& Nölke, A. (2008). Transnational Private Governance and its Limits. New York, NY: Routledge.

Greenwood, M. (2007). Stakeholder Engagement: Beyond the Myth of Corporate Responsibility. Journal of Business Ethics, 74(4), 315-327. https://doi.org/10.1007/s10551-007-9509-y 
Guba, E. G. (1981). Criteria for assessing the trustworthiness of naturalistic inquiries. Educational Communication and Technology Journal, 29(2), 75-91. https://doi.org/10.1007/BF02766777

Guba, E. G., \& Lincoln, Y. S. (1989). Fourth generation evaluation. Newbury Park, CA: SAGE.

Guba, E. G., \& Lincoln, Y. S. (1994). Competing Paradigms in Qualitative Research. In N. K. Denzin \& Y. S. Lincoln (Eds.), Handbook of qualitative research (pp. 105-117). Thousand Oaks, CA: SAGE.

Hall, P. A., \& Taylor, R. C. R. (1996). Political Science and the Three New Institutionalisms. Political Studies, 44(5), 936-957. https://doi.org/10.1111/j.1467-9248.1996.tb00343.x

Hallström, K. T. (2004). Organizing International Standardization: ISO and the IASC in Quest of Authority. Cheltenham: Edward Elgar Pub.

Hansen, T. B. (2011). Lobbying of the IASB: An Empirical Investigation. Journal of International Accounting Research, 10(2), 57-75. https://doi.org/10.2308/jiar-10078

Harrison, J., MacGibbon, L., \& Morton, M. (2001). Regimes of Trustworthiness in Qualitative Research: The Rigors of Reciprocity. Qualitative Inquiry, 7(3), 323-345. https://doi.org/10.1177/107780040100700305

Herbohn, K. ., \& Herbohn, J. . (1999). Accounting for Forests in Social, Economic and Political Contexts. Accounting Forum, 23(4), 408-440. https://doi.org/10.1111/14676303.00023

Hewa, S. I., Mala, R., \& Chen, J. (2018). IASB's independence in the due process: an examination of interest groups' influence on the development of IFRS 9. Accounting \& Finance. https://doi.org/10.1111/acfi.12426

Hines, R. D. (1991). The FASB's conceptual framework, financial accounting and the maintenance of the social world. Accounting, Organizations and Society, 16(4), 313 331. https://doi.org/10.1016/0361-3682(91)90025-A

Hoffmann, S. (2011). What They Mean When They Use Quantifiers - An Empirical Investigation of IASB's Staff Analysis Paper on ED 9. SSRN Electronic Journal, 54(1), 35-51. https://doi.org/10.2139/ssrn.1857512

Hoffmann, S., \& Zülch, H. (2014). Lobbying on accounting standard setting in the parliamentary environment of Germany. Critical Perspectives on Accounting, 25(8), 709-723. https://doi.org/10.1016/j.cpa.2014.04.003

Holder, A. D., Karim, K. E., Lin, K. J., \& Woods, M. (2013). A content analysis of the comment letters to the FASB and IASB: Accounting for contingencies. Advances in Accounting, 29(1), 134-153. https://doi.org/10.1016/j.adiac.2013.03.005

Homero Junior, P. F. (2018). Reconstitution of the field of accounting regulation in Brazil during the adoption of the IFRS. Universidade de São Paulo, São Paulo. https://doi.org/10.11606/T.12.2018.tde-03042018-163010 
Hood, C., \& Heald, D. (2006). Transparency: The key to better governance? London, UK: Oxford University Press.

Hoogervorst, H., \& Prada, M. (2015). Working in the Public Interest: The IFRS Foundation and the IASB. (p. 12). London.

Hope, A. (1979). Accounting Policy: Theory or Pragmatism or Both. Submissions on the Accounting Standards Committee's Document: Setting Accounting Standards, Vol. 11, A.S.C.

Hopper, T., Lassou, P., \& Soobaroyen, T. (2017). Globalisation, accounting and developing countries. Critical Perspectives on Accounting, 43, 125-148.

https://doi.org/10.1016/j.cpa.2016.06.003

Hopwood, A. G. (1994). Some reflections on 'The harmonization of accounting within the EU.' European Accounting Review, 3(2), 241-254.

https://doi.org/10.1080/09638189400000020

Hopwood, A. G., \& Miller, P. (1994). Accounting as social and institutional practice. Cambridge, UK: Cambridge University Press.

Howarth, D. (2000). Discourse. Buckingham: Open University Press.

Howarth, D. (2010). Power, discourse, and policy: articulating a hegemony approach to critical policy studies. Critical Policy Studies, 3(3-4), 309-335. https://doi.org/10.1080/19460171003619725

Howarth, D. (2013). Poststructuralism and After: Structure, Subjectivity and Power. Basingstoke, Hampshire: Palgrave Macmillan.

Howieson, B. A. (2009). Agenda formation and accounting standards setting: lessons from the standards setters. Accounting \& Finance, 49(3), 577-598. https://doi.org/10.1111/j.1467629X.2009.00299.x

Hughes, S. B., Larson, R. K., Sander, J. F., \& Xiques, G. (2017). Difficulties converging US GAAP and IFRS through joint projects: The case of business combinations. Advances in Accounting, 39, 1-20. https://doi.org/10.1016/j.adiac.2017.09.001

Humphrey, C., Loft, A., \& Woods, M. (2009). The global audit profession and the international financial architecture: Understanding regulatory relationships at a time of financial crisis. Accounting, Organizations and Society, 34(6-7), 810-825. https://doi.org/10.1016/j.aos.2009.06.003

Hussey, R. (2018). Accounting for Leases and the Failure of Convergence. Athens Journal of Business \& Economics, 4(1).

IASB. (2003). International Accounting Standard - IAS 17 - Leases. (p. 20). London: IFRS Foundation.

IASB. (2006a). AP9A: Agenda proposal—Leasing. London.

IASB. (2006b). Information for observers. Joint IASB-FASB Meeting. Agenda Paper 4. (p. 5). 
London.

IASB. (2006c). International Accounting Standards Board meeting | AP9: Leasing. London.

IASB. (2006d). SAC and trustees meeting. Agenda paper 8B (SAC). (p. 5). London.

IASB. (2009a). Discussion Paper - DP/2009/1 - Leases: Preliminary Views. (p. 121).

London: IASC Foundation Publications Department.

IASB. (2009b). Discussion Paper - DP/2009/1 - Snapshot: Leases-Preliminary Views.

(IASC Foundation, Ed.) (p. 5). London.

IASB. (2009c). DP/2009/1 - IASB Agenda Reference 6A: Comment Letter Summary. (p. 26).

London. Retrieved from http://www.ifrs.org/Current-Projects/IASB-

Projects/Leases/DPMar09/Documents/DPLeasesPreliminaryViews.pdf

IASB. (2010a). Exposure Draft - ED/2010/9 - Leases: Basis for Conclusions. (p. 64). London: IFRS Foundation.

IASB. (2010b). Exposure Draft - ED/2010/9 - Leases. (p. 66). London: IFRS Foundation.

IASB. (2010c). Exposure Draft - ED/2010/9 - Snapshot: Leases. (IFRS Foundation, Ed.) (p. 12). London.

IASB. (2010d). IASB meeting, agenda referente 2. Topic: IASB due process. (p. 4). London.

IASB. (2011). ED/2010/9 - IASB Agenda Reference 5A: Comment letter summary - main issues. (p. 70). London.

IASB. (2013a). ED/2013/6 - IASB Agenda Reference 3A: Summary of Feedback on the 2013 ED. (p. 76). London.

IASB. (2013b). Exposure Draft - ED/2013/6 - Leases: Basis for Conclusions. (p. 161). IFRS Foundation.

IASB. (2013c). Exposure Draft - ED/2013/6 - Leases. (p. 89). London: IFRS Foundation.

IASB. (2013d). Exposure Draft - ED/2013/6 - Snapshot: Leases. (p. 15). London: IFRS Foundation.

IASB. (2013e). Leases-Summary of outreach meetings with investors and analysts on proposed accounting by lessee. (p. 8). London.

IASB. (2013f). Redeliberations Plan: IASB Agenda ref 3B. (p. 7). London.

IASB. (2015). Leases: Practical implications of the new Leases Standard. (p. 25). London.

IASB. (2016a). Due Process Protocol. (p. 29). London.

IASB. (2016b). International Financial Reporting Standards - IFRS 16 - Leases: Basis for Conclusions. (p. 90). London: IFRS Foundation. 
IASB. (2016c). International Financial Reporting Standards - IFRS 16 - Leases: Effects Analysis. (IFRS Foundation, Ed.) (p. 103). London.

IASB. (2016d). International Financial Reporting Standards - IFRS 16 - Leases: Project Summary and Feedback Statement. (p. 19). London: IFRS Foundation.

IASB. (2016e). International Financial Reporting Standards - IFRS 16 - Leases. (p. 90). London: IFRS Foundation.

IASB. (2016f). PRESS RELEASE: IASB shines light on leases by bringing them onto the balance sheet. (IFRS Foundation, Ed.) (p. 3). London.

IASB, \& FASB. (2010). PRESS RELEASE: IASB and US FASB publish proposals to improve the financial reporting of leases. (IFRS Foundation \& FASB, Eds.) (p. 3). London.

IASB, \& FASB. (2013). PRESS RELEASE: IASB and FASB propose changes to lease accounting. (IFRS Foundation \& Financial Accounting Foundation, Eds.) (p. 3). London.

IASC Fountarion. (2006). Due process handbook for the IASB. (p. 22). London.

IFRS Foundation. (2014). Report of the IFRS Advisory Council Chairmen to the Trustees and the IASB on the February 2014 Advisory Council meeting 1. (p. 5). London. Retrieved from http://www.ifrs.org/-/media/feature/meetings/2014/february/ac/meeting-summaryfebruary-2014.pdf

IFRS Foundation. (2015). Working in the Public Interest: The IFRS Foundation and the IASB. (p. 12). London: IFRS Foundation. Retrieved from http://www.ifrs.org/about-us/thepublic-interest/

IFRS Foundation. (2016a). Constitution. (p. 18). London.

IFRS Foundation. (2016b). Due Process Handbook. Retrieved from http://www.ifrs.org/about-us/how-we-set-standards/

IFRS Foundation. (2018a). Conceptual Framework for Financial Reporting. (p. 29). London. Retrieved from https://www.ifrs.org/projects/2018/conceptual-framework/\#publisheddocuments

IFRS Foundation. (2018b). Who we are and what we do. Retrieved from http://www.ifrs.org/about-us/who-we-are/\#about-us

IFRS Foundation. (2020). How we develop standards. Retrieved from http://archive.ifrs.org/How-we-develop-standards/Pages/How-we-developstandards.aspx

Islam, J., Khan, H. Z., Hughes, M., \& Ali, M. (2018). Politicisation of the accounting standard-setting process and the influence of key-players: An investigation into the withdrawal of the mandatory status of the Statement of Accounting Concepts No. 4 (SAC 4) in Australia. Accounting History, 23(3), 296-313. https://doi.org/10.1177/1032373217733811

Jackson, P. T. (2011). The Conduct of Inquiry in International Relations: Philosophy of 
science and its implications for the study of world politics. (Routledge, Ed.). New York, NY: Routledge. Retrieved from http://www.tandfebooks.com/isbn/9780203843321

Jamal, K., \& Tan, H. T. (2010). Joint effects of principles-based versus rules-based standards and auditor type in constraining financial managers' aggressive reporting. Accounting Review, 85(4), 1325-1346. https://doi.org/10.2308/accr.2010.85.4.1325

Jørgensen, M., \& Phillips, L. (2002). Discourse Analysis as Theory and Method. Discourse Analysis as Theory and Method. London: SAGE Publications. https://doi.org/10.4135/9781849208871

Jorissen, A., Lybaert, N., Orens, R., \& van der Tas, L. (2013). A geographic analysis of constituents' formal participation in the process of international accounting standard setting: Do we have a level playing field? Journal of Accounting and Public Policy, 32(4), 237-270. https://doi.org/10.1016/j.jaccpubpol.2013.04.005

Kabir, H., \& Rahman, A. (2018). How Does the IASB Use the Conceptual Framework in Developing IFRSs? An Examination of the Development of IFRS 16 Leases. Journal of Financial Reporting, 3(1), 93-116. https://doi.org/10.2308/jfir-52232

Kam, V. (1990). Accounting Theory (2nd ed.). New York: John Wiley \& Sons, Inc.

Kenny, S. Y., \& Larson, R. K. (2009). Interpreting IFRS: Understanding the role of the International Financial Reporting Interpretations Committee. Journal of Accountancy, 208(4), 60-64.

Knutson, P. H. (1993). Financial Reporting in the 1990s and Beyond: A Position Paper. Charlottesville: Association for Investment Management and Research.

Königsgruber, R. (2010). A political economy of accounting standard setting. Journal of Management and Governance, 14(4), 277-295. https://doi.org/10.1007/s10997-0099101-1

Kuhn, T. S. (1996). The Structure of Scientific Revolutions (3rd ed.). Chicago: The University of Chicago Press. https://doi.org/10.1017/CBO9780511613975

Laclau, E. (1990). New Reflections on the Revolution of Our Time. London: Verso.

Laclau, E. (1994). The Making of Political Identities. (E. Laclau, Ed.). London: Verso.

Laclau, E. (2007a). Emancipation(s). London: Verso.

Laclau, E. (2007b). Why do Empty signifiers matter to Politics? In Emancipation(s) (pp. 3646). London: Verso.

Laclau, E. (2013). A razão populista. São Paulo, SP: Três estrelas.

Laclau, E. (2014). Posfácio. In D. de Mendonça \& L. P. Rodrigues (Eds.), Pós-estruturalismo e teoria do discurso: em torno de Ernesto Laclau (2nd ed.). Porto Alegre, RS: Editora Universitária da PUCRS.

Laclau, E., \& Mouffe, C. (1985). Hegemony and Socialist Strategy: Towards a Radical 
Democratic Politics. London: Verso.

Laclau, E., \& Zac, L. (1994). Minding the Gap: The Subject of Politics. In E. Laclau (Ed.), The Making of Political Identities (pp. 11-39). London: Verso.

Largay III, J. A. (2001). Commentaries on Acccounting for Leases. Accounting Horizons, 15(3), 273-273. https://doi.org/10.2308/acch.2001.15.3.273

Larson, R. K., \& Herz, P. J. (2011). The academic community's participation in global accounting standard-setting. Research in Accounting Regulation, 23(1), 34-45. https://doi.org/10.1016/j.racreg.2011.03.006

Larson, R. K., \& Herz, P. J. (2013). A Multi-Issue/Multi-Period Analysis of the Geographic Diversity of IASB Comment Letter Participation. Accounting in Europe, 10(1), 99-151. https://doi.org/10.1080/17449480.2013.772716

Larson, R. K., \& Kenny, S. Y. (2011). The financing of the IASB: An analysis of donor diversity. Journal of International Accounting, Auditing and Taxation, 20(1), 1-19. https://doi.org/10.1016/j.intaccaudtax.2010.12.003

Lather, P. (1993). Fertile Obsession: Validity After Poststructuralism. The Sociological Quarterly, 34(4), 673-693. https://doi.org/10.1111/j.1533-8525.1993.tb00112.x

Latour, B. (1987). Science in Action: How to follow scientists and engineers through society. Cambridge: Harvard University Press.

Laughlin, R. C. (1995). Empirical research in accounting: alternative approaches and a case for "middle-range" thinking. Accounting, Auditing \& Accountability Journal, 8(1), 6387. https://doi.org/10.1108/09513579510146707

Laughlin, R. C. (1999). Critical accounting: nature, progress and prognosis. Accounting, Auditing \& Accountability Journal, 12(1), 73-78. https://doi.org/10.1108/09513579910259942

Laughlin, R. C., \& Puxty, A. G. (1983). Accounting Regulation: an Alternative Perspective. Journal of Business Finance \& Accounting, 10(3), 451-479. https://doi.org/10.1111/j.1468-5957.1983.tb00445.x

Leuz, C., Pfaff, D., \& Hopwood, A. G. (2004). The Economics and Politics of Accounting: International Perspectives on Research Trends, Policy, and Practice. Oxford: Oxford University Press.

Li, T. M. (2011). Rendering society technical: government through Community and the Ethnographic turn at the World Bank in Indonesia. In D. Mosse (Ed.), Adventures in Aidland: the Anthropology of Professionals in International Development (pp. 57-80). New York, NY: Berghahn Books.

Lincoln, Y. S., \& Guba, E. G. (1985). Naturalistic Inquiry. London, UK: SAGE Publications.

Lincoln, Y. S., \& Guba, E. G. (1986). But is it rigorous? Trustworthiness and authenticity in naturalistic evaluation. New Directions for Program Evaluation, 30, 73-84. https://doi.org/10.1002/ev.1427 
Lincoln, Y. S., Lynham, S. A., \& Guba, E. G. (2018). Paradigmatic Controversies, Contradictions, and Emerging Confluences, Revisited. In N. K. Denzin \& Y. S. Lincoln (Eds.), The SAGE Handbook of Qualitative Research. Thousand Oaks, California: Sage Publications, Inc.

Lipe, R. C. (2001). Lease Accounting Research and the G4+1 Proposal. Accounting Horizons, 15(3), 299-310. https://doi.org/10.2308/acch.2001.15.3.299

Lloyd, S. (2016). Investor Perspective: A new lease of life. (p. 16). London.

Luthardt, U., \& Zimmermann, J. (2009). A European view on the legitimacy of accounting procedures: Towards a deliberative-accountability framework for analysis. Research in Accounting Regulation, 21(2), 79-88. https://doi.org/10.1016/j.racreg.2009.06.001

Macintosh, N. B. (2002). Accounting, Accountants and Accountability: Poststructuralist positions. London: Routledge. Taylor \& Francis Group.

Madsen, P. E. (2013). The pursuit of high quality accounting standards. Accounting Horizons, 27(4), 867-876. https://doi.org/10.2308/acch-10368

Malsch, B., Gendron, Y., \& Grazzini, F. (2011). Investigating interdisciplinary translations. Accounting, Auditing \& Accountability Journal, 24(2), 194-228. https://doi.org/10.1108/09513571111100681

Marcelino, M. M., Miguel, N., Rodrigues, B., \& Cariano, A. (2017). Contabilidade das operações de leasing: análise de possíveis ocorrências de lobbying no processo de emissão da IFRS 16. Revista de Educação e Pesquisa Em Contabilidade, 11(4), 467484. https://doi.org/10.17524/repec.v11i4.1686

Marchart, O. (2014). Teoria do discurso, pós-estruturalismo e paradigma da Escola de Essex. In D. de Mendonça \& L. P. Rodrigues (Eds.), Pós-estruturalismo e teoria do discurso: em torno de Ernesto Laclau (2nd ed.). Porto Alegre, RS: Editora Universitária da PUCRS.

Marques, L. R. (2014). Contribuições da Democracia Radical e da teoria do discurso de Ernesto Laclau ao estudo da gestão da educação. In D. de Mendonça \& L. P. Rodrigues (Eds.), Pós-estruturalismo e teoria do discurso: em torno de Ernesto Laclau (2nd ed.). Porto Alegre, RS: Editora Universitária da PUCRS.

Martell, L. (2016). The Sociology of Globalization (2nd ed.). Cambridge, UK: Polity Press.

Martinez-Diaz, L. (2005). Strategic Experts and Improvising Regulators: Explaining the IASC's Rise to Global Influence, 1973-2001. Business and Politics, 7(3), 1-26. https://doi.org/10.2202/1469-3569.1135

Matherly, M., \& Shortridge, R. T. (2009). A pragmatic model to estimate journal quality in accounting. Journal of Accounting Education, 27(1), 14-29. https://doi.org/10.1016/j.jaccedu.2009.07.001

Matos, E. B. S. de. (2013). Critérios de Reconhecimento, Mensuração e Apresentação das operações de leasing segundo a minuta de pronunciamento (ED/2010/9) do IASB: análise da opinião dos usuários da informação contábil. (Dissertação de Mestrado, 
Programa Multiinstitucional e Inter-Regional de Pós-Graduação em Ciências Contábeis (UnB/UFPB/UFRN), Universidade de Brasília).

Matos, E. B. S. de, Góis, A. D., Nasu, V. H., \& Murcia, F. D.-R. (2020). Estamos Utilizando as Referências Adequadas? Comparação das Citações Utilizadas na Literatura Nacional e Internacional sobre Leasing. Sociedade, Contabilidade e Gestão, 15(1), 99-121. https://doi.org/10.21446/scg_ufrj.v0i0.26941

Matos, E. B. S. de, Gonçalves, R. de S., Niyama, J. K., \& Marques, M. de M. (2013). Convergência internacional: análise da relação entre o processo normativo e a composição dos membros do IASB. Advances in Scientific and Applied Accounting, 6(1), 66-91. https://doi.org/10.14392/ASAA/2013060104

Matos, E. B. S. de, \& Murcia, F. D.-R. (2019a). IFRS 16: uma visão contábil prática e crítica da nova norma de leasing sob a ótica das arrendatárias. Revista Brasileira de Contabilidade, (238), 50-65. https://doi.org/10.17648/rbc-vol0n238-1887

Matos, E. B. S. de, \& Murcia, F. D. (2019b). Contabilidade e Arrendamento Mercantil/ Leasing: Revisão da Literatura Nacional e Internacional (2000-2018). Revista de Educação e Pesquisa Em Contabilidade (REPeC), 13(1), 68-88. https://doi.org/10.17524/repec.v13i1.1999

Matos, E. B. S. de, \& Niyama, J. K. (2013). Nível de percepção dos usuários da informação contábil sobre os critérios de reconhecimento, mensuração e apresentação constantes da minuta de pronunciamento do FASB/IASB - ED/2010/9 - Leases. Enfoque: Reflexão Contábil, 32(2), 101-117. https://doi.org/10.4025/enfoque.v32i2.20270

Matos, N. B., \& Niyama, J. K. (2018). IFRS 16 - Leases: Challenges, Perspectives and Implications in the Light of Substance Over Form. Revista de Educação e Pesquisa Em Contabilidade (REPeC), 12(3), 323-340. https://doi.org/10.17524/repec.v12i3.1858

May, T. (2011). Social Research: Issues, methods and process (4th ed.). Berkshire, UK: McGraw-Hill Open University Press.

Mayntz, R. (2010). Legitimacy and Compliance in Transnational Governance. Max Planck Institute for the Study of Societies. MPIfG working paper, 10/5.

McGregor, W. (1996). Accounting for Leases: A New Approach. Financial Accounting Series No. 163-A. Norwalk, CT: Financial Accounting Foundation.

McGregor, W. (2012). Personal Reflections on Ten Years of the IASB. Australian Accounting Review, 22(3), 225-238. https://doi.org/10.1111/j.1835-2561.2012.00184.x

Mehrpouya, A., \& Salles-Djelic, M.-L. (2019). Seeing like the market; exploring the mutual rise of transparency and accounting in transnational economic and market governance. Accounting, Organizations and Society, 76, 12-31. https://doi.org/10.1016/j.aos.2019.01.003

Mellado, L., \& Parte, L. (2017). Determinantes corporativos de la intensidad del lobby en el proceso de elaboración de la norma de arrendamientos. Revista de Contabilidad, 20(2), 131-142. https://doi.org/10.1016/j.rcsar.2016.09.001 
Mendonça, D. de. (2009). Como olhar "o político" a partir da teoria do discurso. Revista Brasileira de Ciência Política, 1, 153-169.

Mendonça, D. de. (2014). A impossibilidade da Emancipação: notas a partir da teoria do discurso. In Pós-estruturalismo e teoria do discurso: em torno de Ernesto Laclau (2nd ed.). Porto Alegre, RS: Editora Universitária da PUCRS.

Mendonça, D. de, \& Rodrigues, L. P. (2014). Em torno de Ernesto Laclau: pós-estruturalismo e Teoria do Discurso. In D. de Mendonça \& L. P. Rodrigues (Eds.), Pós-estruturalismo e teoria do discurso: em torno de Ernesto Laclau (2nd ed.). Porto Alegre, RS: Editora Universitária da PUCRS.

Merton, R. K. (1973). The Sociology of Science: Theoretical and Empirical Investigations. Chicago: The University of Chicago Press.

Meyer, J. W., \& Rowan, B. (1977). Institutionalized Organizations: Formal Structure as Myth and Ceremony. American Journal of Sociology, 83(2), 340-363.

https://doi.org/10.1086/226550

Michele, P., Nicola, M., Claudio, T., Monica, V., Laura, R., Alberto, Q., \& Elisa, R. (2016). Who Influences Whom? An Exploratory Analysis of the Interrelations between Accounting Research and the IASB's Standard Setting Activity. Financial Reporting, 6(1), 77-94.

Moll, J., \& Hoque, Z. (2011). Budgeting for legitimacy: The case of an Australian university. Accounting, Organizations and Society, 36(2), 86-101.

https://doi.org/10.1016/j.aos.2011.02.006

Monson, D. W. (2001). The conceptual framework and accounting for leases. Accounting Horizons, 15(3), 275-287. https://doi.org/10.2308/acch.2001.15.3.275

Morais, A. I. (2013). Why companies choose to lease instead of buy? Insights from academic literature. Academia Revista Latinoamericana de Administración, 26(3), 432-446. https://doi.org/10.1108/ARLA-07-2013-0091

Morales-Díaz, J., \& Zamora-Ramírez, C. (2018). IFRS 16 (Leases) Implementation: Entity’s Decisions Impact on Financial Statements. Aestimatio: The IEB Journal of Finance, 17, 60-97. https://doi.org/10.5605/IEB.17.4

Morgan, G. (1988). Accounting as reality construction: Towards a new epistemology for accounting practice. Accounting, Organizations and Society, 13(5), 477-485. https://doi.org/10.1016/0361-3682(88)90018-9

Morley, J. (2016). Internal lobbying at the IASB. Journal of Accounting and Public Policy, 35(3), 224-255. https://doi.org/10.1016/j.jaccpubpol.2015.12.003

Mouffe, C. (2015). Sobre o Político. São Paulo, SP: Martins Fontes.

Müller, J. (2014). An accounting revolution? The financialisation of standard setting. Critical Perspectives on Accounting, 25(7), 539-557. https://doi.org/10.1016/j.cpa.2013.08.006

Nailor, H., \& Lennard, A. (2000). LEASES: Implementation of a New Approach. Financial 
Accounting Series No. 206-A. Norwalk, CT: Financial Accounting Foundation.

Nascimento, A. R. do. (2011). Controle gerencial como prática social e organizacional: análise crítica a partir de três paradigmas de pesquisa. Universidade de São Paulo, São Paulo. https://doi.org/10.11606/T.12.2011.tde-10082011-203453

Neumann, I. B., \& Sending, O. J. (2010). Governing the Global Polity: Practice, Mentality, Rationality. Ann Arbor, MI: The University of Michigan Press.

Nobes, C. (2013). The continued survival of international differences under IFRS. Accounting and Business Research, 43(2), 83-111. https://doi.org/10.1080/00014788.2013.770644

Norval, A. (2014). Prefácio da primeira edição. In D. de Mendonça \& L. P. Rodrigues (Eds.), Pós-estruturalismo e teoria do discurso: em torno de Ernesto Laclau (2nd ed.). Porto Alegre, RS: Editora Universitária da PUCRS.

Nye, J. S., \& Keohane, R. O. (1971). Transnational Relations and World Politics: An Introduction. International Organization, 25(03), 329. https://doi.org/10.1017/S0020818300026187

Ordelheide, D. (2004). The Politics of Accounting: A Framework. In C. Leuz, D. Pfaff, \& A. Hopwood (Eds.), The Economics and Politics of Accounting: International Perspectives on Research Trends, Policy, and Practice (pp. 269-284). Oxford: Oxford University Press.

Orens, R., Jorissen, A., Lybaert, N., \& Van Der Tas, L. (2011). Corporate Lobbying in Private Accounting Standard Setting: Does the IASB have to Reckon with National Differences? Accounting in Europe, 8(2), 211-234. https://doi.org/10.1080/17449480.2011.621672

Palea, V. (2015). The political economy of fair value reporting and the governance of the standards-setting process: Critical issues and pitfalls from a continental European union perspective. Critical Perspectives on Accounting, 29, 1-15. https://doi.org/10.1016/j.cpa.2014.10.004

Parker, M., \& Thomas, R. (2011). What is a critical journal? Organization, 18(4), 419-427. https://doi.org/10.1177/1350508411403535

Pelger, C. (2016). Practices of standard-setting - An analysis of the IASB's and FASB's process of identifying the objective of financial reporting. Accounting, Organizations and Society, 50, 51-73. https://doi.org/10.1016/j.aos.2015.10.001

Pelger, C., \& Spieß, N. (2017). On the IASB's construction of legitimacy - the case of the agenda consultation project. Accounting and Business Research, 47(1), 64-90. https://doi.org/10.1080/00014788.2016.1198684

Perry, J., \& Nöelke, A. (2005). International Accounting Standard Setting: A Network Approach. Business and Politics, 7(3), 1-32. https://doi.org/10.2202/1469-3569.1136

Phillips, N., \& Hardy, C. (2002). Discourse analysis: investigating processes of social construction. Thousand Oaks, CA: SAGE Publications. Retrieved from http://www.loc.gov/catdir/toc/fy036/2002002730.html 
Porter, T. (2005). Private Authority, Technical Authority, and the Globalization of Accounting Standards. Business and Politics, 7(03), 1-30. https://doi.org/10.2202/14693569.1138

Posner, E. (2010). Sequence as explanation: The international politics of accounting standards. Review of International Political Economy, 17(4), 639-664. https://doi.org/10.1080/09692291003723748

Quack, S. (2010). Law, expertise and legitimacy in transnational economic governance: an introduction. Socio-Economic Review, 8(1), 3-16. https://doi.org/10.1093/ser/mwp029

Ram, R., \& Newberry, S. (2013). IFRS for SMEs: the IASB's Due Process. Australian Accounting Review, 23(1), 3-17. https://doi.org/10.1111/j.1835-2561.2012.00174.x

Ram, R., \& Newberry, S. (2017). Agenda Entrance Complexity in International Accounting Standard Setting: The Case of IFRS for SMEs. Abacus, 53(4), 485-512. https://doi.org/10.1111/abac.12122

Rear, D., \& Jones, A. (2013). Discursive struggle and contested signifiers in the arenas of education policy and work skills in Japan. Critical Policy Studies, 7(4), 375-394. https://doi.org/10.1080/19460171.2013.843469

Reither, C. L. (1998). What are the Best and the Worst Accounting Standards? Accounting Horizons, 12(3), 283-292.

Remling, E. (2018). Logics, assumptions and genre chains: a framework for poststructuralist policy analysis. Critical Discourse Studies, 15(1), 1-18. https://doi.org/10.1080/17405904.2017.1382382

Richardson, A. J. (2008). Due Process and Standard-setting: An Analysis of Due Process in Three Canadian Accounting and Auditing Standard-setting Bodies. Journal of Business Ethics, 81(3), 679-696. https://doi.org/10.1007/s10551-007-9540-z

Richardson, A. J., \& Eberlein, B. (2011). Legitimating Transnational Standard-Setting: The Case of the International Accounting Standards Board. Journal of Business Ethics, 98(2), 217-245. https://doi.org/10.1007/s10551-010-0543-9

Richardson, L. (1994). Writing: A method of inquiry. In N. K. Denzin \& Y. S. Lincoln (Eds.), Handbook of qualitative research (pp. 516-529). Thousand Oaks, CA: SAGE.

Richardson, L. (1997). Fields of play: Constructing an academic life. New Brunswick, NJ: Rutgers University Press.

Risse, T. (2013). Transnational Actors and World Politics. In W. Carlsnaes, T. Risse, \& B. A. Simmons (Eds.), Handbook of International Relations (2nd ed.). London: SAGE Publications Ltd.

Rodrigues, L. L., \& Craig, R. (2007). Assessing international accounting harmonization using Hegelian dialectic, isomorphism and Foucault. Critical Perspectives on Accounting, 18(6), 739-757. https://doi.org/10.1016/j.cpa.2006.02.007

Rosenfield, P. (2006). Contemporary Issues in Financial Reporting: a user-oriented 
approach. Contemporary Issues in Financial Reporting. Abingdon: Routledge. https://doi.org/10.4324/9780203088159

Roslender, R. (2006). Critical Theory. In Z. Hoque (Ed.), Methodological Issues in Accounting Research: Theories and Methods. London: Spiramus.

Ryan, S. G., Herz, R. H., Iannaconi, T. E., Maines, L. A., Palepu, K. G., Schipper, K., ... Vincent, L. (2001). Evaluation of the Lease Accounting Proposed in G4+1 Special Report. Accounting Horizons, 15(3), 289-298. https://doi.org/10.2308/acch.2001.15.3.289

Sales Jr., R. (2014). Laclau e Foucault: desconstrução e genealogia. In D. de Mendonça \& L. P. Rodrigues (Eds.), Pós-estruturalismo e teoria do discurso: em torno de Ernesto Laclau (2nd ed.). Porto Alegre, RS: Editora Universitária da PUCRS.

Samsonova-Taddei, A., \& Humphrey, C. (2014). Transnationalism and the transforming roles of professional accountancy bodies. Accounting, Auditing \& Accountability Journal, 27(6), 903-932. https://doi.org/10.1108/AAAJ-05-2013-1345

SEC. (2005). Report and Recommendations Pursuant to Section 401(c) of the Sarbanes-Oxley Act of 2002 On Arrangements with Off-Balance Sheet Implications, Special Purpose Entities, and Transparency of Filings by Issuers (Vol. 401). Washington. Retrieved from https://www.sec.gov/news/studies/soxoffbalancerpt.pdf

Shafer, W. E., \& Gendron, Y. (2005). Analysis of a failed jurisdictional claim. Accounting, Auditing \& Accountability Journal, 18(4), 453-491. https://doi.org/10.1108/09513570510609324

Shapiro, I. (2002). Problems, Methods, and Theories in the Study of Politics, or What's Wrong with Political Science and What to Do About it. Political Theory, 30(4), 596619. https://doi.org/10.1177/0090591702030004008

Shortridge, R. T., \& Smith, P. A. (2009). Understanding the changes in accounting thought. Research in Accounting Regulation, 21(1), 11-18. https://doi.org/10.1016/j.racreg.2008.11.010

Simmons, B. A. (2001). The International Politics of Harmonization: The Case of Capital Market Regulation. International Organization, 55(3), 589-620. https://doi.org/10.1162/00208180152507560

Slaughter, A.-M. (2004). A new world order. Princeton, New Jersey: Princeton University Press.

Smith, M. (2003). Research Methods in Accounting. Thousand Oaks, California: SAGE Publications.

Southwell, M. (2014). Em torno da construção de hegemonia educativa: contribuições do pensamento de Ernesto Laclau ao problema da transmissão da cultura. In D. de Mendonça \& L. P. Rodrigues (Eds.), Pós-estruturalismo e teoria do discurso: em torno de Ernesto Laclau (2nd ed.). Porto Alegre, RS: Editora Universitária da PUCRS.

Spencer, A. W., \& Webb, T. Z. (2015). Leases: A review of contemporary academic literature 
relating to lessees. Accounting Horizons, 29(4), 997-1023. https://doi.org/10.2308/acch51239

Stenka, R., \& Jaworska, S. (2019). The use of made-up users. Accounting, Organizations and Society, 78, 101055. https://doi.org/10.1016/j.aos.2019.07.001

Stirling, A. (2008). "Opening Up" and "Closing Down": Power, Participation, and Pluralism in the Social Appraisal of Technology. Science, Technology, \& Human Values, 33(2), 262-294. https://doi.org/10.1177/0162243907311265

Strange, S. (1998). What Theory? The Theory in Mad Money. SSRN Electronic Journal. https://doi.org/10.2139/ssrn.146958

Street, D. L. (2006). The G4's role in the evolution of the international accounting standard setting process and partnership with the IASB. Journal of International Accounting, Auditing and Taxation, 15(1), 109-126.

https://doi.org/10.1016/j.intaccaudtax.2006.01.007

Suchman, M. C. (1995). Managing Legitimacy: Strategic and Institutional Approaches. Academy of Management Review, 20(3), 571-610. https://doi.org/10.5465/AMR.1995.9508080331

Suddaby, R., Cooper, D. J., \& Greenwood, R. (2007). Transnational regulation of professional services: Governance dynamics of field level organizational change. Accounting, Organizations and Society, 32(4-5), 333-362. https://doi.org/10.1016/j.aos.2006.08.002

Suddaby, R., \& Greenwood, R. (2005). Rhetorical Strategies of Legitimacy. Administrative Science Quarterly, 50(1), 35-67. https://doi.org/10.2189/asqu.2005.50.1.35

Suddaby, R., \& Viale, T. (2011). Professionals and field-level change: Institutional work and the professional project. Current Sociology, 59(4), 423-442.

https://doi.org/10.1177/0011392111402586

Sunder, S. (2011). IFRS monopoly: the Pied Piper of financial reporting. Accounting and Business Research, 41(3), 291-306. https://doi.org/10.1080/00014788.2011.569055

Sutton, T. G. (1984). Lobbying of accounting standard-setting bodies in the U.K. and the U.S.A.: A Downsian analysis. Accounting, Organizations and Society, 9(1), 81-95. https://doi.org/10.1016/0361-3682(84)90031-X

Tandy, P. R., \& Wilburn, N. L. (1996). The academic community's participation in standard setting: Submission of comment letters on SFAS Nos. 1-117. Accounting Horizons, 10(3), 92-111.

Tinker, A. (1984). Theories of the state and the state of accounting: Economic reductionism and political voluntarism in accounting regulation theory. Journal of Accounting and Public Policy, 3(1), 55-74. https://doi.org/10.1016/0278-4254(84)90012-7

Torfing, J. (1999). New Theories of Discourse. Oxford: Blackwell Publishers.

Tsingou, E. (2008). Transnational private governance and the Basel process: banking regulation and supervision, private interests and Basel II. In J.-C. Graz \& A. Nölke 
(Eds.), Transnational Private Governance and its Limits (pp. 58-69). New York, NY: Routledge.

Urry, J. (2000). Sociology Beyond Societies: Mobilities for the twenty-first century. Annals of Tourism Research (Vol. 28). London: Routledge. Taylor \& Francis Group.

Visoto, M. C. R. (2018). Contabilidade de leasing (IFRS 16): a percepção dos usuários da informação contábil de acordo com os critérios propostos pelo ED/2013/6. (Dissertação de Mestrado, Programa de Pós-Graduação em Ciências Contábeis - PPGCONT, Universidade de Brasília). Retrieved from https://doi.org/10.1080/10426914.2018.1512126\%0Ahttps://doi.org/10.1016/j.jmatprotec .2018.10.035\%0Ahttps://doi.org/10.1007/s40430-018-14896\%0Ahttps://doi.org/10.1007/s40436-018-02211\%0Ahttps://doi.org/10.1080/21693277.2017.1357055\%0Ahttp://dx.doi.org/10

Voss, B. de L. (2016). Discursive constructions of social and environmental accounting in Brazil: the case of Petrobras. Universidade de São Paulo, São Paulo. https://doi.org/10.11606/T.12.2016.tde-09062016-172826

Walker, R. G., \& Robinson, P. (1993). A critical assessment of the literature on political activity and accounting regulation. Research in Accounting Regulation, 7, 3-40.

Warren, R., Carter, D. B., \& Napier, C. J. (2019). Opening up the politics of standard setting through discourse theory: the case of IFRS for SMEs. Accounting, Auditing \& Accountability Journal, 33(1), 124-151. https://doi.org/10.1108/AAAJ-04-2018-3464

Watts, R. L. (1977). Corporate Financial Statements, A Product of the Market and Political Processes. Australian Journal of Management, 2(1), 53-75. https://doi.org/10.1177/031289627700200104

Watts, R. L., \& Zimmerman, J. L. (1978). Towards a Positive Theory of the Determination of Accounting Standards. The Accounting Review, 53(1), 112-134. Retrieved from http://www.jstor.org/stable/245729\%0Ahttp://about.jstor.org/terms

Watts, R. L., \& Zimmerman, J. L. (1979). The demand for and supply of accounting theories: the market for excuses. Accounting Review, 54(2), 273-305. Retrieved from http://www.jstor.org/stable/10.2307/245516

Weetman, P. (2001). Controlling the standard-setting agenda: the role of FRS 3. Accounting, Auditing \& Accountability Journal, 14(1), 85-109. https://doi.org/10.1108/09513570110381088

Weffort, E. F. J. (2005). O Brasil e a Harmonização Contábil Internacional: influências dos sistemas jurídico e educacional, da cultura e do mercado. São Paulo, SP: Atlas.

Whittington, G. (2008). Harmonisation or discord? The critical role of the IASB conceptual framework review. Journal of Accounting and Public Policy, 27(6), 495-502. https://doi.org/10.1016/j.jaccpubpol.2008.09.006

Wickramasinghe, D. (2006). Power and Accounting: a guide to Critical Research. In Z. Hoque (Ed.), Methodological Issues in Accounting Research: Theories and Methods. London: Spiramus. 
Williams, J. (2013). Pós-estruturalismo (2nd ed.). Petrópolis, RJ: Vozes.

Williams, P. F. (1987). The legitimate concern with fairness. Accounting, Organizations and Society, 12(2), 169-189. https://doi.org/10.1016/0361-3682(87)90005-5

Williams, P. F. (2014). The Myth of Rigorous Accounting Research. Accounting Horizons, 28(4), 869-887. https://doi.org/10.2308/acch-50880

Williams, P. F., \& Ravenscroft, S. P. (2015). Rethinking Decision Usefulness. Contemporary Accounting Research, 32(2), 763-788. https://doi.org/10.1111/1911-3846.12083

Willmott, H. (1990). Serving the Public Interest? A Critical Analysis of a Professional Claim. In D. J. Cooper \& T. M. Hopper (Eds.), Critical Accounts (pp. 315-331). London, UK: The Macmillan Press.

Willmott, H. (2000). Organising the profession: a theoretical and historical examination of the development of the major accountancy bodies in the UK. In J. R. Edwards (Ed.), The History of Accounting: Critical Perspectives on Business and Management (pp. 233269). London: Routledge.

Wingard, C., Bosman, J., \& Amisi, B. (2016). The legitimacy of IFRS. Meditari Accountancy Research, 24(1), 134-156. https://doi.org/10.1108/MEDAR-02-2014-0032

Wolk, H. I., Dodd, J. L., \& Rozycki, J. J. (2008). Accounting Theory: Conceptual Issues in a Political and Economic Environment (7th ed.). Thousand Oaks, CA: Sage Publications, Inc.

Yen, A. C., Hirst, D. E., \& Hopkins, P. E. (2007). A Content Analysis of the Comprehensive Income Exposure Draft Comment Letters. Research in Accounting Regulation, 19, $53-$ 79. https://doi.org/10.1016/S1052-0457(06)19003-7

Young, J. J. (1994). Outlining regulatory space: Agenda issues and the FASB. Accounting, Organizations and Society, 19(1), 83-109. https://doi.org/10.1016/0361-3682(94)900132

Young, J. J. (1996). Institutional thinking: The case of financial instruments. Accounting, Organizations and Society, 21(5), 487-512. https://doi.org/10.1016/03613682(95)00031-3

Young, J. J. (2003). Constructing, persuading and silencing: the rhetoric of accounting standards. Accounting, Organizations and Society, 28(6), 621-638. https://doi.org/10.1016/S0361-3682(02)00016-8

Young, J. J. (2006). Making up users. Accounting, Organizations and Society, 31(6), 579600. https://doi.org/10.1016/j.aos.2005.12.005

Young, J. J. (2014). Separating the political and technical: Accounting standard-setting and purification. Contemporary Accounting Research, 31(3), 713-747. https://doi.org/10.1111/1911-3846.12046

Young, J. J. (2018). What it means to be critical. Critical Perspectives on Accounting, 50, 1314. https://doi.org/10.1016/j.cpa.2017.08.004 
Young, J. J., \& Mouck, T. (1996). Objectivity and the role of history in the development and review of accounting standards. Accounting, Auditing \& Accountability Journal, 9(3), 127-147. https://doi.org/10.1108/09513579610122036

Young, J. J., \& Oakes, L. S. (2009). Reflections on the practice of research. Accounting Forum, 33(4), 280-284. https://doi.org/10.1016/j.accfor.2009.01.004

Young, J. J., \& Williams, P. F. (2010). Sorting and comparing: Standard-setting and "ethical" categories. Critical Perspectives on Accounting, 21(6), 509-521. https://doi.org/10.1016/j.cpa.2010.02.002

Zeff, S. A. (2002). "Political" Lobbying on proposed standards: A challenge to the IASB. Accounting Horizons, 16(1), 43-54. https://doi.org/10.2308/acch.2002.16.1.43

Zeff, S. A. (2012). The Evolution of the IASC into the IASB, and the Challenges it Faces. The Accounting Review, 87(3), 120202131311000. https://doi.org/10.2308/accr-10246

Zhang, X. (2014). Research on Accounting Standards Setting Problems. Journal on Business Review, 3(4), 2014. https://doi.org/10.5176/2010-4804_3.4.338

Zürn, M., \& Stephen, M. (2010). The View of Old and New Powers on the Legitimacy of International Institutions. Politics, 30(1_suppl), 91-101. https://doi.org/10.1111/j.14679256.2010.01388.x 


\section{APÊNDICE A - Modelos e Lançamentos Contábeis Propostos}

Com o intuito de embasar a discussão da tese, mais especificamente com relação ao conteúdo da norma, apresento neste apêndice algumas discussões aplicadas aos modelos contábeis de leasing e aos critérios de contabilização: da norma inicial (IAS 17), dos projetos intermediários (EDs) e da norma final (IFRS 16), conforme descrito a seguir:

(i) IAS 17 (IASB, 2003);

(ii) $\quad \mathrm{ED} / 2010 / 9$ (IASB, 2010b);

(iii) ED/2013/6 (IASB, 2013c); e

(iv) IFRS 16 (IASB, 2016e).

Apresento todos os modelos tanto para arrendadoras quanto para arrendatárias. A discussão compreende tais documentos tendo em vista que estas são as normas ou as propostas normativas consolidadas que já envolvem aspectos de reconhecimento, mensuração e apresentação de informações contábeis propriamente ditas. Não discuto, aqui, os estudos que embasaram as propostas de mudança normativa, como os do G4+1 (McGregor, 1996; Nailor \& Lennard, 2000), e nem o DP/2009/1 (IASB, 2009a), pois esses são documentos que apresentam possibilidades de visões a serem utilizadas na norma a ser emitida, mas não possuem, ainda, modelos contábeis claros e fixos propostos.

(i) IAS 17 - Leases

A IAS 17 (IASB, 2003) possui sua tradução para o português, editada como sendo o Pronunciamento Técnico CPC 06 (R1) (CPC, 2010). Nela, ambas as partes do contrato devem, inicialmente, classificar os arrendamentos em: financeiro ou operacional.

$\mathrm{O}$ arrendamento financeiro é aquele em que há transferência substancial dos riscos e benefícios (do arrendador para o arrendatário) inerentes à propriedade. O operacional é o que não há tal transferência. Para fins de simplificação e comparação, apresento na Figura 39 as descrições dos modelos contábeis para o arrendamento financeiro, assim como uma proposta de lançamentos contábeis tomando como base tal modelo (Figura 40). 
Figura 39 - Descrição dos modelos de Arrendamento Financeiro - IAS 17

\begin{tabular}{|c|c|c|}
\hline IAS 17 & Arrendatário & Arrendador \\
\hline Reconhecimento & $\begin{array}{l}\text { Reconhecer, no começo do prazo e em contas específicas, } \\
\text { os arrendamentos como ativos e passivos nos seus } \\
\text { balanços. }\end{array}$ & $\begin{array}{l}\text { Baixa do Ativo imobilizado e } \\
\text { reconhecimento dele como } \\
\text { "contas a receber". }\end{array}$ \\
\hline $\begin{array}{l}\text { Mensuração } \\
\text { Inicial }\end{array}$ & $\begin{array}{l}\text { Valor justo da propriedade arrendada ou, se inferior, ao } \\
\text { valor presente dos pagamentos mínimos do } \\
\text { arrendamento mercantil } \\
\text { (taxa de desconto: taxa de juros implícita; se não for } \\
\text { identificável: taxa incremental de financiamento do } \\
\text { arrendatário). }\end{array}$ & $\begin{array}{l}\text { Valor igual ao investimento } \\
\text { líquido no arrendamento. }\end{array}$ \\
\hline $\begin{array}{l}\text { Mensuração } \\
\text { Subsequente }\end{array}$ & $\begin{array}{l}\text { Ativo: Baixa por meio de despesa de depreciação } \\
\text { (amortização) relativa a ativos depreciáveis (amortizáveis) } \\
\text { pela vida útil do bem (se houver expectativa da } \\
\text { transferência da propriedade ao final do contrato) ou pelo } \\
\text { prazo do contrato. } \\
\text { Passivo: Apropriação da taxa de juros a cada período. } \\
\text { Baixa dos passivos pelos pagamentos, que devem ser } \\
\text { segregados entre encargo financeiro e redução do passivo } \\
\text { em aberto. }\end{array}$ & $\begin{array}{l}\text { Aumento das contas a receber } \\
\text { pelo reconhecimento dos juros } \\
\text { por meio de uma receita } \\
\text { financeira. Os recebimentos do } \\
\text { arrendamento são tratados pelo } \\
\text { arrendador como amortização } \\
\text { de capital e receita } \\
\text { financeira. }\end{array}$ \\
\hline Opções & $\begin{array}{l}\text { Reconhecer se for razoavelmente certo que o arrendatário } \\
\text { exercerá a opção. }\end{array}$ & Não cita. \\
\hline BP & $\begin{array}{l}\text { Ativo imobilizado (ou intangível) e } \\
\text { Passivo financeiro. }\end{array}$ & Ativo financeiro. \\
\hline DFC & $\begin{array}{l}\text { Principal: Redução do fluxo de caixa operacional } \\
\text { Encargo Financeiro: Redução do fluxo de caixa de } \\
\text { financiamento }\end{array}$ & $\begin{array}{l}\text { Aumento do fluxo de caixa } \\
\text { operacional/financeiro. }\end{array}$ \\
\hline DRE & $\begin{array}{l}\text { Depreciação: despesa operacional } \\
\text { Encargo Financeiro: despesa financeira }\end{array}$ & $\begin{array}{l}\text { Juros: Receita } \\
\text { Financeira/Operacional } \\
\end{array}$ \\
\hline Impairment & Sim & Sim \\
\hline
\end{tabular}

Fonte: Elaborado pelo Autor com base na IAS 17 (IASB, 2003).

Inicialmente, com relação à classificação dos arrendamentos, espera-se que exista simetria para arrendadores e arrendatários, porém não existe controle dessa questão de forma direta. No modelo de arrendamento financeiro, para arrendatárias, observa-se que, em decorrência do "recebimento" dos riscos e benefícios inerentes ao bem subjacente, a entidade reconhece tal bem em suas DFs, portanto, surge um ativo (na categoria a qual ele pertence) e um passivo decorrente do reconhecimento desse ativo. Em um primeiro momento, ambos possuem o mesmo valor, que é o valor presente dos pagamentos mínimos. Após isso, a mensuração de cada item é realizada de forma individualizada, sendo o ativo depreciado (ou amortizado) e o passivo sofre, como ajuste, um aumento decorrente do reconhecimento dos encargos financeiro e uma redução decorrente dos pagamentos realizados.

Já para arrendadora, no arrendamento financeiro, há, de forma a manter a simetria com a arrendatária, uma baixa do ativo subjacente e um reconhecimento de um recebível pelo valor do investimento no arrendamento. Nesse momento também é reconhecido um ganho/perda, caso haja (diferença entre a baixa do ativo arrendado e o reconhecimento do recebível). Após o 
reconhecimento, os ajustes referem-se ao reconhecimento da receita financeira dos recebíveis e sua consequente baixa em decorrência dos recebimentos. Não há, nesse modelo, reconhecimento de passivos.

Para simplificação da compreensão dos movimentos contábeis, apresento, na Figura 40, uma proposta de contabilização de arrendamento financeiro com base nos critérios da IAS 17 (IASB, 2003).

Figura 40 - Lançamentos Contábeis de Arrendamento Financeiro - IAS 17

\begin{tabular}{|c|c|c|c|}
\hline \multicolumn{4}{|c|}{ IAS 17 - Arrendamento Financeiro } \\
\hline & Arrendatário & & Arrendador \\
\hline Inicial & $\begin{array}{l}\text { Pelo Recebimento do Bem } \\
\text { D: Bens Arrendados (Ativo Imobilizado) } \\
\text { C: Obrigações com Arrendamento (Passivo) } \\
\text { Pelo reconhecimento inicial dos juros a transcorrer } \\
\text { D: Encargos a Apropriar (Passivo, conta redutora de "obrigações com arrendamento") } \\
\text { C: Obrigações com Arrendamento (Passivo) }\end{array}$ & \multirow[t]{2}{*}{ Inicial } & $\begin{array}{l}\text { Pela entrega (e baixa) do bem } \\
\text { D: Contas a Receber (Ativo) } \\
\text { C: Receita inicial da transação (Resultado) } \\
\text { Pela baixa do bem } \\
\text { D: Custo do Bem (Resultado) } \\
\text { C: Ativo imobilizado (Ativo) }\end{array}$ \\
\hline \multirow{3}{*}{ Mensais } & $\begin{array}{l}\text { Pela apropriação da despesa de depreciação } \\
\text { D: Despesa de Depreciação de Bens Arrendados (Resultado) } \\
\text { C: Depreciação Acumulada de Bens Arrendados (Redutora de Ativo) }\end{array}$ & & $\begin{array}{l}\text { Pelo reconhecimento inicial dos juros a transcorrer } \\
\text { D: Contas a Receber (Ativo) } \\
\text { C: Juros a apropriar (Ativo, conta redutora de "contas a receber") }\end{array}$ \\
\hline & $\begin{array}{l}\text { Pela apropriação dos juros mensais pelo regime de competência } \\
\text { D: Despesa Financeira de Arrendamento (Resultado) } \\
\text { C: Encargos a Apropriar (Passivo, conta redutora de "obrigações com arrendamento") }\end{array}$ & \multirow{2}{*}{ Mensais } & $\begin{array}{l}\text { Pela realização dos juros } \\
\text { D: Juros a apropriar (Ativo, conta redutora de "contas a receber") } \\
\text { C: Receita de arrendamento (Resultado) }\end{array}$ \\
\hline & $\begin{array}{l}\text { Pelo pagamento das contraprestações } \\
\text { D: Obrigações com Arrendamento - Parcela do principal (Passivo) } \\
\text { D: Obrigações com Arrendamento - Parcela dos juros (Passivo) } \\
\text { C: Bancos (Ativo) }\end{array}$ & & $\begin{array}{l}\text { Pelo recebimento das parcelas } \\
\text { D: Banco (Ativo) } \\
\text { C: Contas a Receber - Parcela do principal (Ativo) } \\
\text { C: Contas a Receber - Parcela dos juros (Ativo) } \\
\end{array}$ \\
\hline
\end{tabular}

Fonte: Elaborado pelo Autor.

Observa-se, portanto, que, como há variação de contas patrimoniais, espera-se consequente variação nos indicadores que envolvem tais contas, com maior efeito para as arrendatárias, que terão reconhecimento de passivos, que podem impactar em operações que envolvam covenants, por exemplo. Não há, para a arrendatária, variação no EBITDA (Earnings Before Interest, Taxes, Depreciation and Amortization), já que suas despesas seriam reconhecidas em linhas abaixo do indicador.

Já no arrendamento operacional (Figura 41), no qual não há transferência dos riscos e benefícios do arrendador ao arrendatário, o tratamento contábil ocorre de forma mais simplificada. 
Figura 41 - Descrição dos modelos de Arrendamento Operacional - IAS 17

\begin{tabular}{|c|l|l|}
\hline IAS 17 & \multicolumn{1}{|c|}{ Arrendatário } & \multicolumn{1}{|c|}{ Arrendador } \\
\hline Reconhecimento & $\begin{array}{l}\text { Pagamentos da prestação como despesa do } \\
\text { período. Não há reconhecimento de ativos } \\
\text { ou passivos. }\end{array}$ & $\begin{array}{l}\text { Ativos sujeitos a arrendamentos no balanço } \\
\text { de acordo com a sua natureza. }\end{array}$ \\
\hline Mensuração & $\begin{array}{l}\text { Despesa na base da linha reta, salvo se } \\
\text { outra base sistemática for representativa do } \\
\text { padrão temporal do benefício do usuário. }\end{array}$ & $\begin{array}{l}\text { Receita na base da linha reta durante o } \\
\text { prazo do arrendamento mercantil. } \\
\text { Despesa de depreciação na mesma base dos } \\
\text { demais bens imobilizados. }\end{array}$ \\
\hline Opções & Apenas em decorrência do pagamento. & Apenas em decorrência do recebimento. \\
\hline BP & Off-balance. & Ativo imobilizado. \\
\hline DFC & Redução do fluxo de caixa Operacional. & $\begin{array}{l}\text { Aumento do fluxo de caixa } \\
\text { operacional/financeiro. }\end{array}$ \\
\hline DRE & Valor total como despesa operacional. & $\begin{array}{l}\text { Depreciação: Despesa operacional } \\
\text { Juros: Receita Financeira. }\end{array}$ \\
\hline Impairment & Sim & Sim \\
\hline
\end{tabular}

Fonte: Elaborado pelo Autor com base na IAS 17 (IASB, 2003).

No arrendamento operacional, então, o bem continua reconhecido na arrendadora, sem qualquer reconhecimento de ativos e passivos por parte da arrendatária. Consequentemente, despesas de depreciação referentes ao ativo subjacente são de responsabilidade da arrendadora. A arrendatária, em um contraponto, possui uma despesa mensal referente aos pagamentos de arrendamento (ver Figura 42), sendo essa despesa considerada como operacional e possuindo efeito no EBITDA. Assim, a existência de "reconhecimento" off-balance faz com que não haja variação nos indicadores que se utilizam de dados de ativo e passivo.

Figura 42 - Lançamentos Contábeis de Arrendamento Operacional - IAS 17

\begin{tabular}{|c|c|c|c|}
\hline \multicolumn{4}{|c|}{ IAS 17 - Arrendamento Operacional } \\
\hline & Arrendatário & & Arrendador \\
\hline & $\begin{array}{l}\text { Pelo reconhecimento da despesa } \\
\text { D: Despesa com arrendamento (Resultado) } \\
\text { C: Arrendamentos a pagar (Passivo) }\end{array}$ & Inicial & $\begin{array}{l}\text { Pela aquisição do bem } \\
\text { D: Bens Arrendados (Ativo Imobilizado) } \\
\text { C: Bancos (Ativo) } \\
\end{array}$ \\
\hline Mensais & $\begin{array}{l}\text { Pelo pagamento da parcela } \\
\text { D: Arrendamentos a pagar (Passivo) } \\
\text { C: Bancos (Ativo) }\end{array}$ & Mensais & $\begin{array}{l}\text { Pelo reconhecimento periódico da receita } \\
\text { D: Contas a Receber (Ativo) } \\
\text { C: Receita com arrendamento (Resultado) } \\
\text { Pelo recebimento da receita } \\
\text { D: Bancos (Ativo) } \\
\text { C: Contas a Receber (Ativo) } \\
\text { Pela realização da Depreciação do bem } \\
\text { D: Despesa de depreciação de Bens Arrendados (Resultado) } \\
\text { D: Depreciação acumulada de Bens Arrendados (Redutora de Ativo) }\end{array}$ \\
\hline
\end{tabular}

$$
\text { Exposure draft - ED/2010/9 - Leases }
$$

No ED/2010/9 (IASB, 2010b), os normatizadores (FASB e IASB) propõem um novo modelo contábil único para arrendatárias e, para arrendadoras dois modelos distintos a depender 
da transferência dos riscos e benefícios do arrendamento. Na Figura 43 apresento o modelo das arrendatárias e, na Figura 44, a proposta de contabilização desse modelo.

Figura 43 - Descrição do modelo para Arrendatárias - ED/2010/9

\begin{tabular}{|c|l|}
\hline ED/2010/9 & \multicolumn{1}{c|}{ Arrendatário } \\
\hline Reconhecimento & $\begin{array}{l}\text { Na "data de início do arrendamento" reconhecer um ativo (imobilizado, separado dos } \\
\text { demais bens) de direito de uso e um passivo para a realização dos pagamentos. }\end{array}$ \\
\hline $\begin{array}{c}\text { Mensuração } \\
\text { Inicial }\end{array}$ & $\begin{array}{l}\text { Valor do passivo igual ao valor presente dos pagamentos mínimos do arrendamento } \\
\text { (taxa de desconto: taxa que o arrendador cobra do arrendatário; se não for identificável: } \\
\text { taxa incremental de financiamento do arrendatário). } \\
\text { O valor do Ativo (direito de uso) é igual ao do passivo (mais custos diretos iniciais). }\end{array}$ \\
\hline $\begin{array}{c}\text { Mensuração } \\
\text { Subsequente }\end{array}$ & $\begin{array}{l}\text { Ativo: Baixa por meio de despesa de amortização (custo amortizado) pelo prazo do } \\
\text { contrato ou pela vida útil do bem (se menor). } \\
\text { Passivo: Custo amortizado por meio do método da taxa de juros efetiva. Baixa dos passivos } \\
\text { pelos pagamentos. }\end{array}$ \\
\hline Opções & $\begin{array}{l}\text { Mensurar de acordo com a probabilidade de ocorrência. Valor será com base no peso de } \\
\text { cada probabilidade estimada. Opção de compra não deve ser incluída. }\end{array}$ \\
\hline BP & $\begin{array}{l}\text { Ativo imobilizado (direito de uso) separado dos demais itens. } \\
\text { Passivo financeiro, separado dos demais itens. }\end{array}$ \\
\hline DFC & Pagamentos como saídas do fluxo de financiamento. \\
\hline DRE & $\begin{array}{l}\text { Despesas de amortização do bem } \\
\text { Despesas financeiras/juros da atualização dos encargos. }\end{array}$ \\
\hline Impairment & Sim \\
\hline Reavaliação & Sim (mudança significativa) \\
\hline
\end{tabular}

Fonte: Elaborado pelo Autor com base no ED/2010/9 (IASB, 2010b).

O modelo do "direito de uso" introduz o reconhecimento de ativos e de passivos para todas as operações de arrendamento, com exceção daquelas com prazo inferior a doze meses ou com valor considerado como imaterial (IASB, 2010b, 2010c). A mensuração desses itens é feita com referência à mensuração do passivo, que é representado pelo valor presente dos pagamentos mínimos, seguindo como base o custo amortizado. O valor do ativo, portanto, deriva do valor do passivo e isso faz com que, inicialmente, ambos apresentem o mesmo valor e configuram partes do mesmo lançamento contábil, conforme Figura 44.

Figura 44 - Lançamentos Contábeis do Arrendatário - ED/2010/9

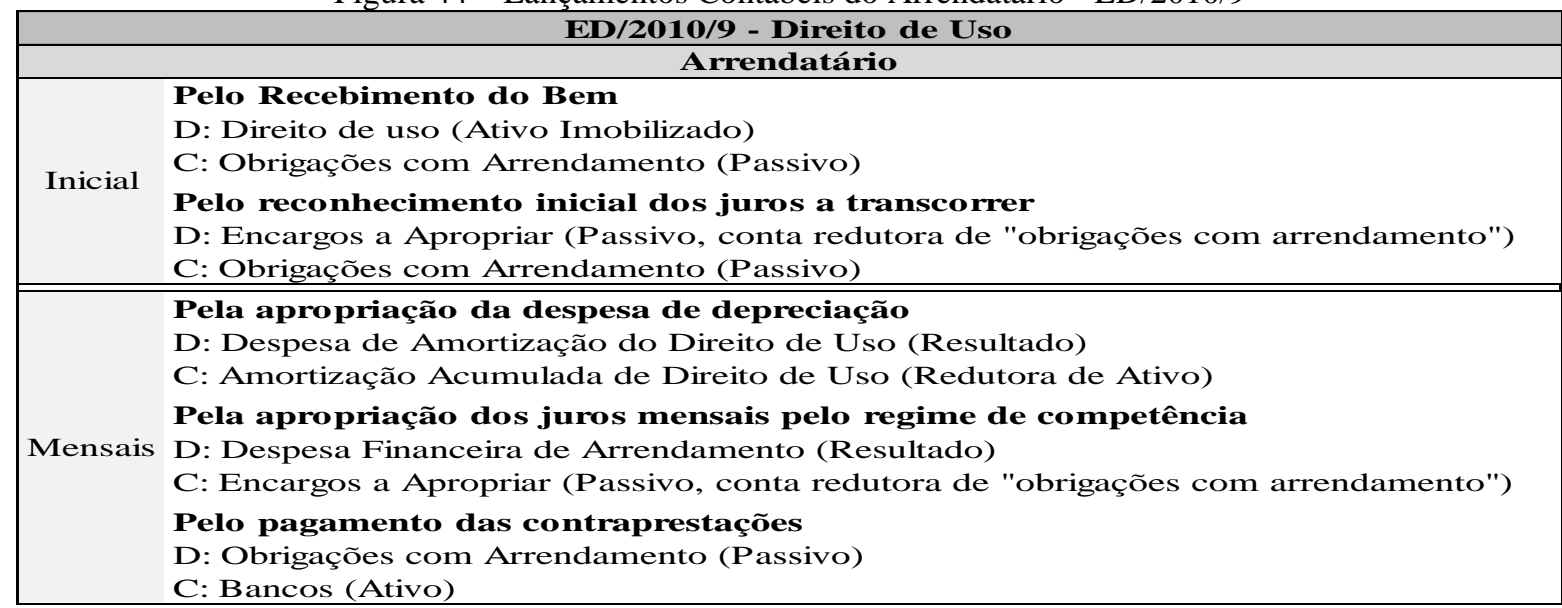

Fonte: Elaborado pelo Autor. 
Como há o reconhecimento de ativo, agora este item sofre amortização (a proposta não fala em depreciação) na própria arrendatária. Nos efeitos sobre indicadores, observa-se que todos os pagamentos entram como saída de fluxo de financiamento, tendo efeito, portanto, na DFC. Os efeitos, no cálculo do EBITDA, ficaram excluídos. Ainda, há um aumento de ativos e passivos, o que faz com que tal método possua grandes diferenças nos indicadores que envolvem o Balanço Patrimonial quando comparado ao modelo de arrendamento operacional da IAS 17, ou seja, impacta principalmente aquelas empresas que possuem maior carteira operacional.

Essa proposta de norma também introduz a questão da reavaliação, devendo ela ser realizada sempre que a empresa perceber que houve alguma mudança significativa nas condições de mercado ou nas intenções com o arrendamento. Essa reavaliação se mostra útil principalmente quando da mensuração das opções dos contratos (VRG [Valor Residual Garantido], pagamentos contingentes, opções de renovações), pois o tempo é considerado como fator auxiliador para que a empresa tenha mais certeza da execução (ou não) de tais opções. Em contraponto, Biondi et al. (2011) demonstram ceticismo quanto à reavaliação, uma vez que levaria o ativo (que claramente possui conexão com o passivo) a ser avaliado ao valor justo e apresentar diferenças de valores com relação aos passivos, pois a contrapartida dos ganhos ou perdas da reavaliação seria reconhecida no resultado do exercício (DRE).

Biondi et al. (2011) também apresentam uma visão crítica sobre o reconhecimento das opções. Os autores se mostram favoráveis ao reconhecimento de todas as opções, não somente daquelas com probabilidade de ocorrência significativa, pois entendem que, além de diminuir possibilidades de estruturação de contratos, o reconhecimento total faria com que os contratos passassem a ter somente opções que são "prováveis" de ocorrer, não havendo opções estruturadas para modificar o reconhecimento contábil.

O modelo para as arrendadoras já segue um padrão distinto, com possibilidade de duas classificações (POA - Performance Obligation Approach - e DR - derecognition approach), conforme apresento na Figura 45. 
Figura 45 - Descrição dos modelos para Arrendadoras - ED/2010/9

\begin{tabular}{|c|c|c|}
\hline \multirow{2}{*}{ ED/2010/9 } & \multicolumn{2}{|c|}{ Arrendador } \\
\hline & Performance Obligation Approach & Derecognition Approach \\
\hline Reconhecimento & $\begin{array}{l}\mathrm{Na} \text { "data de início do arrendamento" } \\
\text { reconhecer um ativo de direito de receber } \\
\text { pagamentos de arrendamento e um passivo } \\
\text { de arrendamento. Não deve baixar o ativo } \\
\text { subjacente. }\end{array}$ & $\begin{array}{l}\mathrm{Na} \text { "data de início do arrendamento" } \\
\text { reconhecer um ativo de direito de receber } \\
\text { (contra receita) pagamentos de } \\
\text { arrendamento; } \\
\text { Baixar o ativo subjacente (contra custo). } \\
\text { Se houver um ativo residual, reclassificá-lo. }\end{array}$ \\
\hline $\begin{array}{l}\text { Mensuração } \\
\text { Inicial }\end{array}$ & $\begin{array}{l}\text { Ativo: Valor presente dos recebimentos de } \\
\text { arrendamento, mais custos diretos iniciais. } \\
\text { (taxa: taxa que o arrendador cobra do } \\
\text { arrendatário); } \\
\text { Passivo: Mesmo valor reconhecido no ativo. }\end{array}$ & $\begin{array}{l}\text { Ativo: Valor presente dos recebimentos de } \\
\text { arrendamento, mais custos diretos iniciais. } \\
\text { (taxa: taxa que o arrendador cobra do } \\
\text { arrendatário); } \\
\text { Ativo residual (caso haja). }\end{array}$ \\
\hline $\begin{array}{l}\text { Mensuração } \\
\text { Subsequente }\end{array}$ & $\begin{array}{l}\text { Ativo: Custo amortizado pelo método da } \\
\text { taxa de juros efetiva. Baixa dos ativos pelos } \\
\text { recebimentos. Depreciação do ativo. } \\
\text { Passivo: Obrigação remanescente com base } \\
\text { no uso, por parte do arrendatário, do ativo. }\end{array}$ & $\begin{array}{l}\text { Ativo: Custo amortizado pelo método da } \\
\text { taxa de juros efetiva. Baixa dos ativos } \\
\text { pelos pagamentos. }\end{array}$ \\
\hline Opções & $\begin{array}{l}\text { Mensurar de acordo com a probabilidade de } \\
\text { ocorrência. Valor será com base no peso de } \\
\text { cada probabilidade estimada. Opção de } \\
\text { compra não deve ser incluída. }\end{array}$ & $\begin{array}{l}\text { Mensurar de acordo com a probabilidade } \\
\text { de ocorrência. Valor será com base no } \\
\text { peso de cada probabilidade estimada. } \\
\text { Opção de compra não deve ser incluída. }\end{array}$ \\
\hline BP & $\begin{array}{l}\text { Ativo: Ativo subjacente juntamente com os } \\
\text { imobilizados. Direito de recebimento } \\
\text { apresentado como ativo financeiro. } \\
\text { Passivo: Obrigação de fornecer o bem é } \\
\text { apresentada como passivo financeiro. }\end{array}$ & $\begin{array}{l}\text { Ativo: Direito de recebimento separado } \\
\text { dos demais ativos financeiros. Caso haja } \\
\text { ativo subjacente residual, apresentar em } \\
\text { imobilizado, também separado dos demais. }\end{array}$ \\
\hline DRE & $\begin{array}{l}\text { Receita com juros do arrendamento, receita } \\
\text { pelo cumprimento do contrato e } \\
\text { depreciação do ativo, todos separados. }\end{array}$ & $\begin{array}{l}\text { Receitas e despesas iniciais podem ser } \\
\text { apresentadas separadamente ou pelo seu } \\
\text { valor líquido (atividades operacionais). } \\
\text { Receita de juros. }\end{array}$ \\
\hline DFC & Entradas do fluxo operacional. & Entradas do fluxo operacional. \\
\hline Impairment & Sim & Sim \\
\hline Reavaliação & Sim (mudança significativa) & Sim (mudança significativa) \\
\hline
\end{tabular}

Fonte: Elaborado pelo Autor com base no ED/2010/9 (IASB, 2010b).

Conforme demonstrado na Figura 45, os dois modelos possuem diferenças já desde o reconhecimento inicial. No modelo do Performance Obligation Approach - POA (ou direito de uso), o arrendador reconhece ativos e passivos de arrendamento, além do ativo subjacente. Assim, no reconhecimento inicial do direito de recebimento, a contrapartida é o reconhecimento de uma obrigação (de fornecer o bem pelo prazo acordado). Observe que, aqui, a mensuração ocorre de forma distinta daquela das arrendatárias. Enquanto nas arrendatárias a mensuração do ativo é determinada com base no valor do passivo, nas arrendadoras a mensuração do passivo é determinada com base no valor do ativo. O reconhecimento de receitas ocorre à medida que os juros incorrem (contra o ativo) e à medida que o prazo do contrato passa, ou seja, quando há o cumprimento do contrato (passivo). Há, ainda, o reconhecimento da depreciação decorrente da utilização do bem arrendado. Para facilitar a visualização dos movimentos contábeis, 
apresento, na Figura 46, uma proposta de lançamentos contábeis para os dois modelos das arrendadoras com base no ED/2010/9.

Figura 46 - Lançamentos Contábeis do Arrendador - ED/2010/9

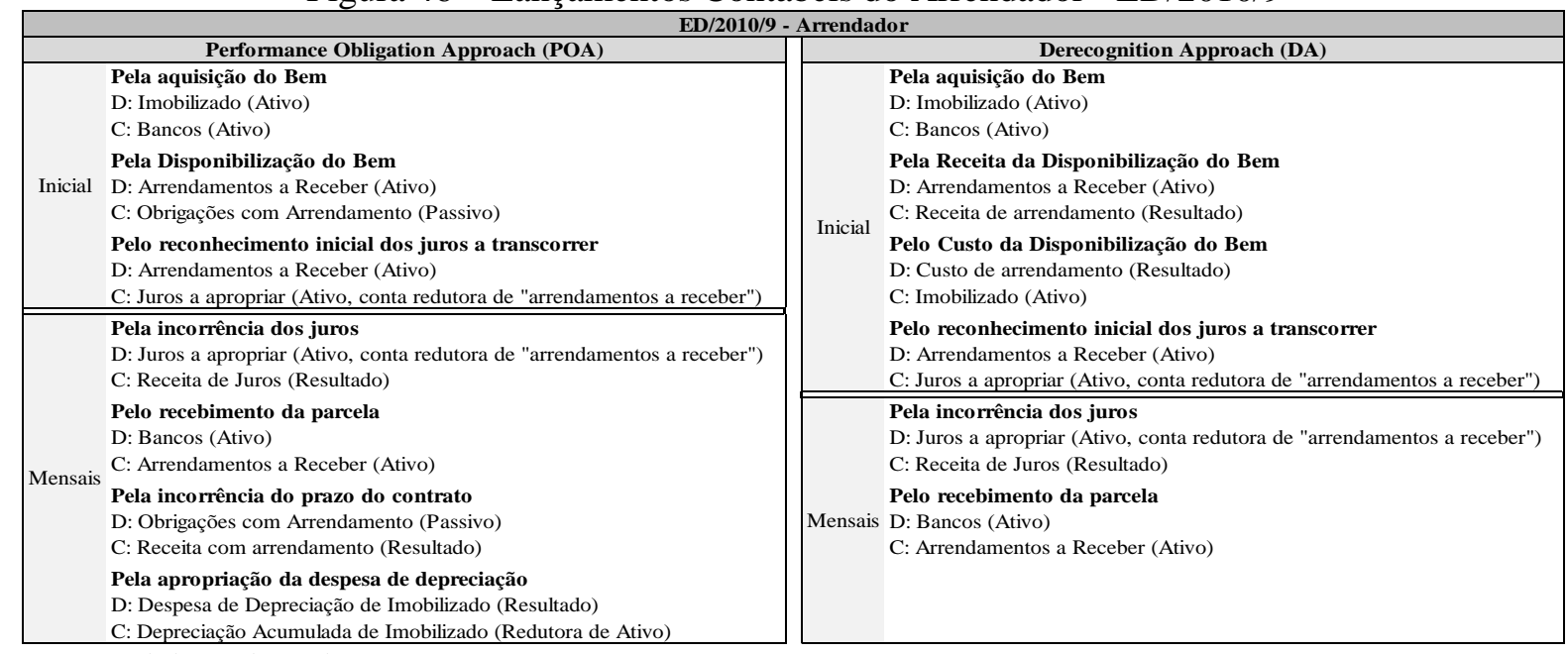

Fonte: Elaborado pelo Autor.

No segundo modelo, derecognition approach (DA), como há transferência dos riscos e benefícios, o ativo subjacente sobre uma baixa. Portanto, inicialmente, $\mathrm{o}$ arrendador deve baixar o ativo (ou parte) e reconhecer essa parte como um recebível (observa-se que não há reconhecimento de passivos). Nesse movimento, há um reconhecimento de uma receita (pelo recebível) e um custo (pela baixa do imobilizado), podendo gerar um ganho (ou perda, em teoria possível) inicial na transação. Após isso, o reconhecimento mensal de receitas ocorre por meio da incorrência dos juros do recebível.

Com relação aos efeitos sobre os indicadores, esses podem ser diversos. No POA, o reconhecimento dos ativos e passivos se anulam, restando como saldo líquido o valor do ativo subjacente que foi reconhecido. Já no DA, o ativo é representado pelo recebível e há efeitos imediatos no resultado, ou seja, há efeitos, no início da operação, sobre o EBITDA e demais indicadores de desempenho. No DA, como não há reconhecimento de passivos, indicadores de endividamento não sofrem alterações, ao contrário do que ocorre no POA. Com relação à IAS 17, os maiores efeitos ocorrem para arrendadores que possuem maior carteira de “arrendamentos operacionais”, pois estes agora terão que reconhecer ativos e passivos, além do resultado no momento inicial da transação. 
Ao afirmar que os modelos apresentados no ED anterior (ED/2010/9) seriam inconsistentes entre si por serem assimétricos entre as partes do arrendamento (arrendador e arrendatário), o normatizador internacional (IASB, 2013c, 2013d, 2013b) propõe um novo modelo, tendo como objetivo trazer simetria entre a contabilização dos arrendadores e arrendatários. Como a classificação proposta possibilita dois modelos distintos, apresento, primeiramente, as opções para arrendatários (Figura 47) e em seguida para arrendadores (Figura 49).

Figura 47 - Descrição dos modelos para Arrendatárias - ED/2013/6

\begin{tabular}{|c|c|c|}
\hline \multirow{2}{*}{ ED/2013/6 } & \multicolumn{2}{|c|}{ Arrendatário } \\
\hline & Tipo A & Tipo B \\
\hline Reconhecimento & \multicolumn{2}{|c|}{$\begin{array}{l}\mathrm{Na} \text { "data de início do arrendamento" reconhecer um ativo de direito de uso (imobilizado, } \\
\text { porém separado dos demais bens) e um passivo de arrendamento. }\end{array}$} \\
\hline $\begin{array}{l}\text { Mensuração } \\
\text { Inicial }\end{array}$ & \multicolumn{2}{|c|}{$\begin{array}{l}\text { Valor do passivo igual ao custo da propriedade arrendada por meio do valor presente dos } \\
\text { pagamentos mínimos do arrendamento. } \\
\text { (taxa: taxa que o arrendador cobra do arrendatário; se não for identificável: taxa } \\
\text { incremental de financiamento do arrendatário). } \\
\text { O valor do direito de uso é igual ao do passivo (mais custos diretos iniciais). }\end{array}$} \\
\hline $\begin{array}{l}\text { Mensuração } \\
\text { Subsequente }\end{array}$ & $\begin{array}{l}\text { Ativo: Baixa por meio de despesa de } \\
\text { amortização (custo amortizado) pelo } \\
\text { prazo do contrato ou pela vida útil do } \\
\text { bem (se menor). } \\
\text { Passivo: Aumento pelo } \\
\text { reconhecimento dos juros pelo método } \\
\text { da taxa de juros efetiva. Baixa pelos } \\
\text { pagamentos. } \\
\text { *Despesa de juros e amortização devem } \\
\text { ser contabilizadas separadamente. }\end{array}$ & $\begin{array}{l}\text { Ativo: Baixa por meio de despesa de } \\
\text { amortização (custo amortizado). Seu valor será } \\
\text { calculado juntamente com os juros, de forma } \\
\text { que, após os juros calculados, o valor da } \\
\text { amortização será tal que manterá a despesa } \\
\text { total como sendo fixa. } \\
\text { Passivo: Aumento pelo reconhecimento dos } \\
\text { juros pelo método da taxa de juros efetiva. } \\
\text { Baixa pelos pagamentos. } \\
\text { *Despesa de juros e amortização devem ser } \\
\text { contabilizadas de forma unificada. }\end{array}$ \\
\hline Opções & \multicolumn{2}{|c|}{$\begin{array}{l}\text { Reconhecidas se houver incentivo econômico significativo; pagamentos variáveis baseados } \\
\text { em índices ou taxas, VRG e opção de compra. }\end{array}$} \\
\hline $\mathbf{B P}$ & \multicolumn{2}{|c|}{$\begin{array}{l}\text { Ativo imobilizado (direito de uso) separado dos demais itens. } \\
\text { Passivo financeiro, separado dos demais itens. }\end{array}$} \\
\hline DRE & $\begin{array}{l}\text { Despesas de amortização e Despesas } \\
\text { financeiras separadas das demais. }\end{array}$ & $\begin{array}{l}\text { Despesas de amortização e financeiras como } \\
\text { uma despesa operacional única. }\end{array}$ \\
\hline DFC & $\begin{array}{l}\text { Pagamento do principal em fluxo de } \\
\text { financiamento. } \\
\text { Pagamento dos juros de acordo com a } \\
\text { IAS } 7 \text {. }\end{array}$ & $\begin{array}{l}\text { Total do pagamento como fluxo de caixa } \\
\text { operacional. }\end{array}$ \\
\hline Impairment & \multicolumn{2}{|l|}{ Sim } \\
\hline Reavaliação & \multicolumn{2}{|c|}{ Sim (mudança do prazo, fatores relevantes, mudança no VRG } \\
\hline
\end{tabular}
Fonte: Elaborado pelo Autor com base no ED/2013/6 (IASB, 2013c).

A classificação do arrendamento depende da natureza do ativo arrendado e do tempo de arrendamento frente à vida útil total daquele bem, sendo o Tipo A para bens que não sejam 
imóveis e o Tipo B para os bens imóveis. Entre os dois modelos, a diferença ocorre apenas na mensuração subsequente, e nos tratamentos dados na DRE e na DFC, conforme pode ser visto na Figura 48.

Figura 48 - Lançamentos Contábeis do Arrendatário - ED/2013/6

\begin{tabular}{|c|c|c|c|}
\hline \multicolumn{4}{|c|}{ ED/2013/6 - Arrendatário } \\
\hline & Tipo A & & Tipo B \\
\hline Inicial & $\begin{array}{l}\text { Pelo Recebimento do Bem } \\
\text { D: Direito de uso (Ativo Imobilizado) } \\
\text { C: Obrigações com Arrendamento (Passivo) } \\
\text { Pelo reconhecimento inicial dos juros a transcorrer } \\
\text { D: Encargos a Apropriar (Passivo, conta redutora de "obrigações com arrendamento") } \\
\text { C: Obrigações com Arrendamento (Passivo) }\end{array}$ & Inicial & $\begin{array}{l}\text { Pelo Recebimento do Bem } \\
\text { D: Direito de uso (Ativo Imobilizado) } \\
\text { C: Obrigações com Arrendamento (Passivo) } \\
\text { Pelo reconhecimento inicial dos juros a transcorrer } \\
\text { D: Encargos a Apropriar (Passivo, conta redutora de "obrigações com arrendamento") } \\
\text { C: Obrigações com Arrendamento (Passivo) }\end{array}$ \\
\hline Mensais & $\begin{array}{l}\text { Pela apropriação da despesa de depreciação } \\
\text { D: Despesa de Amortização do Direito de Uso (Resultado) } \\
\text { C: Amortização Acumulada de Direito de Uso (Redutora de Ativo) } \\
\text { Pela apropriação dos juros mensais pelo regime de competência } \\
\text { D: Despesa Financeira de Arrendamento (Resultado) } \\
\text { C: Encargos a Apropriar (Passivo, conta redutora de "obrigações com arrendamento") } \\
\text { Pelo pagamento das contraprestações } \\
\text { D: Obrigações com Arrendamento (Passivo) } \\
\text { C: Bancos (Ativo) }\end{array}$ & Mensais & $\begin{array}{l}\text { Pela apropriação da despesa de depreciação e dos juros pela Competência } \\
\text { D: Despesa operacional (Resultado) } \\
\text { C: Amortização Acumulada de Direito de Uso (Redutora de Ativo) } \\
\text { C: Encargos a Apropriar (Passivo, conta redutora de "obrigações com arrendamento") } \\
\text { Pelo pagamento das contraprestações } \\
\text { D: Obrigações com Arrendamento (Passivo) } \\
\text { C: Bancos (Ativo) }\end{array}$ \\
\hline
\end{tabular}

Fonte: Elaborado pelo Autor.

Inicialmente, para arrendatárias, reconhece-se um passivo com base no valor presente dos pagamentos mínimos e, após a mensuração de tal valor, utiliza-o para o reconhecimento do ativo de direito de uso. O reconhecimento e a mensuração iniciais se dão da mesma forma como ocorre no arrendamento financeiro da IAS 17 e no modelo do direito de uso do ED/2010/9. Para a mensuração subsequente do Tipo A, observa-se o reconhecimento de despesa de amortização (contra o ativo) e despesa financeira (pelo reconhecimento dos juros pela competência), assim como nas normas anteriores.

A diferença aparece no Tipo B, em que tanto a despesa de amortização quanto a despesa financeira são reconhecidas de forma conjunta como uma despesa operacional, mantendo esta despesa operacional fixa e os valores de ativos e passivos sempre iguais entre si. Isso fará com que, no início do contrato, o Tipo A reconheça despesas maiores que, ao longo do tempo serão diminuídas (juros são maiores no início, devido ao montante maior da dívida), e o Tipo B terá uma despesa operacional fixa por todo o período. Devido aos diversos efeitos possíveis, exemplos numéricos podem ser vistos em publicação do IASB sobre o assunto (IASB, 2013d).

Como essas diferenças são espelhadas na DRE e na DFC das arrendatárias, os indicadores entre os dois modelos serão diferentes. Ressalta-se que, se for observado o contrato completo, as despesas, ativos e passivos, ao final, serão iguais nos dois modelos, porém terão variações de valores reconhecidos durante a vigência desses contratos.

Para as arrendadoras, os modelos seguem o mesmo padrão de classificação (Tipo A e Tipo B), sendo os demais critérios apresentados na Figura 49. 
Figura 49 - Descrição dos modelos para Arrendadoras - ED/2013/6

\begin{tabular}{|c|c|c|}
\hline \multirow{2}{*}{ ED/2013/6 } & \multicolumn{2}{|l|}{ Arrendador } \\
\hline & Tipo A & Tipo B \\
\hline Reconhecimento & $\begin{array}{l}\mathrm{Na} \text { "data de início do arrendamento" reconhecer um } \\
\text { ativo de direito de receber pagamentos de } \\
\text { arrendamento e "derecognize" o ativo subjacente. } \\
\text { Se houver um ativo residual, este deve ser } \\
\text { reclassificado. A diferença do direito a receber } \\
\text { versus o ativo subjacente é ganho/perda do período. }\end{array}$ & $\begin{array}{l}\text { Apresentar os ativos subjacentes nos } \\
\text { seus balanços de acordo com a } \\
\text { natureza. Não há outros ativos e } \\
\text { passivos reconhecidos. }\end{array}$ \\
\hline $\begin{array}{l}\text { Mensuração } \\
\text { Inicial }\end{array}$ & $\begin{array}{l}\text { Ativo: Valor presente dos recebimentos de } \\
\text { arrendamento, mais custos diretos iniciais. } \\
\text { (taxa: taxa que o arrendador cobra do arrendatário). }\end{array}$ & $\begin{array}{l}\text { Receita na base da linha reta durante } \\
\text { o prazo do arrendamento. Despesa } \\
\text { de depreciação na mesma base dos } \\
\text { demais bens imobilizados. }\end{array}$ \\
\hline $\begin{array}{l}\text { Mensuração } \\
\text { Subsequente }\end{array}$ & $\begin{array}{l}\text { Ativo: Custo amortizado por meio do método da } \\
\text { taxa de juros efetiva. Baixa dos ativos pelos } \\
\text { pagamentos. }\end{array}$ & $\begin{array}{l}\text { Replicação mensal da mensuração } \\
\text { inicial. }\end{array}$ \\
\hline Opções & $\begin{array}{l}\text { Incluir pelo valor presente do que se espera que } \\
\text { seja recebido. }\end{array}$ & $\begin{array}{l}\text { Apenas em decorrência do } \\
\text { pagamento. }\end{array}$ \\
\hline BP & $\begin{array}{l}\text { Ativo: Direito de recebimento apresentado de } \\
\text { forma separada dos demais ativos financeiros. Caso } \\
\text { haja ativo subjacente residual, apresentar em } \\
\text { imobilizado, também separado dos demais. }\end{array}$ & Ativo imobilizado. \\
\hline DRE & $\begin{array}{l}\text { Receitas e despesas podem ser apresentadas } \\
\text { separadamente ou pelo seu valor líquido } \\
\text { (operacional) a depender do modelo de negócios. }\end{array}$ & $\begin{array}{l}\text { Depreciação: Despesa operacional. } \\
\text { Juros: Receita de aluguel. }\end{array}$ \\
\hline DFC & Recebimentos como entradas do fluxo operacional. & $\begin{array}{l}\text { Aumento do fluxo de caixa } \\
\text { operacional. }\end{array}$ \\
\hline Impairment & Sim. & \\
\hline Reavaliação & $\begin{array}{l}\text { Sim (mudança do prazo, fatores relevantes, mudança } \\
\text { taxas/índices). }\end{array}$ & m pagamentos baseados em \\
\hline
\end{tabular}

Fonte: Elaborado pelo Autor com base no ED/2010/9 (IASB, 2010b).

Os modelos para arrendadoras não trazem muitas novidades, sendo o Tipo A similar ao modelo do ED/2010/9 (Derecognition Approach) e o Tipo B semelhante ao Arrendamento Operacional da IAS 17, ou seja, há apenas a mudança de nomenclaturas.

Nesse sentido, espera-se que os efeitos sejam os mesmos daqueles já apresentados sobre esses modelos específicos, assim como os lançamentos apresentados na Figura 50.

Figura 50 - Lançamentos Contábeis do Arrendador - ED/2013/6

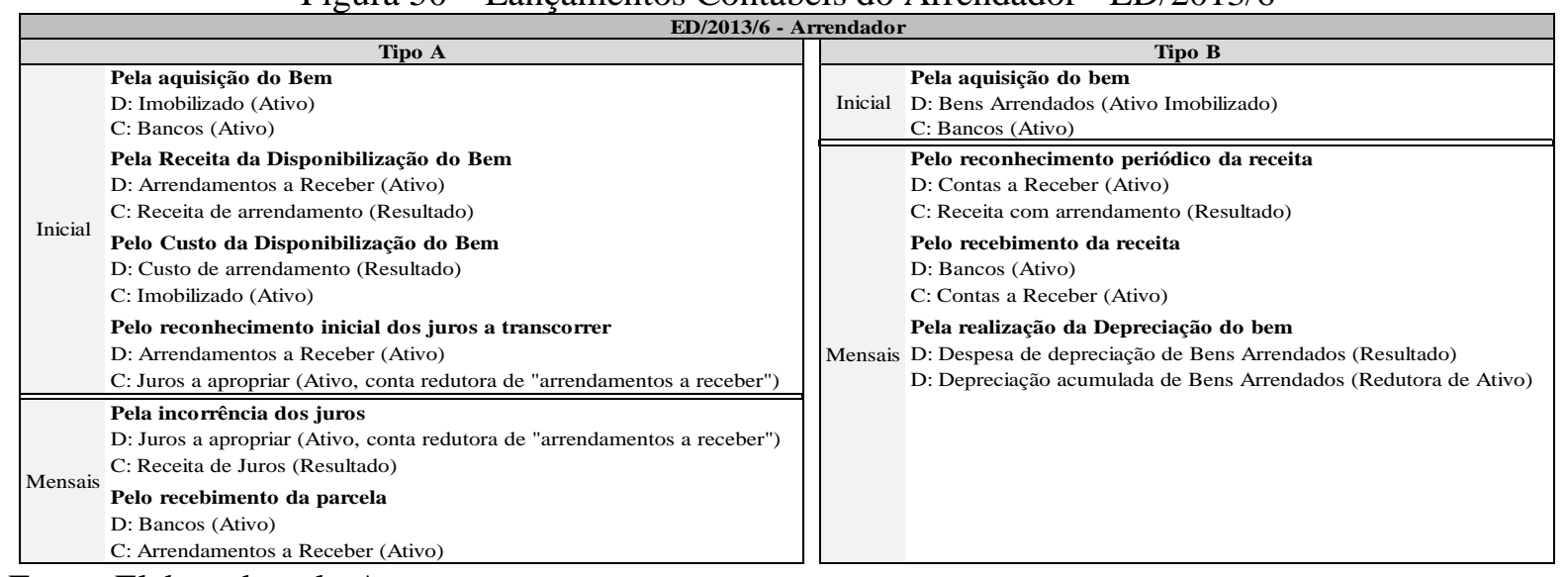

Fonte: Elaborado pelo Autor. 
O IASB argumenta que essa divisão de Tipo A e Tipo B garante a simetria entre arrendadora/arrendatária e reflete de forma mais coerente as diversas precificações realizadas pelos arrendadores nas suas operações (IASB, 2013d). Porém, as críticas anteriormente apresentadas sobre modelos duplos de contabilização (Biondi et al., 2011) também podem ser utilizadas aqui, como estruturação de operações e até mesmo off-balance, presente no Tipo B (arrendadoras).

\section{IFRS 16 - Leases}

Considerando a tempestividade do tema e da discussão sobre a IFRS 16 (IASB, 2016e), que foi editada em 2016, adiantei, juntamente com meu orientador, a publicação de um paper que discutiu os critérios de contabilização das arrendatárias e as principais discussões acerca da implementação da IFRS 16 (E. B. S. de Matos \& Murcia, 2019a) e outros dois que contemplam uma revisão de literatura (E. B. S. de Matos \& Murcia, 2019b) e de citações (E. B. S. de Matos et al., 2020) sobre do tema de arrendamento mercantil. Por isso, a discussão sobre a IFRS 16 e seu conteúdo se encontram, nesta tese, de forma resumida.

Seguindo o padrão de mudanças nas propostas normativas que ocorreram ao longo do processo, a IFRS também mudou, não tendo sido similar ao documento anterior emitido. A diferença é que agora essa já é a norma final, ou seja, em teoria esse é o modelo considerado pelo IASB como sendo o mais condizente com sua estrutura conceitual. Nele, como já apresentado, há um modelo único para as arrendatárias e um modelo com possibilidade de duas classificações para as arrendadoras.

$\mathrm{Na}$ Figura 51, apresento o modelo das arrendatárias, que é o do direito de uso, semelhante ao apresentado no ED/2010/9 (E. B. S. de Matos \& Murcia, 2019a). 
Figura 51 - Descrição do modelo para Arrendatária - IFRS 16

\begin{tabular}{|c|l|}
\hline IFRS 16 & \multicolumn{1}{c|}{ Arrendatário } \\
\hline Reconhecimento & $\begin{array}{l}\text { Na "data de início do arrendamento" reconhecer um ativo de direito de uso e um passivo } \\
\text { de arrendamento. }\end{array}$ \\
\hline $\begin{array}{c}\text { Mensuração } \\
\text { Inicial }\end{array}$ & $\begin{array}{l}\text { Ativo: Avaliado ao custo. Tende a refletir a mensuração do passivo mais custos diretos } \\
\text { iniciais. } \\
\text { Passivo: Valor presente dos pagamentos. } \\
\text { (Taxa: taxa de juros implícita no contrato; se não for determinável, utilizar a taxa } \\
\text { incremental de empréstimo do arrendatário). }\end{array}$ \\
\hline $\begin{array}{c}\text { Mensuração } \\
\text { Subsequente }\end{array}$ & $\begin{array}{l}\text { Ativo: Direito de uso avaliado ao custo, menos valores de depreciação acumulada. } \\
\text { Passivo: Aumenta pelo incorrência dos juros e decresce em decorrência dos pagamentos. }\end{array}$ \\
\hline Opções & $\begin{array}{l}\text { Incluir pagamentos variáveis que dependem de índices/taxas, VRG, opção de compra que } \\
\text { é razoavelmente certa. }\end{array}$ \\
\hline BP & $\begin{array}{l}\text { Ativo: Direito de uso separado dos demais ativos. } \\
\text { Passivo: Obrigações do arrendamento separadas dos demais passivos. }\end{array}$ \\
\hline DRE & $\begin{array}{l}\text { Juros: Custo financeiro; } \\
\text { Depreciação: Despesa operacional. } \\
\text { *Juros } \text { e depreciação devem ser apresentados de forma separada. }\end{array}$ \\
\hline DFC & $\begin{array}{l}\text { Pagamento do principal: fluxo de caixa de financiamento. } \\
\text { Pagamento dos juros: Seguir a IAS 7 }\end{array}$ \\
\hline Impairment & Sim \\
\hline Reavaliação & Sim (mudança no prazo do arrendamento ou da opção de compra) \\
\hline
\end{tabular}

Fonte: (E. B. S. de Matos \& Murcia, 2019a).

Como o modelo contábil da IFRS 16 (IASB, 2016e) para as arrendatárias é semelhante ao proposto no ED/2010/9 (IASB, 2013c), as características gerais, impactos financeiros e nos indicadores e as críticas são as mesmas, assim como os lançamentos contábeis (Figura 52).

Figura 52 - Lançamentos Contábeis do Arrendatário - IFRS 16

\begin{tabular}{|c|c|}
\hline \multicolumn{2}{|r|}{ IFRS 16 - Direito de Uso } \\
\hline \multicolumn{2}{|r|}{ Arrendatário } \\
\hline \multirow{5}{*}{ Inicial } & Pelo Recebimento do Bem \\
\hline & D: Direito de uso (Ativo Imobilizado) \\
\hline & C: Obrigações com Arrendamento (Passivo) \\
\hline & Pelo reconhecimento inicial dos juros a transcorrer \\
\hline & $\begin{array}{l}\text { D: Encargos a Apropriar (Passivo, conta redutora de "obrigações com arrendamento") } \\
\text { C: Obrigações com Arrendamento (Passivo) }\end{array}$ \\
\hline \multirow{10}{*}{ Mensais } & Pela apropriacão da despesa de depreciacão \\
\hline & D: Despesa de Depreciação do Direito de Uso (Resultado) \\
\hline & C: Depreciação Acumulada de Direito de Uso (Redutora de Ativo) \\
\hline & Pela apropriação dos juros mensais pelo regime de competência \\
\hline & D: Despesa Financeira de Arrendamento (Resultado) \\
\hline & C: Encargos a Apropriar (Passivo, conta redutora de "obrigações com arrendamento") \\
\hline & Pelo pagamento das contraprestações \\
\hline & D: Obrigações com Arrendamento - Principal (Passivo) \\
\hline & D: Obrigações com Arrendamento - Juros (Passivo) \\
\hline & C: Bancos (Ativo) \\
\hline
\end{tabular}

Fonte: Adaptado de Matos e Murcia (2019a)

A justificativa para retroagir a um modelo já proposto e bastante criticado (Biondi et al., 2011) foi a de que esse era o modelo que melhor espelha as operações de arrendamento realizadas pelo mundo (IASB, 2016e).

Já para os modelos das arrendadoras (Figura 53), por mais que tenham ocorrido diferentes mudanças ao longo do processo, a norma final apresentou modelo de classificação 
igual ao que já era vigente com a IAS 17, ou seja, não houve mudanças e impactos para essas empresas.

Figura 53 - Descrição dos modelos para Arrendadoras - IFRS 16

\begin{tabular}{|c|l|l|}
\hline \multirow{2}{*}{ IFRS 16 } & \multicolumn{1}{|c|}{ Financeiro } & \multicolumn{1}{|c|}{ Operacional } \\
\cline { 2 - 3 } Reconhecimento & $\begin{array}{l}\text { Baixa do Ativo imobilizado e } \\
\text { reconhecimento dele como "contas a } \\
\text { receber". }\end{array}$ & $\begin{array}{l}\text { Ativos sujeitos a arrendamentos mercantis } \\
\text { operacionais nos seus balanços de acordo } \\
\text { com a natureza do ativo. Receita na base da } \\
\text { linha reta durante o prazo do arrendamento. }\end{array}$ \\
\hline $\begin{array}{c}\text { Mensuração } \\
\text { Inicial }\end{array}$ & $\begin{array}{l}\text { Valor igual ao investimento líquido no } \\
\text { arrendamento. }\end{array}$ & $\begin{array}{l}\text { Despesa de depreciação na mesma base dos } \\
\text { demais bens imobilizados. }\end{array}$ \\
\hline $\begin{array}{c}\text { Mensuração } \\
\text { Subsequente }\end{array}$ & $\begin{array}{l}\text { Aumento de "contas a receber" pelo } \\
\text { reconhecimento dos juros por meio de uma } \\
\text { receita financeira, em um padrão que } \\
\text { mantenha constante a taxa de juros. Baixa } \\
\text { do ativo por meio dos recebimentos. }\end{array}$ & $\begin{array}{l}\text { Receita no resultado na base da linha reta } \\
\text { durante o prazo do arrendamento. Despesa de } \\
\text { depreciação na mesma base dos demais bens } \\
\text { imobilizados. }\end{array}$ \\
\hline Opçães & $\begin{array}{l}\text { Incluir pagamentos variáveis que dependem } \\
\text { de índices/taxas, VRG, opções de compra } \\
\text { razoavelmente certas. }\end{array}$ & Apenas em decorrência do pagamento. \\
\hline BP & Ativo financeiro. & Ativo imobilizado. \\
\hline DRE & Juros: Receita Financeira. & $\begin{array}{l}\text { Depreciação: Despesa operacional } \\
\text { Juros: Receita Financeira. }\end{array}$ \\
\hline DFC & Não cita. & Não cita. \\
\hline Impairment & Sim. & \multicolumn{2}{|l}{} \\
\hline Reavaliação & Não cita. &
\end{tabular}

Fonte: Elaborado pelo Autor com base na IFRS 16 (IASB, 2016e).

Apesar da não existência de mudanças de classificação contábil no caso das arrendadoras, alguns critérios sofreram modificações textuais, o que pode impactar em alguns números reconhecidos, como as condições para o reconhecimento de opções contratuais. Esses pontos, por mais que existam na norma, por serem subjetivos, estão sujeitos às intenções do preparador da informação. Portanto, a proposta de lançamentos contábeis para as arrendadoras, com base na IFRS 16, permanece a mesma daquela presente na IAS 17, conforme apresento na Figura 54.

Figura 54 - Lançamentos Contábeis do Arrendador - IFRS 16

\begin{tabular}{|c|c|c|c|}
\hline \multicolumn{4}{|c|}{ IFRS 16 - Arrendador } \\
\hline & Financeiro & & Operacional \\
\hline \multirow[b]{2}{*}{ Inicial } & $\begin{array}{l}\text { Pela entrega (e baixa) do bem } \\
\text { D: Contas a Receber (Ativo) } \\
\text { C: Receita inicial da transação (Resultado) }\end{array}$ & Inicial & $\begin{array}{l}\text { Pela aquisição do bem } \\
\text { D: Bens Arrendados (Ativo Imobilizado) } \\
\text { C: Bancos (Ativo) }\end{array}$ \\
\hline & $\begin{array}{l}\text { Pela baixa do bem } \\
\text { D: Custo do Bem (Resultado) } \\
\text { C: Ativo imobilizado (Ativo) } \\
\text { Pelo reconhecimento inicial dos juros a transcorrer } \\
\text { D: Contas a Receber (Ativo) } \\
\text { C: Juros a apropriar (Ativo, conta redutora de "contas a receber") }\end{array}$ & \multirow{2}{*}{ Mensais } & $\begin{array}{l}\text { Pelo reconhecimento periódico da receita } \\
\text { D: Contas a Receber (Ativo) } \\
\text { C: Receita com arrendamento (Resultado) } \\
\text { Pelo recebimento da receita } \\
\text { D: Bancos (Ativo) } \\
\text { C: Contas a Receber (Ativo) }\end{array}$ \\
\hline Mensais & $\begin{array}{l}\text { Pela realização dos juros } \\
\text { D: Juros a apropriar (Ativo, conta redutora de "contas a receber") } \\
\text { C: Receita de arrendamento (Resultado) } \\
\text { Pelo recebimento das parcelas } \\
\text { D: Banco (Ativo) } \\
\text { C: Contas a Receber (Ativo) }\end{array}$ & & $\begin{array}{l}\text { Pela realização da Depreciação do bem } \\
\text { D: Despesa de depreciação de Bens Arrendados (Resultado) } \\
\text { D: Depreciação acumulada de Bens Arrendados (Redutora de Ativo) }\end{array}$ \\
\hline
\end{tabular}

Fonte: Elaborado pelo Autor. 
APÊNDICE B - Documentos Formais que Compõem o Processo Normativo de Leasing

Figura 55 - Documentos que Compõem o Processo Normativo de Leasing

\begin{tabular}{|c|c|c|c|c|}
\hline Fase do Processo Normativo & Tipo de Documento & Subtipo & Data & Detalhamento \\
\hline Planejamento do Projeto & Research documents & Research & jul/96 & G4+1 - Leases: Implementation of a New Approach \\
\hline Planejamento do Projeto & Research documents & Research & fev/00 & G4+1 - Accounting for Leases: A New Approach \\
\hline Planejamento do Projeto & Board deliberations & Board discussion and papers & mar/06 & Preliminary Discussion of a Project on Leases \\
\hline Planejamento do Projeto & Board deliberations & Board discussion and papers & $\mathrm{abr} / 06$ & Leases - A Discussion of Options Available to the Boards \\
\hline Planejamento do Projeto & Consultation & Other feedback received & jun/06 & SACAND TRUSTEE MEETINGS - AGENDA PAPER 8B (SAC) \\
\hline Planejamento do Projeto & Issued documents & Project proposal & $\mathrm{jul} / 06$ & INFORMATION FOR OBSERVERS - Leasing (Agenda Paper 9) \\
\hline Planejamento do Projeto & Issued documents & Project proposal & jul/06 & $\begin{array}{l}\text { INFORMATION FOR OBSERVERS - Agenda Proposal - Leasing } \\
\text { (Agenda Paper 9A) }\end{array}$ \\
\hline $\begin{array}{l}\text { Desenvolvimento e Publicação } \\
\text { do Discussion paper }\end{array}$ & Board deliberations & Board discussion and papers & fev/07 & Project Overview and summary \\
\hline $\begin{array}{l}\text { Desenvolvimento e Publicação } \\
\text { do Discussion paper }\end{array}$ & Board deliberations & Board discussion and papers & fev/07 & History of Lease Accounting \\
\hline $\begin{array}{l}\text { Desenvolvimento e Publicação } \\
\text { do Discussion paper }\end{array}$ & Board deliberations & Board discussion and papers & fev/07 & Academic research on Lease Accounting \\
\hline $\begin{array}{l}\text { Desenvolvimento e Publicação } \\
\text { do Discussion paper }\end{array}$ & Board deliberations & Board discussion and papers & fev/07 & Asset and Liability definitions \\
\hline $\begin{array}{l}\text { Desenvolvimento e Publicação } \\
\text { do Discussion paper }\end{array}$ & Board deliberations & Board discussion and papers & fev/07 & Identification of Assets and Liabilities arising in in a simple Lease \\
\hline $\begin{array}{l}\text { Desenvolvimento e Publicação } \\
\text { do Discussion paper }\end{array}$ & Board deliberations & Board discussion and papers & fev/07 & Analysis of different accounting models for a simple Lease \\
\hline $\begin{array}{c}\text { Desenvolvimento e Publicação } \\
\text { do Discussion paper }\end{array}$ & Board deliberations & Board discussion and papers & fev/07 & Characteristics and terms of common lease contracts \\
\hline $\begin{array}{l}\text { Desenvolvimento e Publicação } \\
\text { do Discussion paper }\end{array}$ & Board deliberations & Board discussion and papers & fev/07 & Initial Recognition Of Assets And Liabilities In Lease Contracts \\
\hline $\begin{array}{l}\text { Desenvolvimento e Publicação } \\
\text { do Discussion paper }\end{array}$ & Board deliberations & Board discussion and papers & fev/07 & $\begin{array}{l}\text { Identification of Assets and Liabilities arising in a Lease with a } \\
\text { Lessee option to review }\end{array}$ \\
\hline $\begin{array}{l}\text { Desenvolvimento e Publicação } \\
\text { do Discussion paper }\end{array}$ & Board deliberations & Board discussion and papers & fev/07 & $\begin{array}{l}\text { Analysis of Different Accounting Models For A Lease With A } \\
\text { Lessee Option To Renew }\end{array}$ \\
\hline $\begin{array}{l}\text { Desenvolvimento e Publicação } \\
\text { do Discussion paper }\end{array}$ & Board deliberations & Board discussion and papers & fev/07 & Options to Terminate A Lease \\
\hline
\end{tabular}




\begin{tabular}{|c|c|c|c|c|}
\hline $\begin{array}{l}\text { Desenvolvimento e Publicação } \\
\text { do Discussion paper }\end{array}$ & Board deliberations & Board discussion and papers & mar/07 & Leases - Covering memo \\
\hline $\begin{array}{c}\text { Desenvolvimento e Publicação } \\
\text { do Discussion paper }\end{array}$ & Board deliberations & Board discussion and papers & $\operatorname{mar} / 07$ & $\begin{array}{l}\text { Leases - Identification of assets and liabilities arising in a simple } \\
\text { lease }\end{array}$ \\
\hline $\begin{array}{l}\text { Desenvolvimento e Publicação } \\
\text { do Discussion paper }\end{array}$ & Board deliberations & Board discussion and papers & $\operatorname{mar} / 07$ & Leases - Analysis of different accounting models for a simple lease \\
\hline $\begin{array}{l}\text { Desenvolvimento e Publicação } \\
\text { do Discussion paper }\end{array}$ & Board deliberations & Board discussion and papers & $\operatorname{mar} / 07$ & Leases - History of lease accounting \\
\hline $\begin{array}{l}\text { Desenvolvimento e Publicação } \\
\text { do Discussion paper }\end{array}$ & Board deliberations & Board discussion and papers & $\operatorname{mar} / 07$ & Leases - Academic research on lease accounting \\
\hline $\begin{array}{l}\text { Desenvolvimento e Publicação } \\
\text { do Discussion paper }\end{array}$ & Board deliberations & Board discussion and papers & $\mathrm{abr} / 07$ & Leases - Scope \\
\hline $\begin{array}{l}\text { Desenvolvimento e Publicação } \\
\text { do Discussion paper }\end{array}$ & Board deliberations & Board discussion and papers & mai/07 & Leases - Options to terminate or extend a lease \\
\hline $\begin{array}{l}\text { Desenvolvimento e Publicação } \\
\text { do Discussion paper }\end{array}$ & Board deliberations & Board discussion and papers & mai/07 & Leases - Options to terminate or extend a lease \\
\hline $\begin{array}{l}\text { Desenvolvimento e Publicação } \\
\text { do Discussion paper }\end{array}$ & Board deliberations & Board discussion and papers & mai/07 & $\begin{array}{l}\text { Leases - Different approaches to accounting for options to extend } \\
\text { or terminate a lease }\end{array}$ \\
\hline $\begin{array}{l}\text { Desenvolvimento e Publicação } \\
\text { do Discussion paper }\end{array}$ & Board deliberations & Board discussion and papers & jun/07 & Leases - Cover paper \\
\hline $\begin{array}{l}\text { Desenvolvimento e Publicação } \\
\text { do Discussion paper }\end{array}$ & Board deliberations & Board discussion and papers & jun/07 & Measurement of a lessee's liability to the lessor \\
\hline $\begin{array}{l}\text { Desenvolvimento e Publicação } \\
\text { do Discussion paper }\end{array}$ & Board deliberations & Board discussion and papers & jun/07 & Measurement of a lessee's right to use asset \\
\hline $\begin{array}{l}\text { Desenvolvimento e Publicação } \\
\text { do Discussion paper }\end{array}$ & Board deliberations & Board discussion and papers & jun/07 & Initial recognition of assets and liabilities in lease contracts \\
\hline $\begin{array}{l}\text { Desenvolvimento e Publicação } \\
\text { do Discussion paper }\end{array}$ & Board deliberations & Board discussion and papers & out/07 & Leases - Purpose of meeting and overview of papers \\
\hline $\begin{array}{l}\text { Desenvolvimento e Publicação } \\
\text { do Discussion paper }\end{array}$ & Board deliberations & Board discussion and papers & out/07 & Leases - Other lessee obligations \\
\hline $\begin{array}{l}\text { Desenvolvimento e Publicação } \\
\text { do Discussion paper }\end{array}$ & Board deliberations & Board discussion and papers & out/07 & Leases - Variable lease payment \\
\hline $\begin{array}{l}\text { Desenvolvimento e Publicação } \\
\text { do Discussion paper }\end{array}$ & Board deliberations & Board discussion and papers & jul/08 & Leases: Cover note \\
\hline $\begin{array}{l}\text { Desenvolvimento e Publicação } \\
\text { do Discussion paper }\end{array}$ & Board deliberations & Board discussion and papers & $\mathrm{jul} / 08$ & Leases: Overview of approach for Discussion paper \\
\hline $\begin{array}{l}\text { Desenvolvimento e Publicação } \\
\text { do Discussion paper }\end{array}$ & Board deliberations & Board discussion and papers & $\mathrm{jul} / 08$ & Leases: Options to extend or terminate a lease \\
\hline
\end{tabular}




\begin{tabular}{|c|c|c|c|c|}
\hline $\begin{array}{l}\text { Desenvolvimento e Publicação } \\
\text { do Discussion paper }\end{array}$ & Board deliberations & Board discussion and papers & jul/08 & Leases: Contingent rentals \\
\hline $\begin{array}{l}\text { Desenvolvimento e Publicação } \\
\text { do Discussion paper }\end{array}$ & Board deliberations & Board discussion and papers & $\mathrm{jul} / 08$ & $\begin{array}{l}\text { Leases: Lessee's measurement of the right of use asset and } \\
\text { obligation to make rental payments }\end{array}$ \\
\hline $\begin{array}{l}\text { Desenvolvimento e Publicação } \\
\text { do Discussion paper }\end{array}$ & Board deliberations & Board discussion and papers & $\mathrm{jul} / 08$ & Leases: Lease classification \\
\hline $\begin{array}{l}\text { Desenvolvimento e Publicação } \\
\text { do Discussion paper }\end{array}$ & Consultation & Leases Working Group & out/08 & $\begin{array}{l}\text { INFORMATION FOR OBSERVERS - Leases Working Group } \\
\text { Meeting - Agenda Paper - Draft IASB Invitation to Comment- } \\
\text { IASB discussion paper on Leases }\end{array}$ \\
\hline $\begin{array}{l}\text { Desenvolvimento e Publicação } \\
\text { do Discussion paper }\end{array}$ & Board deliberations & Board discussion and papers & nov/08 & Leases: Cover note \\
\hline $\begin{array}{l}\text { Desenvolvimento e Publicação } \\
\text { do Discussion paper }\end{array}$ & Board deliberations & Board discussion and papers & nov/08 & $\begin{array}{l}\text { Leases: Consideration of Lease Term, Purchase Options, } \\
\text { Contingent Rentals and Residual Value Guarantees } \\
\end{array}$ \\
\hline $\begin{array}{l}\text { Desenvolvimento e Publicação } \\
\text { do Discussion paper }\end{array}$ & Board deliberations & Board discussion and papers & nov/08 & Leases: Subsequent Measurement \\
\hline $\begin{array}{l}\text { Desenvolvimento e Publicação } \\
\text { do Discussion paper }\end{array}$ & Board deliberations & Board discussion and papers & nov/08 & Lease presentation \\
\hline $\begin{array}{l}\text { Desenvolvimento e Publicação } \\
\text { do Discussion paper }\end{array}$ & Board deliberations & Board discussion and papers & nov/08 & Lease accounting: Subleases \\
\hline $\begin{array}{l}\text { Desenvolvimento e Publicação } \\
\text { do Discussion paper }\end{array}$ & Board deliberations & Board discussion and papers & $\mathrm{jan} / 09$ & IASB January 2009 Meeting Update \\
\hline $\begin{array}{l}\text { Desenvolvimento e } \\
\text { Publicação do Discussion } \\
\text { paper }\end{array}$ & Issued documents & Discussion paper & $\operatorname{mar} / 09$ & Discussion paperDP/2009/1 - Leases - Preliminary views \\
\hline $\begin{array}{c}\text { Desenvolvimento e } \\
\text { Publicação do Discussion } \\
\text { paper }\end{array}$ & Issued documents & Snapshot & $\operatorname{mar} / 09$ & Snapshot: Leases_Preliminary Views \\
\hline $\begin{array}{l}\text { Desenvolvimento e Publicação } \\
\text { do Discussion paper }\end{array}$ & Board deliberations & Webcasts & mai/09 & $\begin{array}{l}\text { 13 May } 2009 \text { - Introduction to the Discussion paper: Leases - } \\
\text { Preliminary Views }\end{array}$ \\
\hline $\begin{array}{l}\text { Desenvolvimento e Publicação } \\
\text { do Discussion paper }\end{array}$ & Consultation & $\begin{array}{l}\text { Global Preparers Forum } \\
\text { meeting }\end{array}$ & $\mathrm{jul} / 09$ & GLOBAL PREPARERS FORUM - AGENDA PAPER 2 \\
\hline $\begin{array}{l}\text { Desenvolvimento e Publicação } \\
\text { do Discussion paper }\end{array}$ & Board deliberations & Webcasts & $\operatorname{mar} / 10$ & 31 March 2010 - Update on the lease project \\
\hline $\begin{array}{l}\text { Desenvolvimento e Publicação } \\
\text { do Discussion paper }\end{array}$ & Board deliberations & Webcasts & $\mathrm{abr} / 10$ & $Q \& A s$ \\
\hline $\begin{array}{l}\text { Desenvolvimento e Publicação } \\
\text { do Discussion paper }\end{array}$ & Board deliberations & Webcasts & jun/10 & $\begin{array}{l}10 \text { June } 2010 \text { - Updates to the proposals on accounting for lease } \\
\text { contracts }\end{array}$ \\
\hline
\end{tabular}




\begin{tabular}{|c|c|c|c|c|}
\hline $\begin{array}{l}\text { Desenvolvimento e Publicação } \\
\text { do Discussion paper }\end{array}$ & Board deliberations & Webcasts & ago/10 & $\begin{array}{l}18 \text { August } 2010 \text { - IASB staff will present a live webcast to discuss } \\
\text { the exposure draft Leases }\end{array}$ \\
\hline $\begin{array}{l}\text { Desenvolvimento e Publicação } \\
\text { do Discussion paper }\end{array}$ & Board deliberations & Webcasts & nov/10 & $\begin{array}{l}\text { 1 November } 2010 \text { - This webcast will address common questions } \\
\text { the staff are asked about the lease accounting proposals. }\end{array}$ \\
\hline $\begin{array}{c}\text { Desenvolvimento e Publicação } \\
\text { do Exposure draft }\end{array}$ & Board deliberations & Board discussion and papers & mai/09 & Lessor Accounting - Right-of-use Model \\
\hline $\begin{array}{c}\text { Desenvolvimento e Publicação } \\
\text { do Exposure draft }\end{array}$ & Board deliberations & Board discussion and papers & mai/09 & Lessor Accounting - Right-of-Use Model: Additional Examples \\
\hline $\begin{array}{l}\text { Desenvolvimento e Publicação } \\
\text { do Exposure draft }\end{array}$ & Board deliberations & Board discussion and papers & jun/09 & Cover note \\
\hline $\begin{array}{c}\text { Desenvolvimento e Publicação } \\
\text { do Exposure draft } \\
\end{array}$ & Board deliberations & Board discussion and papers & jun/09 & Sale and Leaseback Transactions \\
\hline $\begin{array}{l}\text { Desenvolvimento e Publicação } \\
\text { do Exposure draft }\end{array}$ & Board deliberations & Board discussion and papers & jun/09 & Impairment of right-of-use asset \\
\hline $\begin{array}{c}\text { Desenvolvimento e Publicação } \\
\text { do Exposure draft }\end{array}$ & Board deliberations & Board discussion and papers & jun/09 & Revaluation of right-of-use asset \\
\hline $\begin{array}{l}\text { Desenvolvimento e Publicação } \\
\text { do Exposure draft }\end{array}$ & Board deliberations & Board discussion and papers & jun/09 & Initial direct costs \\
\hline $\begin{array}{l}\text { Desenvolvimento e Publicação } \\
\text { do Exposure draft }\end{array}$ & Board deliberations & Board discussion and papers & jun/09 & Transition \\
\hline $\begin{array}{l}\text { Desenvolvimento e Publicação } \\
\text { do Exposure draft } \\
\end{array}$ & Board deliberations & Board discussion and papers & $\mathrm{jul} / 09$ & Cover note \\
\hline $\begin{array}{l}\text { Desenvolvimento e Publicação } \\
\text { do Exposure draft }\end{array}$ & Board deliberations & Board discussion and papers & jul/09 & Lessor Accounting \\
\hline $\begin{array}{c}\text { Desenvolvimento e } \\
\text { Publicação do Exposure draft }\end{array}$ & Feedback on DP & Comment letter summary (DP) & set/09 & IASB Agenda Reference $6 A$ \\
\hline $\begin{array}{l}\text { Desenvolvimento e Publicação } \\
\text { do Exposure draft }\end{array}$ & Board deliberations & Board discussion and papers & set/09 & Cover note \\
\hline $\begin{array}{l}\text { Desenvolvimento e Publicação } \\
\text { do Exposure draft }\end{array}$ & Board deliberations & Board discussion and papers & set/09 & Comment letter Summary \\
\hline $\begin{array}{l}\text { Desenvolvimento e Publicação } \\
\text { do Exposure draft }\end{array}$ & Board deliberations & Board discussion and papers & set/09 & Plan for Deliberations \\
\hline $\begin{array}{c}\text { Desenvolvimento e Publicação } \\
\text { do Exposure draft }\end{array}$ & Board deliberations & Board discussion and papers & out/09 & 10-10D - Join meeting papers: Leases [Zip] \\
\hline $\begin{array}{l}\text { Desenvolvimento e Publicação } \\
\text { do Exposure draft }\end{array}$ & Board deliberations & Board discussion and papers & nov/09 & 5A to 5H: Leases: Lease accounting [Zip] \\
\hline $\begin{array}{l}\text { Desenvolvimento e Publicação } \\
\text { do Exposure draft }\end{array}$ & Board deliberations & Board discussion and papers & dez/09 & 4 to $4 F:$ Leases [Zip] \\
\hline
\end{tabular}




\begin{tabular}{|c|c|c|c|c|}
\hline $\begin{array}{l}\text { Desenvolvimento e Publicação } \\
\text { do Exposure draft }\end{array}$ & Board deliberations & Board discussion and papers & $\mathrm{jan} / 10$ & Cover memo (revised 11 January) \\
\hline $\begin{array}{l}\text { Desenvolvimento e Publicação } \\
\text { do Exposure draft }\end{array}$ & Board deliberations & Board discussion and papers & $\mathrm{jan} / 10$ & $\begin{array}{l}\text { Subsequent measurement of leases with options and contingent } \\
\text { rentals under amortised cost }\end{array}$ \\
\hline $\begin{array}{l}\text { Desenvolvimento e Publicação } \\
\text { do Exposure draft }\end{array}$ & Board deliberations & Board discussion and papers & $\mathrm{jan} / 10$ & Scope - Exclusion of short-term leases \\
\hline $\begin{array}{l}\text { Desenvolvimento e Publicação } \\
\text { do Exposure draft }\end{array}$ & Board deliberations & Board discussion and papers & $\mathrm{jan} / 10$ & Lessor accounting and investment properties \\
\hline $\begin{array}{l}\text { Desenvolvimento e Publicação } \\
\text { do Exposure draft }\end{array}$ & Board deliberations & Board discussion and papers & $\mathrm{jan} / 10$ & $\begin{array}{l}\text { Reposted from December } 2009 \text { meeting - Scope - Purchases and } \\
\text { sales of the underlying asset }\end{array}$ \\
\hline $\begin{array}{l}\text { Desenvolvimento e Publicação } \\
\text { do Exposure draft }\end{array}$ & Board deliberations & Board discussion and papers & fev/10 & 10 to 10G: Leases [Zip] \\
\hline $\begin{array}{l}\text { Desenvolvimento e Publicação } \\
\text { do Exposure draft }\end{array}$ & Board deliberations & Board discussion and papers & $\operatorname{mar} / 10$ & 9 to 9 G: Leases [Zip] \\
\hline $\begin{array}{l}\text { Desenvolvimento e Publicação } \\
\text { do Exposure draft }\end{array}$ & Board deliberations & Board discussion and papers & $\mathrm{abr} / 10$ & 2A to 2I: Leases: Lessor accounting [Zip] \\
\hline $\begin{array}{l}\text { Desenvolvimento e Publicação } \\
\text { do Exposure draft }\end{array}$ & Board deliberations & Board discussion and papers & $\mathrm{abr} / 10$ & 9 to 9 C: Leases [Zip] \\
\hline $\begin{array}{l}\text { Desenvolvimento e Publicação } \\
\text { do Exposure draft }\end{array}$ & Board deliberations & Board discussion and papers & mai/10 & 5 to 5J: Leases [Zip] \\
\hline $\begin{array}{l}\text { Desenvolvimento e Publicação } \\
\text { do Exposure draft }\end{array}$ & Board deliberations & Board discussion and papers & jun/10 & 3 to 3E: Leases [Zip] \\
\hline $\begin{array}{l}\text { Desenvolvimento e Publicação } \\
\text { do Exposure draft }\end{array}$ & Board deliberations & Board discussion and papers & jun/10 & Cover note \\
\hline $\begin{array}{l}\text { Desenvolvimento e Publicação } \\
\text { do Exposure draft }\end{array}$ & Board deliberations & Board discussion and papers & jun/10 & Lessor accounting - Accounting models \\
\hline $\begin{array}{l}\text { Desenvolvimento e Publicação } \\
\text { do Exposure draft }\end{array}$ & Board deliberations & Due process steps & jun/10 & Staff paper-Agenda reference 2 \\
\hline $\begin{array}{l}\text { Desenvolvimento e Publicação } \\
\text { do Exposure draft }\end{array}$ & Board deliberations & Webcasts & jun/10 & Webcast: Intro to ED - AM Session \\
\hline $\begin{array}{l}\text { Desenvolvimento e Publicação } \\
\text { do Exposure draft }\end{array}$ & Board deliberations & Webcasts & jun $/ 10$ & Webcast: Intro to ED - PM Session \\
\hline $\begin{array}{l}\text { Desenvolvimento e Publicação } \\
\text { do Exposure draft }\end{array}$ & Consultation & $\begin{array}{l}\text { Global Preparers Forum } \\
\text { meeting }\end{array}$ & jun $/ 10$ & Leases: Break-out session \\
\hline $\begin{array}{l}\text { Desenvolvimento e Publicação } \\
\text { do Exposure draft }\end{array}$ & Consultation & $\begin{array}{c}\text { Global Preparers Forum } \\
\text { meeting }\end{array}$ & jun $/ 10$ & Leases: Break-out session - Lessor: accounting model \\
\hline $\begin{array}{l}\text { Desenvolvimento e Publicação } \\
\text { do Exposure draft }\end{array}$ & Board deliberations & Board discussion and papers & $\mathrm{jul} / 10$ & 2 to $2 \mathrm{~J}:$ Leases [Zip] \\
\hline
\end{tabular}




\begin{tabular}{|c|c|c|c|c|}
\hline $\begin{array}{l}\text { Desenvolvimento e } \\
\text { Publicação do Exposure draft }\end{array}$ & Issued documents & Exposure draft & ago/10 & Exposure draft ED/2010/9 - Leases \\
\hline $\begin{array}{l}\text { Desenvolvimento e } \\
\text { Publicação do Exposure draft }\end{array}$ & Issued documents & Snapshot & ago/10 & Snapshot: Leases \\
\hline $\begin{array}{c}\text { Desenvolvimento e } \\
\text { Publicação do Exposure draft }\end{array}$ & Issued documents & Press release & ago/10 & $\begin{array}{l}\text { IASB and US FASB publish proposals to improve the financial } \\
\text { reporting of leases }\end{array}$ \\
\hline $\begin{array}{l}\text { Desenvolvimento e Publicação } \\
\text { do Exposure draft } 2\end{array}$ & Consultation & Leases Working Group & $\mathrm{fev} / 07$ & Lease Accounting Working Group \\
\hline $\begin{array}{l}\text { Desenvolvimento e Publicação } \\
\text { do Exposure draft } 2\end{array}$ & Consultation & $\begin{array}{c}\text { Capital Markets Advisory } \\
\text { Committee }\end{array}$ & jun/10 & $\begin{array}{l}\text { Meeting of IASB representatives with the Analyst Representative } \\
\text { Group and the Global Preparers Forum June } 2010\end{array}$ \\
\hline $\begin{array}{l}\text { Desenvolvimento e Publicação } \\
\text { do Exposure draft } 2\end{array}$ & Consultation & Outreach on the project & ago/10 & 2010 outreach on the exposure draft \\
\hline $\begin{array}{l}\text { Desenvolvimento e Publicação } \\
\text { do Exposure draft } 2\end{array}$ & Consultation & World Standard-Setters & set/10 & World Standard-setters Conference \\
\hline $\begin{array}{l}\text { Desenvolvimento e Publicação } \\
\text { do Exposure draft } 2\end{array}$ & Board deliberations & Board discussion and papers & out $/ 10$ & Summary of Outreach Activities To Date \\
\hline $\begin{array}{l}\text { Desenvolvimento e Publicação } \\
\text { do Exposure draft } 2\end{array}$ & Consultation & $\begin{array}{l}\text { Capital Markets Advisory } \\
\text { Committee }\end{array}$ & nov/10 & $\begin{array}{l}\text { Meeting of IASB representatives with the Analyst Representative } \\
\text { Group November } 2010\end{array}$ \\
\hline $\begin{array}{l}\text { Desenvolvimento e Publicação } \\
\text { do Exposure draft } 2\end{array}$ & Consultation & Round tables & $\operatorname{dez} / 10$ & Hong Kong - 20 December 2010 \\
\hline $\begin{array}{c}\text { Desenvolvimento e } \\
\text { Publicação do Exposure draft } \\
2\end{array}$ & Feedback on 2010 ED & $\begin{array}{c}\text { Comment letter summary } \\
(2010 \mathrm{ED})\end{array}$ & jan/11 & IASB Agenda reference $5 A$ \\
\hline $\begin{array}{l}\text { Desenvolvimento e Publicação } \\
\text { do Exposure draft } 2\end{array}$ & Board deliberations & Board discussion and papers & $\mathrm{jan} / 11$ & Cover memo \\
\hline $\begin{array}{l}\text { Desenvolvimento e Publicação } \\
\text { do Exposure draft } 2\end{array}$ & Board deliberations & Board discussion and papers & $\mathrm{jan} / 11$ & Comment letter summary \\
\hline $\begin{array}{l}\text { Desenvolvimento e Publicação } \\
\text { do Exposure draft } 2\end{array}$ & Board deliberations & Board discussion and papers & $\mathrm{jan} / 11$ & Redeliberations plan \\
\hline $\begin{array}{l}\text { Desenvolvimento e Publicação } \\
\text { do Exposure draft } 2\end{array}$ & Board deliberations & Board discussion and papers & $\mathrm{jan} / 11$ & Definition of a lease: some preliminary thoughts \\
\hline $\begin{array}{l}\text { Desenvolvimento e Publicação } \\
\text { do Exposure draft } 2\end{array}$ & Board deliberations & Board discussion and papers & $\mathrm{jan} / 11$ & Lessor Accounting \\
\hline $\begin{array}{l}\text { Desenvolvimento e Publicação } \\
\text { do Exposure draft } 2\end{array}$ & Consultation & Round tables & $\mathrm{jan} / 11$ & Chicago, Illinois - Wednesday 5 January 2011 \\
\hline $\begin{array}{l}\text { Desenvolvimento e Publicação } \\
\text { do Exposure draft } 2\end{array}$ & Consultation & Round tables & $\mathrm{jan} / 11$ & Norwalk, Connecticut - Thursday 6 January 2011 \\
\hline
\end{tabular}




\begin{tabular}{|c|c|c|c|c|}
\hline $\begin{array}{l}\text { Desenvolvimento e Publicação } \\
\text { do Exposure draft } 2\end{array}$ & Board deliberations & Board discussion and papers & fev/11 & Examples to distinguish a service from a lease: Education Session \\
\hline $\begin{array}{l}\text { Desenvolvimento e Publicação } \\
\text { do Exposure draft } 2\end{array}$ & Board deliberations & Board discussion and papers & $\mathrm{fev} / 11$ & Cover memo \\
\hline $\begin{array}{l}\text { Desenvolvimento e Publicação } \\
\text { do Exposure draft } 2\end{array}$ & Board deliberations & Board discussion and papers & fev/11 & Accounting for variable lease payments \\
\hline $\begin{array}{l}\text { Desenvolvimento e Publicação } \\
\text { do Exposure draft } 2\end{array}$ & Board deliberations & Board discussion and papers & $\mathrm{fev} / 11$ & APPENDIX A - Application of Approaches (5A) \\
\hline $\begin{array}{l}\text { Desenvolvimento e Publicação } \\
\text { do Exposure draft } 2\end{array}$ & Board deliberations & Board discussion and papers & fev/11 & Accounting for options to extend or terminate a lease \\
\hline $\begin{array}{l}\text { Desenvolvimento e Publicação } \\
\text { do Exposure draft } 2\end{array}$ & Board deliberations & Board discussion and papers & $\mathrm{fev} / 11$ & Principles relating to the definition of a lease \\
\hline $\begin{array}{l}\text { Desenvolvimento e Publicação } \\
\text { do Exposure draft } 2\end{array}$ & Board deliberations & Board discussion and papers & fev/11 & Principles relating to the definition of a lease: Specified asset \\
\hline $\begin{array}{l}\text { Desenvolvimento e Publicação } \\
\text { do Exposure draft } 2\end{array}$ & Board deliberations & Board discussion and papers & fev/11 & $\begin{array}{l}\text { Principles relating to the definition of a lease: Right to control the } \\
\text { use of an asset }\end{array}$ \\
\hline $\begin{array}{l}\text { Desenvolvimento e Publicação } \\
\text { do Exposure draft } 2\end{array}$ & Board deliberations & Board discussion and papers & $\mathrm{fev} / 11$ & Types of leases-the case for other-than-finance leases \\
\hline $\begin{array}{l}\text { Desenvolvimento e Publicação } \\
\text { do Exposure draft } 2\end{array}$ & Board deliberations & Board discussion and papers & fev/11 & Other lease payment considerations \\
\hline $\begin{array}{l}\text { Desenvolvimento e Publicação } \\
\quad \text { do Exposure draft } 2\end{array}$ & Consultation & $\begin{array}{l}\text { Capital Markets Advisory } \\
\text { Committee }\end{array}$ & $\mathrm{fev} / 11$ & $\begin{array}{l}\text { Meeting of IASB representatives with the Analyst Representative } \\
\text { Group February } 2011\end{array}$ \\
\hline $\begin{array}{l}\text { Desenvolvimento e Publicação } \\
\text { do Exposure draft } 2\end{array}$ & Consultation & Global Preparers Forum & fev/11 & Definition of a lease and two types of leases \\
\hline $\begin{array}{l}\text { Desenvolvimento e Publicação } \\
\quad \text { do Exposure draft } 2\end{array}$ & Consultation & Global Preparers Forum & fev/11 & Leases Board Paper-Two types of leases \\
\hline $\begin{array}{l}\text { Desenvolvimento e Publicação } \\
\text { do Exposure draft } 2\end{array}$ & Board deliberations & Board discussion and papers & $\operatorname{mar} / 11$ & Cover memo \\
\hline $\begin{array}{l}\text { Desenvolvimento e Publicação } \\
\text { do Exposure draft } 2\end{array}$ & Board deliberations & Board discussion and papers & $\operatorname{mar} / 11$ & Confirmation of the right-of-use model \\
\hline $\begin{array}{l}\text { Desenvolvimento e Publicação } \\
\quad \text { do Exposure draft } 2\end{array}$ & Board deliberations & Board discussion and papers & $\operatorname{mar} / 11$ & Scope \\
\hline $\begin{array}{l}\text { Desenvolvimento e Publicação } \\
\text { do Exposure draft } 2\end{array}$ & Board deliberations & Board discussion and papers & $\operatorname{mar} / 11$ & Cover memo \\
\hline $\begin{array}{l}\text { Desenvolvimento e Publicação } \\
\quad \text { do Exposure draft } 2\end{array}$ & Board deliberations & Board discussion and papers & $\operatorname{mar} / 11$ & Accounting for short-term leases \\
\hline $\begin{array}{l}\text { Desenvolvimento e Publicação } \\
\text { do Exposure draft } 2\end{array}$ & Board deliberations & Board discussion and papers & $\operatorname{mar} / 11$ & Supplement: presentation of short-term leases \\
\hline
\end{tabular}




\begin{tabular}{|c|c|c|c|c|}
\hline $\begin{array}{l}\text { Desenvolvimento e Publicação } \\
\text { do Exposure draft } 2\end{array}$ & Board deliberations & Board discussion and papers & $\operatorname{mar} / 11$ & Leases: Distinguishing between a lease and a purchase or sale \\
\hline $\begin{array}{l}\text { Desenvolvimento e Publicação } \\
\text { do Exposure draft } 2\end{array}$ & Board deliberations & Board discussion and papers & $\operatorname{mar} / 11$ & Accounting for purchase options \\
\hline $\begin{array}{l}\text { Desenvolvimento e Publicação } \\
\text { do Exposure draft } 2\end{array}$ & Board deliberations & Board discussion and papers & $\operatorname{mar} / 11$ & $\begin{array}{l}\text { APPENDIX B - Illustration of approaches in a lease with a } \\
\text { bargain purchase option }(5 D)\end{array}$ \\
\hline $\begin{array}{l}\text { Desenvolvimento e Publicação } \\
\text { do Exposure draft } 2\end{array}$ & Board deliberations & Board discussion and papers & $\operatorname{mar} / 11$ & Cover memo \\
\hline $\begin{array}{l}\text { Desenvolvimento e Publicação } \\
\text { do Exposure draft } 2\end{array}$ & Board deliberations & Board discussion and papers & $\operatorname{mar} / 11$ & Initial direct costs \\
\hline $\begin{array}{l}\text { Desenvolvimento e Publicação } \\
\text { do Exposure draft } 2\end{array}$ & Board deliberations & Board discussion and papers & $\operatorname{mar} / 11$ & Inception vs. commencement \\
\hline $\begin{array}{l}\text { Desenvolvimento e Publicação } \\
\text { do Exposure draft } 2\end{array}$ & Board deliberations & Board discussion and papers & $\operatorname{mar} / 11$ & Sale and leaseback: cover memo \\
\hline $\begin{array}{l}\text { Desenvolvimento e Publicação } \\
\text { do Exposure draft } 2\end{array}$ & Board deliberations & Board discussion and papers & $\operatorname{mar} / 11$ & Sale and leaseback: when does transaction occur? \\
\hline $\begin{array}{l}\text { Desenvolvimento e Publicação } \\
\text { do Exposure draft } 2\end{array}$ & Board deliberations & Board discussion and papers & $\operatorname{mar} / 11$ & Sale and leaseback: recognition of gains or losses \\
\hline $\begin{array}{l}\text { Desenvolvimento e Publicação } \\
\text { do Exposure draft } 2\end{array}$ & Board deliberations & Board discussion and papers & $\operatorname{mar} / 11$ & Sale and leaseback: partial asset or whole asset approach \\
\hline $\begin{array}{l}\text { Desenvolvimento e Publicação } \\
\text { do Exposure draft } 2\end{array}$ & Board deliberations & Board discussion and papers & $\operatorname{mar} / 11$ & Sale and leaseback: lessee accounting \\
\hline $\begin{array}{l}\text { Desenvolvimento e Publicação } \\
\text { do Exposure draft } 2\end{array}$ & Board deliberations & Board discussion and papers & $\operatorname{mar} / 11$ & Determination of the discount rate in a lease \\
\hline $\begin{array}{l}\text { Desenvolvimento e Publicação } \\
\text { do Exposure draft } 2\end{array}$ & Board deliberations & Board discussion and papers & $\operatorname{mar} / 11$ & Contracts that contain a lease: which components to separate \\
\hline $\begin{array}{l}\text { Desenvolvimento e Publicação } \\
\text { do Exposure draft } 2\end{array}$ & Board deliberations & Board discussion and papers & $\operatorname{mar} / 11$ & $\begin{array}{l}\text { Contracts that contain a lease: how to allocate between } \\
\text { components }\end{array}$ \\
\hline $\begin{array}{l}\text { Desenvolvimento e Publicação } \\
\text { do Exposure draft } 2\end{array}$ & Consultation & Outreach on the project & $\operatorname{mar} / 11$ & $\begin{array}{l}2011 \text { targeted outreach on the definition of a lease and types of } \\
\text { leases }\end{array}$ \\
\hline $\begin{array}{l}\text { Desenvolvimento e Publicação } \\
\text { do Exposure draft } 2\end{array}$ & Board deliberations & Board discussion and papers & $\mathrm{abr} / 11$ & Cover тето \\
\hline $\begin{array}{l}\text { Desenvolvimento e Publicação } \\
\text { do Exposure draft } 2\end{array}$ & Board deliberations & Board discussion and papers & $\mathrm{abr} / 11$ & $\begin{array}{l}\text { Accounting for variable lease payments_-disguised minimum } \\
\text { lease payments }\end{array}$ \\
\hline $\begin{array}{l}\text { Desenvolvimento e Publicação } \\
\text { do Exposure draft } 2\end{array}$ & Board deliberations & Board discussion and papers & $\mathrm{abr} / 11$ & $\begin{array}{l}\text { Accounting for variable lease payments_- high threshold lease } \\
\text { payments }\end{array}$ \\
\hline $\begin{array}{l}\text { Desenvolvimento e Publicação } \\
\text { do Exposure draft } 2\end{array}$ & Board deliberations & Board discussion and papers & $a b r / 11$ & Definition of a lease \\
\hline
\end{tabular}




\begin{tabular}{|c|c|c|c|c|}
\hline $\begin{array}{l}\text { Desenvolvimento e Publicação } \\
\text { do Exposure draft } 2\end{array}$ & Board deliberations & Board discussion and papers & $\mathrm{abr} / 11$ & APPENDIX - Definition of a lease - application examples (ID) \\
\hline $\begin{array}{l}\text { Desenvolvimento e Publicação } \\
\quad \text { do Exposure draft } 2\end{array}$ & Board deliberations & Board discussion and papers & $\mathrm{abr} / 11$ & Types of leases-Cover memo \\
\hline $\begin{array}{l}\text { Desenvolvimento e Publicação } \\
\text { do Exposure draft } 2\end{array}$ & Board deliberations & Board discussion and papers & $\mathrm{abr} / 11$ & $\begin{array}{l}\text { Types of leases-Is more than one accounting approach } \\
\text { necessary? }\end{array}$ \\
\hline $\begin{array}{l}\text { Desenvolvimento e Publicação } \\
\text { do Exposure draft } 2\end{array}$ & Board deliberations & Board discussion and papers & $\mathrm{abr} / 11$ & $\begin{array}{l}\text { Determining a lease to be a finance lease or an other-than-finance } \\
\text { lease }\end{array}$ \\
\hline $\begin{array}{l}\text { Desenvolvimento e Publicação } \\
\text { do Exposure draft } 2\end{array}$ & Board deliberations & Board discussion and papers & $\mathrm{abr} / 11$ & Lessee accounting-other-than-finance leases \\
\hline $\begin{array}{l}\text { Desenvolvimento e Publicação } \\
\text { do Exposure draft } 2\end{array}$ & Board deliberations & Board discussion and papers & $\mathrm{abr} / 11$ & $\begin{array}{l}\text { APPENDIX C - Lease with even payments, with payment made at } \\
\text { the end of the period }(1 \mathrm{H})\end{array}$ \\
\hline $\begin{array}{l}\text { Desenvolvimento e Publicação } \\
\text { do Exposure draft } 2\end{array}$ & Board deliberations & Board discussion and papers & $\mathrm{abr} / 11$ & Lessor accounting_other-than-finance leases \\
\hline $\begin{array}{l}\text { Desenvolvimento e Publicação } \\
\text { do Exposure draft } 2\end{array}$ & Board deliberations & Board discussion and papers & $\mathrm{abr} / 11$ & $\begin{array}{l}\text { APPENDIX A - Illustration of Approach } 2 \text { and Approach } 3 \text { when } \\
\text { pattern does not equal benefit pattern (II) }\end{array}$ \\
\hline $\begin{array}{l}\text { Desenvolvimento e Publicação } \\
\text { do Exposure draft } 2\end{array}$ & Board deliberations & Board discussion and papers & $\mathrm{abr} / 11$ & Lessee accounting_finance leases \\
\hline $\begin{array}{l}\text { Desenvolvimento e Publicação } \\
\text { do Exposure draft } 2\end{array}$ & Board deliberations & Board discussion and papers & abr/11 & Lessor accounting-finance leases-underlying asset \\
\hline $\begin{array}{l}\text { Desenvolvimento e Publicação } \\
\quad \text { do Exposure draft } 2\end{array}$ & Board deliberations & Board discussion and papers & abr/11 & Lessor accounting-finance leases-measurement \\
\hline $\begin{array}{l}\text { Desenvolvimento e Publicação } \\
\text { do Exposure draft } 2\end{array}$ & Board deliberations & Board discussion and papers & mai/11 & Cover Memo \\
\hline $\begin{array}{l}\text { Desenvolvimento e Publicação } \\
\quad \text { do Exposure draft } 2\end{array}$ & Board deliberations & Board discussion and papers & mai/11 & Sharia-compliant leases-lessor issues \\
\hline $\begin{array}{l}\text { Desenvolvimento e Publicação } \\
\text { do Exposure draft } 2\end{array}$ & Board deliberations & Board discussion and papers & mai/11 & $\begin{array}{l}\text { APPENDIX - Financial Reporting Issues relating to Islamic } \\
\text { Finance }(2 A)\end{array}$ \\
\hline $\begin{array}{l}\text { Desenvolvimento e Publicação } \\
\text { do Exposure draft } 2\end{array}$ & Board deliberations & Board discussion and papers & mai/11 & $\begin{array}{l}\text { Contract modifications or changes in circumstances after the date } \\
\text { of inception of the lease }\end{array}$ \\
\hline $\begin{array}{l}\text { Desenvolvimento e Publicação } \\
\quad \text { do Exposure draft } 2\end{array}$ & Board deliberations & Board discussion and papers & mai/11 & Distinguishing between lease accounting approaches \\
\hline $\begin{array}{l}\text { Desenvolvimento e Publicação } \\
\text { do Exposure draft } 2\end{array}$ & Board deliberations & Board discussion and papers & mai/11 & Lessee accounting_other-than-finance lease \\
\hline $\begin{array}{l}\text { Desenvolvimento e Publicação } \\
\quad \text { do Exposure draft } 2\end{array}$ & Board deliberations & Board discussion and papers & mai/11 & $\begin{array}{l}\text { APPENDIX A - Lease with increasing payments, with payment } \\
\text { made at the beginning of the period }(2 D)\end{array}$ \\
\hline $\begin{array}{l}\text { Desenvolvimento e Publicação } \\
\text { do Exposure draft } 2\end{array}$ & Board deliberations & Board discussion and papers & mai/11 & Lessor accounting_finance lease-measurement and presentation \\
\hline
\end{tabular}




\begin{tabular}{|c|c|c|c|c|}
\hline $\begin{array}{l}\text { Desenvolvimento e Publicação } \\
\text { do Exposure draft } 2 \\
\end{array}$ & Board deliberations & Board discussion and papers & mai/11 & Lessor accounting_other-than-finance lease \\
\hline $\begin{array}{l}\text { Desenvolvimento e Publicação } \\
\text { do Exposure draft } 2\end{array}$ & Board deliberations & Board discussion and papers & mai/11 & $\begin{array}{l}\text { APPENDIX A - Illustration of Approaches - Lease of a } \\
\text { depreciating asset where the fair value exceeds the carrying value } \\
\text { at commencement }(2 F)\end{array}$ \\
\hline $\begin{array}{l}\text { Desenvolvimento e Publicação } \\
\text { do Exposure draft } 2 \\
\end{array}$ & Board deliberations & Board discussion and papers & mai/11 & $\begin{array}{l}\text { APPENDIX B - Illustration of sale or assignment of lease } \\
\text { receivables under Approach } 1 \text { and Approach } 2(2 F)\end{array}$ \\
\hline $\begin{array}{l}\text { Desenvolvimento e Publicação } \\
\text { do Exposure draft } 2 \\
\end{array}$ & Board deliberations & Board discussion and papers & mai/11 & Reassessment of options in a lease \\
\hline $\begin{array}{l}\text { Desenvolvimento e Publicação } \\
\text { do Exposure draft } 2 \\
\end{array}$ & Board deliberations & Board discussion and papers & mai/11 & Reassessment of discount rate in a lease \\
\hline $\begin{array}{l}\text { Desenvolvimento e Publicação } \\
\text { do Exposure draft } 2 \\
\end{array}$ & Board deliberations & Board discussion and papers & mai/11 & $\begin{array}{l}\text { APPENDIX B - Illustration of Approaches - Reassessing the } \\
\text { discount rate when lease payments change }(2 \mathrm{H})\end{array}$ \\
\hline $\begin{array}{l}\text { Desenvolvimento e Publicação } \\
\text { do Exposure draft } 2 \\
\end{array}$ & Board deliberations & Board discussion and papers & mai/11 & Lessee accounting approaches \\
\hline $\begin{array}{l}\text { Desenvolvimento e Publicação } \\
\text { do Exposure draft } 2 \\
\end{array}$ & Board deliberations & Board discussion and papers & jun/11 & Cover memo \\
\hline $\begin{array}{l}\text { Desenvolvimento e Publicação } \\
\text { do Exposure draft } 2 \\
\end{array}$ & Board deliberations & Board discussion and papers & jun/11 & Lessee accounting: subsequent measurement issues \\
\hline $\begin{array}{l}\text { Desenvolvimento e Publicação } \\
\text { do Exposure draft } 2\end{array}$ & Board deliberations & Board discussion and papers & jun/11 & Residual value guarantees-lessees \\
\hline $\begin{array}{l}\text { Desenvolvimento e Publicação } \\
\text { do Exposure draft } 2 \\
\end{array}$ & Board deliberations & Board discussion and papers & jun/11 & APPENDIX B - Agenda Paper $2 B(2 B)$ \\
\hline $\begin{array}{l}\text { Desenvolvimento e Publicação } \\
\text { do Exposure draft } 2\end{array}$ & Board deliberations & Board discussion and papers & jun/11 & Cover memo \\
\hline $\begin{array}{l}\text { Desenvolvimento e Publicação } \\
\text { do Exposure draft } 2 \\
\end{array}$ & Board deliberations & Board discussion and papers & jun/11 & Lessor accounting \\
\hline $\begin{array}{l}\text { Desenvolvimento e Publicação } \\
\text { do Exposure draft } 2 \\
\end{array}$ & Board deliberations & Board discussion and papers & jun/11 & $\begin{array}{l}\text { APPENDIX A1 - Lessor Examples: Lease where the lessor is a } \\
\text { financial institution ( } 2 A)\end{array}$ \\
\hline $\begin{array}{l}\text { Desenvolvimento e Publicação } \\
\text { do Exposure draft } 2 \\
\end{array}$ & Board deliberations & Board discussion and papers & jun/11 & Subleases \\
\hline $\begin{array}{l}\text { Desenvolvimento e Publicação } \\
\text { do Exposure draft } 2 \\
\end{array}$ & Board deliberations & Board discussion and papers & jun/11 & Accounting for short-term leases \\
\hline $\begin{array}{l}\text { Desenvolvimento e Publicação } \\
\text { do Exposure draft } 2 \\
\end{array}$ & Board deliberations & Board discussion and papers & jun/11 & Sharia-compliant leases_lessor issues [repost from May] \\
\hline $\begin{array}{l}\text { Desenvolvimento e Publicação } \\
\text { do Exposure draft } 2\end{array}$ & Board deliberations & Board discussion and papers & jun/11 & $\begin{array}{l}\text { APPENDIX - Financial Reporting Issues relating to Islamic } \\
\text { Finance }(2 D)\end{array}$ \\
\hline
\end{tabular}




\begin{tabular}{|c|c|c|c|c|}
\hline $\begin{array}{l}\text { Desenvolvimento e Publicação } \\
\text { do Exposure draft } 2\end{array}$ & Consultation & $\begin{array}{l}\text { Capital Markets Advisory } \\
\text { Committee }\end{array}$ & jun/11 & $\begin{array}{l}\text { IASB representatives with the Capital Markets Advisory } \\
\text { Committee and the Global Preparers Forum } 22 \text { June } 2011 \mathrm{~g}\end{array}$ \\
\hline $\begin{array}{l}\text { Desenvolvimento e Publicação } \\
\quad \text { do Exposure draft } 2\end{array}$ & Board deliberations & Board discussion and papers & $\mathrm{jul} / 11$ & Cover memo \\
\hline $\begin{array}{l}\text { Desenvolvimento e Publicação } \\
\text { do Exposure draft } 2\end{array}$ & Board deliberations & Board discussion and papers & jul/11 & APPENDIX A - Cover memo (5) \\
\hline $\begin{array}{l}\text { Desenvolvimento e Publicação } \\
\text { do Exposure draft } 2\end{array}$ & Board deliberations & Board discussion and papers & $\mathrm{jul} / 11$ & Presentation—Lessee Statement of Financial Position \\
\hline $\begin{array}{l}\text { Desenvolvimento e Publicação } \\
\text { do Exposure draft } 2\end{array}$ & Board deliberations & Board discussion and papers & $\mathrm{jul} / 11$ & Presentation-Lessee Statement of Cash Flows \\
\hline $\begin{array}{l}\text { Desenvolvimento e Publicação } \\
\text { do Exposure draft } 2\end{array}$ & Board deliberations & Board discussion and papers & $\mathrm{jul} / 11$ & Lessee disclosures-Short term leases \\
\hline $\begin{array}{l}\text { Desenvolvimento e Publicação } \\
\text { do Exposure draft } 2\end{array}$ & Board deliberations & Board discussion and papers & $\mathrm{jul} / 11$ & Lessee disclosures \\
\hline $\begin{array}{l}\text { Desenvolvimento e Publicação } \\
\text { do Exposure draft } 2\end{array}$ & Board deliberations & Board discussion and papers & $\mathrm{jul} / 11$ & APPENDIX B - Lease Disclosures - Illustrations (5D) \\
\hline $\begin{array}{l}\text { Desenvolvimento e Publicação } \\
\text { do Exposure draft } 2\end{array}$ & Board deliberations & Board discussion and papers & $\mathrm{jul} / 11$ & $\begin{array}{l}\text { Accounting for variable lease payments? Variable lease payments } \\
\text { that depend on an index or a rate }\end{array}$ \\
\hline $\begin{array}{l}\text { Desenvolvimento e Publicação } \\
\text { do Exposure draft } 2\end{array}$ & Board deliberations & Board discussion and papers & $\mathrm{jul} / 11$ & $\begin{array}{l}\text { APPENDIX A - Illustrative reassessment examples of variable } \\
\text { lease payment }\end{array}$ \\
\hline $\begin{array}{l}\text { Desenvolvimento e Publicação } \\
\text { do Exposure draft } 2\end{array}$ & Board deliberations & Board discussion and papers & $\mathrm{jul} / 11$ & Embedded derivatives \\
\hline $\begin{array}{l}\text { Desenvolvimento e Publicação } \\
\text { do Exposure draft } 2\end{array}$ & Board deliberations & Board discussion and papers & $\mathrm{jul} / 11$ & Lessor Accounting \\
\hline $\begin{array}{l}\text { Desenvolvimento e Publicação } \\
\text { do Exposure draft } 2\end{array}$ & Board deliberations & Board discussion and papers & $\mathrm{jul} / 11$ & Addendum to Agenda Paper $5 G$ (Lessor Accounting) \\
\hline $\begin{array}{l}\text { Desenvolvimento e Publicação } \\
\text { do Exposure draft } 2\end{array}$ & Board deliberations & Board discussion and papers & set/11 & Cover memo \\
\hline $\begin{array}{l}\text { Desenvolvimento e Publicação } \\
\text { do Exposure draft } 2\end{array}$ & Board deliberations & Board discussion and papers & set/11 & Scope-inventory \\
\hline $\begin{array}{l}\text { Desenvolvimento e Publicação } \\
\quad \text { do Exposure draft } 2\end{array}$ & Board deliberations & Board discussion and papers & set/11 & Presentation: lessor statement of financial position \\
\hline $\begin{array}{l}\text { Desenvolvimento e Publicação } \\
\text { do Exposure draft } 2\end{array}$ & Board deliberations & Board discussion and papers & set/11 & Presentation: lessor statement of cash flows \\
\hline $\begin{array}{l}\text { Desenvolvimento e Publicação } \\
\quad \text { do Exposure draft } 2\end{array}$ & Board deliberations & Board discussion and papers & set/11 & $\begin{array}{l}\text { Applicability of financial asset guidance to the right to receive } \\
\text { lease payments }\end{array}$ \\
\hline $\begin{array}{l}\text { Desenvolvimento e Publicação } \\
\text { do Exposure draft } 2\end{array}$ & Board deliberations & Board discussion and papers & set/11 & Lessor subsequent measurement issues \\
\hline
\end{tabular}




\begin{tabular}{|c|c|c|c|c|}
\hline $\begin{array}{l}\text { Desenvolvimento e Publicação } \\
\text { do Exposure draft } 2\end{array}$ & Board deliberations & Board discussion and papers & set/11 & Lessor accounting: residual value guarantees \\
\hline $\begin{array}{l}\text { Desenvolvimento e Publicação } \\
\text { do Exposure draft } 2 \\
\end{array}$ & Board deliberations & Board discussion and papers & set/11 & Lessee transition \\
\hline $\begin{array}{l}\text { Desenvolvimento e Publicação } \\
\text { do Exposure draft } 2 \\
\end{array}$ & Consultation & World Standard-Setters & set/11 & World Standard Setters meeting \\
\hline $\begin{array}{l}\text { Desenvolvimento e Publicação } \\
\text { do Exposure draft } 2\end{array}$ & Board deliberations & Board discussion and papers & out/11 & Cover memo \\
\hline $\begin{array}{l}\text { Desenvolvimento e Publicação } \\
\text { do Exposure draft } 2\end{array}$ & Board deliberations & Board discussion and papers & out/11 & $\begin{array}{l}\text { Lessor accounting_variable lease payments and measurement of } \\
\text { residual asset }\end{array}$ \\
\hline $\begin{array}{l}\text { Desenvolvimento e Publicação } \\
\text { do Exposure draft } 2\end{array}$ & Board deliberations & Board discussion and papers & out/11 & $\begin{array}{l}\text { Fair value requirement for lease receivables and transfers of } \\
\text { lease receivables }\end{array}$ \\
\hline $\begin{array}{l}\text { Desenvolvimento e Publicação } \\
\text { do Exposure draft } 2\end{array}$ & Board deliberations & Board discussion and papers & out/11 & Presentation: Lessor statement of comprehensive income \\
\hline $\begin{array}{l}\text { Desenvolvimento e Publicação } \\
\text { do Exposure draft } 2\end{array}$ & Board deliberations & Board discussion and papers & out $/ 11$ & Lessor disclosures \\
\hline $\begin{array}{l}\text { Desenvolvimento e Publicação } \\
\text { do Exposure draft } 2 \\
\end{array}$ & Board deliberations & Board discussion and papers & out/11 & Consequential amendments to IAS 40 \\
\hline $\begin{array}{l}\text { Desenvolvimento e Publicação } \\
\text { do Exposure draft } 2\end{array}$ & Board deliberations & Board discussion and papers & out/11 & Lessor accounting \\
\hline $\begin{array}{l}\text { Desenvolvimento e Publicação } \\
\text { do Exposure draft } 2\end{array}$ & Board deliberations & Board discussion and papers & out/11 & Lessee transition \\
\hline $\begin{array}{l}\text { Desenvolvimento e Publicação } \\
\text { do Exposure draft } 2\end{array}$ & Board deliberations & Board discussion and papers & out/11 & Lessor transition \\
\hline $\begin{array}{l}\text { Desenvolvimento e Publicação } \\
\text { do Exposure draft } 2 \\
\end{array}$ & Board deliberations & Board discussion and papers & out/11 & Transition reliefs and disclosures \\
\hline $\begin{array}{l}\text { Desenvolvimento e Publicação } \\
\text { do Exposure draft } 2\end{array}$ & Board deliberations & Board discussion and papers & out/11 & Transition - other considerations \\
\hline $\begin{array}{l}\text { Desenvolvimento e Publicação } \\
\text { do Exposure draft } 2 \\
\end{array}$ & Board deliberations & Board discussion and papers & out/11 & Transition - sale and leaseback \\
\hline $\begin{array}{l}\text { Desenvolvimento e Publicação } \\
\text { do Exposure draft } 2\end{array}$ & Board deliberations & Board discussion and papers & out/11 & Lessor approaches \\
\hline $\begin{array}{c}\text { Desenvolvimento e Publicação } \\
\text { do Exposure draft } 2\end{array}$ & Board deliberations & Board discussion and papers & out/11 & Leases Hand-out (2) \\
\hline $\begin{array}{l}\text { Desenvolvimento e Publicação } \\
\text { do Exposure draft } 2\end{array}$ & Board deliberations & Board discussion and papers & nov/11 & Lessor disclosures (discussion deferred from October) \\
\hline $\begin{array}{l}\text { Desenvolvimento e Publicação } \\
\text { do Exposure draft } 2\end{array}$ & Board deliberations & Board discussion and papers & nov/11 & $\begin{array}{l}\text { Transition - other considerations (discussion deferred from } \\
\text { October) }\end{array}$ \\
\hline
\end{tabular}




\begin{tabular}{|c|c|c|c|c|}
\hline $\begin{array}{l}\text { Desenvolvimento e Publicação } \\
\text { do Exposure draft } 2\end{array}$ & Board deliberations & Board discussion and papers & nov/11 & \begin{tabular}{|l} 
Transition - sale and leaseback (discussion deferred from \\
October)
\end{tabular} \\
\hline $\begin{array}{l}\text { Desenvolvimento e Publicação } \\
\quad \text { do Exposure draft } 2\end{array}$ & Board deliberations & Board discussion and papers & nov/11 & IFRS 1 - exemption for leases \\
\hline $\begin{array}{l}\text { Desenvolvimento e Publicação } \\
\text { do Exposure draft } 2\end{array}$ & Board deliberations & Board discussion and papers & nov/11 & Cover memo \\
\hline $\begin{array}{l}\text { Desenvolvimento e Publicação } \\
\text { do Exposure draft } 2\end{array}$ & Board deliberations & Board discussion and papers & nov/11 & $\begin{array}{l}\text { Consequential amendments for business combinations and } \\
\text { borrowing costs and transition requirements }\end{array}$ \\
\hline $\begin{array}{l}\text { Desenvolvimento e Publicação } \\
\text { do Exposure draft } 2\end{array}$ & Board deliberations & Board discussion and papers & nov/11 & Transition - secured borrowings \\
\hline $\begin{array}{l}\text { Desenvolvimento e Publicação } \\
\text { do Exposure draft } 2\end{array}$ & Board deliberations & Board discussion and papers & nov/11 & Agenda Papers 2 to $2 \mathrm{~K}$ [Zip] \\
\hline $\begin{array}{l}\text { Desenvolvimento e Publicação } \\
\text { do Exposure draft } 2\end{array}$ & Consultation & Global Preparers Forum & nov/11 & Definition of a lease and two types of leases \\
\hline $\begin{array}{l}\text { Desenvolvimento e Publicação } \\
\text { do Exposure draft } 2\end{array}$ & Board deliberations & Board discussion and papers & $\operatorname{dez} / 11$ & Agenda Papers 5 to 5C: Leases [Zip] \\
\hline $\begin{array}{l}\text { Desenvolvimento e Publicação } \\
\text { do Exposure draft } 2\end{array}$ & Board deliberations & Board discussion and papers & $\mathrm{fev} / 12$ & Cover note \\
\hline $\begin{array}{l}\text { Desenvolvimento e Publicação } \\
\text { do Exposure draft } 2\end{array}$ & Board deliberations & Board discussion and papers & $\mathrm{fev} / 12$ & Working Group Meeting Summary \\
\hline $\begin{array}{l}\text { Desenvolvimento e Publicação } \\
\text { do Exposure draft } 2\end{array}$ & Board deliberations & Board discussion and papers & $\mathrm{fev} / 12$ & Lessee accounting - introduction and overview \\
\hline $\begin{array}{l}\text { Desenvolvimento e Publicação } \\
\text { do Exposure draft } 2\end{array}$ & Board deliberations & Board discussion and papers & $\mathrm{fev} / 12$ & Lessee accounting approaches \\
\hline $\begin{array}{l}\text { Desenvolvimento e Publicação } \\
\text { do Exposure draft } 2\end{array}$ & Board deliberations & Board discussion and papers & fev/12 & Addendum to Agenda Paper $2 C$ (Lessee accounting approaches) \\
\hline $\begin{array}{l}\text { Desenvolvimento e Publicação } \\
\text { do Exposure draft } 2\end{array}$ & Board deliberations & Board discussion and papers & fev/12 & Lessee accounting - Illustrations \\
\hline $\begin{array}{l}\text { Desenvolvimento e Publicação } \\
\text { do Exposure draft } 2\end{array}$ & Board deliberations & Board discussion and papers & fev/12 & $\begin{array}{l}\text { Leases excluded from the scope of receivable and residual } \\
\text { approach }\end{array}$ \\
\hline $\begin{array}{l}\text { Desenvolvimento e Publicação } \\
\quad \text { do Exposure draft } 2\end{array}$ & Board deliberations & Board discussion and papers & $\mathrm{fev} / 12$ & $\begin{array}{l}\text { Consequences of lessee accounting discussion and lessor } \\
\text { investment property decision }\end{array}$ \\
\hline $\begin{array}{l}\text { Desenvolvimento e Publicação } \\
\text { do Exposure draft } 2\end{array}$ & Consultation & $\begin{array}{l}\text { Capital Markets Advisory } \\
\text { Committee }\end{array}$ & $\mathrm{fev} / 12$ & $\begin{array}{l}\text { Meeting of IASB representatives with the Capital Markets } \\
\text { Advisory Committee }\end{array}$ \\
\hline $\begin{array}{l}\text { Desenvolvimento e Publicação } \\
\quad \text { do Exposure draft } 2\end{array}$ & Consultation & Global Preparers Forum & $\operatorname{mar} / 12$ & Lessee accounting: subsequent measurement of the right-of-use \\
\hline $\begin{array}{l}\text { Desenvolvimento e Publicação } \\
\text { do Exposure draft } 2\end{array}$ & Consultation & Outreach on the project & $\mathrm{abr} / 12$ & $\begin{array}{l}2012 \text { targeted outreach on the subsequent measurement of ROU } \\
\text { assets }\end{array}$ \\
\hline
\end{tabular}




\begin{tabular}{|c|c|c|c|c|}
\hline $\begin{array}{l}\text { Desenvolvimento e Publicação } \\
\text { do Exposure draft } 2\end{array}$ & Board deliberations & Board discussion and papers & $\mathrm{mai} / 12$ & Summary of feedback received during outreach activities \\
\hline $\begin{array}{l}\text { Desenvolvimento e Publicação } \\
\text { do Exposure draft } 2\end{array}$ & Board deliberations & Board discussion and papers & jun/12 & Cover memo \\
\hline $\begin{array}{l}\text { Desenvolvimento e Publicação } \\
\text { do Exposure draft } 2\end{array}$ & Board deliberations & Board discussion and papers & jun/12 & $\begin{array}{l}\text { Lease accounting: overview of papers to be discussed at this } \\
\text { meeting }\end{array}$ \\
\hline $\begin{array}{l}\text { Desenvolvimento e Publicação } \\
\text { do Exposure draft } 2\end{array}$ & Board deliberations & Board discussion and papers & jun $/ 12$ & Lessee accounting approaches \\
\hline $\begin{array}{l}\text { Desenvolvimento e Publicação } \\
\text { do Exposure draft } 2\end{array}$ & Board deliberations & Board discussion and papers & jun/12 & Lessor accounting - consequences of lessee decisions \\
\hline $\begin{array}{l}\text { Desenvolvimento e Publicação } \\
\text { do Exposure draft } 2\end{array}$ & Board deliberations & Board discussion and papers & jun $/ 12$ & How to determine 'the line' for different types of leases \\
\hline $\begin{array}{l}\text { Desenvolvimento e Publicação } \\
\text { do Exposure draft } 2\end{array}$ & Consultation & $\begin{array}{c}\text { Capital Markets Advisory } \\
\text { Committee }\end{array}$ & jun/12 & $\begin{array}{l}\text { Meeting of IASB representatives with the Capital Markets } \\
\text { Advisory Committee and the Global Preparers Forum }\end{array}$ \\
\hline $\begin{array}{l}\text { Desenvolvimento e Publicação } \\
\text { do Exposure draft } 2\end{array}$ & Consultation & Global Preparers Forum & jun/12 & Update on Leases project \\
\hline $\begin{array}{l}\text { Desenvolvimento e Publicação } \\
\text { do Exposure draft } 2\end{array}$ & Consultation & Global Preparers Forum & jun $/ 12$ & $\begin{array}{l}\text { Lease accounting: overview of papers to be discussed at this } \\
\text { meeting }\end{array}$ \\
\hline $\begin{array}{l}\text { Desenvolvimento e Publicação } \\
\text { do Exposure draft } 2\end{array}$ & Consultation & Global Preparers Forum & jun $/ 12$ & Lessee accounting approaches \\
\hline $\begin{array}{l}\text { Desenvolvimento e Publicação } \\
\text { do Exposure draft } 2\end{array}$ & Consultation & Global Preparers Forum & jun $/ 12$ & Lessor accounting — consequences of lessee decisions \\
\hline $\begin{array}{l}\text { Desenvolvimento e Publicação } \\
\text { do Exposure draft } 2\end{array}$ & Consultation & Global Preparers Forum & jun/12 & How to determine 'the line' for different types of leases \\
\hline $\begin{array}{l}\text { Desenvolvimento e Publicação } \\
\text { do Exposure draft } 2\end{array}$ & Board deliberations & Board discussion and papers & $\mathrm{jul} / 12$ & Cover paper \\
\hline $\begin{array}{l}\text { Desenvolvimento e Publicação } \\
\text { do Exposure draft } 2\end{array}$ & Board deliberations & Board discussion and papers & $\mathrm{jul} / 12$ & Lessee - Statement of Financial Position \\
\hline $\begin{array}{l}\text { Desenvolvimento e Publicação } \\
\text { do Exposure draft } 2\end{array}$ & Board deliberations & Board discussion and papers & $\mathrm{jul} / 12$ & Lessee - Statement of Cash Flows \\
\hline $\begin{array}{l}\text { Desenvolvimento e Publicação } \\
\text { do Exposure draft } 2\end{array}$ & Board deliberations & Board discussion and papers & $\mathrm{jul} / 12$ & Lessee Disclosures \\
\hline $\begin{array}{l}\text { Desenvolvimento e Publicação } \\
\text { do Exposure draft } 2\end{array}$ & Board deliberations & Board discussion and papers & $\mathrm{jul} / 12$ & Lessee transition - measurement of the ROU asset \\
\hline $\begin{array}{l}\text { Desenvolvimento e Publicação } \\
\text { do Exposure draft } 2\end{array}$ & Board deliberations & Board discussion and papers & $\mathrm{jul} / 12$ & $\begin{array}{l}\text { Lessor accounting : measurement of the underlying asset when a } \\
\text { lease terminates prematurely }\end{array}$ \\
\hline $\begin{array}{l}\text { Desenvolvimento e Publicação } \\
\text { do Exposure draft } 2\end{array}$ & Board deliberations & Board discussion and papers & $\mathrm{jul} / 12$ & Interim disclosures \\
\hline
\end{tabular}




\begin{tabular}{|c|c|c|c|c|}
\hline $\begin{array}{l}\text { Desenvolvimento e Publicação } \\
\text { do Exposure draft } 2\end{array}$ & Board deliberations & Board discussion and papers & $\mathrm{jul} / 12$ & $\begin{array}{l}\text { Exposure draft comment period and permission to begin the } \\
\text { balloting process }\end{array}$ \\
\hline $\begin{array}{l}\text { Desenvolvimento e Publicação } \\
\text { do Exposure draft } 2\end{array}$ & Board deliberations & Board discussion and papers & $\mathrm{jul} / 12$ & Due process \\
\hline $\begin{array}{l}\text { Desenvolvimento e Publicação } \\
\quad \text { do Exposure draft } 2\end{array}$ & Board deliberations & Due process steps & $\mathrm{jul} / 12$ & IASB Agenda Reference $3 G$ \\
\hline $\begin{array}{l}\text { Desenvolvimento e Publicação } \\
\text { do Exposure draft } 2\end{array}$ & Board deliberations & Board discussion and papers & set/12 & Cover paper \\
\hline $\begin{array}{l}\text { Desenvolvimento e Publicação } \\
\text { do Exposure draft } 2\end{array}$ & Board deliberations & Board discussion and papers & set/12 & Sweep issue — sale and leaseback transactions \\
\hline $\begin{array}{l}\text { Desenvolvimento e Publicação } \\
\text { do Exposure draft } 2\end{array}$ & Board deliberations & Board discussion and papers & set/12 & Sweep Issues: SLE Approach and Lease Classification \\
\hline $\begin{array}{l}\text { Desenvolvimento e Publicação } \\
\text { do Exposure draft } 2\end{array}$ & Consultation & $\begin{array}{l}\text { Capital Markets Advisory } \\
\text { Committee }\end{array}$ & out/12 & $\begin{array}{l}\text { Meeting of IASB representatives with the Capital Markets } \\
\text { Advisory Committee }\end{array}$ \\
\hline $\begin{array}{l}\text { Desenvolvimento e Publicação } \\
\text { do Exposure draft } 2\end{array}$ & Consultation & World Standard-Setters & out/12 & World Standard Setters meeting \\
\hline $\begin{array}{l}\text { Desenvolvimento e Publicação } \\
\text { do Exposure draft } 2\end{array}$ & Board deliberations & Board discussion and papers & $\mathrm{jan} / 13$ & Cover paper \\
\hline $\begin{array}{l}\text { Desenvolvimento e Publicação } \\
\text { do Exposure draft } 2\end{array}$ & Board deliberations & Board discussion and papers & $\mathrm{jan} / 13$ & $\begin{array}{l}\text { Sweep issue-lease components and classification of leases [Zip } \\
\text { File] }\end{array}$ \\
\hline $\begin{array}{l}\text { Desenvolvimento e Publicação } \\
\text { do Exposure draft } 2\end{array}$ & Board deliberations & Board discussion and papers & fev/13 & Cover note \\
\hline $\begin{array}{l}\text { Desenvolvimento e Publicação } \\
\quad \text { do Exposure draft } 2\end{array}$ & Board deliberations & Board discussion and papers & fev/13 & Sweep issue: Consequential amendments to IAS 40 \\
\hline $\begin{array}{l}\text { Desenvolvimento e Publicação } \\
\text { do Exposure draft } 2\end{array}$ & Board deliberations & Board discussion and papers & fev/13 & Cover paper \\
\hline $\begin{array}{l}\text { Desenvolvimento e Publicação } \\
\text { do Exposure draft } 2\end{array}$ & Board deliberations & Board discussion and papers & fev/13 & Sweep Issue - Transition [Zip File] \\
\hline $\begin{array}{l}\text { Desenvolvimento e Publicação } \\
\text { do Exposure draft } 2\end{array}$ & Board deliberations & Webcast & mai/13 & $\begin{array}{l}\text { On } 20 \text { May } 2013 \text { IASB staff will give a live web presentation on } \\
\text { the proposals included in the recently issued Exposure draft on } \\
\text { lease accounting including a question and answer session. }\end{array}$ \\
\hline $\begin{array}{l}\text { Desenvolvimento e } \\
\text { Publicação do Exposure draft } \\
2\end{array}$ & Issued documents & Exposure draft & mai/13 & Exposure draft ED/2013/6 - Leases \\
\hline $\begin{array}{l}\text { Desenvolvimento e } \\
\text { Publicação do Exposure draft } \\
\qquad \begin{array}{l}2 \\
\text { Paf }\end{array}\end{array}$ & Issued documents & Exposure draft & mai/13 & Exposure draft Leases: Basis for Conclusions \\
\hline
\end{tabular}




\begin{tabular}{|c|c|c|c|c|}
\hline $\begin{array}{c}\text { Desenvolvimento e } \\
\text { Publicação do Exposure draft } \\
\mathbf{2}\end{array}$ & Issued documents & Exposure draft & mai/13 & Exposure draft Leases: Illustrative Examples \\
\hline $\begin{array}{l}\text { Desenvolvimento e Publicação } \\
\text { do Exposure draft } 2\end{array}$ & Issued documents & Snapshot & mai/13 & Snapshot: Leases \\
\hline $\begin{array}{c}\text { Desenvolvimento e } \\
\text { Publicação do Exposure draft } \\
\mathbf{2} \\
\end{array}$ & Issued documents & Press release & mai/13 & IASB and FASB propose changes to lease accounting \\
\hline $\begin{array}{l}\text { Desenvolvimento e Publicação } \\
\text { do Exposure draft } 2\end{array}$ & Issued documents & Investor Spotlight & mai/13 & Potential changes to lessee accounting \\
\hline $\begin{array}{l}\text { Desenvolvimento e Publicação } \\
\text { do Exposure draft } 2\end{array}$ & Issued documents & Roundtables & set/13 & Tuesday, 10 September 2013 - São Paulo, SP \\
\hline $\begin{array}{l}\text { Desenvolvimento e Publicação } \\
\text { do Exposure draft } 2\end{array}$ & Issued documents & Roundtables & set/13 & Monday 16 September 2013 - London \\
\hline $\begin{array}{l}\text { Desenvolvimento e Publicação } \\
\text { do Exposure draft } 2\end{array}$ & Issued documents & Roundtables & set $/ 13$ & Monday 23 September 2013 - Norwalk \\
\hline $\begin{array}{l}\text { Desenvolvimento e Publicação } \\
\text { do Exposure draft } 2\end{array}$ & Issued documents & Roundtables & out $/ 13$ & Thursday 3 October 2013 - Los Angeles \\
\hline $\begin{array}{l}\text { Desenvolvimento e Publicação } \\
\text { do Exposure draft } 2\end{array}$ & Issued documents & Roundtables & out $/ 13$ & Friday 4 October 2013 - Singapore \\
\hline $\begin{array}{l}\text { Desenvolvimento e Publicação } \\
\text { da Norma }\end{array}$ & Consultation & $\begin{array}{c}\text { Capital Markets Advisory } \\
\text { Committee }\end{array}$ & jun/13 & $\begin{array}{l}\text { Leases: Revised Exposure draft - costs and benefits of lessee } \\
\text { accounting proposals [PDF] }\end{array}$ \\
\hline $\begin{array}{l}\text { Desenvolvimento e Publicação } \\
\text { da Norma }\end{array}$ & Consultation & $\begin{array}{c}\text { Capital Markets Advisory } \\
\text { Committee }\end{array}$ & jun $/ 13$ & Leases: Snapshot [PDF] \\
\hline $\begin{array}{l}\text { Desenvolvimento e Publicação } \\
\text { da Norma }\end{array}$ & Consultation & $\begin{array}{l}\text { Capital Markets Advisory } \\
\text { Committee }\end{array}$ & jun $/ 13$ & Effects analysis for Leases [PDF] \\
\hline $\begin{array}{c}\text { Desenvolvimento e Publicação } \\
\text { da Norma }\end{array}$ & Consultation & Global Preparers Forum & jun/13 & $\begin{array}{l}\text { Leases: Revised Exposure draft - costs and benefits of lessee } \\
\text { accounting proposals [PDF] }\end{array}$ \\
\hline $\begin{array}{l}\text { Desenvolvimento e Publicação } \\
\text { da Norma }\end{array}$ & Consultation & Global Preparers Forum & jun $/ 13$ & Leases: Snapshot [PDF] \\
\hline $\begin{array}{l}\text { Desenvolvimento e Publicação } \\
\text { da Norma }\end{array}$ & Consultation & Global Preparers Forum & jun $/ 13$ & Effects analysis for Leases [PDF] \\
\hline $\begin{array}{c}\text { Desenvolvimento e Publicação } \\
\text { da Norma }\end{array}$ & Feedback on 2013 ED & Outreach meetings & set/13 & $\begin{array}{l}\text { Leases-Summaryof outreach meetings with investors and } \\
\text { analystson proposed accounting by lessees }\end{array}$ \\
\hline $\begin{array}{l}\text { Desenvolvimento e Publicação } \\
\text { da Norma }\end{array}$ & Consultation & $\begin{array}{l}\text { Accounting Standards Advisory } \\
\text { Forum }\end{array}$ & set/13 & $\begin{array}{l}\text { Agenda Paper 3: Leases: } 2013 \text { Exposure draft - Feedback on the } \\
\text { Main Proposals [PDF] }\end{array}$ \\
\hline $\begin{array}{l}\text { Desenvolvimento e Publicação } \\
\text { da Norma }\end{array}$ & Consultation & $\begin{array}{c}\text { Capital Markets Advisory } \\
\text { Committee }\end{array}$ & out $/ 13$ & Lessor accounting proposals [PDF] \\
\hline
\end{tabular}




\begin{tabular}{|c|c|c|c|c|}
\hline $\begin{array}{l}\text { Desenvolvimento e Publicação } \\
\text { da Norma }\end{array}$ & Consultation & IFRS Advisory Council & out $/ 13$ & Leases $[P D F]$ \\
\hline $\begin{array}{c}\text { Desenvolvimento e Publicação } \\
\text { da Norma }\end{array}$ & Consultation & IFRS Advisory Council & out/13 & $\begin{array}{l}\text { Leases - Summary of outreach meetings with investors and } \\
\text { analysts on proposed accounting by lessees [PDF] }\end{array}$ \\
\hline $\begin{array}{c}\text { Desenvolvimento e } \\
\text { Publicação da Norma }\end{array}$ & Feedback on 2013 ED & $\begin{array}{c}\text { Comment letter summary } \\
(2013 \mathrm{ED})\end{array}$ & nov/13 & IASB Agenda ref $3 A$ \\
\hline $\begin{array}{l}\text { Desenvolvimento e Publicação } \\
\text { da Norma }\end{array}$ & Feedback on 2013 ED & $\begin{array}{c}\text { Comment letter summary }(2013 \\
\text { ED) }\end{array}$ & nov/13 & IASB Agenda ref $3 B$ \\
\hline $\begin{array}{c}\text { Desenvolvimento e Publicação } \\
\text { da Norma }\end{array}$ & Feedback on 2013 ED & $\begin{array}{c}\text { Comment letter summary }(2013 \\
\text { ED) }\end{array}$ & nov/13 & IASB Agenda ref 3 \\
\hline $\begin{array}{c}\text { Desenvolvimento e Publicação } \\
\text { da Norma }\end{array}$ & Board deliberations & Board discussion and papers & nov/13 & Agenda paper 3-3B: Leases \\
\hline $\begin{array}{l}\text { Desenvolvimento e Publicação } \\
\text { da Norma }\end{array}$ & Consultation & Global Preparers Forum & nov/13 & Leases project - Overview of feedback on the proposals [PDF] \\
\hline $\begin{array}{l}\text { Desenvolvimento e Publicação } \\
\text { da Norma }\end{array}$ & Consultation & $\begin{array}{l}\text { Accounting Standards Advisory } \\
\text { Forum }\end{array}$ & $\operatorname{dez} / 13$ & Agenda Paper 7: Leases [PDF] \\
\hline $\begin{array}{c}\text { Desenvolvimento e Publicação } \\
\text { da Norma }\end{array}$ & Board deliberations & Board discussion and papers & $\mathrm{jan} / 14$ & Agenda paper 3: Leases: Cover memo [PDF] \\
\hline $\begin{array}{l}\text { Desenvolvimento e Publicação } \\
\text { da Norma }\end{array}$ & Board deliberations & Board discussion and papers & $\mathrm{jan} / 14$ & Agenda paper 3A: Leases: Lessor Accounting Model [PDF] \\
\hline $\begin{array}{l}\text { Desenvolvimento e Publicação } \\
\text { da Norma }\end{array}$ & Board deliberations & Board discussion and papers & $\mathrm{jan} / 14$ & Agenda paper 3B: Leases: Lessor Type A Accounting [PDF] \\
\hline $\begin{array}{c}\text { Desenvolvimento e Publicação } \\
\text { da Norma }\end{array}$ & Board deliberations & Board discussion and papers & $\mathrm{jan} / 14$ & Agenda paper 3C: Leases: Lessee small ticket leases [PDF] \\
\hline $\begin{array}{c}\text { Desenvolvimento e Publicação } \\
\text { da Norma }\end{array}$ & Board deliberations & Board discussion and papers & $\mathrm{jan} / 14$ & Agenda paper 3D: Leases: Lessee Accounting Model [PDF] \\
\hline $\begin{array}{l}\text { Desenvolvimento e Publicação } \\
\text { da Norma }\end{array}$ & Board deliberations & Board discussion and papers & $\mathrm{jan} / 14$ & $\begin{array}{l}\text { Agenda paper 3E: Leases: Examples_Lessee and Lessor } \\
\text { Accounting Models [PDF] }\end{array}$ \\
\hline $\begin{array}{c}\text { Desenvolvimento e Publicação } \\
\text { da Norma }\end{array}$ & Consultation & $\begin{array}{c}\text { Capital Markets Advisory } \\
\text { Committee }\end{array}$ & fev/14 & Lessee accounting model [PDF] \\
\hline $\begin{array}{c}\text { Desenvolvimento e Publicação } \\
\text { da Norma }\end{array}$ & Consultation & IFRS Advisory Council & fev/14 & Leases - Cover note and questions for the Council [PDF] \\
\hline $\begin{array}{l}\text { Desenvolvimento e Publicação } \\
\text { da Norma }\end{array}$ & Consultation & IFRS Advisory Council & fev/14 & Leases - Presentation $[P D F]$ \\
\hline $\begin{array}{c}\text { Desenvolvimento e Publicação } \\
\text { da Norma }\end{array}$ & Consultation & IFRS Advisory Council & fev/14 & Leases - The letter from CMAC [PDF] \\
\hline $\begin{array}{c}\text { Desenvolvimento e Publicação } \\
\text { da Norma }\end{array}$ & Consultation & IFRS Advisory Council & fev/14 & Leases - Summary of user outreach [PDF] \\
\hline
\end{tabular}




\begin{tabular}{|c|c|c|c|c|}
\hline $\begin{array}{l}\text { Desenvolvimento e Publicação } \\
\text { da Norma }\end{array}$ & Board deliberations & Board discussion and papers & $\operatorname{mar} / 14$ & Agenda Paper 3 (267): Leases: Cover Memo [PDF] \\
\hline $\begin{array}{l}\text { Desenvolvimento e Publicação } \\
\text { da Norma }\end{array}$ & Board deliberations & Board discussion and papers & $\operatorname{mar} / 14$ & Agenda Paper 3A (268): Leases: Lessee Accounting Model [PDF] \\
\hline $\begin{array}{l}\text { Desenvolvimento e Publicação } \\
\text { da Norma }\end{array}$ & Board deliberations & Board discussion and papers & $\operatorname{mar} / 14$ & $\begin{array}{l}\text { Agenda Paper 3B (269): Leases: Lessee Balance Sheet } \\
\text { Presentation [PDF] }\end{array}$ \\
\hline $\begin{array}{l}\text { Desenvolvimento e Publicação } \\
\text { da Norma }\end{array}$ & Board deliberations & Board discussion and papers & $\operatorname{mar} / 14$ & Agenda Paper 3C (270): Leases: Lessor Accounting Model [PDF] \\
\hline $\begin{array}{l}\text { Desenvolvimento e Publicação } \\
\text { da Norma }\end{array}$ & Board deliberations & Board discussion and papers & $\operatorname{mar} / 14$ & $\begin{array}{l}\text { Agenda Paper 3D (271): Leases: Lessor Type A Accounting } \\
\text { [PDF] }\end{array}$ \\
\hline $\begin{array}{l}\text { Desenvolvimento e Publicação } \\
\text { da Norma }\end{array}$ & Board deliberations & Board discussion and papers & $\operatorname{mar} / 14$ & $\begin{array}{l}\text { Agenda Paper 3E (270): Leases: Examples-Lessee and Lessor } \\
\text { Accounting Models [PDF] }\end{array}$ \\
\hline $\begin{array}{l}\text { Desenvolvimento e Publicação } \\
\text { da Norma }\end{array}$ & Board deliberations & Board discussion and papers & $\operatorname{mar} / 14$ & Agenda Paper $3 F$ (273): Leases: Lessee small-ticket leases [PDF] \\
\hline $\begin{array}{l}\text { Desenvolvimento e Publicação } \\
\text { da Norma }\end{array}$ & Board deliberations & Board discussion and papers & $\operatorname{mar} / 14$ & Agenda Paper $3 G$ (274): Leases: Lease Term [PDF] \\
\hline $\begin{array}{l}\text { Desenvolvimento e Publicação } \\
\text { da Norma }\end{array}$ & Board deliberations & Board discussion and papers & $\operatorname{mar} / 14$ & $\begin{array}{l}\text { Agenda Paper 3H (275): Leases: Lessee accounting: short-term } \\
\text { leases [PDF] }\end{array}$ \\
\hline $\begin{array}{l}\text { Desenvolvimento e Publicação } \\
\text { da Norma }\end{array}$ & Board deliberations & Board discussion and papers & $\operatorname{mar} / 14$ & Agenda Paper 3I: Leases: Education session [PDF] \\
\hline $\begin{array}{l}\text { Desenvolvimento e Publicação } \\
\text { da Norma }\end{array}$ & Board deliberations & Board discussion and papers & $\operatorname{mar} / 14$ & $\begin{array}{l}\text { Agenda Paper 3I-Addendum: Leases: Feedback from the IASB's } \\
\text { advisory bodies [PDF] }\end{array}$ \\
\hline $\begin{array}{l}\text { Desenvolvimento e Publicação } \\
\text { da Norma }\end{array}$ & Consultation & $\begin{array}{l}\text { Accounting Standards Advisory } \\
\text { Forum }\end{array}$ & $\operatorname{mar} / 14$ & Agenda Paper 4A: Leases - Cover Note [PDF] \\
\hline $\begin{array}{l}\text { Desenvolvimento e Publicação } \\
\text { da Norma }\end{array}$ & Consultation & $\begin{array}{c}\text { Accounting Standards Advisory } \\
\text { Forum }\end{array}$ & $\operatorname{mar} / 14$ & Agenda Paper 4B: Leases - Lessor Accounting Model [PDF] \\
\hline $\begin{array}{c}\text { Desenvolvimento e Publicação } \\
\text { da Norma }\end{array}$ & Consultation & $\begin{array}{l}\text { Accounting Standards Advisory } \\
\text { Forum }\end{array}$ & $\operatorname{mar} / 14$ & Agenda Paper 4C: Leases - Lessor Type A Accounting [PDF] \\
\hline $\begin{array}{c}\text { Desenvolvimento e Publicação } \\
\text { da Norma }\end{array}$ & Consultation & $\begin{array}{l}\text { Accounting Standards Advisory } \\
\text { Forum }\end{array}$ & $\operatorname{mar} / 14$ & Agenda Paper 4D: Leases - Lessee Small-ticket Leases [PDF] \\
\hline $\begin{array}{l}\text { Desenvolvimento e Publicação } \\
\text { da Norma }\end{array}$ & Consultation & $\begin{array}{l}\text { Accounting Standards Advisory } \\
\text { Forum }\end{array}$ & $\operatorname{mar} / 14$ & Agenda Paper 4E: Leases - Lessee Accounting Model [PDF] \\
\hline $\begin{array}{l}\text { Desenvolvimento e Publicação } \\
\text { da Norma }\end{array}$ & Consultation & $\begin{array}{l}\text { Accounting Standards Advisory } \\
\text { Forum }\end{array}$ & $\operatorname{mar} / 14$ & $\begin{array}{l}\text { Agenda Paper 4F: Leases - Examples - Lessee and Lessor } \\
\text { Accounting Models [PDF] }\end{array}$ \\
\hline $\begin{array}{l}\text { Desenvolvimento e Publicação } \\
\text { da Norma }\end{array}$ & Consultation & Global Preparers Forum & $\operatorname{mar} / 14$ & $\begin{array}{l}\text { Leases: Lessee accounting - ways to reduce costs and complexity } \\
{[P D F]}\end{array}$ \\
\hline $\begin{array}{l}\text { Desenvolvimento e Publicação } \\
\text { da Norma }\end{array}$ & Consultation & Global Preparers Forum & $\operatorname{mar} / 14$ & The Leases project [PDF] \\
\hline
\end{tabular}




\begin{tabular}{|c|c|c|c|c|}
\hline $\begin{array}{l}\text { Desenvolvimento e Publicação } \\
\text { da Norma }\end{array}$ & Board deliberations & Board discussion and papers & abr/14 & Agenda Paper 3: Leases: Cover memo [PDF] \\
\hline $\begin{array}{l}\text { Desenvolvimento e Publicação } \\
\text { da Norma }\end{array}$ & Board deliberations & Board discussion and papers & $\mathrm{abr} / 14$ & $\begin{array}{l}\text { Agenda Paper 3A: Leases: Lease modifications and contract } \\
\text { combinations [PDF] }\end{array}$ \\
\hline $\begin{array}{l}\text { Desenvolvimento e Publicação } \\
\text { da Norma }\end{array}$ & Board deliberations & Board discussion and papers & $\mathrm{abr} / 14$ & Agenda Paper 3B: Leases: Variable Lease Payments [PDF] \\
\hline $\begin{array}{c}\text { Desenvolvimento e Publicação } \\
\text { da Norma }\end{array}$ & Board deliberations & Board discussion and papers & abr/14 & Agenda Paper 3C: Leases: In-Substance Fixed Payments [PDF] \\
\hline $\begin{array}{c}\text { Desenvolvimento e Publicação } \\
\text { da Norma }\end{array}$ & Board deliberations & Board discussion and papers & $\mathrm{abr} / 14$ & Agenda Paper 3D: Leases: Discount Rate [PDF] \\
\hline $\begin{array}{l}\text { Desenvolvimento e Publicação } \\
\text { da Norma }\end{array}$ & Board deliberations & Board discussion and papers & mai/14 & Agenda Paper 3: Leases: Cover Memo [PDF] \\
\hline $\begin{array}{l}\text { Desenvolvimento e Publicação } \\
\text { da Norma }\end{array}$ & Board deliberations & Board discussion and papers & mai/14 & Agenda Paper 3A: Leases: Definition of a lease [PDF] \\
\hline $\begin{array}{c}\text { Desenvolvimento e Publicação } \\
\text { da Norma }\end{array}$ & Board deliberations & Board discussion and papers & mai/14 & $\begin{array}{l}\text { Agenda Paper 3B: Leases: Separating Lease and nonlease } \\
\text { components [PDF] }\end{array}$ \\
\hline $\begin{array}{c}\text { Desenvolvimento e Publicação } \\
\text { da Norma }\end{array}$ & Board deliberations & Board discussion and papers & mai/14 & Agenda Paper 3C: Leases: Initial direct costs [PDF] \\
\hline $\begin{array}{l}\text { Desenvolvimento e Publicação } \\
\text { da Norma }\end{array}$ & Board deliberations & Board discussion and papers & jun/14 & Agenda Paper 3: Leases: Cover memo [PDF] \\
\hline $\begin{array}{l}\text { Desenvolvimento e Publicação } \\
\text { da Norma }\end{array}$ & Board deliberations & Board discussion and papers & jun/14 & Agenda Paper 3A: Leases: Subleases [PDF] \\
\hline $\begin{array}{c}\text { Desenvolvimento e Publicação } \\
\text { da Norma }\end{array}$ & Board deliberations & Board discussion and papers & jun/14 & $\begin{array}{l}\text { Agenda Paper 3B: Leases: Lessee Balance Sheet Presentation } \\
\text { [PDF] }\end{array}$ \\
\hline $\begin{array}{l}\text { Desenvolvimento e Publicação } \\
\text { da Norma }\end{array}$ & Board deliberations & Board discussion and papers & jun/14 & Agenda Paper 3C: Leases: Cash flow presentation [PDF] \\
\hline $\begin{array}{c}\text { Desenvolvimento e Publicação } \\
\text { da Norma }\end{array}$ & Consultation & $\begin{array}{c}\text { Capital Markets Advisory } \\
\text { Committee }\end{array}$ & jun/14 & Leases: Lessee disclosures requirements [PDF] \\
\hline $\begin{array}{l}\text { Desenvolvimento e Publicação } \\
\text { da Norma }\end{array}$ & Consultation & Global Preparers Forum & jun/14 & Leases: Lessee disclosures requirements [PDF] \\
\hline $\begin{array}{c}\text { Desenvolvimento e Publicação } \\
\text { da Norma }\end{array}$ & Board deliberations & Board discussion and papers & $\mathrm{jul} / 14$ & Agenda Paper 3: Leases: Cover memo [PDF] \\
\hline $\begin{array}{l}\text { Desenvolvimento e Publicação } \\
\text { da Norma }\end{array}$ & Board deliberations & Board discussion and papers & $\mathrm{jul} / 14$ & $\begin{array}{l}\text { Agenda Paper 3A: Leases: Sale and leaseback transactions } \\
\text { [PDF] }\end{array}$ \\
\hline $\begin{array}{l}\text { Desenvolvimento e Publicação } \\
\text { da Norma }\end{array}$ & Board deliberations & Board discussion and papers & $\mathrm{jul} / 14$ & Agenda Paper 3B: Leases: Lessor disclosure requirements [PDF] \\
\hline $\begin{array}{c}\text { Desenvolvimento e Publicação } \\
\text { da Norma }\end{array}$ & Consultation & $\begin{array}{l}\text { Accounting Standards Advisory } \\
\text { Forum }\end{array}$ & set/14 & Agenda Paper 1: Leases: Project Update: Cover Paper [PDF] \\
\hline
\end{tabular}




\begin{tabular}{|c|c|c|c|c|}
\hline $\begin{array}{l}\text { Desenvolvimento e Publicação } \\
\text { da Norma }\end{array}$ & Consultation & $\begin{array}{l}\text { Accounting Standards Advisory } \\
\text { Forum }\end{array}$ & set/14 & Agenda Paper 1A: Leases: Project Update (August 2014) [PDF] \\
\hline $\begin{array}{l}\text { Desenvolvimento e Publicação } \\
\text { da Norma }\end{array}$ & Consultation & $\begin{array}{l}\text { Accounting Standards Advisory } \\
\text { Forum }\end{array}$ & set/14 & Agenda Paper 1B: Leases: Definition of a Lease [PDF] \\
\hline $\begin{array}{l}\text { Desenvolvimento e Publicação } \\
\text { da Norma }\end{array}$ & Consultation & $\begin{array}{l}\text { Accounting Standards Advisory } \\
\text { Forum }\end{array}$ & set/14 & $\begin{array}{l}\text { Agenda Paper 1C: Leases: ASBJ comments of the Leases Project } \\
\text { [PDF] }\end{array}$ \\
\hline $\begin{array}{l}\text { Desenvolvimento e Publicação } \\
\text { da Norma }\end{array}$ & Board deliberations & Board discussion and papers & out $/ 14$ & Agenda Paper 3: Leases: Cover note [PDF] \\
\hline $\begin{array}{l}\text { Desenvolvimento e Publicação } \\
\text { da Norma }\end{array}$ & Board deliberations & Board discussion and papers & out $/ 14$ & Agenda Paper 3A: Leases: Definition of a lease [PDF] \\
\hline $\begin{array}{l}\text { Desenvolvimento e Publicação } \\
\text { da Norma }\end{array}$ & Board deliberations & Board discussion and papers & nov/14 & $\begin{array}{l}\text { Agenda Paper 3: Leases: Consequential amendments to IAS } 40 \\
{[P D F]}\end{array}$ \\
\hline $\begin{array}{l}\text { Desenvolvimento e Publicação } \\
\text { da Norma }\end{array}$ & Board deliberations & Board discussion and papers & $\operatorname{dez} / 14$ & Agenda Paper 3: Leases: Cover Memo [PDF] \\
\hline $\begin{array}{l}\text { Desenvolvimento e Publicação } \\
\text { da Norma }\end{array}$ & Board deliberations & Board discussion and papers & $\operatorname{dez} / 14$ & $\begin{array}{l}\text { Agenda Paper } 3 A: \text { Leases: Definition of a lease - Ability to } \\
\text { Derive the Benefits from Directing the Use of an Identified Asset } \\
{[P D F]}\end{array}$ \\
\hline $\begin{array}{l}\text { Desenvolvimento e Publicação } \\
\text { da Norma }\end{array}$ & Consultation & $\begin{array}{l}\text { Accounting Standards Advisory } \\
\text { Forum }\end{array}$ & $\mathrm{dez} / 14$ & Agenda Paper 2: Leases: Project Update [PDF] \\
\hline $\begin{array}{l}\text { Desenvolvimento e Publicação } \\
\text { da Norma }\end{array}$ & Board deliberations & Board discussion and papers & $\mathrm{jan} / 15$ & Agenda Paper 3: Leases: Cover Memo [PDF] \\
\hline $\begin{array}{l}\text { Desenvolvimento e Publicação } \\
\text { da Norma }\end{array}$ & Board deliberations & Board discussion and papers & $\mathrm{jan} / 15$ & $\begin{array}{l}\text { Agenda Paper 3A: Leases: Lessee Disclosure Requirements - } \\
\text { FASB [PDF] }\end{array}$ \\
\hline $\begin{array}{l}\text { Desenvolvimento e Publicação } \\
\text { da Norma }\end{array}$ & Board deliberations & Board discussion and papers & $\mathrm{jan} / 15$ & $\begin{array}{l}\text { Agenda Paper 3B: Leases: Lessee Disclosure Requirements - } \\
\text { IASB [PDF] }\end{array}$ \\
\hline $\begin{array}{l}\text { Desenvolvimento e Publicação } \\
\text { da Norma }\end{array}$ & Consultation & $\begin{array}{l}\text { European Financial Reporting } \\
\text { Advisory Group Board }\end{array}$ & $\mathrm{jan} / 15$ & Leases: Current status of IASB redeliberations [PDF] \\
\hline $\begin{array}{l}\text { Desenvolvimento e Publicação } \\
\text { da Norma }\end{array}$ & Board deliberations & Board discussion and papers & fev/15 & Agenda Paper 3: Leases: Cover memo [PDF] \\
\hline $\begin{array}{l}\text { Desenvolvimento e Publicação } \\
\text { da Norma }\end{array}$ & Board deliberations & Board discussion and papers & fev/15 & $\begin{array}{l}\text { Agenda Paper 3A: Leases: Transition-Leases Previously } \\
\text { Classified as Operating Leases [PDF] }\end{array}$ \\
\hline $\begin{array}{l}\text { Desenvolvimento e Publicação } \\
\text { da Norma }\end{array}$ & Board deliberations & Board discussion and papers & fev/15 & $\begin{array}{l}\text { Agenda Paper 3B: Leases: Transition-Sale and Leaseback } \\
\text { Transactions [PDF] }\end{array}$ \\
\hline $\begin{array}{l}\text { Desenvolvimento e Publicação } \\
\text { da Norma }\end{array}$ & Board deliberations & Board discussion and papers & fev/15 & Agenda Paper 3C: Leases: Transition-Subleases [PDF] \\
\hline $\begin{array}{l}\text { Desenvolvimento e Publicação } \\
\text { da Norma }\end{array}$ & Board deliberations & Board discussion and papers & fev/15 & $\begin{array}{l}\text { Agenda Paper 3D: Leases: Transition-Definition of a Lease } \\
{[P D F]}\end{array}$ \\
\hline
\end{tabular}




\begin{tabular}{|c|c|c|c|c|}
\hline $\begin{array}{l}\text { Desenvolvimento e Publicação } \\
\text { da Norma }\end{array}$ & Board deliberations & Board discussion and papers & fev/15 & Agenda Paper 3E: Leases: Leases of Small Assets [PDF] \\
\hline $\begin{array}{l}\text { Desenvolvimento e Publicação } \\
\text { da Norma }\end{array}$ & Board deliberations & Board discussion and papers & fev/15 & $\begin{array}{l}\text { Agenda Paper 3F: Leases: Subleases Sweep Issue: Discount Rate } \\
{[P D F]}\end{array}$ \\
\hline $\begin{array}{l}\text { Desenvolvimento e Publicação } \\
\text { da Norma }\end{array}$ & Board deliberations & Board discussion and papers & $\operatorname{mar} / 15$ & Agenda Paper 3: Leases: Cover Memo [PDF] \\
\hline $\begin{array}{l}\text { Desenvolvimento e Publicação } \\
\text { da Norma }\end{array}$ & Board deliberations & Board discussion and papers & $\operatorname{mar} / 15$ & $\begin{array}{l}\text { Agenda Paper 3A: Leases: Due process, Re-exposure and } \\
\text { Permission to Draft [PDF] }\end{array}$ \\
\hline $\begin{array}{c}\text { Desenvolvimento e Publicação } \\
\text { da Norma }\end{array}$ & Board deliberations & Board discussion and papers & $\operatorname{mar} / 15$ & $\begin{array}{l}\text { Agenda Paper 3B: Leases: Sweep Issue: Disclosures on } \\
\text { Transition [PDF] }\end{array}$ \\
\hline $\begin{array}{l}\text { Desenvolvimento e Publicação } \\
\text { da Norma }\end{array}$ & Board deliberations & Due process steps & $\operatorname{mar} / 15$ & $\begin{array}{l}\text { Leases|Due process, re-exposure and permission to draf - IASB } \\
\text { Agenda ref } 3 A\end{array}$ \\
\hline $\begin{array}{l}\text { Desenvolvimento e Publicação } \\
\text { da Norma }\end{array}$ & Consultation & $\begin{array}{l}\text { Accounting Standards Advisory } \\
\text { Forum }\end{array}$ & $\operatorname{mar} / 15$ & Agenda Paper 3: Leases: Project Finalisation [PDF] \\
\hline $\begin{array}{l}\text { Desenvolvimento e Publicação } \\
\text { da Norma }\end{array}$ & Consultation & IFRS Advisory Council & jun $/ 15$ & Leases: Steps after publication of the Standard [PDF] \\
\hline $\begin{array}{c}\text { Desenvolvimento e Publicação } \\
\text { da Norma }\end{array}$ & Board deliberations & Board discussion and papers & out $/ 15$ & Agenda Paper 3: Leases: Cover memo [PDF] \\
\hline $\begin{array}{l}\text { Desenvolvimento e Publicação } \\
\text { da Norma }\end{array}$ & Board deliberations & Board discussion and papers & out $/ 15$ & Agenda Paper 3A: Leases: Sweep Issues [PDF] \\
\hline $\begin{array}{l}\text { Desenvolvimento e Publicação } \\
\text { da Norma }\end{array}$ & Board deliberations & Board discussion and papers & out $/ 15$ & Agenda Paper 3B: Leases: Effective Date [PDF] \\
\hline $\begin{array}{l}\text { Desenvolvimento e Publicação } \\
\text { da Norma }\end{array}$ & Board deliberations & Board discussion and papers & out $/ 15$ & $\begin{array}{l}\text { Agenda Paper 3C: Leases: Disclosure requirements for leases } \\
\text { within the scope of IFRS } 5 \text { [PDF] }\end{array}$ \\
\hline $\begin{array}{c}\text { Desenvolvimento e } \\
\text { Publicação da Norma }\end{array}$ & Issued Documents & IFRS & jan/16 & 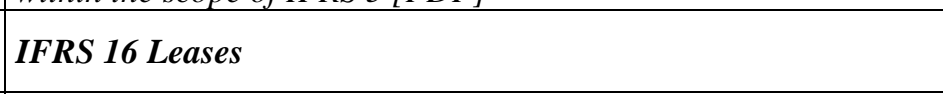 \\
\hline $\begin{array}{c}\text { Desenvolvimento e } \\
\text { Publicação da Norma } \\
\end{array}$ & Issued Documents & Press release & $\mathrm{jan} / 16$ & $\begin{array}{l}\text { Press release: IASB shines light on leases by bringing them onto } \\
\text { the balance sheet }\end{array}$ \\
\hline $\begin{array}{l}\text { Procedimentos Posteriores à } \\
\text { publicação da Norma }\end{array}$ & Issued Documents & Uptade & ago/14 & Project Update: Leases (August 2014) [PDF] \\
\hline $\begin{array}{l}\text { Procedimentos Posteriores à } \\
\text { publicação da Norma }\end{array}$ & Issued Documents & Podcast & ago/14 & Podcast (August 2014) \\
\hline $\begin{array}{l}\text { Procedimentos Posteriores à } \\
\text { publicação da Norma }\end{array}$ & Issued Documents & Uptade & $\operatorname{mar} / 15$ & $\begin{array}{l}\text { Project Update: Practical implications of the new Leases } \\
\text { Standard (March 2015) [PDF] }\end{array}$ \\
\hline $\begin{array}{l}\text { Procedimentos Posteriores à } \\
\text { publicação da Norma }\end{array}$ & Issued Documents & Uptade & out $/ 15$ & Project Updates: Definition of a Lease \\
\hline $\begin{array}{c}\text { Procedimentos Posteriores à } \\
\text { publicação da Norma }\end{array}$ & Issued Documents & Effect Analysis & jan/16 & Effects Analysis [PDF] \\
\hline
\end{tabular}




\begin{tabular}{|c|c|c|l|l|}
$\begin{array}{c}\text { Procedimentos Posteriores à } \\
\text { publicação da Norma }\end{array}$ & Issued Documents & Summary & jan/16 & Project Summary and Feedback Statement [PDF] \\
\hline $\begin{array}{c}\text { Procedimentos Posteriores à } \\
\text { publicação da Norma }\end{array}$ & Issued Documents & Webcast & jan/16 & Webcast: IFRS 16 Leases \\
\hline $\begin{array}{c}\text { Procedimentos Posteriores à } \\
\text { publicação da Norma }\end{array}$ & Issued Documents & Webcast & jan/16 & Video: Introducing the new Leases Standard \\
\hline $\begin{array}{c}\text { Procedimentos Posteriores à } \\
\text { publicação da Norma }\end{array}$ & Issued Documents & Investor Perspective & jan/16 & Investor Perspectives-A New Lease of Life [PDF] \\
\hline
\end{tabular}

Fonte: Elaborado com base nos dados disponíveis em: http://archive.ifrs.org/Current-Projects/IASB-Projects/Leases/Pages/Leases.aspx 


\section{APÊNDICE C - Resumo das Lógicas da Explicação Crítica identificadas}

Figura 56 - Descrição das Lógicas Sociais identificadas

\begin{tabular}{|c|c|}
\hline $\begin{array}{l}\text { Lógicas } \\
\text { Sociais }\end{array}$ & Descrição \\
\hline $\begin{array}{l}\text { Lógica da } \\
\text { financialização }\end{array}$ & $\begin{array}{l}\text { Os produtos do IASB resultam de demandas da economia neoliberal, que privilegia discursos } \\
\text { como o do livre mercado e a valorização do mercado financeiro em prol dos investidores. O } \\
\text { discurso da globalização, portanto, é um dos principais motivadores para a existência da lógica } \\
\text { da financialização nas práticas do IASB. Essa lógica representa a substância do "viés" do IASB } \\
\text { para a criação de normas levando em consideração conceitos econômicos relacionadas com o } \\
\text { mercado financeiro e com os investidores, principalmente pelos shareholders, com base em } \\
\text { uma visão da situação da empresa pelos proprietários. Ela surge por necessidades da própria } \\
\text { regulação e dos usuários externos (e talvez da academia/teoria), que impõe a financialização } \\
\text { para a prática por meio da demanda existente por parte dos usuários externos "relevantes" (o } \\
\text { movimento não é de dentro da profissão para os seus usuários, mas sim dos usuários para } \\
\text { dentro da profissão). A financialização representa uma lógica que caracteriza a normatização } \\
\text { contábil do IASB e não de seus antecessores, ou seja, com efeitos relevantes principalmente a } \\
\text { partir do ano de 2001. Com essa lógica, observamos a ação de que a informação contábil é } \\
\text { voltada para um determinado público e com determinado viés. }\end{array}$ \\
\hline $\begin{array}{l}\text { Lógica da } \\
\text { independência/ } \\
\text { atomização }\end{array}$ & $\begin{array}{l}\text { Nessa lógica, observamos que o board se diz separado de todo e qualquer interessado, o que o } \\
\text { tornaria socialmente neutro e diferenciado de outros possíveis concorrentes. A lógica da } \\
\text { atomização funciona como um fenômeno hierarquizante, sendo que essas hierarquias podem } \\
\text { ser visíveis ou invisíveis. Nessa hierarquia, temos o IASB como o recebedor do discurso de } \\
\text { expertise e único capaz de produzir normas internacionais de alta qualidade. O discurso social } \\
\text { de independência é exatamente a aplicação ilusória dessa ausência de conflitos, em que se } \\
\text { argumenta que existe um ente independente e atomizado do seu meio social capaz de realizar } \\
\text { decisões "técnicas" sem a interferência de conflitos e, portanto, sem a existência de política, } \\
\text { sendo ele "superior" e único quando comparado às possíveis alternativas já existentes ou que } \\
\text { possam ser criadas. Uma das principais formas de defesa do board é exatamente pelo discurso } \\
\text { de que, por ser um órgão independente, suas decisões são neutras e de qualidade, o que lhe } \\
\text { confere uma diferenciação como "único e melhor" normatizador internacional possível. }\end{array}$ \\
\hline $\begin{array}{l}\text { Lógica das } \\
\text { boas práticas }\end{array}$ & $\begin{array}{l}\text { A lógica funciona como pilar da normatização de forma a caracterizar o discurso de qualidade } \\
\text { da regulação. As alegadas boas práticas se amparam na hegemonia do discurso geral da } \\
\text { normatização para, ilusoriamente, demonstrar a modernidade do IASB na elaboração de suas } \\
\text { normas. Essas boas práticas acabam por caracterizar o processo normativo, ao menos na teoria. } \\
\text { Exemplos envolvem a publicidade dada aos documentos, a tentativa de trazer uma governança } \\
\text { em redes, com participação pública, a diminuição do status do próprio regulador em prol do } \\
\text { "amplo debate" e a tentativa de justificativa das decisões tomadas, entre outros. Reforçam a } \\
\text { ideia de naturalidade da qualidade das decisões tomadas, uma vez que há a impressão de haver } \\
\text { ferramentas que envolvem os valores de controle, de participação e de avaliação }\end{array}$ \\
\hline $\begin{array}{l}\text { Lógica dos } \\
\text { constituintes }\end{array}$ & $\begin{array}{l}\text { Traz à tona o discurso de que os "constituintes" são partes integrantes do processo de } \\
\text { construção de normas do IASB. Em um contraponto com o que se espera, o conceito de } \\
\text { constituintes, nos diversos documentos do IASB, apresenta certa similaridade com o conceito } \\
\text { de usuários (ou participantes/atores do processo) e não com os efetivos tomadores de decisões. } \\
\text { O termo (constituinte) aparece principalmente quando o board se refere às etapas de consultas. } \\
\text { Ao levar à compreensão incorreta da forma de funcionamento do processo normativo, o que } \\
\text { dá a entender é que a lógica dos constituintes seria a lógica dos usuários, isto é, os usuários e } \\
\text { as partes interessadas possuiriam poder de decisão, o que não é verdade. }\end{array}$ \\
\hline $\begin{array}{l}\text { Lógica da } \\
\text { expertise }\end{array}$ & $\begin{array}{l}\text { A expertise representa a diferenciação da atomização, ao menos discursivamente, dos demais } \\
\text { agentes, garantindo um lugar de destaque no que se refere à "detenção" do conhecimento. A } \\
\text { lógica social da expertise caracteriza de forma basal o processo normativo do IASB e apresenta } \\
\text { diversos efeitos sobre as práticas naturalizadas nesse processo, por exemplo, a "capacidade } \\
\text { técnica", a "ampla participação", a "experiência prática" e a "visão de mercado". A expertise } \\
\text { é o discurso básico utilizado na regulação contábil com a função de não apenas limitar ações } \\
\text { externas, mas também de ser o discurso central para a aceitação dos produtos normativos por } \\
\text { parte desses mesmos agentes que têm suas participações tolhidas. A expertise seria uma } \\
\text { estratégia que traz prestígio e credibilidade (Abbott, 1988; Willmott, 2000) e diferencia o órgão } \\
\text { (e seus participantes) para que este atinja uma posição de poder. Podemos dizer que, no caso }\end{array}$ \\
\hline
\end{tabular}


do IASB, a expertise é exercida por meio de seus membros e do staff que se diferenciam ao se auto avaliarem como os representantes de uma ampla experiência e com conhecimento técnico superior. Assim, há uma exclusão silenciosa daqueles que não possuem o status social desejado ao debate nem alguma forma de poder entre os envolvidos. A argumentação de expertise reforça um lugar diferenciado no discurso, que é o de locus of knowledge.

Fonte: Elaboração própria.

Figura 57 - Descrição das Lógicas Políticas identificadas

\begin{tabular}{|c|c|}
\hline $\begin{array}{l}\text { Lógicas } \\
\text { Políticas }\end{array}$ & Descrição \\
\hline $\begin{array}{l}\text { Discurso da } \\
\text { essência sobre } \\
\text { a forma }\end{array}$ & $\begin{array}{l}\text { O discurso da essência sobre a forma é crucial como modo de institucionalizar a lógica social } \\
\text { da financialização no projeto de leasing, uma vez que funciona como elemento que direciona } \\
\text { a tomada de decisão no sentido de "modificar a norma". Esse discurso se baseia na noção de } \\
\text { "substância econômica" dos eventos e fatos em detrimento da noção jurídica (do direito). É } \\
\text { mais uma dicotomização política criada com base na prática articulatória de que as práticas } \\
\text { contábeis baseadas na essência econômica seriam boas/atuais enquanto aquelas baseadas na } \\
\text { forma jurídica seriam ruins/antiquadas. A essência sobre a forma ratifica a defesa do board } \\
\text { pela constante utilização do "valor justo". O discurso da essência sobre a forma também } \\
\text { possibilita maior capacidade de julgamento, uma vez que apresenta maior subjetividade } \\
\text { quando comparado ao discurso da forma jurídica. Por um lado, o board apresenta a essência } \\
\text { como mais relevante para a tomada de decisões dos investidores, entretanto, essa essência pode } \\
\text { ser vista de diferentes maneiras a depender da entidade e do usuário. }\end{array}$ \\
\hline $\begin{array}{l}\text { Discurso da } \\
\text { necessidade de } \\
\text { mudança }\end{array}$ & $\begin{array}{l}\text { Uma vez que houve a construção hegemônica de que as normas devem se basear na substância } \\
\text { econômica, abre-se espaço para a crítica à normatização antiga, que, na articulação do board, } \\
\text { era baseada na forma jurídica. A necessidade de mudança de uma norma no contexto } \\
\text { internacional, portanto, se constrói por meio de reiteradas críticas ao modelo normativo } \\
\text { anterior, mostrando suas falhas, e como elas não se enquadram mais ao modelo atual de } \\
\text { negócios com base nas fantasias da globalização, da comparabilidade e da qualidade. Quando } \\
\text { dessa atuação política (momento em que se defende mudança), é possível que o board já possua } \\
\text { suas preferências de conteúdo da norma, o que permitiria a antecipação das necessidades } \\
\text { articulatórias que surgiriam a partir do ponto em que as diferenças fossem realçadas por meio } \\
\text { de alguma particularidade. Eventual antecipação facilitaria a construção hegemônica mais } \\
\text { duradoura que criaria, além das diferenças, equivalências de forma a manter o discurso a longo } \\
\text { prazo sempre coerente. Primeiro, o board possui uma intenção de conteúdo de norma e, após } \\
\text { isso, cria a articulação que agregue as diversas diferenças para que se atraiam por essa } \\
\text { necessidade de mudança. }\end{array}$ \\
\hline $\begin{array}{l}\text { Discurso da } \\
\text { capitalização }\end{array}$ & $\begin{array}{l}\text { Jo momento inicial, utilizando-se da lógica da diferença da "necessidade de mudança", o } \\
\text { iscurso da capitalização foi desenvolvido por meio da articulação de que esta era a melhor } \\
\text { pção para o reconhecimento das operações de arrendamento tomando como base a essência } \\
\text { conômica do que efetivamente representa um arrendamento. Após isso, constrói-se o discurso } \\
\text { specífico da mudança. No caso do arrendamento foi o de capitalização de todas as operações } \\
\text { e arrendamento. O ponto nodal torna-se, portanto, a "capitalização". }\end{array}$ \\
\hline $\begin{array}{l}\text { Discurso do } \\
\text { modelo único }\end{array}$ & $\begin{array}{l}\text { O modelo único envolve exatamente a aplicação das principais críticas que ocorriam à norma } \\
\text { anterior de arrendamento e segue a articulação baseada na fantasia da comparabilidade para o } \\
\text { aumento da qualidade dos negócios internacionais. A articulação de modelo único, então, é } \\
\text { capaz de flutuar mediante significantes como comparabilidade, necessidade de simplificação } \\
\text { e custos versus benefícios. Além disso, flutua sobre o argumento de que esses significantes são } \\
\text { de interesse primário dos investidores. Toda essa variedade foi exatamente a justificativa para } \\
\text { a mudança da norma com base no discurso da "essência sobre a forma", que deveria ser capaz } \\
\text { de espelhar tal variedade. Mas será possível espelhar a alegada variedade de visões do } \\
\text { arrendamento nos diversos mercados com um modelo único? }\end{array}$ \\
\hline $\begin{array}{l}\text { Discurso da } \\
\text { simetria }\end{array}$ & $\begin{array}{l}\text { As normas internacionais mais atuais procuram espelhar como as transações seriam } \\
\text { reconhecidas e mensuradas sob os diversos participantes das operações, então esse discurso } \\
\text { não é restrito à norma de arrendamento, mas foi nessa norma que ele sofreu mais antagonismos } \\
\text { e flutuações durante o processo. Na articulação geral, para defender a tecnicidade e demonstrar } \\
\text { o simbolismo de que não se privilegia nenhuma das partes frente às escolhas contábeis, } \\
\text { argumenta-se que deve haver simetria entre as contabilizações, evitando dupla contagem de } \\
\text { itens contábeis. }\end{array}$ \\
\hline
\end{tabular}

Fonte: Elaboração própria. 
Figura 58 - Descrição das Lógicas Fantasmáticas identificadas

\begin{tabular}{|c|c|}
\hline $\begin{array}{c}\text { Lógicas } \\
\text { Fantasmáticas }\end{array}$ & Descrição \\
\hline $\begin{array}{l}\text { Fantasia da } \\
\text { qualidade da } \\
\text { norma }\end{array}$ & $\begin{array}{l}\text { Essa lógica envolve argumentações de qualidade processual, de conteúdo e de atores } \\
\text { envolvidos. Isso quer dizer que a argumentação da qualidade final da norma é } \\
\text { amplamente baseada nas qualidades dadas ao processo normativo, amparadas nas } \\
\text { alegadas boas práticas de governança. Assim, temos uma relação dessa fantasia com as } \\
\text { lógicas sociais já apresentadas. A fantasia de qualidade da norma procura criar um } \\
\text { discurso que sustenta a necessidade de ser o IASB, especificamente, o regulador } \\
\text { internacional, uma vez que ele argumenta possuir todas as características necessárias para } \\
\text { a criação do melhor cenário internacional possível para a prática da contabilidade. Um } \\
\text { dos pilares de sustentação é o de que a qualidade (técnica) da norma está acima de } \\
\text { qualquer interferência política, até mesmo da funcionalidade de "convergência" das } \\
\text { informações contábeis de forma a atingir o (alegado) interesse público. A qualidade da } \\
\text { norma se torna uma fantasia, portanto, por ser uma das bases argumentativas na } \\
\text { normatização contábil para justificar e explicar a necessidade de mudanças nas normas e, } \\
\text { ao mesmo tempo, "conquistar o público" de forma a mostrar que há sempre incremento } \\
\text { dessa qualidade (imensurável e vazia). Dessa maneira, o board promete essa qualidade ao } \\
\text { público, porém ela se torna ideológica ao ponto de ser uma estratégia política como forma } \\
\text { de garantir a credibilidade e a aceitação de seus produtos. }\end{array}$ \\
\hline $\begin{array}{l}\text { Fantasia da } \\
\text { tecnicidade }\end{array}$ & $\begin{array}{l}\text { Essa fantasia está presente nas mais diversas discussões desta tese e a tecnicidade se } \\
\text { comporta como principal argumento do board para sua aceitação, para a garantia da } \\
\text { qualidade, da neutralidade, da independência e das mais diversas estratégias de boas } \\
\text { práticas de governança. A tecnicidade muitas vezes aparece atrelada a noções de } \\
\text { objetividade. A visão de tecnocracia, na realidade, é uma visão politicamente construída. } \\
\text { A repetição, portanto, funciona como uma maneira de controle que, ao longo do tempo, } \\
\text { mascara o poder exercido por meio da aceitação e do esquecimento. Esse pensamento é } \\
\text { ratificado quando se vê que "a repetição de afirmações até que tenham efeito é a principal } \\
\text { estratégia na racionalização do poder e na forma como o poder define a realidade" } \\
\text { (Flyvbjerg, 1998, p. 113). A partir disso e fundamentado na visão pós-estruturalista que } \\
\text { adoto na tese, posso dizer que a repetição é uma estratégia eficiente na internalização e } \\
\text { institucionalização de determinadas ideias, uma vez que pelo poder linguístico } \\
\text { constroem-se os discursos e com base nele as realidades são moldadas (Laclau \& Mouffe, } \\
\text { 1985). }\end{array}$ \\
\hline $\begin{array}{l}\text { - Fantasia da } \\
\text { comparabilidade } \\
\text { - Fantasia da } \\
\text { globalização }\end{array}$ & $\begin{array}{l}\text { A comparabilidade seria o atributo que a normatização contábil atingiria por meio da } \\
\text { fantasia das normas de alta qualidade aliada à fantasia da tecnicidade. Por meio da } \\
\text { hipotética realização dessas duas fantasias, encontraríamos o "santo graal" da } \\
\text { comparabilidade das informações contábeis, o que traria supostos benefícios para } \\
\text { empresas, para o mercado e para a distribuição de riqueza pelo mundo. A } \\
\text { comparabilidade, assim como a fantasia da qualidade, já aparece na constituição da IFRS } \\
\text { Foundation ao se afirmar, em seu objetivo, que as normas devem possuir alta qualidade e } \\
\text { serem comparáveis com a finalidade de auxiliar, principalmente, os investidores. No caso } \\
\text { dos processos normativos do IASB, a comparabilidade funciona bem nesse contexto ao } \\
\text { ser retoricamente relembrada nas justificativas das mudanças nas normas. Ao } \\
\text { observarmos as articulações, seremos capazes de identificar que o aumento da } \\
\text { comparabilidade (para os investidores) é sempre uma das principais premissas que } \\
\text { justificam as mudanças. A comparabilidade, portanto, pode ser vista mais como uma } \\
\text { estratégia de convencimento do que como um incremento à globalização. Essas fantasias } \\
\text { fazem com que a normatização contábil internacional funcione sem que haja grandes } \\
\text { críticas por parte da comunidade, justamente por internalizar o conceito da } \\
\text { comparabilidade como sempre crescente e vantajoso. Ou seja, promete-se que entidades e } \\
\text { países que adotem as normas apresentarão menores dificuldades de inserção no mercado } \\
\text { internacional em decorrência da comparabilidade de suas informações. Considerando esse } \\
\text { discurso dos benefícios da comparabilidade, deparamo-nos com uma outra fantasia, que é } \\
\text { a fantasia da globalização. Com a comparabilidade advinda das normas internacionais e } \\
\text { com a aplicação dessas normas pelos mais diversos países, os investidores seriam capazes } \\
\text { de investir em entidades localizadas em países com mercados menos desenvolvidos, pois } \\
\text { haveria nesses locais empresas utilizando as mesmas normas dos demais mercados. } \\
\text { Assim, pelo argumento do board, haveria um incremento da função "social" da } \\
\text { contabilidade no auxílio aos mercados emergentes e menos desenvolvidos, que poderiam }\end{array}$ \\
\hline
\end{tabular}




\begin{tabular}{|c|c|}
\hline & $\begin{array}{l}\text { competir com os mercados do considerado "primeiro mundo". A globalização também } \\
\text { funciona como uma fantasia nesse cenário, uma vez que se construiu um status quo } \\
\text { acerca das suas vantagens e da necessidade de um mundo globalizado. A comparabilidade } \\
\text { é, então, um ideal da globalização que atende aos usuários sofisticados do mercado de } \\
\text { capitais internacional. Esse ideal é construído de forma a persuadir os usuários a } \\
\text { entenderem que a comparabilidade é sempre crescente com as normas internacionais e } \\
\text { que ela é sempre vantajosa. }\end{array}$ \\
\hline $\begin{array}{l}\text { - Fantasia da } \\
\text { justiça processual } \\
\text { - Fantasia da } \\
\text { participação } \\
\text { - Fantasia da } \\
\text { transparência } \\
\text { - Fantasia da } \\
\text { accountability }\end{array}$ & 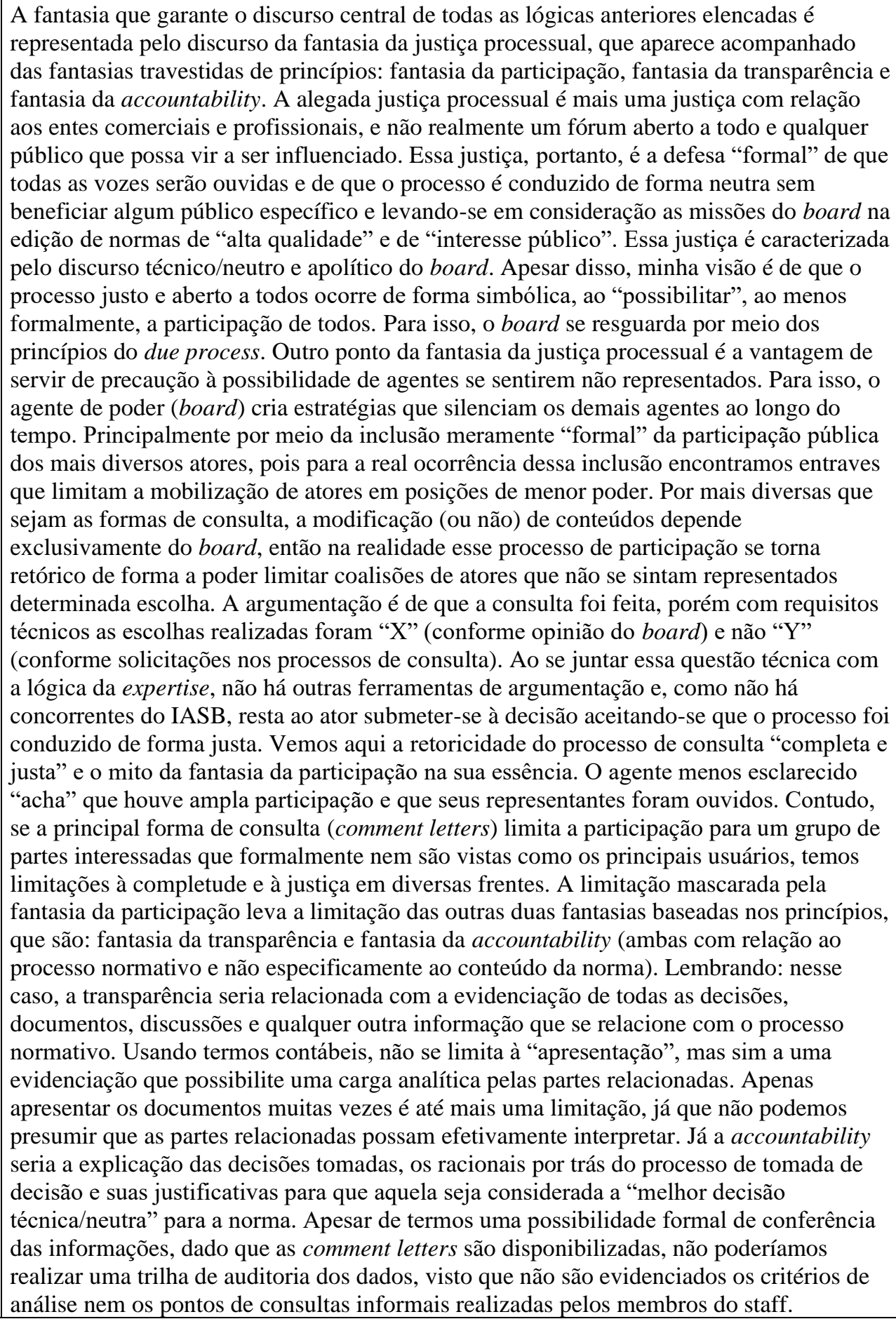 \\
\hline
\end{tabular}

Fonte: Elaboração própria. 